\title{
Metal Prices in the United States Through 2010
}

\begin{tabular}{|c|c|c|c|}
\hline Aluminum & Germanium & Mercury & Silver \\
\hline Antimony & Gold & Molybdenum & Tantalum \\
\hline Arsenic & Hafnium & Nickel & Tellurium \\
\hline Beryllium & Indium & Niobium & Thallium \\
\hline Bismuth & Iron and Steel & Platinum-Group Metals & Tin \\
\hline Cadmium & Iron and Steel Scrap & Rare-Earth Metals & Titanium \\
\hline Cesium & Iron Ore & Rhenium & Tungsten \\
\hline Chromium & Lead & Rubidium & Vanadium \\
\hline Cobalt & Lithium & Selenium & Zinc \\
\hline Copper & Magnesium & Silicon & Zirconium \\
\hline Gallium & Manganese & & \\
\hline
\end{tabular}

Scientific Investigations Report 2012-5188 



\section{Metal Prices in the United States Through 2010}

By U.S. Geological Survey National Minerals Information Center staff

Scientific Investigations Report 2012-5188

U.S. Department of the Interior

U.S. Geological Survey 


\section{U.S. Department of the Interior \\ KEN SALAZAR, Secretary \\ U.S. Geological Survey \\ Marcia K. McNutt, Director}

U.S. Geological Survey, Reston, Virginia: 2013

For more information on the USGS - the Federal source for science about the Earth, its natural and living resources, natural hazards, and the environment, visit http://www.usgs.gov or call 1-888-ASK-USGS.

For an overview of USGS information products, including maps, imagery, and publications, visit http://www.usgs.gov/pubprod

To order this and other USGS information products, visit http://store.usgs.gov

Any use of trade, firm, or product names is for descriptive purposes only and does not imply endorsement by the U.S. Government.

Although this information product, for the most part, is in the public domain, it also may contain copyrighted materials as noted in the text. Permission to reproduce copyrighted items must be secured from the copyright owner.

Suggested citation:

U.S. Geological Survey, 2013, Metal prices in the United States through 2010: U.S. Geological Survey Scientific Investigations Report 2012-5188, 204 p., available only at http://pubs.usgs.gov/sir/2012/5188. 


\section{Contents}

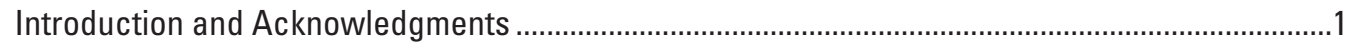

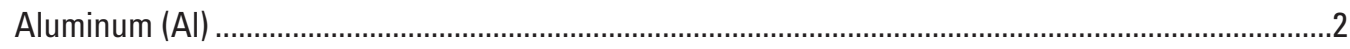

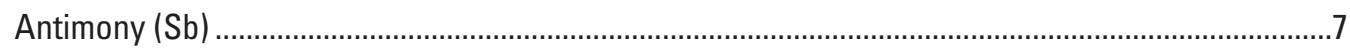

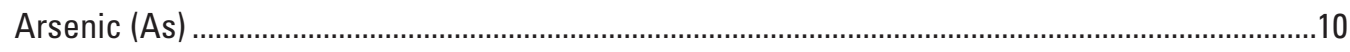

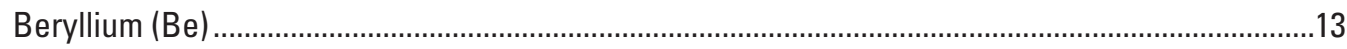

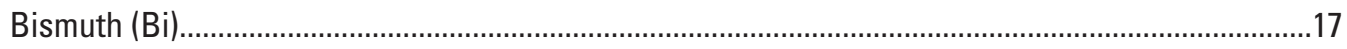

Cadmium (Cd) .

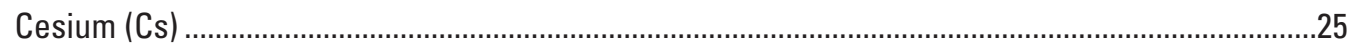

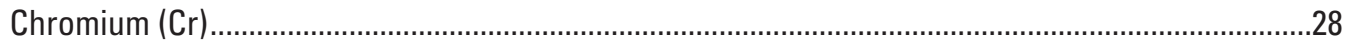

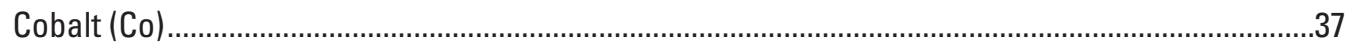

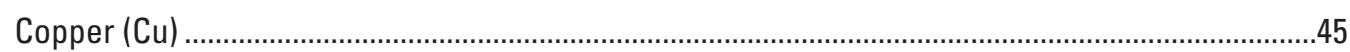

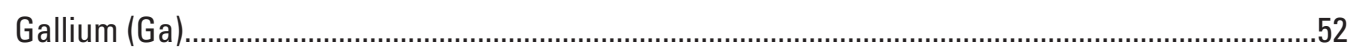

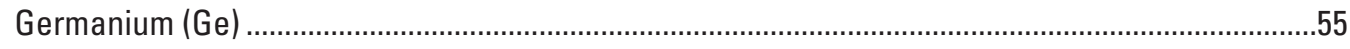

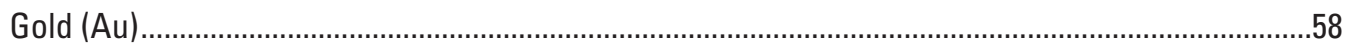

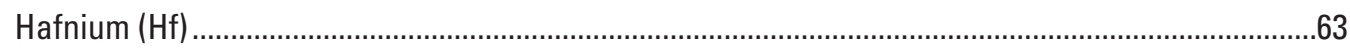

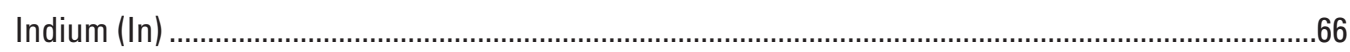

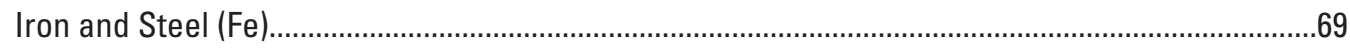

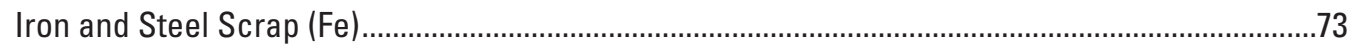

Iron Ore (Fe) ………......................................................................................................

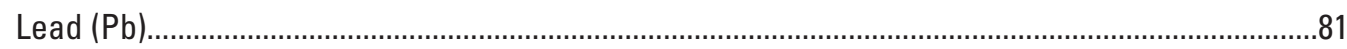

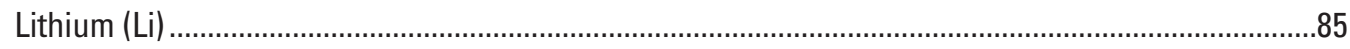

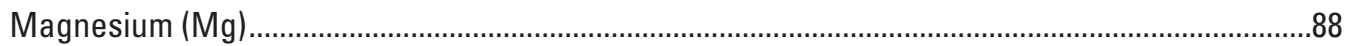

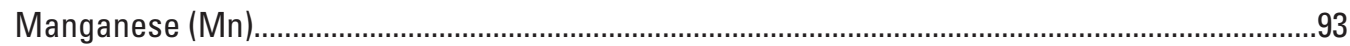

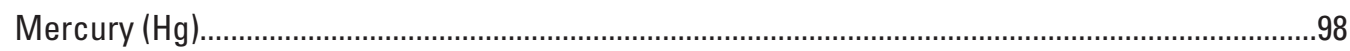

Molybdenum (Mo)

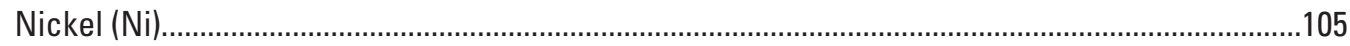

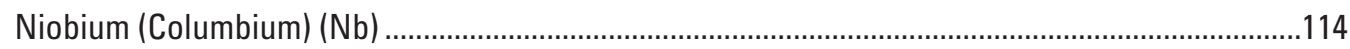

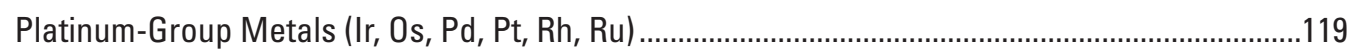

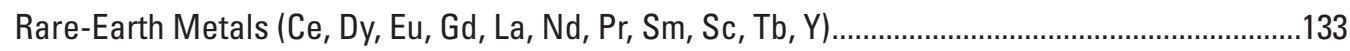

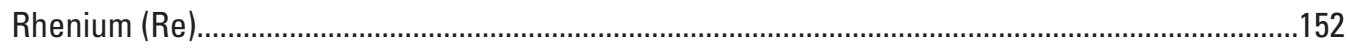

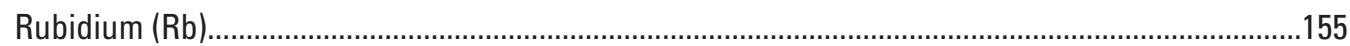

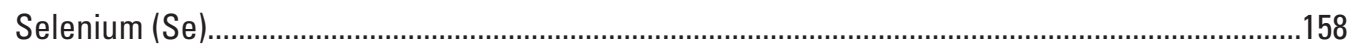

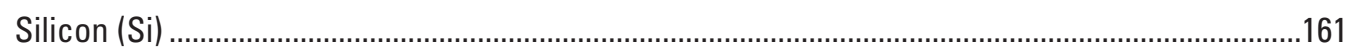

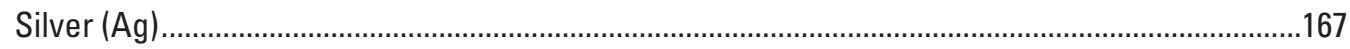

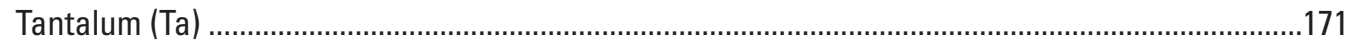

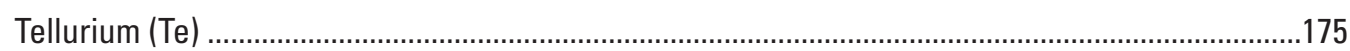

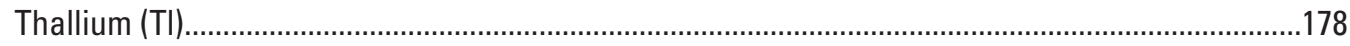

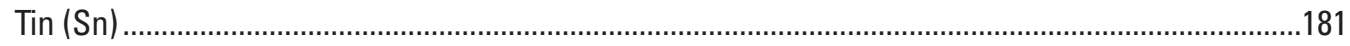

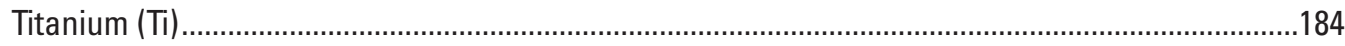

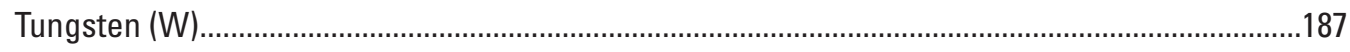

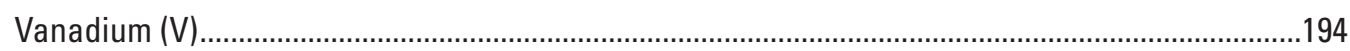

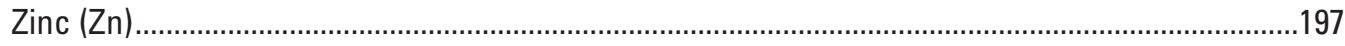




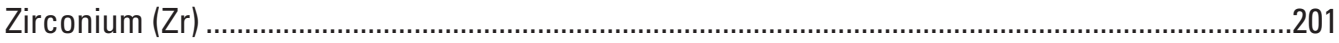

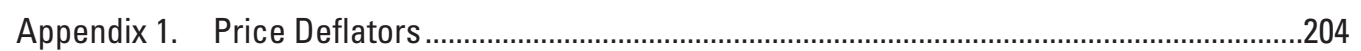




\title{
Metal Prices in the United States Through 2010
}

\author{
By U.S. Geological Survey National Minerals Information Center staff
}

\section{Introduction and Acknowledgments}

This report, which updates and revises the U.S. Geological Survey (USGS) (1999) publication, "Metal Prices in the United States Through 1998," presents an extended price history for a wide range of metals available in a single document. Such information can be useful for the analysis of mineral commodity issues, as well as for other purposes. The chapter for each mineral commodity includes a graph of annual current and constant dollar prices for 1970 through 2010, where available; a list of significant events that affected prices; a brief discussion of the metal and its history; and one or more tables that list current dollar prices.

In some cases, the metal prices presented herein are for some alternative form of an element or, instead of a price, a value, such as the value for an import as appraised by the U.S. Customs Service. Also included are the prices for steel, steel scrap, and iron ore - steel because of its importance to the elements used to alloy with it, and steel scrap and iron ore because of their use in steelmaking. A few minor metals, such as calcium, potassium, sodium, strontium, and thorium, for which price histories were insufficient, were excluded.

The annual prices given may be averages for the year, yearend prices, or some other price as appropriate for a particular commodity. Certain trade journals have been the source of much of this price information-American Metal Market, ICIS Chemical Business, Engineering and Mining Journal, Industrial Minerals, Metal Bulletin, Mining Journal,
Platts Metals Week, Roskill Information Services Ltd. commodity reports, and Ryan's Notes. Price information also is available in minerals information publications of the USGS (1880-1925, 1996-present) and the U.S. Bureau of Mines (1926-95), such as Mineral Commodity Summaries, Mineral Facts and Problems, Mineral Industry Surveys, and Minerals Yearbook. In addition to prices themselves, these journals and publications contain information relevant to prices, which has been helpful in the preparation of this publication.

Prices in this report have been graphed in 1992 constant dollars to show the effects of inflation as measured by the U.S. Bureau of Labor Statistics Consumer Price Index for All Urban Consumers, a widely used measure of overall inflation in the United States. These prices are not tabulated, but a table of the deflators used is given in an appendix. Constant dollar prices can be used to show how prices that producers receive would have less purchasing power.

The individual chapters in this publication were prepared by mineral commodity specialists in the National Minerals Information Center of the USGS and edited by Marilyn Billone. Kenneth Beckman provided guidance on price indexes.

\section{Reference Cited}

U.S. Geological Survey, 1999, Metal prices in the United States through 1998: U.S. Geological Survey, 179 p. 


\title{
Aluminum (AI)
}

\author{
by E. Lee Bray
}

Aluminum metal was first isolated by Hans Christian Oersted in 1825. As late as the early 1880s, it was considered to be a semiprecious metal and was sold in troy-ounce quantities; the retail price of aluminum metal was reported to be higher than that of silver. A commercially viable largescale production method had yet to be developed. Domestic production levels during this period were in the 1,000-to3,000-troy-ounce range, and many uses were considered to be experimental (Mining Engineering, 1987).

In 1886, formal patent applications were filed for the electrolytic reduction process for aluminum. This process, which came to be known as the Hall-Heroult process, led to the mass commercial production of aluminum metal. As the process was developed and refined, production levels increased rapidly. By 1895, domestic production levels had reached 1 million pounds. As production levels continued to increase, domestic producers kept the price of aluminum low to encourage its use by consumers. In the early 1900s, producers held aluminum metal prices at a low, steady level to compete against copper in the electrical industry (U.S. Department of Commerce, 1956, p. II.1-II.4).

With the outbreak of World War I in Europe in 1914, shortages of aluminum metal began to develop, and prices began to rise dramatically because of the increased demand for aluminum in war materials, which included airplanes and munitions. In March 1918, the President imposed price controls on aluminum metal, and the use of aluminum for military equipment and essential civilian needs was placed under Government regulation (Hill, 1921).

The 1920s saw the demand for aluminum metal expand, especially in the growing domestic automobile industry. The advent of the Great Depression, however, brought about a general decrease in demand for aluminum in all sectors of the economy, especially in the automobile and aircraft industries.

In 1939, the production and consumption of aluminum shattered all previous records, enhanced by the preparations for national defense and the expanding conflicts in Europe and Asia. The aviation industry alone consumed twice the quantity of aluminum as in 1937, the previous peak year. In 1940, producers lowered the price of aluminum to enable the metal to compete better with other materials. During the war years, aluminum prices were placed under formal control and held at $\$ 0.15$ per pound (U.S. Department of Commerce, 1956, p. IV.6).

After the war, the aluminum industry benefited from its price advantage compared to copper and other nonferrous metals. Aluminum, which was cheaper and more readily available than some other metals, was used in new applications and made substantial inroads in the construction and transportation industries.

Rearmament programs during the Korean conflict increased the demand for aluminum. In 1951, the allocation of aluminum supplies and the price of aluminum metal were again placed under Government control (Blue, 1954, p. 137-138). At the end of the conflict, domestic aluminum producers began an aggressive program to develop civilian uses for aluminum metal.

During the 1960 s, aluminum prices remained relatively stable in the low- to mid-\$0.20-per-pound range. Production capacity increases were able to keep pace with the continuous growth in demand during this period.

In the early 1970s, the price of aluminum, as well as of other metals, was controlled by the Cost of Living Council in an attempt to check inflation. As these controls were gradually removed during 1974, prices rose to reflect the increased cost of energy brought about by the surge in world oil prices (fig. 1; table 1).

In the late 1970 s and throughout the 1980 s, aluminum prices, for the most part, reflected market supply and demand. During the early 1980s, the aluminum industry suffered from a period of oversupply, high inventories, excess production capacity, and weak demand, causing aluminum prices to tumble. By 1987, however, excess production capacity had been permanently closed, inventories were low, and the worldwide demand for aluminum increased with increasing use of aluminum in automobile parts and beverage cans. This extremely tight supply situation, which continued throughout 1987 and 1988, brought about a dramatic increase in aluminum prices.

During the 1990s, however, the speculative effect of the futures market began to exert its influence on aluminum prices. Prices were not only reacting to the supply-anddemand situation but also to the perceived direction of the market as reflected on the futures exchanges.

In the early 1990 s, the major influence on aluminum prices was the dissolution of the Soviet Union. To generate hard currency, large quantities of Russian aluminum ingot entered the world market. Unfortunately, the aluminum market had just entered an economic downturn and was unable to absorb the Russian material. This period of oversupply, decreasing demand, and increasing inventories depressed world aluminum prices.

By the mid-1990s, production cutbacks, increased demand, declining inventories, and the perceived improvement in the world market led to a dramatic rebound in aluminum prices. Prices began to trend downward again during the late 
1990s as the economic crisis in the Asian market put pressure on the prices of several mineral commodities, including aluminum. The annual average U.S. market price was $\$ 0.65$ per pound of aluminum in both 1998 and 1999. Once again, the aluminum market was entering a period of oversupply. The perceived downward influence of the Asian crisis, however, may have hastened the decline in prices before the actual oversupply conditions developed. In late 1999, prices for aluminum began to rebound from the lows during the Asian economic crisis, but began to decline during the second half of 2001 with the onset of a domestic recession. The annual average U.S. market price was $\$ 0.75$ per pound of aluminum in 2000 and $\$ 0.69$ per pound of aluminum in 2001. Lower prices for aluminum persisted until early 2004, with the annual average U.S. market price in 2002 at $\$ 0.65$ per pound of aluminum, and $\$ 0.68$ per pound in 2003 , as the domestic economy recovered and global demand increased.

From the beginning of 2004 through mid-2008, global demand for aluminum and other mineral commodities rose significantly, led by the emerging economies of Brazil, China, India, and Russia, as well as by increasing domestic consumption for automobiles and home construction. The annual average U.S. market price was $\$ 0.84$ per pound of aluminum in $2004, \$ 1.06$ per pound in $2005, \$ 1.21$ per pound in 2006 , $\$ 1.22$ per pound in 2007 , and $\$ 1.21$ per pound in 2008 . The monthly average U.S. market price increased dramatically until reaching an alltime high of $\$ 1.42$ per pound of aluminum in July 2008, supported by strong demand, low inventories, and strong investment interest in mineral commodities. In the third quarter of 2008 in response to the onset of the global financial crisis, physical and speculative demand for aluminum collapsed, and prices began to decline as consumption by end users declined, especially within the automobile industry and the construction market. The price decline accelerated during the fourth quarter of 2008 and continued throughout most of 2009 in response to the expanding global financial crisis, with the monthly average price reaching $\$ 0.63$ per pound of aluminum in February 2009. Prices stabilized in late 2009 and recovered in 2010, as growth continued in China and other emerging markets, although prices did not reach the previous highs. In 2009, the annual average U.S. market price of aluminum was $\$ 0.79$ per pound, and in 2010 , it was $\$ 1.04$ per pound.

As prices dropped in the fourth quarter of 2008, inventories at London Metal Exchange (LME) warehouses in the United States increased dramatically. At yearend 2007, total aluminum inventories were 463,000 metric tons (t). By yearend 2008, total aluminum inventories at LME warehouses were 1.29 million metric tons (Mt), rising to $2.2 \mathrm{Mt}$ at yearend 2009 , and at yearend 2010, total aluminum inventories were 2.23 Mt. Long-term financing deals by speculators using low-interest credit and low storage rates accounted for much of the inventory buildup in the warehouses. Primary aluminum producers also preferred to sell to LME traders for immediate cash payment rather than sell to manufacturers on credit terms during this period.

The fluctuation of prices, production costs, and the impact of global growth opportunities affected domestic smelting capacity. High electricity prices in the Pacific Northwest outpaced the increase in aluminum prices during the second half of 2000 and continued throughout 2001, leading to production cuts at many smelters. As electricity prices remained relatively high in the Pacific Northwest, many of the closures were made permanent, and several smelters were demolished. During the same period, smelters were constructed and expanded in other parts of the world that had lower priced electricity, specifically in Iceland and the Middle East. Between 1995 and 2004, domestic smelting capacity declined by 6 percent, and by 2009, domestic capacity was 16 percent lower than it had been in 1995 . Smelting capacity in Iceland increased by 165 percent from 1995 to 2004, and by 2009 , capacity was 684 percent higher than it had been in 1995. In the Middle East, capacity of primary aluminum smelters increased by 57 percent from 1995 to 2004, and by 181 percent between 1995 and 2009. Between 2000 and 2009, smelting capacity expanded in Brazil (35 percent), China (390 percent), India (123 percent), and Russia (34 percent) to supply the demand in these emerging economies and in export markets.

\section{References Cited}

Blue, Delwin, 1954, Aluminum, in Minerals yearbook 1951, v. I: U.S. Bureau of Mines, p. 128-150.

Hill, J.M., 1921, Bauxite and aluminum, in Metals, pt. I of Mineral resources of the United States 1918: U.S. Geological Survey, p. 513-526.

Mining Engineering, 1987, Aluminum-The first 100 years and a look to the future: Mining Engineering, v. 39, no. 3, March, p. 178-180.

U.S. Department of Commerce, 1956, Materials surveyAluminum: Compiled by the U.S. Department of Commerce for the Office of Defense Mobilization, $320 \mathrm{p}$. 


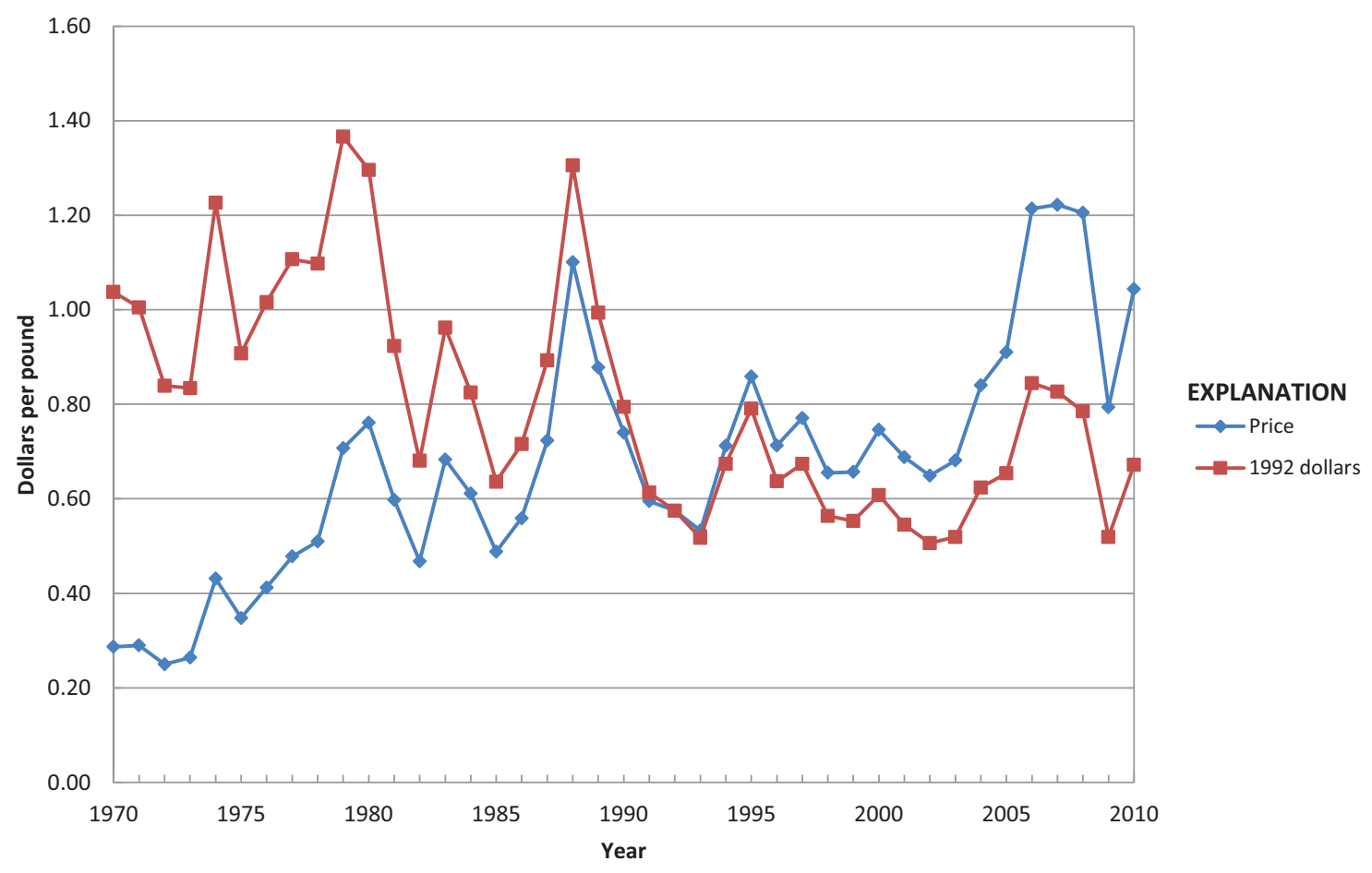

Figure 1. Annual average aluminum price.

\section{Significant events affecting aluminum prices since 1970}

1971-74 Price controls

1973-75 Organization of Petroleum Exporting Countries (OPEC) oil embargo and sharp recession

1986-88 Worldwide supply shortages

$1991 \quad$ Dissolution of the Soviet Union

2004-08 Emergence of economies in Brazil, China, India, and Russia drove demand and prices for commodities

2008-09 Prices for aluminum dropped in the wake of the global financial crises 
Table 1. Annual average primary aluminum price.

[Values in dollars per pound. NA Not available]

\begin{tabular}{|c|c|c|c|c|c|c|c|}
\hline Year & Price & Year & Price & Year & Price & Year & Price \\
\hline 1850 & 17.000 & 1891 & NA & 1932 & 0.233 & 1973 & 0.264 \\
\hline 1851 & NA & 1892 & NA & 1933 & 0.233 & 1974 & 0.431 \\
\hline 1852 & NA & 1893 & NA & 1934 & 0.234 & 1975 & 0.348 \\
\hline 1853 & NA & 1894 & NA & 1935 & 0.200 & 1976 & 0.412 \\
\hline 1854 & NA & 1895 & 0.587 & 1936 & 0.205 & 1977 & 0.478 \\
\hline 1855 & NA & 1896 & 0.507 & 1937 & 0.199 & 1978 & 0.510 \\
\hline 1856 & NA & 1897 & 0.390 & 1938 & 0.200 & 1979 & 0.707 \\
\hline 1857 & NA & 1898 & 0.306 & 1939 & 0.200 & 1980 & 0.761 \\
\hline 1858 & NA & 1899 & 0.327 & 1940 & 0.187 & 1981 & 0.598 \\
\hline 1859 & NA & 1900 & 0.327 & 1941 & 0.165 & 1982 & 0.468 \\
\hline 1860 & NA & 1901 & 0.330 & 1942 & 0.150 & 1983 & 0.683 \\
\hline 1861 & NA & 1902 & 0.330 & 1943 & 0.150 & 1984 & 0.611 \\
\hline 1862 & NA & 1903 & 0.330 & 1944 & 0.150 & 1985 & 0.488 \\
\hline 1863 & NA & 1904 & 0.350 & 1945 & 0.150 & 1986 & 0.559 \\
\hline 1864 & NA & 1905 & 0.350 & 1946 & 0.150 & 1987 & 0.723 \\
\hline 1865 & NA & 1906 & 0.358 & 1947 & 0.150 & 1988 & 1.101 \\
\hline 1866 & NA & 1907 & 0.450 & 1948 & 0.157 & 1989 & 0.878 \\
\hline 1867 & NA & 1908 & 0.287 & 1949 & 0.170 & 1990 & 0.740 \\
\hline 1868 & NA & 1909 & 0.220 & 1950 & 0.177 & 1991 & 0.595 \\
\hline 1869 & NA & 1910 & 0.223 & 1951 & 0.190 & 1992 & 0.575 \\
\hline 1870 & NA & 1911 & 0.201 & 1952 & 0.194 & 1993 & 0.533 \\
\hline 1871 & NA & 1912 & 0.220 & 1953 & 0.209 & 1994 & 0.712 \\
\hline 1872 & 9.000 & 1913 & 0.236 & 1954 & 0.218 & 1995 & 0.859 \\
\hline 1873 & NA & 1914 & 0.186 & 1955 & 0.237 & 1996 & 0.713 \\
\hline 1874 & NA & 1915 & 0.340 & 1956 & 0.240 & 1997 & 0.771 \\
\hline 1875 & NA & 1916 & 0.607 & 1957 & 0.254 & 1998 & 0.655 \\
\hline 1876 & NA & 1917 & 0.516 & 1958 & 0.248 & 1999 & 0.657 \\
\hline 1877 & NA & 1918 & 0.335 & 1959 & 0.247 & 2000 & 0.746 \\
\hline 1878 & NA & 1919 & 0.321 & 1960 & 0.260 & 2001 & 0.688 \\
\hline 1879 & NA & 1920 & 0.327 & 1961 & 0.255 & 2002 & 0.649 \\
\hline 1880 & NA & 1921 & 0.221 & 1962 & 0.239 & 2003 & 0.681 \\
\hline 1881 & NA & 1922 & 0.187 & 1963 & 0.226 & 2004 & 0.840 \\
\hline 1882 & NA & 1923 & 0.254 & 1964 & 0.237 & 2005 & 0.910 \\
\hline 1883 & NA & 1924 & 0.270 & 1965 & 0.245 & 2006 & 1.214 \\
\hline 1884 & NA & 1925 & 0.272 & 1966 & 0.245 & 2007 & 1.222 \\
\hline 1885 & NA & 1926 & 0.270 & 1967 & 0.250 & 2008 & 1.205 \\
\hline 1886 & NA & 1927 & 0.254 & 1968 & 0.256 & 2009 & 0.794 \\
\hline 1887 & 8.000 & 1928 & 0.243 & 1969 & 0.272 & 2010 & 1.044 \\
\hline 1888 & NA & 1929 & 0.243 & 1970 & 0.287 & & \\
\hline 1889 & NA & 1930 & 0.238 & 1971 & 0.290 & & \\
\hline 1890 & NA & 1931 & 0.233 & 1972 & 0.250 & & \\
\hline
\end{tabular}


Table 1. Annual average primary aluminum price-Continued

[Values in dollars per pound. NA Not available.]

Notes:

1850-94, in U.S. Geological Survey Minerals Yearbooks and predecessor volumes.

1895-98, 98-percent-pure aluminum, in American Bureau of Metal Statistics.

1899-1900, 99-percent-pure aluminum ingot, in American Bureau of Metal Statistics.

1901-04, 99.75-percent-pure aluminum ingot in 2,000-pound lots, in American Bureau of Metal Statistics.

1905, 99.75-percent-pure aluminum ingot in 2,000-pound lots, in American Metal Market/Metal Statistics, 1955.

1906-19, 99-percent-pure No. 1 aluminum ingot, in American Metal Market/Metal Statistics, 1955.

1920-21, 98-percent- to 99-percent-pure aluminum, in American Metal Market/Metal Statistics, 1955.

1922-28, 98-percent-pure aluminum metal, in American Metal Market/Metal Statistics, 1955.

1929-35, 99-percent-pure aluminum metal, in American Metal Market/Metal Statistics, 1955.

1936-54, 99-percent-plus pure aluminum virgin ingot, in American Metal Market/ Metal Statistics, 1955.

1955-56, 99-percent-pure aluminum virgin ingot, in Engineering and Mining Journal.

1957-71, 99.5-percent-pure unalloyed aluminum ingot, in Engineering and Mining Journal.

1972, 99.5-percent-pure unalloyed aluminum ingot, in Metals Week.

1973-82, U.S. market spot price, in Metals Week.

1983-92, 99.7-percent-pure aluminum ingot, U.S. market spot price, in Metals Week.

1993-2010, 99.7-percent-pure aluminum ingot, U.S. market spot price, in Platts (Platt's) Metals Week. 


\title{
Antimony (Sb)
}

\author{
by James F. Carlin, Jr.
}

Archaeological and historical studies indicate that antimony and its mineral sulfides have been used by humans for at least 6 millennia. In ancient times, powdered stibnite, the most common mineral form of antimony sulfide, was, along with lead sulfide, a principal ingredient of kohl, the thick black paste used by the Egyptians and others as a cosmetic for coloring eyebrows and lining the eyes. The Chaldeans knew the art of extracting the metal from its ores and casting it into ornamented vessels by 4000 B.C. It was being used as a plating on copper articles in Egypt by the middle of the third millennium B.C. The alchemist Basil Valentine is sometimes credited with "discovering" the element; in any case, he described the extraction of metallic antimony from its sulfide ore in his treatise "The Triumphal Chariot of Antimony," published sometime between A.D.1350 and 1600. When Gutenberg and others began using cast metal printing type in the mid-15th century, antimony was incorporated in it. As late as the 19th century, the number of uses for antimony and the amount used remained small. Most of it was used in type metal or alloyed with lead for use as bearing metal (babbitt metal) or with tin for use in Britannia metal as candlesticks, dinnerware, eating utensils, and so forth.

Antimony metal accounts for only a small fraction of the antimony consumed in the United States. Alloys containing antimony are used in a variety of applications, including lead-acid storage batteries and special solders for joining pipes that carry potable water. Domestically, most antimony is converted to antimony trioxide, which is primarily used in the flame-retardant industry, finding application in such uses as children's clothing and aircraft seats. The major producers of antimony, in order of importance, are China, Bolivia, Russia, and South Africa.

During the past 40 years, antimony has been subject to a few periods of extreme price swings (fig. 1; table 1). Generally, these have been the result of spikes or declines in the American and (or) foreign demand for antimony or changes in the pattern of the world production-where supply disrup- tions in any of the major producing countries can cause a marked price change. In 1970, a combination of high worldwide demand and short supply from a few countries caused a considerable price spike in the early part of that year; the price quickly subsided by yearend. In 1974, sharply increased demand, especially for antimony trioxide, and supply disruptions from China combined to produce the highest antimony price recorded up to that time. During the next 20 years, prices generally subsided. By 1994, China had clearly emerged as the predominant world antimony producer. That year and the following year, severe flooding in the antimony mining regions of China created major supply disruptions that caused the price to triple within 2 years (Roskill Information Services Ltd., 1997, p. 172-179). After 1995, the price fell steadily to a level, in 2001, that had not been seen in 30 years.

From 2002 to 2010 , the antimony price experienced a fairly steady increase, reaching a peak in 2010. This period of increasing prices was attributable to several factors: (a) the increasing domination of the world market supply by China, with occasional stretches of production shortfalls because of mining accidents resulting in Government closure of some antimony mining sites; (b) the increasing role of China as the world's leading antimony consumer; and (c) a general trend of increased global consumption.

The 2008-09 worldwide financial crisis resulted in a moderate decline in antimony consumption and prices. Perhaps because of antimony's diversity of end uses, it was spared the more severe declines experienced by many metals. Furthermore, antimony consumption rebounded reasonably well by 2010 .

\section{Reference Cited}

Roskill Information Services Ltd., 1997, The economics of antimony: London, Roskill Information Services Ltd., $184 \mathrm{p}$. 


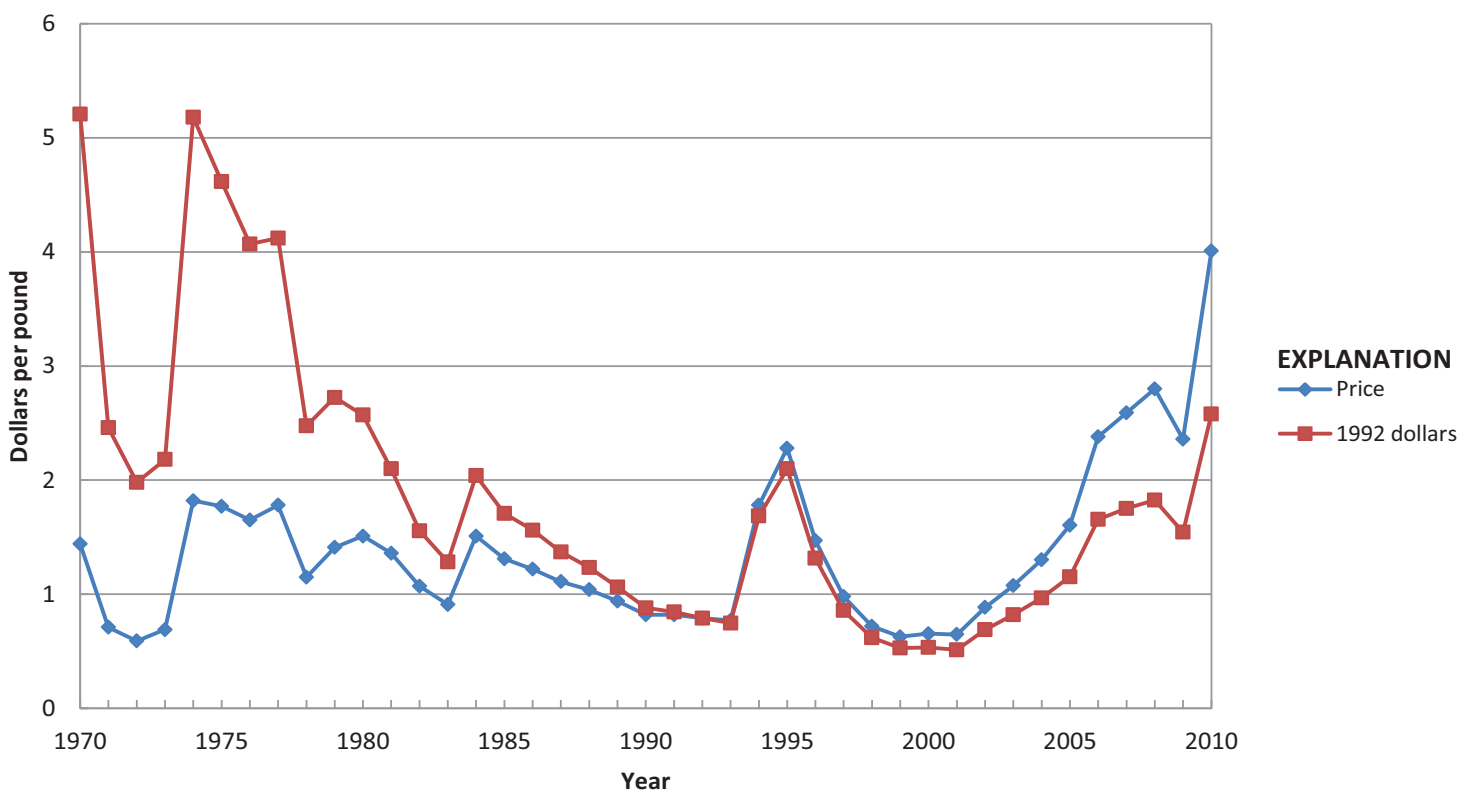

Figure 1. Annual average antimony price.

\section{Significant events affecting antimony prices since 1970}

$1970 \quad$ Strong demand and weak supply worldwide, resulted in a price spike

1974 Increased global demand and decreased supply from China, resulted in a price spike

1994-95 Severe reduction in supply from China, resulted in a price spike

2003-10 Periods of intermittent supply interruptions in China, with mine accidents causing closures

2008-09 The global financial crisis caused a moderate decline in world antimony consumption and price 
Table 1. Annual average antimony price.

[Values in dollars per pound]

\begin{tabular}{|c|c|c|c|c|c|c|c|}
\hline Year & Price & Year & Price & Year & Price & Year & Price \\
\hline 1900 & 0.095 & 1928 & 0.103 & 1956 & 0.360 & 1984 & 1.510 \\
\hline 1901 & 0.082 & 1929 & 0.089 & 1957 & 0.350 & 1985 & 1.310 \\
\hline 1902 & 0.061 & 1930 & 0.077 & 1958 & 0.320 & 1986 & 1.220 \\
\hline 1903 & 0.060 & 1931 & 0.067 & 1959 & 0.310 & 1987 & 1.110 \\
\hline 1904 & 0.064 & 1932 & 0.056 & 1960 & 0.310 & 1988 & 1.040 \\
\hline 1905 & 0.102 & 1933 & 0.065 & 1961 & 0.340 & 1989 & 0.940 \\
\hline 1906 & 0.217 & 1934 & 0.089 & 1962 & 0.350 & 1990 & 0.820 \\
\hline 1907 & 0.148 & 1935 & 0.136 & 1963 & 0.350 & \begin{tabular}{|l|}
1991 \\
\end{tabular} & 0.820 \\
\hline 1908 & 0.080 & 1936 & 0.122 & 1964 & 0.420 & 1992 & 0.790 \\
\hline 1909 & 0.075 & 1937 & 0.154 & 1965 & 0.460 & 1993 & 0.770 \\
\hline 1910 & 0.074 & 1938 & 0.124 & 1966 & 0.460 & 1994 & 1.780 \\
\hline 1911 & 0.075 & 1939 & 0.124 & 1967 & 0.460 & 1995 & 2.280 \\
\hline 1912 & 0.078 & 1940 & 0.140 & 1968 & 0.460 & 1996 & 1.470 \\
\hline 1913 & 0.075 & 1941 & 0.140 & 1969 & 0.580 & \begin{tabular}{|l|l}
1997 \\
\end{tabular} & 0.980 \\
\hline 1914 & 0.088 & 1942 & 0.156 & 1970 & 1.440 & 1998 & 0.718 \\
\hline 1915 & 0.303 & 1943 & 0.159 & 1971 & 0.710 & 1999 & 0.627 \\
\hline 1916 & 0.254 & 1944 & 0.158 & 1972 & 0.590 & 2000 & 0.655 \\
\hline 1917 & 0.207 & 1945 & 0.160 & 1973 & 0.690 & 2001 & 0.647 \\
\hline 1918 & 0.126 & 1946 & 0.170 & 1974 & 1.820 & 2002 & 0.884 \\
\hline 1919 & 0.082 & 1947 & 0.340 & 1975 & 1.770 & 2003 & 1.075 \\
\hline 1920 & 0.085 & 1948 & 0.370 & 1976 & 1.650 & 2004 & 1.303 \\
\hline 1921 & 0.050 & 1949 & 0.390 & 1977 & 1.780 & 2005 & 1.605 \\
\hline 1922 & 0.054 & 1950 & 0.290 & 1978 & 1.150 & 2006 & 2.380 \\
\hline 1923 & 0.078 & 1951 & 0.440 & 1979 & 1.410 & 2007 & 2.590 \\
\hline 1924 & 0.108 & 1952 & 0.440 & 1980 & 1.510 & 2008 & 2.800 \\
\hline 1925 & 0.175 & 1953 & 0.360 & 1981 & 1.360 & 2009 & 2.360 \\
\hline 1926 & 0.159 & 1954 & 0.310 & 1982 & 1.070 & 2010 & 4.010 \\
\hline 1927 & 0.123 & 1955 & 0.320 & 1983 & 0.910 & & \\
\hline
\end{tabular}

Notes:

1900-36, New York dealer price for 99.30-percent- to 99.50-percent-pure antimony, in Engineering and Mining Journal.

1937-66, New York dealer price for 99.30-percent- to 99.50-percent-pure antimony, in Engineering and Mining Journal, Metal and Mineral Markets.

1967-81, New York dealer price for 99.30-percent- to 99.50-percent-pure antimony, in Metals Week.

1982-93, New York dealer price for 99.50-percent- to 99.60-percent-pure antimony, in Metals Week.

1993-2010, New York dealer price for 99.50-percent- to 99.60-percent-pure antimony, in Platts (Platt's) Metals Week. 


\title{
Arsenic (As)
}

\author{
by William E. Brooks
}

Arsenic has a long and varied history. Its name comes from Arabic and means "powder of the mine." It was known to the ancient Chinese, Egyptians, and Greeks in compound form as the minerals arsenopyrite, realgar, and orpiment; however, it was not isolated as an element until the 13th century. In the 1400 s, arsenic-derived "Scheele's Green" was used as a pigment in wallpaper, and arsenic leached from the wallpaper in his room may have contributed to Napoleon's death in 1821. The 1940s play, and later the movie, Arsenic and Old Lace dramatizes the metal's more sinister role.

Arsenic is a widely distributed element that is associated with copper, gold, lead, and other nonferrous metal ores and continues to be an important mineral commodity with many modern applications. The first domestic production of arsenic, which was as a byproduct of the smelting of gold and silver ores, came near the beginning of the 20th century (Greenspoon, 1976, p. 99); however, the United States has not produced arsenic since 1985.

The amount of arsenic metal that is consumed domestically is small and is used as an alloy to strengthen grids in lead-acid storage batteries, in lead shot, small-arms ammunition, wheel weights, and with gallium for substrates in electronics applications. During the early 1970s, demand for arsenic metal was growing, mainly in response to the increased use of the metal in the grids of lead-acid batteries; the price peaked in 1974 at nearly $\$ 2.00$ per pound in current dollars and then stabilized (fig. 1; table 1). During this time, however, the United States and other countries began hearings on the health and environmental impacts of arsenic exposure. During the late 1970s, various domestic and foreign regulations related to arsenic exposure and emissions were adopted.

The arsenic metal price peaked again in 1980 at $\$ 3.00$ per pound in current dollars as world producers raised their prices, partly to compensate for the cost of modernizing their plants and partly in response to the elimination of some capacity by producers unable to modernize their plants. Between 1980 and 1985, owing to an ample supply and a static or possibly declining demand, the arsenic metal price declined, averaging approximately $\$ 1.09$ per pound.

Most of the arsenic used domestically was consumed as arsenic trioxide $\left(\mathrm{As}_{2} \mathrm{O}_{3}\right)$ that was used in the manufacture of chromated copper arsenate (CCA), a preservative for pressuretreated wood. Arsenic trioxide also was used in the manufacture of herbicides and insecticides. Arsenic was widely used in the United States in the production of CCA; however, exposure to arsenic leached from CCA-treated wood was a health concern because it could potentially affect breathing, heart rhythm, and possibly increase the risk for bladder cancer (Agency for Toxic Substances and Disease Registry, 2007). In response to human health concerns, the wood-preserving industry made a voluntary decision to stop using CCA to treat wood used for decks and outdoor residential use by yearend 2003, and imports of $\mathrm{As}_{2} \mathrm{O}_{3}$ decreased dramatically. CCA may still be used for nonresidential wood applications.

China remains as the world's leading source of arsenic; however, because its principal use for CCA in the United States was eliminated, the market stagnated through yearend 2010 .

\section{References Cited}

Agency for Toxic Substances and Disease Registry, 2007, ToxFAQs for arsenic: Agency for Toxic Substances and Disease Registry, accessed May 30, 2007, at http://www.atsdr.cdc.gov/tfacts2.html.

Greenspoon, G.N., 1976, Arsenic, in Mineral facts and problems: U.S. Bureau of Mines Bulletin 667, p. 99-106. 


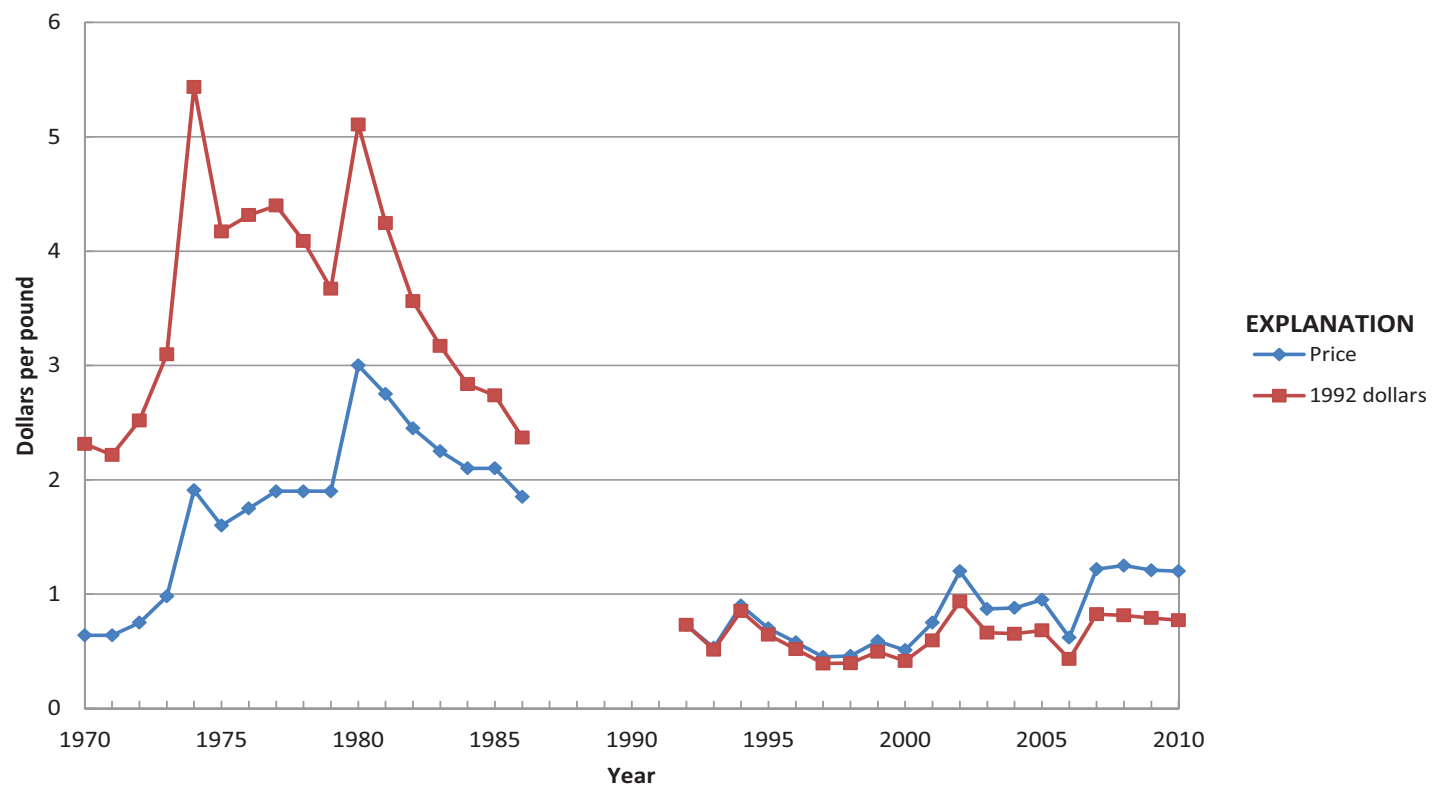

Figure 1. Yearend arsenic metal price.

\section{Significant events affecting arsenic prices since 1970}

1972-74 Consumption of arsenic as an alloy to strengthen grids in lead-acid batteries increased; domestic arsenic production resumed in 1974

Mid-1970s Congressional hearings on effects of arsenic on health and environment

1980

Production capacity declined as plants that did not meet health and environmental standards were closed

1985

Closure of last copper smelter in Tacoma, Wa., and domestic arsenic production ceased

2003

Voluntary decision by wood-preserving industry to stop using chromated copper arsenate (CCA) 


\section{Metal Prices in the United States Through 2010}

Table 1. Yearend arsenic metal price.

[Values in dollars per pound. NA Not available]

\begin{tabular}{|c|c|c|c|c|c|c|c|}
\hline Year & Price & Year & Price & Year & Price & Year & Price \\
\hline 1959 & 0.50 & 1972 & 0.75 & 1985 & 2.10 & 1998 & 0.46 \\
\hline 1960 & 0.50 & 1973 & 0.98 & 1986 & 1.85 & 1999 & 0.59 \\
\hline 1962 & 0.50 & 1975 & 1.60 & 1988 & NA & 2001 & 0.75 \\
\hline 1963 & 0.50 & 1976 & 1.75 & 1989 & NA & 2002 & 1.20 \\
\hline 1965 & 0.56 & 1978 & 1.90 & 1991 & NA & 2004 & 0.88 \\
\hline 1966 & 0.56 & 1979 & 1.90 & 1992 & 0.73 & 2005 & 0.95 \\
\hline 1967 & 0.48 & 1980 & 3.00 & 1993 & 0.53 & 2006 & 0.62 \\
\hline 1968 & 0.56 & 1981 & 2.75 & 1994 & 0.90 & 2007 & 1.22 \\
\hline 1969 & 0.56 & 1982 & 2.45 & 1995 & 0.70 & 2008 & 1.25 \\
\hline
\end{tabular}

Notes:

1959-74, London prices for 99.5-percent-pure metal, in Metal Bulletin.

1975-86, U.S. producer prices for 99-percent- to 99.5-percent-pure metal, in Metals Week.

1992-98, London prices for minimum 99-percent-pure metal, in Metal Bulletin.

1999-2010, London prices for minimum 99-percent-pure metal, in Platts (Platt's) Metals Week. 


\title{
Beryllium (Be)
}

\author{
by Brian W. Jaskula
}

Beryllium is one of the lightest of all metals and has one of the highest melting points of any light metal. It was discovered initially by Vauquelin in 1797 as a constituent of the mineral beryl. Wohler and Bussy working separately produced metallic beryllium as an impure powder in 1828 by reducing beryllium chloride with metallic potassium. By 1916, the first significant quantity of beryllium metal was produced in the United States. It was not until after World War II, with the development of powder fabrication techniques, that a number of markets for beryllium metal were developed.

Beryllium has physical and chemical properties, such as its stiffness, high resistance to corrosion from acids, and high thermal conductivity, which make it useful for various applications in its alloy, oxide, and metallic forms. Beryllium metal is used principally in aerospace and defense applications because of its stiffness, light weight, and dimensional stability over a wide temperature range. Beryllium-copper alloys are used in a wide variety of applications because of their electrical and thermal conductivities, high strength and hardness, good corrosion and fatigue resistance, and nonmagnetic properties. Beryllium oxide is an excellent heat conductor, with high strength and hardness, and acts as an electrical insulator in some applications. The United States, one of only three countries that process beryllium ores and concentrates into beryllium products, supplies most of the rest of the world with these products (Cunningham, 1999). Because of its use in aerospace and defense applications, beryllium is classified as "critical and strategic," and in the past, various beryllium materials have been purchased for the National Defense Stockpile (NDS). Steel, titanium, phosphor bronze, and aluminum nitride can be substituted for beryllium in some applications but usually at a performance penalty. The quoted price for beryllium metal during most of the 1980s and 1990s, as presented in the table and graph, may not reflect true transaction prices for the material (fig. 1; table 1). The quoted prices reflect the more high-end/high-purity form of the material.

In 1956, the Atomic Energy Commission awarded 5-year contracts to two domestic companies for each to produce about 45 metric tons ( $\mathrm{t}$ ) of beryllium annually (Eilertsen, 1958). Beryllium metal was also considered for aircraft structural components and components in inertial guidance systems for advanced missiles. These new applications increased beryllium metal demand, which led to improvements in beryllium processing and a reduction in price.

Prior to 1970 , the United States was nearly 100 percent import dependent for its beryl ore needs. In 1969, however, a bertrandite mine opened in Utah that provided a large, secure source of domestic raw material supply (Petkof, 1985). Dur- ing most of the 1960s, the price for beryllium metal remained stable.

By 1977 and continuing through the 1990s, the effects of inflation rates and rising operating costs were reflected in increased beryllium prices. Energy requirements for producing beryllium metal are high. Processing requires the use of induction furnaces that consume large quantities of energy. Also, because of the toxic nature of beryllium, the industry must maintain careful control of the quantity of beryllium dust and fumes in the workplace. Under the Clean Air Act, the U.S. Environmental Protection Agency issues standards for certain hazardous air pollutants, including beryllium, and the Occupational Safety and Health Administration issues standards for airborne beryllium particles. To comply with these standards, plants are required to install and maintain pollution control equipment. Beryllium dust and fumes have been recognized as the cause of berylliosis, a serious chronic lung disease. Although the exact cause of the disease is uncertain, the problem appears to be controlled when established preventative measures are exercised. In beryllium-processing plants, harmful effects are prevented by maintaining clean workplaces; requiring the use of safety equipment, such as personal respirators; collecting dust, fumes, and mists at the source of deposition in dust collectors; following strict medical programs; and following other procedures to provide safe working conditions (Rossman and others, 1991, p. 267; Kramer, 1995). This control of potential health hazards adds to the cost of beryllium metal and other beryllium products. The additional costs are ultimately passed on to the consumer in the form of increased prices.

In 1979, one of the two domestic beryllium producers discontinued beryllium metal production, leaving the price of the metal to be set by one company (Petkof, 1980). In 1988, the U.S. Government purchased about $27 \mathrm{t}$ of "vacuum hotpressed beryllium billets" worth an estimated \$19 million; the metal was delivered to the NDS by yearend 1989 (Kramer, 1990). The average unit value for the NDS metal was about $\$ 317$ per pound. The quoted price for beryllium metal powder at yearend 1988 and yearend 1989 was \$244 per pound and \$261 per pound, respectively. In 1990, the Defense Logistics Agency awarded a contract to convert some of the beryl ore contained in the NDS to vacuum hot-pressed beryllium billets. The contract was extended through 1992 for a combined total of $73 \mathrm{t}$ of beryllium metal, valued at about $\$ 46$ million, recovered from about 2,940 t of NDS beryl ore (Kramer, $1993 ; 1994)$. The overall unit value of the NDS metal, about $\$ 287$ per pound, was comparable to the price being quoted for beryllium metal powder from yearend 1990 to yearend 
1994, which ranged from $\$ 269$ per pound to $\$ 295$ per pound. Deliveries of the metal to the NDS were completed in the second quarter of 1994.

The beryllium metal purchase and beryl ore conversion came at a time of declining beryllium metal consumption, caused by reduced spending for strategic defense programs. The jump in price in 1995, shown in the graph, reflects a change in the nature of the price quotation, not any single causal event. Beryllium metal currently averages about 10 percent of annual U.S. beryllium demand compared with about 20 percent in the early 1990s. With applications primarily in the aerospace and defense sectors, the dissolution of the Soviet Union in 1991 contributed most to the decline in beryllium metal demand as defense strategic plans changed.

In 2000, the sole U.S. beryllium producer closed its beryllium metal production facility owing to equipment obsolescence, the availability of beryllium metal from the NDS, and other factors (Shedd, 2006). As a result, the U.S. producer price, quoted in American Metal Market, was no longer available, and another pricing source was required. The only source of beryllium metal pricing available was derived from NDS sales; however, this price reflected sales of vacuum-cast ingot for upgrading, which were of significantly lower quality than the beryllium powder that had been priced commercially. In 2005, the U.S. Department of Defense invested in a publicprivate partnership with the U.S. beryllium producer to build a new $\$ 90.4$ million primary beryllium facility in Ohio.

Construction of the facility was completed in 2010. Approximately two-thirds of the facility's output was to be allocated for defense and government-related end uses, the remaining output going to the private sector. Plant capacity was reported to be 73 t per year of high-purity beryllium metal (Jaskula, 2011).

The sharp drop in price beginning in 2000, as shown in the graph, resulted from the change in price series and grade, not necessarily an actual decline in pricing.

\section{References Cited}

Cunningham, L.D., 1999, Beryllium, in Metals and minerals: U.S. Geological Survey Minerals Yearbook 1997, v. I, p. 11.1-11.6.
Eilertsen, D.E., 1958, Beryllium, in Metals and minerals (except fuels): U.S. Bureau of Mines Minerals Yearbook 1956 , v. I, p. 253-258.

Jaskula, B.W., 2011, Beryllium: U.S. Geological Survey Mineral Commodity Summaries 2011, p. 28-29.

Kramer, D.A., 1990, Beryllium, in Metals and minerals: U.S. Bureau of Mines Minerals Yearbook 1988, v. I, p. $165-169$.

Kramer, D.A., 1993, Beryllium in 1992-Annual review: U.S. Bureau of Mines Mineral Industry Surveys, June, 5 p. (Not published in Minerals Yearbook 1992.)

Kramer, D.A., 1994, Beryllium in 1993-Annual review: U.S. Bureau of Mines Mineral Industry Surveys, June, 4 p. (Not published in Minerals Yearbook 1993.)

Kramer, D.A., 1995, Beryllium, in Metals and minerals: U.S. Bureau of Mines Minerals Yearbook 1994, v. I, p. 105-110.

Petkof, Benjamin, 1980, Beryllium, in Metals and minerals: U.S. Bureau of Mines Minerals Yearbook 1978-79, v. I, p. 111-114.

Petkof, Benjamin, 1985, Beryllium, in Mineral facts and problems: U.S. Bureau of Mines Bulletin 675, p. 75-82.

Rossman, M.D., Preuss, O.P., and Powers, M.B., 1991, Beryllium-Biomedical and environmental aspects: Baltimore, Md., Williams \& Wilkins, 319 p.

Shedd, K.B, 2006, Beryllium, in Metals and minerals: U.S. Geological Survey Minerals Yearbook 2005, v. I, p. 11.1-11.6. 


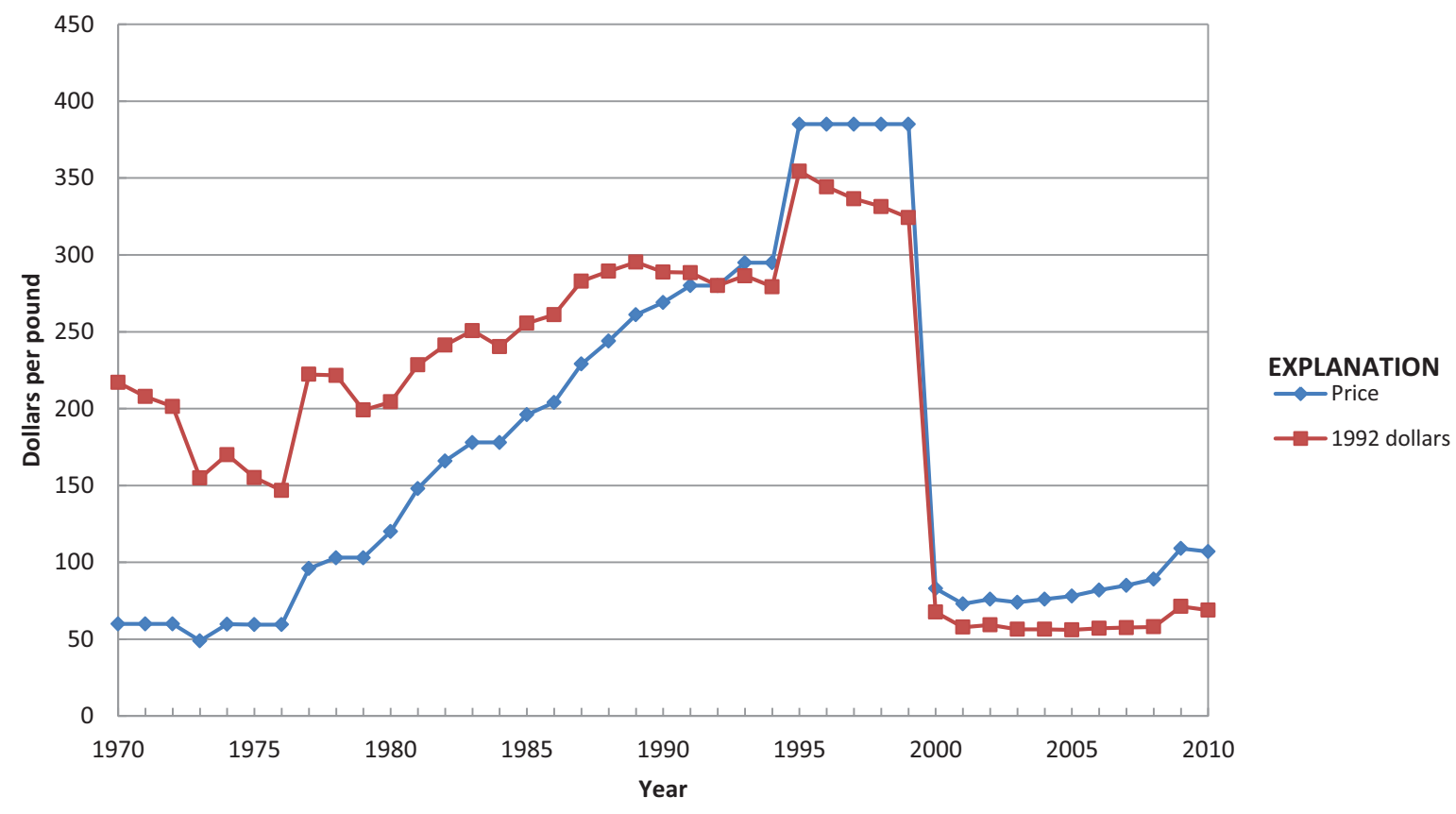

Figure 1. Yearend average beryllium price.

\section{Significant events affecting beryllium prices since 1970}

Effects of inflation rates, increased energy costs, and additional costs associated with complying with air emission standards resulted in increased prices

$1979 \quad$ Beryllium metal price was set by one producer

Purchase of beryllium metal for the National Defense Stockpile (NDS)

Price increase resulted from change in reported beryllium metal grade, not necessarily an actual increase in pricing

Price decrease resulted from change in price series and grade, not necessarily an actual decline in pricing 
Table 1. Yearend average beryllium metal price.

[Values in dollars per pound]

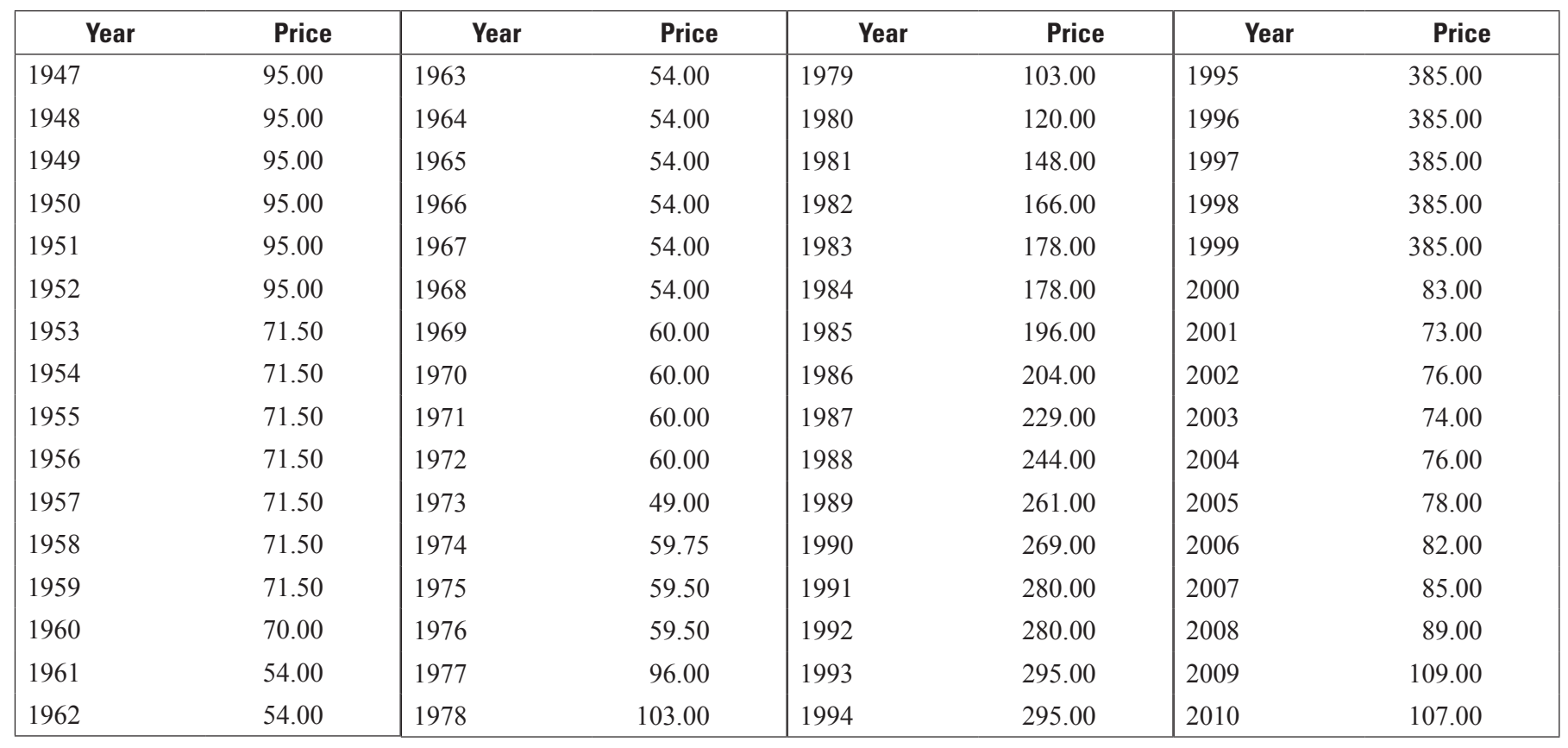

Notes:

1947-52, Beryllium, technical grade, in Engineering and Mining Journal, Metal and Mineral Markets.

1953-59, Beryllium, lumps and beads, 97 percent beryllium, in American Metal Market (AMM).

1960-68, Beryllium, powder or powder blend, 97 percent beryllium, in AMM.

1969-80, Beryllium, powder or powder blend, in U.S. Bureau of Mines, Minerals Yearbook, origin and (or) beryllium content unknown.

1981-85, Beryllium, powder blend, 97 percent beryllium, in AMM.

1986-89, Beryllium, powder blend, 98.5 percent beryllium, provided by Brush Wellman, Inc.

1990-94, Beryllium, powder blend, 98.5 percent beryllium, in AMM.

1995-99, Beryllium, powder, 99 percent beryllium, in AMM.

2000-09, Beryllium metal, in U.S. Department of Defense, Strategic and Critical Materials Operations Report to Congress, beryllium content unknown.

2010, Beryllium, hot-pressed powder, in Defense National Stockpile Center, National Defense Stockpile cash disposals, beryllium content unknown. 


\title{
Bismuth (Bi)
}

\author{
by James F. Carlin, Jr.
}

Bismuth-lead and bismuth-tin alloys are known to have been used during the Middle Ages. Around 1597, the efficacy of bismuth nitrate in the treatment of intestinal disorders was discovered, and this is still used today in stomach ailment remedies. In the 18 th century, pure bismuth metal was produced, demonstrating that bismuth was a distinct element.

Demand for bismuth in the United States was small prior to World War II. The chief use was for medicines; bismuth compounds were used to treat such conditions as digestive disorders, venereal diseases, and burns. Minor amounts of bismuth were consumed in fusible alloys for fire sprinkler systems and fuse wire. Bismuth has always been produced mainly as a byproduct of lead refining. The price, which was controlled by the major producers until the mid-1960s, typically reflected the cost of recovery. In World War II, bismuth, considered to be a strategic and critical material, was used for solders, fusible alloys, in medications, and in atomic research. To stabilize the market, the producers set the price at $\$ 1.25$ per pound during the war and at $\$ 2.25$ per pound from 1950 until 1964 (U.S. Bureau of Mines, 1966) (table 1).

In the early $1970 \mathrm{~s}$, demand for bismuth as a metallurgical additive to aluminum, iron, and steel increased rapidly. This, combined with increased consumption in other categories, caused the producer price to increase dramatically in 1974 to a peak of $\$ 12.00$ per pound in June (fig. 1). By August, the price dropped back to $\$ 9.00$ per pound, where it remained through the rest of the year. During 1974, a 21-percent decrease in domestic consumption affected all categories of bismuth consumption (Wyche, 1976).

Prices trended sharply downward from 1975 to 1982 owing to increased world production, with little growth in consumption. ASARCO Incorporated, the only domestic producer, suspended its list price on October 1, 1980. Until then, the annual average price reported was the Asarco price for 99.99-percent-pure bismuth. After 1980, the New York dealer price was reported (Carlin, 1981).

In Bolivia, the only country where bismuth was mined as a principal product, production virtually ceased in 1980 owing to the sustained low price of bismuth (Metal Bulletin, 1982). During the recession of 1981-82, declining domestic consumption and an excess of stocks held by world producers caused the price to drop to a low of $\$ 1.30$ per pound in January 1983.

In 1984, the price began to climb as consumption increased worldwide, especially in the United States and Japan. In 1988, a series of miners' strikes in Peru, one of the largest producers of bismuth in the world, cut off all shipments for several months (King, 1988; Mining Journal, 1988). This led to the price reaching nearly $\$ 7$ per pound, even though domestic consumers were able to compensate for this loss by obtaining bismuth elsewhere.

In late 1989, the price of bismuth began to drop owing to lower consumption, increased imports, large world stocks, and dealer reaction to the plan to sell 510 metric tons ( $t)$ of the bismuth in the National Defense Stockpile (NDS) within 10 years (American Metal Market, 1990). The Defense Logistics Agency (DLA) sold more than $59 \mathrm{t}$ from the NDS in 1990 and more than $57 \mathrm{t}$ in 1991. U.S. imports also increased in 1989 and 1990, which further increased the supply of bismuth and helped keep the price near $\$ 3.00$ per pound. In 1992, the DLA released $91 \mathrm{t}$ of bismuth from the NDS and announced a new plan to release the remaining $740 \mathrm{t}$ during a 10 -year period (Jasinski, 1993).

In the early 1990s, research began on the evaluation of bismuth as a nontoxic replacement for lead in such uses as ceramic glazes, fishing sinkers, food-processing equipment (Murray, 1993), free-machining brasses for plumbing applications (Feder, 1991), lubricating greases, and shot for waterfowl hunting (Lowry, 1993). During the mid-1990s, growth in these areas remained slow in spite of direct or indirect Government backing of bismuth for lead replacement. The 1996 Amendments to the 1986 Safe Drinking Water Act required lead-free plumbing for new installations and repairs of facilities providing potable water by August 1998. Also, the U.S. Fish and Wildlife Service gave final approval for the use of bismuth-tin shot for waterfowl hunting (U.S. Fish and Wildlife Service, 1997). In 1997, after extended negotiations with local and Nebraska State authorities on environmental remediation, Asarco closed its Omaha smelter, the only site of domestic bismuth production. Also in 1997, the DLA sold all the bismuth remaining in the NDS (American Metal Market, 1997). Thus, the United States became completely dependent on imports for its supply of primary bismuth.

At the end of the 1990s, total bismuth demand increased moderately as consumption for new uses, especially hunting and plumbing applications, began to increase. Supply remained adequate and prices remained low. Owing to low prices for bismuth, the reopening of the Tasna Mine in Bolivia, closed since 1980, was delayed. When production started, bismuth, copper, gold, and tungsten were to be coproducts (Mining Journal, 1999). In the original plan, bismuth was to be the main product (Tice, 1997).

During the late 1990s and through 2010, environmental and legislative pressure continued to mount against the use 
of lead in numerous countries and in several specific lead applications. These actions resulted in a growing market for bismuth, which was seen as being nontoxic.

From 1990 to 2010, use of bismuth in some of its major applications began to subside as companies found that they could get approximate quality levels and lower their costs by using less bismuth. These trends were especially noted in the use of bismuth as an additive to free-machining aluminum and steel products, and also in a few of the medicinal applications.

In 2007, two of the major international bismuth refiners agreed to merge their operations to become the world's leading bismuth refiner. The merger had the effect of giving the newly merged company better control of the bismuth supply side, and therefore tended to boost the bismuth price higher than it may have otherwise been. Also in 2007, the increasing role of private investment commodity funds generally had the effect of causing higher metal prices.

In 2008-09, the worldwide financial crisis and recession had a marked effect on global bismuth consumption and price. By 2009, the average bismuth price was almost one-half of the 2007 average price.

\section{References Cited}

American Metal Market, 1990, DLA schedules sale of bismuth: American Metal Market, v. 98, July 23, no. 142, p. 2.

American Metal Market, 1997, DLA's bismuth stocks emptied: American Metal Market, v. 105, no. 218, November 10, p. 16.

Carlin, J.F., Jr., 1981, Bismuth, in Metals and minerals: U.S. Bureau of Mines Minerals Yearbook 1980, v. I, p. 129-132.

Feder, B.J., 1991, A new form of brass, to cut lead in drinking water: New York Times, May 15, p. C7.
Jasinski, S.M., 1993, Bismuth in 1992-Annual review: U.S. Bureau of Mines Mineral Industry Surveys, 6 p. (Not published in Minerals Yearbook 1992.)

King, A.G., 1988, Bismuth rise caused by Peru strike: American Metal Market, v. 96, no. 155, August 9, p. 2.

Lowry, Ed, 1993, Bismuth shot-The ballistic potential: American Rifleman, v. 141, no. 9, September, p. 54-61.

Metal Bulletin, 1982, Bismuth metal: Metal Bulletin Handbook 1982, v. 2, Statistics, p. 87-89.

Mining Journal, 1988, Peru strike boosts bismuth: [London] Mining Journal, v. 310, no. 7953, January 29, p. 77.

Mining Journal, 1999, Minor metals in December: [London] Mining Journal, v. 332, no. 8514, January 15, p. 27.

Murray, C.J., 1993, Bismuth alloy replaces lead, eliminates toxicity: Design News, v. 49, no. 10, May 17, p. 124-125.

Tice, Kelley, 1997, A mine's tale-Taking care of bismuth: American Metal Market, v. 105, no.174, September 9, p. 1-2.

U.S. Bureau of Mines, 1966, Bismuth: U.S. Bureau of Mines Commodity Data Summaries: p. 16-17.

U.S. Fish and Wildlife Service, 1997, Approval of bismuth-tin shot as non-toxic for waterfowl and coots hunting: Federal Register, v. 62, no. 12, January 31, p. 4873-4876.

Wyche, Charlie, 1976, Bismuth, in Metals, Minerals, and Fuels: U.S. Bureau of Mines Minerals Yearbook 1974, v. I, p. 223-227. 


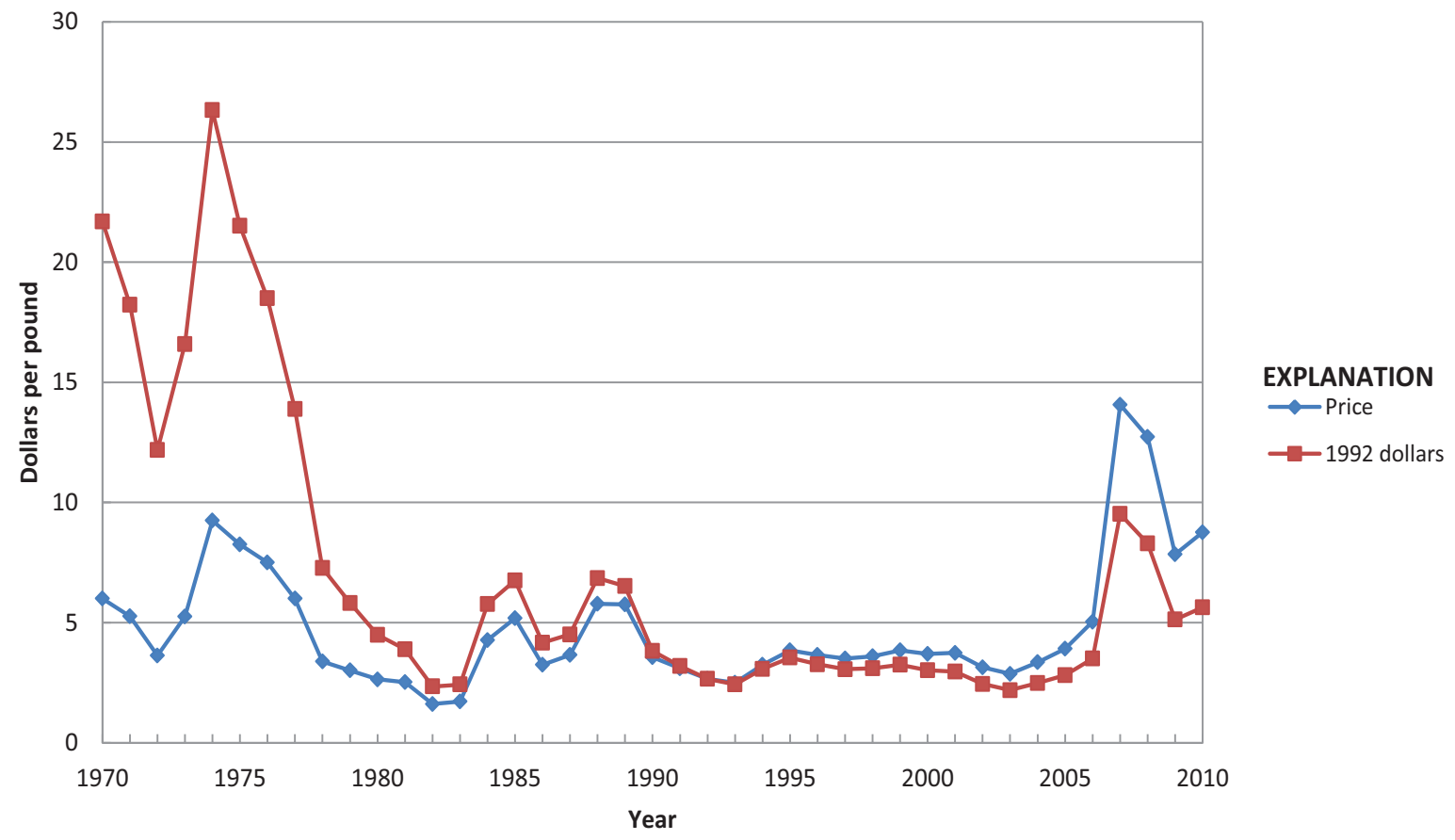

Figure 1. Annual average bismuth price. 


\section{Significant events affecting bismuth prices since 1970}

1970-74 Major increase in demand for bismuth as a metallurgical additive to aluminum, iron, and steel caused price to reach an allime high

1975-81 World production increased faster than consumption

1980

1981-82

1984

1988

Bolivia ceased production; ASARCO Incorporated suspended producer price

1989-90

Economic recession

Bismuth consumption increased, especially in the United States and Japan

Miners' strikes cut off all shipments from Peru for several months

U.S. consumption decreased, especially for metallurgical additives and chemicals; this, combined with increased imports, large world stocks, and impending releases from Government stockpiles caused the price to drop, in spite of bismuth's increasing potential for replacing lead in environmentally sensitive applications

U.S. Department of Defense (DOD), having lowered the goal for bismuth in the National Defense Stockpile (NDS) from 990 to 480 metric tons (t), began selling the excess bismuth

A significant increase in domestic consumption, especially in the chemicals and pharmaceutical category, combined with a moderate decline in world mine production tightened supply

1996 Amendments to 1986 Safe Drinking Water Act; U.S. Fish and Wildlife Service gave final approval to Bi-97-percent-Sn shot for waterfowl hunting

1997 Omaha, Nebr. plant (the sole U.S. producer of primary bismuth) closed in June; the NDS exhausted its supply of bismuth in November

1998-2004 Prices remained low and supplies remained adequate as efforts to reduce use of bismuth in free machining aluminum and steel applications counter growth in nonferrous alloys

2005-07 Increased global demand and speculative interest resulted in higher prices for most metals; two of the world's leading refined bismuth producers agreed to combine their operations

2008-09 Global financial crisis reduced demand

$2010 \quad$ Recovery in world demand 
Table 1. Annual average bismuth price.

[Values in dollars per pound]

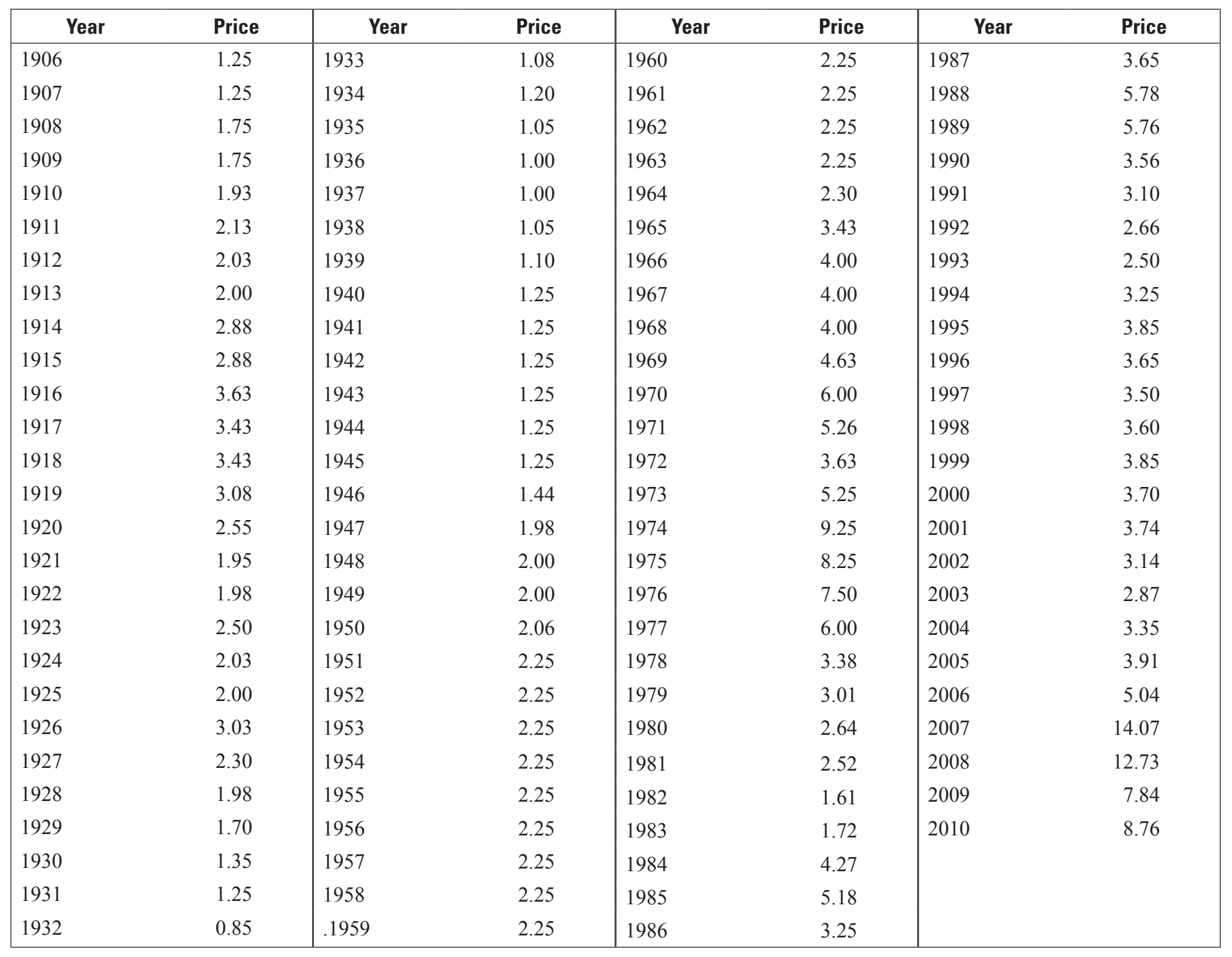

Notes:

1906-23, ASARCO Incorporated, producer price for 99.99-percent-pure bismuth, in U.S. Geological Survey, Mineral Resources of the United States. 1924-31, ASARCO Incorporated, producer price for 99.99-percent-pure bismuth, in U.S. Bureau of Mines, Mineral Resources of the United States. 1932-80, ASARCO Incorporated, producer price for 99.99-percent-pure bismuth, in U.S. Bureau of Mines, Minerals Yearbook.

1981-93, New York dealer price for 99.99-percent-pure bismuth, in Metals Week.

1993-2010, New York dealer price for 99.99-percent-pure bismuth, in Platts (Platt’s) Metals Week. 


\title{
Cadmium (Cd)
}

\author{
by Amy C. Tolcin
}

Cadmium was discovered in 1817 by F. Strohmeyer as an impurity in pharmaceutical zinc carbonate. The first use of cadmium was in a sulfide form in paint pigments. Cadmium metal was first produced commercially in Germany in the 19th century as a byproduct of the smelting of cadmium-bearing zinc ores of Upper Silesia. Cadmium was first produced in the United States in 1906, and by 1917, the United States had become the world's leading producer.

Cadmium minerals are not found in sufficient commercial quantities to be considered a main product in ore deposits. The metal is produced as a byproduct in the recovery of primary zinc from zinc ores and also from some lead or complex copper-lead-zinc ores. The feed material for cadmium production consists of fume and dust that are collected as flue dust in baghouses during the pyrometallurgical processing of zinc and residues that result from electrolytic zinc production. The availability of cadmium is, in most cases, dependent on the amount of zinc produced. Germany was the only important producer of cadmium until World War I. Production of cadmium in the United States began in 1907. By 1917, the United States had become the world's leading producer and held that position for more than 50 years. During this period, the price of cadmium was dictated by either market forces or, during World War II and the Korean Conflict, Governmentimposed regulations. The last of these regulations, enacted during the Korean Conflict, was revoked on May 15, 1952. Since that time, the price of cadmium has been determined primarily by supply and demand.

Following the end of Government regulations, the price of cadmium metal fluctuated widely between 1953 and 1973, reflecting the variation in supply and demand (table 1). Domestic prices rose concurrent with generally strong economic conditions most of 1973 and increased to $\$ 4.09$ per pound by 1974, surpassing the European market quotations (fig. 1). During the next few years, the price trended slowly downward despite continuing currency inflation. By 1982, depressed by the recessions of 1980 and 1981-82, the price had dropped to the lowest level since the end of World War II-\$1.11 per pound of cadmium metal.

What began as a modest increase in 1986 and 1987 turned into the largest recorded annual increase of cadmium price in 1988. By March of 1988, the domestic price for a pound of cadmium metal reached $\$ 9.10$. The market was so tight in early 1988 that major producers did not have any material to sell on the spot market and would not make any commitments for near-term sales at a specific price. The price increase was attributed to the tight supply of cadmium, heavy speculative trading, and world labor disputes, which disrupted the supply of cadmium metal. The supply squeeze was further affected by the purchases of large quantities of cadmium by the nickel-cadmium battery industry, particularly in Japan. For the first 8 months (after which producers stopped quoting prices), the price averaged $\$ 7.90$, a nearly 300 percent increase from that of the previous year. The price fell precipitously in the following 5 years, dropping to $\$ 0.45$ in 1993 . Since that year, the price for cadmium has fluctuated between $\$ 0.28$ and $\$ 1.80$ per pound of metal. Some industry analysts attribute the volatility of cadmium prices to the fact that 95 percent of all cadmium is sold under long-term contracts, usually by primary zinc producers, and the price of cadmium is strongly influenced by the 5 percent of cadmium sold on the spot market, which is more reflective of supply and demand.

The price for cadmium in the next several years will probably be affected by the ban on the use of cadmium in selected applications in countries of the European Union, increasingly strict U.S. environmental regulations limiting domestic use of cadmium in all its forms, and an increased supply of primary cadmium from zinc smelting and secondary cadmium from recycling (European Union, 2011; Organisation for Economic Co-operation and Development, 1997, p. 3-5).

As the byproduct of other metals production, cadmium is not subject to the normal supply demand dynamics of most metals. The inelastic supply-demand situation associated with byproduct commodities invariably leads to volatile pricing, and such has been the case for cadmium for the past 20 to 30 years.

Cadmium prices remained at historically low levels in 2000. As world supply tightened toward yearend, however, prices for cadmium began to inch upward. Reduced primary production — offsetting increased secondary cadmium output - and continued moderate demand led to a balanced world cadmium market in 2000. At yearend 2002, the price of cadmium increased significantly to $\$ 0.90$ per pound from $\$ 0.25$ per pound in January owing to the closure of Metaleurop SA's cadmium production facility at its Noyelles-Godault smelter in France, creating a supply deficit in the refined cadmium market of 4,100 metric tons. The price increase continued into 2003, although moderated, and reached an average of $\$ 0.59$ per pound for the year. In 2005, the annual average cadmium price increased to $\$ 1.50$ per pound from $\$ 0.54$ per pound in 2004 owing to China's rising consumption and lower than anticipated global production growth, which was constrained by a scarcity of zinc concentrates. The average price of cadmium in 2006 decreased to $\$ 1.35$ per pound. During early 2006 , cadmium prices fell sharply as consumers drew down material from excess stocks rather than buy on the 
spot market. After a slight increase from April to June 2006, prices again turned downward during the summer-a decline largely attributed to temporary oversupply rather than a lack of demand. The 2007 average price for cadmium was $\$ 3.45$ per pound. Cadmium's considerable price increase was attributed to a lack of available material on the spot market during the year. The 2008 average price for cadmium decreased to $\$ 2.69$ per pound. Prices declined sharply after the first quarter of 2008 , coinciding with the escalation of the global financial crisis that began around midyear. In 2009, cadmium prices recovered slightly; prices rose to $\$ 1.59$ per pound in December from $\$ 0.83$ per pound in January, averaging $\$ 1.30$ per pound for the year.

\section{References Cited}

European Union, 2011, Chemicals/REACH-EU to ban cadmium in jewelry, brazing sticks and all plastics: Brussels, Belgium, European Union press release, May 20, 1 p.

Organisation for Economic Co-operation and Development, 1997, OECD workshop on the effective collection and recycling of nickel-cadmium batteries: Lyon, France, Organisation for Economic Co-operation and Development, $30 \mathrm{p}$.

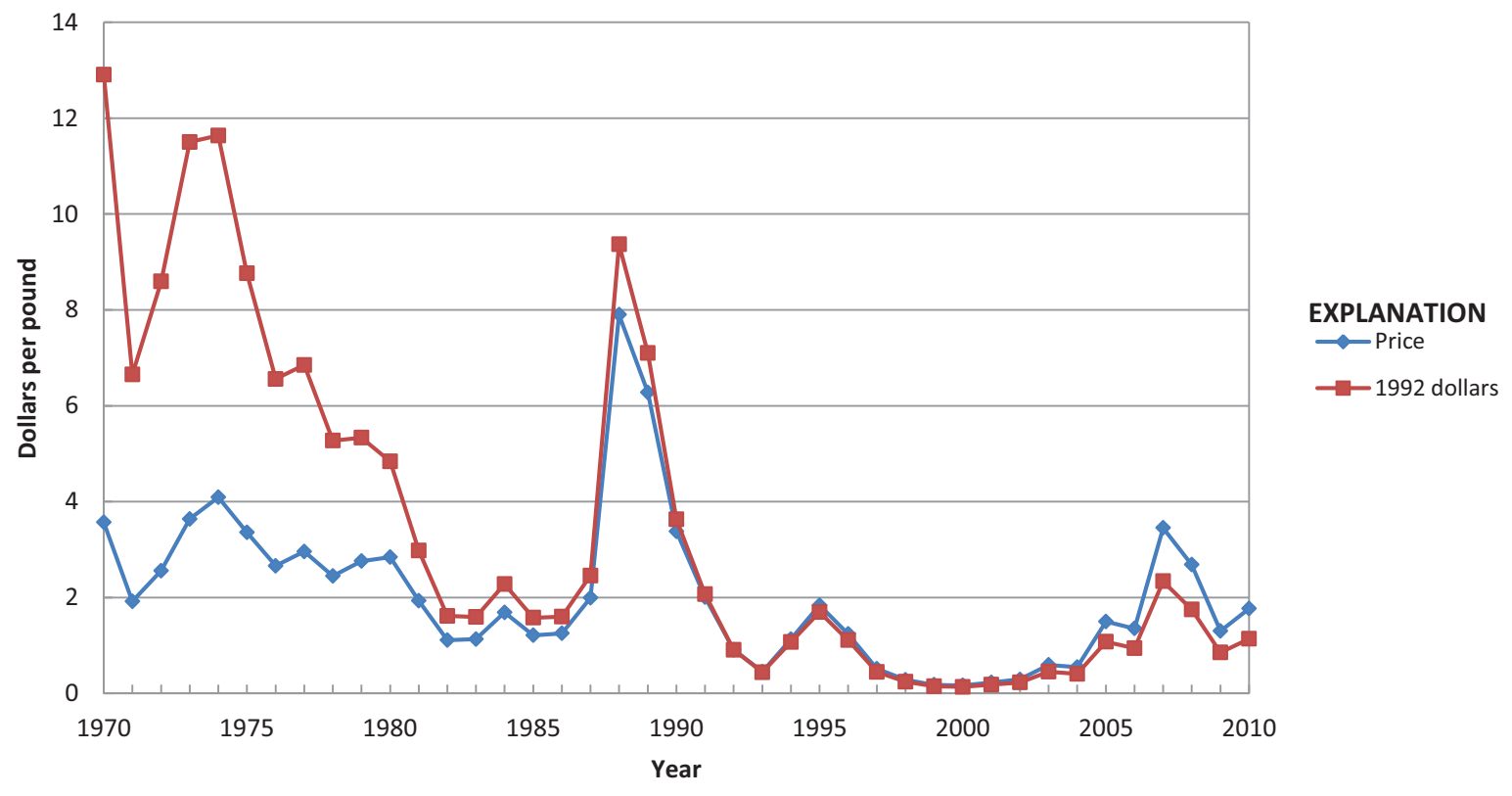

Figure 1. Annual average cadmium price.

\section{Significant events affecting cadmium prices since 1970}

1971-74 Doubling of price, despite anti-inflation price controls

1973-74 Oil embargo by the Organization of Petroleum Exporting Countries

1980-82 Two recessions (1980 and 1981-82); plummeting price

$1982 \quad$ Lowest cadmium price since end the of World War II

1988 Tight supply of cadmium metal, speculative trading; largest recorded annual increase in cadmium price

2002

2004

2008-09 Closure of Metaleurop's Noyelles-Godault smelter reduces cadmium supply; price increases Battery manufacturing industry relocates to China; rate of Chinese cadmium consumption increases significantly Global economic crisis; price declines 


\section{Metal Prices in the United States Through 2010}

Table 1. Annual average cadmium price.

[Values in dollars per pound]

\begin{tabular}{|c|c|c|c|c|c|c|c|}
\hline Year & Price & Year & Price & Year & Price & Year & Price \\
\hline 1900 & 0.650 & 1928 & 0.600 & 1956 & 1.700 & 1984 & 1.690 \\
\hline 1901 & 0.680 & 1929 & 0.600 & 1957 & 1.700 & 1985 & 1.210 \\
\hline 1902 & 0.540 & 1930 & 0.600 & 1958 & 1.520 & 1986 & 1.250 \\
\hline 1903 & 0.530 & 1931 & 0.550 & 1959 & 1.360 & 1987 & 1.990 \\
\hline 1904 & 0.590 & 1932 & 0.550 & 1960 & 1.520 & 1988 & 7.900 \\
\hline 1905 & 0.650 & 1933 & 0.550 & 1961 & 1.680 & 1989 & 6.280 \\
\hline 1906 & 0.760 & 1934 & 0.550 & 1962 & 1.720 & 1990 & 3.380 \\
\hline 1907 & 1.020 & 1935 & 0.700 & 1963 & 2.260 & 1991 & 2.010 \\
\hline 1908 & 0.750 & 1936 & 0.980 & 1964 & 3.000 & 1992 & 0.910 \\
\hline 1909 & 0.520 & 1937 & 1.220 & 1965 & 2.580 & 1993 & 0.450 \\
\hline 1910 & 0.550 & 1938 & 0.980 & 1966 & 2.420 & 1994 & 1.130 \\
\hline 1911 & 0.670 & 1939 & 0.640 & 1967 & 2.640 & 1995 & 1.840 \\
\hline 1912 & 0.760 & 1940 & 0.820 & 1968 & 2.650 & 1996 & 1.240 \\
\hline 1913 & 0.770 & 1941 & 0.900 & 1969 & 3.270 & 1997 & 0.510 \\
\hline 1914 & 0.890 & 1942 & 0.900 & 1970 & 3.570 & 1998 & 0.280 \\
\hline 1915 & 1.190 & 1943 & 0.900 & 1971 & 1.920 & 1999 & 0.177 \\
\hline 1916 & 1.560 & 1944 & 0.900 & 1972 & 2.560 & 2000 & 0.164 \\
\hline 1917 & 1.470 & 1945 & 0.900 & 1973 & 3.640 & 2001 & 0.227 \\
\hline 1918 & 1.480 & 1946 & 1.090 & 1974 & 4.090 & 2002 & 0.292 \\
\hline 1919 & 1.220 & 1947 & 1.700 & 1975 & 3.360 & 2003 & 0.594 \\
\hline 1920 & 1.170 & 1948 & 1.830 & 1976 & 2.660 & 2004 & 0.546 \\
\hline 1921 & 0.980 & 1949 & 2.000 & 1977 & 2.960 & 2005 & 1.497 \\
\hline 1922 & 1.090 & 1950 & 2.170 & 1978 & 2.450 & 2006 & 1.353 \\
\hline 1923 & 0.880 & 1951 & 2.550 & 1979 & 2.760 & 2007 & 3.451 \\
\hline 1924 & 0.700 & 1952 & 2.230 & 1980 & 2.840 & 2008 & 2.686 \\
\hline 1925 & 0.600 & 1953 & 2.000 & 1981 & 1.930 & 2009 & 1.300 \\
\hline 1926 & 0.600 & 1954 & 1.700 & 1982 & 1.110 & 2010 & 1.767 \\
\hline 1927 & 0.600 & 1955 & 1.700 & 1983 & 1.130 & & \\
\hline
\end{tabular}

Notes:

1900-66, Producer price for 99.95-percent-pure cadmium, in Engineering and Mining Journal.

1967-93, Producer price for 99.95-percent-pure cadmium, in Metals Week. Major producers suspended price quotes during the last 4 months of 1988; 1988 price is January to August average.

1994-2010, New York dealer price for 99.99-percent-pure cadmium, in Platts (Platt's) Metals Week. 


\title{
Cesium (Cs)
}

\author{
by William E. Brooks
}

Cesium, the most electropositive and least abundant of the five naturally occurring alkali metals, was the first element to be discovered spectroscopically (Perel'man, 1965, p. 1). Cesium was first produced in its metallic state in 1881 . Industrial uses of cesium did not emerge until 1926, when it was used as a getter and in radio tubes (Burt, 1993, p. 749). Although there are cesium occurrences in the United States, cesium is not mined domestically and the United States is 100 percent reliant on imports. Historically, the most important use for cesium has been in research and development, primarily in chemical and electrical applications. Radioactive isotopes of cesium are generated in fuel rods in nuclear powerplants and have important biomedical and industrial applications.

Owing to the small size of the industry, quoted cesium prices are those of individual companies. The price of cesium varies with the purity of the material and inversely with the quantity purchased, and the metal has been marketed in purities ranging from 99 percent to 99.98 percent.

The annual prices presented in the graph and table may not be comparable from year to year owing to differences in purities, quantity of material purchased, and (or) the source of the price (fig. 1; table 1). For example, prior to 1960 , the prices published in the U.S. Bureau of Mines Minerals Yearbook (MYB) were for purchases of less than 1 pound of cesium metal. From 1960 through 1991, the cesium metal prices published in the MYB were for purchases of at least 1 pound of material and are significantly lower than the pre1960 prices owing to discounts for the larger quantity purchased. The prices for 1992 through 2010 represent the price charged for a 1-gram ampoule of 99.98-percent-pure cesium metal and are an order of magnitude higher than the 1960 to 1991 prices.

\section{References Cited}

Burt, R.O., 1993, Cesium and cesium compounds, in Ullmann's encyclopedia of industrial chemistry (4th ed.): Weinheim, Germany, VCH Verlagsgesellschaft mbH, v. 5, p. 749-763.

Perel'man, F.M., 1965, Rubidium and caesium: New York, The Macmillan Co., 144 p. 
Metal Prices in the United States Through 2010

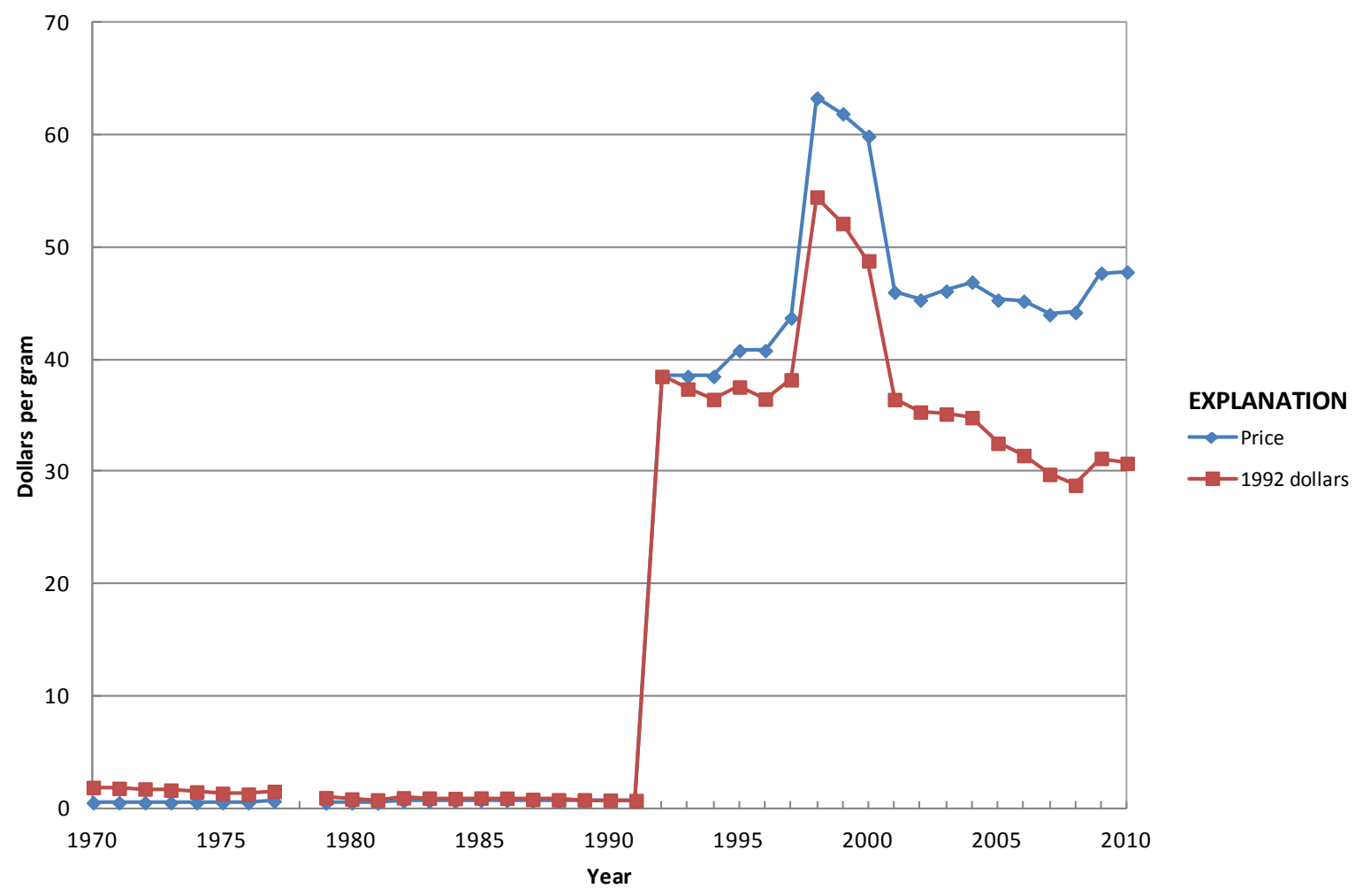

Figure 1. Annual average cesium price. 
Table 1. Annual average cesium price.

[Values in dollars per gram. NA Not available]

\begin{tabular}{|ll|ll|ll|lc|}
\hline \multicolumn{1}{|c|}{ Year } & Price & \multicolumn{2}{c}{ Year } & Price & Year & Price & \multicolumn{2}{c|}{ Year } & Price \\
\hline 1959 & 2.23 & 1972 & 0.52 & 1985 & 0.72 & 1998 & 63.30 \\
1960 & 1.19 & 1973 & 0.52 & 1986 & 0.72 & 1999 & 61.90 \\
1961 & 0.83 & 1974 & 0.52 & 1987 & 0.66 & 2000 & 59.90 \\
1962 & 0.83 & 1975 & 0.52 & 1988 & 0.66 & 2001 & 46.00 \\
1963 & 0.52 & 1976 & 0.52 & 1989 & 0.69 & 2002 & 45.30 \\
1964 & 0.52 & 1977 & 0.66 & 1990 & 0.69 & 2003 & 46.10 \\
1965 & 0.58 & 1978 & NA & 1991 & 0.69 & 2004 & 46.90 \\
1966 & NA & 1979 & 0.50 & 1992 & 38.50 & 2005 & 45.30 \\
1967 & 0.58 & 1980 & 0.50 & 1993 & 38.50 & 2006 & 45.20 \\
1968 & 0.58 & 1981 & 0.50 & 1994 & 38.50 & 2007 & 44.00 \\
1969 & 0.52 & 1982 & 0.66 & 1995 & 40.80 & 2008 & 44.20 \\
1970 & 0.52 & 1983 & 0.66 & 1996 & 40.80 & 2009 & 47.70 \\
1971 & 0.52 & 1984 & 0.66 & 1997 & 43.70 & 2010 & 47.80 \\
\hline
\end{tabular}

Notes:

1959, Average of the prices attributed to American Potash \& Chemical Corp. \& Penn Rare Metals Co.

1960, 99+-percent-pure cesium, 10-pound lots.

1961-62, Penn Rare Metals Division, Kawecki Chemical Co., 99.9-percent-pure cesium, 1- to 9-pound lots.

1963-64, Average of the range of prices for 99+-percent-pure cesium in American Metal Market.

1965, Average of the range of prices for 99.6-percent-pure cesium, 1- to 9-pound lots attributed to the Penn Rare Metals Division of Kawecki Chemical Co.

1967-68, Average of the range of prices for 99.5-percent-pure cesium, 1- to 9-pound lots attributed to the Penn Rare Metals Division of Kawecki Chemical Co.

1969, Average of the range of prices for 99+-percent-pure cesium.

1970-77, Average of the range of prices for 99+-percent-pure cesium in American Metal Market.

1979-81, American Metal Market yearend price for 99+-percent-pure cesium.

1982-86, KBI Division, Cabot Corp., average of the yearend price for technical- and high-purity-grade cesium.

1987-88, KBI Division, Cabot Corp., average of the yearend price for technical- and high-purity-grade cesium in lots of less than 50 pounds.

1989-91, KBI Division, Cabot Corp.

1992-2010, Alfa Aesar and other chemical catalogs. Prices for purchases of 99.98-percent-pure cesium in 1-gram ampoules. 


\title{
Chromium (Cr)
}

\author{
by John F. Papp
}

Chromium was discovered in 1797 by Nicolas-Louis Vauquelin (Weeks, 1968, p. 271-283). The chromite mineral, comprising primarily chromium, iron, and oxygen, was subsequently found to be useful as a refractory material. Chromite was first exploited for the production of pigments (Gray, 1988) and the manufacture of refractory materials. Today, the major use of chromium is in the metallurgical industry to make stainless steel; substantially less chromium is used in the refractory and chemical industries (Papp, 1994, p. 7, 17). The major chromium commodity materials are chromite ore, ferrochromium, and chromium metal. The major traded chromium commodity is ferrochromium, which replaced chromite ore as the United States leading source of chromium between 1981 and 1983 (Papp and Lipin, 2001, p. 32-33). Chromium commodity value histories have been provided for these three materials to meet the needs of different users of such information. At least since 1994, stainless steel trade has become a significant factor in U.S. chromium supply, with scrap exports exceeding mill product imports in recent years.

The structure of the chromium industry is important to understanding chromium material prices. Ferrochromium was originally produced mainly near stainless steel producers; however, production has since moved to locations in proximity to chromite ore producers. Leading ferrochromium producers are vertically integrated chromite ore-ferrochromium producers, and mines and plants are often collocated. Historically, the United States has been a major world producer of stainless steel and of chromium chemicals, but has produced only small amounts of chromite ore and ferrochromium. After World War II, the United States built a stockpile of chromium commodities for national security reasons. After the dissolution of the Soviet Union in 1991, the Federal Government started to sell its stockpile. The Defense Logistics Agency (DLA) negotiated a price for the chromium material with the potential purchaser. The DLA disposed of its stocks of metallurgical-grade chromite ore in 2001, ferrochromium silicon in 2002, chemical- and refractory-grade chromite ore in 2004, and continued selling high- and low-carbon ferrochromium and chromium metal into 2010.

Import data for various forms of chromium are important because their value is a good indicator of price. Before 1980, the United States imported most of its chromium needs in the form of chromite ore because ferrochromium was domestically produced. At that time, the U.S. import value reflected average price and likely reflected world market prices because the United States imported a variety of grades (Papp and Lipin, 2001, p. 28-30). Historically, when the United States imported all grades of chromite ore, the unit value of imports was likely representative of chromite ore production costs; however, since the United States no longer produces ferrochromium, the leading commercial chromium material, and refractory applications have declined significantly, chromite ore imports are limited to chemical production and casting sand - small and specialized portions of the chromite ore market. As domestic ferrochromium production capacity declined, imported ferrochromium surpassed chromite ore as the major commodity source of chromium for the United States. Stainless steel and stainless steel scrap trade has since grown in importance to the U.S. economy, rivaling that of ferrochromium. Markets for chromium metal developed along with the jet engine, many parts of which need alloys that require chromium metal.

Reported U.S. trade statistics (that is, quantity and value) for chromite ore date back to 1884; ferrochromium, 1910; and chromium metal, 1923. Trade journal prices for chromium metal go back only to 1964 . Thus, chromite ore is the chromium commodity for which the reported historical trade journal price and U.S. import value series is longest (fig. 1; table 1). Since U.S. import data were first collected, technological changes have resulted in a change in the predominant grade of chromite ore and ferrochromium traded. The United States has been a consumer of a broad range of chromium materials, and to a large degree, prices of chromium-containing materials have been sustained by demand in the United States and other industrialized nations. As a chromium-chemical-manufacturing nation, the United States also imported chromite ore for chemical production. As a steel-producing nation, the United States imported chromite ore for refractory and alloy production. Between about 1970 and 2000, the United States made the transition from primarily producing to primarily importing ferrochromium for its steel industry. As a result, the United States imported declining amounts of metallurgical-grade chromite ore during that time period. The United States is a major alloy- and stainless steel-producing nation, and chromium ferroalloy imports, including a broad range of grades and sources, reflect that. The United States imports and exports stainless steel mill products, but mostly exports stainless steel scrap.

Chromite ore and other chromium materials are not traded on commodity or futures exchanges. Thus, the price for chromite ore or any other chromium material is not publicly negotiated or available. After surveying consumers and producers, some trade journals publish a composite price or price range based on their survey. Included among these at various times have been American Metal Market, Industrial Minerals, Metal Bulletin, Metals Price Report, Platts Metals Week, and Ryan's Notes. Although the prices for chromium 
materials reported in such periodicals might represent price in the market being surveyed, no representation of quantity of trade is made. Usually, more than one source and (or) grade of material reported by the trade journals have disparate characteristics. In this situation, price is an average and does not apply to any specific product. A broadly descriptive name like "chromite ore" covers many sources and grades of material. The U.S. import value reported to the U.S. Customs Service, U.S. Department of Homeland Security, and published by the U.S. Bureau of the Census, U.S. Department of Commerce, includes a declared value of the imported material estimated at the point of export. It excludes U.S. import duties, freight, insurance, and other charges incurred in shipping the merchandise to the United States. Chromite ore values are annual mass-weighted-average values based on quantity, content, and customs value of imports as reported in U.S. customs statistics.

Chromite ore is graded by its chromic oxide $\left(\mathrm{Cr}_{2} \mathrm{O}_{3}\right)$ content, and its price is reported in trade journals on a grossweight basis (U.S. dollars per metric ton, gross weight). Commercially traded chromite ore grades range from 35 percent to 55 percent $\mathrm{Cr}_{2} \mathrm{O}_{3}$. Suppose, for example, that a particular chromite ore is graded at 42 percent to 45 percent $\mathrm{Cr}_{2} \mathrm{O}_{3}$ and priced at $\$ 100$ per metric ton, gross weight. To calculate the cost of the chromium contained in this material, remember that chromic oxide is 68.42 percent chromium. Consequently, 1 ton of this material then contains between 0.287 and 0.308 ton of chromium yielding a unit value of between $\$ 325$ and $\$ 348$ per ton of contained chromium. Ferrochromium typically contains between 50 percent and 65 percent chromium, and its price is reported in trade journals in dollars per pound of contained chromium. Chromium metal is typically in excess of 99 percent pure, and its price is reported in trade journals in dollars per pound, gross weight (Papp, 1995).

Because nonferrochromium-grade chromite ore is often a byproduct of ferrochromium-grade ore, ferrochromium industry demand is the main driving force of chromite ore production (O'Driscoll, 1998). The relationship is indicated by the lead sometimes shown by ferrochromium price compared to chromite ore price. Annually averaged price data show that price peaks for ferrochromium and chromite ore were coincident in 1982 and 1989, and ferrochromium price led chromite ore price in 1975-76 and 1995-96. In the first two cases, annual averaging hides the price change relationship. In the second two cases, increased demand for ferrochromium drove up ferrochromium prices, but the chromite ore price increase lagged by 1 year.

The cause(s) of specific price changes is often not readily apparent, especially when reported prices do not result from open market activity or reflect only a portion of the market. Prices are negotiated between buyer and seller and remain confidential to them. In a general global sense, the lower price limit is set by the costs of production. A lower limit on price is cost of production, because an individual producer cannot sustain sales at a price that is less than production cost.
Because each producer has a different cost of production and buyers seek to purchase at the lowest price, one would expect low-cost producers to satisfy demand before high-cost producers; the level of consumption would then determine the highest cost producer that could remain in the market. Since each producer seeks to maximize selling price, they may do so by selling for marginally less than the highest cost producer sustained by the level of consumption. The marketplace is likely not so well organized and orderly, since no one knows what is the level of consumption and what price would be sustained by it. Nor are factors like commercial relations, material grade and quality, and historical experience and practice taken into account.

It appears that chromium commodity market prices fluctuate, often for no apparent reason. No markets are transparent, some are translucent, but many are opaque. That is, economic factors like the cost of production, the amount of production, the amount of consumption, price, and the amount of stocks held by producers, consumers, and traders are not commonly available information. However, sometimes events can be associated with price changes or a consensus as to the cause of price changes can be reached among market analysts, participants, and spectators.

Events that affect prices can be of several types based on the extent of their effect: global events (events that affect a large part of the world), international events (events that affect more than one country), area events (events that affect an area possibly extending over more than one country), or local events (events that affect a limited geographic area). Examples of these might be as follows: global event - the recession that followed the world financial crisis; international events - dissolution of the Soviet Union or policy changes that resulted in strong economic growth in China; area event-snowslide damage in 2010 that interrupted rail service in Turkey limiting chromite ore movement from mine to port; and local eventsafety issues or equipment failures that affect one plant or operation. Some events may take longer than others to affect prices. For example, shortage of electrical power in an area affects manufacturers at the same time the shortage occurs; however, a reduction in air travel, as what happened with the severe acute respiratory syndrome (SARS) threat and after the September 11, $2001(9 / 11)$ terrorist attacks, impacts the market more slowly and for an extended period of time. Since many things happen concurrently, the effect of each on prices is obfuscated by the cacophony of events.

As indicated by the preceding analysis, any event that affects cost of production or transportation to the consumer would be expected to affect price. In addition, price can be affected by the market participants' expectations. For example, futures markets are supposed to provide cost security for producers and consumers by integrating expected changes in supply and demand into a time-dependent future price that can be traded. If "the market" (also known as investors or speculators) expects there to be a supply shortfall/demand excess, prices go up; however, when the market expects there to be a supply excess/demand shortfall, prices go down. In effect, 
today's expectations shaped by anticipated future events affect price. This appears to be a particularly useful explanation of price changes, especially when lacking actual and specific events.

The predominant influence on the price of chromite ore is the relationship between supply and demand and general economic conditions. Stock levels relative to anticipated consumption also affect material price. When supply does not meet demand or when stocks appear to be insufficient, price is expected to increase. Because stainless steel is the major end use for chromium, world stainless steel production or anticipated production plays a major role in determining chromium demand and is, therefore, a major influence on chromite ore and ferrochromium prices. Strong demand for chromium from the international stainless steel market resulted in price increases from 1987 through 1989. Chromium industry production capacity growth exceeded stainless steel industry chromium consumption growth, which continued but at a rate lower than that of ferrochromium production capacity. The result was excess production capacity in the chromium ferroalloy industry that resulted in lower ferrochromium prices. In 1991, the dissolution of the Soviet Union resulted in decreased demand for chromium from those markets and added chromium products from the Soviet Union to world markets. Both of these events exacerbated the downward pressure on ferrochromium prices. The Asian financial crisis (1997-98) resulted in a lower world demand for stainless steel that put more downward pressure on ferrochromium prices.

The chromium industry's production-capacity expansion to meet sustained stainless steel demand was delayed by chromium-consuming countries and their antiapartheid policies, and by dissolution of the Soviet Union, an event that reduced demand and put chromium-containing materials on the market until 1994 as stocks in the Soviet Union were sold off. It took until 1995 for world demand to catch up with installed capacity as indicated by the ferrochromium value increase in that year.

In 2003, the price of chromium rose following 2 consecutive years of strengthening of the South African rand against the U.S. dollar; in 2003 alone, the rand increased 24 percent against the U.S. dollar. The rising cost of ferrochromium production and a strengthening South African rand, along with increased demand for ferrochromium and limited supply of stainless steel scrap, caused the price of ferrochromium to reach historically high levels in 2004. Carbon for electrodes was in short supply as were electrical power and transportation in South Africa. From 1991 to 2006, South African chromite ore and ferrochromium smelter production capacity more than doubled while that of other countries declined. Kazakhstan and India became the second and third leading chromite ore producers. Indian chromite ore and ferrochromium production capacity also expanded while that of Albania, Croatia, Japan, Zimbabwe, and other countries decreased.

Data for chromium consumption by the leading consumers (China, Germany, Japan, and the United States) show that China moved from the least amount of consumption to the greatest amount from 1995 to 2006 and was the only leading consumer that substantially increased its consumption. Percentage changes of the chromium price are similar to those for China's consumption. Chromium consumption growth was driven throughout the time period by stainless steel production growth in Asia; growth in Taiwan in the early part of the time period; growth in the Republic of Korea and India throughout the time period reported here; and growth in China that started about 2000 and dominated the end of the time period. China's growth rate was more than double that of any of the other countries. After 1993, chromite mine production and stainless steel production rose similarly. Percentage changes of world stainless steel and chromite mine production were similar for the time period. Percentage change of chromium price was similar to that of stainless steel production as was chromite mine production (Papp and others, 2007, p. 67-76).

In 2007, China had the second ranked economy after that of the United States. China's impact on the mineral and metals markets is greater than its proportional economic size might indicate because China, unlike developed countries, is building infrastructure, a process that is mineral and metal intensive. Prices rise, fall, or stay the same, but generally prices have risen during the long term (at least in current dollars) and fluctuated in the short term. In addition, the magnitude of short-term price variations exceeds that of long-term trends. Looking at frequently quoted prices (such as those in the trade journals that report prices daily or weekly, or commodity exchanges that quote prices even more frequently) obscures long-term trends.

Two major events that affected metal prices from 1991 to 2006- dissolution of the Soviet Union and growth in China starting about 1998 - may be associated with these common trends of production dips that were followed by declining prices in the early part of the time period and were coincident with dissolution of the Soviet Union, while rising production after the dip and dramatically increasing prices at the end of the time period were coincident with economic growth in China. Dissolution of the Soviet Union reduced consumption and added to supply. Sustained demand growth in China exceeded world supply growth and support infrastructure (electrical power and transportation) causing stock depletion and rising prices (Papp and others, 2007, p. 95-109).

The price of metallurgical grade chromite ore (40 percent $\mathrm{Cr}_{2} \mathrm{O}_{3}$ ) from South Africa declined in the 1990s because of reduced ferrochromium consumption owing to reduced stainless steel production. Between 1999 and 2001, ferrochromium consumption declined owing to falling stainless steel production, increased availability of stainless steel scrap from Soviet Union, and high industry stocks. Since 2001, consumption has increased largely owing to increased demand for stainless steel in China. Constrained electrical supply in South Africa limited chromite ore and ferrochromium production resulting in a price surge in 2008 , subsequently mitigated by the recession that resulted from the world financial crisis that took place at about that time (Roskill Information Services Ltd., 2009, p. 419-439). 
The price of ferrochromium is strongly influenced by the stainless steel industry, which is cyclic; as a result so is the price of ferrochromium (fig. 2, table 2). Ferrochromium prices fluctuate more sharply than stainless steel owing to destocking and restocking during production cycles. The 2002 price minimum resulted from coincident falling stainless steel demand and ferrochromium overcapacity, high industry stocks amassed in 2000, and increasing availability of Russian stainless steel scrap. In 2003-04, stainless steel production rose driven by Chinese production, inventories were reduced, and ferrochromium production capacity utilization was high (90 percent for leading producers), the rand strengthened against the U.S. dollar (the currency of ferrochromium trade), and raw materials prices rose. World stainless steel production grew from 2004 to 2008 driven by increased Chinese demand with production driving ferrochromium prices steadily upward. Supply issues in 2008 drove prices up. Ferrochromium production in South Africa, the leading ferrochromium supplier, was restricted by limited electrical power supply. Anticipated supply shortfall led to panic buying (investment), which drove demand over supply and resulted in surging prices. Global recession resulting from the global financial crisis gained momentum in 2008, driving demand down and bringing supply in excess, resulting in declining prices (Roskill Information Services Ltd., 2009, p. 419-439).

After World War II, gas turbine engines moved into commercial airline use and electrical power generation. They are now used to power civilian and military flight, electrical power generation and surface transportation. The high temperature oxidizing environments generated by these engines require superalloys that include chromium. The price of chromium metal depends on superalloy consumption, availability of Chinese and Russian metal, and processing costs (fig. 3; table 3). Chromium-containing superalloys are used in jet aircraft engines used in transportation and international travel. Severe acute respiratory syndrome (SARS) and 9/11 reduced air travel (Roskill Information Services Ltd., 2009, p. 419-439) that was followed by reduced demand for chromium metal and were thought to have contributed to the chromium metal price decline that occurred during that time period.

\section{References Cited}

Gray, Alan, 1988, Lead chrome pigments, in Lewis, P.A., ed., Properties and economics: New York, Wiley-Interscience Publication, Pigments Handbook, v. 1, p. 315-325.

O’Driscoll, Mike, 1998, Chromite supply-A question of ownership: Industrial Minerals, no. 366, March, p. 51.

Papp, J.F., 1994, Chromium life cycle study: U.S. Bureau of Mines Information Circular 9411, 94 p.

Papp, J.F., 1995, Chromium metal: U.S. Bureau of Mines Information Circular 9430, 64 p.

Papp, J.F., and Lipin, B.R., 2001, Chromium: U.S. Geological Survey Open File Report 01-381, 161 p., accessed July 8, 2011, at http://pubs.er.usgs.gov/djvu/OFR/2001/ ofr_01_381.djvu.

Papp, J.F., Corathers, L.A., Edelstein, D.L., Fenton, M.D., Kuck, P.H., and Magyar, M.J., 2007, Cr, Cu, Mn, Mo, $\mathrm{Ni}$, and steel commodity price influences, version 1.1: U.S. Geological Survey Open-File Report 2007-1257, 50 p., accessed June 23, 2011, at http://pubs.usgs.gov/ of/2007/1257/ofr2007-1257v1.1.pdf.

Roskill Information Services Ltd., 2009, The economics of chromium: London, United Kingdom, Roskill Information Services Ltd., 11th ed., 439 p.

Weeks, M.E., and Leichester, H.M., 1968, Discovery of the elements (7th ed.): Easton, Pa., Journal of Chemical Education, 896 p. 


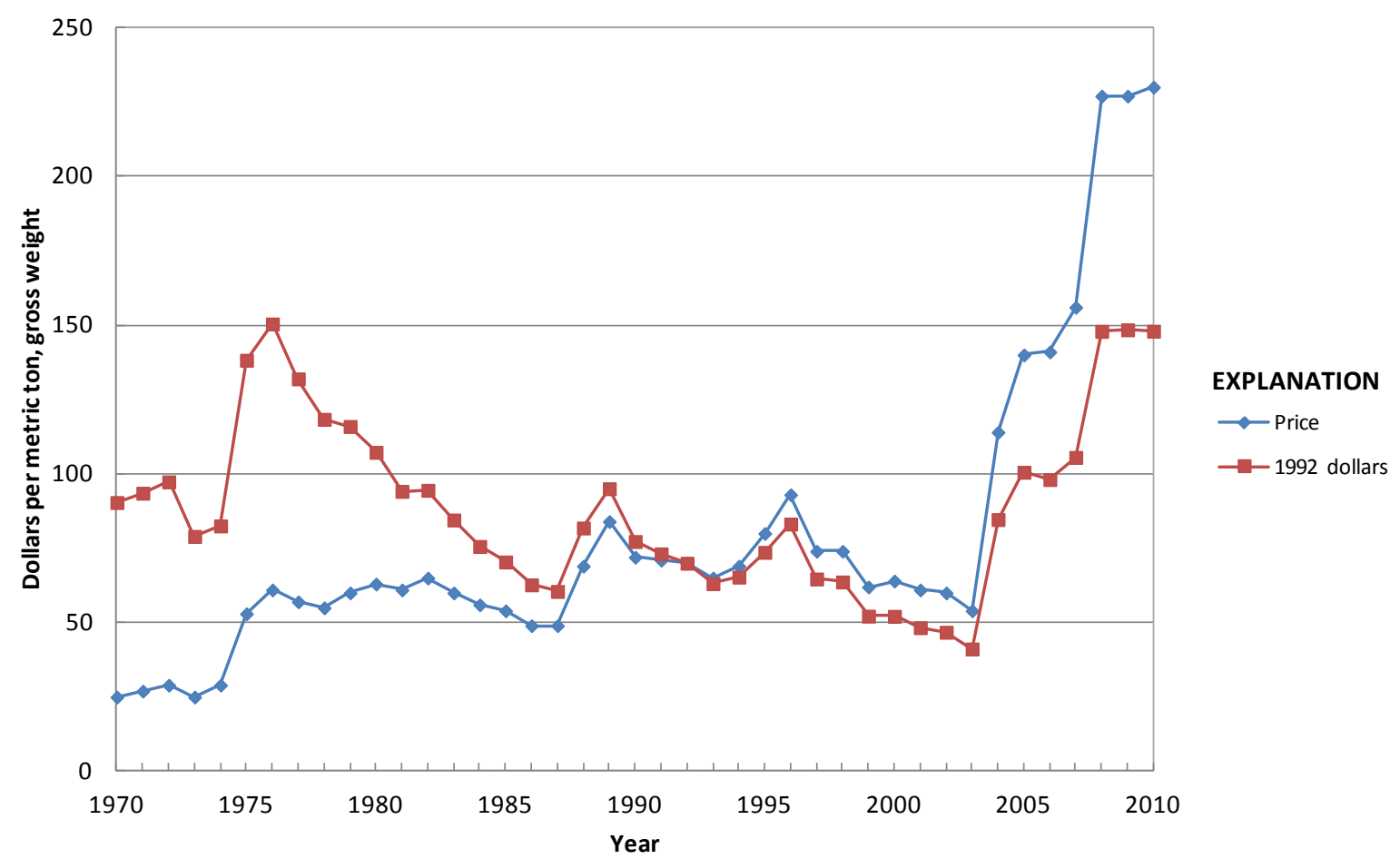

Figure 1. Chromite ore value.

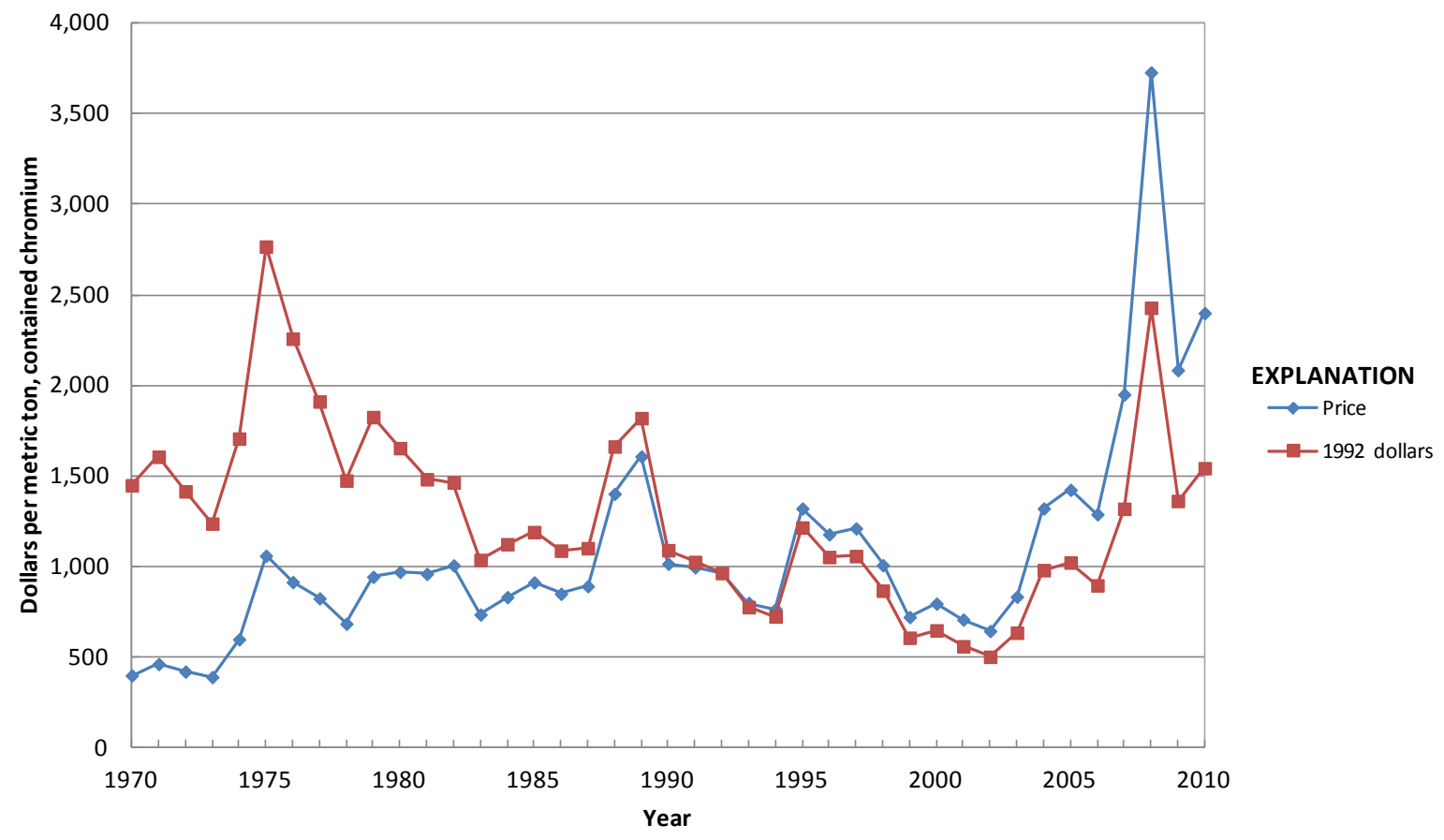

Figure 2. Ferrochromium value. 


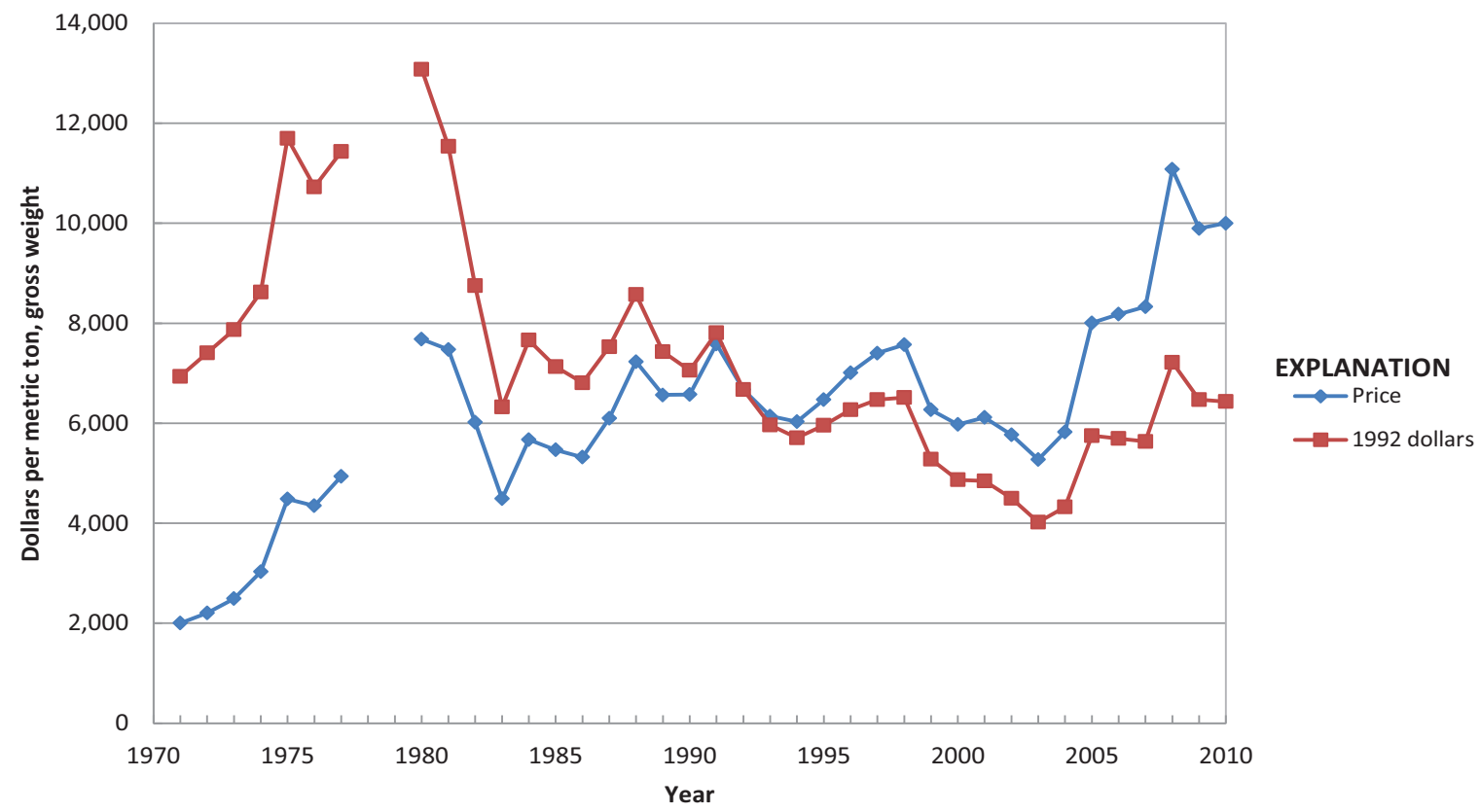

Figure 3. Chromium metal value.

Significant events affecting chromite ore prices since 1970

1975 Price peak following that of ferrochromium

1987-89 Increased stainless steel production

1991 Dissolution of the Soviet Union

1997-98 Asian financial crisis

1998-2010 China's economic growth

2008-09 Global financial crisis 
Table 1. Chromite ore value.

[Values in dollars per metric ton, gross weight]

\begin{tabular}{|c|c|c|c|c|c|c|c|}
\hline Year & Price & Year & Price & Year & Price & Year & Price \\
\hline 1940 & 13 & 1958 & 25 & 1976 & 61 & 1994 & 69 \\
\hline 1941 & 12 & 1959 & 23 & 1977 & 57 & 1995 & 80 \\
\hline 1943 & 20 & 1961 & 18 & 1979 & 60 & 1997 & 74 \\
\hline 1944 & 21 & 1962 & 18 & 1980 & 63 & 1998 & 74 \\
\hline 1946 & 17 & 1964 & 18 & 1982 & 65 & 2000 & 64 \\
\hline 1947 & 19 & 1965 & 18 & 1983 & 60 & 2001 & 61 \\
\hline 1948 & 24 & 1966 & 18 & 1984 & 56 & 2002 & 60 \\
\hline 1949 & 22 & 1967 & 19 & 1985 & 54 & 2003 & 54 \\
\hline 1950 & 20 & 1968 & 19 & 1986 & 49 & 2004 & 114 \\
\hline 1954 & 26 & 1972 & 29 & 1990 & 72 & 2008 & 227 \\
\hline 1955 & 23 & 1973 & 25 & 1991 & 71 & 2009 & 227 \\
\hline 1956 & 25 & 1974 & 29 & 1992 & 70 & 2010 & 230 \\
\hline 1957 & 27 & 1975 & 53 & 1993 & 65 & & \\
\hline
\end{tabular}

Note:

Annual mass weighted-average chromite ore value based on quantity and declared free-on-board value of U.S. imports as reported in U.S. Customs statistics, as reported by the U.S. Department of Commerce. Based on U.S. chromite ore import statistics from 1946 through 2009, average chromic oxide content plus or minus average deviation is $43.6 \pm 1.9$ percent; and chromium content, $29.8 \pm 1.3$ percent. 
Table 2. Ferrochromium value.

[Values in dollars per metric ton contained chromium. NA Not available]

\begin{tabular}{|c|c|c|c|c|c|c|c|}
\hline Year & Price & Year & Price & Year & Price & Year & Price \\
\hline 1947 & 295 & 1963 & 376 & 1979 & 945 & 1995 & 1,322 \\
\hline 1948 & 344 & 1964 & 360 & 1980 & 972 & 1996 & 1,179 \\
\hline 1949 & 352 & 1965 & 395 & 1981 & 961 & 1997 & 1,212 \\
\hline 1950 & 363 & 1966 & 367 & 1982 & 1,008 & 1998 & 1,009 \\
\hline 1951 & 411 & 1967 & 394 & 1983 & 737 & 1999 & 723 \\
\hline 1952 & 442 & 1968 & 382 & 1984 & 833 & 2000 & 797 \\
\hline 1953 & 556 & 1969 & 370 & 1985 & 914 & 2001 & 709 \\
\hline 1954 & NA & 1970 & 401 & 1986 & 851 & 2002 & 646 \\
\hline 1955 & 448 & 1971 & 464 & 1987 & 893 & 2003 & 835 \\
\hline 1956 & 484 & 1972 & 422 & 1988 & 1,403 & 2004 & 1,322 \\
\hline 1957 & 516 & 1973 & 392 & 1989 & 1,609 & 2005 & 1,425 \\
\hline 1958 & 540 & 1974 & 600 & 1990 & 1,017 & 2006 & 1,290 \\
\hline 1959 & 512 & 1975 & 1,061 & 1991 & 997 & 2007 & 1,951 \\
\hline 1960 & 462 & 1976 & 916 & 1992 & 966 & 2008 & 3,728 \\
\hline 1961 & 449 & 1977 & 826 & 1993 & 801 & 2009 & 2,085 \\
\hline 1962 & 435 & 1978 & 686 & 1994 & 767 & 2010 & 2,400 \\
\hline
\end{tabular}

Note:

Annual mass weighted-average ferrochromium value based on content quantity and declared free-on-board value of U.S. imports as reported in U.S. Customs statistics by the U.S. Department of Commerce. Based on U.S. ferrochromium import statistics from 1947 through 1997, average chromium content plus or minus average deviation is $59.2 \pm 3.4$ percent. 
Table 3. Chromium metal value.'

[Values in dollars per metric ton, gross weight. NA Not available]

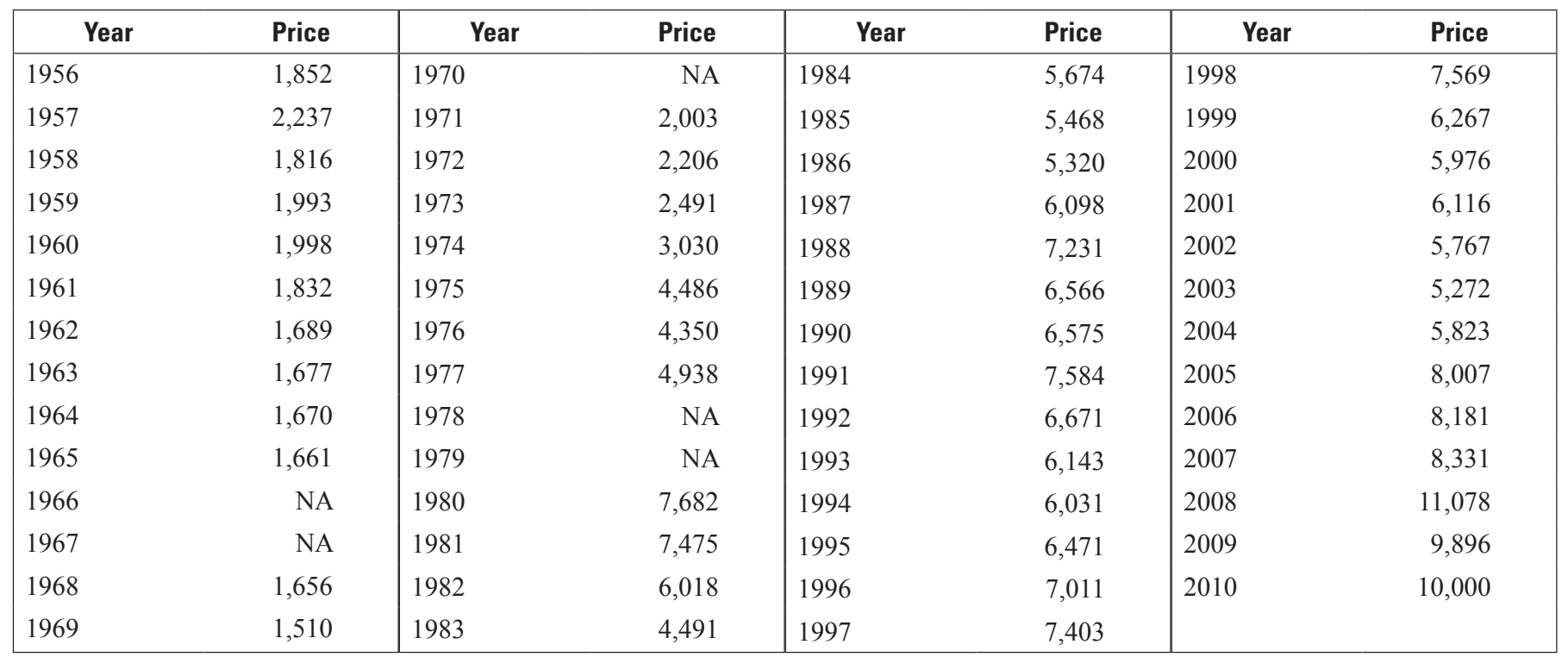

${ }^{1}$ Annual mass weighted-average chromium metal value based on quantity and declared free-on-board value of U.S. imports as reported in U.S. Customs statistics reported by the U.S. Department of Commerce. Chromium metal is typically in excess of 99-percent pure. 


\title{
Cobalt (Co)
}

\author{
by Kim B. Shedd
}

The element cobalt was named after "kobald," a mythical spirit of Germanic folklore. Medieval miners thought that kobalds poisoned their copper ores, but the actual culprits were the arsenic-bearing cobalt minerals cobaltite and smaltite (Young, 1960, p. 1-4).

The earliest known use of cobalt was to color blue glass beads more than 4,000 years ago in ancient Persia. In the early 1900 s, the glass and ceramics industries were still the leading consumers of cobalt. During the next 4 decades, many new uses were developed for cobalt metal and its compounds, and by the mid-1940s, many of cobalt's current uses had been developed (Davis, 1948; Young, 1960, p. 1-4). By 2010, cobalt was used in numerous diverse commercial, industrial, and military applications, many of which were considered strategic and critical. On a global basis, the leading use of cobalt was in rechargeable battery electrodes. Superalloys, which were used to make parts for gas turbine engines, were another major use for cobalt. Cobalt metal or chemicals also were used to make catalysts for the petroleum and chemical industries; cemented carbides (also called hardmetals) and diamond tools; corrosion- and wear-resistant alloys; drying agents for inks, paints, and varnishes; dyes and pigments; ground coats for porcelain enamels; high-speed steels; magnetic recording media; magnets; and rubber-adhesion promoters for steel-belted radial tires.

Various forms of cobalt metal, including briquettes, cathode (electrolytic cobalt), fines, granules (shot), ingot, powder, and rondelles, have been produced and marketed. Cobalt prices presented in the table for 1969 onward are for cobalt cathode, which is produced by electrowinning (fig. 1; table 1). In the electrolytic cell, cobalt metal is deposited on a permanent cathode, usually as a sheet of cobalt metal. Following removal from the cathode, the sheet of cobalt can be broken into small pieces and sold as "broken cathode" or cut into squares and sold as "cut cathode." In 2010, U.S. spot prices quoted in Platts Metals Week were for cathode with a minimum cobalt content of 99.8 percent.

In addition to general economic conditions and supplyand-demand fundamentals, other factors have influenced cobalt prices over time. Although the number of producers has increased, cobalt has been produced in a limited number of countries. The Democratic Republic of the Congo [also known as Congo (Kinshasa) and formerly as Zaire or the Belgian Congo] has been the dominant cobalt producer for most of the period since the 1920s. Therefore, political and civil unrest in that country has affected cobalt supply and prices. Until late 1990, when a mine collapse in Zaire led to reduced mine production and an increase in recovery of cobalt from stock- piled partially refined materials, most cobalt was produced as a byproduct of either copper or nickel mining, resulting in a certain degree of supply inelasticity. Cobalt is considered to be a strategic and critical metal, and as a result, purchases for and sales from Government stockpiles have added to demand and supply, respectively. Finally, the reasons for cobalt price changes are not always evident, and sometimes have been attributed to market manipulation, perceptions of supply-anddemand conditions, or speculation.

Prior to the mid-1990s, the price of cobalt metal was set primarily by producers. Before World War II, the leading Belgian, British, Canadian, Finnish, and French producers agreed to control cobalt supply and to maintain a uniform price. Following the War, prices quoted by the Belgian Congo were generally followed by other producers (Young, 1960, p. 8). From the mid-1980s through the mid-1990s, Zaire and Zambia cooperated in setting the producer price (Jones, 1986; Cobalt Development Institute, 1987). During times when producers controlled the market, the majority of cobalt sales were conducted directly between producers or their sales agents and consumers. These sales were conducted under medium- or long-term agreements at the producer price or at the producer price discounted for quality and quantity. In the early 1990s, the African producers lost much of their influence on cobalt prices (Kielty, 1992, p. 2). This was the result of reduced production from Zaire and Zambia at a time when an increasing amount of cobalt was entering the free market from other countries. The producer price was renamed the "reference price" in 1994, but lost its relevance within a few years. In 2010, cobalt was sold either under contract with a producer or on the free market. The volume of free market sales has varied over time and from country to country.

In the free market, sales are negotiated between producers and consumers, traders and consumers, or traders and other traders. Cobalt can originate from producers, either officially or unofficially; from Government stockpile releases; or from consumers with excess metal. Free market prices published by trade journals, such as Metal Bulletin, Platts Metals Week, and Ryan's Notes, are derived from information collected from producers, consumers, and traders. This approach provides historic rather than current prices, is not fully transparent, relies on the knowledge and experience of the journalist(s) compiling the prices, and has the potential for bias or manipulation, particularly when a reported price change is the result of a small tonnage of material traded (Tunna, 2004; Roskill Information Services Ltd., 2011, p. 223).

Historically, cobalt prices were relatively stable until the late 1970s, when a series of events resulted in concerns 
about cobalt supply and a rapid increase in prices to more than $\$ 40$ per pound. The key factors and events leading up to the "cobalt crisis" included the cessation of cobalt sales from the U.S. Government stockpile in 1976, a drawdown of Zairian producer inventories following 2 years of sales exceeding production, a sharp increase in demand, a reduction in cobalt allocations by the Zairian producer, limited world cobalt production capacity, and an invasion of the copper-cobalt mining region in Zaire (Mining Journal, 1979; Kirk, 1985). Although Zaire's annual production actually exceeded that of the previous year, the "cobalt crisis" had long-term impacts on the cobalt market. For the first time in many years, a strong free market in cobalt developed, and cobalt prices became unstable.

Following the "crisis," production capacity and recycling and recovery of cobalt from secondary materials increased, and consumers began conserving or substituting cobalt where possible. The recession in the early 1980s added to the reduction in demand and an oversupply developed (Kielty, 1988). Beginning in the mid-1980s, Zaire and Zambia worked together to stabilize cobalt prices. They established a joint producer price and limited sales of cobalt to the free market (Kramer and Salak, 1984). In addition, Zaire acted as a "swing producer" by reducing its production and inventories to meet demand (Kielty, 1990, p. 2-3, 10). From late 1986 until mid1990, Zaire and Zambia were successful in returning stability to cobalt prices.

Free market price stability ended during the second half of 1990. In early 1990, delayed shipments from African producers, planned cutbacks in nickel production by Canadian nickel-cobalt producers, assumptions regarding reduced inventory levels in Zaire, and tightening of free market cobalt supplies caused concern about future cobalt availability. In July, the free market cobalt price began to rise following reports of strikes in Zaire and political unrest in Zambia. News of a cavein at Zaire's Kamoto copper cobalt mine in late September added to concerns about cobalt availability.

During 1990, Russia began exporting cobalt to Western markets. The breakup of the Soviet Union, a reduction in cobalt consumption by the Russian military sector, and an increase in demand for hard currency led to increased exports in 1991. As a result, Russia became a net exporter of cobalt, and Russian cobalt developed into a significant component of Western supply. Most of this cobalt was sold by traders in the free market.

The free market cobalt price slowly decreased during the first 9 months of 1991. Speculation continued during this period regarding potential supply shortages, but demand was limited by the economic recession. Political and economic tensions in Zaire continued to increase. The price of cobalt began to rapidly increase following news of renewed unrest in September and October and increased to more than $\$ 30$ per pound in December 1991 through January 1992.

During 1992 and 1993, the free market cobalt price trended downward to approximately $\$ 11$ per pound by early December 1993. The decrease was attributed to reduced con- sumption because of lower U.S. defense spending, a decrease in demand from the commercial aircraft sector, and an overall economic downturn in the United States, Europe, and Japan; reduced demand because of a drawdown of consumer inventories; and good availability of cobalt on the free market.

Despite several years of decline in world refined cobalt production, supplies of cobalt remained adequate through most of 1993. The U.S. Government began selling excess cobalt from the National Defense Stockpile (NDS) in 1993. The NDS cobalt was available to traders as well as to consumers, thus providing more cobalt to the free market. Although cobalt from the NDS and Russia was a lower quality than that typically offered to the market, consumers found ways to take advantage of the availability and lower cost of cobalt from these sources.

Beginning in mid-December 1993 and ending in mid-January 1994, the free market cobalt price more than doubled and reached a high of $\$ 24$ per pound. This price increase reflected a growing concern about cobalt supply prompted by delays by the African producers in announcing their 1994 pricing policy, consumers' reduced inventory levels resulting from buying on an as-needed basis, press reports that the copper-cobalt mining region in Zaire had declared autonomy from the rest of the country, expectations for reduced production in 1994, and traders' reports of reduced supplies of Russian cobalt. The magnitude and speed of the price increase, however, suggested market manipulation (Kielty, 1994). In 1994, world mine production of cobalt fell to its lowest level in 30 years.

In 1994 and 1995, the supply of cobalt increased. World production increased, cobalt from Russia and the NDS continued to contribute to supply, and the amount of cobalt recovered from intermediate materials and recycled from scrap increased. Economic conditions improved, and world demand increased. During this 2-year period, the free market price was high and somewhat unstable, although the overall trend was upward, reaching more than $\$ 32$ per pound by December 1995. High cobalt prices, combined with forecasts for large increases in nickel demand, resulted in the initiation of a substantial number of projects that could produce cobalt within 3 to 6 years, either as a byproduct of nickel or copper mining or from the processing of cobalt-bearing intermediate materials stockpiled during past copper production.

Beginning in 1996, the annual average free market cobalt price began a 7-year decline, in spite of significant short-term fluctuations in price during the period. World cobalt production continued to increase in 1996 and was expected to continue to trend upward, owing to expanded production from existing nickel producers, renewed interest in investing in Congo (Kinshasa)'s copper-cobalt industry, and the anticipation of significant amounts of cobalt production from refining nickel laterite ores using new pressure acid leaching technology (Day, 1996; Searle, 1997). Market sentiment shifted from concern about availability to forecasts of potential oversupply as future production increased at a faster rate than demand (Ryan's Notes, 1996). Demand remained strong, but the free 
market cobalt price fell below $\$ 21$ per pound during the second half of 1996.

During 1997, world production was approximately equal to that of 1996, and demand remained strong. The free market cobalt price fluctuated between approximately $\$ 19$ and $\$ 26$ per pound. From 1998 to early 1999, the price declined from a high of approximately $\$ 26$ per pound in January 1998 to a low of $\$ 8$ per pound in January 1999. This price decrease suggests that plenty of cobalt was available to meet demand. World production and sales and shipments of cobalt from the NDS were higher in 1998 than in 1997. Additional possible contributing factors for decreasing prices included reduced demand from the former Soviet Union; consumers buying only as needed, drawing down inventories, and delaying purchases while waiting for the price to bottom out; producers offering cobalt at low prices to reduce their inventories and (or) to gain market share; and traders pushing down prices to buy cheaper cobalt at a later date and (or) to gain market share (Cobalt Development Institute, 1999; Metal Bulletin, 1999; Ryan's Notes, 1999; Searle, 1999).

The free market cobalt price increased sharply in late January 1999 and by mid-February had more than doubled to $\$ 20$ per pound. It then gradually declined until midyear, when it increased to more than $\$ 22$ per pound. High prices during the first half of 1999 may have been from concern about a pending shortage in supply, which did not materialize. One analyst attributed the rise to market manipulation, although reduced inventory levels were noted (Cobalt Development Institute, 2000; Kielty, 2000).

In 1999, an Australian nickel producer introduced an Internet-based system for selling its cobalt. The Cobalt Open Sales System listed the availability and asking prices of the company's cobalt, as well as information on sales. For the next decade, this system offered some market transparency and was considered a benchmark for cobalt prices, in spite of representing only a small portion of the total market. During this period, several producers and other suppliers briefly sold cobalt via the Internet (WMC Ltd., 1999; Metal Bulletin, 2000).

Following the highs of mid-1999, the free market cobalt price generally trended downward for several years. From 1999 through 2003, cobalt supply steadily increased, owing to increases in production and continuing shipments of excess cobalt from the NDS. Global demand for cobalt increased until 2001, when it decreased for the first time since 1992 owing to weak economic conditions in major consuming countries such as the United States and Japan, and a decrease in the production of rechargeable batteries owing to high inventories. The terrorist attacks in the United States on September 11, 2001, led to economic uncertainty, concern that renewed U.S. industrial activity would be delayed, and financial problems for the U.S. commercial airline industry, a major consumer of superalloys (Searle, 2002; Shedd, 2002).

The free market cobalt price remained weak for most of 2002. U.S. consumption declined, particularly from the superalloy sector; global cobalt production continued to increase, and by September, the price had dropped to a low of $\$ 6$ per pound. From late 2002 through early 2004, the price increased - first gradually, then steeply, to reach a peak of \$29 per pound in January 2004. The increase was attributed to tight supply owing to a decrease in the production of refined cobalt in Congo (Kinshasa), an apparent change in the sales strategy for Russian cobalt, a brief strike at a Canadian nickel-cobalt operation, increased consumption from China and the battery industry, expectations of increased consumption from the superalloy industry, and a buildup of stocks by consumers and traders. In 2004, China imported increasing amounts of cobalt ores and concentrates from Congo (Kinshasa) and became the world's leading producer of refined cobalt; more than one-half of China's cobalt consumption was for battery production (Metal Bulletin, 2003; Searle, 2004; Chen, 2005; Tomlinson, 2005; Roskill Information Services, Ltd., 2007, p. 287).

Following the peak in early 2004, the free market cobalt price generally trended downward for the next 2 years, reaching a low of nearly $\$ 12$ per pound in late 2005 . Supply and demand were roughly in balance. From 2006 through early 2008 , the price was unstable but gradually and then steeply trended upward as demand for cobalt increased and supply tightened. The price doubled in 2006, and then doubled again by March 2008, when it reached a peak of $\$ 54$ per pound. The escalation in price was attributed to concern about availability during a period of good demand for cobalt from all consuming sectors. Contributing factors included reductions in power supply to African producers, lost production by an Australian producer following an interruption in gas supply, and low producer inventories. A consolidation of cobalt suppliers was also cited as contributing to increased prices. In late 2006, the leading Russian producer committed most of its cobalt output to the world's leading cobalt refiner under a 5-year supply agreement, and shortly thereafter, a leading trading firm was selected to market all of the cobalt produced in Norway. During this time, much of the increase in consumption was for the production of batteries in China, which depended heavily on imported raw materials. Reduced exports of unprocessed cobalt concentrates from Congo (Kinshasa) in 2006 and 2007 led Chinese consumers to draw down stocks in 2007 to meet demand (Ryan's Notes, 2006; Cobalt Development Institute, 2007, 2008; Roskill Information Services, Ltd., 2007, p. 288; Baker, 2008, p. 3, 5, 8-9; Darton Commodities Ltd., 2008, p. 1, 3, 5).

Following the peak in March 2008, the free market cobalt price declined sharply as exports of raw materials from Congo (Kinshasa) increased, Chinese production of refined cobalt increased, and consumers postponed purchases in a declining market. By August, the price had decreased by more than 50 percent to approximately $\$ 25$ per pound. It rebounded briefly to nearly $\$ 39$ per pound in September, before decreasing to less than $\$ 13$ per pound in December. The decrease during the fourth quarter of 2008 was in response to the global financial crisis and economic downturn that followed. These events caused reduced demand for commodities and rapidly decreasing prices, which led to reductions in cobalt production and 
delays to future production from new projects (Darton Commodities Ltd., 2008, p. 1, 3, 5-6; Platts Metals Week, 2008; Seeking Alpha, 2008).

During 2009, the free market cobalt price was unstable, but generally trended upward, reaching a high of $\$ 23.50$ per pound in November. Global demand was less than that of 2008, despite an increase from China, and global production of refined cobalt was higher than that of 2008. Higher prices towards the end of the year were attributed to increased demand, particularly from the battery sector, combined with concerns about short-term supply because of strikes in Canada and a delayed restart of production from a Zambian refinery. Speculative purchases in advance of the launch of a cobalt futures contract on the London Metal Exchange (LME) were also cited as contributing to higher prices (CRU International Ltd., 2009, p. 5).

The LME cobalt futures contract was launched in February 2010. Under terms of the contract, cobalt metal was to be traded in 1-metric-ton lots of minimum 99.3-percent cobalt with warehouses in Asia, Europe, and the United States as delivery points. By yearend, cobalt from 11 producers had been approved for delivery against the contract. Before the cobalt contract was launched, some companies announced that they planned to use LME cobalt prices as reference prices for their sales contracts (Metal Bulletin, 2010; London Metal Exchange Ltd., The, 2010).

Although the free market cobalt price fluctuated during 2010 , the overall trend was downward to a low of $\$ 16$ per pound in November, before recovering slightly by yearend. Cobalt demand increased with the improved global economic situation and increased industrial activity, and was higher than that of 2007, the year preceding the global financial crisis. Supply also increased, particularly from production from new copper-cobalt operations in Congo (Kinshasa). Global increases in cobalt supply from existing producers and new projects were expected to outpace increases in consumption within a few years, which could lead to an oversupply of cobalt and downward pressure on prices (Collignon, 2011).

\section{References Cited}

Baker, Calum, 2008, Strategic issues for cobalt: The Cobalt Conference, Cobalt Development Institute, Toronto, Ontario, Canada, May 14-15, 2008, Presentation, 23 p.

Chen, Guang-yu, 2005, China cobalt market update: The Cobalt Conference, Cobalt Development Institute, Paris, May 18-19, 2005, Presentation, 8 p.

Cobalt Development Institute, 1987, Statistics: Cobalt News, March, p. 9-10.

Cobalt Development Institute, 1999, Statistics review 1998:

Cobalt News, April, p. 12-13.
Cobalt Development Institute, 2000, Comment: Cobalt News, January, p. 2.

Cobalt Development Institute, 2007, Comment: Cobalt News, April, p. 2.

Cobalt Development Institute, 2008, Comment: Cobalt News, January, p. 2.

Collignon, Maartje, 2011, The global outlook for cobalt: The Cobalt Conference, Cobalt Development Institute, Hong Kong, China, May 18-19, 2011, Presentation, 9 p.

CRU International Ltd., 2009, CRU monitor-Nickel cobalt intermediates: London, United Kingdom, CRU International Ltd., November, 14 p.

Darton Commodities Ltd., 2008, Cobalt market reviewDecember 2008: Guildford, United Kingdom, Darton Commodities Ltd., December 17, 14 p.

Davis, H.W., 1948, Cobalt, in Minerals yearbook 1946: U.S. Bureau of Mines, p. 391-399.

Day, Martyn, 1996, Future sources of cobalt: Cobalt News, July, p. 11-16.

Jones, Monique, 1986, Cobalt market-1985 review: Cobalt News, March, p. 6-10.

Kielty, Edward, 1988, Cobalt-More stable times: Metals Week nickel, moly, cobalt conference, Tucson, Ariz., October 26-28, 1988, Presentation, 13 p.

Kielty, Edward, 1990, What next for cobalt?-1991-A year to manage change: Metals Week Conference, Tucson, Ariz., October 25-26, 1990, Presentation, 26 p.

Kielty, Edward, 1992, Cobalt review and outlook: Metals Week Ferroalloys Conference, Tucson, Ariz., November 5-6, 1992, Presentation, 22 p.

Kielty, Edward, 1994, Cobalt-An unpredictable market: Engineering and Mining Journal, v. 195, no. 3, March, p. $28-30$.

Kielty, Edward, 2000, Cobalt - Where we have been is where we are: Engineering and Mining Journal, v. 201, no. 3, March, p. 19-21.

Kirk, W.S., 1985, A third pricing phase-Stability?: American Metal Market, v. 93, no. 163, August 23, p. 9, 12.

Kramer, David, and Salak, John, 1984, Cobalt \$11.70/lb.Zaire, Zambia: American Metal Market, v. 92, no. 52, March 15, p. 1, 16. 
London Metal Exchange Ltd., The, 2010, Minor metalsLME cobalt and LME molybdenum: London, United Kingdom, London Metal Exchange brochure, 6 p., accessed February 8, 2011, at http://www.lme.com/downloads/LMEMinor-Metal-brochure-V2-1210.pdf.

Metal Bulletin, 1999, Consumers and producers wary of cobalt market: Metal Bulletin, no. 8341, January 11, p. 11.

Metal Bulletin, 2000, Opening up the cobalt market: Metal Bulletin, no. 8474, May 11, p. 19.

Metal Bulletin, 2003, Has cobalt's time come?: Metal Bulletin, no. 8822, December 29, p. 14.

Metal Bulletin, 2010, LN Metals agrees LME formula Co contract with Jiangsu: Metal Bulletin, no. 9136, February 15 , p. 16.

Mining Journal, 1979, Cobalt, in Mining annual review 1979: Mining Journal, 1979, p. 80-81.

Platts Metals Week, 2008, Cobalt markets cool amid supplier/consumer standoff: Platts Metals Week, v. 79, no. 17, April 28, p. 11-12.

Roskill Information Services Ltd., 2007, The economics of cobalt: London, United Kingdom, Roskill Information Services Ltd., 11th ed., $291 \mathrm{p}$.

Roskill Information Services Ltd., 2011, Tungsten-Market outlook to 2016: London, United Kingdom, Roskill Information Services Ltd., 10th ed., $230 \mathrm{p}$.

Ryan's Notes, 1996, Processing of cobalt intermediates could lead to more market stability, v. 2, no. 22, May 27, p. 1.

Ryan's Notes, 1999, Cobalt prices are hanging by a thread, v. 5 , no. 1 , January 4, p. 2.

Ryan's Notes, 2006, OMG to use and sell Norilsk's Co: Ryan's Notes, v. 12, no. 47, November 27, p. 1-2.
Searle, Peter, 1997, Strategic issues for cobalt: Cobalt News, April, p. 7-10.

Searle, Peter, 1999, 1998 was indeed a remarkable year, but...: The Cobalt Conference, Cobalt Development Institute, London, May 26-27, 1999, Presentation, 8 p.

Searle, Peter, 2002, Strategic directions for cobalt as seen in 2002: The Cobalt Conference, Cobalt Development Institute, Paris, May 14-15, 2002, Presentation, 9 p.

Searle, Peter, 2004, A strategic view of the cobalt market: The Cobalt Conference, Cobalt Development Institute, Toronto, Ontario, Canada, May 19-20, 2004, Presentation, 12 p.

Seeking Alpha, 2008, OM Group, Inc. Q2 2008 earnings call transcript, August 7, accessed May 3, 2012, at http://seekingalpha.com/article/90304-om-group-inc-q22008-earnings-call-transcript.

Shedd, K.B., 2002, Cobalt: U.S. Geological Survey Mineral Commodity Summaries 2002, p. 50-51.

Tomlinson, Philip, 2005, Strategic issues for cobalt: The Cobalt Conference, Cobalt Development Institute, Paris, May 18-19, 2005, Presentation, 7 p.

Tunna, Nigel, 2004, Pricing mechanisms for the cobalt market: The Cobalt Conference, Cobalt Development Institute, Toronto, Ontario, Canada, May 19-20, 2004, Presentation, $7 \mathrm{p}$.

WMC Ltd., 1999, WMC markets cobalt on the internet: Melbourne, Victoria, Australia, WMC Ltd. press release, August 16, 1 p.

Young, R.S., 1960, Cobalt—Its chemistry, metallurgy, and uses: New York, Reinhold Publishing Corp., 424 p. 


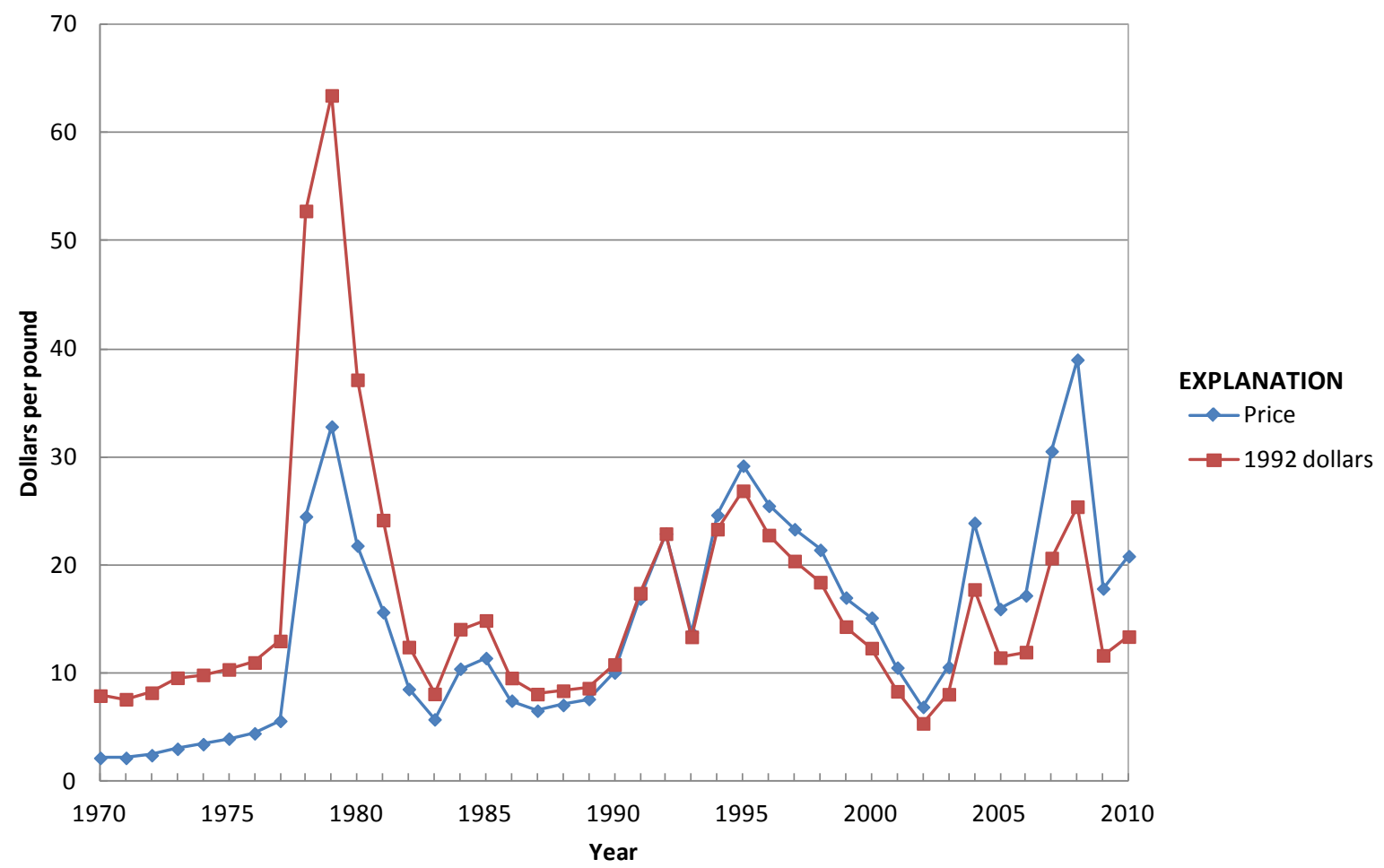

Figure 1. Average annual cobalt prices. 


\section{Significant events affecting cobalt prices since 1970}

1970-76 Sales of significant quantities of cobalt from U.S. Government stockpile

1978

$1981-82$

1984

1990

$1990-91$

Strong cobalt demand; Zaire's copper cobalt mining region invaded; free market developed

Sharp recession

Zaire and Zambia established a joint producer price and limited sales of cobalt to the free market

1991

Strikes in Zaire and political unrest in Zambia; cave-in at Zaire's Kamoto copper cobalt mine; Russia began exporting cobalt to Western markets

1992-93

Recession

1993-94

Unrest in Zaire; dissolution of the Soviet Union and increased cobalt exports from Russia

Economic downturn and decrease in U.S. defense spending

1993-2009

Low global production and concern about cobalt supply led to a sharp increase in prices

1994-2005

Sales of cobalt from the U.S. Government stockpile

$1995-2010$

1996

Zaire renamed the Democratic Republic of the
investing in Congo's copper-cobalt industry

Yearly increases in global production of refined cobalt

Zaire's and Zambia's producer price was changed to a reference price

Last year that Zaire's and Zambia's reference price was updated

1998

1999-2009

First cobalt production from new pressure acid leaching technology for refining nickel laterite ores

2001

Internet-based cobalt sales via Cobalt Open Sales System

September 11th terrorist attacks in the United States; first year that global cobalt demand decreased since 1992; beginning of rapid increase in Chinese production and consumption of refined cobalt

2001-02 Slowdown in world economy

2003-04

Tight supply during a period of increasing demand

2006-07

2008-09

Batteries overtook superalloys as leading use of cobalt

China became the world's leading producer of refined cobalt

2010

Reduced exports of raw materials from Congo (Kinshasa); consolidation of cobalt suppliers

Financial crisis and global economic downturn

Launch of cobalt contract on the London Metal Exchange (LME) 


\section{$44 \quad$ Metal Prices in the United States Through 2010}

Table 1. Annual average cobalt price.

[Values in dollars per pound]

\begin{tabular}{|ll|ll|lr|rr|}
\hline \multicolumn{1}{r}{ Year } & Price & \multicolumn{2}{r|}{ Year } & Price & Year & Price & \multicolumn{2}{c|}{ Year } & Price \\
\hline 1937 & 1.29 & 1956 & 2.58 & 1975 & 3.98 & 1994 & 24.66 \\
1938 & 1.36 & 1957 & 2.03 & 1976 & 4.47 & 1995 & 29.21 \\
1939 & 1.40 & 1958 & 2.00 & 1977 & 5.62 & 1996 & 25.50 \\
1940 & 1.50 & 1959 & 1.77 & 1978 & 24.52 & 1997 & 23.34 \\
1941 & 1.50 & 1960 & 1.54 & 1979 & 32.83 & 1998 & 21.43 \\
1942 & 1.50 & 1961 & 1.50 & 1980 & 21.82 & 1999 & 17.02 \\
1943 & 1.50 & 1962 & 1.50 & 1981 & 15.67 & 2000 & 15.16 \\
1944 & 1.50 & 1963 & 1.50 & 1982 & 8.56 & 2001 & 10.55 \\
1945 & 1.50 & 1964 & 1.50 & 1983 & 5.76 & 2002 & 6.91 \\
1946 & 1.50 & 1965 & 1.63 & 1984 & 10.44 & 2003 & 10.60 \\
1947 & 1.58 & 1966 & 1.65 & 1985 & 11.43 & 2004 & 23.93 \\
1948 & 1.65 & 1967 & 1.85 & 1986 & 7.49 & 2005 & 15.96 \\
1949 & 1.76 & 1968 & 1.85 & 1987 & 6.56 & 2006 & 17.22 \\
1950 & 1.80 & 1969 & 1.92 & 1988 & 7.09 & 2007 & 30.55 \\
1951 & 2.18 & 1970 & 2.20 & 1989 & 7.64 & 2008 & 39.01 \\
1952 & 2.40 & 1971 & 2.20 & 1990 & 10.09 & 2009 & 17.86 \\
1953 & 2.43 & 1972 & 2.45 & 1991 & 16.92 & 2010 & 20.85 \\
1954 & 2.60 & 1973 & 3.04 & 1992 & 22.93 & & \\
1955 & 2.60 & 1974 & 3.47 & 1993 & 13.79 & & \\
\hline
\end{tabular}

Notes: Annual average prices were derived from price changes reported in the following sources:

1937-77, contract or producer price, domestic quotation for cobalt metal, in U.S. Bureau of Mines Minerals Yearbook; origins of prices are unknown.

1978, free market price, cobalt metal, in Engineering and Mining Journal, v. 180, no. 3, 1979, p. 138.

1979, free market price, cobalt metal, in Engineering and Mining Journal, v. 181, no. 3, 1980, p. 112.

1980, European free market price, 99.5-percent cobalt metal, in Metal Bulletin Handbook, 1981, p. 73.

1981, European free market price, 99.5-percent cobalt metal, in Metal Bulletin Handbook, 1982, p. 51, and U.S. spot price, 99.5-percent cobalt cathode, in

Metals Week.

1982-92, U.S. spot price, 99.5-percent cobalt cathode, in Metals Week.

1993, U.S. spot price, 99.8-percent cobalt cathode, in Metals Week.

1994-2010, U.S. spot price, 99.8-percent cobalt cathode, in Platts (Platt's) Metals Week. 


\title{
Copper (Cu)
}

\author{
by Daniel L. Edelstein
}

Copper, the first metal used by humans more than 10,000 years ago, is one of the most important materials in the development of civilization. Though copper is usually found in nature in association with sulfur, native copper metal found in a few places around the world was the most likely source of early copper used first for decorative and then for utilitarian purposes. The alloying of copper with tin to form bronze, a harder, stronger, and more readily cast metal, gave rise to an era bearing its name. With the dawn of the industrial revolution in Europe and the first transmission of electricity in the 18 th century, demand for greater quantities and higher purity led to significant improvements in the mining, processing, and refining of copper metal. Its relatively low-cost availability and excellent electrical conductivity (second only to silver), combined with its properties of high ductility and thermal conductivity, malleability, and corrosion resistance, have resulted in copper becoming a major industrial metal that ranks third after iron and aluminum in terms of quantities used. Currently, more than 70 percent of copper used is in electric and electronic applications distributed throughout all sectors of the economy, and it is ubiquitous in our lives through use in the generation and distribution of electricity and the circuitry of all of our electronic items. Other uses include plumbing tube, heat exchangers, building hardware and roofing, and coinage. New uses of copper are found in such applications as siliconbased computer chips, solar and wind power generation, superconducting cables for the electric grid, antimicrobial touch surfaces, and rotors in energy-efficient motors.

Historically, wirebar was the dominant form of copper traded, and the price for refined copper wirebar was the "bellwether" price for copper. By the mid-1970s, however, technology had changed to continuous casting and drawing of wire rod directly from refined cathode, thus bypassing the need to cast wirebar. Even though more than 50 percent of primary copper produced in the United States is traded as rod by integrated mine producers, the high-grade copper cathode price is used as the "base" price for most transactions.

About 60 percent of domestic primary refined copper is produced from a multistage process, beginning with the mining and concentrating of ores, and followed by smelting and electrolytic refining to produce a high-grade cathode. The remaining 40 percent is produced from acid leaching of copper ores and wastes and solvent extraction and electrowinning of refined copper from the pregnant solution. Though historically most domestic producers have had a high degree of vertical integration, copper products from each stage of processing have their own independent markets and are traded globally. Each product has its own pricing procedure that is linked, for the most part, to its copper content and the market price for refined copper. For example, copper concentrates, which contain between 20 percent and 35 percent copper, are purchased on the basis of the refined copper market value of their recoverable copper content, with charges taken for smelting and refining. Penalties may be assessed by the smelter/refiner for unwanted contaminants or low grade, and credits may be given for recoverable byproducts. Even though the smelting and refining charges are driven by processing cost factors, they may fluctuate significantly according to the market balance for concentrates and may be influenced by copper prices in protected markets and price sharing arrangements with miners. Similarly, prices for copper scrap are discounted from the refined value of the recoverable copper content to allow for processing costs and profit. Though the discount from refined copper must be sufficient to account for processing costs, market conditions for each type of scrap will affect the price.

Until the late 1970s, domestic copper prices were generally referenced to the U.S. producer price (fig.1; table 1). The traditional U.S. producer price, which normally included a charge for delivery and insurance, was based on annually negotiated sales contracts, with prices changing at least quarterly. The producer price system offered stability and served the interests of both the producer and the consumer. Producer prices tended to be higher than commodity exchange prices during weak markets and less than the exchange prices during high demand periods. During periods of tight supply, U.S. mills, most of which were producer-owned subsidiaries, were given allocations assuring them of reasonably priced supplies. Although the producer pricing provided stability for contract purchases, it created a two-tiered price structure, where spot purchases and exchange prices were significantly different from producer prices. During the peak demand period of the Vietnam War, 1964-69, the average London Metal Exchange Ltd. spot price was $\$ 0.575$ per pound, compared with only $\$ 0.38$ per pound for the domestic producer price.

Beginning with the nationalization of foreign production in Africa and Chile in the 1960s and early 1970s, the U.S. producers' influence on domestic and world markets weakened, and domestic producer pricing became more market sensitive, changing frequently to track global prices. Periods of surplus supply, which took place from the mid-1970s to the mid-1980s also contributed to the decreased influence of U.S. producer prices on world markets as surplus supplies flowed to the exchanges. As a result, U.S. producers abandoned classic producer pricing, some in 1978 and others in the early 1980s, and changed to a COMEX-based pricing system. Using the first-position COMEX price as a base, producers began to 
quote premiums that generally included transportation and insurance costs (Jolly, 1991). The producer price quote came to reflect a weighted average of the delivered price of copper to domestic consumers by domestic producers. Since the adoption of COMEX-based pricing, the producer price margin has averaged about 5 cents per pound of copper, generally increasing at times of low prices and decreasing during high prices and ranging between an annual average of 2 cents and 7 cents per pound. During the high-price period from 2004 to 2010, the producer premium averaged 5.6 cents per pound, not significantly different from the 30 -year average. While the traditional producer prices provided a buffer to price shifts, speculative influence on a COMEX-based pricing system has resulted in increased price volatility, especially during tight markets, such as from late 1987 through 1989, 1995 through 1997, and 2003 through 2010. Periods of stock surpluses and generally lower prices tend to create greater price stability. In response to the greater volatility of COMEX-based pricing, producers and consumers have increasingly used futures markets to hedge their sales and purchases.

Strike periods that take place with expiration of labor contracts have a significant effect on copper prices. The two 6-month strikes in 1946 and 1959, the 9-month strike in 1967-68, and the 5-month strike in 1980 were of particular significance. The 1967-68 strike had the most significant impact because it coincided with a period of high international demand occasioned by the Vietnam War and an unusually high period of worldwide economic growth. Government releases of stockpile material were used to alleviate shortages during each of these incidents, with the exception of the 1980 strike, which took place during a period of high commercial inventories and low Government stocks.

Since at least 1990, mines with capacities that are larger than 100,000 metric tons per year $(\mathrm{t} / \mathrm{yr})$ of copper have constituted from 65 percent to 70 percent of global copper mine capacity, and the largest 20 copper mines have accounted for about 40 percent of global capacity. Given a frequently close balance between production and consumption, disruptions to production at any given large mine can affect prices. For example, from 1989 to 1991, a series of events tempered what might have otherwise been a modest oversupply period. These events included political insurgencies and labor strikes at foreign producers that closed a 180,000-t/yr mine in Papua New Guinea and severely reduced production in Zaire [now Congo (Kinshasa)]. In 2003, in the face of high global inventories, the leading global copper mine producer altered its mine plan by processing lower grade ores and effectively reducing its capacity by $200,000 \mathrm{t} / \mathrm{yr}$ of copper. Similarly, a pit wall failure in Indonesia and a mine strike in Mexico reduced production and contributed to a price spike in 2006.

Governments' interventions in economic policies or directly in copper markets have had significant effects on copper prices. The U.S. Government has taken action during periods of war and national emergency to control prices and levy tariffs, to impose export quotas, to provide price supports, to lend monies for expansion and exploration, to guarantee pro- duction purchases, and to buy and sell for the national stockpile. Most of these strategies, including the use of price controls (1971-74) were applied most recently during the Vietnam War. Beginning in the mid-1960s with the nationalization of copper mines in Chile, Congo (Kinshasa), and Zambia, the private copper mining industry (principally U.S. owned) lost a significant share of its net equity and influence in copper and its ability to adjust production at times of surplus. In 1978 and 1983, which were periods of depressed copper prices, the U.S. industry unsuccessfully filed suit with the International Trade Commission to restrict imports of "low-priced" copper. Currency devaluations by copper-exporting counties had served to lower their costs and maintain production levels. In 1967, the Intergovernmental Council of Copper Exporting Countries (CIPEC) was formed by countries accounting for about 40 percent of global copper mine production. Its attempt to intervene in the depressed copper market in 1975 by limiting production of member countries to 90 percent of normal production and by reducing CIPEC-country copper exports by 15 percent was not fully observed and was unsuccessful in stimulating a price rise (Mikesell, 1979, p. 187-215).

Although the price of copper has been influenced by business cycles, government policy, and technological changes, production costs and the balance or imbalance between supply and demand have ultimately been the principal determinants. The above influences, combined with the large capital investment and long lead times required to develop new mines, have resulted in a highly cyclical copper industry. World mine production reached a peak in 1974 at the height of a major economic recession; this followed capacity growth stimulated by the high-demand Vietnam War years. The resulting oversupply kept prices depressed for 4 years. Strong growth in consumption in the latter part of the 1970s led to tight supplies, high prices, and expansions in global capacity. When a sharp economic recession began in 1981, world mine production and capacity were again reaching peak levels. The resulting oversupply depressed prices for 5 years and resulted in the initial shutdown of about one-third of U.S. mine production. The large surplus and low prices discouraged new production for 3 years and set the stage for the tight supplies and high prices that ensued from 1987 to 1990 . Similarly, a recession in 2001 led to a large inventory surplus and a sustained period of low prices.

World copper inventories began to rise in 1990 with the onset of a global recession and, except for a dip in 1992, continued to rise through most of 1993. Though relatively high by historical standards, copper prices declined as copper inventories rose. In 1992, a short-lived dip in inventories that was attributed to a bottleneck in smelter capacity caused prices to spike upward for several months before resuming their downward trend. Despite rising London Metal Exchange (LME) inventories, a second spike in prices took place in mid1993; a spot shortage of copper developed that was attributed to market control by several large market participants. Prices plummeted in September when the LME intervened to limit 
price backwardation (forward prices selling at a discount to spot prices).

Prices rose sharply in 1994 following a strong growth in world demand, which had stagnated during the preceding 3 years, and the onset of a production deficit. The rapid growth in world demand, fueled by the United States and Asia, stimulated a surge in new capacity development, particularly in South America. Changing political/investment climates, including increased government stability and privatization efforts, made foreign investment more attractive to companies that sought to protect themselves from future downturns by investing in lower cost production. An anticipated surplus in production was delayed, in part, by higher-than-expected consumption and by production disruptions, including political strife in Africa, which reduced expected output. In June 1996, copper prices plummeted from the high level of the previous 18 months, the producer price falling to $\$ 0.94$ per pound, following revelations by Sumitomo that it had lost several billion dollars on unauthorized copper trades and speculation by industry that Sumitomo held large unreported copper inventories (Platt's Metals Week, 1996). Following the sharp drop in prices, however, an increasingly tight copper supply caused prices to rise to $\$ 1.20$ per pound.

With the onset of the Asian economic crises in 1997, demand failed to keep pace with production increases, and a global copper surplus developed. Yearend 1998 inventories held in global metal exchange warehouses (COMEX, LME, and the Shanghai Futures Exchange) rose to 760,000 metric tons ( $\mathrm{t}$ ) from 457,000 $\mathrm{t}$ at yearend 1997. The constant dollar copper price in 1998 fell to the lowest level since the Great Depression of the 1930s. Prices continued their downward trend for the first half of 1999, and exchange warehouse stocks reached a new record high of almost 900,000 t. Prices trended upward in the second half of 1999 to about $\$ 0.80$ per pound as stocks stabilized and North American and South American producers announced production cutbacks.

In 2000, strong consumption growth (led by Asia) and mine production cutbacks resulted in the global productionto-consumption balance shifting from a surplus to a deficit. Combined yearend inventories on the global exchanges fell by more than one-half to about $524,000 \mathrm{t}$, and the monthly average COMEX price ranged between $\$ 0.77$ and $\$ 0.91$ per pound. The deficit market, however, was short lived owing to the onset of a global recession in 2001. Demand for refined copper in 2001 declined for the first time in 10 years, inventories rose, and the COMEX price fell below $\$ 0.70$ per pound of copper. Global exchange inventories continued to rise through April 2002, peaking at more than 1.5 million metric tons (Mt). By yearend, however, inventories began to fall owing to cutbacks in production and the emergence of China as the leading global consumer of refined copper, displacing the United States. Apparent consumption of copper in China rose to 2.8 Mt in 2002 from only $1.5 \mathrm{Mt}$ in 1999 . Though trending downward through the first three quarters of 2003 to below $1 \mathrm{Mt}$, large overhanging exchange inventories kept prices relatively low, and the COMEX copper price averaged only about $\$ 0.77$ per pound for the first three quarters of 2003.

In October 2003, in response to a continued slide in global exchange inventories and concerns over supply disruptions, prices began a steep climb, the COMEX price peaking at yearend at $\$ 1.04$ per pound. This marked the beginning of an upward trend in copper prices to increasingly higher record levels that persisted until the onset of the global financial crisis during the fourth quarter of 2008. By yearend 2004, global exchange inventories had fallen to $124,000 \mathrm{t}$, and the COMEX copper price had risen to a then record-high monthly average of $\$ 1.43$ per pound. Though volatile, copper prices on average continued to climb. In May 2006, the COMEX price reached a new record daily high of $\$ 4.08$ per pound of copper, and in April 2008 reached a new record monthly average high of $\$ 3.94$ per pound. According to data compiled by the International Copper Study Group (ICSG) (2010, p. 9), the balance between refined copper production and consumption showed an almost continuous production deficit and a cumulative production deficit (2003-07) of almost 1.4 Mt of refined copper. Though trending slightly upward from yearend 2004, global exchange inventories remained very low by historical standards.

Several factors contributed to the market imbalance and rise in prices. According to ICSG data (International Copper Study Group, 2010, p. 25), global consumption of refined copper rose by 16 percent $(2.5 \mathrm{Mt}$ ) from 2003 to 2007 , led by a 60-percent growth $(1.9 \mathrm{Mt})$ in China's apparent consumption of refined copper. Meanwhile, despite a 2.7-millionmetric-ton-per-year (Mt/yr) growth in global mine production capacity (International Copper Study Group, 2011b, p. 13), mine production rose by only $1.7 \mathrm{Mt}$. Factors that contributed to a lower mine capacity utilization rate (85.4 percent in 2007 compared with 89.7 percent in 2003) included shortages of equipment, supplies, utilities, and labor that accompanied the coincident production growth and demand increases for copper and other mineral and agricultural commodities; technical problems associated with capacity expansion and startup of new operations; and labor and political unrest, at least in part attributed to higher copper prices. The above limitations reduced miners' ability to produce additional copper at any price. Despite a significant increase in production costs, prices rose significantly above marginal production costs as increased investment interest in commodities spurred a global runup in prices across mineral commodities.

Global copper consumption and prices continued their upward trend through the first 9 months of 2008. In October, however, with the onset of the global financial crisis, prices began a sharp downward spiral that did not come to a halt until December 24, when the COMEX price fell to $\$ 1.25$ per pound of copper, the lowest level since September 2004. Despite a year-on-year growth for the first 8 months of 2008, global consumption of copper for the full-year 2008 was down slightly from that of the previous year. 
Copper prices trended sharply upward in 2009 and 2010, the COMEX price rebounding to an average monthly price of $\$ 3.19$ per pound in December 2009, and a new record-high daily price and monthly average price of $\$ 4.27$ and $\$ 4.17$ per pound, respectively, in December 2010. Though global exchange inventories rose to almost 790,000 $\mathrm{t}$ at yearend 2009 , cutbacks in production in response to the economic crises and a 38-percent growth (2008-09) in China's apparent consumption spurred concerns over future supply adequacy and renewed speculative interest (International Copper Study Group, 2011a, p. 19). Global recovery outside of China in 2010, which helped sustain a renewed growth in global copper consumption and a continuing downward trend in mine capacity utilization, led to a decline in global exchange inventories, increased speculative interest, and the runup in prices.

\section{References Cited}

International Copper Study Group, 2010, ICSG 2010 statistical yearbook: Lisbon, Portugal, International Copper Study Group, July, 79 p.
International Copper Study Group, 2011a, Copper bulletin: Lisbon, Portugal, International Copper Study Group, v. 18, no. 3, March, 54 p.

International Copper Study Group, 2011b, Directory of copper mines and plants - 2009 to 2014: Lisbon, Portugal, International Copper Study Group, March, 118 p.

Jolly, J.L., 1991, Copper, in Metal prices in the United States through 1991: U.S. Bureau of Mines, p. 45-52.

Mikesell, R.F., 1979, The world copper industry: Baltimore, Johns Hopkins University Press, 393 p.

Platt's Metals Week, 1996, Sumitomo copper position raises market anxiety: Platt's Metals Week, v. 67, no. 25, June 7, p. 1.

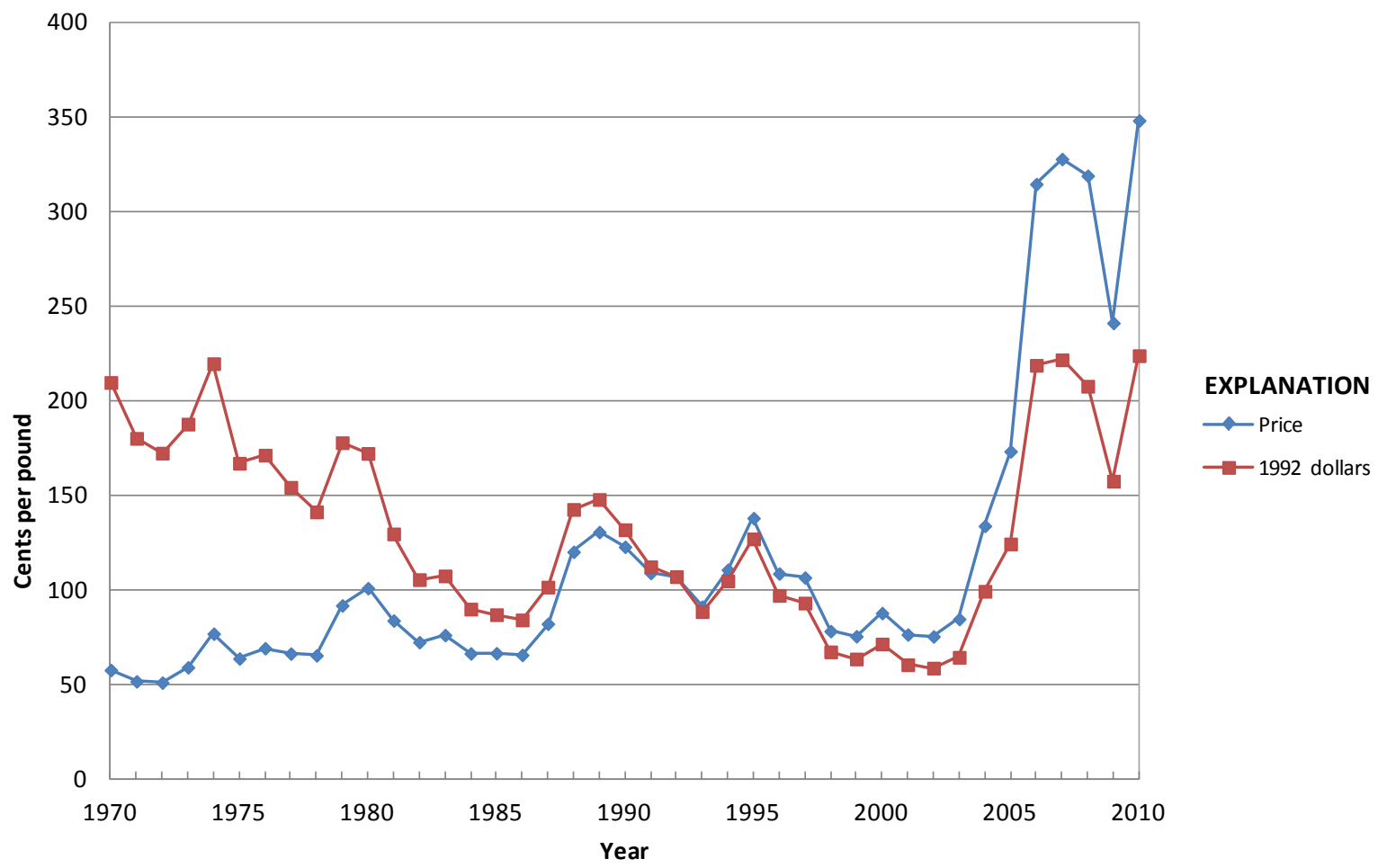

Figure 1. Annual average U.S. producer copper prices. 


\section{Significant events affecting copper prices since 1970}

1970-73 Continued high wartime demand, though export controls and set-asides instituted to meet defense needs were eased; two-tier pricing generates Government concern; price controls limit price rise; nationalization of U.S.owned Chilean properties; the Organization of Petroleum Exporting Countries oil embargo begins

1974 End of price controls and strong demand caused first-half price rise before second-half economic reversal; last wartime-related stockpile release (229,000 metric tons); fixed exchange rates abandoned

1975-77 Demand dropped precipitously owing to recession; copper inventories rose to record levels; high price volatility

1978-80 Record copper consumption and lower stock levels; rising precious metals prices; 5-month labor strike; beginning of Commodity Exchange, Inc. (COMEX)-based pricing

$1981 \quad$ Large growth in domestic and world production; rising inventories

1982-84 Recession; inventory buildup; U.S. production sharply curtailed; expansion of COMEX-based pricing

$1985-6$

1987-89

Drawdown of high copper inventories; cutback in capacity at U.S. mines; cost cutting and efficiency moves

1990-92

Historically low inventories; growing world consumption; prices peaked at \$1.68 in December 1988

Global supply constraints balanced recession; dissolution of the Soviet Union and political turmoil in Africa; precarious supply/demand balance led to price volatility

1993 Stagnant world demand and rising inventories; London Metal Exchange (LME) intervention in market caused sharp price drop in September

1994-95 Strong global demand growth, sharp inventory decline, highest annual price to date; LME opened U.S. warehouses

1996 Sumitomo Corp. revealed huge trading losses, and prices plummeted at midyear despite global inventory decline

1997-98 Asian economic crises and rapid expansion of global capacity combined to generate large global surplus

1999-2000 Asian demand growth and production cutbacks reduced oversupply and encouraged higher prices

2001-02 Global recession reduced demand and led to large inventory buildup; China displaced the United States as leading world consumer of refined copper

2004-07 Explosive growth in China's demand, production disruptions, and delays in new capacity constrained supply; global exchange inventories fell to minimal levels and copper prices rose to new record-high levels, buoyed by investment interest

2008 Onset of global economic crisis in fourth quarter caused prices to plummet and inventories to rise

2009-10 Copper prices rebounded owing to extraordinary growth in China's apparent consumption, continued supply constraints, and renewed interest in commodity investment; China accounted for 38 percent to 39 percent of world demand, up from 12 percent in 2000 
Table 1. Annual average U.S. producer copper price.

[Values in cents per pound]

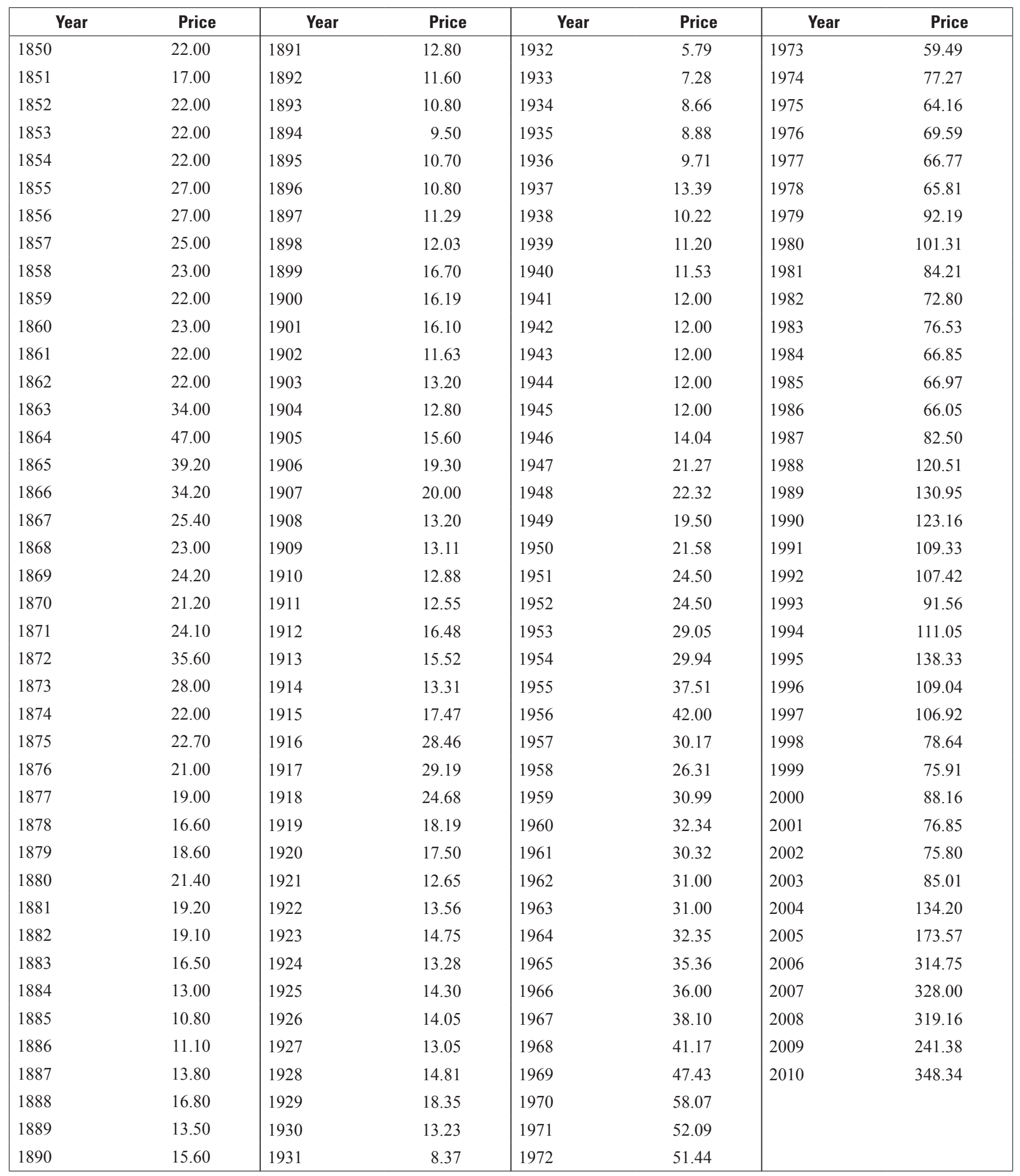


Notes:

1850-96, New York price for Lake copper (99.9-percent-pure copper), in Loughlin, G.F., Prefatory note on the report on gold, silver, copper, lead, and zinc, Mineral Resources of the United States 1922, Part I, U.S. Geological Survey, 1925, p. 127a.

1897-98, New York price for Lake copper (99.9-percent-pure copper), in Engineering and Mining Journal.

1899-1908, Electrolytic (99.9-percent-pure copper) refinery price in New York, in Engineering and Mining Journal.

1909-22, Electrolytic (99.9-percent-pure copper) domestic f.o.b. refinery, in American Metal Market.

1923-72, Electrolytic (99.9-percent-pure copper) domestic delivered to Connecticut price, in American Metal Market.

1973-77, U.S. producer electrolytic (99.9-percent-pure copper) wirebar, in Metals Week.

1978-92, U.S. producer cathode (99.99-percent-pure copper), in Metals Week.

1993-2010, U.S. producer cathode (99.99-percent-pure copper), in Platts (Platt's) Metals Week. 


\title{
Gallium (Ga)
}

\author{
by Brian W. Jaskula
}

In 1875, French chemist Lecoq de Boisbaudran isolated an element and named it gallium, a derivative of Gallia, the Latin name for France. Gallium was initially produced in the United States in 1915 from residues obtained in the redistillation of spelter in the extraction of zinc from zinc concentrates (Petkof, 1985).

Prices shown in the graph are for gallium of 99.9999-percent purity (fig. 1; table 1). This grade has been used since the 1960s in gallium-arsenide (GaAs)-based optoelectronic devices, including light-emitting diodes (LEDs), laser diodes, and solar cells. From 1936 to 1960, prices for 99.9-percent-pure gallium were quoted at $\$ 3,000$ per kilogram; this grade of metal, however, had very limited uses in commercial applications. Most of its consumption was for experimental purposes; small quantities were used in hightemperature thermometers and low-melting-point alloys, and as a specialized mirror coating. Consequently, there was little relationship between prices prior to 1960 and those after that time, when commercial applications were developed.

Gallium is recovered primarily as a byproduct from the refining of bauxite to alumina. As a byproduct metal, price trends for gallium are not significantly influenced by macroeconomic factors; rather, they are driven by gallium supply and demand relationships. The large drop in prices in the early 1960s was principally because of technologic improvements in gallium recovery and purification processes. Commercial gallium extraction techniques were introduced in the late 1950s (Beja, 1951; de la Breteque, 1957). As these processes were improved, the availability of gallium became greater, but the demand did not increase.

Introduction of the GaAs-based LED changed the consumption pattern of gallium from that of a laboratory curiosity to a metal with some consumer applications. LEDs, used in consumer applications such as displays in digital watches and handheld calculators, were responsible for large annual increases in demand from 1966 to 1973 . To capture the LED market, gallium prices continued to drop throughout this period.

Research and development of GaAs's semiconducting properties, which were begun in the mid-1960s, has continued as potential applications for the material continue to be evaluated (Brodsky, 1990). GaAs-based integrated circuits have been developed and have made inroads into low-volume applications, such as sophisticated military warfare systems and supercomputers. Because these are low-volume applications and the quantity of gallium used per unit produced is small, gallium's raw material cost is not a significant factor in the item's final cost. The demand for gallium, therefore, has not increased to a level that cannot be met by existing supplies, and there has been no incentive to increase gallium's price. Although gallium prices have decreased as its uses have grown, it is still used in small quantities compared with many other metals and only in specialized applications where its properties are crucial.

By 2010, GaAs demand was driven mainly by cellular handsets and other high-speed wireless applications, and increasingly by feature-rich, application-intensive, third- and fourth-generation "smartphones," which employ considerably higher GaAs content than standard cellular handsets. The rapidly growing high-brightness LED industry was also a significant driver for GaAs- and GaN (gallium nitride)-based technologies. The backlighting of computer notebook screens, flat-screen computer monitors, and flat-screen televisions was the driving force for high-brightness LED consumption in 2010.

Most gallium prices are directly negotiated between the producer and consumer, with larger volume consumers able to negotiate lower prices. Producer-quoted prices, therefore, may not represent actual selling prices; in most cases, they provide an indication of the trend of gallium prices. Producer-quoted gallium prices have not been published since 2001. Prices since 2002 are based on the average value of U.S. gallium imports as provided by the U.S. Census Bureau.

\section{References Cited}

Beja, Maurice, 1951, Method of extracting gallium oxide from aluminous substances: U.S. Patent 2,574,008, 5 p.

Brodsky, M.H., 1990, Progress in gallium arsenide semiconductors: Scientific American, v. 262, no. 2, February, p. $68-75$.

de la Breteque, Pierre, 1957, Method of recovering gallium from an alkali aluminate lye: U.S. Patent 2,793,179, 6 p.

Petkof, Benjamin, 1985, Gallium, in Mineral facts and problems 1985: U.S. Bureau of Mines, p. 291-296. 


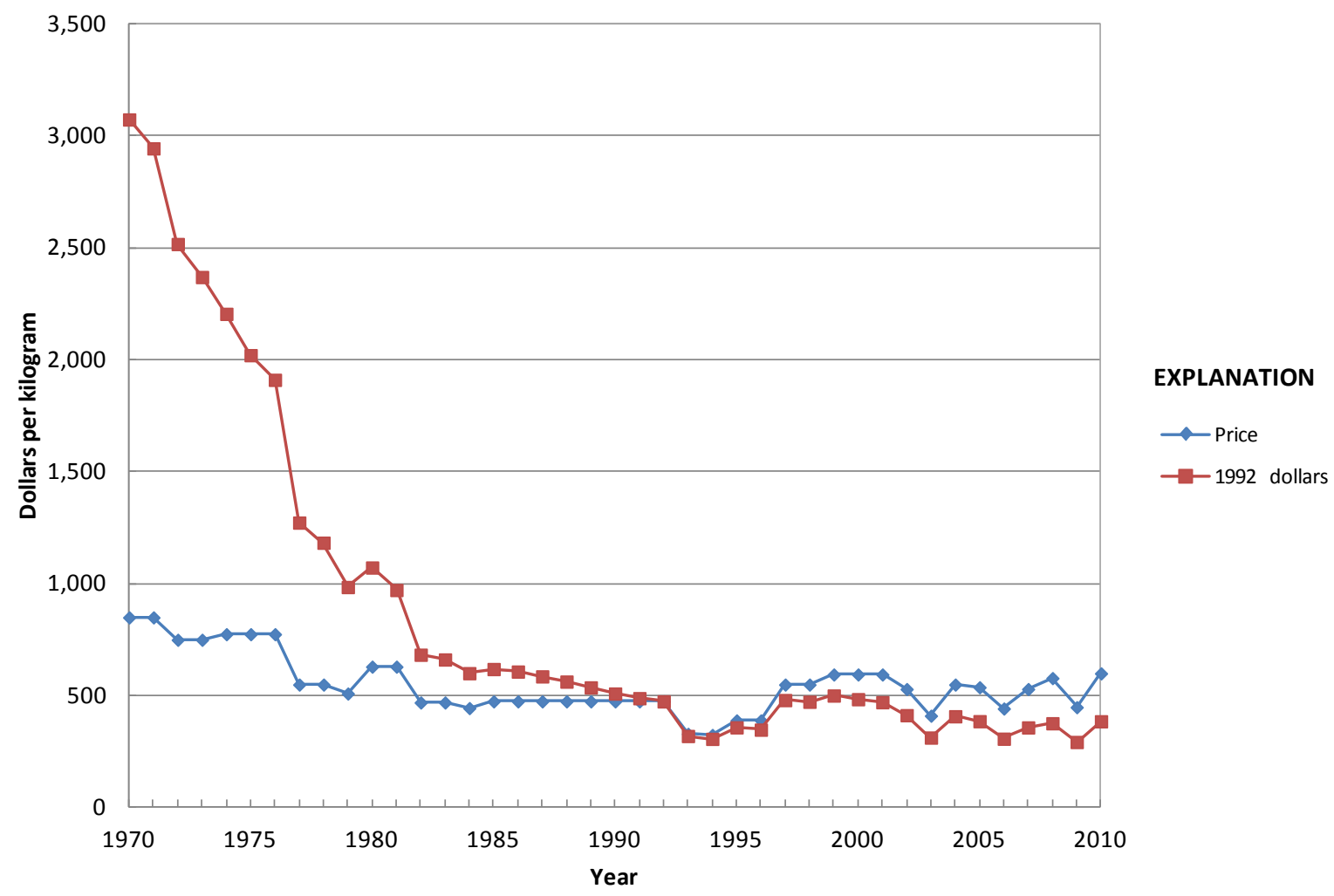

Figure 1. Annual average gallium prices.

\section{Significant events affecting gallium prices since 1970}

1970-73 U.S. gallium demand increased significantly because of widespread use of light-emitting diodes (LEDs)

2009-10 U.S. gallium demand increased significantly owing to rapid growth of feature-rich, gallium arsenide (GaAs)intensive "smartphones," LED-backlit computer notebook screens, flat-screen computer monitors, and flatscreen televisions 


\section{Metal Prices in the United States Through 2010}

Table 1. Annual average gallium price.

[Values in dollars per kilogram]

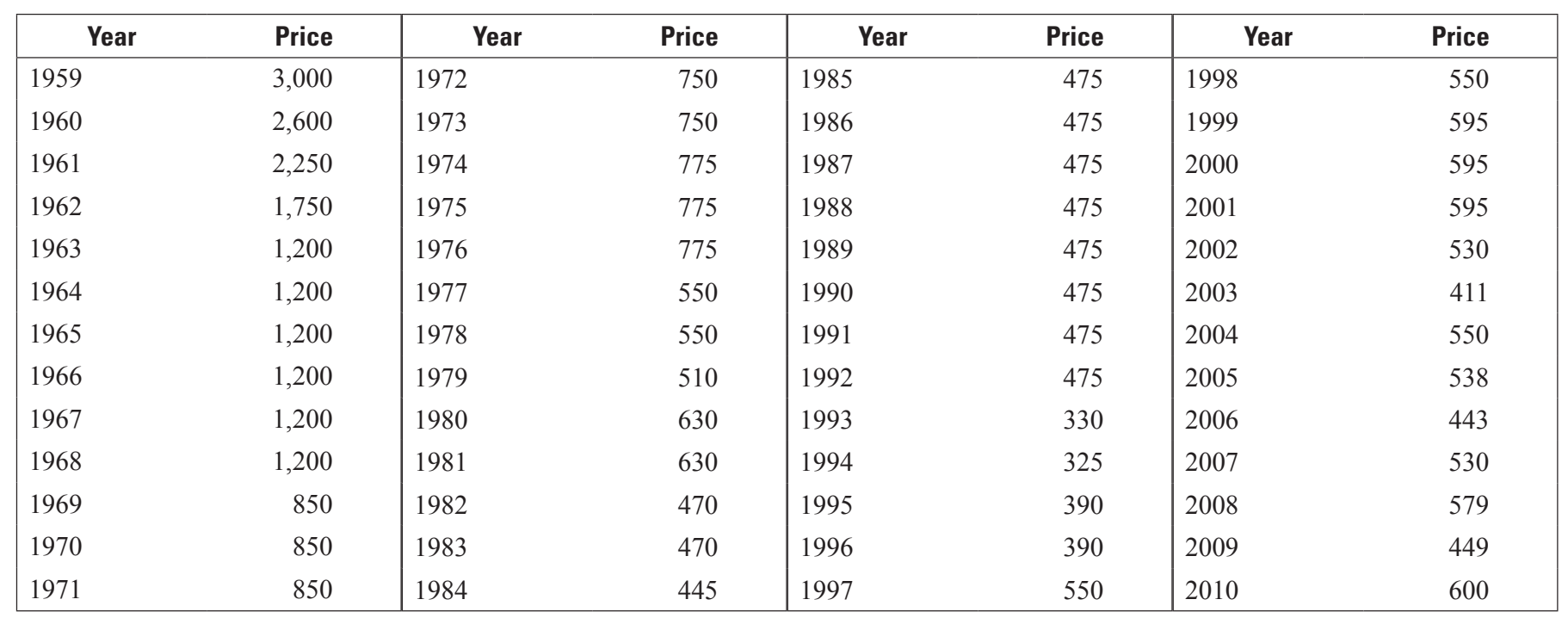

Notes:

1959-2001, 99.9999-percent-pure metal in American Metal Market.

2002-10, average value of U.S. imports for consumption. 


\title{
Germanium (Ge)
}

\author{
by David E. Guberman
}

Germanium was discovered by Clemens Winkler of Germany in 1886, although its existence had been predicted by D.I. Mendeleev in his periodic table of elements in 1869 . Germanium is a hard, grayish-white element; has a metallic luster; has the same crystal structure as diamond; and is brittle, like glass. It is a semiconductor, with electrical properties between those of a metal and an insulator. Germanium and its compounds remained almost entirely items of interest for research until World War II, although the use of germanium dioxide in treating anemia was reported in 1922 (Gregory, 1942).

With the invention and development of the crystal diode and the transistor in the 1940s, germanium became an important industrial material (Bardeen and Brattain, 1948). Prior to 1945 , the amount of germanium produced was very small, a few hundred pounds per year. From 1945 to 1949, the demand for electronic uses resulted in substantial growth of the germanium industry and higher prices for the metal.

After 1953, germanium prices started to decline progressively and, by 1966 , bottomed out at $\$ 175$ per kilogram of metal, the lowest price ever quoted (table 1). This price prevailed for the next 2 years, rose in 1969, and rose again in 1970 because of inflationary trends in the market. Prices remained constant at \$293 per kilogram from 1971 through 1976 (fig. 1).

The invention and development of the germanium transistor opened the door for countless applications of solid-state electronics. From 1950 through the early 1970s, this area provided an excellent market for germanium. In the 1970s, demand for germanium in transistors, diodes, and rectifiers declined, owing mainly to the increasing use of electronicgrade silicon as a replacement. The reduced demand for germanium in the electronics field was offset, however, by dramatic increases in demand in fiber-optic communication networks (Roskill's Letters From Japan, 1997), in infrared night vision systems (Metal Bulletin, 1975), and as a polymerization catalyst (Metal Bulletin, 1995). These end uses represented 77 percent of worldwide germanium consumption for 1998 .

Increased consumption and tight supply caused dramatic increases in both domestic and foreign prices for germanium metal beginning in 1979. By December 1981, the domestic germanium metal quoted price was set at $\$ 1,060$ per kilogram and remained there for 13 years. During most of this period, the free market price remained lower than the published producer price for germanium metal owing to the development of a worldwide excess of supply relative to demand.
Germanium was designated a strategic and critical material and was included in the National Defense Stockpile (NDS) in 1984 with an initial goal of 30,000 kilograms of germanium metal. In 1987, a new NDS goal of 146,000 kilograms was established on the basis of U.S. Department of Defense estimates for actual emergency conditions of mobilization. In 1991, the goal was adjusted downwards to 68,000 kilograms. In 1995, the Defense Logistics Agency, which managed the NDS, planned to sell germanium from the stockpile at the rate of 4,000 kilograms per year through 2005 . The release rate was increased to 6,000 kilograms per year in 1997, the first year of actual sales, and to 8,000 kilograms per year in 1998 (U.S. Department of Defense, 1998).

Starting in 1995, the producer price rose again and fluctuated around $\$ 1,500$ per kilogram. It reached $\$ 2,000$ per kilogram in 1996. The higher price levels were because of increased demand and shortages in production. The gradual releases of germanium from the United States, Russian, and Ukrainian stockpiles concurrent with the lowering of world military tensions tended to stabilize prices.

In 1998, germanium prices increased despite an oversupply that resulted from slight decreases in world demand for optical fibers and polyethylene terephthalate, and an increase in total supply owing to greater amounts of recycling and continued releases of germanium from national stockpiles. This increase in price was probably due to anticipated demand in the satellite communications sector, and, when this increase in demand did not take place in 1999, germanium prices began to fall. This same mechanism prevailed in 2000. Demand in satellite applications did not increase, and prices continued to fall. Germanium prices continued to decline until 2004.

The use of germanium in infrared equipment and solar cells for satellites by military and civilian security forces increased after the terrorist attacks of September 11, 2001, and with United States military operations in Afghanistan and Iraq. Demand for germanium and prices increased in late 2006-07 owing to increased use in the construction of fiberoptic networks in many regions of the world. The fiber-tothe-home market began to gain momentum during this time period. Germanium also began to be used in greater quantities for terrestrial-based solar cells and light-emitting diodes. China removed toll trading tax benefits for germanium and most other minor metals in April 2007, effectively decreasing the supply of germanium to the world market and increasing prices (Metal Bulletin, 2007).

A downturn in the global economy began during the second half of 2008 and continued in 2009. The market price of germanium declined throughout 2009 owing to weakened 
global demand. Free market prices for germanium dioxide in 2009, published by Metal-Pages, began the year at about $\$ 920$ per kilogram and declined by 37 percent to $\$ 580$ per kilogram by yearend. The free market prices for germanium metal began the year at $\$ 1,425$ per kilogram and declined by 34 percent to $\$ 940$ per kilogram by yearend 2009 . The market prices of germanium dioxide and metal were relatively stable during the first three quarters of 2010 and increased in the last quarter. Germanium prices have proven to be relatively volatile at times owing to limited supply sources and the lack of substitutability in many applications. It should be noted that price changes can potentially be caused by changes in the source of price quotations.

\section{References Cited}

Bardeen, John, and Brattain, W.H., 1948, The transistorA semiconductor triode: Physics Review, v. 74, Series 2, July 15 , p. 230-231.
Gregory, T.C., 1942, Germanium, in The condensed chemical dictionary: New York, Reinhold, p. 320.

Metal Bulletin, 1975, Minor, precious metals-Germanium: Metal Bulletin, no. 5971, March 4, p. 21.

Metal Bulletin, 1995, Germanium dioxide prices continue to firm: Metal Bulletin, no. 7982, May 25, p. 7.

Metal Bulletin, 2007, China to cancel minor toll trading benefits: Metal Bulletin, no. 8991, April 16, p. 12.

Roskill's Letters From Japan, 1997, Germanium-Growth in demand led by the use of high-purity germanium tetrachloride in optical fibres: Roskill's Letters From Japan, no. 256, August, p. 2-6.

U.S. Department of Defense, 1998, Strategic and critical materials report to the Congress: U.S. Department of Defense, January 13, 43 p.

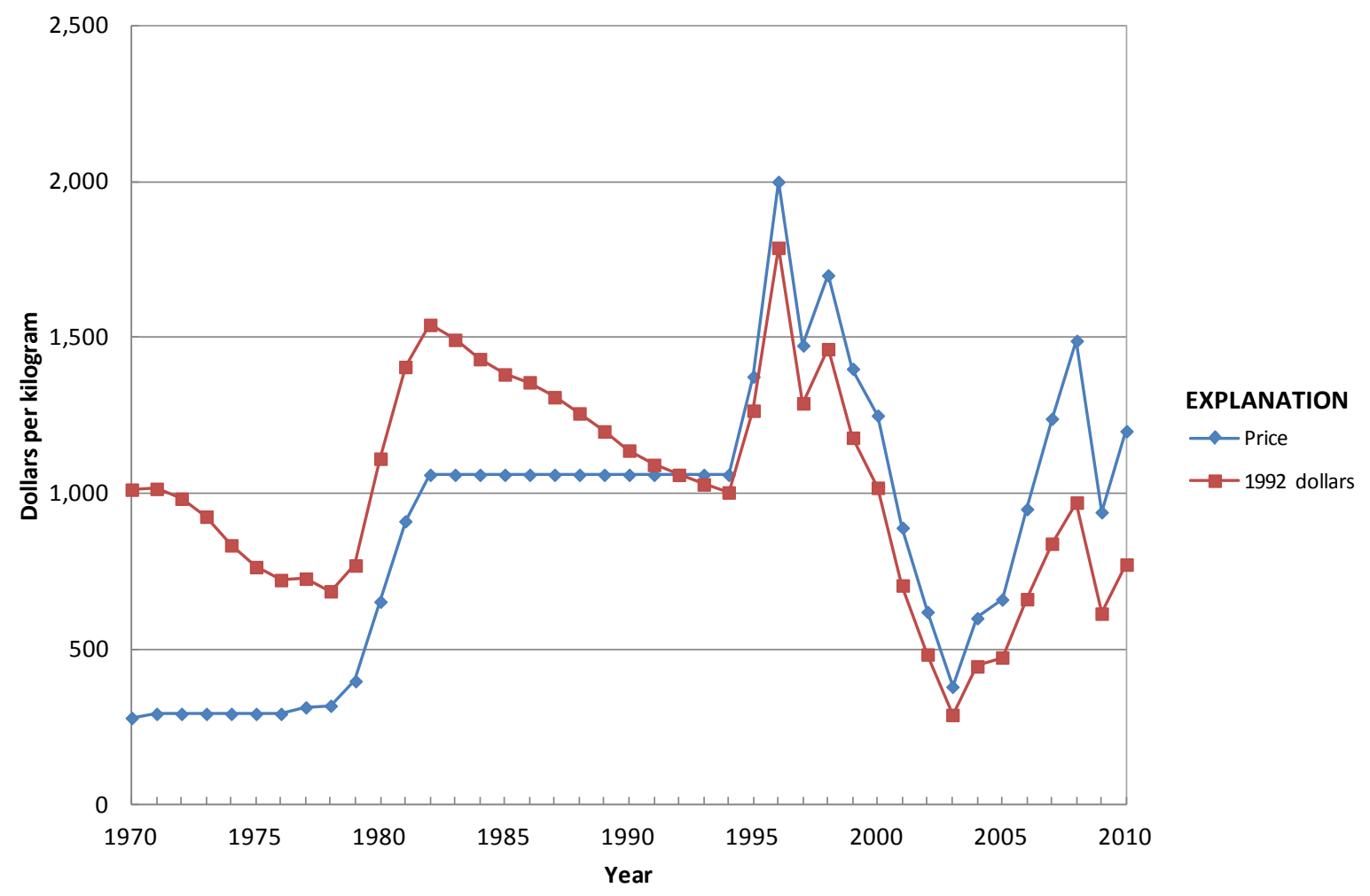

Figure 1. Annual average germanium price. 


\section{Significant events affecting germanium prices since 1970}

1979-82 Increased demand, tight supply

$1984 \quad$ National Defense Stockpile (NDS) authorization, goal 30,000 kilograms

1987 New authorized NDS goal of 146,000 kilograms

$1991 \quad$ NDS goal lowered to 68,000 kilograms

1996 Increased demand, production shortages

1997 NDS stockpile sales began

2001 Events on September 11, 2001, increased military demand for infrared devices

2006-07 Increased global demand, relatively tight supply

2008-10 Global economic crisis, prices declined

Table 1. Annual average germanium price.

[Values in dollars per kilogram]

\begin{tabular}{|c|c|c|c|c|c|c|c|}
\hline Year & Price & Year & Price & Year & Price & Year & Price \\
\hline 1945 & 441 & 1962 & 300 & 1979 & 398 & 1996 & 2,000 \\
\hline 1946 & 397 & 1963 & 270 & 1980 & 653 & 1997 & 1,475 \\
\hline 1948 & 507 & 1965 & 270 & 1982 & 1,060 & 1999 & 1,400 \\
\hline 1949 & 727 & 1966 & 175 & 1983 & 1,060 & 2000 & 1,250 \\
\hline 1951 & 397 & 1968 & 175 & 1985 & 1,060 & 2002 & 620 \\
\hline 1952 & 484 & 1969 & 185 & 1986 & 1,060 & 2003 & 380 \\
\hline 1953 & 720 & 1970 & 280 & 1987 & 1,060 & 2004 & 600 \\
\hline 1954 & 650 & 1971 & 293 & 1988 & 1,060 & 2005 & 660 \\
\hline 1955 & 650 & 1972 & 293 & 1989 & 1,060 & 2006 & 950 \\
\hline 1959 & 350 & 1976 & 293 & 1993 & 1,060 & 2010 & 1,200 \\
\hline 1960 & 300 & 1977 & 314 & 1994 & 1,060 & & \\
\hline 1961 & 300 & 1978 & 319 & 1995 & 1,375 & & \\
\hline
\end{tabular}

Notes:

1945-57, Domestic price for 99.9-percent-pure germanium, in Engineering and Mining Journal, Metal and Mineral Markets.

1957-66, Domestic price for zone-refined germanium (99.9999-percent pure), in Engineering and Mining Journal, Metal and Mineral Markets.

1967-81, Domestic price for zone-refined germanium (99.9999-percent pure), in Metals Week.

1982-93, U.S. producer price for zone-refined germanium (99.9999-percent pure), in Metals Week.

1993-94, U.S. producer price for zone-refined germanium (99.9999-percent pure), in Platt's Metals Week.

1995-2010, U.S. producer price quotes for zone-refined germanium (99.9999-percent pure), in Metal Bulletin. 


\title{
Gold (Au)
}

\author{
by Micheal W. George
}

Gold was highly regarded by ancient civilizations that possessed it because of its scarcity, durability, and malleability. In ancient times, gold was used for jewelry, craft, or ceremonial purposes and not for its monetary value. Its characteristic yellow color was reminiscent of the sun, which was worshiped as a deity. Because of its high specific gravity, it was first recovered from streambed gravels as nuggets or flakes, where it occurred in metallic form, and thus required no complicated metallurgical extraction from ores; it was essentially imperishable and was easily worked.

These beautiful and seemingly indestructible nuggets were prized possessions that could be fashioned into bars of different set weights, and into ornaments and items of adornment that also served as portable wealth. At first crude, but increasingly refined and specialized over the years, these manufactured forms eventually diverged, at least partly, into jewelry and money. For more than five millennia, until well into the 20th century, they were the only quantitatively important uses of gold.

During that time, there remained, and in some developing countries remains today, a functional overlap between jewelry and money; that is, items of gold jewelry have been used as money, and gold money has been made into items of jewelry. Crude forms of jewelry/money appear to have originated soon after the founding of the first cities. The invention of money is commonly ascribed to the Mesopotamians or, more specifically, the Sumerians, who lived in what is now southern Iraq. The art of working gold and silver into jewelry and (or) money seems to have arisen in Crete, Egypt, and Sumer at roughly the same time - probably around 3000 B.C. From the beginning, the universal perception of gold as a store of wealth has been implicit in its use as money and jewelry (Green, 2007).

Increases in gold price have had a good basis in history. From 1344 to 1717 , the price for gold almost quadrupled, reaching the equivalent of $\$ 20.67$ per troy ounce. That price was maintained for more than 200 years until the enactment of the Gold Reserve Act, which increased the price of gold to $\$ 35$ per troy ounce, on January 30, 1934. Pressure for still another increase in price gathered momentum less than 15 years later. Prices as high as $\$ 105$ per troy ounce had been proposed, and world trade brought prices up to $\$ 70$ per troy ounce (Colorado School of Mines, 1959).

In November 1961, the London gold pool, in which central banks of the United States and seven other nations agreed to buy and sell gold to support the \$35-per-troy-ounce price, was established (Ryan and McBreen, 1962, p. 607). On March 17, 1968, the governors of the member central banks announced that they would no longer buy and sell gold in the private market but would sell gold to each other for $\$ 35$ per troy ounce. Thus, a two-tier market was established-an official market and a private market - in which the price was determined by supply and demand (Ryan, 1969, p. 535).

Following the establishment of the two-tier price system, a fixed price of $\$ 35$ per troy ounce for official monetary transactions and a floating market price for private transactions, the U.S. Government asked Engelhard Minerals and Chemicals Corp. (known today as Engelhard), to quote a daily price. Engelhard initiated a buying quotation - the lowest price at which it could obtain sufficient gold of 99.95 percent purity to meet its requirements. A selling quotation $\$ 0.60$ above the buying price, later reduced to $\$ 0.40$, was also established (Ryan, 1969, p. 535). Thus, the basis for the average domestic market price for gold shown in the table was established (fig. 1; table 1).

On August 15, 1971, the President announced the suspension of convertibility of dollars into gold. Following provisions of Public Law 92-268, the Par Value Modification Act, enacted March 31, 1972, the official price of gold was increased to $\$ 38$ per troy ounce on May 8, 1972 (West, 1975, p. 557).

Following amendments to the Par Value Modification Act contained in Public Law 93-110, enacted on September 21,1973 , the dollar's par value was devalued by 10 percent, to 0.829848 Special Drawing Rights [a unit of account in the International Monetary Fund (IMF)]. This fixed the official price of gold at $\$ 42.22$ per troy ounce effective at 12:01 a.m., October 18, 1973. That price remains unchanged (West, 1975, p. 560).

Gold occupies a unique position among the world's commodities; it is an internationally traded commodity and a long-established, universally acceptable storehouse of value, considered by many people worldwide to be superior to fiat paper currencies with fleeting longevity or fluctuating unpredictable value. It has been said many times that gold is "forever;" its high intrinsic and monetary value usually dictates that, in time, most of it will be recycled to serve again. Because of its historically high value, much of the gold mined throughout history is still in circulation in one form or another (Lucas, 1993, p. 505).

As a consequence of the dual roles played by gold, as commodity and as money, its price cannot be viewed as one would view the price of other goods or services in a free market. Gold also cannot be viewed strictly from the standpoint of the U.S. market alone because international political and 
economic events that may influence the market for gold as a commodity may be outweighed by developments perceived to favor gold as a medium of exchange.

During 1969 and 1970, the United States experienced a mild recession, while the Republic of South Africa was permitted to sell gold to the IMF at $\$ 35$ per troy ounce or less to meet its foreign exchange needs (Hoyt, 1971, p. 521).

By December 1971, the U.S. dollar had been devalued by 7.9 percent per exchange agreements reached during the Smithsonian Accords in Washington, D.C. Affected by previous year's devaluation, the official U.S. gold price was raised to $\$ 38$ per troy ounce on May 8,1972 ; speculative buying was encouraged by monetary policy changes made by the European Economic Community and by restricted supplies of newly mined gold (West, 1974, p. 567).

In 1973, the gold market was influenced by a weakening and devaluation of the U.S. dollar, lowered confidence in currency values, higher inflation rates, unsettled world trade, and, for the third consecutive year, lower mine production. The official U.S. gold price was increased to $\$ 42.22$ per troy ounce on September 21. An embargo was begun on petroleum shipments to the United States by the Organization of Petroleum Exporting Countries (OPEC) in mid-October. The two-tier gold price system, begun in 1968, was terminated on November 13, 1973 (West, 1975, p. 557).

The OPEC embargo contributed to rising oil prices, worldwide inflation, and general economic uncertainty in 1974. Following provisions of Public Law 93-373, enacted August 14, 1974, the President was given the authority to repeal the prohibition on the holding of gold by private citizens, and effective December 31, 1974, the prohibition was repealed and gold prices rose on speculation. The gold price trend was reversed in December by the U.S. Treasury's announcement that it would offer 62,200 kilograms (kg) ( 2 million troy ounces) of Treasury gold for public sale beginning on January 6,1975 . Investor and speculator interest was diminished by the announcement by the IMF that it would sell 778,000 kg (25 million troy ounces) of gold on the open market beginning in 1976. The Treasury, however, was able to sell 38,900 kg (1.25 million troy ounces) from its gold stock during 1975 (West, 1977, p. 669).

Monthly IMF auctions were begun in midyear 1976 to provide capital for low-interest loans to developing countries. The IMF planned to sell a total of one-sixth of its gold stocks, or $778,000 \mathrm{~kg}$ (25 million troy ounces), during a 5-year period, and planned to restore an equal portion to member countries. In addition, a reduced inflation outlook drove prices down until October, when the low gold price and renewed anxiety about the economy served to reverse price trends. The Treasury gold stock was down at yearend owing to its use in Bicentennial medals, which were made by the Bureau of the Mint (West and Butterman, 1978, p. 591).

The world economy was stagnant in 1977 . Limited success in controlling inflation led to higher gold prices, which benefitted the IMF auctions that continued throughout the year. There was a hiatus in Treasury sales (Butterman, 1980, p. 428).

IMF auctions continued during 1978, and the Treasury resumed gold stock selling (Butterman, 1980, p. 428). Middle East oil-producing countries and investors began purchasing gold with their eroding dollar assets.

Economic conditions worsened during the next 3 years. Political events in Iran, Afghanistan, and elsewhere propelled the price of gold to a high of $\$ 850$ per troy ounce by January 21,1980 . The IMF completed its 5-year auction program in May 1980. The Treasury sold no more gold in 1980 or 1981 (Lucas, 1981, p. 347). After the U.S. hostages were released by Iran on January 20, 1981, political tension was lessened, which led to less hoarding and reduced gold prices. The Japanese began to invest in the gold market.

Although the U.S. strict monetary policy contributed to a recession and high interest rates in 1982, the advent of computer trading contributed to short-term volatility in the gold price. Lingering effects of the world economic recession on the mineral industry led to profit taking during the first part of 1983. Speculative gold trading to midyear strengthened price but was followed by profit taking (Lucas, 1984, p. 385). Oil prices weakened, while gold supplies from mines and official sources increased.

In 1984, the price declined owing to increasing strength of the U.S. dollar and investor selling. Weakened price and a favorable market outlook contributed to increases in demand for gold-bearing fabricated products. The U.S. dollar weakened in the first quarter of 1985 against major European currencies and the Japanese yen. It continued weakening in 1986, which encouraged gold investment (Lucas, 1988, p. 441) as oil prices declined sharply.

By 1987, there was a sharp reversal in world stock markets with a continued weakness of the U.S. dollar combined with growing concern regarding U.S. budget and trade deficits and increasing U.S. private and Third World debt. Stability of the international monetary arrangements was questioned. Volatile investment markets generated increased gold-trading activity (Lucas, 1988, p. 441). During 1988, gold prices declined in response to a variety of factors, such as the withdrawal of the Soviet troops from Afghanistan, which gave investors the perception that political stability was at hand; weakening oil prices combined with an increase in interest rates by the U.S. Federal Reserve led to reduced inflationary expectations, increasing U.S. dollar strength, as well as improving U.S. trade results (Lucas, 1989, p. 64-65).

Official sector gold sales increased in 1989 as central banks adopted a more aggressive policy of gold management. In addition, a change of attitude developed toward gold, aided by concerns about the security of bonds and other financial assets and a setback in the U.S. stock markets in mid-October (Gold Fields Mineral Services Limited, 1990, p. 8).

The rise in Japanese interest rates in 1990 provided alternate investment havens. The former Soviet Union was reported to have sold significant amounts of gold for hard 
currency. The Chinese sold out of equity swap agreements that were negotiated in mid-1989. The gold price drifted down as a result of the Persian Gulf War and the recession (Gold Fields Mineral Services Limited, 1991, p. 8-9).

The brief multination conflict that started in 1991 in the Persian Gulf did little to affect the perception of moderating political stability generally or to influence the price of gold for any sustained period of time. The collapse and restructuring of the Soviet Union, however, did much to reduce investor interest in gold (Gold Fields Mineral Services Limited, 1992, p. 5).

The end of the 1992 bear market encouraged a return of European and U.S. investor confidence. In 1993, the high gold price, which particularly affected the local currencies of the Middle East and Asia, resulted in reduced hoarding of coins and large amounts of gold scrap being introduced into the market (Roskill Information Services Ltd., 1995, p. i).

During 1994, the gold market held onto the gains achieved during the previous year, but the U.S. dollar price lacked direction and volatility. Hoarding of gold continued to be reduced as investors deserted the market (Roskill Information Services Ltd., 1995, p. i).

The average dollar price of gold remained almost unchanged between 1994 and 1996. Late in the fourth quarter of 1996, the Dutch Government provided a key catalyst by selling one-third of its reserves (Gold Fields Mineral Services Limited, 1997, p. 5). Fears that other central banks might sell their gold reserves followed (CRU International Ltd., 1996, p. 19).

During 1997 through 2001, central banks of several countries sold large shares of gold holdings to meet commoncurrency criteria for the European Union or to demonetize. Bank failures or insolvencies in East and Southeast Asian countries created uncertainty in investment circles. The price of gold returned to the low levels of 1979 (Gold Fields Mineral Services Limited, 1998, p. 5).

The gold price started to increase in late 2001 after the terrorist attacks on September 11, and continued to climb into 2010. The annual average price of gold in 2001, the lowest level since 1978 , was $\$ 272.22$ per troy ounce. After 9 continuous years of near-double-digit-percentage yearly increases, the average annual price in 2010 was $\$ 1,227.51$ per troy ounce or 351 percent greater than the 2001 price. The driving force behind the price surge has been the increased investments, lack of sales from central banks, producer dehedging, and decreased mine production. Many investors turned to gold as a safe haven investment because of the multiple wars, global economic downturns, and devaluation of the U.S. dollar.

In 2003, a gold exchange traded fund (ETF) first appeared. Gold ETFs have gained popularity with many investors. According to some industry analysts, investing in gold in the traditional manner is not as accessible and carries higher costs owing to insurance, storage, and higher markups. The claimed advantage of the ETF is that the investor can purchase gold ETF shares through a stockbroker without being concerned about these problems, and the ETFs are treated by regulators as securities. Each share represents one-tenth of an ounce of allocated gold. With the advancement of ETFs, investors had easier access to gold as an investment. By the end of 2010, there were 23 ETFs and 2 physically backed Canadian funds, which had physical gold holdings of 2,190 metric tons (CPM Group, 2011, p. 41-46).

\section{References Cited}

Butterman, W.C., 1980, Gold, in Metals and minerals: U.S. Bureau of Mines Minerals Yearbook 1977, v. I, p. 427-445.

Colorado School of Mines, 1959, The price for gold: Colorado School of Mines Mineral Industries Bulletin, v. 2, no. 6, November, p. 10.

CPM Group, 2011, The CPM Group gold yearbook 2011: New York, CPM Group, 245 p.

CRU International Ltd., 1996, Gold: CRU International Ltd. Quarterly Market Service, November, 60 p.

Gold Fields Mineral Services Limited, 1990, Gold 1990: [London], Gold Fields Mineral Services Limited, 64 p.

Gold Fields Mineral Services Limited, 1991, Gold 1991: [London], Gold Fields Mineral Services Limited, 64 p.

Gold Fields Mineral Services Limited, 1992, Gold 1992: [London], Gold Fields Mineral Services Limited, 64 p.

Gold Fields Mineral Services Limited, 1997, Gold 1997: [London], Gold Fields Mineral Services Limited, 71 p.

Gold Fields Mineral Services Limited, 1998, Gold 1998: [London], Gold Fields Mineral Services Limited, 63 p.

Green, Timothy, 2007, The ages of gold: [London], Gold Fields Mineral Services Limited, 446 p.

Hoyt, C.D., 1971, Gold, in Metals, minerals, and fuels: U.S. Bureau of Mines Minerals Yearbook 1969, v. I, p. 521-538.

Lucas, J.M., 1981, Gold, in Metals and minerals: U.S. Bureau of Mines Minerals Yearbook 1980, v. I, p. 347-373.

Lucas, J.M., 1984, Gold, in Metals and minerals: U.S. Bureau of Mines Minerals Yearbook 1983, v. I, p. 385-411.

Lucas, J.M., 1988, Gold, in Metals and minerals: U.S. Bureau of Mines Minerals Yearbook 1986, v. I, p. 421-458.

Lucas, J.M., 1989, Gold: U.S. Bureau of Mines Mineral Commodity Summaries 1989, p. 64-65.

Lucas, J.M., 1993, Gold, in Metals and minerals: U.S. Bureau of Mines Minerals Yearbook 1990, v. I, p. 495-522.

Roskill Information Services Ltd., 1995, Gold-Market update, analysis, and outlook: Roskill Information Services Ltd., 145 p., 3 apps., unpaginated. 
Ryan, J.P., 1969, Gold, in Metals, minerals and fuels:

U.S. Bureau of Mines Minerals Yearbook 1968, v. I-II, p. 529-549.

Ryan, J.P., and McBreen, K.M., 1962, Gold, in Metals and minerals (except fuels): U.S. Bureau of Mines Minerals Yearbook 1961, v. I, p. 597-618.

West, J.M., 1974, Gold, in Metals, minerals, and fuels: U.S. Bureau of Mines Minerals Yearbook 1972, v. I, p. 567-588.
West, J.M., 1975, Gold, in Metals, minerals, and fuels: U.S. Bureau of Mines Minerals Yearbook 1973, v. I, p. 557-581.

West, J.M., 1977, Gold, in Metals, minerals, and fuels: U.S. Bureau of Mines Minerals Yearbook 1975, v. I, p. 669-696.

West, J.M., and Butterman, W.C., 1978, Gold, in Metals, minerals, and fuels: U.S. Bureau of Mines Minerals Yearbook 1976, v. I, p. 591-615.

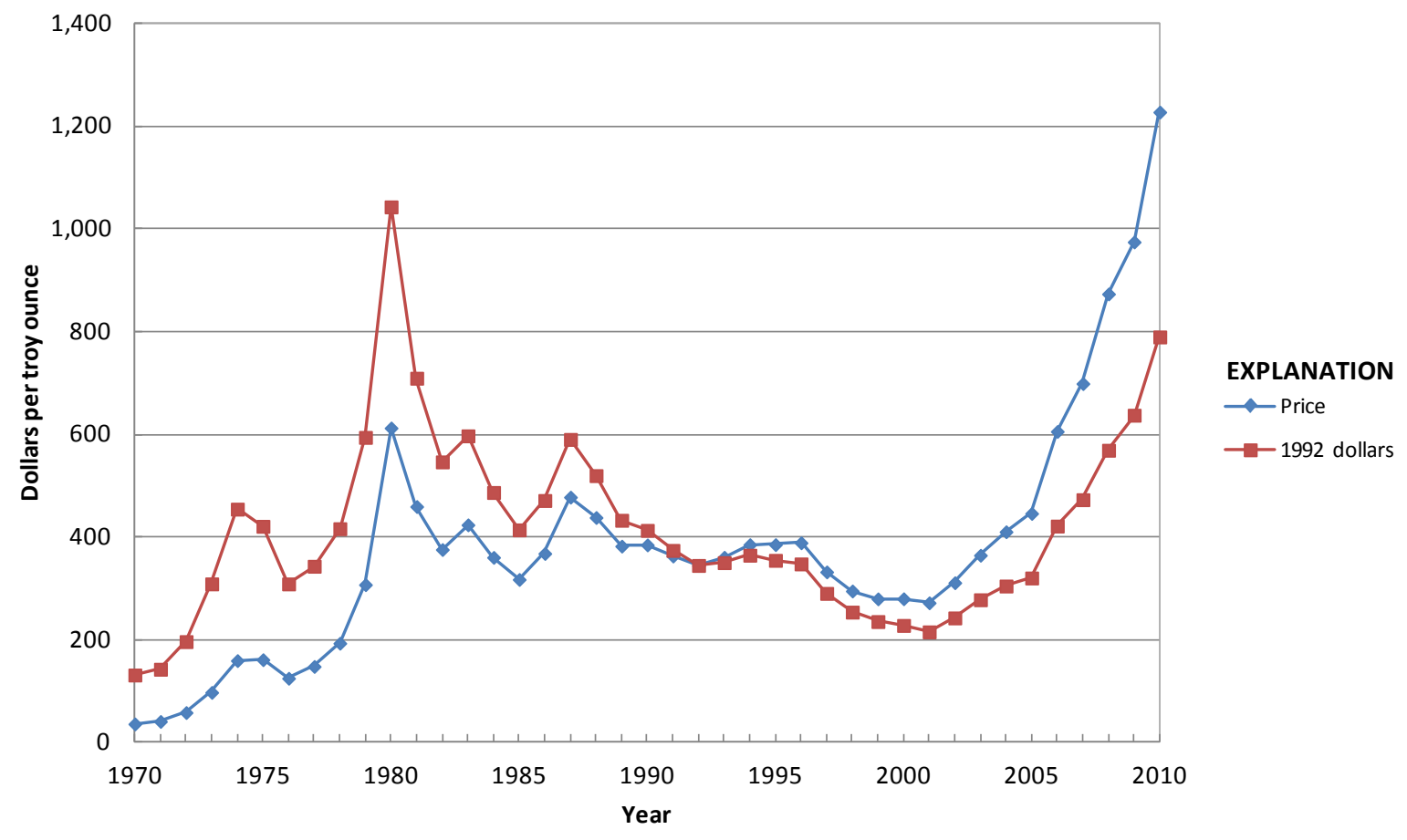

Figure 1. Annual average gold price. 


\section{Significant events affecting U.S. gold prices since 1970}

1971 President suspended convertibility of dollar into gold; dollar devalued by 7.9 percent

1972

1973

Official U.S. gold price increased to $\$ 38$ per troy ounce

1974

Official U.S. gold price increased to $\$ 42.22$ per troy ounce, dollar devalued, two-tier gold price terminated,

Organization of Petroleum Exporting Countries (OPEC) oil embargo begins

1975

U.S. citizens allowed to hold gold bullion and coins for the first time in 40 years

1976

U.S. Treasury began public sales of gold stocks

International Monetary Fund (IMF) began 5-year gold sales program; IMF auctions and lower inflation outlook drove gold prices down

1977 Hiatus in U.S. Treasury gold sales

1978

1979

U.S. Treasury resumed selling gold; Middle Eastern investors increased gold purchases

1980

Soviet Union invaded Afghanistan; political upheaval in Iran; taking of U.S. hostages

Gold price peaked at an historic daily high of $\$ 850$ per troy ounce on January 21; IMF completes 5-year gold sales program

1982-88 Fluctuating world currency exchange rates, increasing concern about U.S. trade and budget deficits and banking problems, and Third World debt

1989-91 Conflict in the Persian Gulf and the breakup of the Soviet Union; erosion of gold's role as a safe haven for investors; generally weak economic growth worldwide

1992-96 Gold price remained relatively stable

1997-2001 Central banks of several countries sold large shares of gold holdings to meet common-currency criteria for

European Union or to demonetize; bank failures or insolvencies in East and Southeast Asian countries

$2001 \quad$ September 11 terrorist attacks

2002-10 Prices surged because of increase in investment in gold stemming from political and economic concerns

Table 1. Annual average gold price.

[Values in dollars per troy ounce]

\begin{tabular}{|c|c|c|c|c|c|c|c|}
\hline Year & Price & Year & Price & Year & Price & Year & Price \\
\hline 1968 & 40.06 & 1979 & 307.50 & 1990 & 384.93 & 2001 & 272.22 \\
\hline 1969 & 41.51 & 1980 & 612.56 & 1991 & 363.29 & 2002 & 311.33 \\
\hline 1971 & 41.25 & 1982 & 375.91 & 1993 & 360.91 & 2004 & 410.52 \\
\hline 1972 & 58.60 & 1983 & 424.00 & 1994 & 385.41 & 2005 & 446.20 \\
\hline 1974 & 159.74 & 1985 & 317.66 & 1996 & 389.08 & 2007 & 698.95 \\
\hline 1975 & 161.49 & 1986 & 368.24 & 1997 & 332.38 & 2008 & 873.50 \\
\hline 1976 & 125.32 & 1987 & 477.95 & 1998 & 295.24 & 2009 & 974.68 \\
\hline 1977 & 148.31 & 1988 & 438.31 & 1999 & 279.91 & 2010 & $1,227.51$ \\
\hline 1978 & 193.55 & 1989 & 382.58 & 2000 & 280.10 & & \\
\hline
\end{tabular}

Notes:

1968-93, Englehard domestic market price, 99.95-percent-pure gold, in Metals Week.

1994-2010, Englehard domestic market price, 99.95-percent-pure gold, in Platts (Platt's) Metals Week. 


\title{
Hafnium (Hf)
}

\author{
by Joseph Gambogi
}

In 1923, hafnium was discovered when Dirk Coster and George Charles von Hevesey separated it from zirconium. Anton Eduard van Arkel and Jan Hendrik de Boer first produced metal 2 years later by using the crystal bar process - hafnium tetrachloride passed over a tungsten filament (van Arkel and de Boer, 1925). Hafnium and zirconium occur together in the ore mineral zircon. Until the 1940s, fractional crystallization of zirconium-hafnium compounds was used to produce limited quantities of hafnium oxide and metal powder. In 1948, hafnium metal powder was quoted at $\$ 32$ per gram (\$32,000 per kilogram). Because of the high costs associated with this technique, a more economical means of recovery was sought. Development of improved methods to separate the two elements began in the 1940s. In 1949, the price of hafnium metal powder dropped to $\$ 22$ per gram $(\$ 22,000$ per kilogram). That same year, Carbide \& Chemicals Corp., Oak Ridge, Tenn., developed a liquid-liquid solvent extraction technique to remove hafnium from zirconium, technology that had grown out of the Manhattan Project (Powell, 1961). Commercial production of hafnium arose from the need to produce hafnium-free zirconium metal for use in nuclear reactors. In 1950, a decision was made to use zirconium in the prototype land-based Nautilus nuclear reactor for future use in submarines (Wilson and Staehle, 1960, p. 1). In 1951, hafnium was selected as the material to be used in the reactor's control rods.

Hafnium was an expensive laboratory metal in 1945 when development work on an improved magnesiumreduction process (Kroll process) began at the U.S. Bureau of Mines' (USBM) Northwest Electrodevelopment Experiment Station in Albany, Oreg. (Etherington, Dalzell, and Lillie, 1955 , p. 2). A pilot plant to produce zirconium metal using the Kroll process began operating in 1947 and was expanded in 1949, 1950, and twice in 1951 (Kroll, 1937; Kroll, Schlechten, and Yerkes, 1946; Kroll, Schlechten, and others, 1947; Kroll, Anderson, and others, 1948). It was not until 1951, however, that the USBM facility produced several kilograms of hafnium metal grading 28 percent hafnium and the balance zirconium. By yearend 1951, the USBM produced 3,916 kilograms of hafnium oxide that was used to produce 1,395 kilograms of hafnium sponge (Smith and Stephens, 1960, p. 84).

Hafnium's commercial availability coincided with the expiration of U.S. Department of Defense contracts for nuclear reactors in 1962. The price remained stable at about $\$ 165$ per kilogram (\$75 per pound) for 15 years, and the continued availability of the metal resulted from the growth and development of the commercial nuclear industry (table 1). In 1979, equipment failures and operator error caused a partial core meltdown at the Three Mile Island (TMI) nuclear power plant in Pennsylvania. The TMI and subsequent nuclear accidents elsewhere led to more stringent safety regulations in the industry as well as public opposition to nuclear power, which limited construction of new reactors.

In the 1990s, hafnium use in the nuclear industry was primarily for control rods in existing nuclear reactors and as an alloying agent in certain superalloys. During this period, U.S. consumption and prices for hafnium declined and then flattened (fig. 1). No additional orders for nuclear reactors were placed, and following the end of the cold war, defense spending declined.

In the 2000s, although nuclear power construction in much of the world was flat, nuclear power in Asia increased significantly. As of April 2010, in east and south Asia, there were 112 nuclear power reactors in operation, 37 reactors under construction, and plans to construct an additional 84 (World Nuclear Association, 2010.)

Because there are only a few producers of hafnium, published prices are not available. U.S. imports of unwrought hafnium are included under the Harmonized Tariff Schedule category 8112.92.2000 that includes all unwrought hafnium including bar, sponge, powder, and waste and scrap. The import value of unwrought hafnium from France was considered to be the best available price for hafnium; however, because this price may include a variety of material, it may not necessarily reflect market conditions. The price of hafnium metal from 2000 to 2010 fluctuated significantly and reached a peak of $\$ 606$ per kilogram in 2004. Rising prices from 2003 (\$193 per kilogram) to 2010 (\$563 per kilogram) were paralleled by increased demand from the nuclear industry. Increasing global construction of nuclear powerplants was expected to increase future demand for hafnium metal.

\section{References Cited}

Etherington, H., Dalzell, R.C., and Lillie, D.W., 1955, Zirconium and its applications to nuclear reactors, chap. 1 of Lustman, B., and Kerze, F., Jr., eds., The metallurgy of zirconium: New York, McGraw-Hill, p. 1-18.

Kroll, W.J., 1937, The formation of titanium and zirconium: Zeitschrift für Anorganishe und Allgemeine Chemie, v. 234, p. $42-50$.

Kroll, W.J., Anderson, C.T., Holmes, H.P., Yerkes, L.A., and Gilbert, H.L., 1948, Large scale laboratory production of ductile zirconium: Transcripts of the Electrochemistry Society, v. 94, p. 1-20. 
Kroll, W.J., Schlechten, A.W., Carmody, W.R., Yerkes, L.A., Holmes, H.P., and Gilbert, H.L., 1947, Recent progress in the metallurgy of malleable zirconium: Transcripts of the Electrochemistry Society, v. 92, p. 99-113.

Kroll, W.J., Schlechten, A.W., and Yerkes, L.A., 1946, Ductile zirconium from zircon sand: Transcripts of the Electrochemistry Society, v. 89, p. 365-376.

Powell, J.E., 1961, Separation of rare earths by ion exchange, chap. 5 of Spedding, F.H., and Daane, A.H., eds., The rare earths: New York, John Wiley \& Sons, p. 55-73.

Smith, E.W., and Stephens, W.W., 1960, Hafnium reduction process, chap. 3 of Thomas, D.E., and Hayes, E.T., eds., The metallurgy of hafnium: U.S. Atomic Energy Commission, p. 83-106. van Arkel, A.E., and de Boer, J.H., 1925, Preparation of pure titanium, zirconium, hafnium, and thorium metal: Zeitschrift für Anorganische und Allgemeine Chemie, v. 148, p. 345-350.

Wilson, W.H., and Staehle, R.W., 1960, History of hafnium, chap. 1 of Thomas, D.E., and Hayes, E.T., eds., The metallurgy of hafnium: U.S. Atomic Energy Commission, p. 1-8.

World Nuclear Association, 2010, Asia's nuclear energy growth: London, United Kingdom, World Nuclear Association, April, accessed October, 12, 2011, at http://www. world-nuclear.org/info/inf47.html.

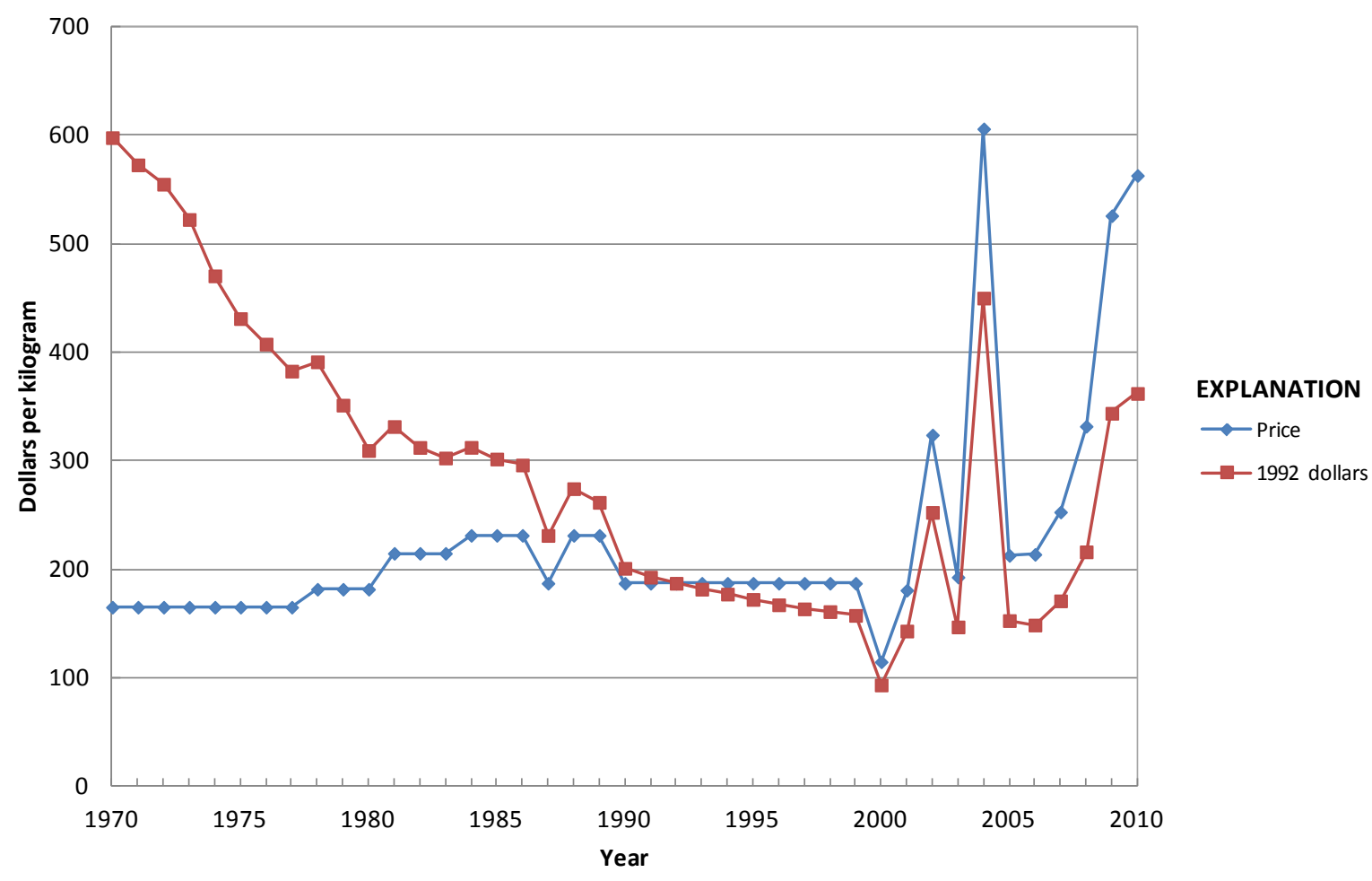

Figure 1. Yearend hafnium sponge metal price.

\section{Significant events affecting hafnium prices since 1970}


Table 1. Yearend hafnium sponge metal price.

[Values in dollars per kilogram]

\begin{tabular}{|c|c|c|c|c|c|c|c|}
\hline Year & Price & Year & Price & Year & Price & Year & Price \\
\hline 1961 & 88 & 1974 & 165 & 1987 & 187 & 2000 & 115 \\
\hline 1962 & 88 & 1975 & 165 & 1988 & 231 & 2001 & 181 \\
\hline 1964 & 165 & 1977 & 165 & 1990 & 187 & 2003 & 193 \\
\hline 1965 & 165 & 1978 & 182 & 1991 & 187 & 2004 & 606 \\
\hline 1967 & 165 & 1980 & 182 & 1993 & 187 & 2006 & 214 \\
\hline 1968 & 160 & 1981 & 215 & 1994 & 187 & 2007 & 253 \\
\hline 1969 & 165 & 1982 & 215 & 1995 & 187 & 2008 & 332 \\
\hline 1970 & 165 & 1983 & 215 & 1996 & 187 & 2009 & 526 \\
\hline 1971 & 165 & 1984 & 231 & 1997 & 187 & 2010 & 563 \\
\hline
\end{tabular}

Notes:

1959-99, prices are an average of range, converted from pounds, in American Metal Market.

2000-10, unit value based on the duty-paid unit value of imported unwrought hafnium from France. 


\title{
Indium (In)
}

\author{
by Amy C. Tolcin
}

The invention of the spectroscope in 1860 led to the discovery of several new elements, including cesium, indium, rubidium, and thallium. In fact, the word "indium" originates from the distinctive indigo blue lines the element emits in the spectroscope. Indium is produced mainly from residues generated during zinc ore processing. Prior to 1940, indium was used almost entirely for experimental purposes, although domestic production had begun in 1926. Because of its rarity, about the same as that of silver (Weeks, 1973, p. 242), and lack of industrial applications, indium was sold only in small quantities during this period. The first commercial application came in 1933, when small amounts of indium were added to certain gold dental alloys. The Indium Corporation of America (ICA) was founded in 1934 and became the major domestic producer. From 1940 through 1945, prices were usually determined through individual negotiations between the producer and consumer (Ludwick, 1959, p. 9).

The first large-scale application for indium was as a coating for bearings in high-performance aircraft engines during World War II (Slattery, 1995, p. 157). Indium increased hardness and helped prevent seizure and corrosion of the bearings. After the war, production gradually increased as new uses were found in fusible alloys, solders, and electronics. A producer price for indium was first established by ICA in 1946, and it remained at the same level through 1963.

From 1973 through 1980, demand increased, especially for use in nuclear control rods, and easily accessible supplies of raw materials gradually decreased. Indium Corporation of America depleted its source of feedstock in Bolivia and then obtained source material from Europe. The inability to meet demand was the major factor in the price reaching \$20 per troy ounce during 1980, when the annual average price was $\$ 17$. To increase supply, world producers expanded production capacities.

Orders for nuclear control rods dropped when the rate of nuclear power expansion decreased in the United States following the Three Mile Island accident in 1979. Increased production led to an oversupply during the recessions of the early 1980s. By 1983, the price had plummeted to less than $\$ 3$ per troy ounce (annual average was \$3.19). In 1988, in response to growing demand, especially in the Japanese electronics industry, it climbed to nearly $\$ 10$ per troy ounce.

In the middle and late 1980s, the development of indium phosphide semiconductors and indium-tin-oxide (ITO) thin films for LCDs aroused much interest. By 1992, the thin-film application had become the largest end use (Jasinski, 1993).

In 1989, indium was included in the list of materials to be added to the National Defense Stockpile (NDS) (Schmitt,
1989). The original stockpile goal was 42 metric tons (t); this was reduced to $7.7 \mathrm{t}$ in 1992. During that same year, the Defense Logistics Agency, manager of the NDS, began purchasing indium. The NDS had acquired its highest level, 1.56 t of indium, by 1994. According to the NDS Annual Materials Plan for 1996, indium was to be eliminated from the stockpile, but sales would be limited to 1.1 metric tons per year (American Metal Market, 1997). Slightly more than this amount was sold in 1997 , leaving the inventory at $0.44 \mathrm{t}$, which was sold in December 1998.

In 1995, a tight supply situation with strong demand forced the price to increase steadily to a \$16.25-per-troy-ounce high. The following year, increased supply and the implementation of an efficient recycling process led to a decrease in price down to a \$6.53-per-troy-ounce low (Roskill Information Services Ltd., 1996, p. 34). This dramatic rise-and-fall is hidden in the annual average statistics, which indicate a drop of only $\$ 0.20$ from 1995 to 1996 .

In 1998, indium demand declined owing to the second successive year of somewhat less LCD production and the introduction of a new thin-film coating technology that requires only one-third as much indium per unit as the older process (Roskill Information Services Ltd., 1998, p. 2). After fluctuating moderately in 1997, the price was steady in 1998.

Annual average prices for indium continued to decline through 2002 owing to an oversupply in the metal market, which was largely attributed to excessive Chinese production in the late 1990s and early 2000s and stagnant demand.

In 2003, demand for indium began to increase significantly, especially in Japan and the Republic of Korea, owing to considerable growth in the LCD market. As LCD technology and manufacturing matured, prices for devices containing LCDs fell, which bolstered consumer demand for the technology. On the supply side, indium production was constricted owing to shortages of primary raw material in China and the closure of a primary indium production facility in France. This led to a shortage of metal, causing prices to rise during 2003 to 2005 .

After the indium price approximately tripled in 2004 from that of 2003, the price of indium in 2005 reached historical peaks of more than $\$ 30$ per troy ounce before declining to yearend. A brief price leveling that took place at the end of 2005 was attributed to industry stockpiling. Japanese ITO producers in particular were thought to hold large stocks of indium bought in the 2004-05 fiscal year. This, in addition to an unexpected slowdown in demand for LCDs, led to a price dip at yearend. 
In 2006, indium prices increased during the first quarter and then declined rapidly through yearend. Although the availability of primary indium feedstock was further reduced and production capacity at ITO refineries and LCD plants in China, Japan, the Republic of Korea, and Taiwan increased, continued recycling efforts, especially in Japan, compensated for primary supply shortages and alleviated price pressures. By 2007, global secondary indium production significantly increased and accounted for a greater share of indium production than primary. In mid-2008, indium prices rebounded after generally declining during 2007. However, as the recession set in globally, prices once again declined in late 2008 through the first half of 2009. In the second half of 2009, ITO demand began to pick up, particularly in the Republic of Korea, where exports of flat-panel displays increased significantly owing to China's household appliance subsidy program and the weaker won, causing prices to rally.

\section{References Cited}

American Metal Market, 1997, DLA planning sale of indium: American Metal Market, v. 105, no. 35, February 20, p. 12.
Jasinski, S.M., 1993, Indium: U.S. Bureau of Mines Mineral Commodity Summaries 1993, p. 84-85.

Ludwick, M.T., 1959, Indium, discovery, occurrence, development, and characteristics: Utica, N.Y., Indium Corporation of America, $770 \mathrm{p}$.

Roskill Information Services Ltd., 1996, The economics of indium: London, Roskill Information Services Ltd., 111 p.

Roskill's Letter from Japan, 1998, Indium-Prices may fall: Roskill's Letter from Japan, no. 270, October, p. 2.

Schmitt, Bill, 1989, Pentagon report urges stockpiling of indium, rhodium, and ruthenium: American Metal Market, v. 97, no. 78, April 21, p. 1.

Slattery, J.A., 1995, Indium and indium compounds, in KirkOthmer encyclopedia of chemical technology (4th ed.): New York, John Wiley, v. 14, p. 155-160.

Weeks, R.A., 1973, Gallium, germanium, and indium, in Brobst, D.A., and Pratt, W.P., eds., United States mineral resources: U.S. Geological Survey Professional Paper 820, p. 237-246.

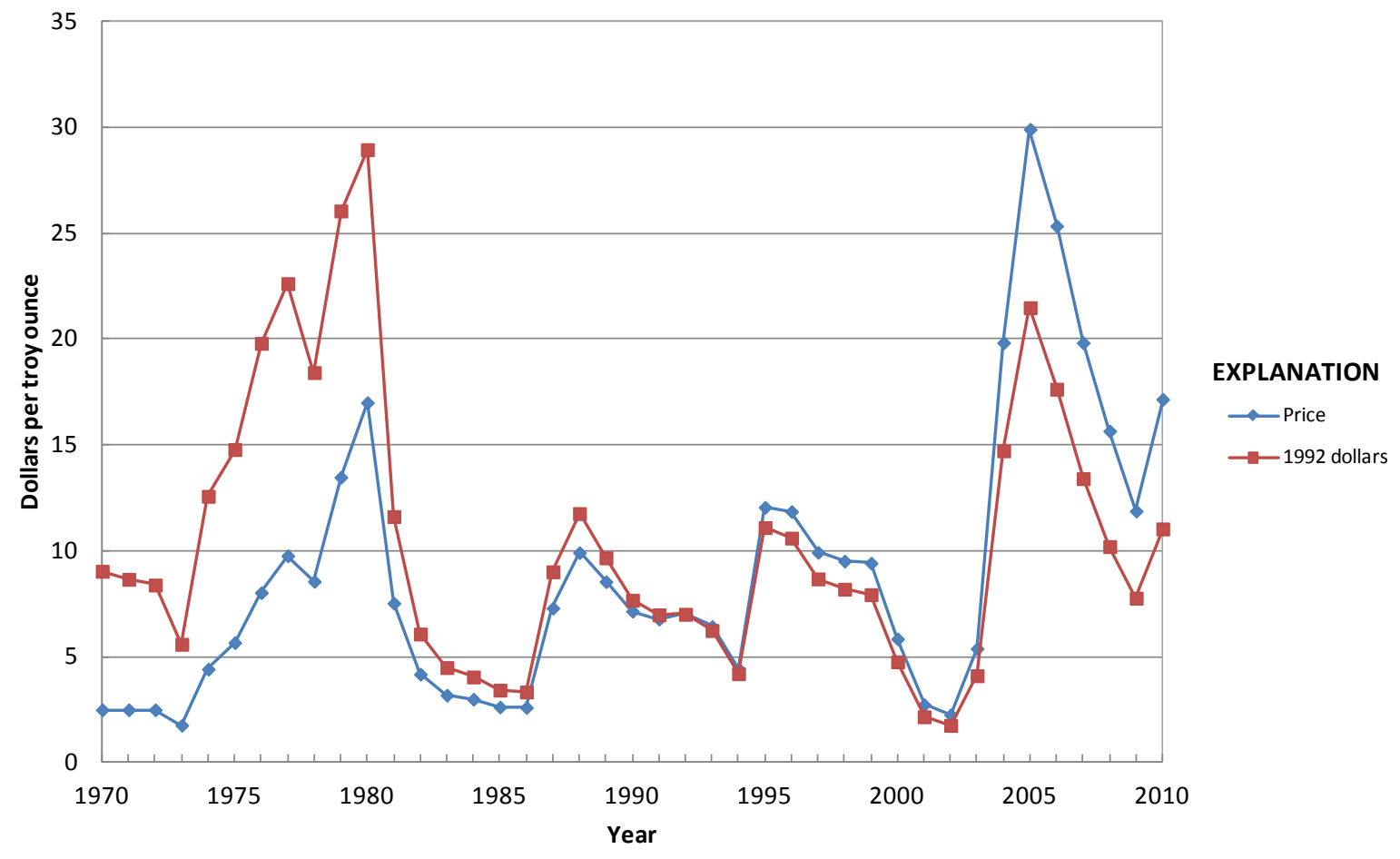

Figure 1. Annual average indium price. 


\section{Significant events affecting indium prices since 1970}

1973-80 Period of high demand, significant increase for nuclear control rods

$1979 \quad$ Lower demand after nuclear powerplant accident at Three Mile Island

1980-82 Economic recessions

1985 Development of indium phosphide semiconductors and indium-tin-oxide thin films

1989 Indium added to National Defense Stockpile (NDS) acquisition plan

1992-94 NDS acquisition of indium; price declined

1995

1996

1997

1997-98

2003-05

Steady price increase owing to tight supply and strong demand

Steady price decline owing to greater supply and significant recycling

Release of more than one-half of NDS holdings

Reduced demand owing to decrease in production of liquid crystal displays (LCDs) and to shift to more efficient thin-film technology

2005-08

Reduced supply owing to closure of primary production facility in France and several zinc mine closures in China; price increases

2008-09

Significant increases in secondary capacity and production in Japan

Global economic crisis

Table 1. Annual average indium price.

[Values in dollars per troy ounce]

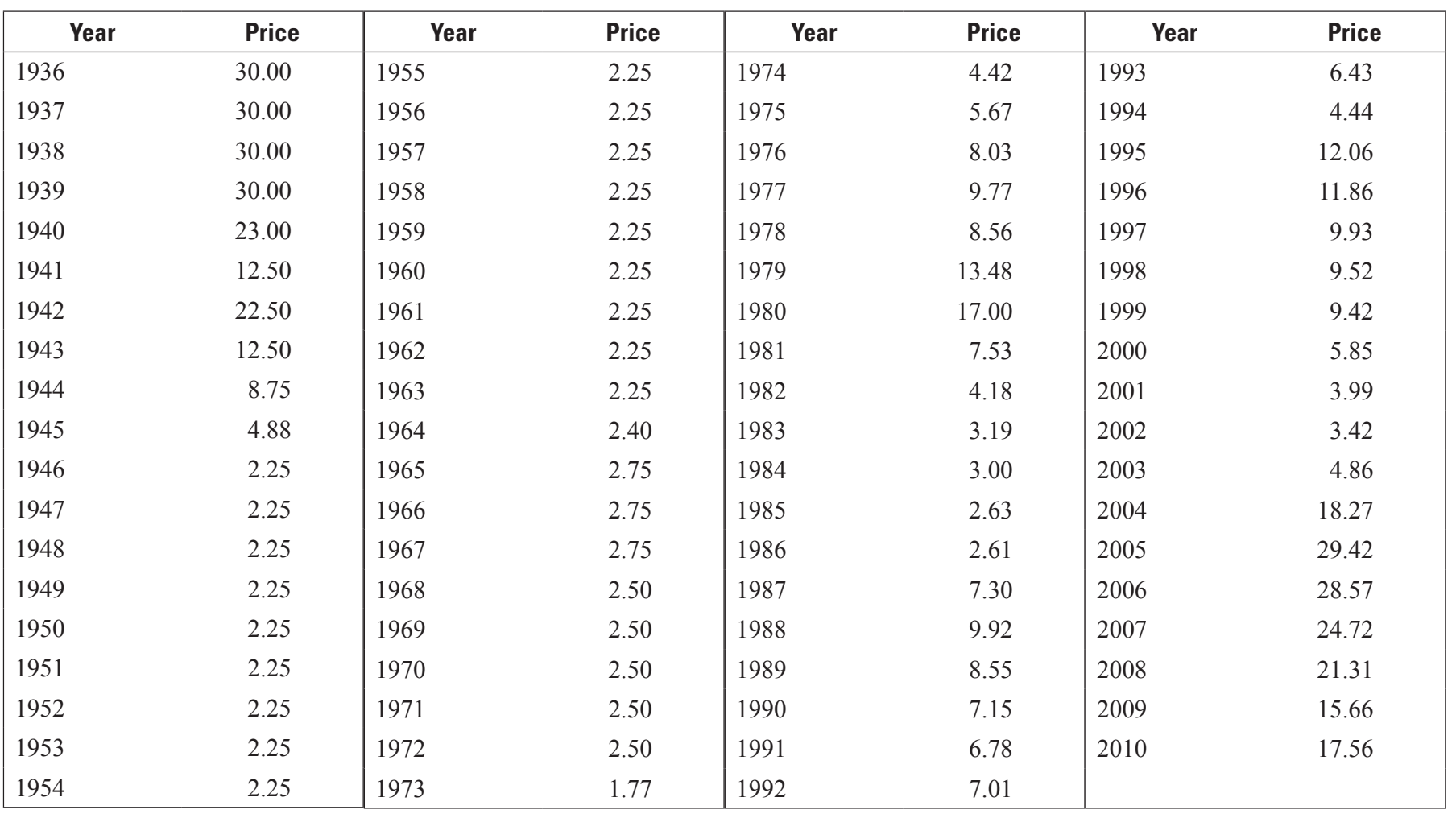

Notes:

1936-66, 99.97-percent-pure indium, Indium Corporation of America, producer price.

1967-93, 99.97-percent-pure indium, U.S. producer price, in Metals Week.

1994-2010, 99.97-percent-pure indium, U.S. producer price, in Platts (Platt's) Metals Week. 


\title{
Iron and Steel (Fe)
}

\author{
by Michael D. Fenton
}

Of the metallic elements, iron is the most useful and most abundant, as well as the cheapest. The term "iron" refers to alloys that contain too much carbon to be formable by forging or rolling. The term "steel" refers to an alloy of iron that is malleable in some temperature ranges and contains manganese, carbon, and often other alloying elements. Hundreds of individual alloy specifications known as "grades" have been developed to produce combinations of strength, ductility, hardness, toughness, magnetic permeability, and corrosion resistance to meet the need of modern consumers. The ability of steel to be permanently deformed by plastic working allows it to be formed into many shapes and sizes (Lankford and others, 1985, p. 773). Principal methods of hot and cold steel working are hammering, pressing, piercing, extrusion, rolling, drawing, and forging.

Price indices of groups of steel products have been reported by the major trade publications to show at a glance the overall movement of steel prices since 1897 (American Metal Market) and 1926 (Iron Age) (table 1). For the purpose of this publication, hot-rolled carbon steel bar was selected because it has been produced continuously since the adoption of the Bessemer steelmaking process in 1875; its historical price series is indicative of prices for the range of steel products; and its price does not incorporate the cost of extensive processing after hot rolling.

For the entire period of this review, except during World War I, prices of hot-rolled carbon steel bar fluctuated within a narrow range, in constant dollar terms. During World War I, steep price increases brought about price controls, which were also imposed on the industry during World War II (Campbell, 1948). During the 1960 s, prices increased very slowly, but the energy crisis of 1970 started a period of rapid price escalation as energy costs of steel companies increased rapidly and inflation dominated the economy. Wages of steel industry workers were automatically increased because of inflation protection clauses in their union contracts. Price increases were necessary to keep pace with rapidly escalating costs. From 1971 through 1974 , price controls were instituted in an attempt to halt price inflation, but were abandoned when they proved ineffective and administratively impractical (fig. 1).

During the early 1970s, a new approach to steelmaking gained prominence that caused record highs in steel production (1973) and scrap consumption (1974). Small steel plants were erected to produce simple products such as hot-rolled bars of steel. The first plants began production in 1965. These new plants, called minimills, did not have blast furnaces to process iron ore, but instead modern electric furnaces and continuous casters were used to melt ferrous scrap and cast the raw steel into products at the lowest possible cost. Competition with blast-furnace-based steel mills increased as thin-slab continuous casting equipment was adopted, first in 1989, to produce products at thinner gauges with ever-improving quality at increasingly lower costs (American Metal Market, 1997; 33 Metal Producing, 1998). Minimills have been able to capture a significant share of the market by setting prices that the previously dominant steel companies were unable to match.

One of the relatively simple products that the minimill companies have come to dominate is hot-rolled steel bar. Discounts from the quoted prices have been widely available, and this was especially true during the late 1970s and early 1980s as minimill companies gained dominance of the market for hot-rolled steel bar. In 1984, the major steel mills stopped revising their quoted prices. In 1987, American Metal Market discontinued the publication of the major mill price and began to report the quoted prices of the minimills, which were more representative of market transaction prices. This change was marked by the 29 percent drop in the quoted price, to $\$ 17.12$.

The first half of the 1990s were years of increasing domestic demand for steel products and increasing domestic capacity to satisfy this demand. U.S. exports and imports of ferrous scrap reached record highs in 1990, but there was still a trade deficit. By 1997, the American Iron and Steel Institute (AISI) reported an indirect steel-trade surplus of 1.1 million metric tons, the first surplus since AISI began tracking the measurement in 1984 and perhaps since the late 1970s (American Iron and Steel Institute, 1998). This surplus confirmed that U.S. manufacturers were among the world's most competitive producers of high-quality, steel-containing goods in 1997.

Despite rising domestic steel mill capacity, imports of semifinished steel increased significantly in 1993; these imports were needed to make up for the domestic shortage of hot metal capacity in order to satisfy the U.S. market demand for finished steel mill products. Domestic producers were also unable to keep up with demand for finished steel products. An unfavorable currency exchange rate made foreign steel prices much more competitive.

A financial crisis began in Asia in 1997 when Thailand devalued its currency (Garino, 1999). Prospering economies in China, Hong Kong, Indonesia, Japan, the Republic of Korea, Malaysia, Singapore, Taiwan, and Thailand were seriously weakened. Steel consumption began to decline in these countries as they imported less steel and canceled some new steel production projects. Generally, significant production decreases in Asia were not feasible because sales were needed to repay loans granted by the International Monetary Fund to 
support the economies of these countries (Becker, 1998). The financial crisis of 1997 continued to have an adverse effect on steel industries throughout the world until early 1999.

The U.S. steel industry began to rebound modestly during early 1999 owing to a reduced availability of low-priced steel imports and continued strong steel-product demand. As 2000 began, the U.S. economic expansion- the longest in U.S. history - was showing signs of weakening. Meanwhile, from 1998 to 2003, prices for steel products declined to record lows in 2001, when an economic recession in the United States occurred between March 2001 and November 2001.

From 2004 through 2007, increasing global demand, company consolidations that decreased competition, and a weakening dollar, combined to result in large annual price increases (Fletcher, 2008). In late 2007, domestic demand for steel decreased, because of the weakening housing construction and automobile markets, which caused U.S. steel prices to decline below those in Europe and China. Prices of steel mill products spiked significantly during mid-2008, because of a combination of possible factors - rising costs of raw materials, strong global demand, and diminishing imports into the United States of less expensive steel products, caused by a weak dollar, which, in turn, allowed U.S. steelmakers to raise the prices to take advantage of demand by U.S. manufacturers.

The U.S. and global economic crises in late 2008 eventually brought about a global decline in steel demand. World apparent steel consumption declined in 2009 as did steel production. Steel prices decreased significantly from late 2008 through 2009, and then rebounded significantly, as the world economy began to recover, and steel consumption and production increased.

\section{References Cited}

American Iron and Steel Institute, 1998, AISI issues report on 1997 U.S. indirect steel trade-First surplus achieved in 14 years of tracking: Washington, D.C., American Iron and Steel Institute press release, April 15, 2 p.

American Metal Market, 1997, Minis playing hot band hand: American Metal Market, v. 105, no. 27, February 7, p. 1.

Becker, George, 1998, Steel import woes have deep roots: American Metal Market, v. 106, no. 208, October 29, p. 10.

Campbell, R.F., 1948, The history of basic metals price control in World War II: New York, Columbia University Press, $263 \mathrm{p}$.

Fletcher, M.A., 2008, Steel—Forging a comeback: The Washington Post, May 28, p. D1.

Garino, R.J., 1999, Bull or bear, place your bets: Scrap, v. 56, no. 1, January/February, p. 44.

Lankford, W.T., Jr., Samways, N.L., Craven, R.F., and McGannon, H.E., eds., 1985, The making, shaping and treating of steel: Pittsburgh, Pa., Herbick \& Held, 1,572 p.

33 Metal Producing, 1998, Mini-mills moving up: 33 Metal Producing, v. 36, no. 1, January, p. 34. 


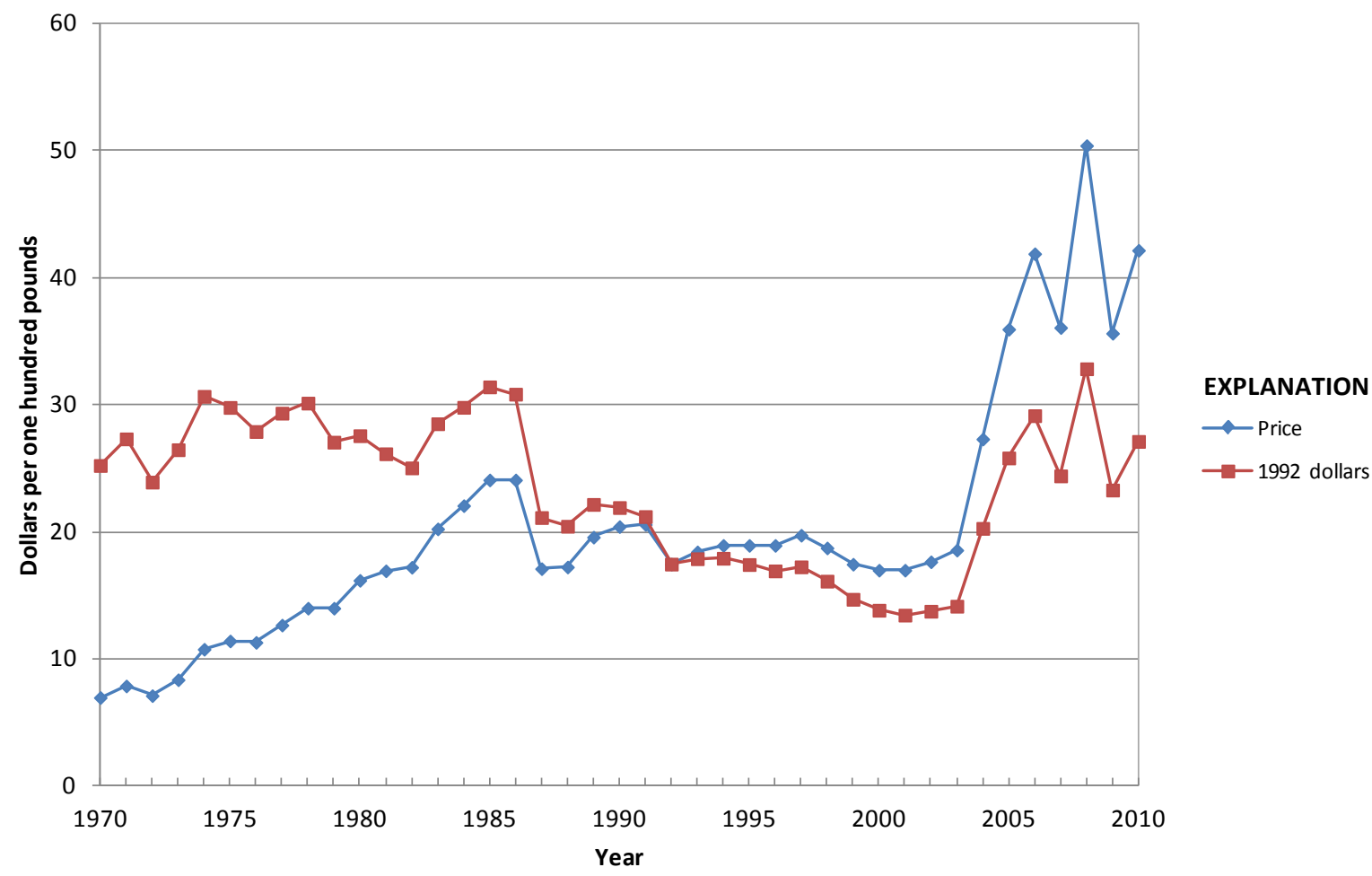

Figure 1. Annual average hot-rolled steel bar price.

\section{Significant events affecting steel prices since 1970}

$1970 \quad$ Beginning of energy crisis

1971-74 Price controls in effect

1973

1974

Peak raw steel and pig iron production and peak scrap consumption by steel mills; export restrictions imposed Peak scrap consumption (steel mills and ferrous foundries)

1989

1990

First thin-slab continuous caster for flat-rolled steel products began operating at minimill facility

1997-99

U.S. exports and imports of ferrous scrap reached record highs

2002-08

Asian financial crisis

$2008-09$

Significant price increases, spiking in 2008

Global financial crisis 


\section{Metal Prices in the United States Through 2010}

Table 1. Annual average hot-rolled steel bar price.

[Values in dollars per one hundred pounds]

\begin{tabular}{|c|c|c|c|c|c|c|c|}
\hline Year & Price & Year & Price & Year & Price & Year & Price \\
\hline 1897 & 0.99 & 1926 & 1.99 & 1955 & 4.47 & 1984 & 22.08 \\
\hline 1898 & 0.95 & 1927 & 1.84 & 1956 & 4.81 & 1985 & 24.10 \\
\hline 1900 & 1.61 & 1929 & 1.92 & 1958 & 5.35 & 1987 & 17.12 \\
\hline 1901 & 1.44 & 1930 & 1.73 & 1959 & 5.68 & 1988 & 17.25 \\
\hline 1903 & 1.56 & 1932 & 1.58 & 1961 & 5.68 & 1990 & 20.43 \\
\hline 1904 & 1.33 & 1933 & 1.64 & 1962 & 5.68 & 1991 & 20.60 \\
\hline 1905 & 1.48 & 1934 & 1.81 & 1963 & 5.74 & 1992 & 17.48 \\
\hline 1906 & 1.51 & 1935 & 1.80 & 1964 & 5.93 & 1993 & 18.44 \\
\hline 1907 & 1.60 & 1936 & 1.92 & 1965 & 5.93 & 1994 & 18.95 \\
\hline 1911 & 1.26 & 1940 & 2.15 & 1969 & 6.56 & 1998 & 18.75 \\
\hline 1912 & 1.25 & 1941 & 2.15 & 1970 & 6.98 & 1999 & 17.47 \\
\hline 1913 & 1.38 & 1942 & 2.15 & 1971 & 7.89 & 2000 & 17.00 \\
\hline 1914 & 1.15 & 1943 & 2.15 & 1972 & 7.13 & 2001 & 17.00 \\
\hline 1915 & 1.31 & 1944 & 2.15 & 1973 & 8.38 & 2002 & 17.66 \\
\hline 1916 & 2.48 & 1945 & 2.21 & 1974 & 10.78 & 2003 & 18.58 \\
\hline 1917 & 3.49 & 1946 & 2.47 & 1975 & 11.43 & 2004 & 27.32 \\
\hline 1918 & 2.89 & 1947 & 2.72 & 1976 & 11.32 & 2005 & 35.96 \\
\hline 1925 & 2.04 & 1954 & 4.22 & 1983 & 20.25 & & \\
\hline
\end{tabular}

Notes:

1897-February 1987, hot-rolled carbon steel bars merchant, Pittsburgh base, dollars per hundredweight, in American Metal Market.

March 1987-2010, hot-rolled carbon SBQ (special bar quality) 1000 series, in American Metal Market. 


\title{
Iron and Steel Scrap (Fe)
}

\author{
by Michael D. Fenton
}

Iron and steel (ferrous) scrap is generated within steel mills and foundries (home scrap) or industrial plants (prompt or industrial scrap) while fabricating new iron and steel products, and from objects discarded because of obsolescence (obsolete scrap). Ferrous scrap recycling is a complex industry that is dependent on the vigor of the two major consumers of scrap — steel mills and ferrous foundries. Thousands of scrap facilities employ tens of thousands of people to collect, process, and distribute scrap in several regional U.S. markets and the international export market.

In a free-market economy when Government price controls are not in effect, scrap prices react quickly to changes in supply and demand. Scrap prices seem to be more sensitive to demand changes. When demand for steel mill and foundry products is low, demand for scrap is low, and prices fall. Dealers cannot influence sales of scrap if mills and foundries do not need it to charge their furnaces. Dealers can hold back some scrap from mills and foundries when prices are below their costs to purchase and process it. Scrap generated by industrial plants, however, must be disposed of each month to the highest bidder to make room for more scrap. Prices are also influenced by technological changes in steel mills and foundries, processing and upgrading to desired physical and chemical qualities, the use of scrap substitutes, environmental controls and other Government laws and regulations, and foreign demand. Scrap metal prices quoted in major trade publications, such as American Metal Market, have been considered by many economists to be an excellent barometer of current industrial demand. Of particular interest is the No. 1 Heavy Melting Steel (No. 1) composite price of three cities-Chicago, Ill., Philadelphia, Pa., and Pittsburgh, Pa.- - which has been recorded by American Metal Market since 1907 (table 1).

During the past 90 years, the price of No. 1 responded to supply-and-demand forces in a free-market economic environment, and price fluctuations were sometimes dramatic from year to year. The Great Depression (1929-33) was a period of declining manufacturing activity, with alltime record lows in demand and prices for scrap from 1931 to 1933. During World Wars I and II, demand increased to the point that the Government adopted price controls to halt scrap price inflation (Campbell, 1948). The price of No. 1 nearly tripled as a result of high demand during World War II. The Government also adopted price controls during the Korean conflict.

During the early 1970 s, a new approach to steelmaking gained prominence, which caused record highs in steel production (1973) and scrap consumption (1974) (fig. 1). New, comparatively small steel plants were built to produce simple products, such as hot-rolled bars of steel. These new plants, called minimills, did not have blast furnaces to process iron ore; instead, modern electric furnaces and continuous casters were used to melt ferrous scrap and to cast the raw steel into products at the lowest possible cost (Iron and Steelmaker, 1998). Minimills have been able to capture a significant share of the market by setting prices that the previously dominant steel companies were unable to match. By 1990, U.S. exports and imports of ferrous scrap to feed minimills built in the United States and abroad reached record highs.

Ferrous scrap prices declined significantly during 1991 as domestic and world demand for scrap decreased. Domestic demand began to increase during 1992, and world demand remained weak. The period from 1993 to the first half of 1997 was one of strengthening demand for ferrous scrap and rising prices. Developing countries in Asia, Eastern Europe, and Latin America experienced significant economic growth. Minimill capacity increased worldwide, and integrated steel mills increased efficiency and scrap usage.

A financial crisis began in Asia in 1997 when Thailand devalued its currency. Prospering economies in China, Hong Kong, Indonesia, Japan, the Republic of Korea, Malaysia, Singapore, Taiwan, and Thailand were seriously weakened. Asian ferrous scrap purchases decreased, and prices of scrap declined, which adversely affected the United States scrap industry (Gavaghan, 1998).

The Asian financial crisis of 1997 continued to have an adverse financial effect on steel industries throughout the world until early 1999. During this period, U.S. mills reduced steel scrap consumption, which led to an oversupply of scrap. The U.S. steel industry began to rebound modestly during early 1999 owing to a reduced availability of low-priced steel imports and continued strong steel-product demand. The U.S. scrap industry began a slow but steady recovery as a result of increasing demand for scrap in Asia and North America and a reduced supply of scrap from the Commonwealth of Independent States. As 2000 began, the U.S. economic expansion-the longest in U.S. history, beginning in March 1991 — was showing signs of weakening. Meanwhile, from 1997 to 2001, prices for steel products and ferrous scrap declined steadily to record lows. Owing to an economic recession that occurred between March and November, scrap prices in 2001 were at the lowest level since 1986.

Ferrous scrap prices generally increased from late 2001 to an historic high in 2008, resulting from economic growth in the United States and developing countries, especially China, and steadily increasing worldwide apparent steel consumption 
and demand for scrap by growing steel-producing industries. World Steel Dynamics (WSD) reported a shortage of scrap and scrap substitutes by 2004, which may have caused the spike in scrap prices in 2004. WSD predicted that the obsolete scrap supply would increase only slightly more than demand through 2015 (American Metal Market, 2004). The International Iron and Steel Institute (now the World Steel Association) also determined that scrap availability would barely meet steel industry demand through 2015 (Yayan, 2005).

Prices of steel mill products spiked significantly during mid-2008, perhaps caused by a decreasing availability of steel scrap and a strong domestic and global demand for scrap and steel mill products. The U.S. and global economic crises eventually brought about a global decline in steel demand in late 2008. World apparent steel consumption declined as did steel production and demand for scrap and scrap substitutes. Scrap prices decreased significantly from late 2008 through 2009, and then rebounded to nearly 2008 highs in early 2011 . As the world economy began to recover, steel consumption and production increased, and demand for scrap increased.

\section{References Cited}

American Metal Market, 2004, Steelmakers face ongoing shortfall in metallics-WSD: American Metal Market, v. 112, no. 49-1, December 6, p. 1.

Campbell, R.F., 1948, The history of basic metals price control in World War II: New York, Columbia University Press, $263 \mathrm{p}$.

Gavaghan, B.P., 1998, World steel industry faces uncertain economic future: Iron and Steelmaker, v. 25, no. 12, December, p. 25-26.

Iron and Steelmaker, 1998, I\&SM continuous caster roundup: Iron and Steelmaker, v. 25, no. 11, p. 14-31.

Yayan, Veysel, 2005, OECD Special meeting at high-level on steel issues: The outlook for steel conference: Brussels, Belgium, January 12-13, 2005, 7 p., accessed October 7, 2011, at http://www.oecd.org/dataoecd/17/54/34356750.pdf.

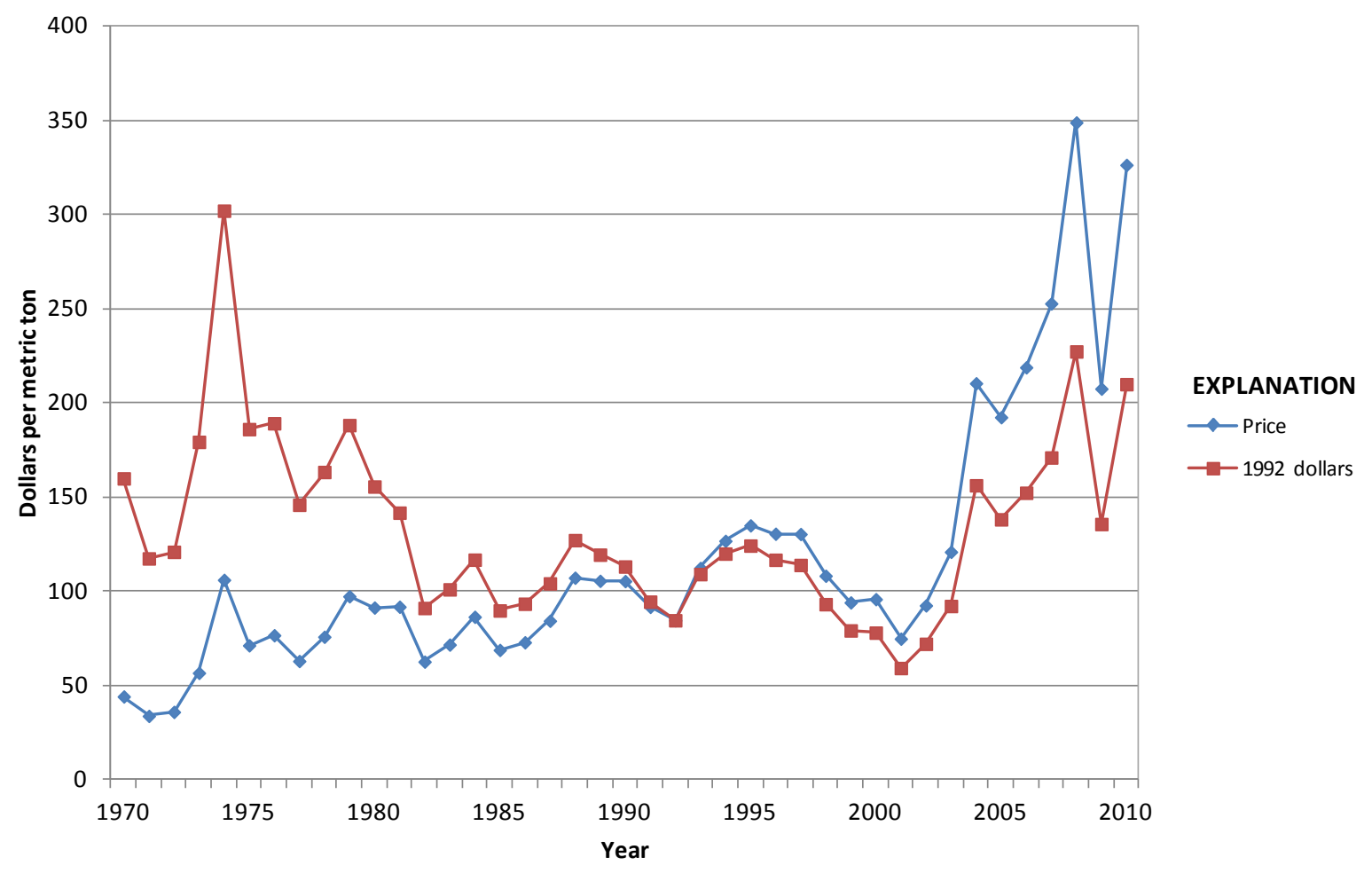

Figure 1. Annual average U.S. steel scrap price. 


\section{Significant events affecting steel scrap prices since 1970}

1973 Peak raw steel and pig iron production and peak scrap consumption by steel mills; price controls and export restrictions imposed

1974 Peak scrap consumption (steel mills + ferrous foundries); export restrictions imposed

$1989 \quad$ First thin-slab continuous caster for flat-rolled steel products began operating at minimill facility

$1990 \quad$ U.S. exports and imports of ferrous scrap reached record highs

1997-99 Asian financial crisis

2008 Scrap prices spiked temporarily during midyear

2008-09 Global financial crisis

Table 1. Annual average U.S. steel scrap price.

[Values in dollars per metric ton]

\begin{tabular}{|c|c|c|c|c|c|c|c|}
\hline Year & Price & Year & Price & Year & Price & Year & Price \\
\hline 1907 & 16.27 & 1933 & 9.20 & 1959 & 37.09 & 1985 & 68.93 \\
\hline 1908 & 13.40 & 1934 & 10.74 & 1960 & 32.68 & 1986 & 73.00 \\
\hline 1909 & 15.49 & 1935 & 11.52 & 1961 & 35.80 & 1987 & 84.41 \\
\hline 1910 & 14.48 & 1936 & 14.48 & 1962 & 27.89 & 1988 & 107.26 \\
\hline 1911 & 12.20 & 1937 & 17.63 & 1963 & 26.47 & 1989 & 105.61 \\
\hline 1912 & 13.08 & 1938 & 13.21 & 1964 & 35.92 & 1990 & 105.46 \\
\hline 1913 & 11.94 & 1939 & 15.95 & 1965 & 33.73 & 1991 & 91.79 \\
\hline 1914 & 10.33 & 1940 & 18.22 & 1966 & 30.18 & 1992 & 84.67 \\
\hline 1915 & 12.07 & 1941 & 19.12 & 1967 & 27.19 & 1993 & 112.44 \\
\hline 1916 & 17.13 & 1942 & 18.87 & 1968 & 25.53 & 1994 & 126.82 \\
\hline 1917 & 28.62 & 1943 & 18.87 & 1969 & 30.08 & 1995 & 135.03 \\
\hline 1918 & 28.11 & 1944 & 18.33 & 1970 & 44.24 & 1996 & 130.60 \\
\hline 1919 & 18.05 & 1945 & 18.84 & 1971 & 33.92 & 1997 & 130.45 \\
\hline 1920 & 23.57 & 1946 & 19.83 & 1972 & 36.05 & 1998 & 108.30 \\
\hline 1921 & 12.46 & 1947 & 35.08 & 1973 & 56.76 & 1999 & 94.15 \\
\hline 1922 & 15.58 & 1948 & 40.89 & 1974 & 106.13 & 2000 & 95.88 \\
\hline 1923 & 18.89 & 1949 & 27.06 & 1975 & 71.37 & 2001 & 74.90 \\
\hline 1924 & 16.91 & 1950 & 34.78 & 1976 & 76.74 & 2002 & 92.56 \\
\hline 1925 & 16.91 & 1951 & 42.46 & 1977 & 63.05 & 2003 & 120.99 \\
\hline 1926 & 15.33 & 1952 & 41.23 & 1978 & 75.92 & 2004 & 210.45 \\
\hline 1927 & 13.94 & 1953 & 39.27 & 1979 & 97.41 & 2005 & 192.44 \\
\hline 1928 & 14.13 & 1954 & 28.29 & 1980 & 91.42 & 2006 & 218.91 \\
\hline 1929 & 15.97 & 1955 & 39.12 & 1981 & 91.86 & 2007 & 252.80 \\
\hline 1930 & 13.25 & 1956 & 52.61 & 1982 & 62.72 & 2008 & 348.86 \\
\hline 1931 & 9.58 & 1957 & 46.36 & 1983 & 71.76 & 2009 & 207.58 \\
\hline 1932 & 7.29 & 1958 & 37.21 & 1984 & 86.52 & 2010 & 326.34 \\
\hline
\end{tabular}

Note:

Composite price of No. 1 Heavy Melting Steel scrap at Chicago, Ill., Philadelphia, Pa., and Pittsburgh, Pa., (three-city average). As defined by the Institute of Scrap Recycling Industries, Inc., No. 1 Heavy Melting Steel is wrought iron and (or) steel scrap $1 / 4$ inch and more in thickness. Individual pieces not more than 60 x 24 inches (changing box size) are prepared in a manner to ensure compact charging in American Metal Market. 


\title{
Iron Ore (Fe)
}

\author{
by John D. Jorgenson
}

The first known use of iron ore from the United States was in 1608 when several barrels of ore from Maryland or Virginia were shipped to England for testing. The first regular U.S. production of iron ore was established in Massachusetts in about 1645 at a blast furnace north of Boston. During the next 100 years, many new mines were opened as iron making spread southward and westward. By 1885, iron ore had been discovered in Michigan and Wisconsin, and annual iron ore production had increased to more than 2 million metric tons.

From well before 1900 and into 2000, virtually all iron ore has been used to make steel, so the iron ore industry's fortunes were and continue to be inextricably linked to those of the steel industry. In 1904, the United States was the world's largest iron ore producer, accounting for about 60 percent of total world output of 46 million metric tons. Despite this, the United States was already a net importer of iron ore, if only by a small margin. After domestic production peaked at 127 million metric tons during World War II, it became apparent that U.S. reserves of high-grade ore would be seriously depleted by the 1950s. It was in this decade that production of high-grade pelletized concentrate began.

Iron ore is used to make iron and steel. Iron is the most useful, abundant, and cheapest of the metallic elements. In metallurgical terms, "iron" refers to alloys that contain too much carbon to be formable by forging or rolling. The term "steel" refers to an alloy of iron that is malleable at some temperature ranges and contains carbon, manganese, and often some other alloying elements. Steel is made using the blast furnace/basic oxygen furnace $(\mathrm{BF} / \mathrm{BOF})$ process or the electric arc furnace (EAF) process. The $\mathrm{BF} / \mathrm{BOF}$ process first makes iron by smelting iron ore in a blast furnace and then using that iron to make steel in a BOF. In the EAF process, iron and steel scrap (and often direct reduced iron) are melted to produce steel.

Almost all (98 percent) iron ore is used to make iron and steel, so its price is determined by what steelmakers are willing to pay for it and that is based on how the ore performs in the iron-making process - whether it raises or lowers the cost of producing steel. The performance of iron ore in the ironmaking process is determined by its chemical composition and by its structure or form, both of which affect blast furnace productivity. The chemical constituents that affect the productivity of a blast furnace are iron content, levels of the undesirable substances silica and alumina, moisture and impurities, and levels of the desirable substances limestone and dolomite.

Primary market product forms also affect blast furnace productivity - fines (fine ores), lump, and pellets. Fines are defined as iron ore with the majority of individual particles measuring less than 4.75 millimeters ( $\mathrm{mm})(3 / 16$ inch) in diameter. Lump is iron ore with the majority of individual particles measuring more than $4.75 \mathrm{~mm}$ in diameter. Fines and lump are produced from the same ore and are separated by screening and sorting; neither product is concentrated. Pellets, the third product form, begin as a fine-grained concentrate. A binder, often clay, is added to the concentrate, which is then rolled into balls. The balls then pass through a furnace, where they are indurated and become pellets, usually measuring from 9.55 to $16.0 \mathrm{~mm}$ ( $3 / 8$ to $5 / 8$ inch) in diameter. Minor quantities of iron ore concentrate are also sold.

Although fines and lump ores cost about the same to produce, fines sell at lower prices than lump because they must be agglomerated (sintered) by the steel mill before they can be charged to the blast furnace. This is done to improve permeability of the furnace burden and to prevent loss of fines up the stack. Pellets can be charged directly into the blast furnace as can lump ore, but the latter can decrepitate in the furnace, thereby lowering its value to the steel mill operator. Pellets are usually the most desirable form of iron ore because they contribute the most to the productivity of the blast furnace. Lump ore is the next most desirable ore in terms of blast furnace productivity. The least desirable form is fines.

If the chemistry and structure of an iron ore are favorable, then iron- and steel-making costs are reduced, and the steelmaker is willing to pay a higher per-unit price for this ore than for one with less favorable properties. Although an ore with a high iron content and good structure is desirable for increasing productivity in a blast furnace, preference may be given to a lower quality ore if the price is low enough to compensate for its less favorable characteristics. However, in direct reduction, ore-quality parameters are very stringent. The direct reduction process uses pellets and lump with chemical characteristics that have historically supported a price premium over blast furnace grades. Fines-based direct reduction processes have been developed more recently.

A steelmaker's preference for pellets compared to fines is reflected in the prices. From 1976 through 2009, the average price for Brazilian fines was $\$ 36.85$ per metric ton, and the average for Brazilian pellets was $\$ 59.00$ per metric ton (tables 1 and 2). Although iron ore prices rose from 1976 to 2009 , when adjusted for inflation, the price of fines rose and the price of pellets declined. The price for fines in constant dollars during the period increased by 13 percent and the price for pellets in constant dollars dropped by 31 percent. The inflation adjustment factor used was the Consumer Price Index for All Urban Consumers (CPI) from the U.S. Bureau of Labor Statistics. The CPI base year used was 1992. 
Another factor that affects which form of iron ore is used is steel demand. When demand is low, European and Japanese steelmakers switch to fines because they do not have to be concerned with productivity targets. In a tight market, more pellets and lump are consumed.

Until the 1980s, there were two international iron ore price structures, each related to a specific geographic areaNorth America and the other market economy countries (Franz and others, 1986). In North America, more than three-quarters of iron ore production capacity was owned directly by its consumers, the integrated steel companies. These equity ownership conditions led to stable "cost-plus" pricing, meaning the iron ore producers were paid what it cost them to produce the ore, plus royalty and management fees. Prior to this, there was very little need to be competitive (Marcus and others, 1996). Demand was high, and the North American iron ore industry was growing, as it had for 25 years. Pellet production capacity expanded steadily from its first commercialization in 1955 to a peak capacity of 127 million metric tons in 1980.

In 1982, major structural changes occurred in the domestic iron ore industry, one of which was the development of a U.S. spot market for pellets. Most spot sales are individually negotiated, one-time contracts made directly between buyer and seller. The spot market led to the beginning of price competition and a winding down of the traditional U.S. Lower Lakes iron ore pricing system, which had served the iron ore industry for 100 years. Previously, only annual sales, multiyear contracts, or equity ownership transactions existed. The North American iron ore industry had to cut capacity and lower prices to make domestic ore competitive with imported material. This meant that the industry had to lower production costs to remain in business, which was done by greatly improving labor productivity, reducing wages, negotiating lower cost power contracts and royalty agreements, pressing suppliers to reduce prices for materials, lobbying legislators for tax breaks, and paying off debt. The results were dramatic. Domestic mines cut costs by 30 percent, reduced capacity by one-third, and lowered prices by 42 percent by the late 1980 s. Domestic producers have continued their efforts to reduce costs. The spot market has persisted and, with the reduction of steel mill ownership of iron ore mines to less than 60 percent by 2008 , has grown stronger.

Exported iron ore is traded in the seaborne market, and prices are determined by global market forces. Two iron ore price lists, one for prices of ore to Europe and the other for prices to Japan and other Asian countries, have been widely published. All iron ore is priced in U.S. dollars, which facilitates comparison. The unit pricing system is used to accommodate variations in iron content. Prices are quoted in U.S. cents per ton unit of iron. A unit is $1 / 100$, or 1 percent, of the weight of a ton of iron so that 1 metric ton unit corresponds to $1 / 100$ th of a metric ton. This means that a steelmaker that buys 1 ton of ore that is about 65 percent iron is paying for 1 ton of iron contained in that ore and will receive about $1 \frac{1}{2}$ tons of ore.

Global iron ore prices are usually set during lengthy negotiations between Brazilian iron ore producers and German steelmakers and between Australian producers and Japanese and other Asian steelmakers. Australia and Brazil with roughly equal shares dominate the export market and have a combined share of world iron ore seaborne exports of about 65 percent; the next largest exporter, India, has only about a 10-percent share. In the late 1980s, Europe and Japan were the leading importers, with roughly equal shares, and had a combined share of world imports of nearly 60 percent. More recently, China has taken over the role as world's leading importer with about 50 percent of world imports. Other large importing countries include Japan (15 percent), Germany (from 5 to 6 percent), and the Republic of Korea (from 5 to 6 percent).

Annual contract pricing was the norm until 2009, with the price agreed on for ore sold to Europe applicable for the calendar year effective January 1 of that year. For ore sold to Asia, prices were set for the Japanese fiscal year, which began on April 1 and ended on March 31. The price for iron ore fines was usually settled first because it was the predominant type of ore used in Europe and Asia. Prices for pellets and lump ore were then set based as a premium on the fines prices.

The steel recession that resulted from the OPEC oil embargo in the 1970s created downward pressure on iron ore prices that can be seen in the Brazilian fines price for 1978, the lowest level of the 1976-through-1998 period. (See price tables). As the world economy recovered, iron ore prices peaked in 1982. After 1982, prices dropped as a result of decreased consumption owing to the 1981-82 recession, which, combined with major increases in iron ore production capacity in Australia, Brazil, and Venezuela, created an oversupply. During this period, one U.S. steelmaker permanently closed 16 percent of its production capacity. U.S. iron ore production fell from 73.4 million tons in 1981 to 36.0 million tons in 1982.

Iron ore prices continued to fall until 1989, when economic conditions began to improve (figs. 1 and 2). Decreasing steel production caused prices to fall from 1991 until 1994 when they began rising as the world steel industry enjoyed a number of years of increased production. In 1997, domestic steelmakers increased net shipments of steel mill products for the seventh consecutive year, the longest consecutive increase in shipments ever.

During the second half of 1998, the U.S. steel industry became a victim of the world's growing financial crisis (Hogan, 1999). With the spread of the Asian economic recession, steel demand and regional export opportunities declined and Asian steel producers, particularly in Japan and the Republic of Korea, started to divert more of their products for export, much of it aimed at the United States. Despite high demand for steel, U.S. steel shipments decreased by about 3 percent compared with those of 1997. Lower steel production in the United States and the rest of the world in 1998 caused the Brazilian fines price for 1999 to fall to $\$ 26.96$, a decrease of more than 9 percent.

Lower global steel production beginning in 1998 caused the value (constant 1992 dollars) of world iron ore production to decrease by almost 20 percent between 1998 and 2002. 
With the decline in the market leading into 2001, many highcost producers in the United States declared bankruptcy or ceased production, resulting in consolidations in the iron ore and steel industries. This period was also characterized by union concessions to the iron ore industry and increases in mine and plant operating efficiencies, each serving to reduce operating costs. The consolidations in the iron ore industry can best be exemplified by comparing control of iron ore production in the United States in 2000 with that of 2004. In 2000, three companies controlled slightly more than 50 percent of domestic iron ore production, with nine companies controlling the balance. By 2004, three companies controlled 90 percent of production, with two companies controlling the balance.

During this same period in the United States, integrated steel companies, the consumers of iron ore, underwent major structural changes-U.S. Steel Corp. and Nucor Corp. increased their market shares; Bethlehem Steel Corp. and LTV Corp. filed for bankruptcy; and Mittal Steel USA (part of ArcelorMittal) was formed from Ispat Inland Inc. and Wilbur Ross's International Steel Group Inc. Many of the smaller steel producers in the United States went out of business; in 2000, they represented over one-third of the U.S. steel industry, and by 2004, they represented less than one-fourth (Jorgenson, 2006). U.S. iron ore production capacity appears to be in close balance with steel industry consumption requirements at yearend 2010, considering the transport logistics for the U.S. iron ore and steel industries, much of which is centered in the Great Lakes region (Clevenstine, 2011). Over the next several years, it is expected that no undue pressures will be exerted on the price of iron ore in the North American market barring a steep drop in demand for steel.

Worldwide, an unprecedented period of economic expansion began in 2001 fueled by increased consumption of industrial and consumer goods in China. The three leading iron ore producers were able to take advantage of the increased demand for iron ore, as Brazil's Vale S.A. (Rio de Janeiro) (formerly Companhia Vale do Rio Doce), Australia's BHP Billiton Ltd. (Melbourne), and Rio Tinto plc (London, United
Kingdom) expanded the production capacity of their iron ore operations and opened new mines. These expansions led to an increase of more than 110 percent in world production of iron ore between 2001 and 2008. In spite of this increased production, the 2001-08 period was one during which demand far outstripped world supply, as indicated by a more than fourfold increase in the price (current dollars) of lump ore and a five-fold increase in the price (current dollars) of fine ore into the Asian market. The economic downturn in 2009 resulted in a major correction in prices for iron ore in the form of fines, lump, and pellets, but an apparent economic rebound in 2010 brought world iron ore production and pricing back in line with 2008 levels.

\section{References Cited}

Clevenstine, Peter, 2011, Minnesota Mesabi RangeProviding sustainable iron ore to the North American steel industry: Montreal, Quebec, Canada, Proceedings of the Third Montreal Iron Ore Symposium, Canadian Institute of Mining, Metallurgy, and Petroleum, May 23-25, 53 p.

Franz, Juergen, Stenberg, Bo, and Strongman, John, 1986, Iron ore-Global prospects for the industry, 1985-95: World Bank Industry and Finance Series, v. 12, p. 32.

Hogan, W.T., 1999, Iron and steel-A historic year for steel: Engineering \& Mining Journal, v. 199, no. 3, March, p. $74-78$.

Jorgenson, J.D., 2006, Challenges facing the North American iron ore industry: U.S. Geological Survey Open-File Report 2006-1061, 51 p.

Marcus, P.F., Kirsis, K.M., and Kakela, P.J., 1996, North American iron ore industry-Opportunities and threats: PaineWebber World Steel Dynamics Core Report, January, variously paginated. 


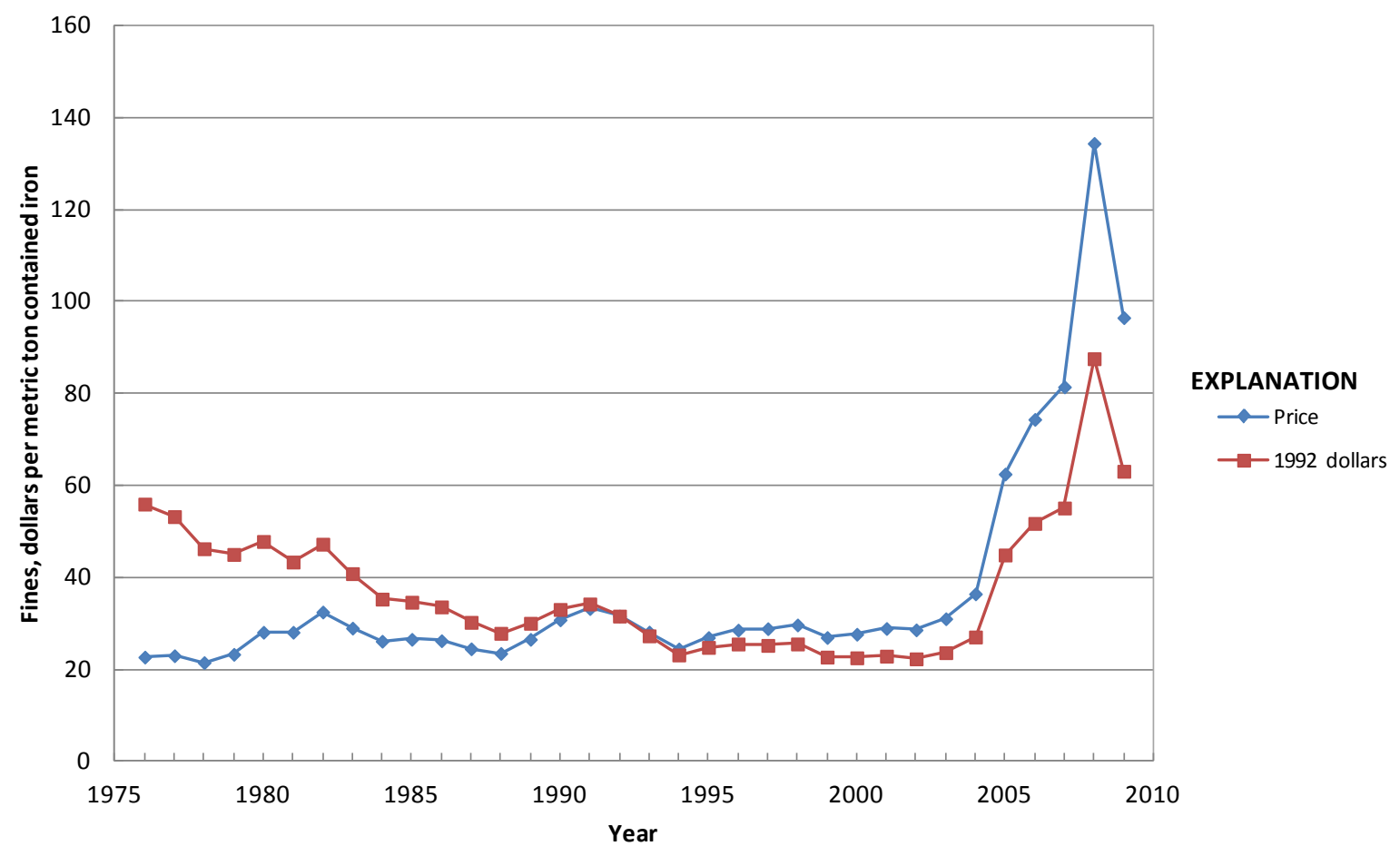

Figure 1. Annual Brazilian iron ore fines price.

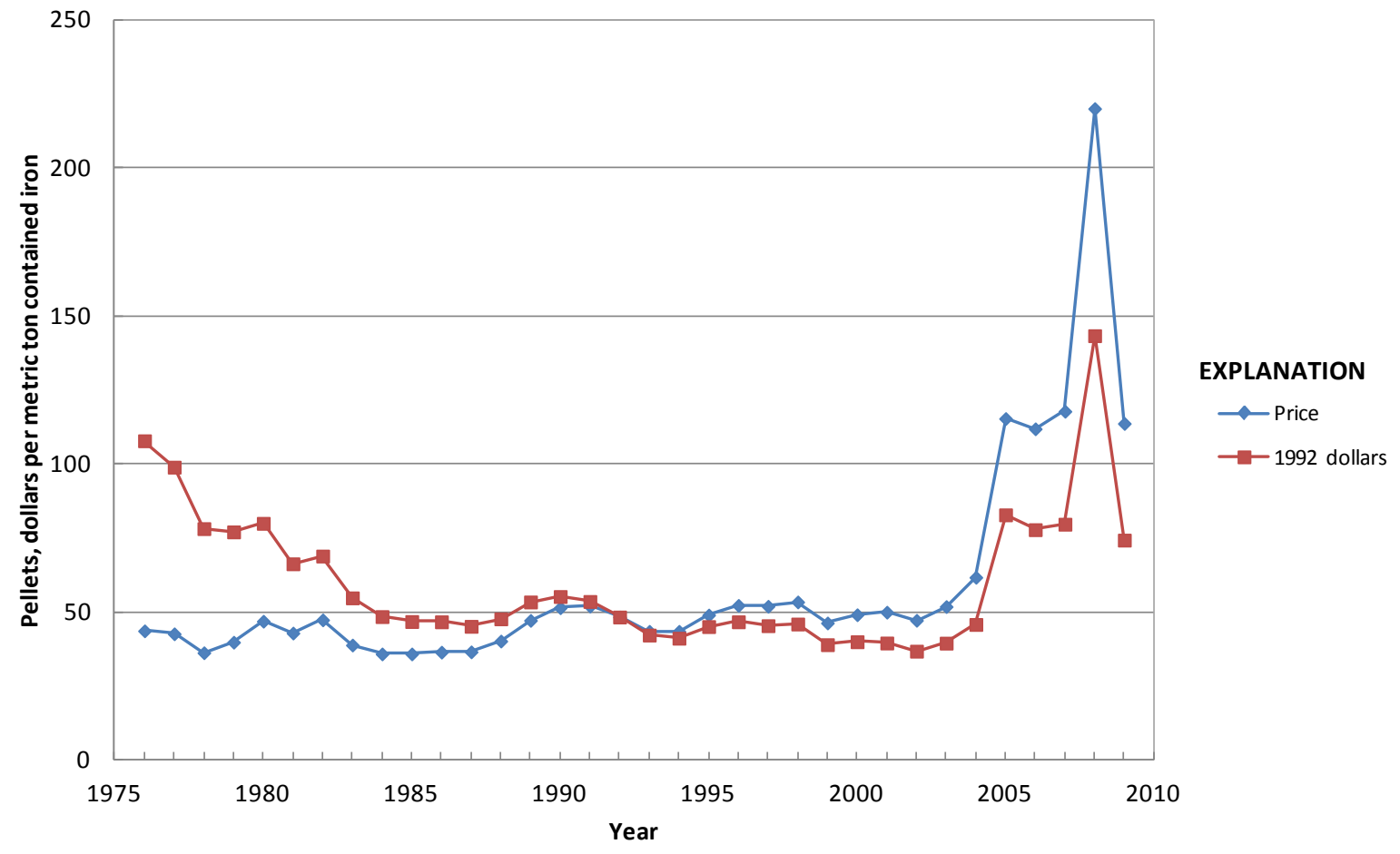

Figure 2. Annual Brazilian iron ore pellet price. 


\section{Significant events affecting iron ore prices since 1970}

1973-75 Organization of Petroleum Exporting Countries (OPEC) oil embargo and deep recession

1981-82 Deep domestic recession

1997-99 Asian financial crisis

2001-04 Consolidations in the U.S. steel and iron ore industries

2003

2008-09

China surpasses Japan as world's leading importer of iron ore

Global economic crisis

Table 1. Annual Brazilian iron ore fines price.

[Values in dollars per metric ton contained iron. NA Not available]

\begin{tabular}{|c|c|c|c|c|c|c|c|}
\hline Year & Price & Year & Price & Year & Price & Year & Price \\
\hline 1976 & 22.70 & 1985 & 26.56 & 1994 & 24.47 & 2003 & 31.04 \\
\hline 1977 & 23.00 & 1986 & 26.26 & 1995 & 26.95 & 2004 & 36.45 \\
\hline 1979 & 23.30 & 1988 & 23.50 & 1997 & 28.88 & 2006 & 74.39 \\
\hline 1980 & 28.10 & 1989 & 26.56 & 1998 & 29.69 & 2007 & 81.46 \\
\hline 1982 & 32.50 & 1991 & 33.25 & 2000 & 27.67 & 2009 & 96.51 \\
\hline 1983 & 29.00 & 1992 & 31.62 & 2001 & 28.92 & 2010 & NA \\
\hline 1984 & 26.15 & 1993 & 28.14 & 2002 & 28.62 & & \\
\hline
\end{tabular}

Note:

Prices are for Brazilian iron ore fines sold to Europe, f.o.b. Tubarão terminal, Southern System, Vale S.A. (formerly Cia. Vale do Rio Doce) in TEX Report Co. Ltd., Iron ore manual.

Table 2. Annual Brazilian iron ore pellet price.

[Values in dollars per metric ton contained iron. NA Not available]

\begin{tabular}{|c|c|c|c|c|c|c|c|}
\hline Year & Price & Year & Price & Year & Price & Year & Price \\
\hline 1976 & 43.80 & 1985 & 36.00 & 1994 & 43.64 & 2003 & 52.00 \\
\hline 1977 & 42.80 & 1986 & 36.60 & 1995 & 49.14 & 2004 & 61.88 \\
\hline 1979 & 39.96 & 1988 & 40.35 & 1997 & 52.10 & 2006 & 112.04 \\
\hline 1980 & 47.05 & 1989 & 47.33 & 1998 & 53.56 & 2007 & 117.96 \\
\hline 1982 & 47.50 & 1991 & 52.15 & 2000 & 49.24 & 2009 & 113.84 \\
\hline 1983 & 39.00 & 1992 & 48.47 & 2001 & 50.10 & 2010 & NA \\
\hline 1984 & 36.00 & 1993 & 43.64 & 2002 & 47.36 & & \\
\hline
\end{tabular}

Note:

Prices are for Brazilian iron ore pellets sold to Europe, f.o.b. Tubarão terminal, Southern System, Vale S.A. (formerly Cia. Vale do Rio Doce) in TEX Report Co. Ltd., Iron ore manual. 


\title{
Lead $(\mathrm{Pb})$
}

\author{
by David E. Guberman
}

Lead is a very dense, ductile, malleable, corrosion resistant, blue-gray metal that has been used for at least 5,000 years. Early uses of lead were in building materials, water pipes, and pigments for glazing. The castles and cathedrals of Europe contain considerable quantities of lead in roofs, windows, pipes, and decorative fixtures (Shea, 1996, p. 1). In the United States, lead was first mined in Virginia in 1621. During the colonial period, lead was mined in New York, North Carolina, and several New England States. By the late 1860s, most of the mine production of lead came from the lower and upper Mississippi Valley regions. A westward expansion of mining began soon thereafter. Many gold and silver mines were developed, some of which contained significant concentrations of lead. In addition, the Missouri Lead Belt, in southeastern Missouri, was developed, as well as the Tri-State Lead District, which included Kansas, Missouri, and Oklahoma. By the late 1950s, depletion of lead reserves in the Lead Belt and discontinuation of mining in the Tri-State region encouraged the discovery and development of the Viburnum Trend mining region in southeast Missouri, thus establishing the framework for the current domestic primary lead industry. Missouri has been the foremost lead-mining State since 1907 and has retained that status throughout the century, except for 1962 when mine output was curtailed by a prolonged strike (Hofman, 1918, p. 1-6; Howe, 1980, p. 1-5).

In conjunction with the mining of lead, numerous primary lead smelters and refineries have been operated in the United States since primary lead production was first recorded in 1825 . By 1887, annual production of primary refined lead had reached 132,000 metric tons (t). By 1926, production increased to a high of $725,000 \mathrm{t}$, representing 87 percent of the total refined lead production. As the production of secondary lead increased, production of refined lead from primary sources gradually decreased. In 1997, annual production of primary refined lead was $343,000 \mathrm{t}$, representing 24 percent of the total refined lead production. The price of primary refined lead increased from $\$ 0.04$ per pound in the early 1900s to $\$ 0.12$ per pound in 1959 , reaching a high of about $\$ 0.18$ per pound during the post-World War II economic boom from 1946 to 1948 and the Korean conflict in the early 1950s (table 1). Between 1959 and 1973, lead prices remained fairly stable, ranging from $\$ 0.12$ to $\$ 0.16$ per pound. This stability was due, in part, to the enactment of Public Law 87-374, the Lead and Zinc Mining Stabilization Program, in 1961. The program, which remained in effect through 1969, authorized payments to qualified miners when the market price of lead dropped below $\$ 0.145$ per pound. In the early 1970 s, movement in the price of lead was restrained by anti-inflation price controls.
With the lifting of price controls in December 1973, the price of lead quickly increased, reaching a historic high in 1979 during the post-Vietnam War economic boom (fig. 1). By the late 1990s, the price of lead had increased tenfold compared with the price at the beginning of the century. In terms of 1992 dollars, however, the price of primary refined lead was $\$ 0.39$ per pound in 1998, compared with $\$ 0.59$ per pound in 1959 .

Historically, lead has not been and is not a price-elastic commodity. Its significant uses in any given era have not depended on price and, for the most part, other metals cannot substitute for lead in these cases. Prior to the early 1900s, uses of lead were primarily for shot, bullets, water lines and pipes, pewter, brass, glazes, paints or other protective coatings, burial vault liners, and leaded glass or crystal. With the advent of the electrical age and communications accelerated by technological developments in World War I, cable lead and solders became preeminent. With the growth in production of public and private motorized vehicles and the associated use of starting lighting ignition (SLI) lead-acid storage batteries and terne metal for gas tanks after World War I, demand for lead increased. In addition to their continued use in SLI applications, new uses of storage batteries have included motive sources of power for industrial forklifts, airport ground equipment, mining equipment, and a variety of other electrically powered nonroad utility vehicles, as well as stationary sources of power in industrial-type applications, such as uninterruptible electrical power supply equipment for hospitals, computer and telecommunications networks, and load-leveling equipment for commercial electrical power systems. Most of these uses continued to expand with the population and the national economy, and total demand accelerated further with electronic developments (primarily television and video display tubes) and demand for leaded gasoline after World War II, peaking between 1977 and 1979. With the near phaseout of lead in gasoline, paints, solders, and water systems, and the imposition of expensive environmental production controls, the industry experienced hard times between 1982 and 1986. However, the industry made a dramatic recovery by the late 1980s, owing to massive retrenchment in the primary and secondary producing sectors with attendant cost reductions, and to expansion in demand for industrial-type battery systems, and record SLI battery shipments. Growth in the battery industry continued into the 1990s. By 1997, lead-acid storage batteries represented a record high 87 percent of reported U.S. consumption of lead. Demand for lead in the battery sector is associated, to a significant extent, with the demand for replacement automotive batteries. In 1997 and 1998, there was some softness in the price of lead owing to 2 consecutive years 
of moderate temperatures in the more-populated regions of the United States that reduced the rate of failure of automotivetype batteries.

The lead market in the United States evolved from 1998 to 2010. During this time, secondary lead became an increasingly important component of total domestic lead consumption and production, and reliance on mined lead declined. Domestic secondary refined lead, produced principally from spent lead-acid batteries, accounted for a greater percentage of total reported lead consumption in 2010 than it had in 1998. In 1998 , the 1.06 million metric tons (Mt) of secondary lead produced was equivalent to about 65 percent of reported domestic lead consumption. In 2010, about 1.14 Mt of secondary lead was produced - nearly 80 percent of reported domestic lead consumption. During the same time period, annual recoverable mined lead production in the United States declined by 28 percent, to $356,000 \mathrm{t}$ from 493,000 t, and annual production of primary refined lead decreased 66 percent, to $115,000 \mathrm{t}$ from $337,000 \mathrm{t}$. One of two primary lead smelters operating in the United States closed in 2003, and the other smelter curtailed production levels in 2009. The balance of the lead concentrates that were not smelted and refined domestically were exported directly from mines to China and other foreign consumers. The increased reliance on secondary lead meant that the price and availability of lead scrap became an important component affecting lead prices. Domestic secondary refineries frequently competed with foreign producers for this scrap.

The development of emerging economies in Asia, specifically China, had a significant impact on lead prices. According to the International Lead and Zinc Study Group, refined lead consumption in China was 4.21 Mt in 2010, an increase of 734 percent from $505,000 \mathrm{t}$ consumed in 1998. This increase in consumption was attributed to rapid growth in the leadacid battery industry for automotive and industrial uses and the increased popularity of battery-operated electric bicycles. Mine and refined lead production also increased in China during this period. In contrast to China, refined lead consumption in the United States declined slightly during the corresponding period. The strong demand for lead in China intensified between 2004 and 2007, and this was a major factor behind lead price increases during that period. China removed a value-added tax rebate and imposed a 10 percent tax on exports of refined lead, leading to significantly decreased exports. As a result, an appreciable shortage of refined lead was evident in the world market during 2007, which led to a substantial price increase.

Lead prices declined in the second half of 2008 as the global economic downturn began to slow global lead consumption. The average North American Producer prices in September 2008 were nearly 30 percent lower than they were at the beginning of the year. The global lead market moved into a state of surplus in 2008 , where it remained through yearend 2010. The automotive market was adversely affected during this period, and shipments of lead-acid batteries declined. On a global basis, multiple lead-producing zinc mines closed or were placed on temporary care-and-maintenance status owing to declining zinc and lead prices. Domestically, a leadproducing zinc mine in northeastern Washington was placed on care-and-maintenance status owing to reduced demand for zinc. North American shipments of lead-acid batteries increased in 2010 compared with those of the previous year, and North American Producer prices began to increase in the third quarter of 2010. By yearend 2010, the price of lead was 9 percent greater than it had been at the end of 2009 .

\section{References Cited}

Hofman, H.O., 1918, Metallurgy of lead: New York, N.Y., McGraw-Hill, 664 p.

Howe, W.B., 1980, Viburnum Trend, Missouri-The geology and ore deposits of selected mines: Rolla, Mo., Missouri Department of Natural Resources Report of Investigation $58,56 \mathrm{p}$.

Shea, E.E., 1996, Lead regulation handbook: Rockville, Md., Government Institutes, Inc., 240 p. 


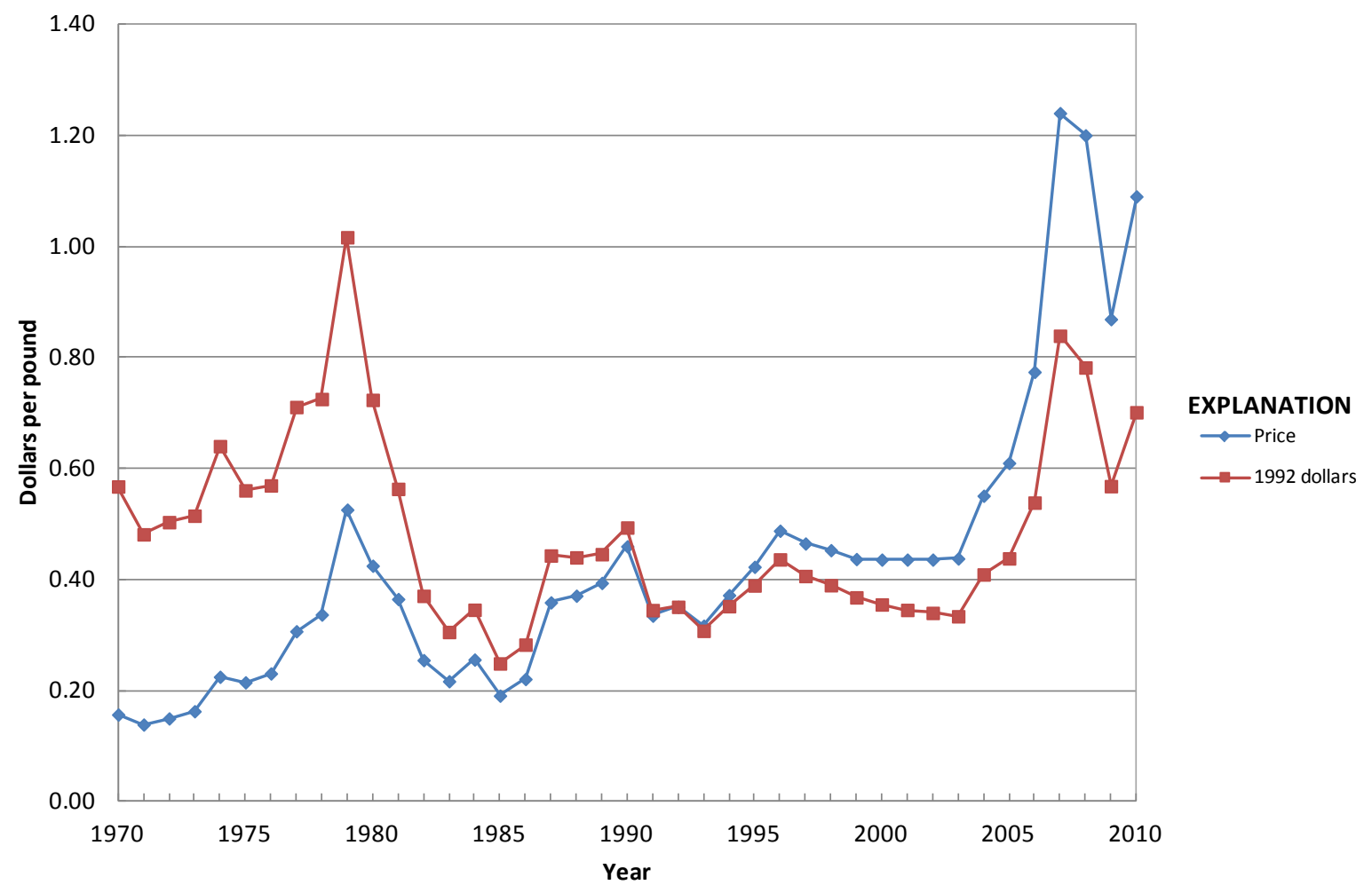

Figure 1. Annual average lead price.

\section{Significant events affecting lead prices since 1970}

1971-73 Price controls in the United States

1976-79 Post Vietnam War boom-highest historical price

1982-86 More stringent environmental controls imposed on production

1986-91 Industry retrenchment with attendant cost reductions

1992-96 Increasing demand, particularly in lead-acid battery sector

1997-98 Moderate weather in more populated regions - demand for replacement automotive batteries slowed

1998

2001-10

2003

Consolidation of the primary and secondary lead industries in the United States

2004-07

Significant annual increases in consumption and production of lead in China and emerging nations

One of two primary lead smelters operating in the United States closed

Prices increased owing to strong demand in China; global deficit of refined lead

2008-09

Economic downturn; global surplus of refined lead; prices declined 
Table 1. Annual average lead price.

[Values in dollars per pound]

\begin{tabular}{|c|c|c|c|c|c|c|c|}
\hline Year & Price & Year & Price & Year & Price & Year & Price \\
\hline 1909 & 0.043 & 1935 & 0.041 & 1961 & 0.109 & 1987 & 0.359 \\
\hline 1910 & 0.044 & 1936 & 0.047 & 1962 & 0.096 & 1988 & 0.371 \\
\hline 1912 & 0.045 & 1938 & 0.047 & 1964 & 0.136 & 1990 & 0.460 \\
\hline 1913 & 0.044 & 1939 & 0.051 & 1965 & 0.160 & 1991 & 0.335 \\
\hline 1915 & 0.047 & 1941 & 0.058 & 1967 & 0.140 & 1993 & 0.317 \\
\hline 1916 & 0.069 & 1942 & 0.065 & 1968 & 0.132 & 1994 & 0.372 \\
\hline 1917 & 0.088 & 1943 & 0.065 & 1969 & 0.149 & 1995 & 0.423 \\
\hline 1918 & 0.074 & 1944 & 0.065 & 1970 & 0.157 & 1996 & 0.488 \\
\hline 1919 & 0.058 & 1945 & 0.065 & 1971 & 0.139 & 1997 & 0.465 \\
\hline 1923 & 0.073 & 1949 & 0.154 & 1975 & 0.215 & 2001 & 0.436 \\
\hline 1924 & 0.081 & 1950 & 0.133 & 1976 & 0.231 & 2002 & 0.436 \\
\hline 1925 & 0.090 & 1951 & 0.175 & 1977 & 0.307 & 2003 & 0.438 \\
\hline 1926 & 0.084 & 1952 & 0.165 & 1978 & 0.337 & 2004 & 0.551 \\
\hline 1927 & 0.068 & 1953 & 0.135 & 1979 & 0.526 & 2005 & 0.61 \\
\hline 1928 & 0.063 & 1954 & 0.141 & 1980 & 0.425 & 2006 & 0.774 \\
\hline 1929 & 0.068 & 1955 & 0.151 & 1981 & 0.365 & 2007 & 1.240 \\
\hline 1930 & 0.055 & 1956 & 0.160 & 1982 & 0.255 & 2008 & 1.200 \\
\hline
\end{tabular}

Notes:

1909-36, Primary producer price, New York (common lead, 99.94-percent pure), in Engineering and Mining Journal.

1937-66, Primary producer price, New York (common lead, 99.94-percent pure), in Engineering and Mining Journal, Metal and Mineral Markets. 1967-70, Primary producer price, New York (common lead, 99.94-percent pure), in Metals Week.

1971-85, Primary producer price, delivered (minimum 99.97-percent pure), in Metals Week.

1986-93, North American producer price, delivered (minimum 99.97-percent pure), in Metals Week.

1994-2010, North American producer price, delivered (minimum 99.97-percent pure), in Platts (Platt's) Metals Week. 


\title{
Lithium (Li)
}

\author{
by Brian W. Jaskula
}

Production of lithium minerals was first reported in the United States in 1898. Spodumene and amblygonite from California and South Dakota were exported for conversion to lithium chemicals. It was not until about 1916, during World War I, that lithium chemical production began in the United States (Schaller, 1917). Shortly thereafter, the United States became the largest producer of lithium minerals and chemicals in the world (Schaller, 1917). Dominant production sites shifted from the original States to North Carolina in 1942 (Broadhurst, 1956, p. 11) and Nevada in 1966 (Skillings Mining Review, 1968). In 1976, the U.S. Bureau of Mines reported that the United States provided nearly 80 percent of the world lithium demand (Quan, 1978). In 1984, lithium carbonate production began in Chile (Foote Prints, 1984). Lithium carbonate production shifted from the United States to South America in the mid-1990s, with two new operations coming onstream - a second operation in Chile in 1996 (Minsal S.A., 1996) - and a facility in Argentina in 1997 (FMC Corporation, 1999, p. 28).

The majority of lithium end uses requires lithium as one of its compounds rather than in the metallic form. Although a few lithium chemicals require lithium metal for their production, the metal used to produce the chemicals is produced and converted by the same company and so is not sold and does not enter the market or affect the prices of commercial lithium metal products (Lithium Corporation of America, 1985, p. 4). Although lithium metal prices were first reported in trade publications in 1952, demand was very low. Small quantities were used as scavengers in the production of low-oxygen copper alloys, but other uses were just beginning to be investigated (Arundale and Mentch, 1955).

From 1952 to 1974, lithium prices remained flat in terms of current dollars; in terms of constant dollars, however, prices decreased (table 1). The potential use of lithium in batteries for electric vehicles was first discussed in the Minerals Yearbook in 1972 (Wininger, 1974). The downward trend in lithium metal prices reversed in 1974. At about the same time, research efforts increased for identifying aluminum lithium alloys for use in aerospace applications. Increased demand for lithium in batteries and alloys resulted in steadily increasing lithium metal prices until 1998 (fig. 1).

From 1999-2006, prices trended downward, but increased in 2007-08 owing to lithium's increased use in battery applications and a temporarily constrained supply. In 2009, lithium metal prices decreased again (Jaskula, 2011). The 1999 price drop was likely the result of the shifting of lithium compound production to the lower cost South American brine-based salars in the mid-1990s, which resulted in lower cost feedstock for lithium metal production. The decline in 2009-10 was the consequence of the worldwide economic downturn that began in late 2008 .

The demand for lithium metal, however, cannot be quantified. Because lithium has been a small industry with very few major producers, published information on lithium metal production and markets is hard to find. From 2001-05, lithium metal prices were not published.

The use of lithium in batteries is expected to continue to expand but not necessarily in the form of lithium metal. The requirement for lithium metal for those batteries may grow more slowly as battery makers search for the optimum battery chemistry, balancing energy density, cost, and safety.

\section{References Cited}

Arundale, J.C., and Mentch, F.B., 1955, Lithium, in Metals and minerals (except fuels): U.S. Bureau of Mines Minerals Yearbook 1952, v. I, p. 650-659.

Broadhurst, S.D., 1956, Lithium resources of North Carolina: North Carolina Department of Conservation and Development Information Circular 15, 37 p.

FMC Corporation, 1999, FMC annual report 1998: FMC Corp., 56 p.

Foote Prints, 1984, New lithium frontier in Chile: Foote Prints, v. 47 , no. 1 , p. $2-14$.

Jaskula, B.W., 2011, Lithium, in Metals and minerals: U.S. Geological Survey Minerals Yearbook 2009, v. I, p. $44.1-44.10$.

Lithium Corporation of America, 1985, Lithium: Lithium Corporation of America company report, $18 \mathrm{p}$.

Minsal S.A., 1996, First lithium carbonate precipitation at Minsal: Santiago, Chile, Minsal S.A. press release, October 30, 1 p.

Quan, C.K., 1978, Lithium, in Metals, minerals, and fuels: U.S. Bureau of Mines Minerals Yearbook 1976, v. I, p. 767-781.

Schaller, W.T., 1917, Lithium minerals in 1916, in Mineral resources of the United States 1916: U.S. Geological Survey, pt. 2, p. 7-17. 
Skillings Mining Review, 1968, Foote Mineral Co.’s lithium operation in Nevada: Skillings Mining Review, v. 57, no. 3, January 20, p. 10.
Wininger, D.C., 1974, Lithium, in Staff, Division of Nonmetallic metals, minor nonmetals, in Metals, minerals, and fuels: U.S. Bureau of Mines Minerals Yearbook 1972, v. I, p. 1,362-1,365.

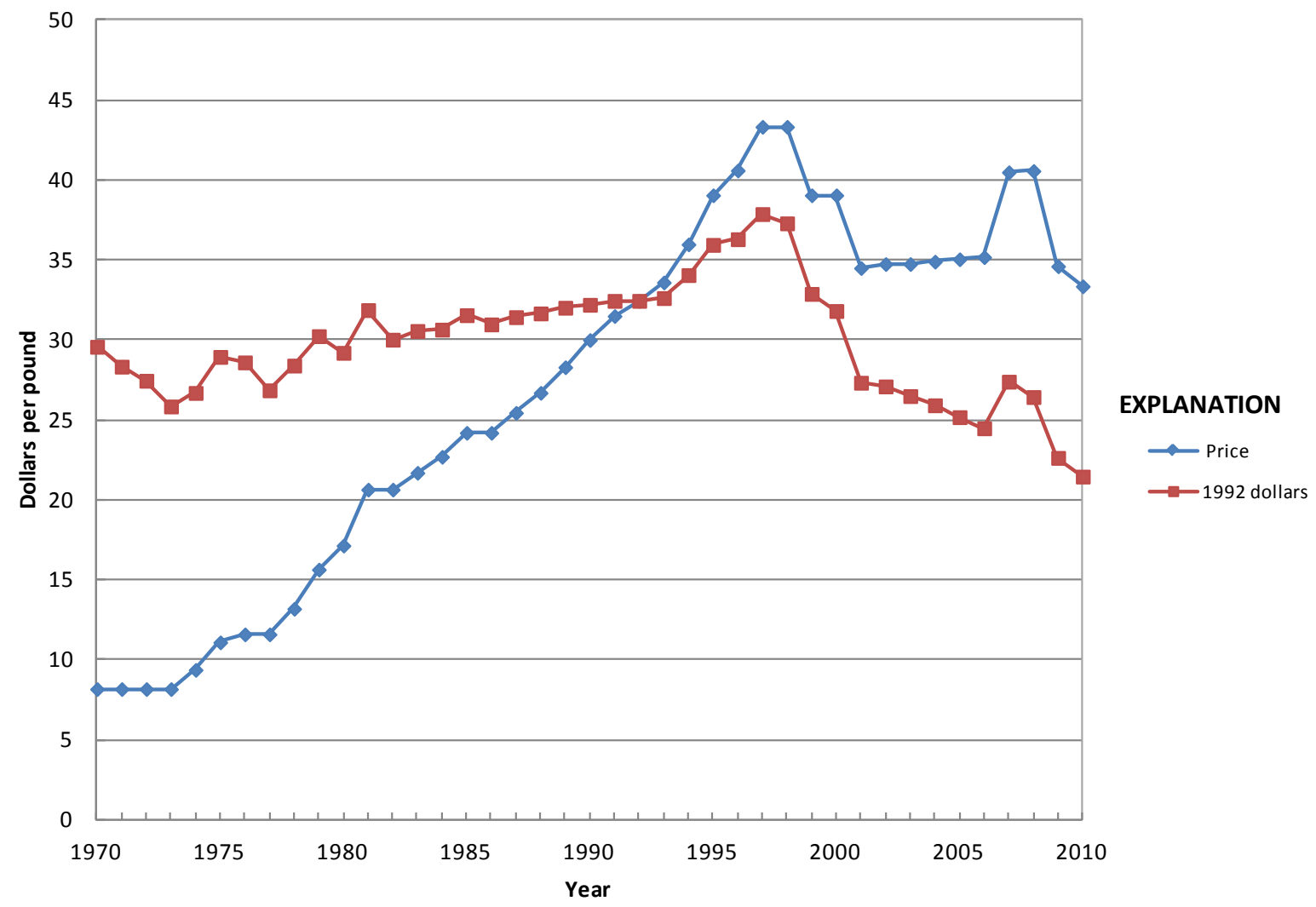

Figure 1. Yearend average lithium price.

\section{Significant events affecting lithium prices since 1970}

$1984 \quad$ Lithium carbonate first produced in Chile

1996-97 Lithium carbonate production shifted from the United States to South America

1999 Lithium prices decreased owing to production from lower cost South American brine-based salars

2007-08 Lithium prices increased owing to expanded battery applications and temporarily constrained supply

2009-10 Lithium prices decreased owing to the worldwide economic downturn. Lithium exploration increased worldwide in anticipation of expanded transportation use 
Table 1. Yearend average lithium price.

[Values in dollars per pound]

\begin{tabular}{|c|c|c|c|c|c|c|c|}
\hline Year & Price & Year & Price & Year & Price & Year & Price \\
\hline 1952 & 9.85 & 1967 & 7.50 & 1982 & 20.65 & 1997 & 43.33 \\
\hline 1953 & 11.00 & 1968 & 7.50 & 1983 & 21.70 & 1998 & 43.33 \\
\hline 1955 & 11.00 & 1970 & 8.18 & 1985 & 24.20 & 2000 & 39.05 \\
\hline 1956 & 11.00 & 1971 & 8.18 & 1986 & 24.20 & 2001 & 34.50 \\
\hline 1958 & 9.00 & 1973 & 8.18 & 1988 & 26.70 & 2003 & 34.75 \\
\hline 1959 & 9.00 & 1974 & 9.38 & 1989 & 28.30 & 2004 & 34.90 \\
\hline 1960 & 9.00 & 1975 & 11.10 & 1990 & 30.00 & 2005 & 35.05 \\
\hline 1961 & 9.00 & 1976 & 11.60 & 1991 & 31.50 & 2006 & 35.18 \\
\hline 1962 & 9.00 & 1977 & 11.60 & 1992 & 32.45 & 2007 & 40.49 \\
\hline 1966 & 7.50 & 1981 & 20.65 & 1996 & 40.60 & & \\
\hline
\end{tabular}

Notes:

1952-57, 98-percent-pure lithium metal, in Engineering and Mining Journal, Metal and Mineral Markets.

1958-65, 99.5-percent-pure lithium metal, in Engineering and Mining Journal, Metal and Mineral Markets.

1966-71, Standard or technical grade lithium of at least 99.8-percent in Oil, Paint, and Drug Reporter.

1972-77, Standard or technical grade lithium of at least 99.8-percent purity, in Chemical Marketing Reporter.

1978-90, Producers average list price for standard or technical grade lithium of at least 99.8-percent purity.

1991-94, Average of producer and published prices for standard or technical grade lithium metal of at least 99.8-percent purity, in Chemical Marketing Reporter.

1995-96, Producers' average list price for standard or technical grade lithium of at least 99.8-percent purity.

1997-2000, Standard or technical grade lithium of at least 99.8-percent purity, in Chemical Market Reporter

2001-05, Lithium metal prices not published. Lithium metal prices were estimated based on lithium carbonate price trends.

2006-10, Average values of Japanese imports of lithium metal, in Roskill's Letters from Japan. 


\title{
Magnesium (Mg)
}

\author{
by Deborah A. Kramer
}

Magnesium is the eighth most abundant element and constitutes about 2 percent of the Earth's crust. It is the third most plentiful element dissolved in seawater, with a concentration averaging 0.13 percent. Although magnesium is found in more than 60 minerals, only dolomite, magnesite, brucite, carnallite, and olivine are of commercial importance. Magnesium metal was first reported to have been produced by Sir Humphry Davy in 1808 by reduction of magnesium oxide with potassium vapor. In 1833, Michael Faraday obtained magnesium by the electrolysis of fused anhydrous magnesium chloride, and in 1852, Robert Bunsen developed an electrolytic cell for this purpose. By the use of a modification of Bunsen's electrolytic cell, magnesium metal was produced on a pilot plant scale in Germany in 1886, and by 1909, had advanced to limited industrial production. The first magnesium plant in the United States was constructed by the General Electric Co. at Schenectady, NY, in 1914. Magnesium production in the United States increased steadily and experienced a sharp increase during World War II because of the use of magnesium in incendiary bombs. From 1941 through 1944, supplies of magnesium were allocated to manufacturers of military components. Seven Government-owned plants were brought onstream during World War II to supply the military demand, and prices were controlled from 1943 through 1945 by the Office of Price Administration.

After the end of the War, the price controls were lifted, and consumer demand was not great enough to sustain the wartime production levels. The rearmament program, between 1947 and 1953, brought a rise in consumption, but when military supplies were replenished, demand declined significantly, and the Government-owned plants were closed. Because the large demand was not sustained, prices after World War II remained constant.

In the 1950s and early 1960s, magnesium prices remained steady (table 1). Development of new rolling techniques and new alloys helped increase magnesium's usage, particularly in machinery and transportation equipment. By maintaining magnesium's price at a constant level, these industries were encouraged to use magnesium components. From 1964 through 1974, magnesium that had been acquired for the National Defense Stockpile in the early 1950s was released because magnesium was removed from the list of strategic and critical materials. This stockpile release provided an additional source of magnesium to supply the growing demand, which kept prices stable.

In 1974, a combination of increased energy costs, rising inflation rates, and the surge in use of aluminum beverage cans, which contain magnesium, led to a dramatic price increase. The price of magnesium nearly doubled within 1 year (fig. 1). Effects of rapid inflation rates continued to be felt through the remainder of the 1970s and into the early 1980s. As inflation rates decreased, the price of magnesium stabilized. In 1987 and 1988, magnesium supplies tightened as aluminum consumption increased. Because magnesium's principal use was as an alloying addition to aluminum, its use was directly related to aluminum consumption. In addition, high-purity magnesium alloys were developed as a measure to increase domestic consumption, particularly in automobiles. This supply shortage led to increased magnesium prices from 1987 to 1988.

In early 1990, North American production increased with the opening of a new 40,000-metric-ton-per-year ( $\mathrm{t} / \mathrm{yr})$ primary magnesium plant in Canada. Much of the Canadian production was imported into the United States, alleviating the supply shortage. As a result, producers' quoted prices dropped in 1990, and by the end of 1991, press reports indicated that the actual selling price of primary magnesium was about $\$ 1.10$ to $\$ 1.20$ per pound. These low prices prompted one U.S. producer, in September 1991, to request countervailing and antidumping duty investigations into imports of magnesium from Canada.

With the dissolution of the former Soviet Union at the end of 1991, however, new suppliers entered the world market. Because stockpiles had been built up over many years, Russia and Ukraine had significant quantities of magnesium available to exchange for hard currency in the world market. In spite of the cessation of magnesium imports from Canada, U.S. imports were strong because of the increased supply of metal, particularly from Russia. As a result, U.S. prices dropped significantly in 1992, and a two-tier price system was established - a U.S. import price and a U.S. transaction price, which reflected prices charged by U.S. producers.

By mid-1992, the U.S. International Trade Commission (ITC) had established antidumping and countervailing duties on magnesium imported from Canada, so this material essentially was eliminated from the U.S. market (U.S. Department of Commerce, 1992). Imports of magnesium from Canada were approximately replaced by imports from Russia, so the change in U.S. magnesium supplies was not significant, and as a result, the U.S. price moderated during 1992 and 1993.

Low unit values for magnesium imported from Russia and Ukraine prompted one U.S. producer to request an antidumping duty investigation of magnesium imports from these two countries, as well as from China, in mid-1994. This resulted in a cessation of magnesium imports from these countries. As domestic demand, mostly for magnesium com- 
ponents for automotive applications, continued to increase, the elimination of imported magnesium from Canada, China, Russia, and Ukraine led to tight U.S. supplies. As a result, the price began to increase. Supplies remained tight through most of 1995 , and by midyear, the price escalated to $\$ 2.35$ per pound, the highest price since magnesium's first U.S. production early in the 20th century.

The ITC established final antidumping determinations in April 1995 for magnesium imports from China, Russia, and Ukraine (U.S. Department of Commerce, 1995a-c). Because the antidumping duty on Russian magnesium was established at 0 percent for all the large producers (as long as they imported the magnesium through specified importing companies), magnesium again could be imported from Russia, which had been the United States' largest magnesium supplier.

By 1996, the price began to drop as Russian magnesium returned to the United States market. At the same time, the countervailing duties on magnesium imports from Canada dropped enough so that Canada began exporting significant quantities of magnesium alloy into the United States. With these sources of imported material, the United States experienced an oversupply of magnesium, and prices dropped dramatically by yearend 1996. Also in 1996, the United States imported more magnesium than it exported for the first time in more than 20 years.

The United States continued to rely on imports of magnesium to meet its increasing demand, so U.S. prices continued to weaken slightly through 1998 , although they were returning to more normal levels following the 1995 price spike. World supply in 1997 and 1998 also increased with production from a new $27,500-\mathrm{t} / \mathrm{yr}$ primary magnesium plant that had been commissioned at the end of 1996 in Israel.

In November 1999, Dow Chemical Co. announced that it would close its $65,000-\mathrm{t} / \mathrm{yr}$ primary magnesium plant in Freeport, Tex., and in October 2001, Alcoa Inc. closed its 45,000-t/yr primary magnesium plant in Addy, Wash. As a result, by the end of 2001, the United States had only one primary magnesium plant, with a capacity of $43,000 \mathrm{t} / \mathrm{yr}$, and became more heavily reliant on imports to supply its needs. In the mid-2000s, primary magnesium plants in Canada, France, and Norway closed, reducing the number of suppliers to the world market. At the same time, China began to assert its dominance in world magnesium production, representing 73 percent of the total by 2004, a significant increase from 35 percent of the 1999 total. Despite these closures, an oversupply in the market led to price declines until 2004. In the third quarter of 2004, U.S. magnesium prices increased. The following factors contributed to the increase in U.S. prices: large aluminum producers, such as Alcan Inc. and Alcoa Inc., began negotiating contracts for their 2005 magnesium needs; anticipation of a decision in the antidumping duty case on imports of magnesium from China and Russia; and the absence of low-cost Chinese magnesium in the U.S. market. Magnesium from China had been sold mostly in Europe. This led to a short-lived price spike in 2004. By 2005, however, U.S. magnesium prices fell. Several reasons were suggested for the downturn in prices, particularly in the latter part of the yearoversupply of magnesium, particularly from Russian producers, and competition from recycled magnesium, which has a lower price. Overcapacity in the automobile industry coupled with the phasing out of one of General Motors Corporation's most comprehensive truck and sport utility vehicle redesign programs also contributed to the price decline (McBeth, 2005).

In general, U.S. magnesium prices fell throughout the first three quarters of 2006, then increased significantly during the last quarter. In mid-October, the price began to increase rapidly because Norsk Hydro ASA announced that it would close its Becancour, Quebec, Canada, primary magnesium plant by the first quarter of 2007; Becancour was a major magnesium alloy supplier to the U.S. auto industry. Another factor that contributed to the fourth quarter price increase was a feedstock supply interruption at VSMPO-Avisma Corporation's primary magnesium plant in Berezniki, Russia. These factors, in addition to reduced supplies from China because of antidumping duties, contributed to an escalation in magnesium prices in 2007.

U.S. magnesium consumers began committing to 2008 annual contracts earlier in 2007 than in the previous year, and contract prices were reported to be significantly higher - about $\$ 1.70$ per pound for 2008 compared with 2007 contract prices of $\$ 1.20$ to $\$ 1.30$ per pound. Consumers feared that prices would increase even further. By the beginning of November, U.S. Magnesium LLC and Dead Sea Magnesium Ltd. reportedly stopped signing contracts for 2008 because they had no magnesium left to sell (McDonell, 2007a, b).

Domestic magnesium prices continued to increase rapidly and reached $\$ 2.80$ to $\$ 3.15$ per pound by the end of January 2008, well above the price spike in 1995. From the end of 2007 through the end of the first quarter of 2008, the average U.S. spot Western price increased by nearly $\$ 1.00$ per pound. In the United States, a decline in imports from Russia and Canada, two of the leading import sources, caused a supply shortage on the spot market.

In the United States, the Platts Metals Week U.S. spot Western price range reached a peak of $\$ 3.50$ to $\$ 3.70$ per pound at the beginning of July. Essentially, two markets developed in 2008 after prices peaked - the U.S. market and the market in the rest of the world. Although they fell from the alltime high in July, U.S. spot prices remained high because of antidumping duties assessed on China and Russia. Although some magnesium from both these countries was imported into the United States, supplies from these countries were not as substantial as in the past. Because of sustained high prices, weak demand in the auto industry, and the global financial downturn, many domestic magnesium consumers did not purchase magnesium on the open market and were reluctant to negotiate 2009 contracts (Jennemann, 2008).

In 2009, prices continued the decline begun in the fourth quarter of 2008. Most of the decline in prices in the United States early in the year resulted from renegotiations of contracts, not spot sales. In addition, consumers were delaying deliveries because of the slowdown in the magnesium end-use 
markets and in consumption in secondary aluminum products (Jennemann, 2009a). By midyear, consumers had significant quantities of magnesium left in their 2009 contracts and were not yet negotiating contracts for 2010; spot magnesium sales were almost nonexistent. By yearend, prices were significantly lower than those at yearend 2008 in response to the weak global economy and weak magnesium demand (Jennemann, 2009b).

Prices in 2010 did not change appreciably, as the U.S. economy began a weak recovery and demand began to increase but remained higher than levels in the late 1990s and early 2000s. Antidumping duties that essentially shut most of the magnesium from China out of the U.S. market since 1995 and reduced shipments from Russia resulted in Israel becoming the principal import source for metal and alloys. U.S. Magnesium also announced increases in production capacity; projected additional supply also moderated any price increases in the United States.

\section{References Cited}

Jennemann, Tom, 2008, Magnesium mart slow on uncertainty: American Metal Market, October 17, accessed November 6, 2008, via http://www.amm.com/.

Jennemann, Tom, 2009a, Magnesium demand ticks up in April: American Metal Market, May 5, accessed May 12, 2009, via http://www.amm.com/.

Jennemann, Tom, 2009b, Magnesium mart looking for contract flexibility: American Metal Market, August 11, accessed August 13, 2009, via http://www.amm.com/.
McBeth, Karen, 2005, Magnesium sees 'wild ride' downhill, bucking metals trend: Platts Metals Week, v. 76, no. 50, December 12, p. 8.

McDonell, Meghann, 2007a, Magnesium contracts met sooner and at higher rates: American Metal Market, v. 115, no. 25-4, June 28, p. 1-2.

McDonell, Meghann, 2007b, Magnesium suppliers cease inking '08 deals: American Metal Market, v. 115, no. 45-1, November 12, p. 1, 6.

U.S. Department of Commerce, 1992, Pure and alloy magnesium from Canada-Recission of investigation and partial dismissal of petition: Federal Register, v. 57, no. 134, July 13, p. 30,939-30,955.

U.S. Department of Commerce, 1995a, Notice of final determination of sales at less than fair value-Pure magnesium and alloy magnesium from the People's Republic of China: Federal Register, v. 60, no. 61, March 30, p. 16,437-16,440.

U.S. Department of Commerce, 1995b, Notice of final determination of sales at less than fair value-Pure magnesium and alloy magnesium from the Russian Federation: Federal Register, v. 60, no. 61, March 30, p. 16,440-16,450.

U.S. Department of Commerce, 1995c, Notice of final determination of sales at less than fair value-Pure magnesium from Ukraine: Federal Register, v. 60, no. 61, March 30, p. $16,432-16,437$. 


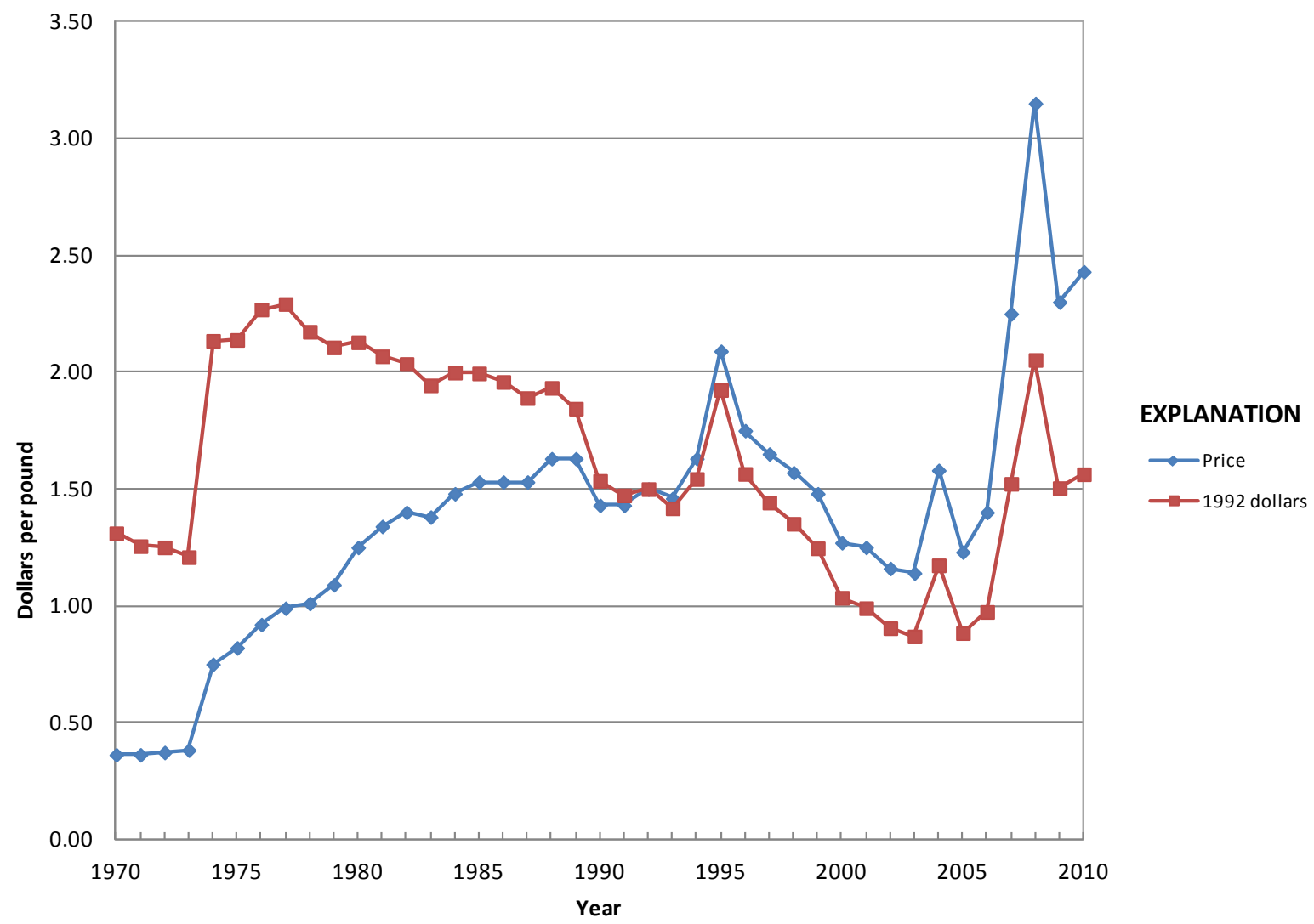

Figure 1. Yearend average magnesium price.

\section{Significant events affecting magnesium prices since 1970}

1974-79 Increased energy costs and rapid inflation boost prices

1987-88 Tight supply of magnesium because of increased aluminum consumption

1991 Antidumping and countervailing duty investigations of magnesium imports from Canada initiated; dissolution of the Soviet Union

1994 Antidumping duty investigation initiated on magnesium imports from China, Russia, and Ukraine

$2008 \quad$ Closure of large primary magnesium plant in Canada leads to supply concerns 
Table 1. Yearend primary magnesium price.

[Values in dollars per pound]

\begin{tabular}{|ll|ll|ll|ll|}
\hline \multicolumn{1}{r|}{ Year } & Price & Year & Price & Year & Price & Year & Price \\
\hline 1915 & 5.030 & 1939 & 0.300 & 1963 & 0.363 & 1987 & 1.530 \\
1916 & 4.130 & 1940 & 0.270 & 1964 & 0.363 & 1988 & 1.630 \\
1917 & 2.020 & 1941 & 0.230 & 1965 & 0.363 & 1989 & 1.630 \\
1918 & 1.810 & 1942 & 0.230 & 1966 & 0.363 & 1990 & 1.430 \\
1919 & 1.830 & 1943 & 0.210 & 1967 & 0.363 & 1991 & 1.430 \\
1920 & 1.600 & 1944 & 0.210 & 1968 & 0.363 & 1992 & 1.500 \\
1921 & 1.600 & 1945 & 0.210 & 1969 & 0.363 & 1993 & 1.460 \\
1922 & 1.600 & 1946 & 0.210 & 1970 & 0.363 & 1994 & 1.630 \\
1923 & 1.250 & 1947 & 0.210 & 1971 & 0.363 & 1995 & 2.090 \\
1924 & 1.070 & 1948 & 0.210 & 1972 & 0.373 & 1996 & 1.750 \\
1925 & 0.860 & 1949 & 0.210 & 1973 & 0.383 & 1997 & 1.650 \\
1926 & 0.800 & 1950 & 0.250 & 1974 & 0.750 & 1998 & 1.570 \\
1927 & 0.680 & 1951 & 0.250 & 1975 & 0.820 & 1999 & 1.480 \\
1928 & 0.550 & 1952 & 0.270 & 1976 & 0.920 & 2000 & 1.270 \\
1929 & 0.570 & 1953 & 0.270 & 1977 & 0.990 & 2001 & 1.250 \\
1930 & 0.480 & 1954 & 0.280 & 1978 & 1.010 & 2002 & 1.160 \\
1931 & 0.300 & 1955 & 0.325 & 1979 & 1.090 & 2003 & 1.140 \\
1932 & 0.290 & 1956 & 0.353 & 1980 & 1.250 & 2004 & 1.580 \\
1933 & 0.280 & 1957 & 0.363 & 1981 & 1.340 & 2005 & 1.230 \\
1934 & 0.260 & 1958 & 0.363 & 1982 & 1.400 & 2006 & 1.400 \\
1935 & 0.260 & 1959 & 0.363 & 1983 & 1.380 & 2007 & 2.250 \\
1936 & 0.260 & 1960 & 0.363 & 1984 & 1.480 & 2008 & 3.150 \\
1937 & 0.300 & 1961 & 0.363 & 1985 & 1.530 & 2009 & 2.300 \\
1938 & 0.300 & 1962 & 0.363 & 1986 & 1.530 & 2010 & 2.430 \\
\hline
\end{tabular}

Notes:

1915-34, Producers' average selling prices for 99-percent-pure magnesium bars.

1935-56, Producer price for 99.8 percent-pure magnesium ingot, in Engineering and Mining Journal.

1957-91, Producer price for 99.8-percent-pure magnesium ingot, in American Metal Market.

1992, U.S. transaction price for 99.8-percent-pure magnesium ingot, in Metals Week.

1993-2010, Average U.S. spot Western price for 99.8-percent-pure magnesium ingot, in Platts (Platt's) Metals Week. 


\title{
Manganese (Mn)
}

\author{
by Lisa A. Corathers
}

From antiquity until the latter part of the 18th century, the manganese oxide mineral, pyrolusite from the Greek words "fire" and "to wash" was considered an iron mineral. Ancient Egyptians and Romans used pyrolusite to control the color of glass. Small additions of pyrolusite decolorized glass by removing the greenish yellow discoloration caused by iron impurities, while further additions colored the glass pink, purple, or black (Wellbeloved, Craven, and Waudby, 1990, p. 78). In 1740, J.H. Pott showed that pyrolusite does not contain iron. Swedish chemist and apothecary Carl Wilhelm Scheele recognized manganese as an element in 1774, and his fellow countryman, Johan Gottlieb Gahn, isolated the metal by reducing the dioxide with carbon in the same year. Until about that time, manganese was principally used as a colorant in glass and pottery. It was apparently for this purpose that manganese ore was first mined in the United States in Virginia and Tennessee in the 1830s (Jones, 1985, p. 483).

Use in steelmaking has since become the major application of manganese. Its use for a specific purpose in the steel industry dates from 1839, when manganese was shown to improve malleability of ferrous articles. In 1856 , Robert Forester Mushet demonstrated that steel could be mass-produced by the Bessemer process, provided manganese was added (Williams, 1981). Manganese has since been essential to commercial production of almost all steels. The bulk manganese ferroalloy industry was established not many years later, and by the 1870 s, cheap ferromanganese containing 75 percent or more manganese was available.

This discussion of manganese price is based on the price of manganese units in metallurgical-grade ore, for which a lengthy history exists. The most important metallic materials containing manganese are the manganese ferroalloys, of which high-carbon ferromanganese and silicomanganese have the greatest uses. (Manganese metal, a minor component of overall manganese demand, is a brittle substance that has little use, except as an alloying element.) The value of manganese in upgraded forms reflects the extraction cost so that for materials used in the United States in 2009, the ratio of price per manganese unit as contained in upgraded form compared to that in ore was, in ascending order: 2.1:1 for high-carbon ferromanganese, 2.3:1 for silicomanganese, and 4.2:1 for manganese metal. Price trends for upgraded materials do not necessarily parallel those for manganese ore because of the following: (1) differences in demand by primary intermediate consuming industries - the iron and steel industries (ferromanganese and silicomanganese) and the aluminum industry (manganese metal); (2) the fact that most ore is used to produce manganese ferroalloys; and (3) differences in world structure and number of upgraded manganese material suppliers.

No central exchange has ever existed for setting the price of manganese ore. Rather, prices have been established by negotiation between buyers and sellers, taking into account such factors as manganese content, content of other elements, physical characteristics, quantity, and, of considerable significance, ocean freight rates. Trade journals, such as American Metal Market and Engineering and Mining Journal Metal and Mineral Markets, published prices reflecting their sense of the market (Jones, 1988). These journals mainly listed the price for metallurgical-grade ore; price listings for ore used in battery and chemical applications were fragmentary or nonexistent, and by 2001, were discontinued altogether. The benchmark price for metallurgical-grade ore is for relatively high-grade ore with a manganese content in the range from 48 percent to 50 percent. Prices stated herein for metallurgicalgrade ore generally meet that standard, although this may not be strictly true throughout the entire time interval tabulated, particularly when the countries that were dominant sources of ore changed (table 1).

The unit pricing system is used with manganese ore to accommodate variations in manganese content. Since 1990, the metric ton unit ( $\mathrm{mtu}$ ) contained manganese, has been used; formerly, pricing had been based on the long ton unit (fig. 1). A unit is $1 / 100$, or 1 percent, of the weight unit, so that 1 mtu corresponds to 0.01 metric ton, or 10 kilograms $(\mathrm{kg})$ of manganese. To determine dollars per metric ton of ore (gross weight), multiply the manganese content percentage by the price; that is, by 50 when the manganese content is 50 percent. For example, an ore priced at $\$ 2$ per mtu that contains 50 percent manganese would have a value of $\$ 2 \times 50=\$ 100$ per metric ton. At the price level of $\$ 2$ per $10 \mathrm{~kg}$ of manganese, the value of the manganese content of the ore also could be expressed as 20 cents per $\mathrm{kg}$ of manganese in ore.

Until 2009, the larger year-to-year users of manganese ore tended to make their purchases by means of annual contracts, which have always been much more important than spot contracts. The U.S. market was once the largest for manganese ore; therefore, prices were usually set in the latter part of the calendar year for the next year's shipments. With the decline in U.S. manganese ferroalloy smelting, however, the Japanese became the most influential in setting annual prices since the early 1990s. The timing of price negotiations generally revolved around the Japanese fiscal year, which begins on April 1. After the price to Japanese consumers has been set (this is known as the international benchmark 
price), settlements on a similar basis usually follow elsewhere (Carmichael, 1992).

The use of annual benchmark pricing started to decline in 2008. For the first time, a major Australian manganese ore producer, BHP Billiton Ltd., and major Japanese consumers negotiated a range in international benchmark prices for metallurgical-grade ore. The contract included a clause that would allow Japanese prices to be reviewed on a quarterly or semiannual basis based on fluctuations in Chinese manganese ore spot-market prices. This was because China had by then become an ever-increasing, globally dominant consumer of manganese ore (Corathers, 2010). By 2009, BHP Billiton had officially abandoned its quarterly pricing system for manganese ore with Japanese consumers, opting rather to negotiate separate deals with each buyer in each market (Ryan's Notes, 2009).

Between 1970 and 2010, manganese ore prices exhibited peaks in 1981, 1990, 2005, and 2008, and valleys in 1987, 1994-95, 2006-07, and 2009. Since 1974, prices have grown at a compound annual rate of about 6.5 percent. This rate is lower than the general rate of inflation as given by the Consumer Price Index (all urban consumers), which advanced from 1974 to the early 1980s at an average of 7.4 percent per year. Since then, however, the manganese compound annual growth rate has been higher than the average general inflation rate ( 3.5 percent per year).

From 1970 to 2009, the U.S. Government continued to sell sizable quantities of stockpiled metallurgical-grade manganese ore that had been mined from domestic and foreign sources. This caused the stockpile to become effectively a medium-sized "mine," which generally added downward pressure on U.S. manganese ore prices, particularly from 1976 to 2004. Stocks of metallurgical-grade ore that had been more than 7 million metric tons in 1970 were reduced to zero by 2009 (DeHuff, 1971; Corathers, 2011). Contributing to the relatively stable ore prices during the 1970s was the development of several major mines based on the enormous manganese deposits of the Kalahari Field in South Africa's Northern Cape Province, typified in the north by the Black Rock Mine and in the south by the Mamatwan Mine (Coffman and Palencia, 1984). The jump in ore price from 1974-76 and again from 1979-81 was attributable to comparatively high rates of domestic and international steel production, and the shock effect of oil price increases between 1974 and 1981.

After an ore price of nearly $\$ 1.70$ per mtu was attained in 1980-81, prices began to decline in 1982 with the onset of a worldwide recession. Prices were relatively flat during the mid-1980s, mainly because the more-efficient use of manganese materials in steelmaking depressed demand for manganese ore. For example, by changing the way in which pig iron was converted into steel, domestic steelmakers reduced their unit consumption of manganese in steelmaking by about one-fifth within 2 years. This reduction was much larger than the steel-related growth in manganese demand that otherwise would have been expected, ordinarily about 1 percent per year.
Between 1988 and 1990, manganese ore prices rose sharply to what was then a 3-year record high from $\$ 1.27$ per mtu in 1987; this was concurrent with a recovery in domestic and world steel production. Prior to the recovery in steel production, the nature of the international manganese ore market was changed when the Soviet Union and China began importing substantial quantities of ore in 1983 and 1984, respectively. The imports were from countries such as Australia, Brazil, and Gabon, whose traditional principal export markets were Japan, Western Europe, and the United States. With so few competitors on the supply side, the market constituted an oligopoly. An apparent shortage of high-grade ore attributable to unusually large ore purchases led to a price of $\$ 3.78$ per mtu in 1990, a record high at the time.

Prices receded from the 1990 peak and remained relatively flat from 1993 until 2005. One of the main reasons was the dissolution of the Soviet Union in 1991 and the subsequent contraction of industrial production in its successor republics; this caused the developing ore market to disappear within a short period of time. Another factor was the reactivation of mining or development at known deposits, as in Western Australia (Chadwick, 1991); this led to modest additions to supply from what might be termed "mini-mines," which nevertheless had a significant impact on price negotiations.

Manganese ore prices between 2004 and 2008 had trended upwards, principally because of increased global consumption, particularly by Brazil, Russia, India, and China (the BRIC countries), and lower production levels in Brazil, China, and South Africa for technical and local economic reasons (Corathers, 2010). Rising fuel costs that increased transportation costs also added to the higher manganese ore prices during this timeframe. The 2-year dip in ore prices between 2006 and 2007 reflected an oversupply of manganese ore on the world market (Corathers, 2008).

The U.S. and global economic crises that began in late 2008 eventually brought about a global decline in manganese ferroalloy and steel demand. World apparent consumption of manganese ferroalloys and steel declined in 2009, as did production. Domestic and global manganese ore prices decreased significantly from late 2008 through 2009 , and then rebounded significantly in 2010 as the world economy began to recover and manganese ferroalloy and steel production increased globally.

\section{References Cited}

Carmichael, Malcolm, 1992, An introduction to manganese, in Bailey, John, ed., Iron and manganese ore databook: Worcester Park, England, Metal Bulletin Books Ltd., p. xli-xlix.

Chadwick, John, 1991, Pilbara progress: Mining Magazine, v. 164 , no. 5, May, p. 278-285. 
Coffman, Joseph, and Palencia, C.M., 1984, Manganese availability-Market economy countries: U.S. Bureau of Mines Information Circular 8978, 26 p.

Corathers, L.A., 2008, Manganese, in Metals and minerals: U.S. Geological Survey Minerals Yearbook 2006, v. I, p. 47.1-47.16.

Corathers, L.A., 2010, Manganese, in Metals and minerals: U.S. Geological Survey Minerals Yearbook 2008, v. I, p. 47.1-47.22.

Corathers, L.A., 2011, Manganese, in Metals and minerals: U.S. Geological Survey Minerals Yearbook 2009, v. I, p. 47.1-47.21.

DeHuff, G.L., 1971, Manganese, in Metals, minerals, and fuels: U.S. Bureau of Mines Minerals Yearbook 1969, v. I-II, p. 673-684.
Jones, T.S., 1985, Manganese, in Mineral facts and problems: U.S. Bureau of Mines Bulletin 675, p. 483-508.

Jones, T.S., 1988, Manganese, in Metals and minerals: U.S. Bureau of Mines Minerals Yearbook 1988, v. I, p. 651-665.

Ryan's Notes, 2009, BHP Billiton drops quarterly Mn ore pricing: Ryan's Notes, v. 15, no. 38, September 21, p. 3-4.

Wellbeloved, D.B., Craven, P.M., and Waudby, J.W., 1990, Manganese and manganese alloys, in Ullmann's encyclopedia of industrial chemistry (5th ed.): New York, VCH Publishers, v. A16, p. 77-121.

Williams, W.M., 1980, Manganese and its importance to nineteenth century metallurgy: Canada Metallurgical Quarterly, v. 19 , no. 4, October-November, p. 403-408. 


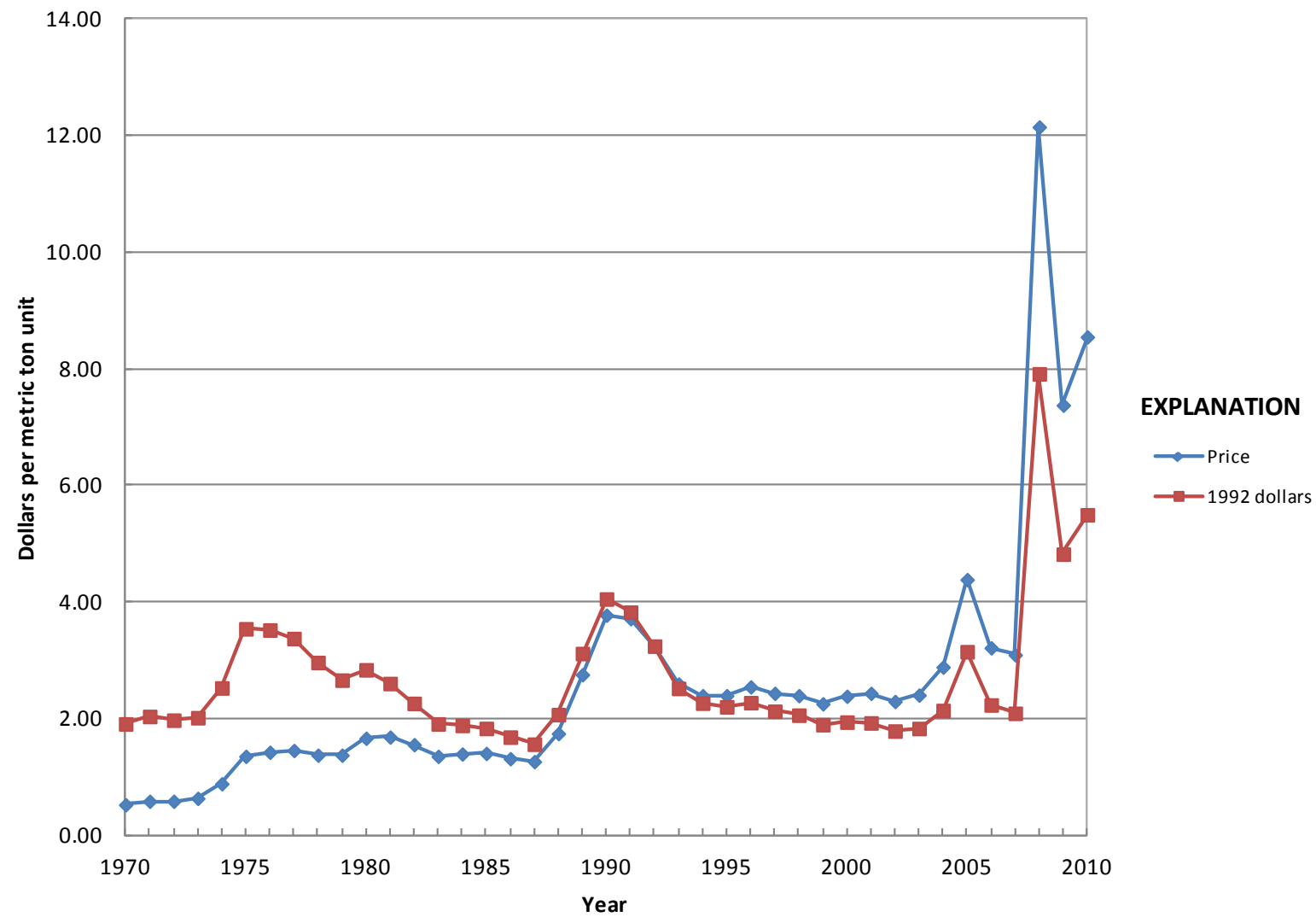

Figure 1. Annual average 48 percent to 50 percent manganese ore price.

\section{Significant events affecting manganese ore prices since 1970}

1970-2009

1973-74

1974, 1978, 1981

Early 1980 s

1980 s

1983-90

1991

2004-08

Late 2008

2010
Sales of excess manganese materials in Government stockpile

High levels of steel production

Sharp increases in oil price

Global economic recession; strong U.S. dollar

Adoption of steelmaking technology that significantly reduces amount of manganese required per ton of steel produced

Significant imports of high-grade ore by China and the Soviet Union

Dissolution of the Soviet Union

Increased steel production by the BRIC countries

U.S. and world economic crises began

Improved domestic and world steel production 
Table 1. Annual average 48 percent-50 percent manganese ore price.

[Values in dollars per metric ton unit, cost, insurance, and freight, U.S. ports]

\begin{tabular}{|c|c|c|c|c|c|c|c|}
\hline Year & Price & Year & Price & Year & Price & Year & Price \\
\hline 1910 & 0.26 & 1936 & 0.26 & 1962 & 0.90 & 1988 & 1.75 \\
\hline 1911 & 0.26 & 1937 & 0.44 & 1963 & 0.80 & 1989 & 2.76 \\
\hline 1912 & 0.25 & 1938 & 0.36 & 1964 & 0.68 & 1990 & 3.78 \\
\hline 1913 & 0.25 & 1939 & 0.32 & 1965 & 0.72 & 1991 & 3.72 \\
\hline 1914 & 0.26 & 1940 & 0.51 & 1966 & 0.75 & 1992 & 3.25 \\
\hline 1915 & 0.31 & 1941 & 0.65 & 1967 & 0.66 & 1993 & 2.60 \\
\hline 1916 & 0.49 & 1942 & 0.72 & 1968 & 0.59 & 1994 & 2.40 \\
\hline 1917 & 0.96 & 1943 & 0.72 & 1969 & 0.49 & 1995 & 2.40 \\
\hline 1918 & 1.25 & 1944 & 0.67 & 1970 & 0.53 & 1996 & 2.55 \\
\hline 1919 & 0.65 & 1945 & 0.73 & 1971 & 0.59 & 1997 & 2.44 \\
\hline 1920 & 0.66 & 1946 & 0.66 & 1972 & 0.59 & 1998 & 2.40 \\
\hline 1921 & 0.28 & 1947 & 0.58 & 1973 & 0.64 & 1999 & 2.26 \\
\hline 1922 & 0.31 & 1948 & 0.64 & 1974 & 0.89 & 2000 & 2.39 \\
\hline 1923 & 0.41 & 1949 & 0.71 & 1975 & 1.36 & 2001 & 2.44 \\
\hline 1924 & 0.38 & 1950 & 0.91 & 1976 & 1.43 & 2002 & 2.30 \\
\hline 1925 & 0.42 & 1951 & 1.12 & 1977 & 1.46 & 2003 & 2.41 \\
\hline 1926 & 0.38 & 1952 & 1.27 & 1978 & 1.38 & 2004 & 2.89 \\
\hline 1927 & 0.38 & 1953 & 1.19 & 1979 & 1.38 & 2005 & 4.39 \\
\hline 1928 & 0.37 & 1954 & 0.95 & 1980 & 1.67 & 2006 & 3.22 \\
\hline 1929 & 0.31 & 1955 & 1.02 & 1981 & 1.69 & 2007 & 3.10 \\
\hline 1930 & 0.27 & 1956 & 1.44 & 1982 & 1.56 & 2008 & 12.15 \\
\hline 1931 & 0.24 & 1957 & 1.56 & 1983 & 1.36 & 2009 & 7.38 \\
\hline 1932 & 0.21 & 1958 & 1.19 & 1984 & 1.40 & 2010 & 8.55 \\
\hline 1933 & 0.19 & 1959 & 0.97 & 1985 & 1.41 & & \\
\hline 1934 & 0.23 & 1960 & 0.93 & 1986 & 1.32 & & \\
\hline 1935 & 0.23 & 1961 & 0.93 & 1987 & 1.27 & & \\
\hline
\end{tabular}

Notes:

1910-37, calculated from U.S. Geological Survey and Bureau of Mines, 1940, Report upon certain deficient strategic minerals: U.S. Geological Survey and Bureau of Mines, p. 8.

1938-41, Barbour, P.E., 1941, Manganese prices, production and imports: Mining and Metallurgical Society of America Bulletin 263, v. 34, no. 5, December, p. $156-161$

1942-62, Engineering and Mining Journal, Metal and Mineral Markets.

1963-77, American Metal Market.

1978-94, Manganese Commodity Specialist, U.S. Bureau of Mines (G.L. DeHuff and T.S. Jones).

1995-2000, Manganese Commodity Specialist, U.S. Geological Survey (T.S. Jones).

2001-10, Manganese Commodity Specialist, U.S. Geological Survey (L.A. Corathers). 


\title{
Mercury (Hg)
}

\author{
by William E. Brooks
}

The most common ore of mercury, cinnabar $(\mathrm{HgS})$, is soft and dark red, and native mercury is one of a few metals that is liquid at room temperatures. In ancient Turkey, cinnabar was retorted for mercury and the mineral was used as a pigment more than 8,000 years ago (Barnes and Bailey, 1972). The cinnabar mine at Almaden, Spain, is the world's oldest producing mercury mine and was discovered and named by ancient people from North Africa; the Arabic name for the metal "azogue" is still used in many parts of South America. Mercury from the Almaden mines was used by the Romans to amalgamate gold. Mercury from Almaden was also used for Spanish colonial gold and silver processing in the New World, and the cinnabar deposits at Huancavelica, Peru, provided a regional source for this important metal.

The chemical symbol for mercury $(\mathrm{Hg})$ is derived from the Greek work "hydrargyrum," and means liquid silver. Cinnabar and mercury are associated with some hydrothermal mineral deposits and occur in fine-grained or sedimentary and volcanic rocks near hot springs or volcanic centers. Mercury may be recovered as a byproduct of processing copper, gold, lead-zinc, or silver ores.

Since 1927, in conformance with the system used at Almaden, the "flask" has been the unique unit for measuring and pricing mercury. One flask weighs 34.5 kilograms, and 1 metric ton $(\mathrm{t})$ of mercury contains approximately 29 flasks (Meyers, 1951). The flask itself is a screw-top, welded-steel container that is approximately the size of a 2-liter bottle.

During the first half of the 1900s, the price of mercury increased significantly during periods of increased demand, namely, World War I, World War II, and a period in the late 1920s when prices were established and maintained by the Spanish-Italian mercury cartel-Mercurio Europeo (Pennington, 1959, p. 47) (table 1). In the 1950s, 10,900 t of mercury was used at Oak Ridge National Laboratory, Tenn., for production of the hydrogen bomb. Following World War II until about 1965, the price was comparatively volatile. This was the result of the erratic demand for mercury during this period and frequent overproduction. In the early 1970s, the average price began to decline (fig. 1).

In 1992, the last mine that produced mercury as a primary mineral commodity in the United States closed. However, domestic mercury production included mercury that was produced as a byproduct from domestic and foreign precious metals mines and mercury that was recovered from recycled mercury-containing scrap. Mercury was widely used in the production of chlorine and caustic soda and for small-scale gold mining in many parts of the world (Fialka, 2006; Brooks and others, 2007). In 2003, the mercury price was $\$ 170$ per flask; however, in 2004, the gold price increased to more than $\$ 400$ per troy ounce and the price of mercury more than doubled to $\$ 400$ per flask as mercury use for small-scale gold mining increased. This trend continued into 2010 as the average gold price increased to more than $\$ 1,200$ per troy ounce, and the price for mercury increased to $\$ 900$ per flask because of its widespread use in small-scale gold mining.

Growing awareness of health and environmental problems associated with mercury has resulted in numerous regulations restricting or eliminating mercury use in various applications, and governing its ultimate disposal. These regulations have the combined effect of lowering consumption, with the exception of mercury used for small-scale gold mining, while at the same time restricting the availability of mercury from byproduct sources and decommissioned chlorine and caustic soda plants.

The Mercury Export Ban Act of 2008 (Public Law 110 414) prohibited the sale and transfer of elemental mercury after January 1, 2013, and addressed the long-term storage of elemental mercury. In anticipation of these restrictions on mercury exports and the increased price of gold, the average price of mercury had increased to $\$ 1,950$ per flask at yearend 2010 .

\section{References Cited}

Barnes, J.W., and Bailey, E.H., 1972, Turkey's major mercury mine today and how it was mined 8000 years ago: World Mining, v. 25, no. 4, p. 49-55.

Brooks, W.E., Sandoval, E., Yepez, M.A., and Howard, H., 2007, Peru mercury inventory 2006: U.S. Geological Survey Open-File Report 2007-1252, 55 p., available at http:// pubs.usgs.gov/of/2007/1252/.

Fialka, J.J., 2006, How mercury rules designed for safety end up polluting: Wall Street Journal, April 20, p. A1, A10.

Meyers, D.K., 1951, History of the mercury flask: Journal of Chemical Education, v. 28, March 22, p. 127.

Pennington, J.W., 1959, Mercury-A materials survey: U.S. Bureau of Mines Information Circular 7941, 92 p. 


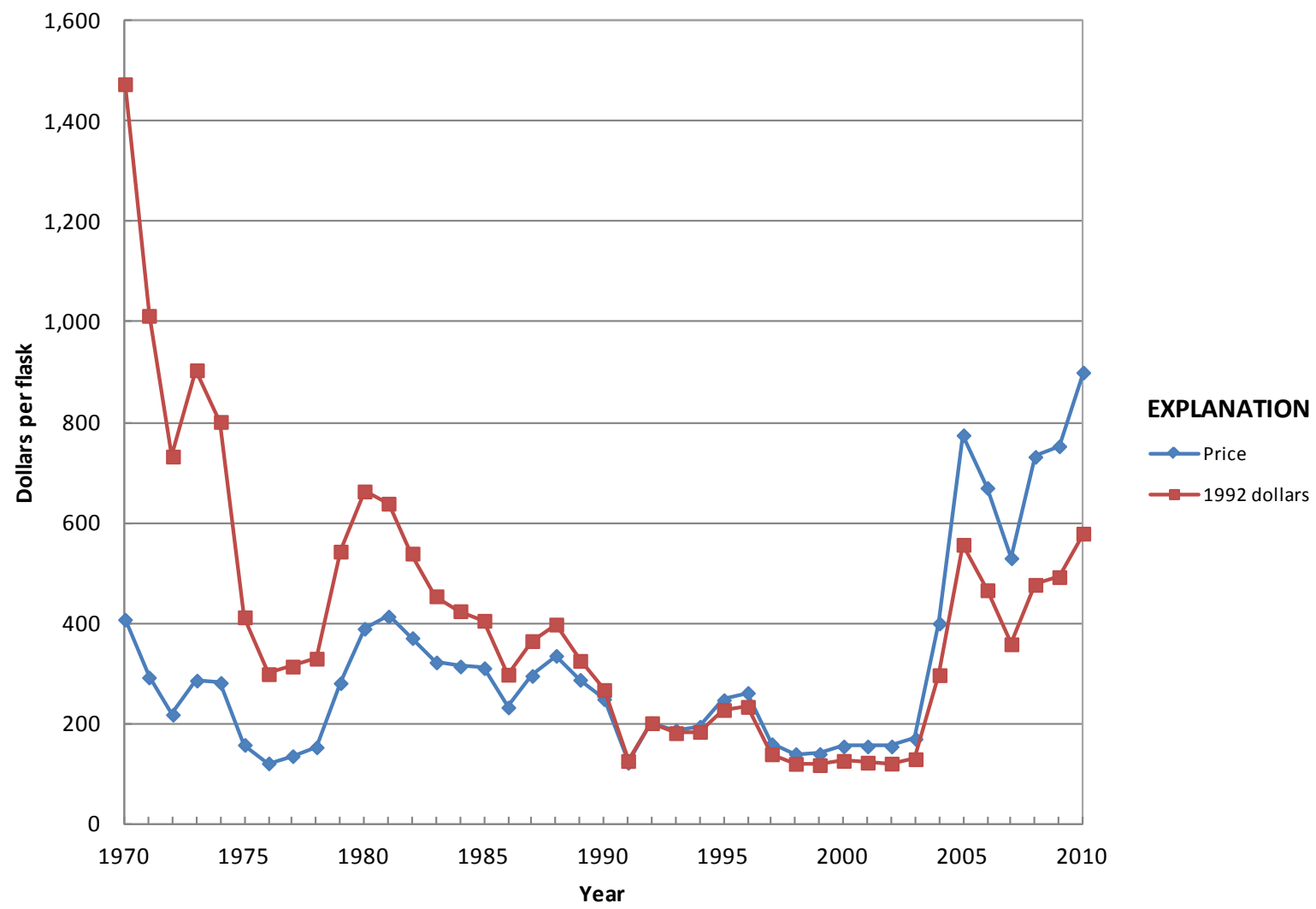

Figure 1. Annual average U.S. mercury price.

\section{Significant events affecting mercury prices since 1970}

1971 Mercury declared a hazardous air pollutant by the U.S. Environmental Protection Agency

2004 Gold price increased to more than $\$ 400$ per troy ounce

2008 Mercury Export Ban Act signed into law 
Table 1. Annual average U.S. mercury price.

[Values in dollars per flask]

\begin{tabular}{|c|c|c|c|c|c|c|c|}
\hline Year & Price & Year & Price & Year & Price & Year & Price \\
\hline 1899 & 43.63 & 1927 & 118.16 & 1955 & 290.35 & 1983 & 322.44 \\
\hline 1900 & 51.00 & 1928 & 123.51 & 1956 & 259.92 & 1984 & 314.38 \\
\hline 1902 & 48.03 & 1930 & 115.01 & 1958 & 229.06 & 1986 & 232.79 \\
\hline 1903 & 41.32 & 1931 & 87.35 & 1959 & 227.48 & 1987 & 295.50 \\
\hline 1905 & 38.50 & 1933 & 59.23 & 1961 & 197.61 & 1989 & 287.72 \\
\hline 1906 & 40.90 & 1934 & 73.87 & 1962 & 191.21 & 1990 & 249.22 \\
\hline 1907 & 41.50 & 1935 & 71.99 & 1963 & 189.45 & 1991 & 122.42 \\
\hline 1908 & 44.84 & 1936 & 79.92 & 1964 & 314.79 & 1992 & 201.39 \\
\hline 1909 & 46.30 & 1937 & 90.18 & 1965 & 570.75 & 1993 & 187.00 \\
\hline 1913 & 39.54 & 1941 & 185.02 & 1969 & 505.04 & 1997 & 159.52 \\
\hline 1914 & 48.31 & 1942 & 196.35 & 1970 & 407.77 & 1998 & 139.84 \\
\hline 1915 & 87.01 & 1943 & 195.21 & 1971 & 292.41 & 1999 & 140.00 \\
\hline 1916 & 125.49 & 1944 & 118.36 & 1972 & 218.28 & 2000 & 155.00 \\
\hline 1917 & 106.30 & 1945 & 134.89 & 1973 & 286.23 & 2001 & 155.00 \\
\hline 1918 & 123.47 & 1946 & 98.24 & 1974 & 281.69 & 2002 & 155.00 \\
\hline 1919 & 92.15 & 1947 & 83.74 & 1975 & 158.12 & 2003 & 170.00 \\
\hline 1920 & 81.12 & 1948 & 76.49 & 1976 & 121.30 & 2004 & 400.00 \\
\hline
\end{tabular}

Notes:

1899-1986, 76-pound flasks, in Engineering and Mining Journal.

1987-93, 76-pound flasks, 99.99-percent-pure mercury, in Metals Week.

1993-2010, 76-pound flasks, 99.99-percent-pure mercury, in Platts (Platt's) Metals Week. 


\title{
Molybdenum (Mo)
}

\author{
by Désirée E. Polyak
}

From the period of the Greek and Roman civilizations to the late 18th century, such terms as "molybdos" or "molybdaena" were applied to minerals that were soft and "leadlike" in character; these minerals probably included those now known as galena, graphite, and molybdenite. This confusion was resolved in 1778 when the Swedish chemist, Karl Scheele, demonstrated that molybdenite, the principal molybdenum mineral, was a discrete mineral sulfide. Four years later, P.J. Hjelm of Sweden reduced the acid-forming oxide of the metal by heating it with charcoal, thereby producing an impure powder of the metal, which he named "molybdenum." Various properties of the element and its compounds were determined during the 19th century, and in 1893, German chemists produced a 96-percent-pure metal by reducing calcium molybdate. About this time, impure metal was reported to have been used experimentally as a substitute for tungsten in tool steels (Sutulov, 1965, p. 13-16). Molybdenum-bearing armorplate was produced in France in 1894; this was the first recorded use of the metal as an alloying element in steel. Soon thereafter, Henri Mossiam, a French chemist, succeeded in producing a 99.9-percent-pure metal by reduction of molybdenum in an electric furnace. Mossiam then conducted studies to establish the element's atomic weight and to determine its physical and chemical properties. These studies stimulated interest in the metal and its compounds and investigations of commercial applications (Schneider, 1963).

It was in 1916 during World War I, when a German company (the American Metal Company) with American headquarters in New York became very interested in the molybdenum deposits in Colorado, specifically the Climax molybdenum deposit. The company quickly expanded with increasing molybdenum demand and Climax Molybdenum Company was formed. When World War I ended in November 1918 , the demand and the price of molybdenum dramatically decreased (table 1) Intense research efforts began to develop new civilian applications for molybdenum, and a number of new low-alloy molybdenum automotive steels were tested and accepted. The industry slowly recovered during the 1920s and 1930s. World War II and the Korean War fostered new uses for molybdenum in fertilizers, high-temperature alloy steel for jet engines, and pigments. Molybdenum production during the war years, as well as the following Cold War years, was deemed a high priority by the U.S. Government (Colorado Geological Survey, 2001, p. 5-6).

By the end of the 1930s, molybdenum had been accepted as an important technical material. The end of World War II, in 1945, once again brought increased research investment to develop new civilian applications, and the post-war reconstruction provided additional markets for molybdenumcontaining structural steels (International Molybdenum Association, undated).

The period from 1959 to 1970 resulted in steadily, but only slightly, increasing prices. The 1970 price of molybdenum was about 35 percent more than the 1959 price; the constant dollar price remained nearly unchanged. Throughout the early 1970s, consumption of molybdenum consistently exceeded production. Much of the extra demand, however, was absorbed by periodic releases from the U.S. Government stockpile. These releases had a price-dampening effect. When the stockpile was depleted in 1977, the price damper was removed. Prices began to increase, and almost every copper mining company in the world was operating or building byproduct molybdenum recovery mill circuits (fig. 1). Steelmakers began to seek cheaper, alternative alloying metals, such as vanadium. The annual average price of molybdenum in 1977 was $\$ 10.70$ per kilogram. By 1979, the annual average price of molybdenum was $\$ 51.00$ per kilogram. The Iranian Revolution created renewed energy concerns, with subsequent strong demand for high molybdenum oilfield steel. However, by the end of 1980 and early 1981, the soaring oil prices collapsed, drastically decreasing demand for molybdenum. Byproduct molybdenum production continued, especially from Third World copper mines. At the same time, automotive and general manufacturing slowed with the growing economic recession. The price of molybdenum dramatically decreased. The annual average price of molybdenum in 1982 was $\$ 9.00$.

Prices continued to decrease through 1986 but then slowly increased for 2 years. Between 1992 and 1995, just after the Persian Gulf War, the dissolution of the Soviet Union, and a recession, prices increased yearly. At the beginning of 1995, molybdenum prices were at their highest level in 15 years ( $\$ 17.40$ per kilogram) owing to a supply shortage. Many companies restarted their byproduct molybdenum circuits or boosted production at their current projects. The price increase was short lived as the annual price of molybdenum in 1996 was $\$ 8.30$ per kilogram.

After the price spike in 1995, the molybdenum market was severely affected by overproduction for the next several years. In 1997, production cutbacks were made by some primary operations, but these were largely cancelled out by increased byproduct molybdenum output from established and new copper operations in Armenia, Chile, Peru, and Russia (Roskill Information Services Ltd., 2003, p. 1). When the dramatically increasing molybdenum prices occurred in 1979-80 or during profitable peak periods in 1994-95, primary molybdenum companies that rushed to reopen found themselves 
priced out of the market because of high production costs, and only the low-cost primary copper companies succeeded in making a profit on byproduct molybdenum.

In 2002, molybdenum prices began to increase owing to a decline in the copper market in 2001. Many byproduct producers in Chile, Mexico, and the United States were forced to decrease production, which in turn decreased molybdenum supply. Antidumping duties were also imposed by the European Union on Chinese ferromolybdenum, which further decreased molybdenum supply (Roskill Information Services Ltd., 2003, p. 1). As a result, molybdenum prices increased sharply in mid-2002. This price spike, however, was short lived as the copper market rebounded.

In the first quarter of 2004, molybdenum prices rose rapidly in response to limited world capacity for roasting of molybdenum concentrates and growing global demand. By mid-2005, molybdenum prices had peaked at record-breaking levels and began to slowly decrease with improved supply. Prices remained well above their historic average until November 2008 when prices dramatically dropped owing to the global financial crisis. Prices stabilized in late 2009 and recovered in 2010 as growth continued in China and other emerging markets, although prices did not reach their previous highs.

\section{References Cited}

Colorado Geological Survey, 2001, Rock talk: Colorado Geological Survey, v. 4, no. 3, July, 12 p.

International Molybdenum Association, undated, Molybdenum history: London, United Kingdom, International Molybdenum Association, 2 p.

Roskill Information Services Ltd., 2003, The economics of molybdenum (8th ed.): London, United Kingdom, Roskill Information Services Ltd., 316 p.

Schneider, V.B., 1963, Molybdenum: Ottawa, Ontario, Canada, Department of Mines and Technical Surveys, Mineral Report 6, 4 p.

Sutulov, Alexander, 1965, [Molybdenum extractive metallurgy]: Concepción, Chile, University of Concepción, 239 p. 


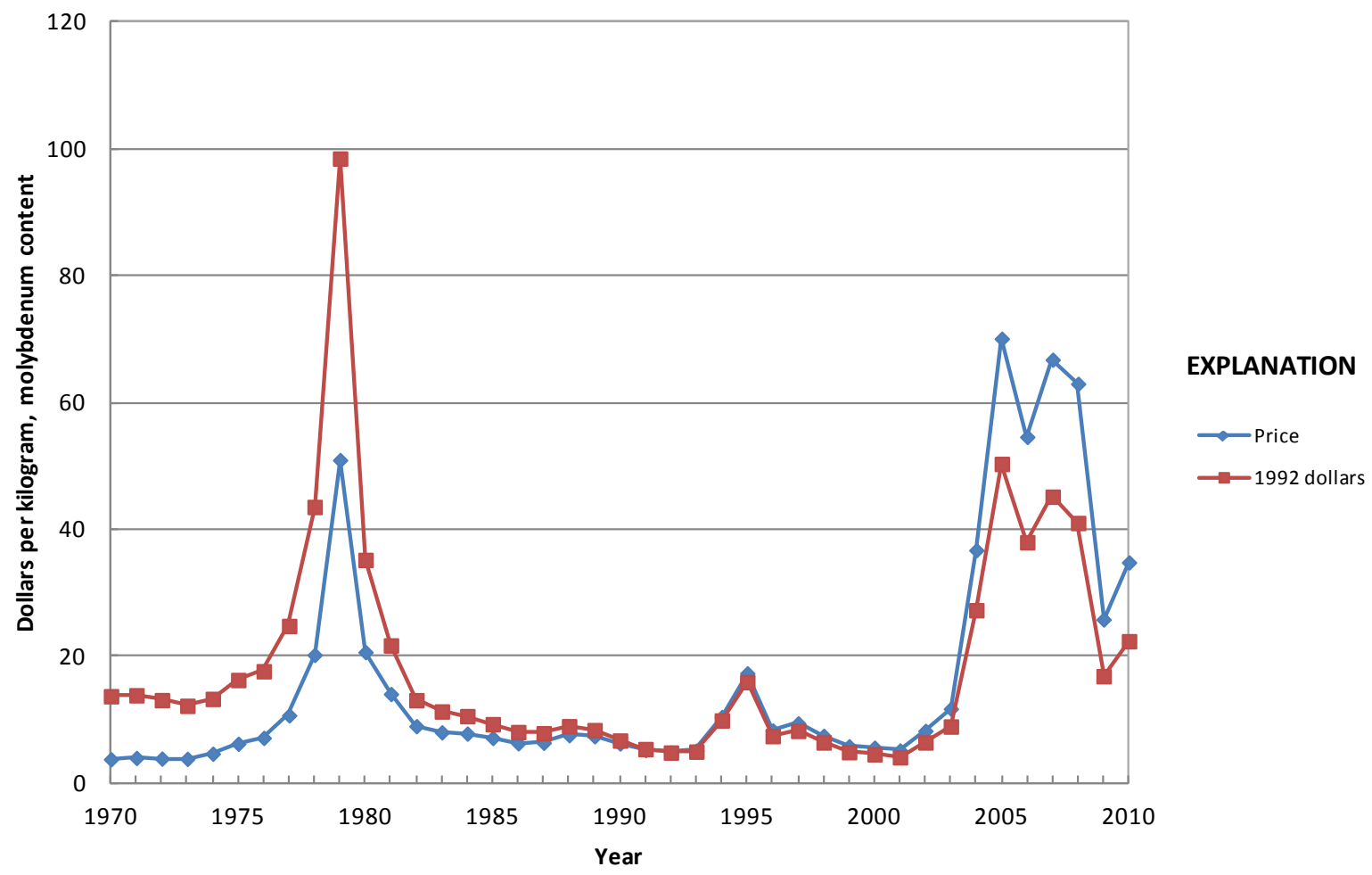

Figure 1. Annual average molybdenum concentrate price.

\section{Significant events affecting molybdenum prices since 1970}

1971-74 Price controls imposed by the U.S. Government, including metal products

1977

U.S. Government release of molybdenum from stockpiles ceased

1978-79 High demand owing to generally strong economic conditions and Iranian Revolution caused copper companies to start operating or building byproduct molybdenum recovery circuits

1981-82 Molybdenum demand decreased owing to recession and overproduction

1994-95 Anticipation of supply shortfall

2002-07 Molybdenum mine production moved strongly upwards in response to greater demand from the iron and steel industry

2008-09 Global financial crisis; prices declined; and many new mining projects were slowed or suspended 
Table 1. Annual average molybdenum concentrate price.

[Values in dollars per kilogram molybdenum content]

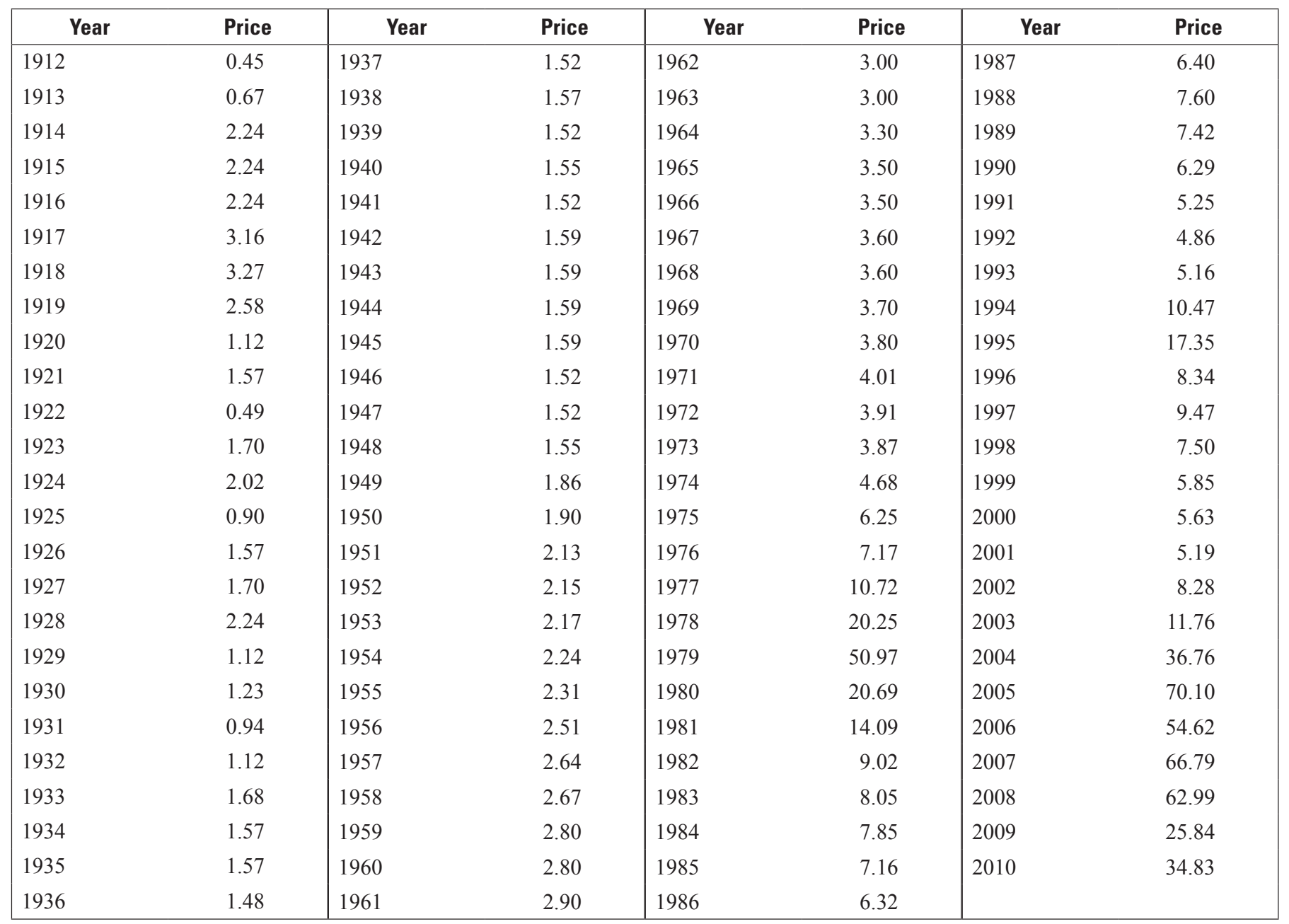

Notes:

1912-55, prices were published by the U.S. Bureau of Mines, but origin is undetermined.

1956-66, prices were published in Engineering and Mining Journal, Metal and Mineral Markets.

1967-92, prices were published in Metals Week.

1993-2010, prices were published in Platt's Metals Week. 


\title{
Nickel (Ni)
}

\author{
by Peter H. Kuck
}

During the 17th century, German miners had difficulty processing certain copper sulfide ores because of an associated mineral that they called kupfernickel, or "Old Nick's copper." The troublesome mineral turned out to be nickel arsenide and is known today as "niccolite" or "nickeline." In 1751, Axel Fredrik Cronstedt isolated a previously unknown chemical element from niccolite. This element was subsequently named "nickel." Nickel was mined on only a limited scale until the large lateritic nickel deposits in New Caledonia came into production about 1875 (Boldt and Queneau, 1967, p. 61-65). The first nickel operations processed sulfide ores - primarily in Canada, Central Europe, China, Pennsylvania, and Scandinavia. Nickel had little economic or industrial significance until 1820 when Michael Faraday succeeded in making synthetic meteoric iron by adding nickel to pure iron. Faraday's alloy was the forerunner of nickel steel, a family of ferrous alloys that continues to play an important role in industrial development. One of the first uses of nickel steel was for ordnance. Nickel-steel armor plate was first produced commercially in France in 1885 (Hall, 1954, p. 1-3, 17). Competitiveness trials of nickel-steel armor took place in the United States in 189091, and within a few years, Bethlehem Iron Co. (forerunner of Bethlehem Steel Corp.) was producing large nickel-steel guns for the U.S. military (Wharton, 1897). The nickel steels developed before World War I contained only 1.5 percent to 4.5 percent nickel, with a carbon content from 0.2 percent to 0.5 percent (Hess, 1917, p. 761-762). Other important early uses were bridge structures, railroad rails, axles, ship propeller shafts, and automobile engine parts (Cammen, 1928, p. 142156). The first commercial chromium-nickel steel-and one of the first grades of stainless steel - was made at St. Chamond, France, in 1891. Like nickel-steel armor, chromium-nickelsteel armor proved to be much superior to the carbon-steel plate then in use, triggering extensive production of the new type of steel (Hall, 1954, p. 17-44).

In 2010, stainless steel production accounted for more than 60 percent of world nickel consumption and was the primary factor in nickel pricing. Stainless steel is defined as an iron alloy that contains at least 10.5 percent chromium. Nickel-bearing stainless steels are termed "austenitic," a reference to their characteristic solid solution microstructure, and typically contain between 6 percent and 22 percent nickel - with 18 percent chromium and 8 percent nickel being the most common composition. The nickel changes the crystal structure of stainless steel from body-centered cubic (ferritic) to face-centered cubic (austenitic) (International Molybdenum Association, 2009, p. 8-9). Austenitic stainless steels are often used where corrosion resistance and toughness are of primary concern (All Metals \& Forge Group, undated).

In the Western World, total stainless steel production has grown at about 4.8 percent per year since 1950 (Vale, S.A., 2010 b, p. 3-7). Since 2007, the austenitic share of global stainless steel production has accounted for between 71 percent and 75 percent of total stainless output, the rest being ferritic or martensitic (a stainless steel with a body-centered tetragonal structure created by quenching austenitic grades). In recent years, the austenitic percentage of stainless steel production for the United States has ranged from 63 percent to 71 percent. U.S. steel plants produce significant amounts of ferritic stainless - most of the balance - for the North American automotive industry. Since 1970, demand for stainless steel in the United States has grown at a much faster rate than that of carbon steel but still constitutes only about 4 percent of total U.S. raw steel production.

The market for duplex stainless steels has grown significantly since the development of the argon oxygen decarburization (AOD) refining process in 1968. Duplex stainless steels have a two-phase microstructure composed of grains of ferritic and austenitic stainless steel. Duplex stainless steels, first produced in 1930, have roughly twice the strength of standard austenitic stainless steels but contain less nickel and are less expensive than many austenitic grades (International Molybdenum Association, 2009, p. 4-7).

Like petroleum, nickel is a critical commodity in wartime. Nickel, as well as cobalt, is needed to make superalloys for engines that propel jet aircraft, guided missiles, and some space vehicles. Pure nickel is used in high-performance batteries, such as those that start jet engines or power satellites. Austenitic stainless steel and nickel-based high-performance alloys are commonly used if chemical corrosion is a serious problem, such as on submarines and surface naval vessels or at food-processing or petroleum-storage facilities. Merchant nickel prices traditionally spike in wartime when demand far exceeds supply and frequently rise in times of political unrest and instability. Producer prices, in contrast, have been frozen during several crises by war-production boards or emergency price-control regulations.

The Korean Conflict is a good illustration of price spiking and distribution controls. During the transition from a civilian to a defense economy, demand for nickel exceeded available supply even though North American nickel mines and plants were operating at full capacity. At the outset of the conflict, the U.S. Government took control of the distribution of nickel, and from 1951 to 1957, all nickel in the United States was under Government allocation. At the same time, the Govern- 
ment also acquired nickel for the national strategic stockpile. The combination of these actions resulted in a severe shortage of nickel for nondefense uses (Davis, 1956, p. 837-838, 841). Shortages continued throughout the conflict despite the addition of significant new production capacity in Canada and the United States and the rehabilitation of a number of older mines and plants. Moreover, the U.S. Government continued to purchase nickel for the strategic stockpile after the conflict ended. As a result, supply did not exceed civilian demand until the latter part of 1957, 4 years after the armistice. The producer price of nickel - tracking consumption-began a gradual rise in 1950 and did not peak until 1957 (table 1). A period of oversupply followed, during which quoted producer and merchant prices for nickel approximately paralleled inflation. This situation produced a constant dollar price for the metal that was fairly stable for more than 10 years.

In 1969, the Canadian nickel, copper, and iron ore industries were shut down by a prolonged series of labor strikes. Canada was the dominant nickel-producing country in the world at the time. Canada's two largest producers, Inco Ltd. and Falconbridge Ltd., accounted for 48 percent of world production the previous year. Because of the strikes, Canadian nickel production was almost 20 percent less than that of 1968 (Morrell, 1971, p. 175-176). The strikes took place at a point in time when global stocks were low and world demand was restricted by available supply.

The 1969 strikes affected nickel prices in two ways. Before the strikes, the major producers, led by the Canadians, controlled the nickel price. The short-term effect was a brief price increase. The long-term effect was to diminish the importance of the producer price. Canadian and non-Canadian producers accelerated efforts to expand existing operations and to bring greenfield projects onstream before prices weakened. Between 1969 and 1974, new mines and processing plants were commissioned in Australia, Canada, the Dominican Republic, and New Caledonia. The increased capacity resulted in a reduction of the Canadians' share of the world market and, thus, their influence on prices - a turning point in the history of nickel marketing.

Between 1966 and 1973, more than 40 deposits of massive nickel sulfides were discovered in Western Australia. Western Mining Corporation Ltd. (now part of the BHP Billiton Group) successfully delineated several deposits around the Kambalda Dome and sharply expanded its mining operations in the Kalgoorlie region in the mid-1970s (Hoatson, Jaireth, and Jaques, 2006, p. 179-187, 234-235). In 2010, Australia was the fourth largest producer of marketable primary nickel in the world because of additional discoveries in Western Australia, the subsequent construction of a major natural gas pipeline from the North West Shelf to Kalgoorlie, and the advent of new extraction technologies.

Nickel prices, reflecting consumption, rose slightly from 1970 until 1975, when the cumulative effect of opening several new production facilities began to be felt (fig. 1). In 1975 , U.S. demand for nickel weakened, partially because of the termination of U.S.-led military operations in Vietnam. In
1977, P.T. Inco commissioned its Soroako mining and smelting complex on the Indonesian island of Sulawesi, bringing additional metal to the marketplace. An oversupply situation and declining consumption caused prices to remain flat until the Inco strike of 1978-79. The strike at Inco's operations in the Sudbury District lasted from September 16, 1978, to June 3, 1979 (Inco Ltd., 1980, p. 4-9). Between February 1979 and the end of the year, Inco raised its Port Colborne price for nickel cathode six times. The effect of the Inco strike on prices was compounded by the fact that major producers had been operating at 55 to 60 percent of capacity to reduce inventories and to improve the price situation.

The Inco strike helped accelerate major changes in nickel pricing. On April 23, 1979, nickel contracts were introduced for the first time on the LME. Nickel became the seventh metal traded on the LME-marking a major turning point in pricing of the metal. Leading nickel producers at first opposed the LME pricing mechanism. Nickel business on the LME, however, grew steadily in spite of the producers' opposition, convincing the producers to reverse their position. Today, nickel prices are set by the LME rather than by the producers. Since 1979, nickel has become a commodity whose price is driven by world supply and demand, irrespective of production costs. Many consumers, as well as producers, were initially opposed to LME trading. Most, however, would now agree that the LME is a practical and effective forum for establishing an international reference price for nickel, improving price transparency, and rapidly disseminating price data. It is difficult to say how much nickel, probably a small proportion, actually sells at the LME price. The LME price has more importance than appears at first glance because it is used as a reference price in long-term contracts. For example, a large nickel producer might ask for a premium to the LME price, and a smaller one might sell at a discount. Because of the LME, producer prices became irrelevant in the early 1980s.

The second oil crisis (1979-82), triggered by the revolution in Iran, had a major dampening effect on world consumption of steel and most metals. The resulting recession that began in summer 1981 caused a marked decline in nickel consumption. Nickel demand in the Western World declined about 8 percent in 1981; this was the first time since the late 1940s that demand had declined for 2 consecutive years. The recession ended in November 1982, but prices continued to weaken until 1985 because of slackening demand. In 1987, the market suddenly changed direction, catching producers off guard. The annual average price surged from its lowest level ever in 1986 to its highest in 1988 (in terms of 1992 constant dollars for 1910-97) (fig. 1).

The monthly average LME cash price rose gradually from $\$ 1.60$ per pound at the beginning of 1987 to $\$ 2.69$ in November. In December 1987 , it suddenly shot up to $\$ 3.48$. The rapid increase continued in 1988, with the monthly price reaching $\$ 8.17$ in April. These price levels would have been unimaginable to the nickel market 4 years earlier. Three factors were primarily responsible for the increase. The first was a substantial and unforeseen increase in demand for stainless 
steel, the largest end use for nickel. More than 50 percent of stainless steel production in the United States and Europe is sold through service centers (companies that buy directly from a stainless mill and sell to customers). Service centers do not publish detailed sales statistics in terms of end use, making it difficult for stainless producers to monitor consumption of their product. The second factor was that nickel producers reduced world production capacity because of low metal prices during the early and mid-1980s. At least five nickel producers closed operations during this period. A third factor was the decreased availability of stainless steel scrap.

Although Western demand for nickel grew continuously between 1985 and 1991, the LME price peaked in 1988 and declined each year afterward until 1994. The reasons for this paradoxical trend were threefold - the former Soviet Union (FSU) began gradually increasing nickel shipments to the West, scrap availability increased worldwide, and world production of primary nickel increased.

The breakup of the Soviet Union in December 1991 produced massive changes in the Russian economy, one of which was the partial privatization of the largest nickel producer in the country, RAO Norilsk Nickel. At the same time, the downsizing of the FSU military-industrial complex caused nickel consumption within Russia to plummet. In 1997, Russia consumed only 20,000 metric tons (t) of primary nickel, compared with 180,000 t in 1989 (International Nickel Study Group, 1998). Russian consumption weakened even more in 1998, slipping to less than $18,000 \mathrm{t}$. These changes led to a surge of primary nickel exports from Russia, putting downward pressure on world prices for primary nickel and nickel-bearing scrap. Russian exports of stainless steel scrap and high-nickel scrap to the European Union (EU) also sharply increased, further depressing world nickel prices. More than a decade later, Russia is still the leading nickel-producing country in the world and reportedly has significant undeveloped resources in its Siberian and Far Eastern regions. In 2010, more than 85 percent of Russia's output came from mines operated in the Arctic by Norilsk Nickel.

Reduced nickel consumption in Russia, a recession in Japan, and economic problems in other parts of East Asia caused the monthly LME cash price to decline from $\$ 3.20$ per pound in June 1997 to $\$ 1.76$ in December 1998. Between 1997 and 1999, Western nickel producers had to struggle to cut costs in the face of weakening prices for the metal. Prices began improving in the first half of 1999, climbing back to the $\$ 2.25$ to $\$ 2.50$ level. The commissioning of three nickel mining and metallurgical complexes in Western Australia at the beginning of 1999, however, put renewed downward pressure on prices. The three complexes used variations of a pressure acid leach (PAL) process to extract nickel and cobalt from limonitic laterite ores. All three operations-Bulong, Cawse, and Murrin Murrin - experienced startup problems associated with the new PAL technology. The Murrin Murrin joint venture was able to overcome the bulk of these problems and was still operating in early 2011. Production at Bulong and Cawse, however, was eventually suspended because of deteriorating nickel prices.

From 2001 to 2005, global nickel consumption grew an average of 3.4 percent per year. This growth was largely fueled by increased use of stainless steel worldwide and the rapidly expanding economy in China. In January 2006, the monthly average LME cash price was $\$ 6.60$ per pound - a relatively high price in historical terms. In the summer of 2006, increasing global production of stainless steel, especially in China, created a temporary nickel supply deficit, driving the monthly LME cash price to an alltime high of $\$ 23.66$ per pound in May 2007. At this point, demand for stainless steel began to falter in many countries, with the exception of China, triggering a gradual price collapse. In the fourth quarter of 2008, the global economy began to soften. The December 2008 average LME cash price was only $\$ 4.39$ per pound.

In August 2005, Inco Ltd. began mining its world-class Voisey's Bay nickel-copper-cobalt deposit in northeastern Labrador (McCutcheon, 2006, p. 38.11-38.12). The development of the deposit has had a major impact on the world nickel market because of the deposit's large reserves, the richness of its ores, and its coastal location on the North Atlantic. In 2009, Vale S.A.-Inco's successor-began construction of a \$2.8 billion hydrometallurgical complex at Long Harbour, Newfoundland, that was designed to process the concentrates from Voisey's Bay and significantly reduce transportation costs for the company (Baird, 2011; Vale S.A., 2010a).

The technology of laterite ore processing has advanced significantly since construction began at Murrin Murrin in 1997. Three hydrometallurgical processing complexes were being readied for commissioning in 2010 - one on the main island of New Caledonia, one in Madagascar, and one in Papua New Guinea. In 2008, a ferronickel smelter was commissioned in the Republic of Korea. Two ferronickel smelters were also commissioned in Brazil at yearend 2010, and a third was under construction in New Caledonia. All seven facilities were designed to process laterite ores. The creation of 337,000 metric tons per year ( $\mathrm{t} / \mathrm{yr}$ ) of new production capacity came at a time when the world was struggling to recover from the global recession of 2008-09.

By March 2009, stocks in LME warehouses had climbed above $100,000 \mathrm{t}$ for the first time in history and were still growing. Fortunately for the producers, stainless steel production in China was at an alltime high. LME stocks eventually peaked at 136,000 t in December 2010 and began to slowly shrink as the recession waned and demand for stainless steel began to recover (International Nickel Study Group, 2011).

\section{Pricing Mechanisms for Nickel Metal}

The principal purpose of the LME since its opening in 1877 has been to serve as a futures market, providing protection to producers, traders, and consumers against unpredictable price fluctuations (Rudolf Wolff \& Co. Ltd., 1995). The LME has a membership of more than 90 firms. Of these, 12 
take part in ring dealing, which consists of open outcry trading sessions that take place twice a day. Unlike other futures markets, the LME also serves as a center for physical trading and has an international network of approved warehouses. In the case of nickel, the bulk of the warehousing is at Rotterdam in the Netherlands and to a lesser degree in Singapore.

Producer participation in the LME has increased considerably since 1985 because of the LME's hedging and options capabilities. In 2010, LME prices were the principal pricing mechanism used worldwide by producers and consumers of nickel. LME prices and archival statistics are available 24 hours a day at the LME Web site, thus minimizing arbitrage. LME prices are also quoted by day in a variety of weekly trade publications. In 2010, the LME pricing system had the support of seven of the leading nickel producers in the world. Three of the seven had subsidiaries who were Associate Trade Members of the Exchange-BHP Billiton Group, Vale S.A., and Xstrata plc (through its principal shareholder, Glencore International AG). The LME is regulated by the Financial Services Authority, an independent nongovernmental body given statutory powers by the British Parliament.

Hedging, a form of insurance available to consumers, producers, and traders, is a key component of the futures market and reduces a producer's exposure to price changes while the raw nickel is moving through different processing stages at the producer's facilities. To guard against sudden price movements, the producer will hedge a planned physical transaction by entering into an offsetting forward contract on the LME. Speculators play an important role in futures trading because they bring liquidity to the market and assume the risk that the hedger is trying to avoid. Five different price series for nickel are available from the LME:

- Cash

- Settlement

- 3-month futures

- 15-month futures

- 27-month futures.

The data shown in the accompanying table since 1979 represent the annual average cash price.

\section{Pricing Mechanisms for Stainless Steel Scrap}

Nickel is less abundant than either chromium or iron in the Earth's crust because of nickel's higher atomic number and differences in the nuclear stability of the respective isotopes of the three elements. As a result, on an elemental basis, ferronickel is about 5 to 9 times more expensive than ferrochromium and 30 to 50 times more expensive than pig iron, depending upon the market situation at the time. As a rule of thumb, austenitic (chromium and nickel) stainless steel scrap is roughly three times more valuable than ferritic (chromium only) stainless steel scrap. Because the highest value material in austenitic stainless steel is nickel, austenitic scrap prices for Types 304 and 316 closely track those of nickel cathode except when ferrochromium is in short supply (fig. 2).

Almost all stainless steel produced in the United States is made in electric-arc furnaces. Nickel-based superalloys and other nickel-chromium alloys also are commonly made in electric-arc furnaces. The characteristics of the electric furnace permit the operator to use a large percentage of scrap, economizing by reducing the consumption of virgin chromium and nickel. Some of the more critical nickel-based superalloys, however, are produced in vacuum-induction furnaces and later refined in consumable melting furnaces.

The stainless steel scrap prices shown in the accompanying table were derived from daily data published by American Metal Market (AMM) (table 2). The data represent consumer buying prices in the Pittsburgh, Pa., area for austenitic stainless steel scrap and are quoted in dollars per long ton gross weight. The scrap is in the form of bundles, solids, and clippings typically containing 18 percent chromium and 8 percent nickel. Turnings of 18-8 alloy are more difficult to handle than bundles and fetch only about 85 percent of the bundle price. AMM also publishes estimated prices that a dealer, broker, or processor would pay for 18-8 scrap delivered to yards in 10 different areas of the United States plus the Montreal area of Canada. On November 1, 2006, AMM revised its pricing methodology and began reporting prices for Type 316 solids and clips. At the same time, AMM dropped its listing for 18/8 bundles, solids and clips and replaced it with one tracking Type 304 solids and clips, effectively creating two new price series. Type 316 scrap contains from 10 percent to 14 percent nickel, compared with 8.0 percent to 10.5 percent nickel for Type 304 (table 2).

Although many types of nickel scrap are recycled in the United States, most is in the form of stainless steel. In 2010, stainless steel scrap accounted for about 85 percent of reclaimed nickel in the country. This included scrap consumed in foundries in addition to that used in raw steelmaking. Scrap accounts for as much as 80 percent of total feed materials at some European stainless steel production facilities but typically from 60 percent to 70 percent in the United States - the remainder being ferroalloys or virgin metals. The bulk of the scrap is conventional austenitic or ferritic stainless steel. The scrap is often blended and may include lesser amounts of low-alloy steel, superalloys and other high-nickel-chromium alloys, and (or) specially processed fines of high-carbon ferrochromium. A high scrap ratio (that is, a high percentage of scrap in the total charge) reduces melting time and electricity consumption but makes final chemical adjustments to the melt more difficult. In past years, a few foreign mills have had to drop their scrap ratio to 30 percent or 40 percent because of problems in purchasing quality scrap at a reasonable price. 


\section{Pricing for Nickel-Based Nonferrous Scrap}

Copper-nickel and superalloy scrap make up a large portion of the remaining 15 percent of nickel reclaimed in the United States. Published price series exist for at least four different types of nickel-based nonferrous scrap. Monthly prices for clips and solids of new scrap are readily available, especially for nickel metal, Monel ${ }^{\circledR}$ (a family of copper-nickel alloys), and Inconel ${ }^{\circledR}$ (a family of nickel-chromium-iron superalloys).

\section{References Cited}

All Metals \& Forge Group, [undated], Stainless steel, accessed September 21, 2011, at http://www.steelforge.com/ferrous/ stainlesssteel.htm.

Baird, Moira, 2011, G.J. Cahill and Kiewit hooking up Long Harbour nickel plant modules: St. John's, Newfoundland, Canada, 1 p., accessed September 21, 2011, via http://www.thetelegram.com.

Boldt, J.R., Jr., and Queneau, Paul, 1967, The winning of nickel: Princeton, N.J., D. Van Nostrand Co., Inc., 487 p.

Cammen, Leon, 1928, Alloy steels, chap. 6 of Principles of metallurgy of ferrous metals: New York, N.Y., American Society of Mechanical Engineers, p. 142-162.

Davis, H.W., 1956, Nickel, in Metals and minerals: U.S. Bureau of Mines Minerals Yearbook 1953, v. I, p. 837-853.

Hall, A.M., 1954, Nickel in iron and steel: New York, John Wiley \& Sons, Inc., 595 p.

Hess, F.L., 1917, Nickel, in Mineral resources of the United States 1915: U.S. Geological Survey, pt. 1, p. 743-766.

Hoatson, D.M., Jaireth, S., and Jaques, A.L., 2006, Nickel sulfide deposits in Australia - Characteristics, resources, and potential: Ore Geology Reviews, v. 29, p. 177-241.
Inco Ltd., 1980, Annual report-1979: Toronto, Ontario, Canada, Inco Ltd., 41 p.

International Molybdenum Association, 2009, Practical guidelines for the fabrication of duplex stainless steels: London, United Kingdom, International Molybdenum Association (2d ed.), $63 \mathrm{p}$.

International Nickel Study Group, 1998, World nickel statistics: The Hague, Netherlands, International Nickel Study Group, v. 8, no. 11, November, p. 64-66.

International Nickel Study Group, 2011, World nickel statistics-Yearbook: Lisbon, Portugal, International Nickel Study Group, v. 20, no. 12, November, 4 sections (A-D).

McCutcheon, Bill, 2006, Nickel, in Canadian Minerals Yearbook-2005: Ottawa, Ontario, Canada, Natural Resources Canada, p. 38.1-38.96.

Morrell, L.G., 1971, The mineral industry of Canada, in Area Reports-International: U.S. Bureau of Mines Minerals Yearbook 1969, v. IV, p. 163-181.

Rudolf Wolff \& Co. Ltd., 1995, Nickel, chap. 15 of Wolff's guide to the London Metal Exchange (5th ed.): Surrey, United Kingdom, Metal Bulletin Books Ltd., p. 127-133.

Vale S.A., 2010a, Vale-Newfoundland and Labrador: Rio de Janiero, Brazil, Vale S.A., 1 p., accessed September 21, 2011, via http://nickel.vale.com/countries/canada/voisey/.

Vale S.A., 2010b, World stainless steel statistics: Toronto, Ontario, Canada, Vale S.A., 19 p. plus country tables.

Wharton, Joseph, 1897, Nickel and cobalt, in Eighteenth Annual Report of the United States Geological Survey, 1896-97: U.S. Geological Survey, pt. 5, p. 329-342. 


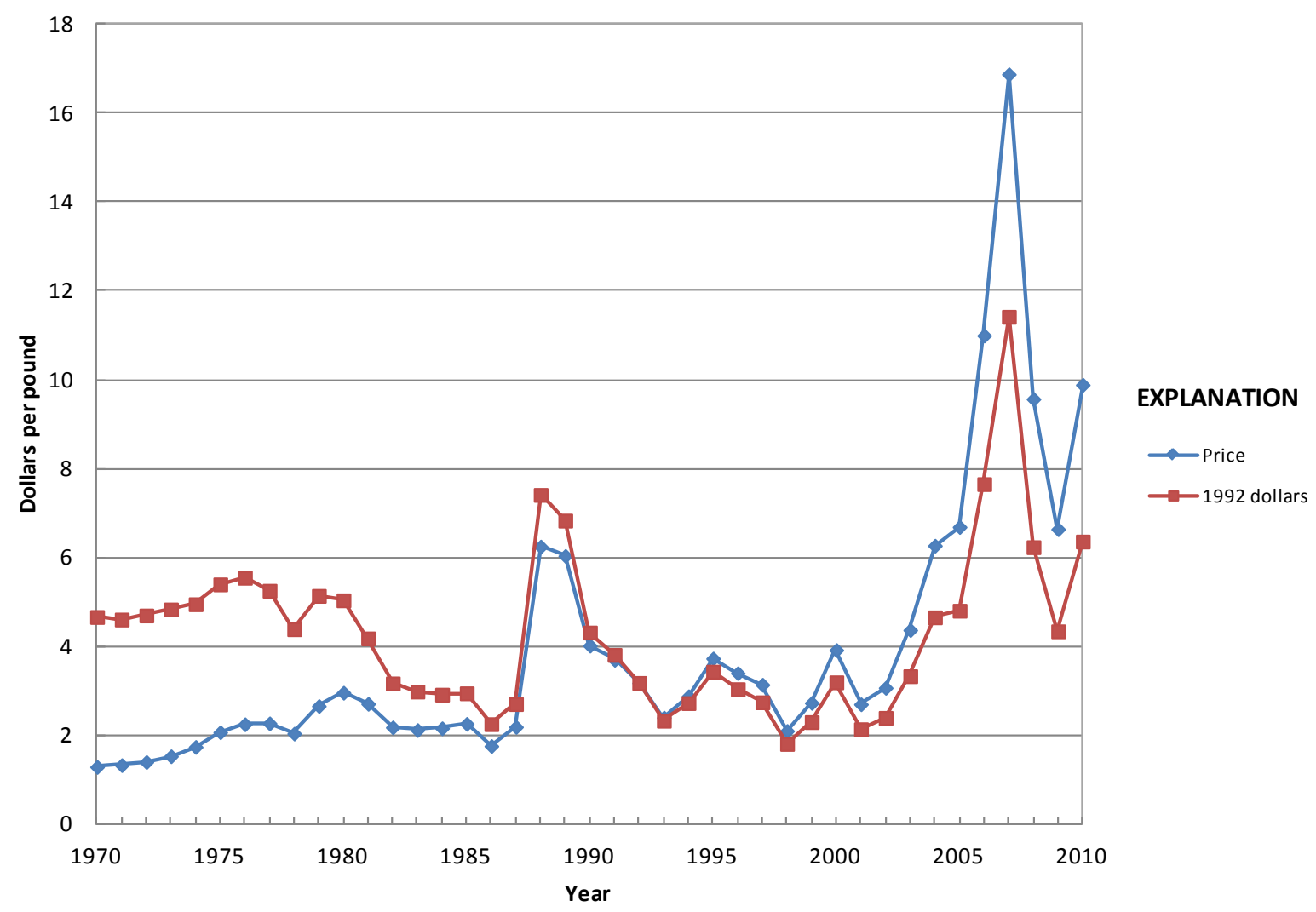

Figure 1. Annual average nickel price.

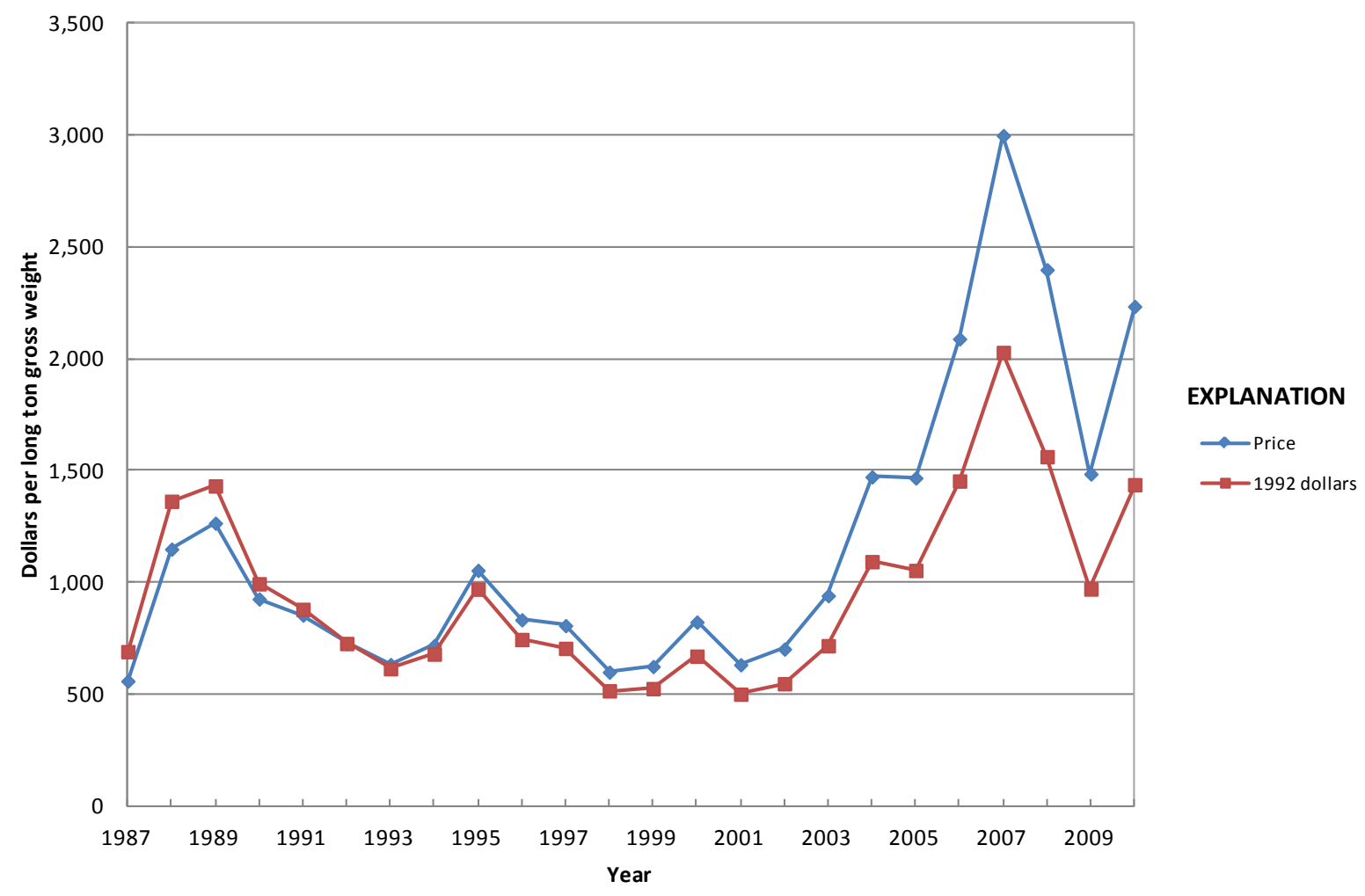

Figure 2. Annual average price for stainless steel scrap. 


\section{Significant events affecting nickel prices since 1970}

1972

1977

1978-79

1979

1981-82

$1987-88$

1987-89

1990

1991

1994

1994-98

1998-2000

2001

2005

2005-06

2006

2007

2008

2008-09

2010
Falconbridge Dominicana C. por A. commissioned its ferronickel smelter at Bonao, Dominican Republic P.T. International Nickel Indonesia (P.T. Inco) commissioned its Soroako mining and smelting complex on the Indonesian island of Sulawesi; laterite mining began in Guatemala

Labor strike in the Sudbury District of Ontario reduced Canadian mine output by more than 40 percent

Nickel became the seventh metal traded on the London Metal Exchange (LME)

A worldwide recession caused nickel demand and prices to fall sharply

The Government of the Dominican Republic levied a substantial export duty on ferronickel; Falconbridge

Dominicana countered by limiting ferronickel shipments and declaring force majeure

Supply shortages; stainless steel production in the Western World passed the 10-million-metric-ton-per-year mark Development of the nickel-metal hydride rechargeable battery

Dissolution of the Soviet Union followed by a sharp rise in exports of Russian nickel

Sherritt Inc. and the Government of Cuba formed a partnership to recover nickel and cobalt from lateritic ores at Moa. The two metals were separated and refined in Alberta, Canada

RAO Norilsk Nickel was formed after the new Government of Russia partially privatized State-owned mining and smelting operations on the Kola and Taimyr Peninsulas

Major restructuring of the specialty steel industry in the United States

BHP Ltd. of Australia and Billiton plc merged, creating a global resources group with interests in nickel and other base metals

Inco Ltd. produced its first nickel and copper concentrates at the Voisey's Bay Mine in Labrador

Acquisitions and mergers drastically changed corporate ownership of the nickel industry

China became the leading stainless-steel-producing country in the world, passing the European Union. China began production of low-grade ferronickel, also known as nickel pig iron

BHP Billiton Group completed construction and commissioning of its Ravensthorpe Mine in Western Australia

Pohang Iron and Steel Co. Ltd. and its partner, Société Minière du Sud Pacifique, S.A., commissioned a worldclass ferronickel smelter at Gwangyang, Republic of Korea. The smelter gives Korean stainless steel producers a secure supply of nickel for the first time

Global recession leads to a dramatic drop in nickel mine production. China was the leading consumer of primary nickel in 2009 and also the leading producer of stainless steel

Vale S.A. commissioned two large mining and processing complexes—one, a hydrometallurgical extraction operation on New Caledonia; the other, a ferronickel smelter in the Brazilian State of Para. 
Table 1. Annual average nickel price.

[Values in dollars per pound.]

\begin{tabular}{|c|c|c|c|c|c|c|c|}
\hline Year & Price & Year & Price & Year & Price & Year & Price \\
\hline 1840 & 1.70 & 1883 & 1.11 & 1926 & 0.36 & 1969 & 1.05 \\
\hline 1841 & 1.70 & 1884 & 0.70 & 1927 & 0.35 & 1970 & 1.29 \\
\hline 1842 & 2.09 & 1885 & 0.65 & 1928 & 0.37 & 1971 & 1.33 \\
\hline 1843 & 2.40 & 1886 & 0.48 & 1929 & 0.35 & 1972 & 1.40 \\
\hline 1844 & 2.75 & 1887 & 0.62 & 1930 & 0.35 & 1973 & 1.53 \\
\hline 1845 & 3.05 & 1888 & 0.58 & 1931 & 0.35 & 1974 & 1.74 \\
\hline 1846 & 3.05 & 1889 & 0.65 & 1932 & 0.35 & 1975 & 2.07 \\
\hline 1847 & 2.89 & 1890 & 0.65 & 1933 & 0.35 & 1976 & 2.25 \\
\hline 1848 & 2.19 & 1891 & 0.55 & 1934 & 0.35 & 1977 & 2.27 \\
\hline 1849 & 1.93 & 1892 & 0.75 & 1935 & 0.35 & 1978 & 2.04 \\
\hline 1850 & 1.93 & 1893 & 0.52 & 1936 & 0.35 & 1979 & 2.66 \\
\hline 1851 & 1.93 & 1894 & 0.57 & 1937 & 0.35 & 1980 & 2.96 \\
\hline 1852 & 1.93 & 1895 & 0.30 & 1938 & 0.35 & 1981 & 2.71 \\
\hline 1853 & 1.70 & 1896 & 0.33 & 1939 & 0.35 & 1982 & 2.18 \\
\hline 1854 & 1.70 & 1897 & 0.33 & 1940 & 0.35 & 1983 & 2.12 \\
\hline 1855 & 1.57 & 1898 & 0.33 & 1941 & 0.35 & 1984 & 2.16 \\
\hline 1856 & 1.57 & 1899 & 0.32 & 1942 & 0.32 & 1985 & 2.26 \\
\hline 1857 & 1.45 & 1900 & 0.50 & 1943 & 0.32 & 1986 & 1.76 \\
\hline 1858 & 1.20 & 1901 & 0.56 & 1944 & 0.32 & 1987 & 2.19 \\
\hline 1859 & 1.20 & 1902 & 0.45 & 1945 & 0.32 & 1988 & 6.25 \\
\hline 1860 & 1.20 & 1903 & 0.40 & 1946 & 0.35 & 1989 & 6.04 \\
\hline 1861 & 1.20 & 1904 & 0.40 & 1947 & 0.35 & 1990 & 4.02 \\
\hline 1862 & 1.08 & 1905 & 0.40 & 1948 & 0.36 & 1991 & 3.70 \\
\hline 1863 & 1.65 & 1906 & 0.40 & 1949 & 0.40 & 1992 & 3.18 \\
\hline 1864 & 2.29 & 1907 & 0.45 & 1950 & 0.45 & 1993 & 2.40 \\
\hline 1865 & 1.68 & 1908 & 0.45 & 1951 & 0.54 & 1994 & 2.88 \\
\hline 1866 & 1.55 & 1909 & 0.40 & 1952 & 0.57 & 1995 & 3.73 \\
\hline 1867 & 1.52 & 1910 & 0.40 & 1953 & 0.60 & 1996 & 3.40 \\
\hline 1868 & 1.14 & 1911 & 0.40 & 1954 & 0.61 & 1997 & 3.14 \\
\hline 1869 & 1.39 & 1912 & 0.40 & 1955 & 0.66 & 1998 & 2.10 \\
\hline 1870 & 1.28 & 1913 & 0.42 & 1956 & 0.65 & 1999 & 2.73 \\
\hline 1871 & 1.32 & 1914 & 0.41 & 1957 & 0.74 & 2000 & 3.92 \\
\hline 1872 & 2.25 & 1915 & 0.41 & 1958 & 0.74 & 2001 & 2.70 \\
\hline 1873 & 3.84 & 1916 & 0.42 & 1959 & 0.74 & 2002 & 3.07 \\
\hline 1874 & 3.10 & 1917 & 0.42 & 1960 & 0.74 & 2003 & 4.37 \\
\hline 1875 & 2.96 & 1918 & 0.41 & 1961 & 0.78 & 2004 & 6.27 \\
\hline 1876 & 2.52 & 1919 & 0.40 & 1962 & 0.80 & 2005 & 6.69 \\
\hline 1877 & 1.60 & 1920 & 0.42 & 1963 & 0.79 & 2006 & 11.00 \\
\hline 1878 & 0.95 & 1921 & 0.42 & 1964 & 0.79 & 2007 & 16.88 \\
\hline 1879 & 0.89 & 1922 & 0.38 & 1965 & 0.79 & 2008 & 9.57 \\
\hline 1880 & 0.95 & 1923 & 0.36 & 1966 & 0.79 & 2009 & 6.64 \\
\hline 1881 & 0.91 & 1924 & 0.30 & 1967 & 0.88 & 2010 & 9.89 \\
\hline 1882 & 0.99 & 1925 & 0.33 & 1968 & 0.95 & & \\
\hline
\end{tabular}


Notes:

1840-1912, Price of refined metal, as supplied by Inco Ltd.

1913-21, Price of refined metal, in Historical Statistics of the United States, Colonial Times to 1970, U.S. Department of Commerce, Bureau of the Census.

1922-45, Price quoted by International Nickel Co. of Canada, Ltd., for electrolytic nickel cathode at New York, in 2-short-ton minimum lots, in the nickel chapter of the U.S. Bureau of Mines Minerals Yearbook.

1946-47, Contract price to U.S. buyers of electrolytic nickel cathode in carlots, free on board (f.o.b.) Port Colborne, Ontario, including duty of 2.50 cents per pound, in the nickel chapter of the U.S. Bureau of Mines Minerals Yearbook.

1948-61, Contract price to U.S. buyers of electrolytic nickel cathode in carlots, f.o.b. Port Colborne, Ontario, including duty of 1.25 cents per pound, in the nickel chapter of the U.S. Bureau of Mines Minerals Yearbook. [Duty was halved on January 1, 1948.]

1962-79, Contract price to U.S. buyers of electrolytic nickel in carlots, f.o.b. Port Colborne, Ontario, in American Metal Market. Weighted average for the year. U.S. import duty of 1.25 cents per pound was suspended on September 27, 1965.

1980-93, London Metal Exchange cash price for primary nickel of minimum 99.80-percent purity, delivered in the form of either cut cathodes or pellets or briquets, lots of 6 metric tons, in Metals Week.

1993-2010, London Metal Exchange cash price for primary nickel of minimum 99.80-percent purity, delivered in the form of either cut cathodes or pellets or briquets, lots of 6 metric tons, in Platt's Metals Week.

Table 2. Annual average price for stainless steel scrap.

[Values in dollars per long ton gross weight.]

\begin{tabular}{|c|c|c|c|c|c|c|c|}
\hline Year & Price & Year & Price & Year & Price & Year & Price \\
\hline 1987 & 560 & 1993 & 634 & 1999 & 625 & 2005 & 1,468 \\
\hline 1988 & 1,150 & 1994 & 719 & 2000 & 824 & 2006 & 2,090 \\
\hline 1990 & 927 & 1996 & 834 & 2002 & 703 & 2008 & 2,399 \\
\hline 1991 & 855 & 1997 & 808 & 2003 & 942 & 2009 & 1,486 \\
\hline
\end{tabular}

Notes:

1987-2005, Derived from the average of the Friday consumer buying price range for 18 percent chromium, 8 percent nickel scrap in bundles, solids, and clips, Pittsburgh, Penn., in American Metal Market (AMM).

2006-10, On November 1, 2006, AMM began reporting prices for Type 316 solids and clips and changed its listing for 18/8 bundles, solids and clips to Type 304 solids and clips. 


\title{
Niobium (Columbium) (Nb)
}

\author{
by John F. Papp
}

Niobium (columbium) was discovered in 1801 when the English chemist Charles Hatchett reported a new element similar to tantalum and named it columbium. Because its physical and chemical properties were similar to those of tantalum, the two metals were often confused. At the same time, columbium and niobium were determined to be two different metals. In 1864 and 1865 , a series of scientific findings clarified that niobium and columbium were the same element (as distinguished from tantalum), and for a century both names were used interchangeably. The name of the element was officially adopted as niobium in 1949 .

Niobium is a refractory metal that conducts heat and electricity well and is characterized by a high melting point, resistance to corrosion, and ease of fabrication. Ferroniobium is used worldwide mostly as an alloying element in steels and in superalloys. Little commercial application was found for niobium until the 1930s, when metallurgists began using it in the form of ferroniobium in steel and as niobium carbide in high-speed cutting tools (Cunningham, 1985a). Acceptable substitutes, such as molybdenum, tantalum, titanium, tungsten, and vanadium, are available for some niobium applications, but substitution may lower performance and (or) cost-effectiveness.

The niobium price is driven by the availability of niobium mineral feed materials, recycling being an insignificant source of supply. Thus, the events affecting the supply of niobium mineral concentrates are discussed herein. A price table and graph, however, are included for standard-grade ferroniobium, the dominant form in which niobium is consumed. In 1979, the increase in demand for "high-purity" ferroniobium in superalloys was significant. The increased niobium demand affected prices for high-purity ferroniobium and for columbite, but had no real impact on the price for standard ferroniobium. The feed material for production of high-purity ferroniobium was columbite, and standard ferroniobium was produced from pyrochlore. In 1998, the price for niobium contained in concentrate was $\$ 4.29$ per pound compared with $\$ 6.88$ per pound for niobium contained in standard ferroniobium.

Brazil and Canada are the major producers of niobium mineral concentrates and converters of the material to ferroniobium. The U.S. niobium mining industry has not been a significant source since 1959. The United States satisfies its niobium requirements primarily by importing ferroniobium and niobium oxide from Brazil, ferroniobium from Canada, and lesser amounts of niobium concentrates for processing from various countries. Many of the applications for niobium are either directly or indirectly defense related because of its use in the aerospace, communications, energy, and transporta- tion industries. Thus, the Defense Logistics Agency classified niobium as strategic and critical, and, over the years, various niobium materials have been purchased for the National Defense Stockpile (NDS).

A significant activity during the 1950 s was the U.S. Government's worldwide program for the purchase of about 6,800 metric tons $(\mathrm{t})$ of combined niobium and tantalum oxides contained in niobium-tantalum ores and concentrates. The purchase program was terminated in 1959 (Cunningham, 1985a, b). The program, which was initiated to encourage increased production of niobium tantalum ores and concentrates of domestic and foreign origin, largely governed the market price for niobium ores and concentrates. It also resulted in the discovery of large low-grade domestic and foreign deposits of niobium minerals. The program, however, was less successful in developing domestic niobium mineral production. The low grade of the discoveries precluded their development at current or expected future prices. Termination of the program was followed by lower market prices, resulting in reduced production worldwide. Marginal producers, who could not operate profitably at lower prices, halted production.

Reshaping of niobium supply and demand began in the 1960s. Discovery of the strengthening effect of small amounts of niobium in structural carbon steel eventually led to a widespread and growing use for niobium in high-strength low-alloy steels. Until the mid-1960s, the world's needs for niobium were provided for mostly by columbite concentrates mined in Nigeria; the Nigerian columbite was produced as a byproduct of tin mining. Development of pyrochlore deposits in Brazil and Canada during this period greatly increased niobium availability (Cunningham, 1985a; Miller, Fantel, and Buckingham, 1986, p. 8; Crockett and Sutphin, 1993, p. 4-5). Pyrochlore deposits are mined primarily for niobium, and columbite and tantalite are recovered mostly as a byproduct/coproduct of other minerals, principally tin. The shift in niobium supply from Nigeria to Brazil and Canada did not have an adverse impact on the niobium price, which changed little or not at all during the 1960 s, owing to the readily available supplies of pyrochlore.

During the 1970s, increased demand, mostly in the form of ferroniobium for steelmaking, continued to be met by the large quantities of pyrochlore concentrates produced in Brazil and Canada. Pyrochlore became the standard feed material for the manufacture of ferroniobium for steelmaking. Columbitetantalite remained as the source material for the production of niobium oxide used in high-purity niobium products. As demand increased in the 1970s, prices began to increase for niobium concentrates and niobium products. With continued 
strong demand for niobium in the manufacture of steels and especially high-purity niobium, the price for niobium concentrates peaked in 1979 (table 1).

In 1980, an important change in niobium supply took place when plants that produced niobium oxide from pyrochlore-based feed materials were established in Brazil and the United States, which resulted in lower prices for niobium oxide and high-purity niobium products (Jones, 1981). This change greatly diminished the need for columbite ores. Until 1980, niobium oxide had been produced mostly from columbite- and tantalite-based materials. Niobium concentrate prices decreased during most of the 1980s, owing to the large quantities of pyrochlore produced in Brazil and Canada and the niobium products produced from this feed material, especially in Brazil.

Brazil's production of niobium concentrates, mostly pyrochlore, accounts for more than 90 percent of 2010 world production of niobium. Pyrochlore concentrates, however, have not been exported from Brazil since 1981. Pyrochlore concentrates produced in Brazil are processed locally, and some of the upgraded niobium products are consumed domestically, with the majority of the products exported. As the dominant niobium producer/supplier, Brazil has maintained a marketing strategy of stable supply and moderate price changes.

A significant change took place in the niobium industry in late 1994. The sole Canadian niobium concentrate producer began ferroniobium production at its niobium mine and plant in Quebec (Teck Corp., 1994, p. 13, 32). The plant converted basically all pyrochlore concentrates produced at the mine to ferroniobium. Prior to commissioning of the plant, niobium concentrates produced at the mine were shipped mostly to Europe, Japan, and the United States for conversion to ferroniobium.

In 1997, the U.S. Department of Defense initiated the sale of ferroniobium from the NDS. From March 1997 through December 1998, the Defense Logistics Agency sold about 211 $\mathrm{t}$ of niobium contained in ferroniobium valued at about $\$ 2.98$ million (Cunningham, 1998; 1999, p. 1; Defense National Stockpile Center, 1998a, b). The overall average unit price for the sales, about $\$ 6.40$ per pound of contained niobium, was somewhat less than that quoted for ferroniobium, $\$ 6.88 \mathrm{per}$ pound of contained niobium (fig. 1; table 2).

In 1998, the leading Brazilian niobium producer initiated plans to raise its ferroniobium production capacity about 50 percent by 2000 . The expansion was aimed at maintaining the stability of world supply and pricing of ferroniobium in response to growing international demand (Metal Bulletin, 1998).

For most of the 1990s, the price for niobium remained stable as the demand for and supply of niobium continued to increase. In 1993, the price of pyrochlore was discontinued; in 2000, the price of columbite, another niobium mineral, was discontinued; and in 2005, the price of ferroniobium was discontinued. In 2005, Brazil accounted for 89 percent of U.S. ferroniobium imports (Magyar, 2007, p. 20.8).
Since 1990, China has increased its consumption and production of steel coinciding with development of its infrastructure, which resulted in increased demand for niobium; however, the world financial crisis in 2008 and subsequent economic slowdown reduced demand in the remainder of the world. According to one industry analyst, "Prices for niobium oxide, other niobium chemicals, niobium metal and various alloys derived from either pyrochlore or other niobiumbearing sources are highly variable and depend on product specifications, volume, and processing considerations" (Cunningham, 2005, p. 20.3). The lack of published prices reflects the limited number of suppliers and the practice of long-term contracts. Standard-grade ferroniobium is the leading commercially traded niobium-containing material. Pyrochlore, the leading mineral source for niobium, is not sold on the open market because the leading producers process the pyrochlore at the mine site into ferroniobium or niobium pentoxide, downstream products that are commercially traded (Roskill Information Services Ltd., 2009, p. 217-222).

\section{References Cited}

Crockett, R.N., and Sutphin, D.M., 1993, International Strategic Minerals Inventory summary report—Niobium (columbium) and tantalum: U.S. Geological Survey Circular 930-M, 36 p.

Cunningham, L.D., 1985a, Columbium, in Mineral facts and problems: U.S. Bureau of Mines Bulletin 675, p. 185-196.

Cunningham, L.D., 1985b, Tantalum, in Mineral facts and problems: U.S. Bureau of Mines Bulletin 675, p. 811-822.

Cunningham, L.D., 1998, Columbium (niobium): U.S. Geological Survey Mineral Commodity Summaries 1998, p. 50-51.

Cunningham, L.D., 1999, Columbium (niobium) and tantalum, in Metals and minerals: U.S. Geological Survey Minerals Yearbook 1997, v. I, p. 21.1-21.12.

Cunningham, L.D., 2005, Columbium (niobium) and tantalum, in Metals and minerals: U.S. Geological Survey Minerals Yearbook 2003, v. I, p. 20.1-20.13.

Defense National Stockpile Center, 1998a, Stockpile accepts ferrocolumbium offers: Fort Belvoir, VA, Defense National Stockpile Center news release, November 13, 1 p.

Defense National Stockpile Center, 1998b, Stockpile accepts ferrocolumbium offers: Fort Belvoir, VA, Defense National Stockpile Center news release, December 10, 1 p.

Jones, T.S., 1981, Columbium (niobium) and tantalum, in Metals and minerals: U.S. Bureau of Mines Minerals Yearbook 1980, v. I, p. 249-260. 
Magyar, M.J., 2007, Columbium (niobium) and tantalum, in Metals and minerals: U.S. Geological Survey Minerals Yearbook 2007, v. I, p. 20.1-20.12.

Metal Bulletin, 1998, CBMM expands to maintain ferroniobium stability: Metal Bulletin, no. 8311, September 21, p. 11.

Miller, F.W., Fantel, R.J., and Buckingham, D.A., 1986, Columbium availability-Market economy countries-A minerals availability appraisal: U.S. Bureau of Mines Information Circular 9085, 20 p.
Roskill Information Services Ltd., 2009, The economics of niobium 2009 (11th ed.): London, United Kingdom, Roskill Information Services Ltd., February, 222 p.

Teck Corp., 1994, Annual report 1994: Vancouver, British Columbia, Canada, Teck Corp., 60 p.

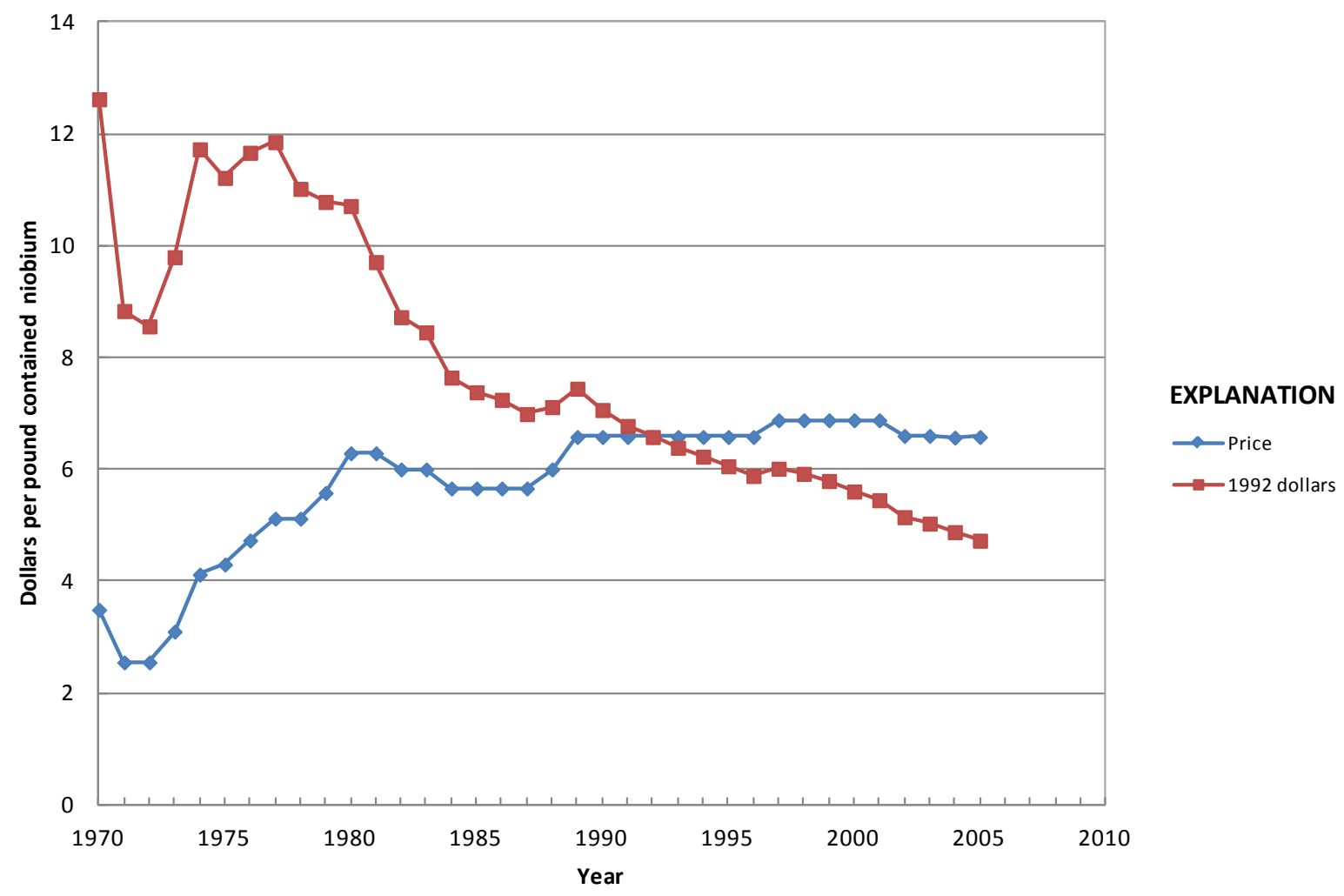

Figure 1. Annual average ferroniobium price.

\section{Significant events affecting niobium prices since 1970}

1970-79 Increased demand

Niobium oxide produced from pyrochlore-based feed material

1994

Exports of Brazilian pyrochlore ceased

Production of ferroniobium began in Canada

1998

Sales of ferroniobium from the National Defense Stockpile (NDS)

1990-2010 Rise of China as a leading steel-producing and consuming nation

2008 Global financial crisis and subsequent economic slowdown 
Table 1. Yearend average columbite concentrate price.

[Values in dollars per pound contained niobium pentoxide]

\begin{tabular}{|c|c|c|c|c|c|c|c|}
\hline Year & Price & Year & Price & Year & Price & Year & Price \\
\hline 1940 & 0.35 & 1958 & 3.40 & 1976 & 2.69 & 1994 & 2.60 \\
\hline 1941 & 0.35 & 1959 & 1.08 & 1977 & 2.76 & 1995 & 3.00 \\
\hline 1942 & 0.53 & 1960 & 1.22 & 1978 & 3.03 & 1996 & 3.00 \\
\hline 1943 & 0.25 & 1961 & 1.00 & 1979 & 6.78 & 1997 & 3.00 \\
\hline 1944 & 0.25 & 1962 & 0.95 & 1980 & 6.50 & 1998 & 3.00 \\
\hline 1945 & 0.60 & 1963 & 0.95 & 1981 & 6.13 & 1999 & 3.00 \\
\hline 1946 & 0.54 & 1964 & 0.85 & 1982 & 4.63 & 2000 & 6.25 \\
\hline 1947 & 0.65 & 1965 & 0.85 & 1983 & 4.63 & 2001 & NA \\
\hline 1948 & 0.73 & 1966 & 1.11 & 1984 & 3.75 & 2002 & NA \\
\hline 1949 & 1.13 & 1967 & 0.97 & 1985 & 3.75 & 2003 & NA \\
\hline 1950 & 2.55 & 1968 & 0.92 & 1986 & 2.75 & 2004 & NA \\
\hline 1951 & 2.56 & 1969 & 1.05 & 1987 & 2.43 & 2005 & NA \\
\hline 1952 & 3.40 & 1970 & 1.12 & 1988 & 2.43 & 2006 & NA \\
\hline 1953 & 3.40 & 1971 & 1.04 & 1989 & 3.25 & 2007 & NA \\
\hline 1954 & 3.40 & 1972 & 1.29 & 1990 & 3.25 & 2008 & NA \\
\hline 1955 & 3.40 & 1973 & 1.42 & 1991 & 2.83 & 2009 & NA \\
\hline 1956 & 3.40 & 1974 & 1.64 & 1992 & 2.83 & 2010 & NA \\
\hline 1957 & 3.40 & 1975 & 1.71 & 1993 & 2.60 & & \\
\hline
\end{tabular}

Notes:

Prices before 1946 were published by the U.S. Bureau of Mines; origns are unknown.

1946-51, published in Metal Bulletin.

1952-58, value of U.S. Government purchases.

1959-66, published in Engineering and Mining Journal, Metal and Mineral Markets.

1967-90, published in Metals Week.

1991-2000, published in Metal Bulletin.

After 2000, published prices wee discontinued. 
Table 2. Yearend average ferroniobium (ferrocolumbium) price.

[Values in dollars per pound contained niobium. NA Not available]

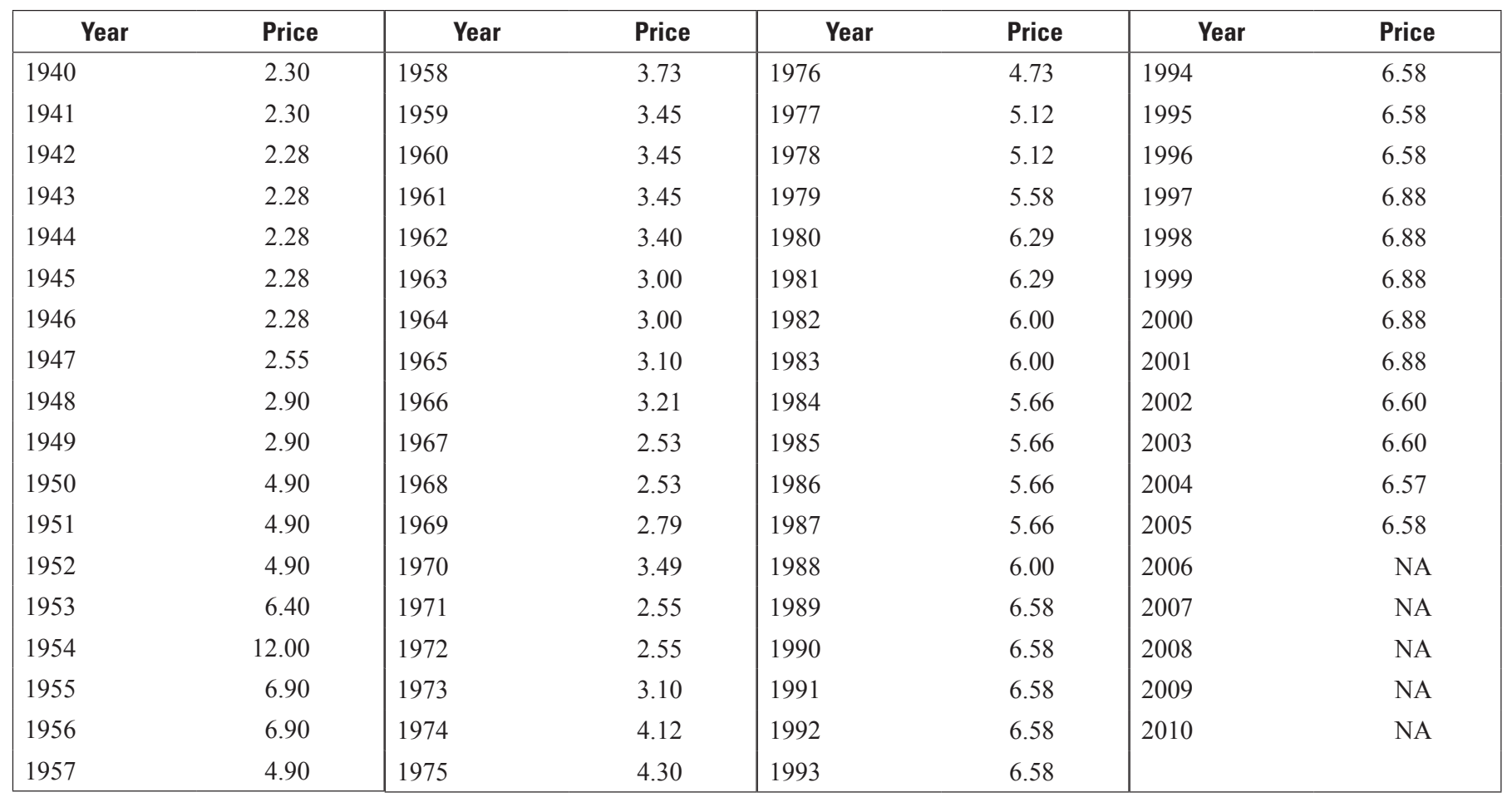

Notes:

1940-66, published in Engineering and Mining Journal, Metal and Mineral Markets.

1967-92, published in Metals Week.

1993-96, published in Platt's Metals Week.

1997-2005, published in American Metal Market.

After 2005, published prices were discontinued. 


\title{
Platinum-Group Metals (Ir, Os, Pd, Pt, Rh, Ru)
}

\author{
by Patricia J. Loferski
}

The platinum-group metals (PGMs) - iridium, osmium, palladium, platinum, rhodium, and ruthenium - are among the rarest mineral commodities in the Earth's crust. Although considered a precious metal today, the 16th century Spanish conquistadors considered platinum an unwanted impurity in the gold and silver that they were mining in New Granada (present-day Colombia). The Spaniards referred to the metal as "platina," a diminutive of "plata," the Spanish word for silver, and for many years it had no commercial value. Today, most of the world's primary PGM production comes from four countries, in descending order of production-South Africa, Russia, Zimbabwe, and the United States. The ratio of palladium to platinum, the two most commercially significant PGMs, in individual PGM ores varies from country to country. South Africa produces about twice as much platinum as palladium, whereas Russia produces about three times as much palladium as platinum (Conradie, 1997, p. 34-40). In Canada, PGMs are byproducts of nickel ore processing. In the United States, PGMs are produced at the Stillwater and East Boulder Mines within the Stillwater Complex in Montana.

The catalytic properties of the six PGMs are outstanding. Platinum's wear and tarnish-resistance characteristics are well suited for making fine jewelry. Other distinctive properties include resistance to chemical attack, excellent high-temperature characteristics, and stable electrical properties. All these properties are important in their industrial applications. Platinum, platinum alloys, and iridium are used as crucible materials for the growth of single crystals, especially oxides for electronic materials. The chemical industry uses a significant amount of either platinum or platinum-rhodium alloy gauze to catalyze the partial oxidation of ammonia to yield nitric oxide, which is the raw material for explosives, fertilizers, and nitric acid. In recent years, a number of PGMs have become important as catalysts in synthetic organic chemistry. Ruthenium dioxide is used as coating on dimensionally stable titanium anodes used in the production of chlorine and caustic soda. Platinum-supported catalysts are used in the refining of crude oil, reforming, and other processes used in the production of high-octane gasoline and aromatic compounds for the petrochemical industry. Since 1979, the automotive industry has emerged as the principal consumer of PGMs. Palladium, platinum, and rhodium have been used as oxidation and reduction catalysts in catalytic converters to treat automobile exhaust emissions. A wide range of PGM alloy compositions is used in low-voltage and low-energy contacts, thick- and thin-film circuits, thermocouples and furnace components, and electrodes (Hilliard and Dunning, 1983, p. 129-142).
Prior to 1980, the most important prices for PGMs were the South African producer prices and the free-market prices fixed daily on the commodity exchanges. In terms of total value of PGM traded, the most important exchange is the New York Mercantile Exchange (NYMEX). Producer prices give a certain amount of stability to the platinum and palladium markets. From about 1980 onward, however, the free-market price of platinum fell to well below the producer price, putting pressure on the producer price and inducing consumers to buy increasing quantities on the free market to meet their requirements. Also, the increased growth of investments in platinum added more pressure on producers to adopt a more realistic price level. Consequently, South African producers largely abandoned producer prices and adopted a pricing policy that more closely reflected market conditions. PGMs are traded on only a few exchanges around the world including NYMEX, the Tokyo Commodity Exchange for Industry, as well as much smaller markets in Johannesburg, Mumbai, and Shanghai.

Beginning in 1957 and continuing through 1958, a drop in demand for platinum by domestic petroleum refiners and persistent selling pressure by the Soviet Union at discount prices caused the platinum price to tumble to the lowest level in a decade (table 4). Soviet sales brought a corresponding decline in the price of palladium to the lowest level since 1933 (table 3). In 1959, prices for platinum and palladium increased, reversing the trend of 1957 through 1958. The more orderly selling policy by the Soviet Union was a significant factor in the PGM market recovery. Also, U.S. Government purchases contributed to the higher price of palladium.

In spring 1963, the Soviet Union disrupted the orderly marketing of PGMs by selling large amounts of metal at below-market prices but curtailed its offerings later in the year. U.S. consumption of PGMs reached the highest level in history, more than 1 million troy ounces. The largest use for platinum was in the chemical industry, and the largest use for palladium was in the electrical industry (Ware, 1964, p. 901-907).

From 1964 to 1968, supplies of platinum were tight, putting upward pressure on prices. In 1965, U.S. suppliers allocated platinum to established customers at $\$ 100$ per troy ounce. U.S. purchases of platinum rose sharply owing to the construction of new petroleum refineries. Prices for PGMs during 1967 reflected the tight supplies that persisted throughout the year. Although the producer price for platinum showed a small increase, dealer prices were up sharply. At the start of 1967 , the producer price for platinum was $\$ 100$ per troy ounce. On January 24, the price was increased to \$109 to $\$ 112$ per troy ounce and was unchanged until December 
when sales were made at $\$ 125$ per troy ounce. Dealer prices, which started the year at $\$ 157$ to $\$ 160$ per troy ounce, began to increase in May and were $\$ 225$ to $\$ 230$ per troy ounce by yearend. The producer price of palladium, which was $\$ 35$ to $\$ 37$ per troy ounce in October 1966 , increased to $\$ 37$ to $\$ 39$ per troy ounce in January 1967 and remained unchanged for the remainder of the year (table 3). The price of rhodium was $\$ 197$ to $\$ 299$ per troy ounce in January 1969 , increased in March and again in December, and closed out the year at \$245 to $\$ 250$ per troy ounce (table 5). During the following year, dealer prices were two to three times the producer prices.

In 1971, prices of PGMs declined owing to the expansion of platinum capacity in South Africa. In each of the previous 8 years, South Africa increased its output. On the strength of an upturn in consumption and growing anticipation that PGMs might be needed in a few years for automotive exhaust emissions control, prices and production posted significant increases in 1972. By the second quarter of 1972, U.S. dealer prices for platinum and palladium had exceeded producer prices. By midyear, the dealer price for iridium had increased from $\$ 145$ to $\$ 148$ per troy ounce to $\$ 525$ per troy ounce (fig. 1). Production and price trends continued the upward trend in 1973. Producer prices, which were under Government control much of the year, increased by 10 percent to 50 percent in February, fluctuated between narrow limits in June, and then advanced again in late September. After price controls were removed from most nonferrous metals in December, rhodium and iridium prices increased by another 14 percent to 15 percent (tables 5 and 1). Ruthenium remained unchanged after a February increase to $\$ 60$ per troy ounce, and osmium stayed at $\$ 200$ per troy ounce through the year (figs. 6 and 2). The dealer price of iridium jumped from $\$ 250$ to $\$ 450$ per troy ounce in July, as the metal became scarce, and ended the year at $\$ 525$ per troy ounce (Butterman, 1975, p. 1040).

PGM prices were mostly flat from 1975 through 1977. In 1977 , the producer price for platinum was steady at $\$ 162$ per troy ounce (fig. 4). The producer price for palladium began 1977 at $\$ 55$ per troy ounce, increased to $\$ 60$ per troy ounce in late January, and remained at that level for the remainder of the year (fig. 3). The price of rhodium was about $\$ 400$ per troy ounce at the beginning of the year and increased to $\$ 450$ per troy ounce in March owing to increased industrial demand and speculation regarding the use of rhodium in automotive catalytic converters (fig. 5). Iridium started the year at $\$ 300$ per troy ounce, decreased to $\$ 250$ per troy ounce in June, and returned to $\$ 300$ per troy ounce for the remainder of the year. The price of osmium was $\$ 200$ per troy ounce for the first 6 months of 1977 but declined to around $\$ 150$ per troy ounce in the last 6 months of the year owing to continued weak demand (table 2). The price of ruthenium remained at around $\$ 60$ per troy ounce from 1974 through 1976 (table 6).

From 1978 to 1980, prices of platinum rose substantially owing to strong investor interest, chronic world inflation, and tight supply. In 1980, platinum, gold, and silver prices soared as a result of speculative activity. The platinum dealer price peaked at $\$ 990$ per troy ounce in March 1980. Palladium prices moved up moderately in 1978 and more sharply in 1979 partly owing to increased investor interest. Rhodium prices increased only moderately in 1978, but in 1979 the price increased sharply. This was in response to larger purchases of the metal by the automotive industry for use as an automotive emissions control catalyst.

In 1981 and 1982, lower world demand for PGMs resulted in lower prices. In 1983, dealer prices for platinum and palladium increased substantially. A major South African producer, Rustenburg Platinum Holdings Ltd., suspended its producer prices for PGMs and began selling most of its output at market prices. Platinum and palladium were recognized more as world commodities than commodities controlled exclusively by South African producers. Trading activity in futures contracts on NYMEX increased substantially.

In 1984, the dealer price for rhodium nearly doubled because of higher demand for rhodium in automobile threeway catalytic converters. The automotive industry became the dominant user of rhodium in the early 1980 s.

In 1986, the dealer price for platinum increased by 60 percent owing to a work stoppage at Impala Platinum Holdings Ltd. in South Africa and anticipation that U.S. imports of platinum from South Africa would be cut off because of the anti-apartheid legislation passed by the U.S. Congress. PGMs were later exempted from the Comprehensive Anti-Apartheid Act of 1986.

In December 1988, the platinum market reacted strongly to an announcement by Ford Motor Co. that it had developed a platinum-free automobile catalyst. Spot platinum prices fell to $\$ 100$ per troy ounce on the day of the announcement, and futures prices in New York fell the maximum of $\$ 25$ per troy ounce for two consecutive days. The average dealer price for platinum in December was $\$ 557$ per troy ounce. By January 1989 , the average price had fallen to $\$ 528$ per troy ounce.

From 1990 to 1998, the annual average New York dealer price of platinum fluctuated within the relatively narrow range of $\$ 375$ and $\$ 475$ per troy ounce. The price history of palladium was similar. The price of rhodium, however, was dramatically different.

In the late 1970s, market economy countries began implementing measures to reduce pollutants in automobile exhausts. The emphasis on controlling air pollution resulted in increased demand for PGMs. Palladium-rhodium and platinum-rhodium oxidation and reduction catalysts were developed for use in catalytic converters. The increased demand caused the annual average price of rhodium to increase from $\$ 312$ per troy ounce in 1983 to $\$ 929$ in 1985 . From 1986 to 1988, the monthly average New York dealer price of rhodium ranged from $\$ 1,150$ to $\$ 1,300$ per troy ounce. In early 1989 , the announcement of problems at South Africa's Rustenburg Platinum precious metals refinery caused the price to jump to more than $\$ 2,000$ per troy ounce. By July 3, 1990, rhodium was being quoted at $\$ 7,000$ per troy ounce. This level could not be sustained, but the price fell no lower than $\$ 4,100$ per troy ounce in November, reached $\$ 4,500$ per troy ounce in early December, and rose sharply to $\$ 5,300$ per troy ounce in 
the last week of 1990. Starting in 1992, the price trend of rhodium turned downward. This was brought on by a recession in market economy countries, reduced sales of automobiles, and, consequently, reduced demand for automobile catalysts. Improved metallurgical recovery increased the supply of rhodium, which also exerted downward pressure on price. In January 1997, the rhodium price sank to $\$ 200$ per troy ounce, its lowest level in nearly 24 years. Prices began to rise again in June, reaching a peak of $\$ 370$ per troy ounce, as delayed shipments from Russia caused a shortage of supply. The price retreated to $\$ 300$ per troy ounce in August but rallied to $\$ 360$ per troy ounce at yearend, following speculative buying in the United States. Prices continued to rise in 1998, reaching $\$ 640$ per troy ounce in April, its highest level since 1994 (Platts Metals Week, 1998).

From 1990 to 1996, prices for ruthenium and iridium remained mostly unchanged within narrow limits. Supply and demand were in balance, and there was little or no upward pressure on prices. At the start of 1997, strong consumer purchasing coupled with increasingly limited availability caused the price of iridium to increase from $\$ 110$ per troy ounce to $\$ 200$ per troy ounce in late January. The price reached \$290 per troy ounce in October but eased slightly to $\$ 270$ per troy ounce at yearend. Strong consumer purchasing and continued tight supply lifted the price to $\$ 575$ per troy ounce in April 1998. The price subsequently began to ease, as industrial demand slackened, and supplies increased.

From late 1999 through early 2001, platinum prices rose owing to increased consumption by the automobile industry; prices were supported both by strong consumer demand and limited physical availability. In 2001, delays in PGM shipments from Russia caused supply disruptions, which led to soaring palladium prices. For several years prior to 2001, palladium was increasingly used in catalytic converters because it was particularly effective for reducing hydrocarbon emissions, which were being more stringently regulated. This increased use of palladium, compounded by the Russian supply disruption, caused the palladium price to reach $\$ 1,083$ per troy ounce in 2001, which was higher than that of platinum for the first time. Following its peak in early 2001, the palladium price plummeted to $\$ 326$ per troy ounce by yearend. Palladium's high price led to a decrease in demand as automakers substituted less-expensive platinum for palladium in catalytic converters for gasoline engines. Other metals were also substituted for palladium in the dental and electronics industries. From late-1999 to mid-2001, rhodium prices increased. The increase was partly because of its substitution for palladium in catalytic converters because of the palladium price rise, and also because larger quantities of rhodium were needed in catalytic converters in order to meet tougher emission standards.

From early 1999 through late 2001, iridium prices held steady at around $\$ 415$ per troy ounce. By early 2004 , the iridium price dropped to $\$ 87$ per troy ounce, owing to decreased demand for iridium crucibles by the electronics industry. Ruthenium prices increased sharply from $\$ 46$ per troy ounce in early 2000 to $\$ 170$ per troy ounce at the end of 2000 , partly because of speculative purchasing. The ruthenium price decreased steadily until the end of 2002, owing both to excess inventories of electronic components and to a price correction back to levels prior to the speculation-driven surge of 2000 .

In late 2001, the platinum price dipped to $\$ 456$ per troy ounce. The platinum price then rose nearly continuously until the end of 2007, when it reached an average monthly price of $\$ 1,492$ per troy ounce. The price rise was the result of a steady increase in demand from the automobile catalytic converter sector. Monthly average palladium prices continued the decrease that started in 2001, and reached $\$ 202$ per troy ounce in early 2003 as a result of excess supply as well as selling by investors. Monthly average palladium prices, however, increased to $\$ 300$ per troy ounce in early 2004 , decreased to $\$ 193$ per troy ounce in late 2004, and then increased steadily to $\$ 355$ per troy ounce by the yearend 2007 . With the palladium price well below that of platinum, automakers switched back to palladium for catalytic converters for gasoline engines. The rhodium price decreased gradually from late 2001 until late 2003, reaching $\$ 500$ per troy ounce. From 2003 to 2007, the rhodium price rose dramatically. The rhodium price increase was driven by increased consumption in automobile catalytic converters and a lack of substitutes for rhodium in reducing nitrous oxide emissions.

In January 2008, platinum mines in South Africa were shut down for 5 days after the state-run utility, Eskom Holdings, Ltd., ran short of electrical-generating capacity. The shutdown led to fears of a supply shortage, and, as a result, prices of platinum, palladium, and rhodium soared. In mid2008 , the price of platinum reached an alltime high of $\$ 2,275$ per troy ounce; palladium was $\$ 585$ per troy ounce, and rhodium soared to an alltime high of $\$ 10,100$ per troy ounce. The resumption of all mining activities, followed by the global economic downturn in 2008, caused PGM prices to plummet. By late 2008 , platinum was $\$ 760$ per troy ounce, palladium was $\$ 170$ per troy ounce, and rhodium was $\$ 1,000$ per troy ounce. Following the extreme price rise of rhodium, manufacturers of catalytic converters worked to minimize the amount of rhodium needed to meet emission standards.

During 2009 and 2010, prices of platinum and palladium gradually increased. Average monthly palladium prices rose higher than those of mid-2008 owing to increased demand from the automotive sector, whereas average monthly platinum prices remained less than their mid-2008 level. In 2009 and 2010, average monthly prices of rhodium remained well below the high prices of 2008 .

Iridium prices spiked in early 2004 as a result of speculative interest and rose from $\$ 87$ to $\$ 230$ per troy ounce. Iridium price decreased to $\$ 145$ per troy ounce by early 2005 , increased gradually throughout 2005 , and then increased rapidly in early 2006 , reaching a monthly average price of $\$ 400$ per troy ounce. The iridium price remained between $\$ 400$ and $\$ 450$ per troy ounce until early 2010, when there was a sharp increase to $\$ 725$ per troy ounce. The large price increase in 2010 was the result of increased purchasing by the electro- 
chemical and electronics sectors, particularly in China. In the electronics sector, iridium crucibles were used to grow highpurity single crystals for production of light-emitting diodes (LEDs). In the electrochemical sector, iridium was used in chloralkali production plants as older mercury-based technology was replaced.

From 2002 to 2006, average monthly ruthenium prices remained below $\$ 100$ per troy ounce. In 2007, ruthenium prices soared to $\$ 694$ per troy ounce owing to purchases by the computer industry. Ruthenium was used in a new computer hard disk technology, known as perpendicular magnetic recording, which greatly increased computer storage capacity. The industry subsequently found ways to use less ruthenium in the hard drives, and the price fell back to $\$ 89$ per troy ounce by early 2009 , where it remained until late 2009 . The ruthenium price rose to $\$ 245$ per troy ounce in mid-2010 owing to increased demand from the electronics sector, and then decreased to $\$ 180$ per troy ounce at the end of 2010 .

Exchange-traded funds (ETFs) were introduced for platinum and palladium in Europe and the United States in 2007 and 2010, respectively. ETFs were essentially paper investments that were backed by bullion and allowed investment without having to take in physical delivery of the metals. Although ETF purchases led to sharp increases in investment demand for platinum and palladium, the metal prices were not greatly affected.
Osmium prices remained at $\$ 450$ per troy ounce from 1998 through 2010 because of its few uses and limited number of consumers.

\section{References Cited}

Butterman, W.C., 1975, Platinum-group metals, in Metals, minerals, and fuels: U.S. Bureau of Mines Minerals Yearbook 1973, v. I, p. 1,037-1,049.

Conradie, A.S., 1997, Platinum-group metals, in South Africa's mineral industry, 1996/1997 (14th ed.): Braamfontein, South Africa, South Africa Department of Minerals and Energy, Minerals Bureau, November, p. 34-40.

Hilliard, H.E., and Dunning, B.W., 1983, Recovery of platinum-group metals and gold from electronic scrap, in Lundy, D.E., and Zysk, E.D., eds., The platinum group metals-An in depth view of the industry: 1983 IPMI International Seminar, Williamsburg, Va., April 10-13, 1983, p. 129-142.

Platt's Metals Week, 1998, Daily prices: Platt's Metals Week, v. 69, no. 16, April 20, p. 17.

Ware, G.C., 1964, Platinum-group metals, in Metals and minerals (except fuels): U.S. Bureau of Mines Minerals Yearbook 1963, v. I, p. 899-911. 


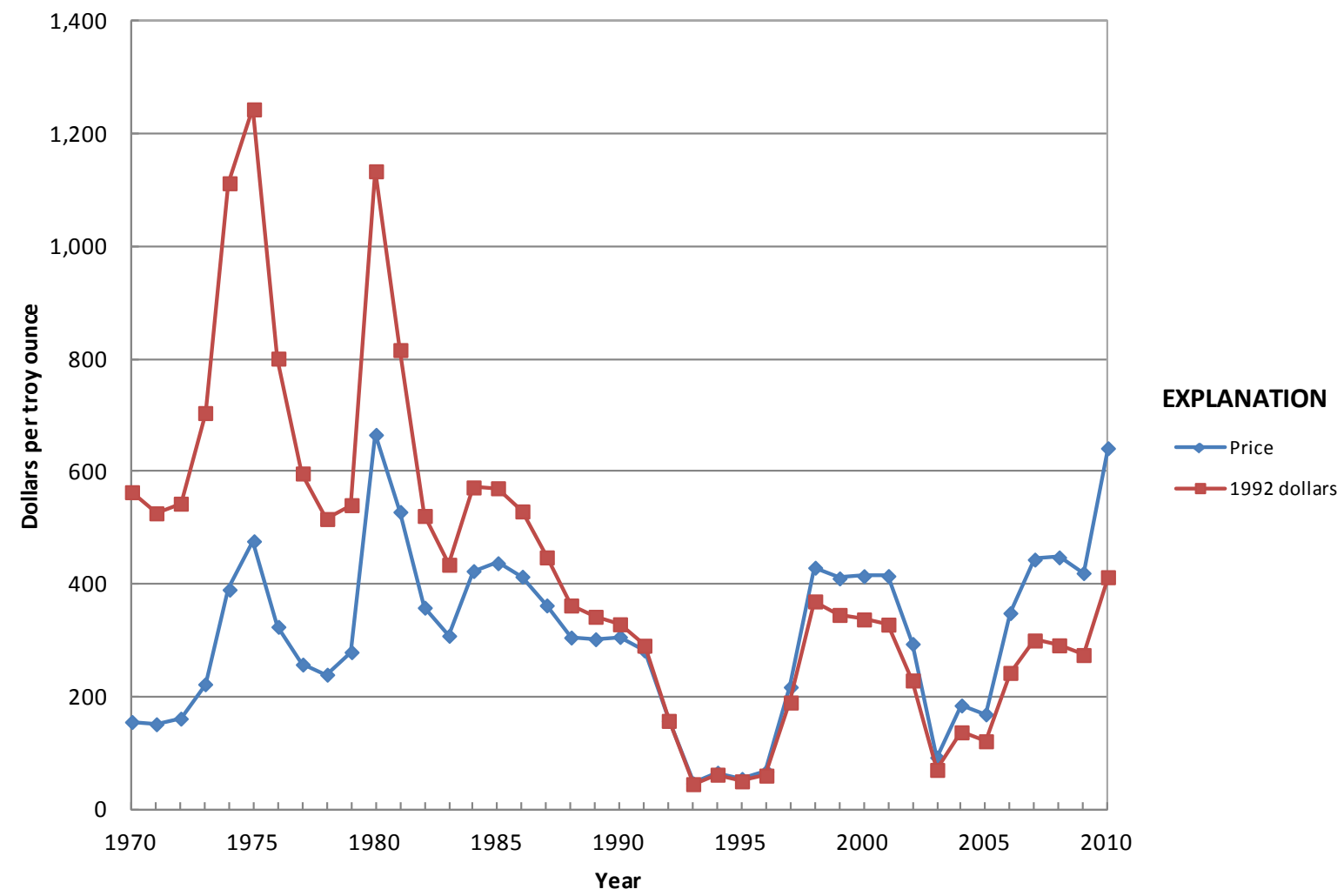

Figure 1. Platinum-Group Metals—Annual average iridium price.

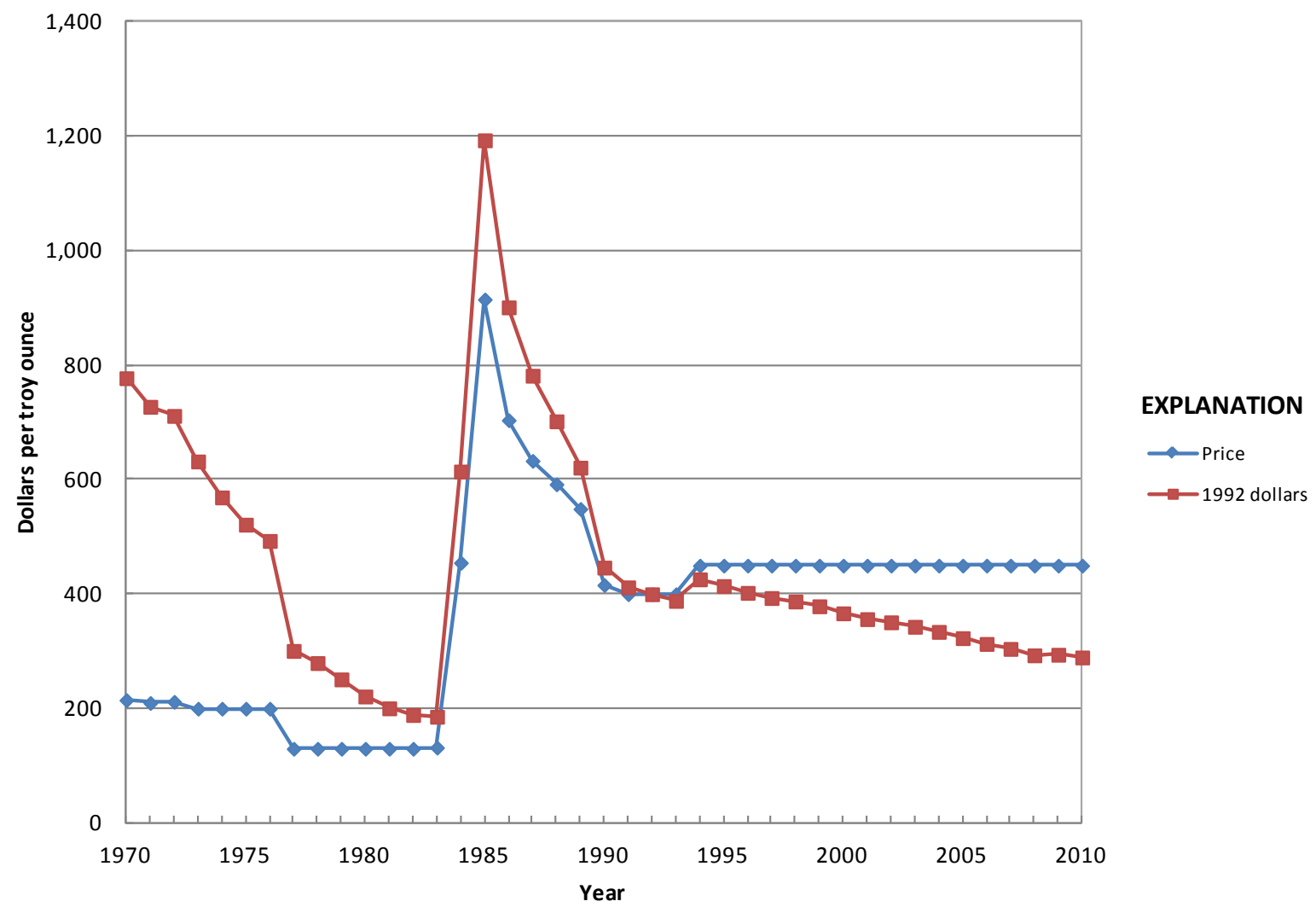

Figure 2. Platinum-Group Metals_Annual average osmium price. 


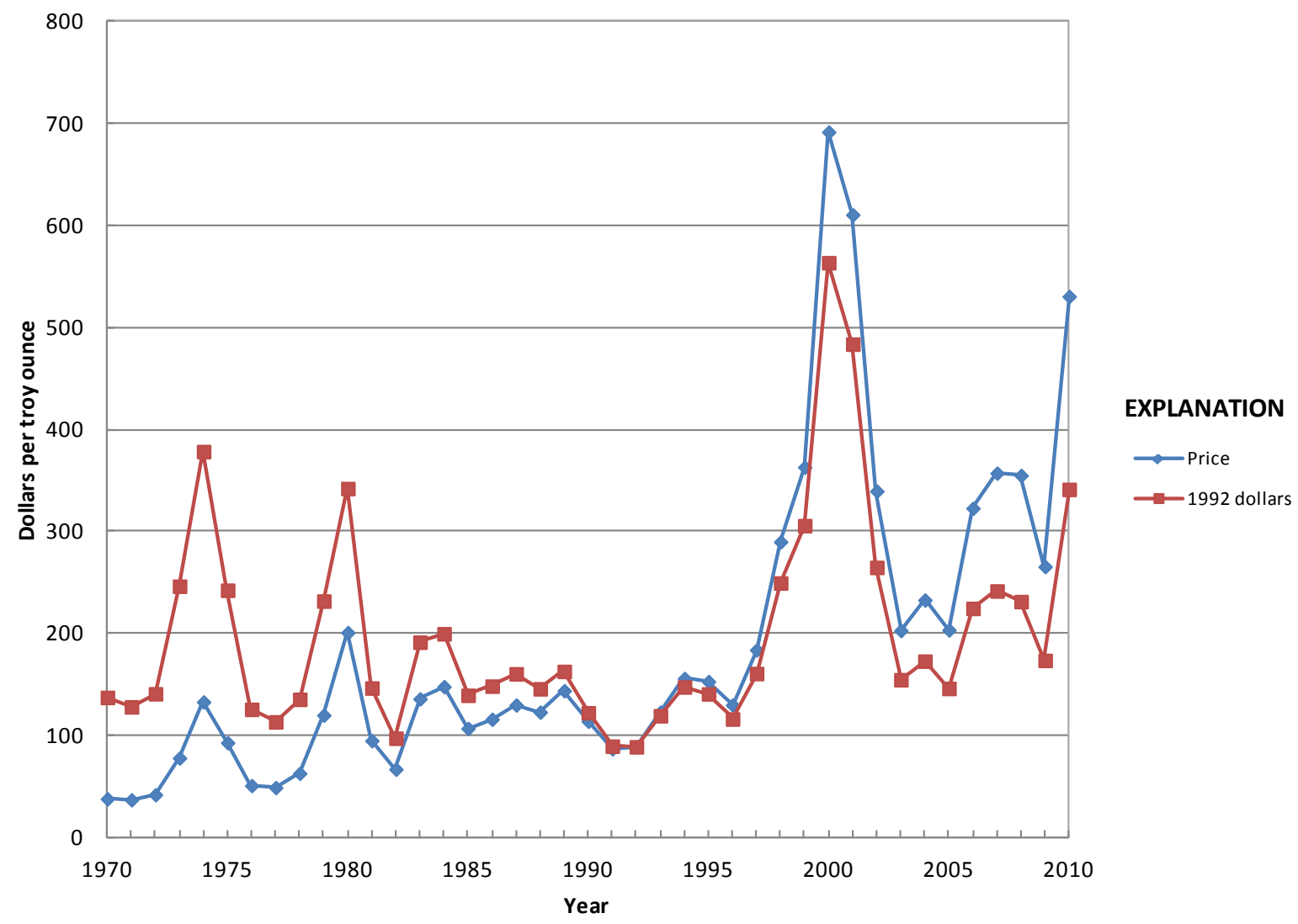

Figure 3. Platinum-Group Metals—Annual average palladium price.

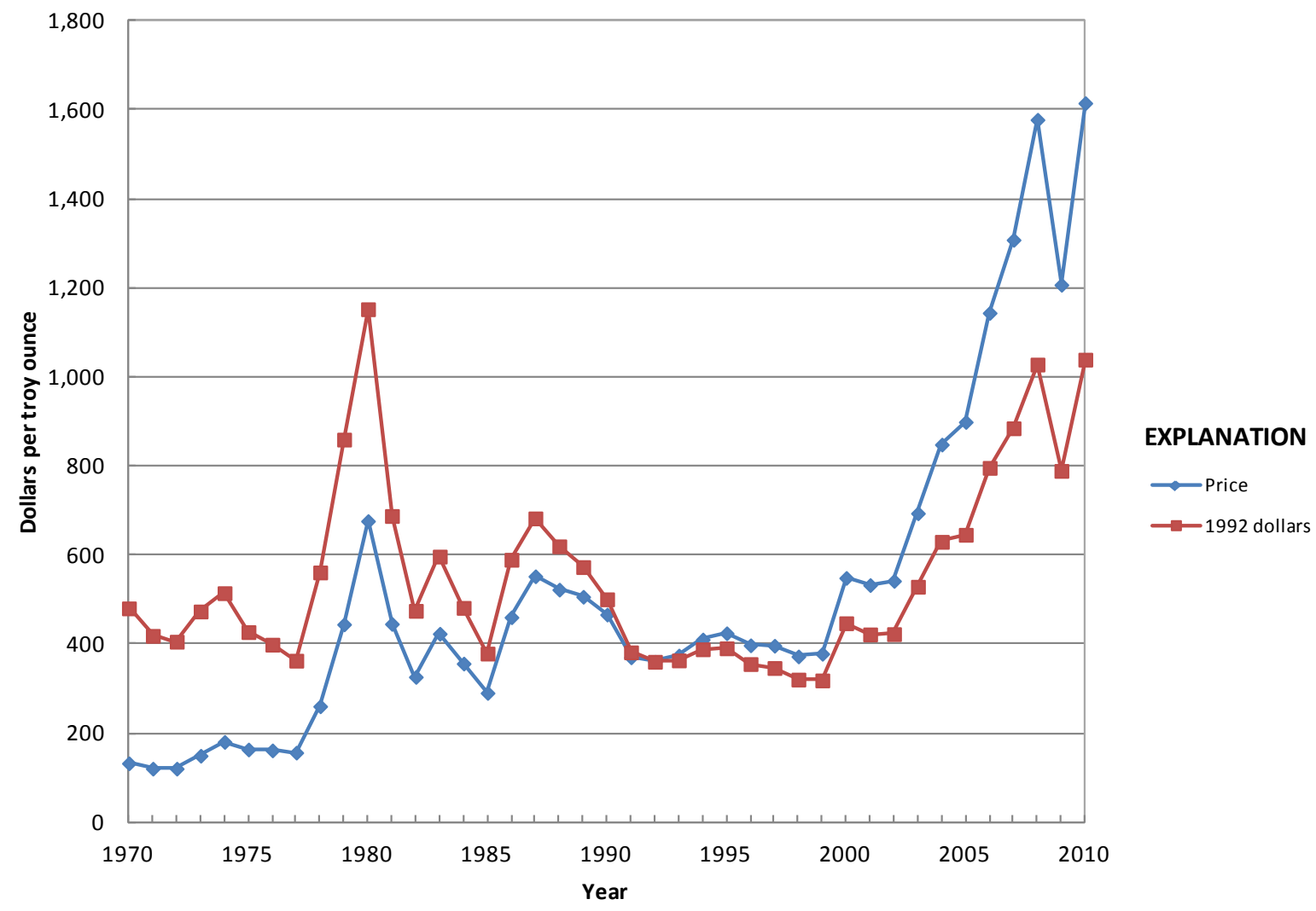

Figure 4. Platinum-Group Metals-Annual average platinum price. 


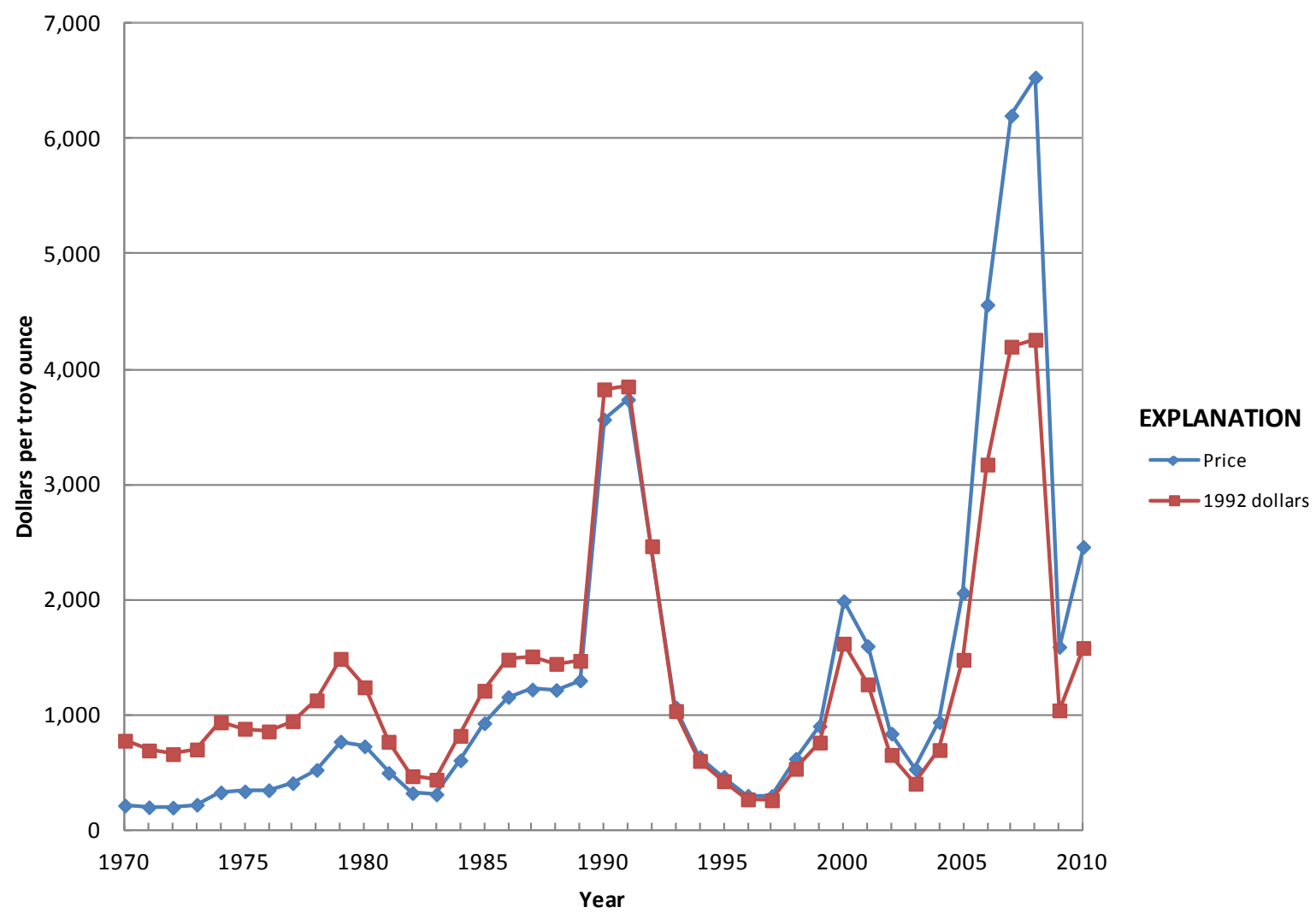

Figure 5. Platinum-Group Metals-Annual average rhodium price.

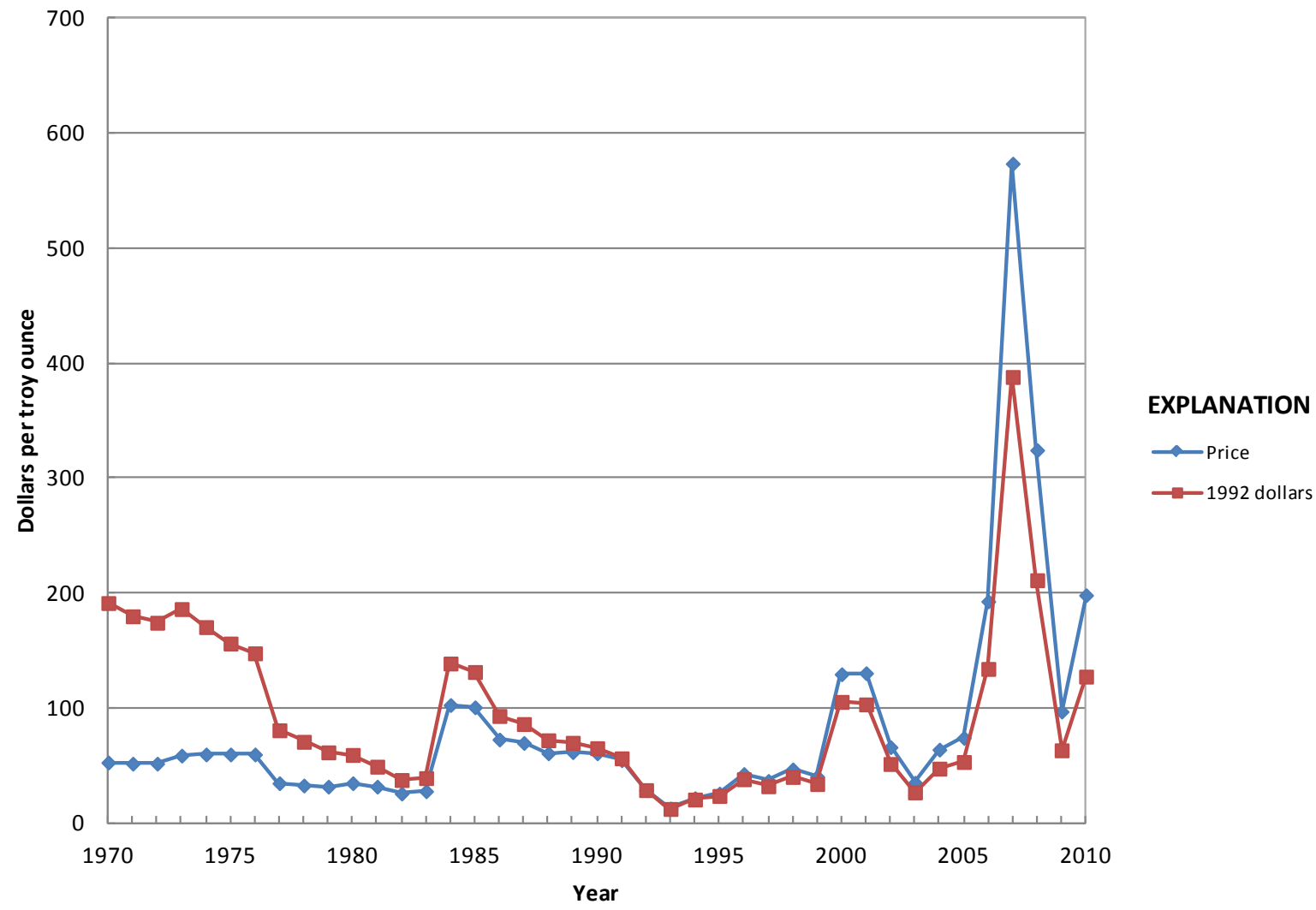

Figure 6. Platinum-Group Metals-Annual average ruthenium price. 


\section{Significant events affecting platinum-group metals (PGM) prices since 1970}

1971

1973

1980

1983

1984

1986

2001

2007

2008

2010
PGM prices declined owing to expansion of production in South Africa

Anticipated demand for platinum and palladium in automobile catalytic converters in the United States put pressure on prices; catalytic converters first used in 1974

Strong investor speculation pushed up prices for all precious metals

Rustenburg Platinum Holdings Ltd. in South Africa suspended its producer price quotations for PGMs; increased trading of futures contracts on the New York Mercantile Exchange (NYMEX)

Price increased for rhodium because of higher demand for rhodium in automobile three-way catalytic converters Platinum price increased after a work stoppage at Impala Platinum Holdings Ltd. in South Africa

Palladium price higher than platinum price for the first time because of disruptions of PGM supplies from Russia Ruthenium price increased owing to use in new computer hard-disk technology

South African PGM mines shut down for 1 week in January because of power supply shortages; prices of platinum, palladium, and rhodium soar. Global economic crisis later in the year results in price declines for PGMs

Iridium price increased because of increased demand from the electrical and electrochemical sectors 
Table 1. Platinum-Group Metals-Annual average iridium price.

[Values in dollars per troy ounce. NA Not available]

\begin{tabular}{|c|c|c|c|c|c|c|c|}
\hline Year & Price & Year & Price & Year & Price & Year & Price \\
\hline 1911 & 62 & 1936 & 104 & 1961 & 72 & 1986 & 414 \\
\hline 1912 & 65 & 1937 & 88 & 1962 & 72 & 1987 & 363 \\
\hline 1913 & 65 & 1938 & 69 & 1963 & 73 & 1988 & 306 \\
\hline 1914 & 65 & 1939 & 113 & 1964 & 85 & 1989 & 303 \\
\hline 1915 & 83 & 1940 & 169 & 1965 & 100 & 1990 & 307 \\
\hline 1916 & 94 & 1941 & 183 & 1966 & 145 & 1991 & 283 \\
\hline 1917 & 150 & 1942 & 168 & 1967 & 188 & 1992 & 158 \\
\hline 1918 & 175 & 1943 & 165 & 1968 & 188 & 1993 & 47 \\
\hline 1919 & 255 & 1944 & 165 & 1969 & 185 & 1994 & 66 \\
\hline 1920 & 331 & 1945 & 165 & 1970 & 156 & 1995 & 55 \\
\hline 1921 & 195 & 1946 & 139 & 1971 & 152 & 1996 & 68 \\
\hline 1922 & 200 & 1947 & 92 & 1972 & 162 & 1997 & 218 \\
\hline 1923 & NA & 1948 & 108 & 1973 & 223 & 1998 & 430 \\
\hline 1924 & 293 & 1949 & 104 & 1974 & 391 & 1999 & 411 \\
\hline 1925 & 363 & 1950 & 146 & 1975 & 477 & 2000 & 415 \\
\hline 1926 & 169 & 1951 & 200 & 1976 & 325 & 2001 & 415 \\
\hline 1927 & 120 & 1952 & 192 & 1977 & 258 & 2002 & 295 \\
\hline 1928 & 294 & 1953 & 178 & 1978 & 240 & 2003 & 93 \\
\hline 1929 & 238 & 1954 & 213 & 1979 & 280 & 2004 & 185 \\
\hline 1930 & 179 & 1955 & 103 & 1980 & 666 & 2005 & 170 \\
\hline 1931 & 114 & 1956 & 105 & 1981 & 529 & 2006 & 349 \\
\hline 1932 & 68 & 1957 & 105 & 1982 & 359 & 2007 & 444 \\
\hline 1933 & 58 & 1958 & 77 & 1983 & 309 & 2008 & 448 \\
\hline 1934 & 59 & 1959 & 77 & 1984 & 424 & 2009 & 420 \\
\hline 1935 & 57 & 1960 & 76 & 1985 & 438 & 2010 & 642 \\
\hline
\end{tabular}

Notes:

1911-29, New York price of refined metal, in Hill., J.M., 1922, The marketing of platinum: Engineering and Mining Journal-Press, p. 718.

1930-66, Producer price at New York of 99-percent-pure iridium, in Engineering and Mining Journal, Metal and Mineral Markets.

1967-93, Metals Week New York Dealer, f.o.b. New York, spot, estimated market price for minimum 99-percent-pure iridium, in Metals Week.

1993-98, Metals Week New York Dealer, f.o.b. New York, spot, estimated market price for minimum 99-percent-pure iridium, in Platt's Metals Week.

1998-2010, Englehard unfabricated price of minimum 99-percent-pure iridium in Platts (Platt's) Metals Week. 
Table 2. Platinum-Group Metals-Annual average osmium price.

[Values in dollars per troy ounce]

\begin{tabular}{|c|c|c|c|c|c|c|c|}
\hline Year & Price & Year & Price & Year & Price & Year & Price \\
\hline 1930 & 67 & 1951 & 208 & 1972 & 212 & 1993 & 400 \\
\hline 1931 & 67 & 1952 & 208 & 1973 & 200 & 1994 & 450 \\
\hline 1932 & 62 & 1953 & 166 & 1974 & 200 & 1995 & 450 \\
\hline 1933 & 63 & 1954 & 144 & 1975 & 200 & 1996 & 450 \\
\hline 1934 & 68 & 1955 & 96 & 1976 & 200 & 1997 & 450 \\
\hline 1935 & 50 & 1956 & 90 & 1977 & 130 & 1998 & 450 \\
\hline 1936 & 55 & 1957 & 90 & 1978 & 130 & 1999 & 450 \\
\hline 1937 & 57 & 1958 & 80 & 1979 & 130 & 2000 & 450 \\
\hline 1938 & 57 & 1959 & 80 & 1980 & 130 & 2001 & 450 \\
\hline 1939 & 57 & 1960 & 80 & 1981 & 130 & 2002 & 450 \\
\hline 1940 & 57 & 1961 & 65 & 1982 & 130 & 2003 & 450 \\
\hline 1941 & 47 & 1962 & 65 & 1983 & 132 & 2004 & 450 \\
\hline 1942 & 47 & 1963 & 65 & 1984 & 455 & 2005 & 450 \\
\hline 1943 & 50 & 1964 & 95 & 1985 & 915 & 2006 & 450 \\
\hline 1944 & 50 & 1965 & 236 & 1986 & 704 & 2007 & 450 \\
\hline 1945 & 50 & 1966 & 350 & 1987 & 633 & 2008 & 450 \\
\hline 1946 & 67 & 1967 & 400 & 1988 & 592 & 2009 & 450 \\
\hline 1947 & 100 & 1968 & 400 & 1989 & 549 & 2010 & 450 \\
\hline 1948 & 100 & 1969 & 335 & 1990 & 416 & & \\
\hline 1949 & 100 & 1970 & 215 & 1991 & 400 & & \\
\hline 1950 & 141 & 1971 & 210 & 1992 & 400 & & \\
\hline
\end{tabular}

Notes:

1930-66, Producer price at New York of 99.5-percent-pure osmium, in Engineering and Mining Journal, Metal and Mineral Markets.

1967-93, Metals Week New York Dealer, f.o.b. New York, spot, estimated market price for minimum 99.5-percent-pure osmium, in Metals Week.

1993-98, Metals Week New York Dealer, f.o.b. New York, spot, estimated market price for minimum 99.5-percent-pure osmium, in Platt's Metals Week.

1998-2010, Metals Week New York Dealer, f.o.b. New York, spot, estimated market price for minimum 99.5-percent-pure osmium, in Platts (Platt's) Metals

Week. 
Table 3. Platinum-Group Metals-Annual average palladium price.

[Values in dollars per troy ounce. NA Not available]

\begin{tabular}{|c|c|c|c|c|c|c|c|}
\hline Year & Price & Year & Price & Year & Price & Year & Price \\
\hline 1911 & 55 & 1936 & 23 & 1961 & 25 & 1986 & 116 \\
\hline 1912 & 55 & 1937 & 23 & 1962 & 25 & 1987 & 130 \\
\hline 1913 & 50 & 1938 & 23 & 1963 & 25 & 1988 & 123 \\
\hline 1914 & 44 & 1939 & 23 & 1964 & 31 & 1989 & 144 \\
\hline 1915 & 56 & 1940 & 24 & 1965 & 33 & 1990 & 114 \\
\hline 1916 & 67 & 1941 & 24 & 1966 & 34 & 1991 & 87 \\
\hline 1917 & 110 & 1942 & 24 & 1967 & 38 & 1992 & 89 \\
\hline 1918 & 135 & 1943 & 24 & 1968 & 45 & 1993 & 123 \\
\hline 1919 & 130 & 1944 & 24 & 1969 & 42 & 1994 & 156 \\
\hline 1920 & 108 & 1945 & 24 & 1970 & 38 & 1995 & 153 \\
\hline 1921 & 59 & 1946 & 24 & 1971 & 37 & 1996 & 130 \\
\hline 1922 & 60 & 1947 & 24 & 1972 & 42 & 1997 & 184 \\
\hline 1923 & NA & 1948 & 24 & 1973 & 78 & 1998 & 290 \\
\hline 1924 & 94 & 1949 & 24 & 1974 & 133 & 1999 & 363 \\
\hline 1925 & 79 & 1950 & 24 & 1975 & 93 & 2000 & 692 \\
\hline 1926 & 70 & 1951 & 24 & 1976 & 51 & 2001 & 611 \\
\hline 1927 & 58 & 1952 & 24 & 1977 & 49 & 2002 & 340 \\
\hline 1928 & 46 & 1953 & 24 & 1978 & 63 & 2003 & 203 \\
\hline 1929 & 40 & 1954 & 21 & 1979 & 120 & 2004 & 233 \\
\hline 1930 & 24 & 1955 & 22 & 1980 & 201 & 2005 & 204 \\
\hline 1931 & 18 & 1956 & 24 & 1981 & 95 & 2006 & 323 \\
\hline 1932 & 18 & 1957 & 24 & 1982 & 67 & 2007 & 357 \\
\hline 1933 & 18 & 1958 & 17 & 1983 & 136 & 2008 & 355 \\
\hline 1934 & 23 & 1959 & 19 & 1984 & 148 & 2009 & 266 \\
\hline 1935 & 23 & 1960 & 25 & 1985 & 107 & 2010 & 531 \\
\hline
\end{tabular}

Notes:

1911-29, New York price of refined metal, in Hill, J.M., 1922, The marketing of platinum: Engineering and Mining Journal-Press, p. 718.

1930-66, Producer price at New York of 99.9-percent-pure palladium, in Engineering and Mining Journal, Metal and Mineral Markets.

1967-93, New York price per troy ounce of 99.9-percent-pure palladium in 100-ounce lots, in Metals Week.

1993-98, New York price per troy ounce of 99.9-percent-pure palladium in 100-ounce lots, in Platt's Metals Week.

1998-2010, Englehard unfabricated price of minimum 99.9-percent-pure palladium in Platts (Platt's) Metals Week. 
Table 4. Platinum-Group Metals-Annual average platinum price.

[Values in dollars per troy ounce. NA Not available]

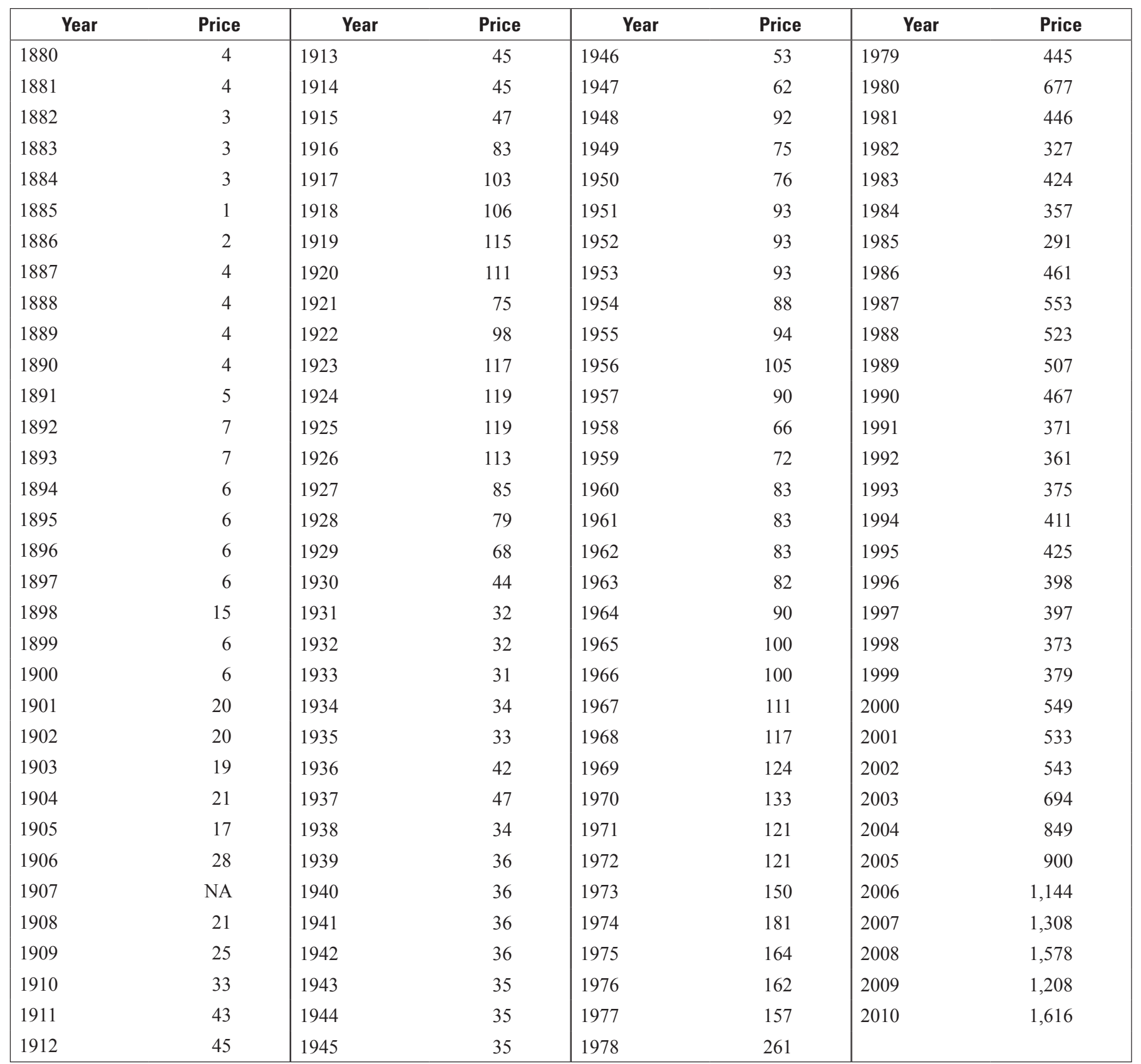

Notes:

1880-1910, Annual average price of crude platinum, in Mineral Resources of the United States: U.S. Geological Survey annual reports. 1911-29, New York price of refined metal, in Hill, J.M., 1922, The marketing of platinum: Engineering and Mining Journal-Press, p. 718. 1930-66, Producer price at New York of 99.9-percent-pure platinum, in Engineering and Mining Journal, Metal and Mineral Markets. 1967-93, New York price per troy ounce of 99.9-percent-pure platinum in 50-ounce lots, in Metals Week.

1993-98, New York price per troy ounce of 99.9-percent-pure platinum in 50-ounce lots, in Platt's Metals Week.

1998-2010, Englehard unfabricated price of minimum 99.9-percent-pure platinum in Platts (Platt's) Metals Week. 
Table 5. Platinum-Group Metals—Annual average rhodium price.

[Values in dollars per troy ounce]

\begin{tabular}{|lr|rr|rr|rr|}
\hline \multicolumn{1}{|c|}{ Year } & Price & Year & Price & Year & Price & Year & Price \\
\hline 1930 & 50 & 1951 & 125 & 1972 & 197 & 1993 & 1,066 \\
1931 & 50 & 1952 & 125 & 1973 & 222 & 1994 & 636 \\
1932 & 43 & 1953 & 125 & 1974 & 329 & 1995 & 463 \\
1933 & 49 & 1954 & 123 & 1975 & 338 & 1996 & 300 \\
1934 & 56 & 1955 & 121 & 1976 & 348 & 1997 & 298 \\
1935 & 53 & 1956 & 121 & 1977 & 409 & 1998 & 620 \\
1936 & 65 & 1957 & 121 & 1978 & 524 & 1999 & 904 \\
1937 & 111 & 1958 & 121 & 1979 & 770 & 2000 & 1,989 \\
1938 & 125 & 1959 & 123 & 1980 & 729 & 2001 & 1,599 \\
1939 & 125 & 1960 & 136 & 1981 & 498 & 2002 & 839 \\
1940 & 125 & 1961 & 139 & 1982 & 323 & 2003 & 530 \\
1941 & 125 & 1962 & 139 & 1983 & 312 & 2004 & 938 \\
1942 & 125 & 1963 & 139 & 1984 & 607 & 2005 & 2,060 \\
1943 & 125 & 1964 & 155 & 1985 & 929 & 2006 & 4,561 \\
1944 & 125 & 1965 & 183 & 1986 & 1,157 & 2007 & 6,203 \\
1945 & 125 & 1966 & 198 & 1987 & 1,222 & 2008 & 6,534 \\
1946 & 125 & 1967 & 225 & 1988 & 1,218 & 2009 & 1,591 \\
1947 & 125 & 1968 & 247 & 1989 & 1,300 & 2010 & 2,459 \\
1948 & 125 & 1969 & 240 & 1990 & 3,565 & & \\
1949 & 125 & 1970 & 215 & 1991 & 3,739 & & \\
1950 & 125 & 1971 & 200 & 1992 & 2,465 & & \\
\hline
\end{tabular}

Notes:

1930-66, Producer price at New York of 99.9-percent-pure rhodium, in Engineering and Mining Journal, Metal and Mineral Markets. 1967-76, Producer price at New York of 99.9-percent-pure rhodium,in Metals Week.

1977-93, Dealer price at New York of 99.9-percent-pure rhodium, in Metals Week.

1993-98, Dealer price at New York of 99.9-percent-pure rhodium, in Platt's Metals Week.

1998-2010, Englehard unfabricated price of 99.9-percent-pure rhodium in Platts (Platt's) Metals Week. 
Table 6. Platinum-Group Metals—Annual average ruthenium price.

[Values in dollars per troy ounce]

\begin{tabular}{|c|c|c|c|c|c|c|c|}
\hline Year & Price & Year & Price & Year & Price & Year & Price \\
\hline 1930 & 42 & 1951 & 93 & 1972 & 52 & 1993 & 13 \\
\hline 1931 & 41 & 1952 & 86 & 1973 & 59 & 1994 & 22 \\
\hline 1932 & 41 & 1953 & 86 & 1974 & 60 & 1995 & 26 \\
\hline 1933 & 42 & 1954 & 67 & 1975 & 60 & 1996 & 43 \\
\hline 1934 & 45 & 1955 & 52 & 1976 & 60 & 1997 & 37 \\
\hline 1935 & 40 & 1956 & 50 & 1977 & 35 & 1998 & 47 \\
\hline 1936 & 38 & 1957 & 50 & 1978 & 33 & 1999 & 41 \\
\hline 1937 & 40 & 1958 & 50 & 1979 & 32 & 2000 & 130 \\
\hline 1938 & 37 & 1959 & 56 & 1980 & 35 & 2001 & 131 \\
\hline 1939 & 37 & 1960 & 55 & 1981 & 32 & 2002 & 66 \\
\hline 1940 & 37 & 1961 & 57 & 1982 & 26 & 2003 & 35 \\
\hline 1941 & 37 & 1962 & 57 & 1983 & 28 & 2004 & 64 \\
\hline 1942 & 37 & 1963 & 57 & 1984 & 103 & 2005 & 74 \\
\hline 1943 & 35 & 1964 & 57 & 1985 & 101 & 2006 & 193 \\
\hline 1944 & 35 & 1965 & 57 & 1986 & 73 & 2007 & 574 \\
\hline 1945 & 35 & 1966 & 57 & 1987 & 70 & 2008 & 325 \\
\hline 1946 & 68 & 1967 & 58 & 1988 & 61 & 2009 & 97 \\
\hline 1947 & 62 & 1968 & 58 & 1989 & 62 & 2010 & 198 \\
\hline 1948 & 92 & 1969 & 56 & 1990 & 61 & & \\
\hline 1949 & 75 & 1970 & 53 & 1991 & 55 & & \\
\hline 1950 & 76 & 1971 & 52 & 1992 & 29 & & \\
\hline
\end{tabular}

Notes:

1930-66, Producer price at New York of refined metal, in Engineering and Mining Journal, Metal and Mineral Markets.

1967-76, Producer price at New York of 99.9-percent-pure ruthenium, in Metals Week.

1977-93, Dealer price at New York of 99.9-percent-pure ruthenium, in Metals Week.

1993-98, Dealer price at New York of 99.9-percent-pure ruthenium, in Platt's Metals Week.

1998-2010, Englehard unfabricated price of 99.9-percent-pure ruthenium in Platts (Platt's) Metals Week. 


\title{
Rare-Earth Metals (Ce, Dy, Eu, Gd, La, Nd, Pr, Sm, Sc, Tb, Y)
}

\author{
by U.S. Geological Survey National Minerals Information Center staff
}

The rare earths are defined as the 17 elements comprised of scandium, yttrium, and the 15 lanthanides (Leigh, 1990, p. 43).

The rare earths were discovered in 1787 by Swedish Army Lieutenant Karl Axel Arrhenius when he collected the black mineral ytterbite (later renamed gadolinite) from a feldspar and quartz mine near the village of Ytterby, Sweden (Weeks and Leicester, 1968, p. 667). Because they have similar chemical structures, the rare-earth elements proved difficult to separate. It was not until 1794 that the first rare-earthcontaining compound, an impure yttrium oxide, was isolated from the mineral ytterbite by Finnish chemist Johann Gadolin (Weeks and Leicester, 1968, p. 671). Separation technology and metallurgical methods advanced in the years after Swedish chemist and mineralogist Carl Gustav Mosander first prepared metallic cerium in 1827 (Mosander, 1827).

Rare earths were first produced commercially in the 1880s in Sweden and Norway from the rare-earth mineral monazite. The first rare-earth production in the United States was recorded in 1893 in North Carolina; however, a small tonnage of monazite was reportedly mined as early as 1887 .

The first large-scale application of rare-earth metals began when Auer von Welsbach patented a pyrophoric alloy that comprised 70 percent mischmetal (a natural mixture of metallic rare-earth elements as derived from ore) and 30 percent iron in 1903 (Greinacher, 1981). Five years later, the mischmetal-iron alloy was commercially marketed in an ignition system for incandescent gas lamps. Rare-earth metals in pure form were first prepared in 1931. In the 1940s, some applications were found for alloying rare-earth metals with ductile iron, but significant uses were not developed until the late 1960s. The use of individual rare-earth metals remained small until the 1950s when separation and metallurgical technologies improved. Demand then increased as lower cost individual rare-earth metals became available (Gschneidner, 1988).

Promethium, one of the lanthanide group of elements, is radioactive. Except for very minor occurrences of this element in nature, most commercially available material is created in the laboratory. Of the 13 isotopes known to occur, promethium's half-lives are short, existing for only a few seconds to a few years. Because it is used in very small quantities and isotope price data are typically based on its radioactivity, promethium prices are not included in this report.

Prices of commercial quantities of a complete range of rare-earth metals were first quoted in the United States in the late 1950s and early 1960s. Prices decreased considerably as availability and extraction technology improved. Rare-earth metal prices vary considerably depending on purity and quantity. Price fluctuations in the late 1950s to 2010 were affected primarily by supply and demand, environmental legislation, and economic factors, especially inflation and energy costs (figs. 1-11; tables 1-11).

The decline in rare-earth metal prices from 1958-71 resulted from the startup of operations at the large rare-earths deposit at Mountain Pass, Calif., in 1952. The period was characterized by widespread commercialization of the individual rare earths, including compounds and metals. A significant development in the late 1960s was the acceptance of rare-earth silicide, and later, mischmetal, as additives in high-strength low-alloy (HSLA) steels.

From 1971-78, rare-earth demand continued to grow, and supply kept pace. Demand for mischmetal increased late in the period as a result of its use in steel for the Alaskan oil pipeline. Beginning in 1978, prices for the rare-earth metals were tied primarily to the U.S. economy. Double-digit inflation and higher energy costs increased operating costs throughout the mining industry. Rare-earth metal prices and operating costs followed the trend and began increasing in 1979.

After the 1981-82 recession, as the economy improved and inflation subsided, rare-earth metal prices stabilized, for the most part. The exception during this period was scandium. The main source of scandium at this time, the Soviet Union, ceased exports in 1984, reportedly because of internal demand for laser research. The price for scandium rose to an astronomical $\$ 75,000$ per kilogram. Scandium's price decreased markedly the following year as production in the United States came online (Hedrick, 1987a).

In 1985, demand for the rare earths used in petroleum fluid-cracking catalysts, their principal market, dropped sharply. The rapid decline was the result of environmental legislation reducing the amount of lead allowed in gasoline. This legislation caused refineries to switch to fluid-cracking catalysts that used significantly lower amounts of rare earths. With demand down, U.S. mine production decreased by nearly 50 percent in 1985, resulting in a substantial increase in rareearth metal prices the following year (Hedrick, 1987b).

Prices for rare-earth metals in the 1980s and 1990s were mixed. Growth in the rare-earth industry between 1986 and 1998 was primarily in the markets for individual high-purity products. Rare-earth metal demand in this period was greatest for neodymium metal used in high-strength neodymiumiron-boron (NIB) permanent magnet alloys. Prices for neodymium and the NIB alloying agent, dysprosium, increased in the mid-1980s as demand increased. As a result of the increased NIB magnet demand, demand and price decreased 
for samarium metal used in the higher cost samarium-cobalt magnets. The price of cerium metal increased in 1992 as demand increased for cerium compounds used in automotive catalytic converters. Lanthanum's price increased in the mid-1990s as demand increased for lanthanum-nickel metal hydride rechargeable batteries used primarily in camcorders, cellular phones, cordless tools, and laptop computers. The price of yttrium metal declined in 1990, as low-cost yttrium from southern China became widely available on world markets. Europium's price declined in 1995, as low-cost Chinese material pushed prices lower amid strong international competition. Prices for most other rare-earth metals stayed fairly stable or declined because of small demand and limited applications.

In 2002, Molycorp Inc.'s Mountain Pass rare-earths mine closed; the company's rare-earths separation and refining plants had closed in 1998. Molycorp continued to sell from its stockpile of bastäsite concentrates, intermediate concentrates, and separated compounds previously processed. As a result of the closure, most of the U.S. demand for rare-earth materials was supplied from China, the world's principal rare-earth supplier. Beginning in 2001, the prices listed in the accompanying tables and figures are bulk shipment prices for metal, free on board (f.o.b.) China, and do not correlate well with earlier prices supplied by U.S. industry. Because of the small quantities of these rare-earth metals that are consumed in the United States, prices for erbium, holmium, lutetium, thulium, and ytterbium were not available.

After China became the leading United States rare earths supplier, its internal policies had a substantial effect on United States and world prices. These policies included setting production quotas, instituting export taxes, and establishing export quotas. In 1990, the Chinese Government declared rare earths to be protected and strategic minerals. As a consequence, foreign investors were prohibited from mining rare earths and were restricted from participating in rare-earth smelting and separation projects, except in joint ventures with Chinese firms (Tse, 2011).

In addition to setting production quotas for rare earths, China also set quotas on the amount of rare earths that can be exported. This policy had the most significant effect on rare-earth prices. In 2005, a rebate on exported rare earths was eliminated, and trade of rare-earth concentrate was banned. Between 2005 and 2007, the Government quota allocated more than 40,000 metric tons $(\mathrm{t})$ of rare-earth production to domestic producers and traders and about 16,000 t to Sinoforeign joint-venture producers. In 2007, the Government introduced an export duty on rare-earth products to restrict the export of products that consume large amounts of energy to produce, in order to protect the domestic supply of strategic minerals. In 2008, the Government reduced the rare-earth export quota for domestic rare-earth producers and traders by 21.6 percent from that of 2007; in 2009, it reduced the quota by an additional 2.5 percent. These cuts in export quotas, which reduced supplies outside of China, led to increased prices for most rare-earth metals.
In 2010, China's Government-allocated first tranche of the rare-earth export quota was slightly more than the allocation for the first tranche for 2009. In the second tranche of the export quota issued in July 2010, the Government allocated 70 percent less than the second half 2009 allocation, resulting in a rare-earth export quota for 2010 that was 37.1 percent less than the quota in 2009 (Tse, 2011). As a result of the drastic cut in the export quota, most rare-earth metal prices skyrocketed in the second half of 2010 .

China's dominant position as the producer of more than 95 percent of the world output of rare-earth minerals, its decisions to restrict exports of rare earths, and the rapid increase in the consumption of rare earths owing to the emergence of new clean-energy and defense-related technologies resulted in heightened concerns about the future availability and prices of rare earths. As a result, industrial countries such as Japan, the United States, and countries of the European Union have continued studies and adopted policies to encourage alternative supplies of rare earths. In the United States, Mountain Pass was expected to resume operation in 2013.

\section{References Cited}

Greinacher, Ekkehard, 1981, History of rare earth applications, rare earth market today, chap. 1 of Industrial application of the rare earth elements: American Chemical Society Symposium Series 164, p. 3-17.

Gschneidner, K.A., Jr., 1988, Past, present and future of rare earth metallurgy in 1787-1987-Two hundred years of rare earths: New York, Rare-earth Information Center and North-Holland, p. 23-32.

Hedrick, J.B., 1987a, Other metals, in Metals and minerals: U.S. Bureau of Mines Minerals Yearbook 1985, v. I, p. 1096-1097.

Hedrick, J.B., 1987b, Rare-earth minerals and metals, in Metals and minerals: U.S. Bureau of Mines Minerals Yearbook 1985, v. I, p. 741-803.

Leigh, G.J., ed., 1990, Nomenclature of inorganic chemistry-Recommendations 1990: Oxford, Blackwell Scientific Publications, 289 p.

Mosander, C.G., 1827, Einiges über das Cerium [Something about cerium]: Liepzig, Germany, Annalen der Physik, (Poggendorff), v. 11, p. 406-416.

Tse, Pui-Kwan, 2011, China's rare-earth industry: U.S. Geological Survey Open-File Report 2011-1042, 11 p., available only at http://pubs.usgs.gov/of/2011/1042/ of2011-1042.pdf.

Weeks, M.E., and Leicester, H.M., 1968, Discovery of the elements (7th ed.): Easton, Pa., Journal of Chemical Education, 896 p. 


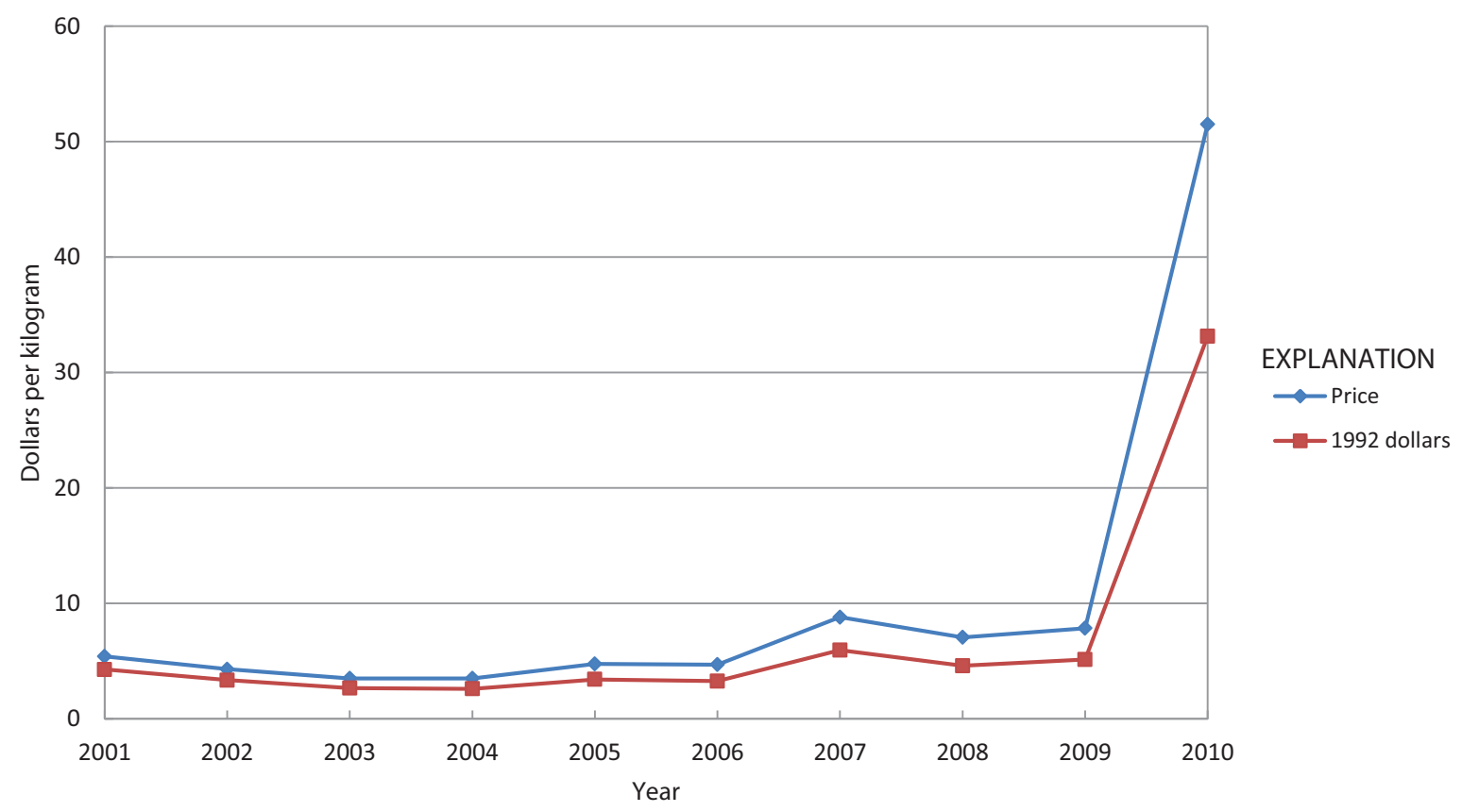

Figure 1. Rare-Earth Metals_-Yearend cerium metal price.

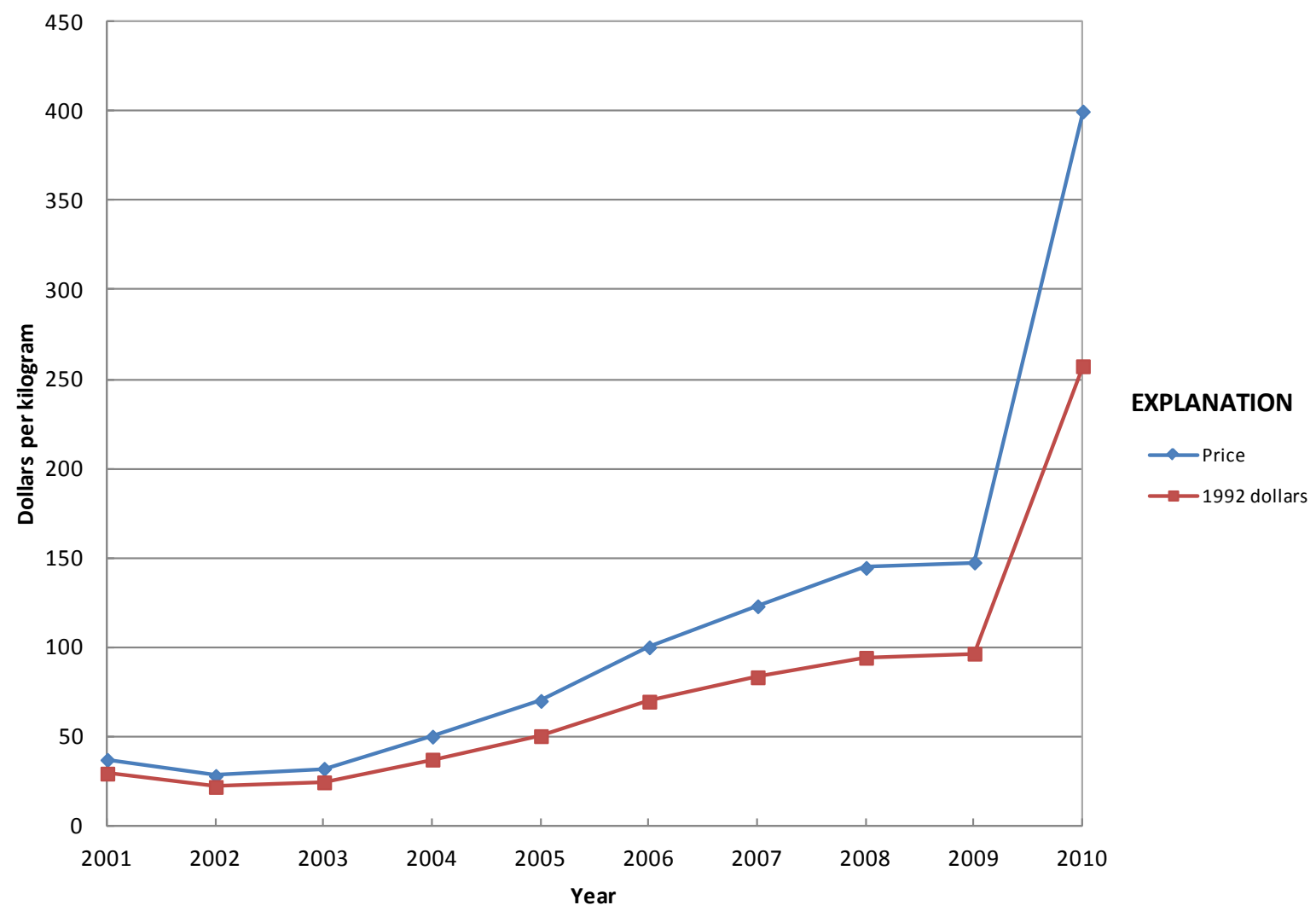

Figure 2. Rare-Earth Metals—Yearend dysprosium metal price. 


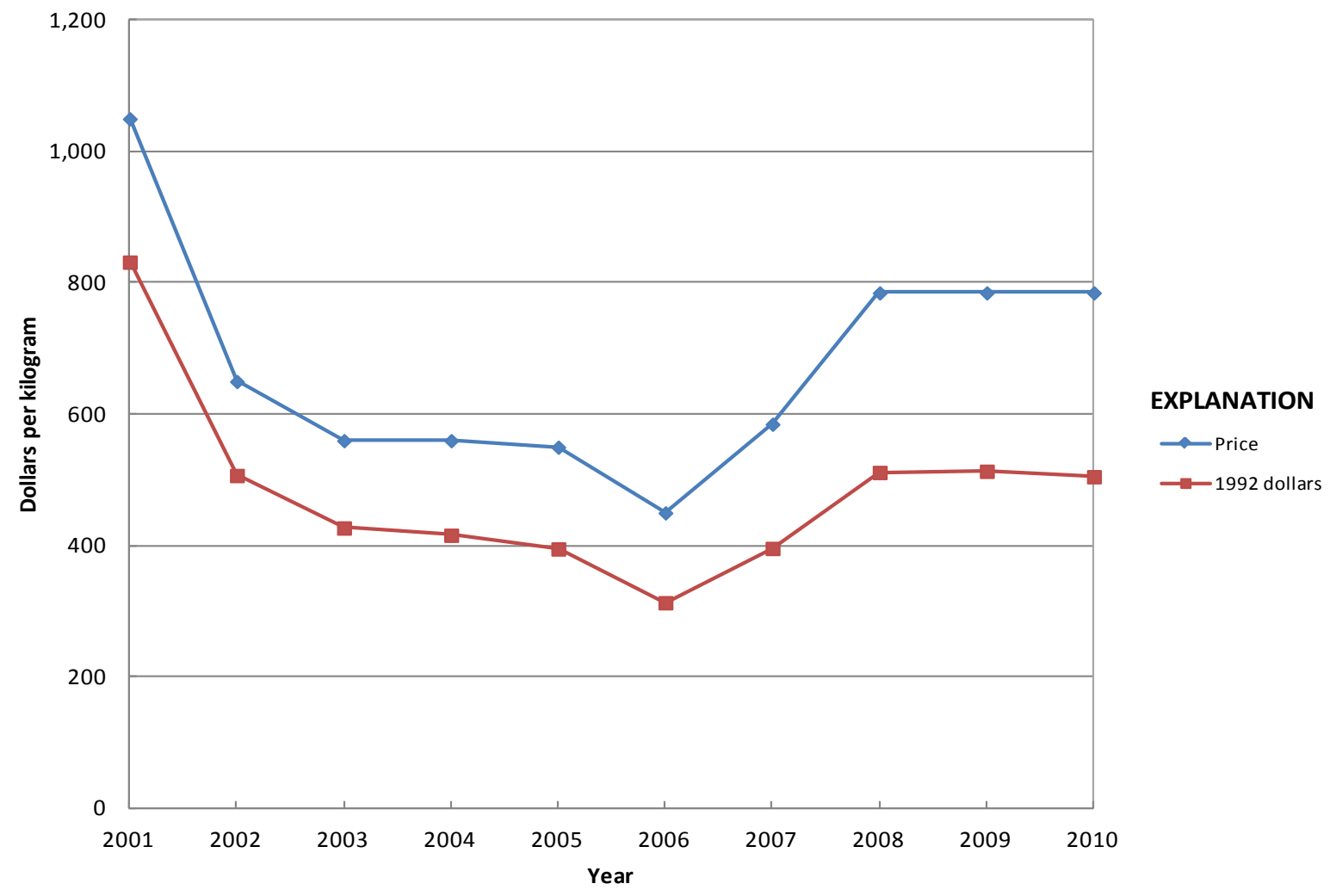

Figure 3. Rare-Earth Metals-Yearend europium metal price.

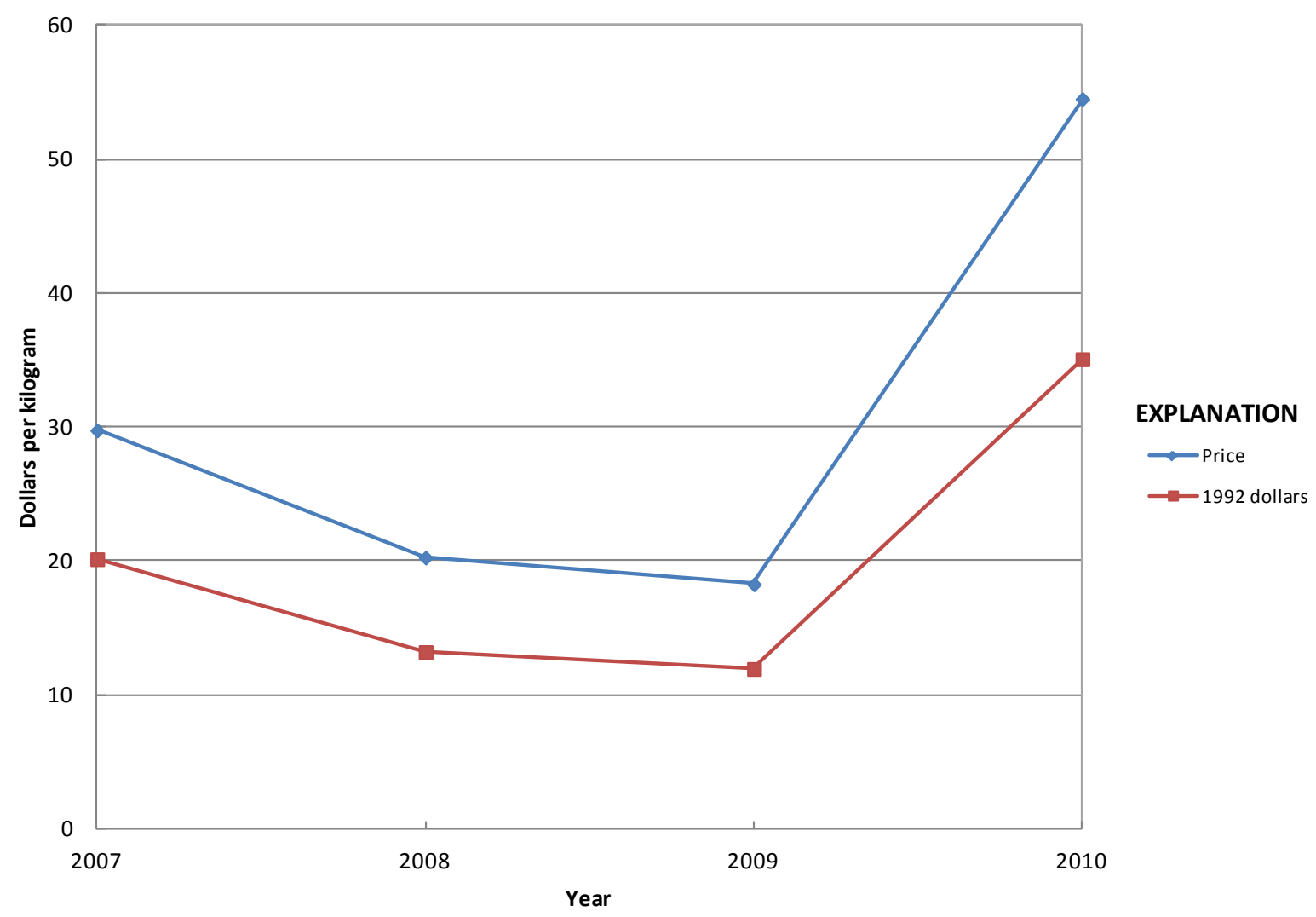

Figure 4. Rare-Earth Metals-Yearend gadolinium metal price. 


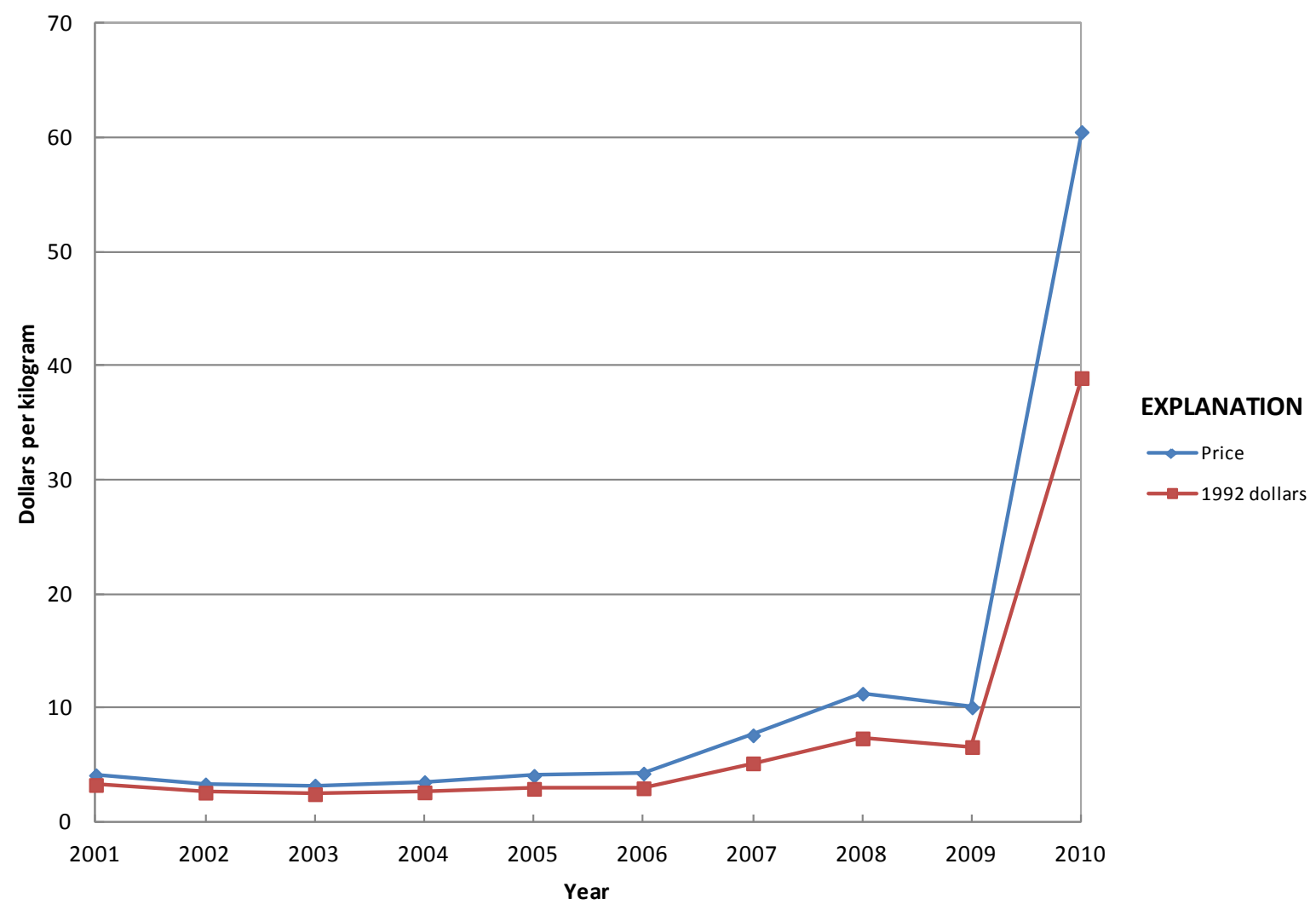

Figure 5. Rare-Earth Metals_-Yearend lanthanum metal price.

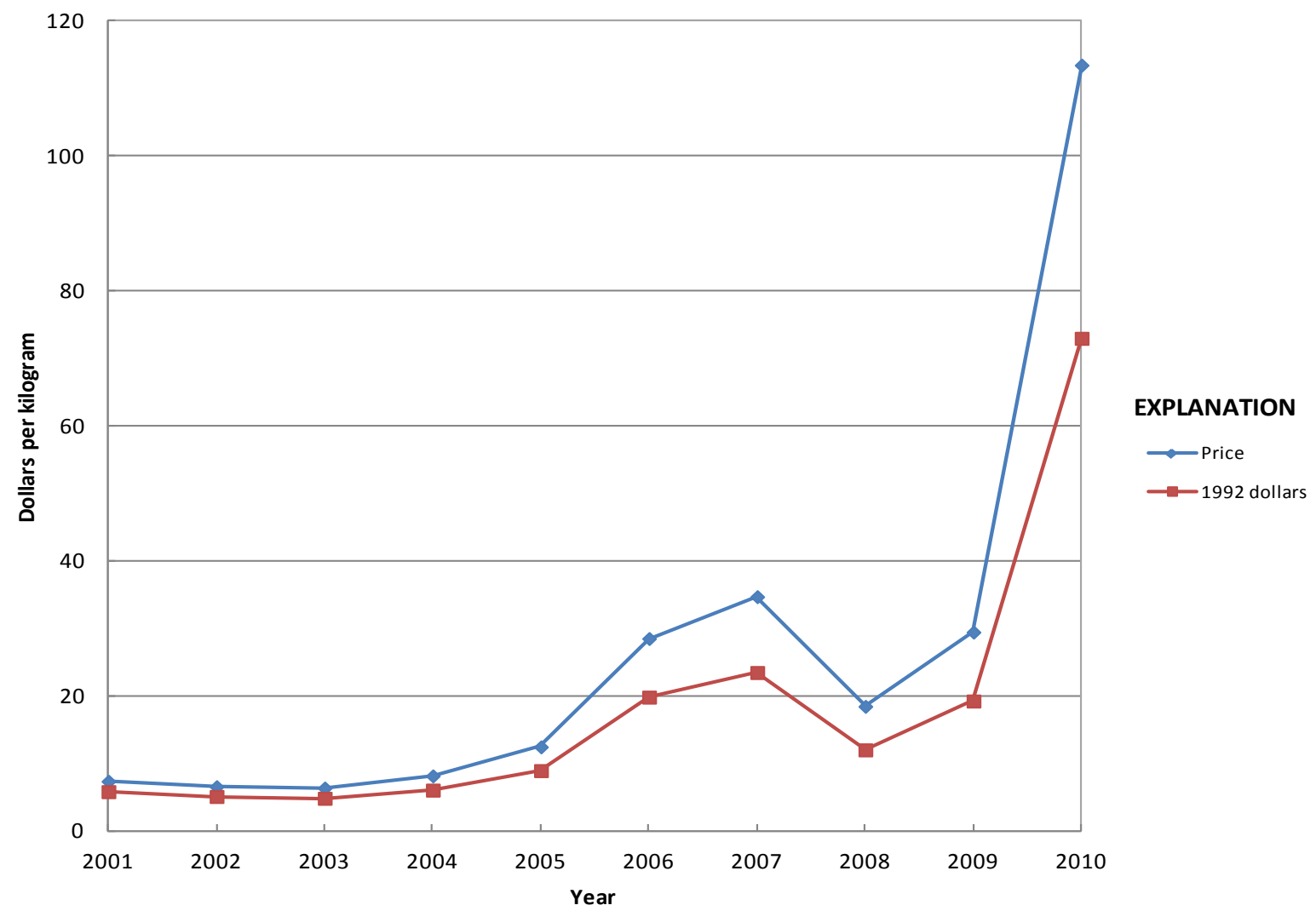

Figure 6. Rare-Earth Metals_-Yearend neodymium metal price. 


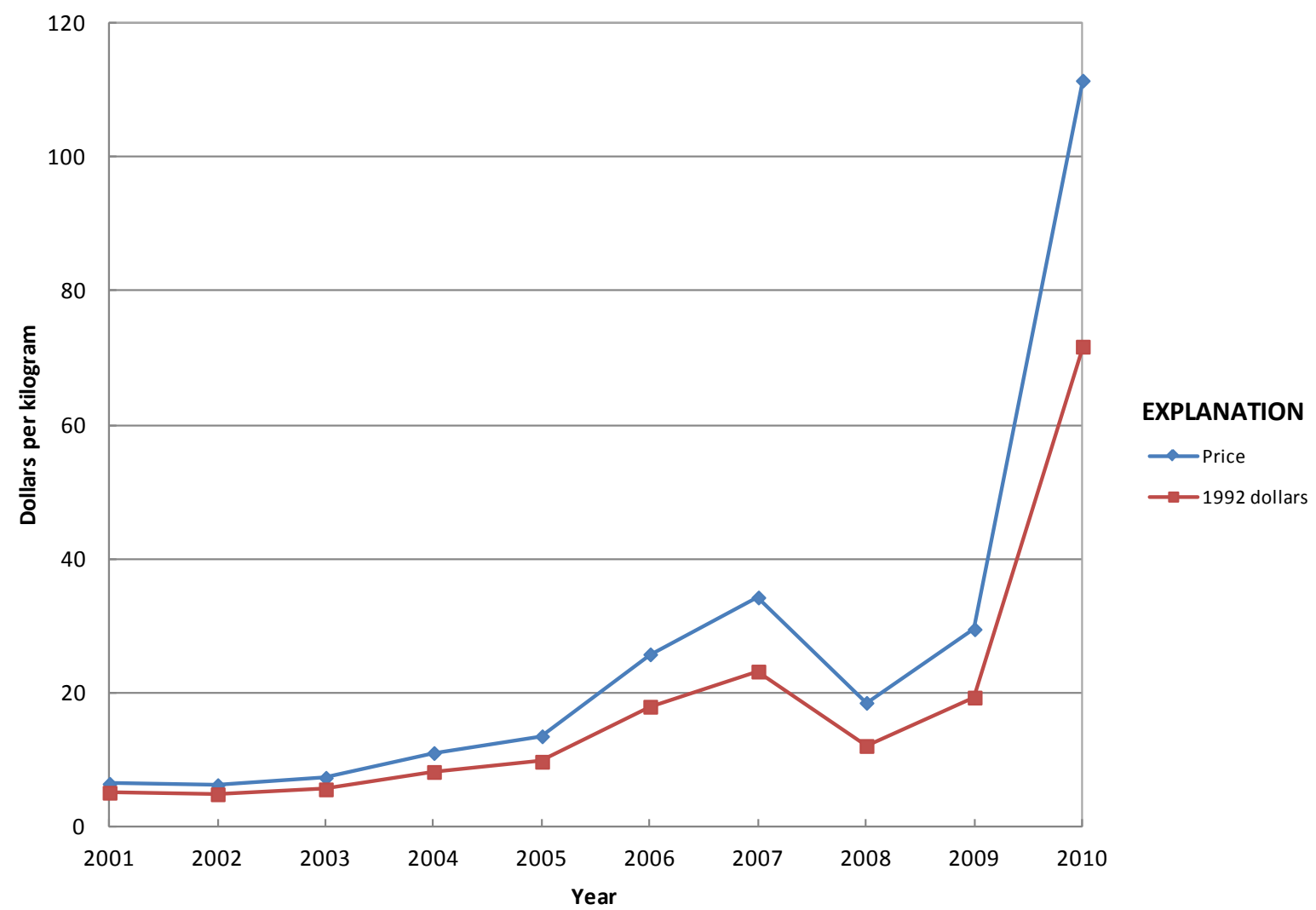

Figure 7. Rare-Earth Metals_-Yearend praesodymium metal price.

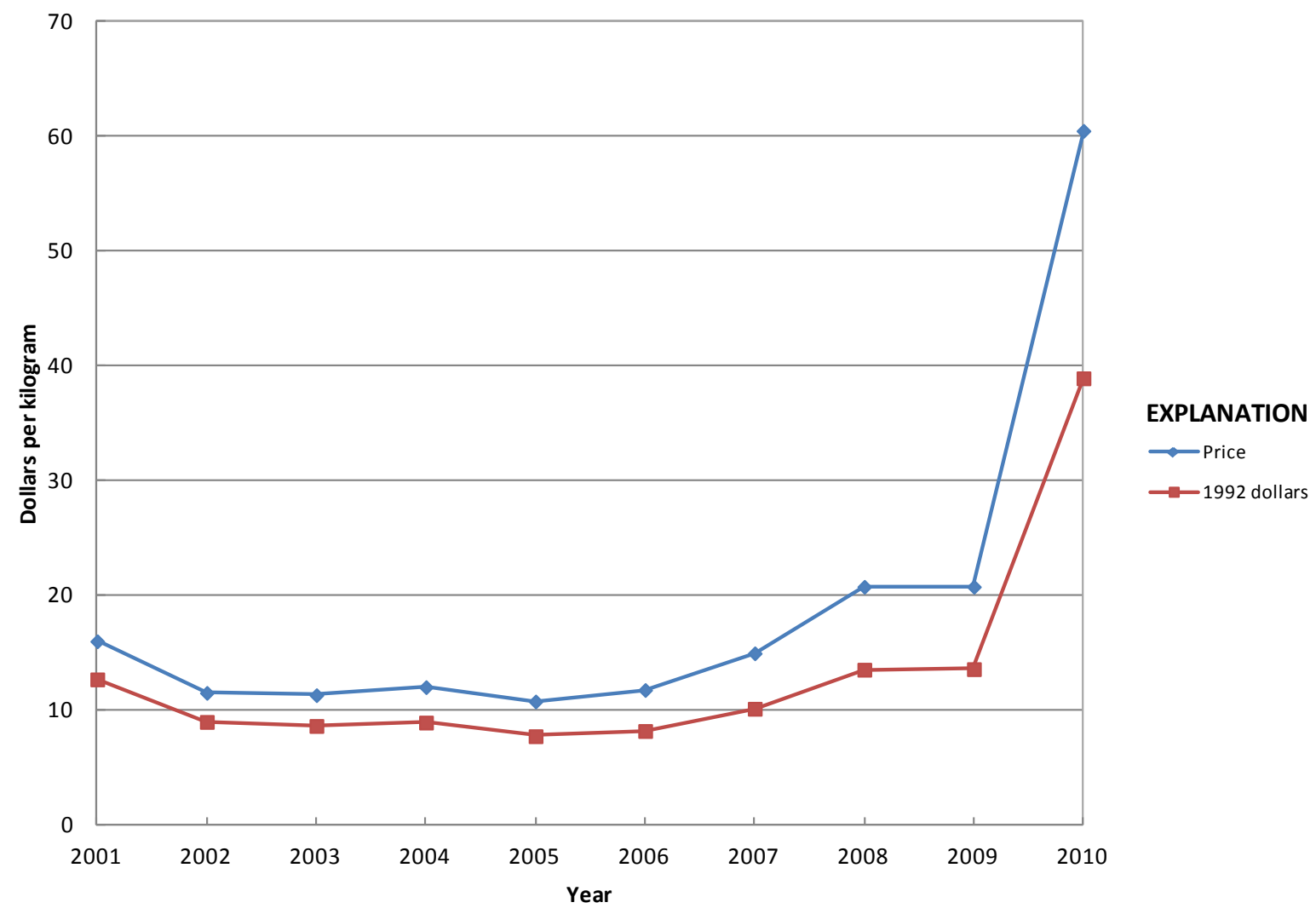

Figure 8. Rare-Earth Metals_-Yearend samarium metal price. 


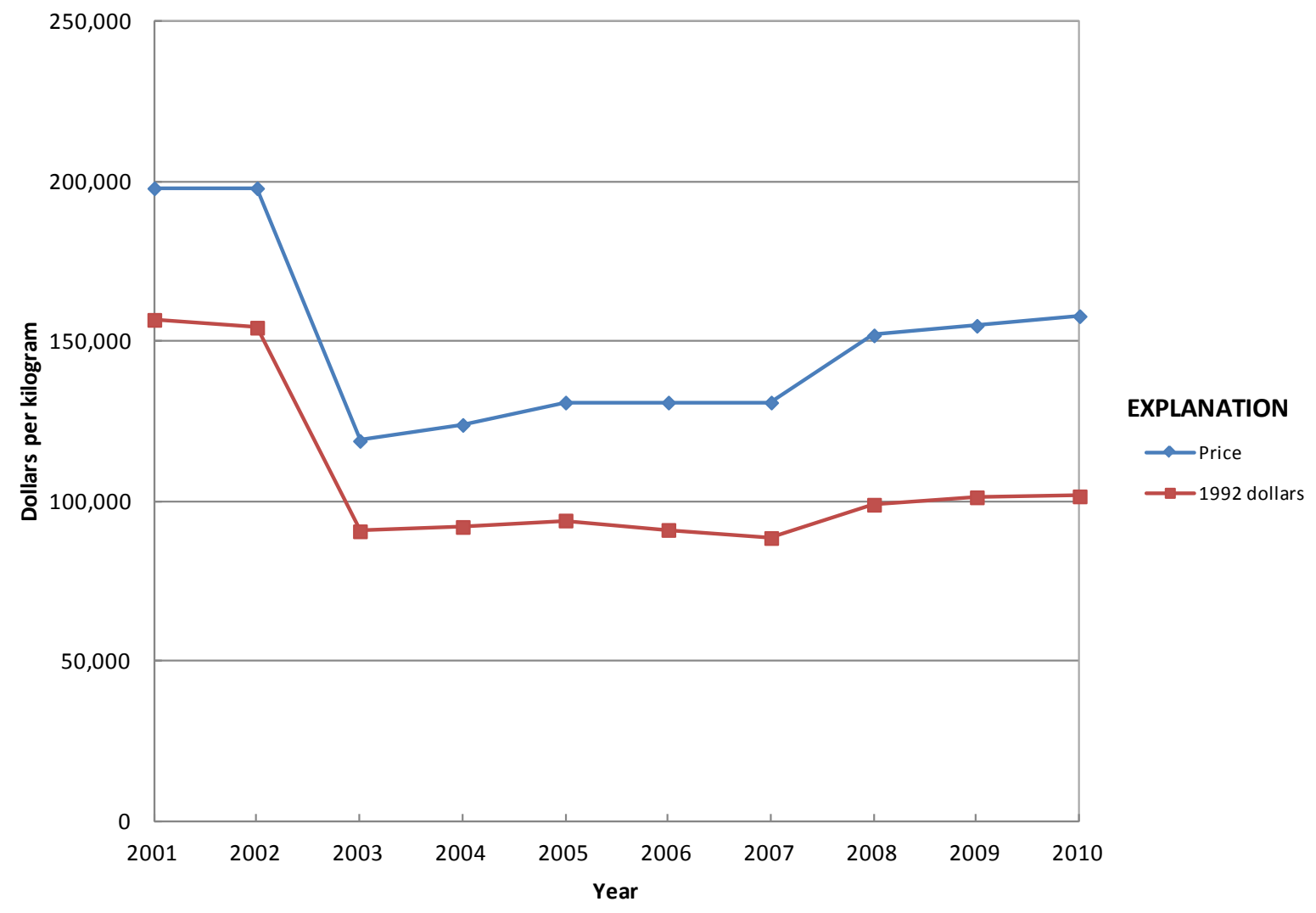

Figure 9. Rare-Earth Metals—Yearend scandium metal price.

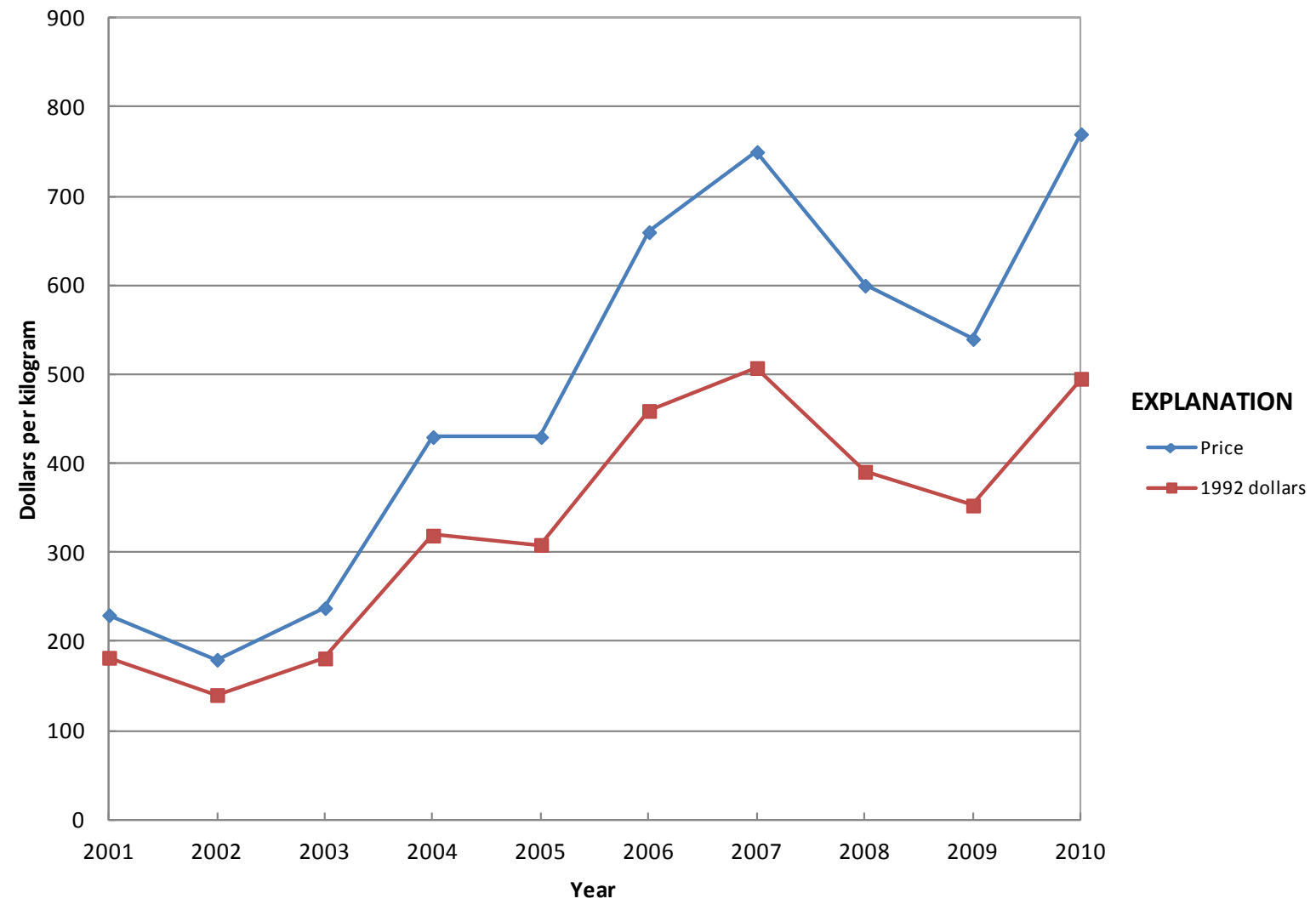

Figure 10. Rare-Earth Metals-Yearend terbium metal price. 


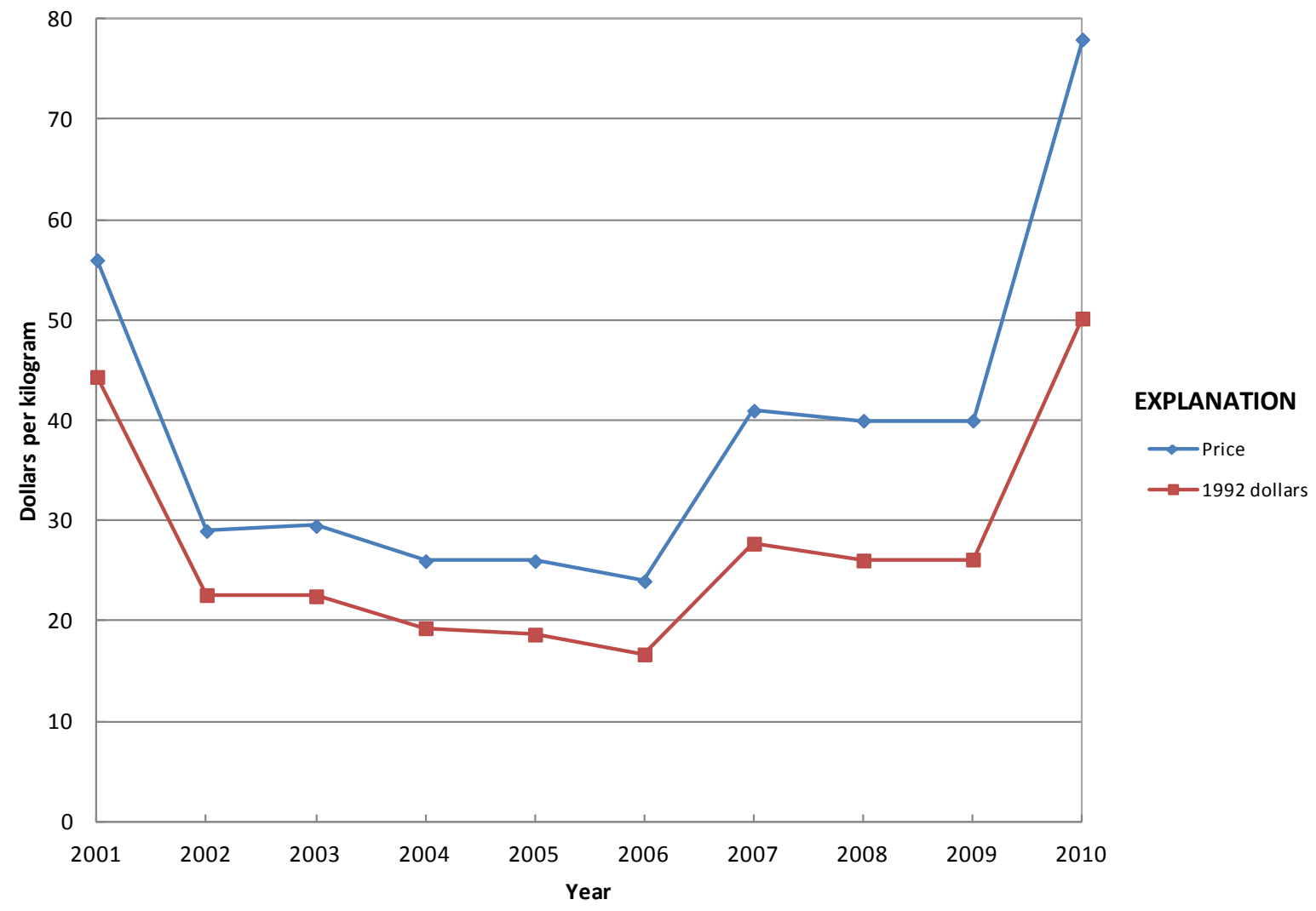

Figure 11. Rare-Earth Metals—Yearend yttrium metal price.

\section{Significant events affecting rare-earth metal prices since 1970}

1971-78 Stable supply and demand

1979-81 Economic recession

1984

1985

Scandium import supply cut by Soviet Union

U.S. environmental regulations limited lead in gasoline, reducing demand for rare-earth-containing petroleum fluid-cracking catalysts; startup of domestic scandium production; mine production of other rare earths declined by 50 percent

1980-90s Increased production from China and increased demand for permanent magnets, automotive catalytic converters, and rechargeable batteries

1990 China's Government declared rare earths and strategic materials to be protected and began regulating production and trade

2002 Mountain Pass, Calif., rare-earth mine closed, leaving China as the dominant world supplier 
Table 1. Rare-Earth Metals-Yearend cerium metal price.

[Values in dollars per kilogram. NA Not available]

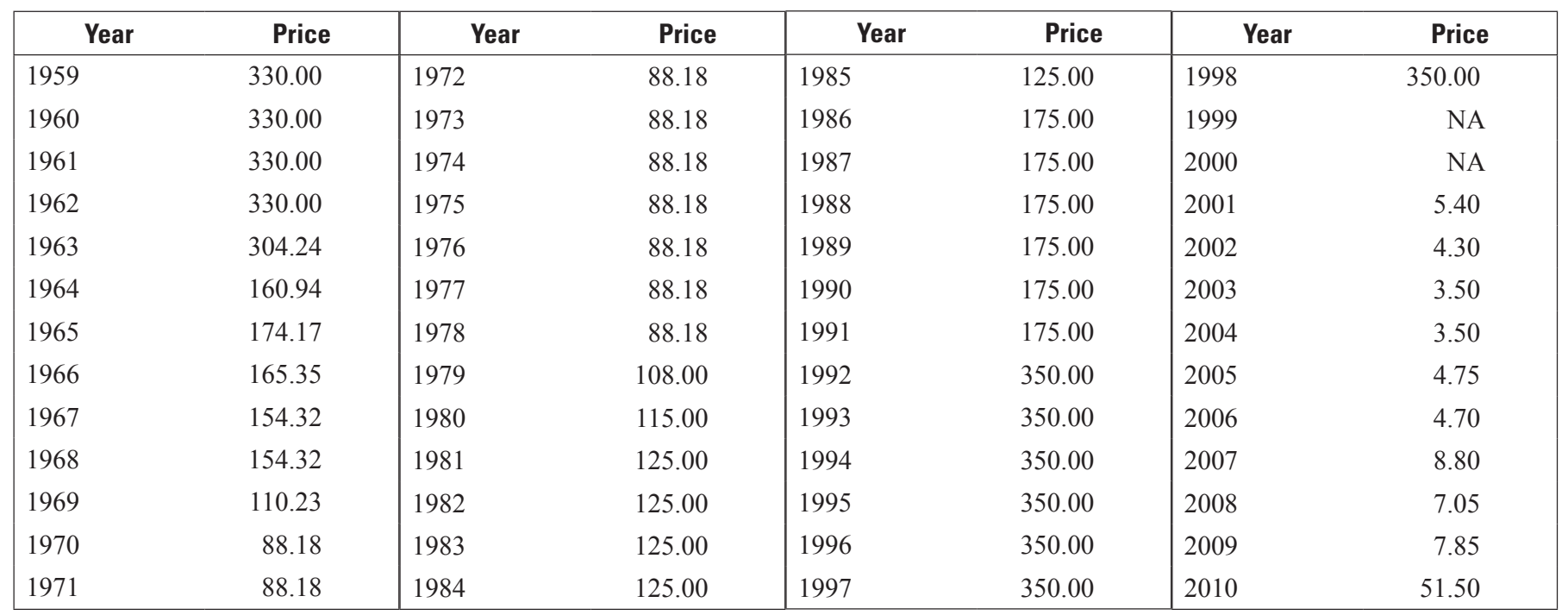

Notes:

1959-62, 100- to 450-gram metal ingot prices, 99.9-percent nominal purity, provided by American Potash \& Chemical Corp.

1963, 1 - to 4-pound metal ingot prices, 99.9-percent nominal purity, provided by American Potash \& Chemical Corp.

1964, 1967-78, 2- to 10-pound metal ingot price, from 99.9-percent-grade oxides, provided by Research Chemicals.

1965-66, 1- to 5-pound metal ingot price, from 99.9-percent-grade oxides, provided by Research Chemicals.

1979-88, 1-kilogram metal ingot, from 99.9-percent-grade oxides, provided by Research Chemicals.

1989-94, 1-kilogram metal ingots, from 99.9-percent-grade oxides, provided by Rhône-Poulenc Basic Chemicals Co.

1995-97, 1- to 5-kilogram cast metal ingots, from 99.9-percent-grade oxides, provided by Rhône-Poulenc Basic Chemicals Co.

1998, 1 - to 5-kilogram cast metal ingots, from 99.9-percent-grade oxides, provided by Rhodia, Inc.

2001-10, minimum 99-percent-pure metal, free on board China, provided by Metal-Pages Ltd. 
Table 2. Rare-Earth Metals-Yearend dysprosium metal price.

[Values in dollars per kilogram. NA Not available]

\begin{tabular}{|c|c|c|c|c|c|c|c|}
\hline Year & Price & Year & Price & Year & Price & Year & Price \\
\hline 1959 & 730.00 & 1972 & 264.55 & 1985 & 300.00 & 1998 & 500.00 \\
\hline 1960 & 730.00 & 1973 & 264.55 & 1986 & 630.00 & 1999 & $\mathrm{NA}$ \\
\hline 1962 & 730.00 & 1975 & 264.00 & 1988 & 630.00 & 2001 & 37.00 \\
\hline 1963 & 661.39 & 1976 & 264.55 & 1989 & 500.00 & 2002 & 28.00 \\
\hline 1965 & 559.97 & 1978 & 264.55 & 1991 & 500.00 & 2004 & 50.00 \\
\hline 1966 & 275.58 & 1979 & 270.00 & 1992 & 500.00 & 2005 & 70.00 \\
\hline 1967 & 341.72 & 1980 & 300.00 & 1993 & 500.00 & 2006 & 100.00 \\
\hline 1968 & 341.72 & 1981 & 300.00 & 1994 & 500.00 & 2007 & 123.00 \\
\hline 1969 & 308.65 & 1982 & 300.00 & 1995 & 500.00 & 2008 & 144.50 \\
\hline
\end{tabular}

Notes:

1959-62, 100- to 450-gram metal ingot prices, 99.9-percent nominal purity, provided by American Potash \& Chemical Corp.

1963, 1- to 4-pound metal ingot prices, 99.9-percent nominal purity, provided by American Potash \& Chemical Corp.

1964, 1967-78, 2- to 10-pound metal ingot price, from 99.9-percent-grade oxides, provided by Research Chemicals.

1965, "over 1 pound" metal ingot prices, provided by Research Chemicals.

1966, 1- to 5-pound metal ingot price, from 99.9-percent-grade oxides, provided by Research Chemicals.

1979-88, 1-kilogram metal ingot, from 99.9-percent-grade oxides, provided by Research Chemicals.

1989-94, 1-kilogram metal ingots, from 99.9-percent-grade oxides, provided by Rhône-Poulenc Basic Chemicals Co.

1995-97, 1- to 5-kilogram cast metal ingots, from 99.9-percent-grade oxides, provided by Rhône-Poulenc Basic Chemicals Co.

1998, 1- to 5-kilogram cast metal ingots, from 99.9-percent-grade oxides, provided by Rhodia, Inc.

2001-10, minimum 99-percent-pure metal, free on board China, provided by Metal-Pages Ltd. 
Table 3. Rare-Earth Metals—Yearend europium metal price.

[Values in dollars per kilogram. NA Not available]

\begin{tabular}{|c|c|c|c|c|c|c|c|}
\hline Year & Price & Year & Price & Year & Price & Year & Price \\
\hline 1959 & $9,250.00$ & 1972 & $5,952.48$ & 1985 & $7,500.00$ & 1998 & $6,500.00$ \\
\hline 1960 & $9,250.00$ & 1973 & $5,952.48$ & 1986 & $7,600.00$ & 1999 & NA \\
\hline 1961 & $9,250.00$ & 1974 & $5,952.48$ & 1987 & $7,600.00$ & 2000 & NA \\
\hline 1962 & $9,250.00$ & 1975 & $5,952.48$ & 1988 & $7,600.00$ & 2001 & $1,050.00$ \\
\hline 1963 & $3,306.93$ & 1976 & $5,952.48$ & 1989 & $7,600.00$ & 2002 & 650.00 \\
\hline 1964 & $4,645.14$ & 1977 & $5,952.48$ & 1990 & $7,600.00$ & 2003 & 560.00 \\
\hline 1965 & $11,023.11$ & 1978 & $5,952.48$ & 1991 & $7,600.00$ & 2004 & 560.00 \\
\hline 1966 & $11,023.11$ & 1979 & $6,500.00$ & 1992 & $7,600.00$ & 2005 & 550.00 \\
\hline 1967 & $7,936.64$ & 1980 & $7,000.00$ & 1993 & $7,600.00$ & 2006 & 450.00 \\
\hline 1968 & $7,936.64$ & 1981 & $7,500.00$ & 1994 & $7,600.00$ & 2007 & 585.00 \\
\hline 1969 & $7,054.79$ & 1982 & $7,500.00$ & 1995 & $5,600.00$ & 2008 & 785.00 \\
\hline 1970 & $7,054.79$ & 1983 & $7,500.00$ & 1996 & $5,600.00$ & 2009 & 785.00 \\
\hline 1971 & $5,952.48$ & 1984 & $7,500.00$ & 1997 & $5,600.00$ & 2010 & 785.00 \\
\hline
\end{tabular}

Notes:

1959-62, 100- to 450-gram metal ingot prices, 99.9-percent nominal purity, provided by American Potash \& Chemical Corp.

1963, 1- to 4-pound metal ingot prices, 99.9-percent nominal purity, provided by American Potash \& Chemical Corp.

1964, 1- to 2-pound metal ingot prices, 99.9-percent nominal purity, provided by Research Chemicals.

1965-66, 1- to 5-pound metal ingot price, from 99.9-percent-grade oxides, provided by Research Chemicals.

1967-78, 2- to 10-pound metal ingot price, from 99.9-percent-grade oxides, provided by Research Chemicals.

1979-88, 1-kilogram metal ingot, from 99.9-percent-grade oxides, provided by Research Chemicals.

1989-94, 1-kilogram metal ingots, from 99.9-percent-grade oxides, provided by Rhône-Poulenc Basic Chemicals Co.

1995-97, 1- to 5-kilogram cast metal ingots, from 99.9-percent-grade oxides, provided by Rhône-Poulenc Basic Chemicals Co.

1998, 1- to 5-kilogram cast metal ingots, from 99.9-percent-grade oxides, provided by Rhodia, Inc.

2001-10, minimum 99-percent-pure metal, free on board China, provided by Metal-Pages Ltd. 
Table 4. Rare-Earth Metals-Yearend gadolinium metal price.

[Values in dollars per kilogram. NA Not available]

\begin{tabular}{|c|c|c|c|c|c|c|c|}
\hline Year & Price & Year & Price & Year & Price & Year & Price \\
\hline 1959 & 730.00 & 1972 & 462.97 & 1985 & 485.00 & 1998 & 400.00 \\
\hline 1960 & 730.00 & 1973 & 462.97 & 1986 & 500.00 & 1999 & NA \\
\hline 1961 & 730.00 & 1974 & 462.97 & 1987 & 500.00 & 2000 & NA \\
\hline 1962 & 730.00 & 1975 & 462.97 & 1988 & 500.00 & 2001 & NA \\
\hline 1963 & 462.97 & 1976 & 462.97 & 1989 & 500.00 & 2002 & NA \\
\hline 1964 & 568.79 & 1977 & 462.97 & 1990 & 500.00 & 2003 & NA \\
\hline 1965 & 537.93 & 1978 & 462.97 & 1991 & 500.00 & 2004 & NA \\
\hline 1966 & 551.16 & 1979 & 430.00 & 1992 & 500.00 & 2005 & NA \\
\hline 1967 & 507.06 & 1980 & 440.00 & 1993 & 500.00 & 2006 & NA \\
\hline 1968 & 507.06 & 1981 & 485.00 & 1994 & 500.00 & 2007 & 29.75 \\
\hline 1969 & 485.02 & 1982 & 485.00 & 1995 & 500.00 & 2008 & 20.25 \\
\hline 1970 & 485.02 & 1983 & 485.00 & 1996 & 500.00 & 2009 & 18.25 \\
\hline 1971 & 462.97 & 1984 & 485.00 & 1997 & 500.00 & 2010 & 54.50 \\
\hline
\end{tabular}

Notes:

1959-62, 100- to 450-gram metal ingot prices, 99.9-percent nominal purity, provided by American Potash \& Chemical Corp.

1963, 1- to 4-pound metal ingot prices, 99.9-percent nominal purity, provided by American Potash \& Chemical Corp.

1964, 1967-78, 2- to 10-pound metal ingot price, from 99.9-percent-grade oxides, provided by Research Chemicals.

1965 , "over 1 pound" metal ingot prices, provided by Research Chemicals.

1966, 1- to 5-pound metal ingot price, from 99.9-percent-grade oxides, provided by Research Chemicals.

1979-88, 1-kilogram metal ingot, from 99.9-percent-grade oxides, provided by Research Chemicals.

1989-94, 1-kilogram metal ingots, from 99.9-percent-grade oxides, provided by Rhône-Poulenc Basic Chemicals Co.

1995-97, 1- to 5-kilogram cast metal ingots, from 99.9-percent-grade oxides, provided by Rhône-Poulenc Basic Chemicals Co.

1998, 1- to 5-kilogram cast metal ingots, from 99.9-percent-grade oxides, provided by Rhodia, Inc.

2007-10, minimum 99-percent-pure metal, free on board China, provided by Metal-Pages Ltd. 
Table 5. Rare-Earth Metals-Yearend lanthanum metal price.

[Values in dollars per kilogram. NA Not available]

\begin{tabular}{|c|c|c|c|c|c|c|c|}
\hline Year & Price & Year & Price & Year & Price & Year & Price \\
\hline 1959 & 340.00 & 1972 & 88.18 & 1985 & 125.00 & \begin{tabular}{|l|}
1998 \\
\end{tabular} & 350.00 \\
\hline 1960 & 340.00 & 1973 & 88.18 & 1986 & 150.00 & 1999 & NA \\
\hline 1961 & 340.00 & 1974 & 88.18 & 1987 & 150.00 & 2000 & $\mathrm{NA}$ \\
\hline 1962 & 340.00 & 1975 & 88.18 & 1988 & 150.00 & 2001 & 4.10 \\
\hline 1963 & 308.65 & 1976 & 88.18 & 1989 & 150.00 & 2002 & 3.30 \\
\hline 1964 & 160.94 & 1977 & 88.18 & 1990 & 150.00 & 2003 & 3.20 \\
\hline 1965 & 189.60 & 1978 & 88.18 & 1991 & 150.00 & 2004 & 3.50 \\
\hline 1966 & 165.35 & 1979 & 108.00 & 1992 & 150.00 & 2005 & 4.05 \\
\hline 1967 & 154.32 & 1980 & 115.00 & 1993 & 150.00 & 2006 & 4.25 \\
\hline 1968 & 154.32 & 1981 & 125.00 & 1994 & 150.00 & 2007 & 7.60 \\
\hline 1969 & 110.23 & 1982 & 125.00 & 1995 & 350.00 & 2008 & 11.25 \\
\hline 1970 & 110.23 & 1983 & 125.00 & 1996 & 350.00 & 2009 & 10.05 \\
\hline 1971 & 88.18 & 1984 & 125.00 & 1997 & 350.00 & 2010 & 60.50 \\
\hline
\end{tabular}

Notes:

1959-62, 100- to 450-gram metal ingot prices, 99.9-percent nominal purity, provided by American Potash \& Chemical Corp.

1963, 1- to 4-pound metal ingot prices, 99.9-percent nominal purity, provided by American Potash \& Chemical Corp.

1964, 1967-78, 2- to 10-pound metal ingot price, from 99.9-percent-grade oxides, provided by Research Chemicals.

1965-66, 1- to 5-pound metal ingot price, from 99.9-percent-grade oxides, provided by Research Chemicals.

1979-88, 1-kilogram metal ingot, from 99.9-percent-grade oxides, provided by Research Chemicals.

1989-94, 1-kilogram metal ingots, from 99.9-percent-grade oxides, provided by Rhône-Poulenc Basic Chemicals Co.

1995-97, 1- to 5-kilogram cast metal ingots, from 99.9-percent-grade oxides, provided by Rhône-Poulenc Basic Chemicals Co.

1998, 1- to 5-kilogram cast metal ingots, from 99.9-percent-grade oxides, provided by Rhodia, Inc.

2001-10, minimum 99-percent-pure metal, free on board China, provided by Metal-Pages Ltd. 
Table 6. Rare-Earth Metals_-Yearend neodymium metal price.

[Values in dollars per kilogram. NA Not available]

\begin{tabular}{|c|c|c|c|c|c|c|c|}
\hline Year & Price & Year & Price & Year & Price & Year & Price \\
\hline 1959 & 420.00 & 1972 & 220.46 & 1985 & 260.00 & 1998 & 450.00 \\
\hline 1960 & 420.00 & 1973 & 220.46 & 1986 & 280.00 & 1999 & NA \\
\hline 1962 & 420.00 & 1975 & 220.46 & 1988 & 280.00 & 2001 & 7.40 \\
\hline 1963 & 385.81 & 1976 & 220.46 & 1989 & 340.00 & 2002 & 6.60 \\
\hline 1965 & 370.38 & 1978 & 220.46 & 1991 & 340.00 & 2004 & 8.20 \\
\hline 1966 & 330.69 & 1979 & 250.00 & 1992 & 340.00 & 2005 & 12.50 \\
\hline 1967 & 253.53 & 1980 & 260.00 & 1993 & 340.00 & 2006 & 28.55 \\
\hline 1968 & 253.53 & 1981 & 260.00 & 1994 & 340.00 & 2007 & 34.75 \\
\hline 1969 & 220.46 & 1982 & 260.00 & 1995 & 450.00 & 2008 & 18.50 \\
\hline
\end{tabular}

Notes:

1959-62, 100- to 450-gram metal ingot prices, 99.9-percent nominal purity, provided by American Potash \& Chemical Corp.

1963, 1- to 4-pound metal ingot prices, 99.9-percent nominal purity, provided by American Potash \& Chemical Corp.

1964, 1967-78, 2- to 10-pound metal ingot price, from 99.9-percent-grade oxides, provided by Research Chemicals.

1965-66, 1- to 5-pound metal ingot price, from 99.9-percent-grade oxides, provided by Research Chemicals.

1979-88, 1-kilogram metal ingot, from 99.9-percent-grade oxides, provided by Research Chemicals.

1989-97, 1- to 5-kilogram cast metal ingots, from 99.9-percent-grade oxides, provided by Rhône-Poulenc Basic Chemicals Co.

1998, 1- to 5-kilogram cast metal ingots, from 99.9-percent-grade oxides, provided by Rhodia, Inc.

2001-10, minimum 99-percent-pure metal, free on board China, provided by Metal-Pages Ltd. 
Table 7. Rare-Earth Metals-Yearend praseodymium metal price.

[Values in dollars per kilogram. NA Not available]

\begin{tabular}{|c|c|c|c|c|c|c|c|}
\hline Year & Price & Year & Price & Year & Price & Year & Price \\
\hline 1959 & 420.00 & 1972 & 352.74 & 1985 & 310.00 & \begin{tabular}{|l|}
1998 \\
\end{tabular} & 540.00 \\
\hline 1960 & 420.00 & 1973 & 352.74 & 1986 & 400.00 & 1999 & NA \\
\hline 1961 & 420.00 & 1974 & 352.74 & 1987 & 400.00 & 2000 & NA \\
\hline 1962 & 420.00 & 1975 & 352.74 & 1988 & 400.00 & 2001 & 6.40 \\
\hline 1963 & 385.81 & 1976 & 352.74 & 1989 & 540.00 & 2002 & 6.20 \\
\hline 1964 & 412.26 & 1977 & 352.74 & 1990 & 540.00 & 2003 & 7.30 \\
\hline 1965 & 401.24 & 1978 & 352.74 & 1991 & 540.00 & 2004 & 11.00 \\
\hline 1966 & 407.86 & 1979 & 290.00 & 1992 & 540.00 & 2005 & 13.50 \\
\hline 1967 & 385.81 & 1980 & 310.00 & 1993 & 540.00 & 2006 & 25.75 \\
\hline 1968 & 385.81 & 1981 & 310.00 & 1994 & 540.00 & 2007 & 34.25 \\
\hline 1969 & 374.79 & 1982 & 310.00 & 1995 & 540.00 & 2008 & 18.50 \\
\hline 1970 & 374.79 & 1983 & 310.00 & 1996 & 540.00 & 2009 & 29.50 \\
\hline 1971 & 352.74 & 1984 & 310.00 & 1997 & 540.00 & 2010 & 111.50 \\
\hline
\end{tabular}

Notes:

1959-62, 100- to 450-gram metal ingot prices, 99.9-percent nominal purity, provided by American Potash \& Chemical Corp.

1963, 1- to 4-pound metal ingot prices, 99.9-percent nominal purity, provided by American Potash \& Chemical Corp.

1964, 1967-78, 2- to 10-pound metal ingot price, from 99.9-percent-grade oxides, provided by Research Chemicals.

1965-66, 1- to 5-pound metal ingot price, from 99.9-percent-grade oxides, provided by Research Chemicals.

1979-88, 1-kilogram metal ingot, from 99.9-percent-grade oxides, provided by Research Chemicals.

1989-97, 1- to 5-kilogram cast metal ingots, from 99.9-percent-grade oxides, provided by Rhône-Poulenc Basic Chemicals Co.

1998, 1- to 5-kilogram cast metal ingots, from 99.9-percent-grade oxides, provided by Rhodia, Inc.

2001-10, minimum 99-percent-pure metal, free on board China, provided by Metal-Pages Ltd. 
Table 8. Rare-Earth Metals—Yearend samarium metal price.

[Values in dollars per kilogram. NA Not available]

\begin{tabular}{|c|c|c|c|c|c|c|c|}
\hline Year & Price & Year & Price & Year & Price & Year & Price \\
\hline 1959 & 440.00 & 1972 & 297.62 & 1985 & 330.00 & 1998 & 300.00 \\
\hline 1960 & 440.00 & 1973 & 297.62 & 1986 & 395.00 & 1999 & NA \\
\hline 1961 & 440.00 & 1974 & 297.62 & 1987 & 395.00 & 2000 & $\mathrm{NA}$ \\
\hline 1962 & 440.00 & 1975 & 297.62 & 1988 & 395.00 & 2001 & 16.00 \\
\hline 1963 & 396.83 & 1976 & 297.62 & 1989 & 395.00 & 2002 & 11.50 \\
\hline 1964 & 407.86 & 1977 & 297.62 & 1990 & 340.00 & 2003 & 11.30 \\
\hline 1965 & 687.84 & 1978 & 297.62 & 1991 & 340.00 & 2004 & 12.00 \\
\hline 1966 & 485.02 & 1979 & 280.00 & 1992 & 300.00 & 2005 & 10.75 \\
\hline 1967 & 352.74 & 1980 & 300.00 & 1993 & 300.00 & 2006 & 11.75 \\
\hline 1968 & 352.74 & 1981 & 330.00 & 1994 & 300.00 & 2007 & 14.95 \\
\hline 1969 & 308.65 & 1982 & 330.00 & 1995 & 300.00 & 2008 & 20.75 \\
\hline 1970 & 319.67 & 1983 & 330.00 & 1996 & 300.00 & 2009 & 20.75 \\
\hline 1971 & 297.62 & 1984 & 330.00 & 1997 & 300.00 & 2010 & 60.50 \\
\hline
\end{tabular}

Notes:

1959-62, 100- to 450-gram metal ingot prices, 99.9-percent nominal purity, provided by American Potash \& Chemical Corp.

1963, 1- to 4-pound metal ingot prices, 99.9-percent nominal purity, provided by American Potash \& Chemical Corp.

1964, 1967-78, 2- to 10-pound metal ingot price, from 99.9-percent-grade oxides, provided by Research Chemicals.

1965 , "over 1 pound" metal ingot prices, provided by Research Chemicals.

1966, 1- to 5-pound metal ingot price, from 99.9-percent-grade oxides, provided by Research Chemicals.

1979-88, 1-kilogram metal ingot, from 99.9-percent-grade oxides, provided by Research Chemicals.

1989-94, 1-kilogram metal ingots, from 99.9-percent-grade oxides, provided by Rhône-Poulenc Basic Chemicals Co.

1995-97, 2- to 5-kilogram cast metal ingots, from 99.9-percent-grade oxides, provided by Rhône-Poulenc Basic Chemicals Co.

1998, 2- to 5-kilogram cast metal ingots, from 99.9-percent-grade oxides, provided by Rhodia, Inc.

2001-10, minimum 99-percent-pure metal, free on board China, provided by Metal-Pages Ltd. 
Table 9. Rare-Earth Metals-Yearend scandium metal price.

[Values in dollars per kilogram]

\begin{tabular}{|c|c|c|c|c|c|c|c|}
\hline Year & Price & Year & Price & Year & Price & Year & Price \\
\hline 1962 & $35,000.00$ & 1975 & $6,172.94$ & 1988 & $25,000.00$ & 2001 & $198,000.00$ \\
\hline 1963 & $35,000.00$ & 1976 & $6,172.94$ & 1989 & $21,500.00$ & 2002 & $198,000.00$ \\
\hline 1964 & $11,889.53$ & 1977 & $6,172.94$ & 1990 & $12,000.00$ & 2003 & $119,000.00$ \\
\hline 1965 & $10,000.00$ & 1978 & $6,172.94$ & 1991 & $8,400.00$ & 2004 & $124,000.00$ \\
\hline 1966 & $10,000.00$ & 1979 & $6,600.00$ & 1992 & $10,000.00$ & 2005 & $131,000.00$ \\
\hline 1967 & $7,936.64$ & 1980 & $7,200.00$ & 1993 & $10,000.00$ & 2006 & $131,000.00$ \\
\hline 1968 & $7,936.64$ & 1981 & $8,000.00$ & 1994 & $10,000.00$ & 2007 & $131,000.00$ \\
\hline 1969 & $7,936.64$ & 1982 & $11,000.00$ & 1995 & $18,000.00$ & 2008 & $152,000.00$ \\
\hline 1970 & $7,936.64$ & 1983 & $11,000.00$ & 1996 & $18,000.00$ & 2009 & $155,000.00$ \\
\hline 1971 & $6,172.94$ & 1984 & $75,000.00$ & 1997 & $18,000.00$ & 2010 & $158,000.00$ \\
\hline 1972 & $6,172.94$ & 1985 & $30,000.00$ & 1998 & $18,000.00$ & & \\
\hline 1973 & $6,172.94$ & 1986 & $25,000.00$ & 1999 & $175,000.00$ & & \\
\hline 1974 & $6,172.94$ & 1987 & $25,000.00$ & 2000 & $175,000.00$ & & \\
\hline
\end{tabular}

Notes:

1962, 1-pound metal ingot prices, 99.5+-percent purity, provided by Atomergic Chemetals, Div. of Gallard Schlesinger.

1963, 100- to 400-gram metal ingot prices, 99.5+-percent purity, provided by Atomergic Chemetals, Div. of Gallard Schlesinger.

1964, 1971-78, 1- to 2-pound metal ingot price, from 99.9-percent-grade oxides, provided by Research Chemicals.

1965-66, 227- to 454-gram metal ingot price, provided by Research Chemicals.

1967-70, 1989-92, 2- to 10-pound metal ingot price, provided by Research Chemicals.

1979-88, 1-kilogram metal ingot, from 99.9-percent-grade oxides, provided by Research Chemicals.

1989-94, 1-kilogram metal ingots, from 99.9-percent-grade oxides, provided by Rhône-Poulenc Basic Chemicals Co.

1995-97, 1- to 5-kilogram cast metal ingots, from 99.9-percent-grade oxides, provided by Rhône-Poulenc Basic Chemicals Co.

1998, 1- to 5-kilogram cast metal ingots, from 99.9-percent-grade oxides, provided by Rhodia, Inc.

1999-2010, Metal ingot pieces, 99.9-percent purity, provided by Alfa Aesar, a Johnson Matthey company. 
Table 10. Rare-Earth Metals_-Yearend terbium metal price.

[Values in dollars per kilogram. NA Not available]

\begin{tabular}{|c|c|c|c|c|c|c|c|}
\hline Year & Price & Year & Price & Year & Price & Year & Price \\
\hline 1959 & $3,750.00$ & 1972 & $1,543.24$ & 1985 & $2,800.00$ & 1998 & $1,300.00$ \\
\hline 1960 & $3,750.00$ & 1973 & $1,543.24$ & 1986 & $2,800.00$ & 1999 & NA \\
\hline 1962 & $3,750.00$ & 1975 & $1,807.79$ & 1988 & $2,800.00$ & 2001 & 230.00 \\
\hline 1963 & $2,314.85$ & 1976 & $1,807.79$ & 1989 & $2,800.00$ & 2002 & 180.00 \\
\hline 1965 & $2,411.86$ & 1978 & $1,807.79$ & 1991 & $2,800.00$ & 2004 & 430.00 \\
\hline 1966 & $2,425.08$ & 1979 & $2,000.00$ & 1992 & $2,800.00$ & 2005 & 430.00 \\
\hline 1967 & $1,895.98$ & 1980 & $2,300.00$ & 1993 & $2,800.00$ & 2006 & 660.00 \\
\hline 1968 & $1,895.98$ & 1981 & $2,800.00$ & 1994 & $2,800.00$ & 2007 & 750.00 \\
\hline 1969 & $1,543.24$ & 1982 & $2,800.00$ & 1995 & $2,200.00$ & 2008 & 600.00 \\
\hline
\end{tabular}

Notes:

1959-62, 100- to 450-gram metal ingot prices, 99.9-percent nominal purity, provided by American Potash \& Chemical Corp.

1963, 1- to 4-pound metal ingot prices, 99.9-percent nominal purity, provided by American Potash \& Chemical Corp.

1964, 1- to 2-pound metal ingot prices, 99.9-percent nominal purity, provided by Research Chemicals.

1965, "over 1 pound" metal ingot prices, provided by Research Chemicals.

1966, 1- to 5-pound metal ingot price, from 99.9-percent-grade oxides, provided by Research Chemicals.

1967-78, 2- to 10-pound metal ingot price, from 99.9-percent-grade oxides, provided by Research Chemicals.

1979-88, 1-kilogram metal ingot, from 99.9-percent-grade oxides, provided by Research Chemicals.

1989-94, 1-kilogram metal ingots, from 99.9-percent-grade oxides, provided by Rhône-Poulenc Basic Chemicals Co.

1995-97, 1- to 5-kilogram cast metal ingots, from 99.9-percent-grade oxides, provided by Rhône-Poulenc Basic Chemicals Co.

1998, 1- to 5-kilogram cast metal ingots, from 99.9-percent-grade oxides, provided by Rhodia, Inc.

2001-10, minimum 99-percent-pure metal, free on board China, provided by Metal-Pages Ltd. 
Table 11. Rare-Earth Metals-Yearend yttrium metal price.

[Values in dollars per kilogram. NA Not available]

\begin{tabular}{|c|c|c|c|c|c|c|c|}
\hline Year & Price & Year & Price & Year & Price & Year & Price \\
\hline 1959 & 540.00 & 1972 & 308.65 & 1985 & 510.00 & \begin{tabular}{|l|}
1998 \\
\end{tabular} & 450.00 \\
\hline 1960 & 540.00 & 1973 & 308.65 & 1986 & 510.00 & 1999 & NA \\
\hline 1961 & 540.00 & 1974 & 308.65 & 1987 & 510.00 & 2000 & NA \\
\hline 1962 & 540.00 & 1975 & 308.65 & 1988 & 510.00 & 2001 & 56.00 \\
\hline 1963 & 716.50 & 1976 & 308.65 & 1989 & 510.00 & 2002 & 29.00 \\
\hline 1964 & 654.77 & 1977 & 308.65 & 1990 & 340.00 & 2003 & 29.50 \\
\hline 1965 & 449.74 & 1978 & 308.65 & 1991 & 340.00 & 2004 & 26.00 \\
\hline 1966 & 396.83 & 1979 & 320.00 & 1992 & 340.00 & 2005 & 26.00 \\
\hline 1967 & 352.74 & 1980 & 390.00 & 1993 & 340.00 & 2006 & 24.00 \\
\hline 1968 & 352.74 & 1981 & 430.00 & 1994 & 340.00 & 2007 & 41.00 \\
\hline 1969 & 319.67 & 1982 & 430.00 & 1995 & 450.00 & 2008 & 40.00 \\
\hline 1970 & 352.74 & 1983 & 430.00 & 1996 & 450.00 & 2009 & 40.00 \\
\hline 1971 & 308.65 & 1984 & 430.00 & 1997 & 450.00 & 2010 & 78.00 \\
\hline
\end{tabular}

Notes:

1959-62, 100- to 450-gram metal ingot prices, 99.9-percent nominal purity, provided by American Potash \& Chemical Corp.

1963, 1- to 4-pound metal ingot prices, 99.9-percent nominal purity, provided by American Potash \& Chemical Corp.

1964, 1967-78, 2- to 10-pound metal ingot price, from 99.9-percent-grade oxides, provided by Research Chemicals.

1965-66, 1- to 5-pound metal ingot price, from 99.9-percent-grade oxides, provided by Research Chemicals.

1979-88, 1-kilogram metal ingot, from 99.9-percent-grade oxides, provided by Research Chemicals.

1989-94, 1-kilogram metal ingots, from 99.9-percent-grade oxides, provided by Rhône-Poulenc Basic Chemicals Co.

1995-97, 1- to 5-kilogram cast metal ingots, from 99.9-percent-grade oxides, provided by Rhône-Poulenc Basic Chemicals Co.

1998, 1- to 5-kilogram cast metal ingots, from 99.9-percent-grade oxides, provided by Rhodia, Inc.

2001-10, minimum 99-percent-pure metal, free on board China, provided by Metal-Pages Ltd. 


\title{
Rhenium (Re)
}

\author{
by Désirée E. Polyak
}

Ida (Tache) and Walter Noddack, German chemists, are generally credited with the discovery of rhenium in 1925 (Habashi, 1997). The total cost for producing the first gram of rhenium in 1928 was estimated to be $\$ 15,000$. At the University of Tennessee in 1942, A.D. Melaven and J.A. Bacon developed a process for extracting the element from the dust that accumulated in roasting molybdenum ore. A plant in Tennessee was the only rhenium producer in the United States for many years and had a total output of several hundred pounds of the metal and its salts each year (Sutulov, 1976, p. 206).

In 1942, the price of the metal in the United States was $\$ 14$ per gram; in Germany, however, the price reportedly was $\$ 4$ per gram. The price of rhenium decreased from \$14 per gram in 1942 to $\$ 1.99$ per gram in 1951 as techniques for extraction were improved (table 1). From 1951 through 1954, interest in rhenium uses was stimulated by research associated with the Korean conflict. Consequently, demand increased and the average price of rhenium in 1952 was $\$ 2.18$ per gram. From 1954 through 1969, prices stabilized as new uses for rhenium were developed - additions of rhenium increase the corrosion resistance of stainless steel; the nuclear properties of rhenium offer potential as a reactor-shielding material for thermal neutrons; and the inherent brittleness of tungsten and molybdenum is inhibited and ductility improved by alloying with rhenium. In 1968, rhenium usage in alloy applications decreased as Atomic Energy Commission programs were completed. This decrease was reversed by the development of rhenium and rhenium-platinum catalysts used in the cracking of petroleum hydrocarbons (National Research Council, 1968, p. 4). The use in catalysts reached a high of 75 percent of the demand for rhenium, resulting in an average of $\$ 2.64$ per gram in 1971, as demand exceeded supply. The price declined to $\$ 0.77$ per gram in 1978 because the supply and demand were balanced (fig. 1). In 1980, the rhenium price increased to $\$ 3.58$ per gram as a result of increased demand related to the doubling of the rhenium in the reforming catalysts used to produce unleaded gasoline (Millensifer, 1997). The price decreased to $\$ 0.84$ per gram in 1982 , with the advent of recessionary conditions. The price continued to decrease to $\$ 0.55$ per gram in 1984, and then it increased to \$0.89 per gram in 1987 .

In 1988 , the price increased to $\$ 1.47$ per gram as a result of demand for new alloys used in turbine engines for aircrafts. This introduction of rhenium-bearing superalloys started to change the pattern of demand. This was reinforced in the early 1990s by the development of a new generation of superalloys. Demand for rhenium saw a particularly sharp increase in 1998 when Cannon-Muskegon, the leading rhenium superalloy producer and the world's single largest consumer of rhenium, announced a 100-percent increase in the rhenium content of its alloys, from 3 percent to 6 percent.

The demand for rhenium continued to increase into the 21 st century owing to the development of new superalloys containing rhenium for use in aircraft engines and groundbased gas turbines. Rhenium production was not able to match demand, causing prices to rapidly increase in a tight supply situation.

Rhenium prices rose sharply starting in mid-2006, as demand for the aerospace industry began to increase dramatically and the rhenium industry was unable to meet the demand. Prices peaked at $\$ 10.40$ per gram in 2008, and decreased in 2009 to $\$ 7.50$ per gram. Prices did not fall to the lows experienced in the mid-1990s.

The market for rhenium is small. Therefore, sudden changes in the supply-demand balance have a very marked effect on prices. Most primary rhenium produced is supplied to a relatively small number of customers. These are mostly companies in the petroleum catalysts and superalloys sectors that buy rhenium under fixed price and fixed term contracts, the details of which are not made public. These contracts allow major consumers some measure of security owing to the large and often sudden movements of the rhenium market that have characterized the industry over the last 30 years (Roskill Information Services Ltd., 2010, p. 124).

\section{References Cited}

Habashi, Fathi, 1997, Rhenium seventy years old, in Byrskin, B.D., ed., 1997, Rhenium and rhenium alloysInternational Symposium on Rhenium and Rhenium Alloys, February 9-13, 1997, Orlando, Fla., Proceedings: Warrendale, Pa., The Minerals, Metals \& Materials Society, p. $15-36$.

Millensifer, T.A., 1997, Rhenium background and markets, in Byrskin, B.D., ed., 1997, Rhenium and rhenium alloysInternational Symposium on Rhenium and Rhenium Alloys, February 9-13, 1997, Orlando, Fla., Proceedings: Warrendale, Pa., The Minerals, Metals \& Materials Society, p. $37-47$.

National Research Council, 1968, Trends in usage of rhenium - A report by the Materials Advisory Board: National Academy of Sciences/National Academy of Engineering, MAB-251, Washington, D.C., December, 9 p. 
Roskill Information Services Ltd., 2010, Rhenium-Market outlook to 2015 (8th ed.): London, United Kingdom, Roskill Information Services Ltd., 130 p.

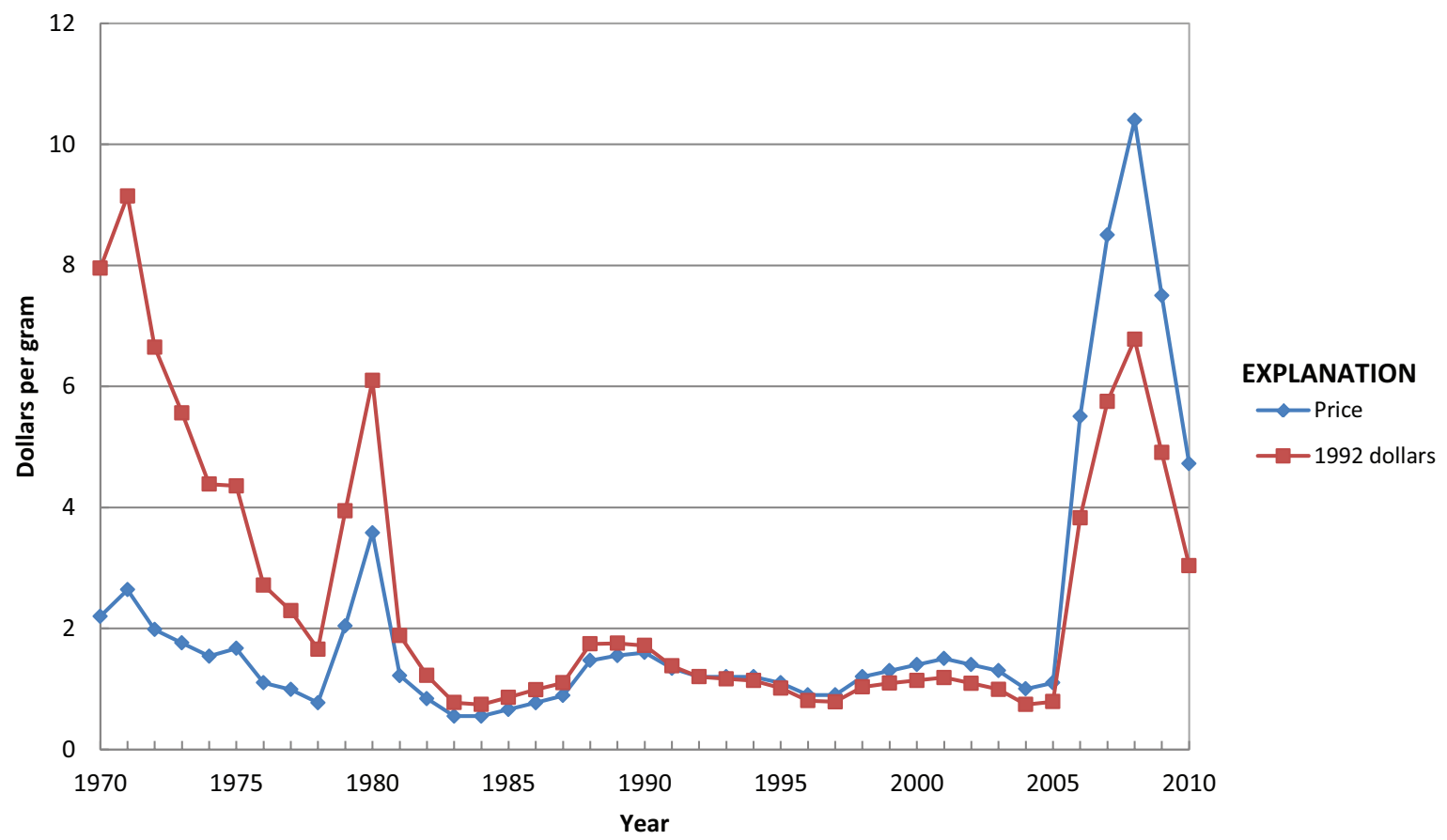

Sutulov, Alexander, 1976, Molybdenum and rhenium 17781977: Concepción, Chile, University of Concepción, 257 p.

Figure 1. U.S. rhenium metal price.

\section{Significant events affecting rhenium prices since 1970}

1970

1980

1988

1991

2006-08

2008-09
Start of rhenium use in catalysts to make unleaded gasoline

Doubling of percentage of rhenium in catalysts used to make unleaded gasoline Introduction of rhenium-bearing superalloys

Dissolution of the Soviet Union

Rhenium prices increase in response to greater demand from the aerospace industry Global financial crisis, prices decline 
Table 1. U.S. rhenium metal powder price.

[Values in dollars per gram. NA Not available]

\begin{tabular}{|c|c|c|c|c|c|c|c|}
\hline Year & Price & Year & Price & Year & Price & Year & Price \\
\hline 1942 & 14.00 & 1960 & 1.50 & 1978 & 0.77 & 1996 & 0.90 \\
\hline 1943 & 10.00 & 1961 & 1.35 & 1979 & 2.09 & 1997 & 0.90 \\
\hline 1945 & 4.50 & 1963 & 1.28 & 1981 & 1.31 & 1999 & 1.30 \\
\hline 1946 & 3.25 & 1964 & 1.46 & 1982 & 0.90 & 2000 & 1.40 \\
\hline 1948 & NA & 1966 & 1.35 & 1984 & 0.66 & 2002 & 1.40 \\
\hline 1949 & NA & 1967 & 1.33 & 1985 & 0.66 & 2003 & 1.30 \\
\hline 1950 & NA & 1968 & 1.28 & 1986 & 0.77 & 2004 & 1.00 \\
\hline 1951 & 1.99 & 1969 & 1.46 & 1987 & 1.10 & 2005 & 1.10 \\
\hline 1952 & 2.18 & 1970 & 2.31 & 1988 & 1.54 & 2006 & 5.50 \\
\hline 1956 & 1.49 & 1974 & 1.65 & 1992 & 1.50 & 2010 & 4.72 \\
\hline 1957 & 1.46 & 1975 & 1.32 & 1993 & 1.50 & & \\
\hline 1958 & 1.45 & 1976 & 1.16 & 1994 & 1.56 & & \\
\hline 1959 & 1.43 & 1977 & 1.05 & 1995 & 1.10 & & \\
\hline
\end{tabular}

Notes:

1942-69, in U.S. Bureau of Mines Minerals Yearbook.

1970-2010, in U.S. Bureau of Mines Commodity Data Summaries (1970-77), Mineral Commodity Summaries (1978-96), and U.S. Geological Survey Mineral Commodity Summaries (1996-97); price based on U.S. Census Bureau customs value.

1998-2010, Price of metal pellets, minimum 99-percent-pure in Metal Bulletin. 


\title{
Rubidium (Rb)
}

\author{
by William E. Brooks
}

Rubidium was discovered in 1861 by means of an optical spectroscope but had extremely limited industrial use until the 1920s (Perel'man, 1965; Wagner, 1993, p. 591). Small quantities of rubidium-containing minerals were mined in the United States prior to the mid-1960s, but rubidium is no longer mined domestically. Historically, the most important use for rubidium has been in research and development, primarily in chemical and electronic applications.

Owing to the small size of the industry, quoted rubidium prices are for those of individual companies. The price varies directly with the purity of the material and inversely with the quantity purchased, and the metal has been marketed in purities ranging from 99.5 percent to 99.8 percent. The annual prices presented in the graph and table may not be comparable from year to year owing to differences in purities, quantity of material purchased, and (or) the source of the price (fig. 1; table 1). For example, prior to 1963 , most of the prices published in the U.S. Bureau of Mines Minerals Yearbook were for purchases of less than 1 pound of rubidium metal. Some pre-1963 prices, along with the prices published for 1963 through 1988, were for the purchase of at least 1 pound of rubidium metal. The price when buying 1 pound of metal is significantly lower than the other prices, owing to discounts for the large quantity purchased. For this report, prices were subsequently converted to a per-gram equivalent. The prices for 1992 through 2002 represent the price charged for a 1-gram ampoule of 99.8-percent-pure rubidium metal, whereas prices for 2003 through 2010 represent the price charged for a 1-gram ampoule of 99.75-percent-pure rubidium metal.

\section{References Cited}

Wagner, F.S., 1993, Rubidium and rubidium compounds, in Ullmann's encyclopedia of industrial chemistry (4th ed.): Weinheim, Germany, VCH Verlagsgesellschaft mbH, v. 21, p. 591-600.

Perel'man, F.M., 1965, Rubidium and caesium: New York, The Macmillan Co., 144 p. 


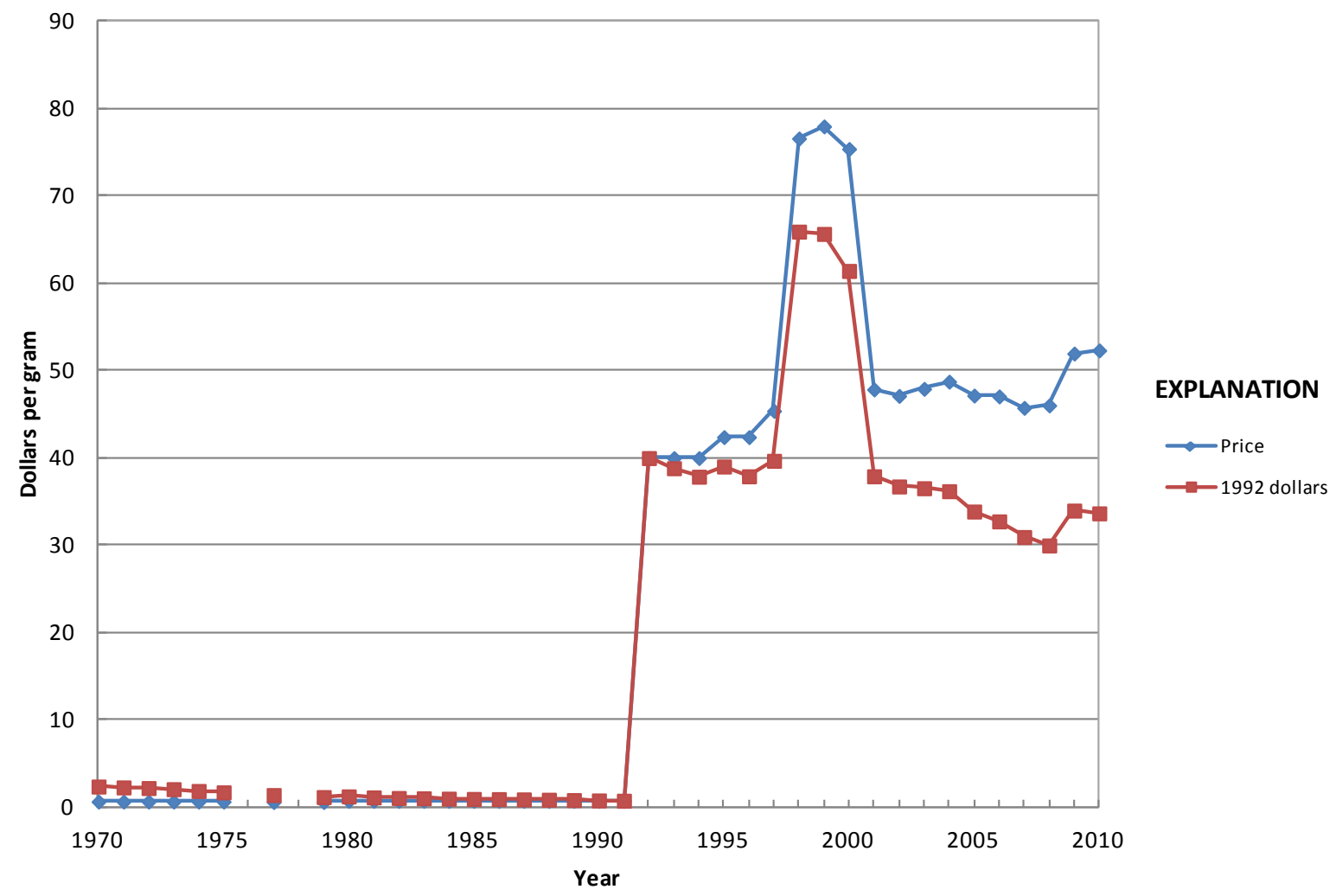

Figure 1. Average annual rubidium price. 
Table 1. Annual average primary rubidium price.

[Values in dollars per gram. NA Not available]

\begin{tabular}{|c|c|c|c|c|c|c|c|}
\hline Year & Price & Year & Price & Year & Price & Year & Price \\
\hline 1959 & 2.26 & \begin{tabular}{|l|}
1972 \\
\end{tabular} & 0.66 & 1985 & 0.74 & \begin{tabular}{|l|}
1998 \\
\end{tabular} & 76.60 \\
\hline 1960 & 0.86 & 1973 & 0.66 & 1986 & 0.74 & 1999 & 77.98 \\
\hline 1961 & 1.00 & 1974 & 0.66 & 1987 & 0.74 & 2000 & 75.40 \\
\hline 1962 & 1.00 & 1975 & 0.66 & 1988 & 0.74 & 2001 & 47.86 \\
\hline 1963 & 0.90 & 1976 & NA & 1989 & 0.74 & 2002 & 47.12 \\
\hline 1964 & 0.90 & \begin{tabular}{|l|l}
1977 \\
\end{tabular} & 0.61 & 1990 & 0.74 & 2003 & 47.93 \\
\hline 1965 & 0.63 & 1978 & NA & 1991 & 0.74 & 2004 & 48.75 \\
\hline 1966 & NA & 1979 & 0.61 & 1992 & 40.00 & 2005 & 47.16 \\
\hline 1967 & 0.63 & 1980 & 0.74 & 1993 & 40.00 & 2006 & 47.06 \\
\hline 1968 & 0.63 & 1981 & 0.74 & 1994 & 40.00 & 2007 & 45.75 \\
\hline 1969 & 0.66 & 1982 & 0.74 & 1995 & 42.40 & 2008 & 46.03 \\
\hline 1970 & 0.66 & 1983 & 0.74 & 1996 & 42.40 & 2009 & 51.97 \\
\hline 1971 & 0.66 & 1984 & 0.74 & 1997 & 45.40 & 2010 & 52.33 \\
\hline
\end{tabular}

Notes: The data in the table above were compiled from information in various U.S. Bureau of Mines Minerals Yearbooks, U.S. Bureau of Mines Mineral Commodity Summaries, and U.S. Geological Survey Mineral Commodity Summaries. It is believed that the data in the previously mentioned publication represents, and (or) were obtained from the following sources:

1959, Average of the price for purities ranging from 99.0 percent to 99.8 percent attributed to American Potash \& Chemical Corp. \& Penn Rare Metals Co. 1960, 99+-percent-pure rubidium metal, 10-pound lots.

1961-62, MSA Research Corp. 99.0-percent-pure rubidium metal, 50-gram lots.

1963-64, Average of the range of prices for 99+-percent-pure rubidium metal, in American Metal Market.

1965, Average of the range of prices for 99.5-percent-pure rubidium, 1- to 9-pound lots attributed to the Penn Rare Metals Division of Kawecki Chemical Co. 1967-68, Average of the range of prices for 99.5-percent-pure rubidium, 1- to 9-pound lots attributed to the Penn Rare Metals Division of Kawecki

Chemical Co.

1969-75, U.S. Bureau of Mines Minerals Yearbook citation for 99.5+-percent-pure rubidium metal.

1977, Average of the range of prices for 99.5-percent-pure rubidium metal attributed to unidentified industry sources.

1979, Average of the range of prices for 99.5-percent-pure rubidium metal attributed to unidentified industry sources.

1980-85, KBI Division, Cabot Corp., average of the yearend price for technical- and high-purity-grade rubidium metal.

1986-88, KBI Division, Cabot Corp., average of the yearend price for technical- and high-purity-grade rubidium metal in lots under 50 pounds.

1989-91, KBI Division, Cabot Corp.

1992-2002, Alfa Aesar and other chemical catalogs. Prices for purchases of 99.8-percent-pure rubidium metal in 1-gram ampoules.

2003-10, Alfa Aesar and other chemical catalogs. Prices for purchases of 99.75-percent-pure rubidium metal in 1-gram ampoules. 


\title{
Selenium (Se)
}

\author{
by Micheal W. George
}

The discovery of selenium is credited to J.J. Berzelius, who isolated it in 1817 from the red residue found in sulfuric acid prepared at the pyrite mining operation at Fahlun, Sweden (Carapella, 1984, p. 842). For almost a century, selenium was merely a scientific curiosity, until its use as a pigment in the manufacture of red glass, ceramics, and glazes was established in 1910 (Hess, 1911). Prices for selenium prior to that time are not generally available. Commercial quantities of selenium were and still are recovered as a byproduct of the electrolytic refining of copper, where it accumulates in anode residues (Hoffman, 1984, p. 495-516).

During World War I, selenium production and demand grew rapidly owing to the increased demand for red glass and the development of selenium as a replacement for manganese dioxide as a decolorizer in clear glass. Domestic production rose rapidly from about 5 metric tons (t) in 1910 to about $50 \mathrm{t}$ in 1918. Although domestic production of selenium fluctuated markedly from year to year, it continued to increase, reaching a peak of $565 \mathrm{t}$ in 1969, during the Vietnam War. Disruptions to copper production, changing technology, and variable demand contributed to year-to-year fluctuations in production. From 1970 through 1980, domestic production fell markedly, with imports accounting for an increasing share of domestic demand. Domestic production of selenium was about $141 \mathrm{t}$ in 1980 and increased to roughly $250 \mathrm{t}$ in $1985,287 \mathrm{t}$ in 1990, and $373 \mathrm{t}$ in 1995.

As calculated from domestic shipments plus net imports, apparent consumption of selenium from 1928 to 2001 fluctuated markedly from year to year during this period owing to economic cycles, military engagements, technical developments, and consumer stockpiling. Growth in consumption was driven by the development of new uses, including applications in rubber compounding, steel alloying, and selenium rectifiers. Consumption generally increased through 1969 when it peaked at almost $900 \mathrm{t}$ owing mainly to defense requirements. By 1970, selenium in rectifiers had largely been replaced by silicon, but its use as a photoconductor in plain-paper copiers had become its leading application. The U.S Government had stockpiled selenium metal because it was critical for selenium rectifiers, which were important for military applications. By 1974, U.S. Government stocks, which had reached a peak of $181 \mathrm{t}$ in 1963, were liquidated. Apparent consumption fell to less than $350 \mathrm{t}$ in 1980 but rose to a fairly stable range of about 500 metric tons per year (t/yr) from 1990 through 1996. During the 1980s, the photoconductor application declined as copiers increasingly used organic photoconductors. Despite substitution for selenium in photoreceptors in the late 1980s, demand from glass manufacturers outstripped supply, stocks declined, and global prices rose (fig. 1; table 1). From 1990 through 2003, worldwide production exceeded or matched demand creating a fairly constant oversupply situation that kept prices relatively low. By the late 1990s, selenium was no longer used in photocopiers.

Starting in 2003, the price rise and volatility for selenium was chiefly attributed to rising but fluctuating demand from Chinese manganese producers. Demand for selenium from Chinese manganese producers increased owing to China's increased production of steel, for which manganese is an alloying element. In China, selenium dioxide $\left(\mathrm{SeO}_{2}\right)$ was substituted for sulfur dioxide used to increase yields in the electrolytic production of manganese (Selenium-Tellurium Development Association, 2002). By using $\mathrm{SeO}_{2}$ instead of sulfur dioxide, plants reduce the power required to operate electrolytic cells. This method requires about 2 kilograms of selenium per metric ton of manganese metal produced (TEX Report, The, 2009). Selenium prices were also influenced by a global run up in metals commodity prices that was sustained until the economic crisis at the end of 2008.

\section{References Cited}

Carapella, S.C., Jr., 1984, Selenium (4th ed.): New York, Van Nostrand Reinhold Encyclopedia of Chemistry, 1,082 p.

Hess, F.L., 1911, Selenium, in Metals: U.S. Geological Survey, Mineral Resources of the United States 1910: pt. I, p. 731.

Hoffman, J.E., 1984, Recovery of selenium from electrolytic copper refinery slimes, in Precious metals-Mining, extraction, and processing: Warrendale, Pa., Mining, Minerals, and Materials Society, $621 \mathrm{p}$.

Selenium-Tellurium Development Association, Inc., 2002, Applications for selenium: Cavite, Philippines, SeleniumTellurium Development Association, Inc., available via http://www.stda.com/.

TEX Report, The, 2009, Cost situation to produce electrolytic manganese metal in China: The TEX Report, v. 41, no. 9655 , January 26, p. 3. 


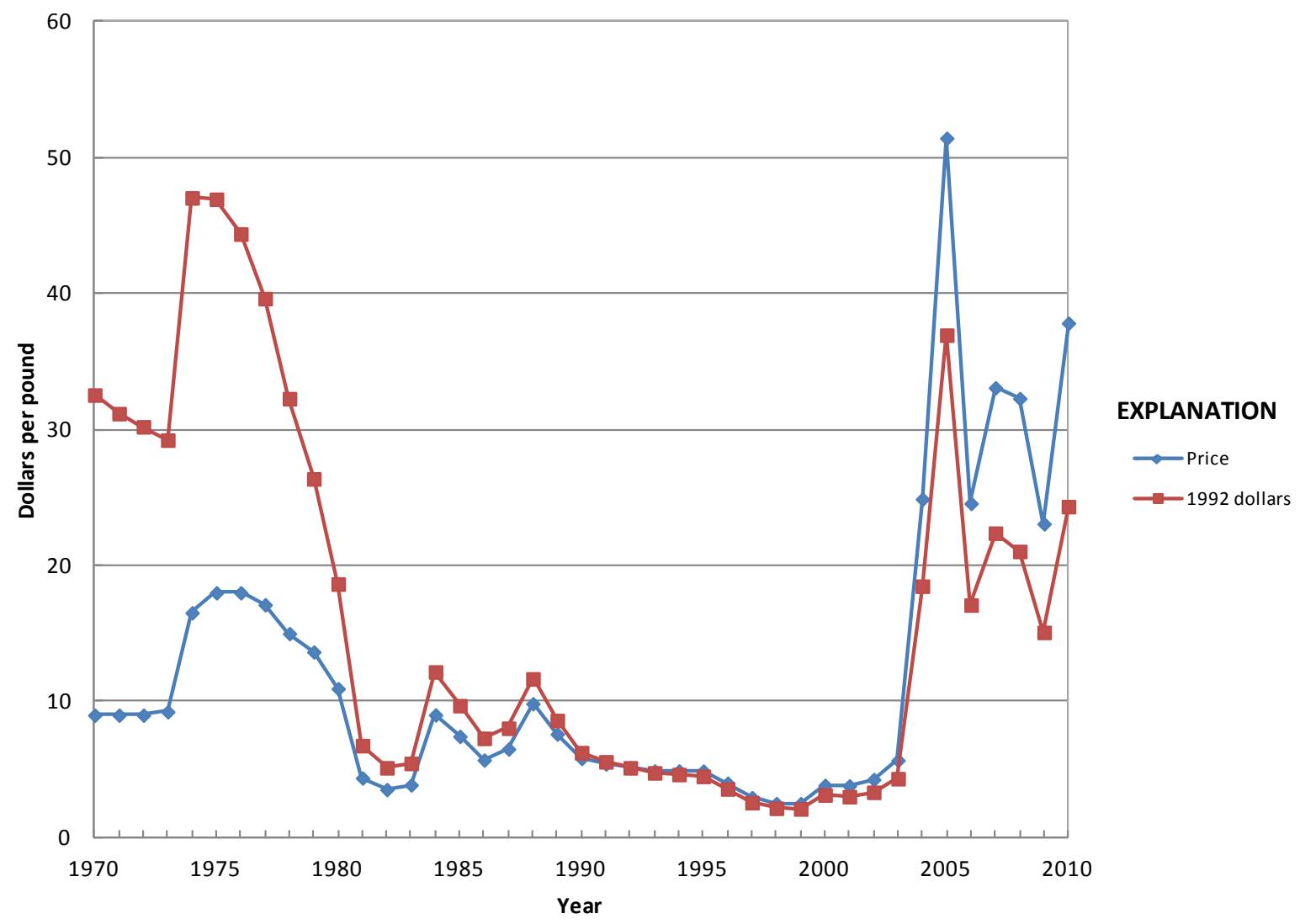

Figure 1. Average annual commercial-grade selenium price.

\section{Significant events affecting selenium prices since 1970}

1974-76 Government stocks liquidated by 1974; low commercial inventories; reduced domestic production from recession and copper industry strike; increased import dependence; continued growth in plain-paper copiers

1976-80 Stock buildup and reduced demand following 1973-75 recession; production level is established at about one-half of 1969 peak

1981-83 Demand surged; stocks remained high; plain-paper copiers and glass manufacturing dominate demand

1984-89 World stocks declined as demand outstrips production; speculation encouraged price fluctuations; domestic demand averaged 1.3 million pounds

1990-91 World production rose; demand slackened owing to recession; stock decline was reversed

1990-99 Organic photoreceptor compounds replaced selenium compounds for plain-paper copiers

2003-10 Increased but fluctuating demand from manganese producers in China; global financial crisis in 2008 reduced demand but supplies remained tight, and prices remained relatively high 
Table 1. Annual average commercial-grade selenium price.

[Values in dollars per pound. NA Not available]

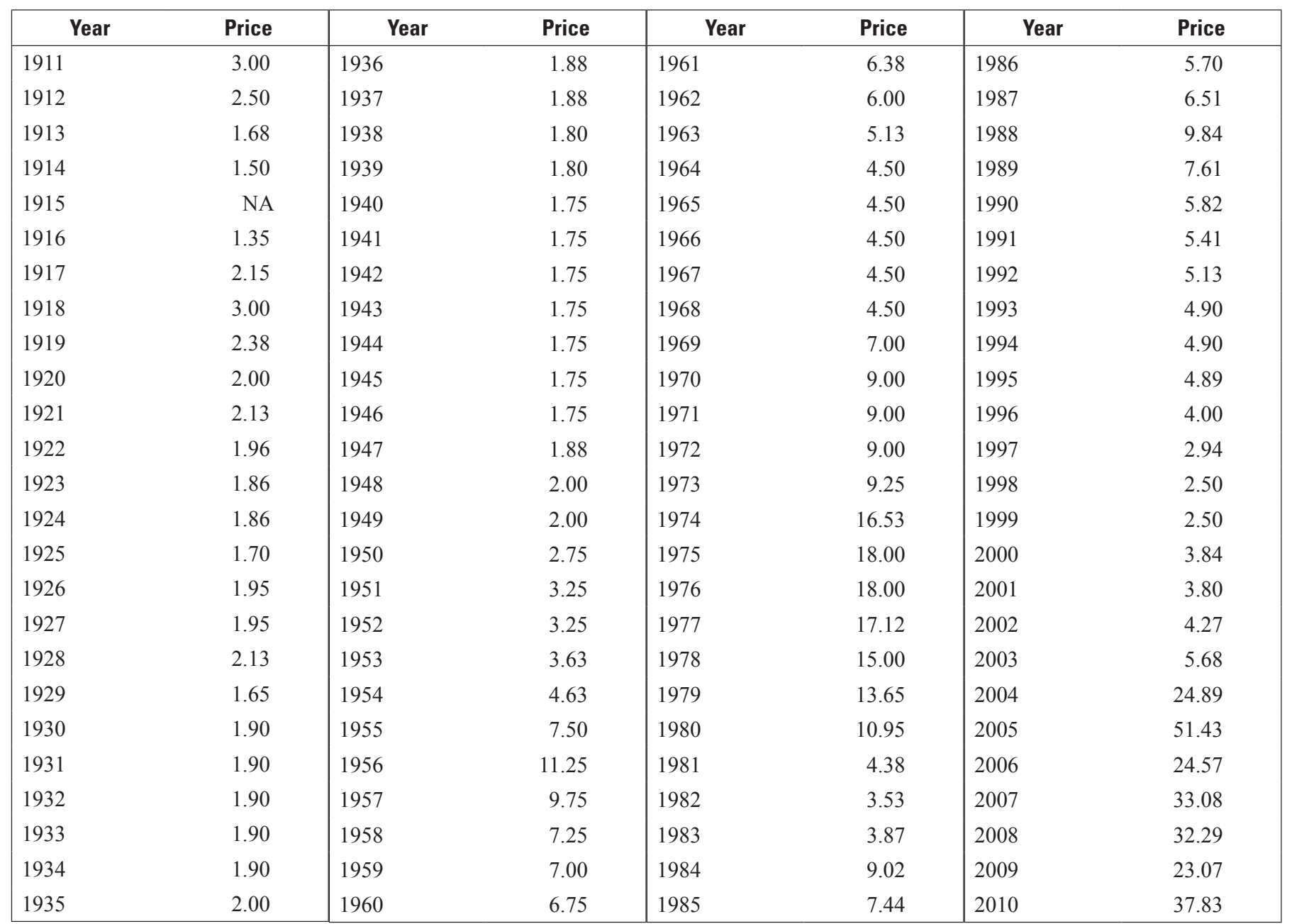

Notes:

1911-20, Domestic price for 99.5-percent-pure selenium powder, in U.S. Geological Survey, Mineral Resources of the United States. 1921-36, Domestic price for 99.5-percent-pure selenium powder, in Engineering and Mining Journal.

1937-66, Domestic price for 99.5-percent-pure selenium powder, in Engineering and Mining Journal, Metal and Mineral Markets. 1967-93, New York dealer price for 99.5-percent-pure selenium powder, in Metals Week.

1993-2010, New York dealer price for 99.5-percent-pure selenium powder, in Platts Metals Week. 


\title{
Silicon (Si)
}

\author{
by Lisa A. Corathers
}

From antiquity, silicon has been of great importance to humankind. Implements made from flint, a variety of quartz (silicon dioxide), were among the first tools and weapons. The use of silicates for pottery dates back to earliest human history, and for glass goes back to about 12,000 B.C. In 1824, Jöns Jacob Berzelius first prepared amorphous silicon by passing silicon tetrachloride over heated potassium.

Silicon is a light chemical element with metallic and nonmetallic characteristics. It is second in importance to manganese in steelmaking. In the form of ferrosilicon, silicon is used for deoxidizing and as a strengthening alloy in the production of iron and steel. Silicon metal is used primarily in the aluminum and chemical industries.

Silicon use as a ferroalloy in the production of steel and cast iron was established late in the 19th century. Silvery pig iron, a silicon ferroalloy generally containing less than 20 percent silicon, was produced by blast furnaces in the 1890s. By the start of the 20th century, electric furnace technology was also used to produce silvery pig iron, as well as ferroalloys with higher nominal silicon content of between 50 percent and 75 percent, and silicon metal. Growth in production and use of silicon ferroalloys was driven by World Wars I and II. Use of ferrosilicon paralleled domestic raw steel production, which increased approximately 7.5 times during the 20th century.

The first significant use of silicon metal as a bulk element occurred around 1920 when it was alloyed with aluminum. After aluminum castings, the second largest use for silicon metal has been in the production of silicones and related chemicals; this began in the 1930s and accelerated during World War II. Since shortly after World War II, relatively small amounts of silicon metal in high-value, high-purity forms have been used in electronic devices, a prime example of which is computer chips.

Principal factors in the cost of silicon and ferrosilicon production are the delivered costs of the ore (quartz or quartzite) and the costs of energy, reductant coke or low ash coal, iron in the form of steel scrap (if required), and labor. These costs, and particularly that of energy, have increased rapidly since 1970. In addition, capital costs for pollution-control equipment have become customary. Bulk ferroalloys produced in submerged arc furnaces are extremely power intensive, especially silicon metal and silicon-containing alloys, which can require up to 14,000 kilowatt hours of electric energy per metric ton of silicon contained in the final product (Dosaj, 1997). Energy is the largest cost component in the production of silicon metal and silicon-containing alloys and can account for one-fifth or more of total costs (de Linde, 1995).
Specifications for silicon metal (98 percent to 99 percent silicon) used by the primary aluminum and specialty chemical industries generally are more stringent than those for metal used by the secondary aluminum industry. Price trends for the small quantities of ultra-pure, high-value silicon produced for electronic (greater than 99.9999 percent silicon) or photovoltaic (solar) cell (99.999 percent to 99.9999 percent silicon) applications are not addressed in this chapter. Data for U.S. exports in 2010 indicate that the cost of ultra-pure silicon averaged about as much as 20 times that for metallurgical and chemical uses.

Based on usage and nominal silicon content, the main types of silicon ferroalloys are 50-percent ferrosilicon, 75 -percent ferrosilicon, and specialty grades. The price trends discussed here are for 50-percent ferrosilicon, simply referred to as "ferrosilicon" in the following text (fig. 1). Trends for 75 -percent ferrosilicon have been much the same as that for 50-percent ferrosilicon since at least 1980. Of the specialty grades, the most important is perhaps magnesium ferrosilicon. Metals Week discontinued publication of magnesium ferrosilicon prices in 1978, followed by American Metal Market in February 2002.

Silicon material prices are quoted in terms of silicon content, and for the United States, the price unit is cents per pound of contained silicon. Silicon metal prices are higher than those for ferrosilicon because silicon metal contains more silicon units and these take more energy to produce. From 1959 through 2010, the ratio for the price of silicon contained in metal to that contained in ferrosilicon fluctuated considerably, averaging about 1.42 (table 1).

Most of the prices presented here were published by Engineering and Mining Journal, Metal and Minerals Markets and its successors (Metals Week in 1967 and Platt's Metals Week in 1993). The updating of U.S. producer prices ended in about 1991, and their listing was formally suspended in 1996. Since 1999, Ryan's Notes has been the sole source of 50-percent ferrosilicon prices following discontinuation by Platts Metals Week. Both Platts Metals Week and Ryan's Notes canvass dealers to provide spot-market prices. The price basis for imports has always been bulk lots, free on board (f.o.b.) shipping point for producers and f.o.b. warehouse, duty paid, for dealer quotes. Silicon metal prices generally have been for metal with a typical iron content of 1 percent.

Consumption of metallurgical-grade silicon alloys and metal in the short term is influenced less by prices than by manufacturing requirements of the aluminum, chemical, ferrous foundry, and steel industries. As a result, silicon material prices tend to vary widely with changes in supply and demand 
by these industries. The price-versus-time curves for ferrosilicon and silicon were quite similar from 1970 through 2010. For both materials, prices rose steeply in 1974 and peaked markedly in 1988, 1996, and 2008. Since 1974, prices have grown at a compound annual rate of about 3.1 percent. This rate is lower than the general rate of inflation as given by the Consumer Price Index (all urban consumers), which advanced since 1974 at an average of 7.4 percent per year, and since the early 1980 s at about 3.5 percent per year.

Prices began to rise in the early 1970 s owing to higher costs of electric power, metallurgical-grade coal, and scrap iron, and the cost of newly installed pollution control devices to comply with governmental standards, which became effective in 1975 (Murphy and Brown, 1985). Prices for silicon materials increased sharply after Government controls imposed on ferroalloy prices were lifted in early 1974. Prices rose steadily from 1977 through 1981 in response to increased consumption, rising inflation, and higher energy costs (fig. 2; table 2).

The 1988 price peaks were attributable to stronger consumption in the aluminum, iron and steel, and specialty chemical industries, and by the end of the year, domestic silicon material producers were operating close to capacity (Gambogi, 1990). Increased consumption and rising prices persuaded some producers throughout the world to restart existing facilities and to make plans for future expansion. By yearend 1990, however, the then-record high prices of 1988 had declined significantly. The sudden decline in prices was caused mainly by oversupply of material resulting from the reactivation of idle capacity, development of new capacity in South America, and escalation of low cost imports from China, South America, and the Soviet Union. As a result of world oversupply, several domestic producers scaled back production.

During 1989 through 1991, a number of domestic producers of silicon materials were alleged to have engaged in price fixing. As a result of the investigation of these charges by the U.S. Department of Justice, two firms pled guilty and received fines in 1995-96 for price fixing of ferrosilicon (Jones, 1998). In 1997, a third firm was found guilty of price fixing of ferrosilicon (Megregian and others, 1998).

In the 1990s, silicon material prices were influenced by the imposition of protective tariffs. Starting in 1980, imports of silicon metal and silicon ferroalloys captured an increasingly large share of the U.S. market, with a resultant decline in U.S. productive capacity utilization. By the late 1980 s, domestic producers had petitioned the U.S. Department of Commerce and the U.S. International Trade Commission for relief from alleged dumping of silicon metal imports from Argentina, Brazil, and China. In mid-1991, the two agencies concluded their investigations and imposed antidumping duties. For ferrosilicon, a similar sequence of events resulted in the imposition of antidumping duties in 1993-94 on a number of foreign sources. In subsequent years, at least some of these duties have been the subject of annual administrative reviews and court challenges that led, in certain cases, to revision or elimination of the duties.
The 1996 price peaks for ferrosilicon and silicon metal, as well as those in 1988, roughly coincided with upturns in world steel production, indicating a period of strong demand. Prices subsequently decreased from 1998 to 2001, partly as a result of the deteriorating economic conditions in Asia and Russia, and partly because of relatively low growth in domestic steel production and declining consumption in the aluminum industry caused by a downturn in U.S. economic conditions.

Between 2000 and 2010, U.S. ferrosilicon and silicon metal prices were affected by domestic industry consolidation, increased import prices, fluctuating worldwide economic conditions, and increased global vertical integration of silicon material production by principal consumers. The first significant trend was the marked decrease in the number of domestic producers and plants, primarily as a result of increased global competition. In 2006, there were only 3 ferrosilicon producers operating at 4 plants, down from 10 producers and 13 plants in 1987. Similarly, there were two silicon metal companies producing at four plants in 2006; in 1987, there were nine companies and nine plants.

While U.S. ferrosilicon and silicon metal production decreased in the first decade of the 2000s, U.S. consumption of silicon materials did not. The country, therefore, had to rely on ever-increasing imports of these materials. In 2006, ferrosilicon and silicon metal imports, respectively, were 42 percent and 303 percent more than those in 1987. General rates of duties were applied on imports of all ferrosilicon and silicon metal (excluding the ultra high-purity grade) unless waived for a particular foreign company via the General System of Preferences or specific free trade agreement, or when a U.S. company's plant was granted foreign-trade-zone status. In 2007 and 2008, China increased tariffs on ferrosilicon and silicon metal exports, which led to higher costs of these materials imported into the United States. U.S. antidumping duties generally continued to be assessed on silicon metal imports from Brazil, China, and Russia.

Despite the economic downturn that began during the third quarter of 2008, both ferrosilicon and silicon metal prices were at an alltime average high in 2008. This was primarily attributed to increased domestic and worldwide demand and concerns over tightening supplies. Prices for ferrosilicon rose earlier in the year mainly because of higher domestic steel consumption coupled with tightening supplies brought on by increased world raw steel production, particularly by the BRIC countries. Higher silicon metal prices in the United States were ascribed to supply concerns that arose from power shortages affecting major suppliers-Brazil, China, and South Africa (Corathers, 2010).

The U.S. and global economic crises that began in late 2008 eventually brought about a decline in global demand for aluminum, chemicals, and steel. World apparent consumption of aluminum, chemicals, and steel declined in 2009, as did production. Ferrosilicon and silicon metal prices decreased significantly from late 2008 through 2009, and then rebounded significantly in 2010 as the world economy began to recover, 
and aluminum, chemical, and steel production increased globally.

The 2010 price increases were also supported by a reduction in silicon material inventories available to the world market caused by increasing vertical integration of silicon producers by primary consumers. U.S. silicone manufacturer Dow Corning Corporation serves as a good example of this. In 2009, Dow Corning acquired the Globe Metais SA silicon metal plant in Brue Branco, Brazil, from Globe Specialty Metals, Inc. (GSM; owner of U.S.-based silicon producer Globe Metallurgical, Inc.). The plant production capacity was 43,600 metric tons per year $(\mathrm{t} / \mathrm{yr})$. Also in 2009, Dow Corning formed a joint venture with GSM - WVA Manufacturing LLC - at GSM's 67,000-t/yr silicon metal facility in Alloy, W. Va. GSM retained 51-percent ownership in, and operational control of, the plant; production was split proportionally between the two companies. Dow Corning continued acquiring silicon metal production capability by forming a joint venture in 2010 with Canada's Timminco Limited, known as Quebec Silicon, to produce silicon metal at Timminco's Becancour Silicon Inc. plant in Becancour, Quebec. Timminco retained 51-percent ownership in, and operational control of, the plant; production, initially set at $47,000 \mathrm{t} / \mathrm{yr}$, was split proportionally between the two companies (Corathers, 2011).

Vertical integration continues in the silicon industry, thereby reducing inventory and putting upward pressure on prices. Another chemical material producer, Germany's Wacker Chemie AG, acquired the Holla Metall silicon metal plant in Norway from Fesil in 2010. As a result, one-third of Wacker's annual silicon metal needs were met, and up to 20 percent of silicon metal was removed from the European spot market (Corathers, 2011). In 2010, chemical producer China National Bluestar Group Co., Ltd. arranged to purchase silicon-material producer Elkem AS from Norwegian Orkla AS; the sale was finalized in 2011 (Orkla ASA, 2011).

\section{References Cited}

Corathers, L.A., 2010, Silicon, in Metals and minerals:

U.S. Geological Survey Minerals Yearbook 2008, v. I, p. 67.1-67.15.
Corathers, L.A., 2011, Silicon, in Metals and minerals: U.S. Geological Survey Minerals Yearbook 2009, v. I, p. 67.167.13 .

de Linde, J.P., 1995, Ferroalloy markets, in Tuset, J.K., Tveit, H., and Page, I.G., eds., INFACON 7-Proceedings of the Seventh International Ferroalloys Congress, Trondheim, Norway, June 11-14, 1995: Trondheim, Norwegian Ferroalloy Research Organization, p. 39-62.

Dosaj, Vishu, 1997, Silicon and silicon alloys-Chemical and metallurgical, in Kroschwitz, J.I., and Howe-Grant, Mary, eds., Kirk-Othmer encyclopedia of chemical technology (4th ed.): New York, John Wiley \& Sons, v. 21, p. $1,104-1,122$.

Gambogi, Joseph, 1990, Silicon, in Metals and minerals: U.S. Bureau of Mines Minerals Yearbook 1988, v. I, p. 845-853.

Jones, T.S., 1998, Silicon, in Metals and minerals: U.S. Geological Survey Minerals Yearbook 1996, v. I, p. 783-791.

Megregian, S.S., Babbitz, Todd, and Kress, Carl, 1998, Antitrust and trade developments in the metals and mining industries: Ryan's Notes 1998 Ferroalloy Conference, Boca Raton, Fla., October 25-27, 1998, handout of talk presented, unpaginated.

Murphy, G.F., and Brown, R.E., 1985, Silicon, in Mineral facts and problems: U.S. Bureau of Mines Bulletin 675, p. $713-728$.

Orkla ASA, 2011, Fourth quarter 2010 report: Oslo, Norway, Orkla ASA, February 9, 15 p., accessed August 6, 2011, at http://hugin.info/111/R/1487483/422955.pdf. 


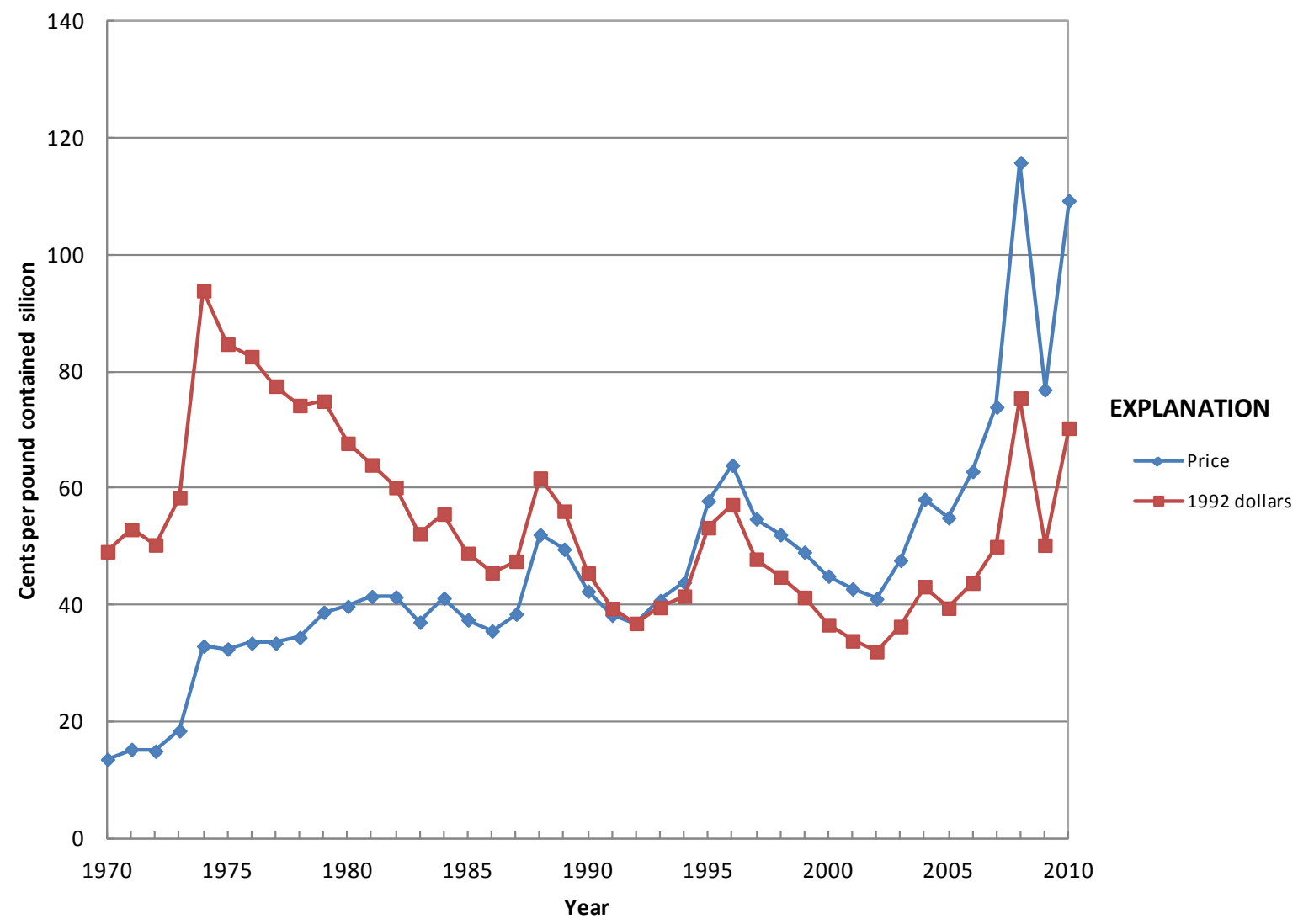

Figure 1. Average annual 50-percent ferrosilicon price.

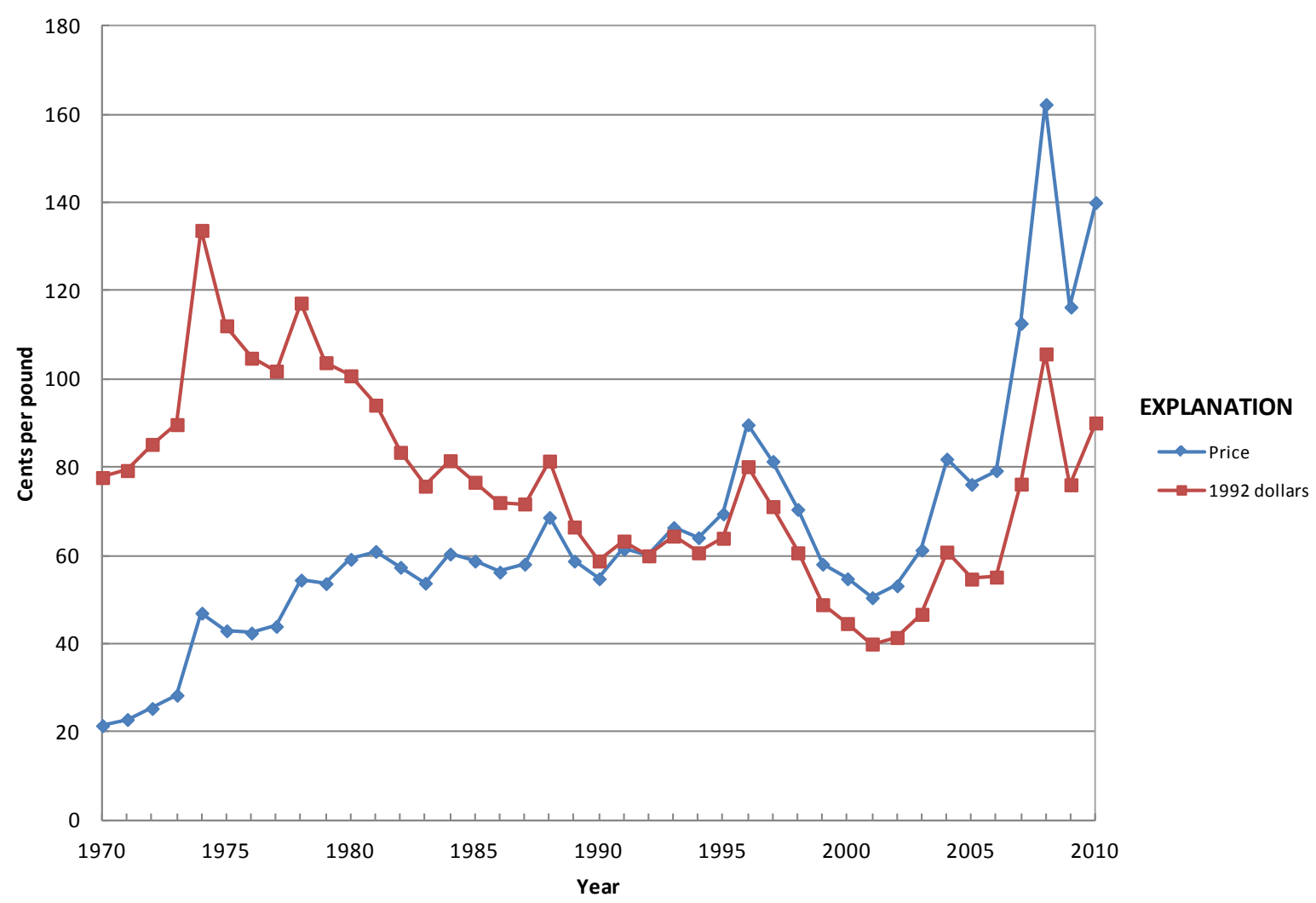

Figure 2. Annual average silicon metal price. 


\section{Significant events affecting silicon prices since 1970}

$1974 \quad$ Lifting of Government price controls

1980s Imports of silicon materials captured a growing share of U.S. market

1988 Strength in production by principal intermediate consuming industries, such as steel

1991-94 Antidumping duties first assessed on U.S. ferrosilicon and silicon metal imports

1996 Period of strong consumption

1997-99 Asian financial crisis

2000-10 U.S. ferrosilicon and silicon metal industries contraction

2006-08 Increased raw steel production by Brazil, Russia, India, and China (the BRIC countries)

2008-09 Global financial crisis

2010 Worldwide vertical integration of ferrosilicon and silicon metal plants

Table 1. Annual average 50-percent ferrosilicon price.

[Values in cents per pound contained silicon]

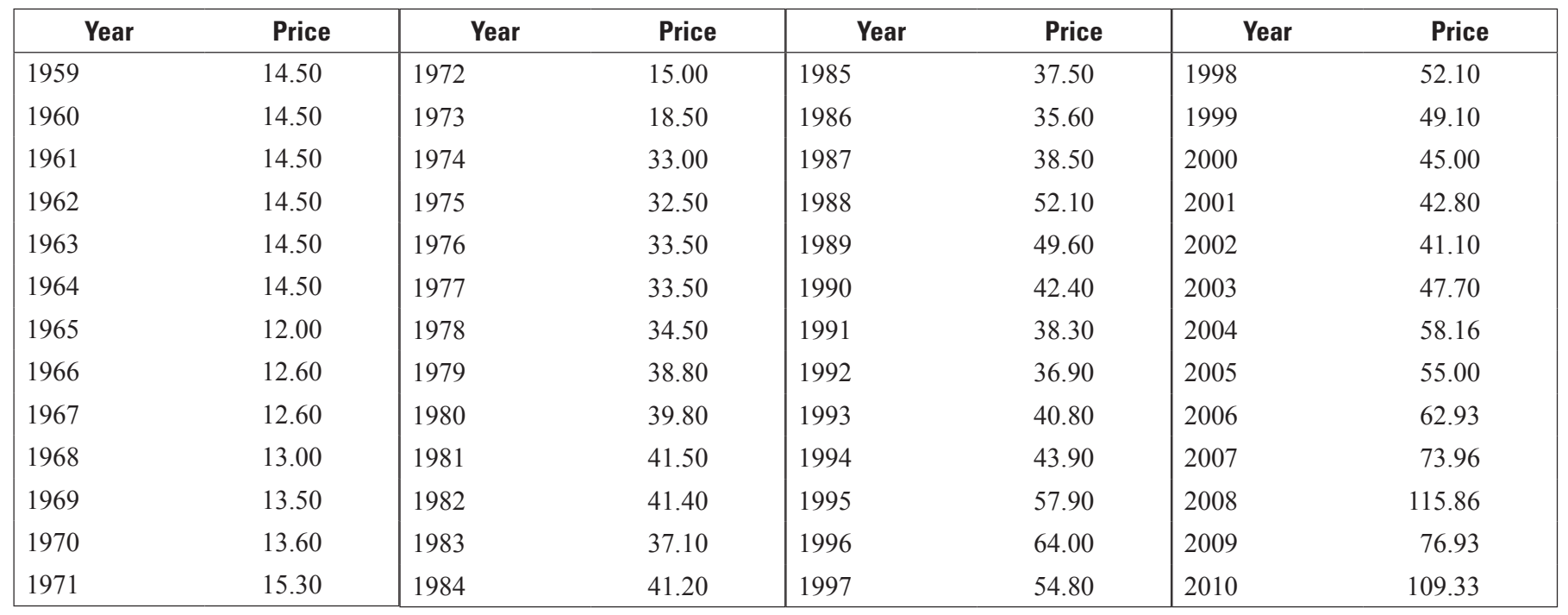

Notes:

1959-66, U.S. producer price, in Engineering and Mining Journal, Metal and Mineral Markets.

1967-79, U.S. producer price, in Metals Week.

1980-93, U.S. dealer import price, in Metals Week.

1993-98, U.S. dealer import price, in Platts (Platt's) Metals Week.

1999-2010, North American transaction price, in Ryan's Notes. 
Table 2. Annual average silicon metal price.

[Values in cents per pound contained silicon]

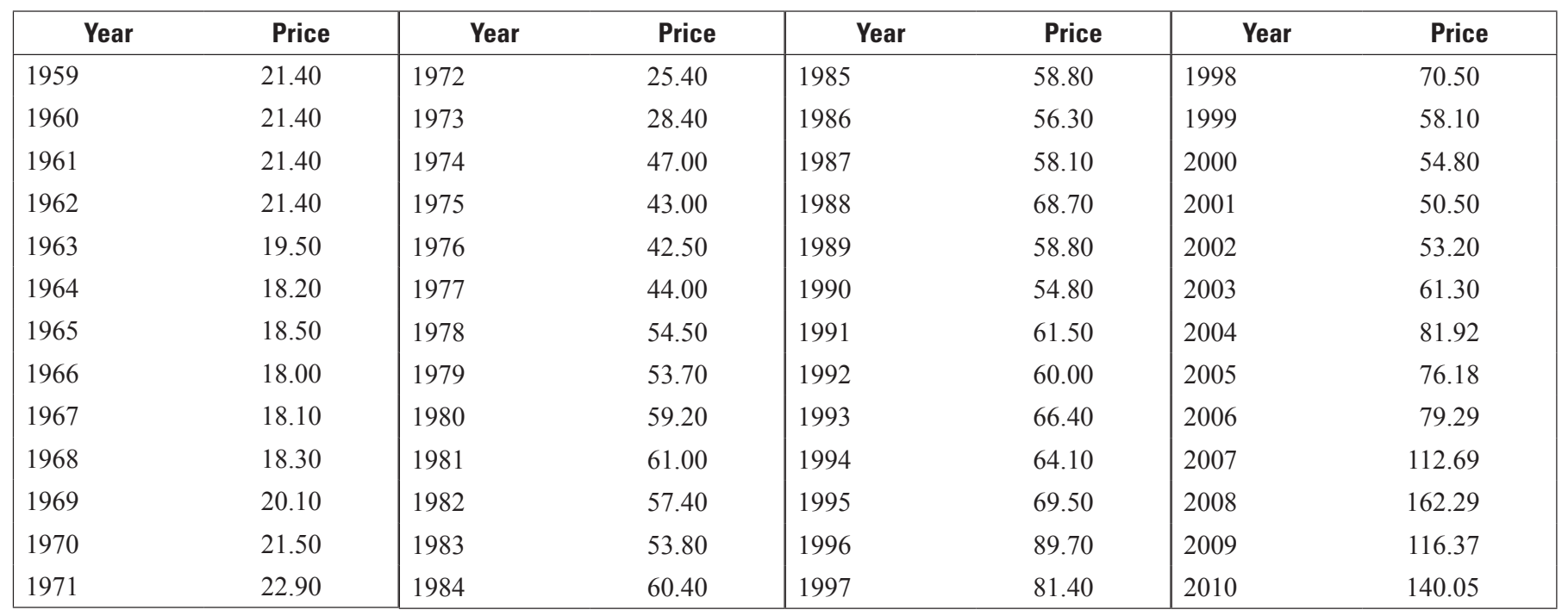

Notes:

1959-66, U.S. producer price, in Engineering and Mining Journal, Metal and Mineral Markets.

1967-79, U.S. producer price, in Metals Week.

1980-93, U.S. dealer import price, in Metals Week.

1993-2010, U.S. dealer import price, in Platts (Platt's) Metals Week. 


\title{
Silver (Ag)
}

\author{
by William E. Brooks
}

Silver has been traded and used for thousands of years as ornaments and utensils, and as the basis of many monetary systems. The metal has played an important part in world history. Silver from the mines at Laurion, Greece, for example, financed the Greek victory over the Persians in 480 B.C. Silver from Potosi, Bolivia, helped Spain become a world power in the 16th and 17th centuries. Also, silver from the gold-silver ores at the Comstock Lode in Virginia City, Nev., helped keep the Union solvent during the Civil War.

The primary source of silver is argentiferous galena, as it is relatively abundant and relatively easy to smelt. However, there are many other ores of silver, including acanthite, anglesite, argentite, cerargyrite, cerussite, proustite, pyragyrite and stephanite, and it also occurs as a native metal. Silver may be present in many geologic environments, and byproduct silver may be obtained from the processing of copper, gold, and lead-zinc ores. More than two-thirds of U.S. and world resources are contained in such polymetallic deposits and the remainder is found in silver deposits.

Pure silver has the whitest color, the highest optical reflectivity, and the highest thermal and electrical conductivity of all the metals. Silver halides are photosensitive; however, the use of silver in photographic applications has declined since its peak in 1999 because of increased use of digital cameras. Owing to its physical properties, silver has many industrial applications, such as in brazing and soldering, catalytic converters, food packaging, wood preservatives, and increasing use in electronics applications. It is a biocide and its use in wound care and medical applications has also increased. It is also used as a catalyst in oxidation reactions; for example, in the production of formaldehyde from methanol and air (Butts and Coxe, 1967, p. 1-15).

Most of the silver mined today is produced as a byproduct of precious or base metals, primarily lead and zinc. Leading silver-producing countries include Mexico, Peru, and China. In the United States, the leading silver-producing State is Alaska, where silver is produced as a byproduct from leadzinc mining.

There are two types of markets for silver - physical markets and futures exchanges. It is possible for these markets to overlap if the buyers of futures contracts take delivery of silver metal when the contracts mature. A notable example of this was in the early 1980s when two buyers and their associates took delivery of millions of ounces of silver when their futures contract matured. Physical markets are operated by bullion dealers, banks, and commodity dealers. Silver is bought from mines and refineries and sold to consumers and brokers to supply industrial and investment demand. The London Bullion
Market, which had its origins in the 17 th century, was the leading physical market until about 1960, when it was overtaken in importance by the New York Market. The London Market fixes a daily price, at which all orders to buy or sell silver can be matched. The New York Market price for silver is the Handy \& Harman quote for unfabricated silver, which the company announces daily at noon. That is the lowest price at which offers can be obtained by Handy \& Harman for silver in commercial bar form. The Handy \& Harman price and the London fixing are for 99.9-percent-pure silver.

Prior to World War II, the major uses for silver, other than in coinage, were for jewelry and sterlingware. During the war, technological advances were made in electronics and photography and after the war, this technology was used to develop new consumer products. Owing to the shortage of copper during World War II, 13,500 tons of silver was borrowed from the U.S. Treasury. The silver was processed and used as conductive wiring, in place of copper, in the electromagnets necessary for uranium enrichment as a part of atomic bomb production. The silver was recovered and then returned to the Treasury.

As the demand for consumer goods increased, so did the demand for silver, and, as a result, the market price increased. The higher market price, however, did not result in increased mine production. The Silver Act of 1946 authorized the U.S. Treasury to purchase domestically mined silver at $\$ 0.905$ per troy ounce and to sell its silver holdings at $\$ 0.91$ per ounce. Through the first half of the 1950s, the market price remained below $\$ 0.91$ per ounce, so domestic mine operators sold their silver to the Treasury (table 1). In the second half of the 1950s, the continued increase in industrial demand for silver and static mine production resulted in the market price increasing to $\$ 0.91$ per ounce and Treasury silver sales were the largest source of silver for industrial consumers (National Academy of Sciences, 1968).

In the late 1950 s and early 1960 s, a second component was added to the demand side of the supply-demand equation - the investor speculator. The silver certificates authorized by the Silver Purchase Act of 1934 were redeemable for silver held by the Treasury. At a market price above $\$ 1.29$, a profit could be made by redeeming the silver certificates, receiving 0.77 ounce of silver from the Treasury, and then selling the silver. In addition, at a market price above $\$ 1.38$, a profit could be made by melting U.S. circulating coinage for its silver content. Realizing that it could not continue to supply industrial consumers with silver, mint coinage, and maintain a stock of silver for redemption of silver certificates, the Government began a program to demonetize silver. Public Law 88-36, which repealed the Silver Purchase Act of 1934 and authorized 
the printing of Federal Reserve Notes not redeemable in silver, was passed in mid-1963. The Coinage Act of 1965 eliminated the use of silver in dimes and quarters and reduced the silver content of half dollars. In 1967, silver coins were withdrawn from circulation, and holders of silver certificates were given 1 year, until June 24, 1968, to redeem the certificates for silver (Silver Institute, The, 1990, p. 6-7).

With the ending of the relationship between silver and the U.S. monetary system in 1968, investor speculator activities and industrial demand became the main determinants of movement in the silver market price. From 1968 through 1971, the price declined, owing in part to an economic recession in the United States and an attempt by the Government to stabilize the price of silver. From 1972 through 1975, the average price increased, owing to such factors as the devaluation of the U.S. dollar and an embargo of oil exports by the Organization of Petroleum Exporting Countries (fig. 1). Prices also increased from 1976 through 1980. Analysts attributed this 5-year period of higher average prices to such factors as a high domestic inflation rate combined with slow growth in U.S. economic activity, another "oil crisis," a U.S. economic recession that began in 1979, and an attempt by a group of investors to "corner" the silver market (Roskill Information Services Ltd., 1984, p. 190-203). By early 1981, the silver market was beginning to adjust to the upward pressure placed on prices in 1979 through 1980. Owing to worldwide recession and reaction to higher silver prices, industrial demand for silver was in decline, and investment demand for silver fell sharply. Supply also fell as the surge of secondary recovery from old scrap and coin remelting subsided. Silver prices reached a cyclical low of $\$ 4.88$ per ounce in June 1982,10 percent of the $\$ 48$ peak 30 months earlier. Because of panic in the financial markets and fear of inflation, investment demand for silver increased sharply in late 1982 and the first quarter of 1983. This influx of investor buying helped push silver prices from the low of $\$ 4.88$ in June 1982 to a peak of \$14.74 in February 1983. In March, this rapid rise in price (the price nearly tripled in 9 months) was reversed as investors took profits and industrial users developed new methods that reduced their per-unit use of silver, substituting lower priced materials for silver. Prices recovered during the summer, but the trend was downward from the fourth quarter of 1983 through 1986. Lower prices discouraged the secondary recovery of silver and forced lessefficient mines to close. On the demand side, lower prices relieved the pressure to use less silver or to use lower cost substitutes for silver in products. After starting 1987 at $\$ 5.44$ per ounce, prices reached a low of $\$ 5.36$ on January 7. Prices increased through the remainder of the year, reaching a high of $\$ 10.20$ on April 27 but closing out the year at $\$ 7.20$. The annual average price for 1987 was $\$ 7.01$ per ounce, the first increase in 4 years.

Owing to various market and economic conditions, the annual average price of silver declined from $\$ 7.01$ per ounce in 1987 to a low of $\$ 3.94$ in 1992 before increasing slightly to $\$ 4.30$ in 1993. Prices began to increase in the first quarter of 1994, reaching \$5.75 per ounce on March 28. The upward momentum was caused by political unrest in Mexico, the world's largest producer, and reports of large shipments to India. In April 1994, prices slipped rapidly to around $\$ 5.00$ per ounce as Indian demand slowed and large supplies from Russia and other East European countries appeared in the market. In September, prices increased again to $\$ 5.71$ per ounce before collapsing to $\$ 4.90$ on November 30. Prices in 1995 were not quite as volatile as in 1994, but the downward trend that began in April 1994 continued (Silver Institute, The, 1995, p. 8-15).

For centuries, the price of silver has been closely coupled with the price of gold, but the demonetization of both metals in much of the world has weakened the link. Throughout most of 1996, the price of silver was adversely affected by the poor performance of gold. Toward the end of 1996, however, the price of silver began to deviate from the price of gold, owing to investors' and speculators' adoption of distinctly different positions in the two markets. This decoupling process continued into 1997, and although the gold market continued to influence the price of silver, the trend in the metals' prices indicated that a total decoupling may have been in the making.

In the first 2 months of 1997, the price of gold decreased by 2 percent and the price of silver also decreased to a 2-year low of $\$ 4.65$ per ounce in the first week of January. By early July, the gold price had decreased to $\$ 315$ per ounce, a 12-year low, and silver decreased to $\$ 4.21$ per ounce on July 17 , its low for the year. By October 1997, gold fell to a 12-year low of $\$ 308$ per ounce; however, the price for silver closed above $\$ 4.60$ per ounce. By late November, gold fell below $\$ 300$ per ounce while the silver price increased to more than $\$ 5.30$. By December 1, the price of silver had increased to $\$ 5.83$, as above-ground stocks of silver declined to the lowest level in many years. The price of silver reached its high on December 24 at $\$ 6.24$ per ounce and the yearend price was $\$ 5.95$ per ounce.

In early February 1998, silver prices rose to a 9-year high of $\$ 7.13$ per ounce after it became known that a U.S. investment firm had purchased 3,978 metric tons of the metal after having made its first purchase in July 1997, when the price was less than $\$ 4.50$ per ounce. By the end of the month, the silver price was $\$ 6.15$ per ounce and prices continued to fall to a low of about $\$ 4.70$ at the end of August. The yearend silver price was $\$ 5.05$ per ounce.

In early 1999 , the silver price increased to $\$ 7.80$ per ounce; however, by yearend, the price was less than $\$ 5.00$ per ounce. The price continued in the $\$ 5.00$ - to $\$ 6.00$-per-ounce range until 2004, when the price increased to as much as $\$ 8.29$ in March; however, by yearend the price was less than $\$ 7.00$ per ounce.

In 2005 , the average silver price was $\$ 7.34$ per ounce, which was 10 percent above the 2004 average price of $\$ 6.69$ per ounce. Prices for copper, gold, and silver all rose significantly during 2005 as part of a boom in mineral commodity investment, and consumption increased at a faster rate than production. 
In April 2006, the silver exchange traded fund (ETF) started trading on the American Stock Exchange. Investors expanded their silver holdings in expectation that the price would increase dramatically upon opening of the ETF. In response, the price of silver increased before the ETF was launched. The silver ETF gave easy access to many investors who had been reluctant or unable to buy silver, and the growth of ETFs has led to an increase in silver investment. One of the most notable effects of the ETF has been the rise in silver prices (Silver Institute, The, 2007, p. 20).

Silver prices have increased owing to investment demand as well as silver's expanded role in the global industrial market. Supply does not appear to be an issue as domestic mine production generally increased from 1,160 metric tons $(t)$ in 2006 to approximately $1,280 \mathrm{t}$ in 2010 . In 1990 , industrial demand was $8,490 \mathrm{t}$, or 39 percent of total fabrication demand, and in 2007, industrial demand had risen to $14,460 \mathrm{t}$ or 55 percent of total silver fabrication demand (Silver Institute, The, 2010, p. 5). The industrial applications of silver include batteries, brazing alloys and solders, catalytic converters, electronics, food packaging, medical uses and wound care, nanosilver, photovoltaics, polyester production from ethylene oxide, radio frequency identification devices (RFIDs), silver inks, supercapacitors, and water purification. The daily price of silver for the month of December peaked at $\$ 30.64$ on December 31; however, the average price of silver at yearend 2010 was $\$ 17.75$.

\section{References Cited}

Butts, A., and Coxe, C.D., 1967, Silver-Economics, metallurgy, and use: Princeton, N.J., Van Nostrand, 488 p.

National Academy of Sciences, 1968, Trends in usage of silver: National Academy of Sciences Publication MAB-24, $15 \mathrm{p}$.

Roskill Information Services Ltd., 1984, The economics of silver ( 3 d ed.): London, Roskill Information Services Ltd., $203 \mathrm{p}$.

Silver Institute, The, 1990, World silver survey, 1950-1990: Washington, D.C., The Silver Institute, 81 p.

Silver Institute, The, 1995, World silver survey, 1995: Washington, D.C., The Silver Institute, 64 p.

Silver Institute, The, 2007, World silver survey, 2007: Washington, D.C., The Silver Institute, 100 p.

Silver Institute, The, 2010, The future of silver industrial demand: Washington, D.C., The Silver Institute, 32 p.

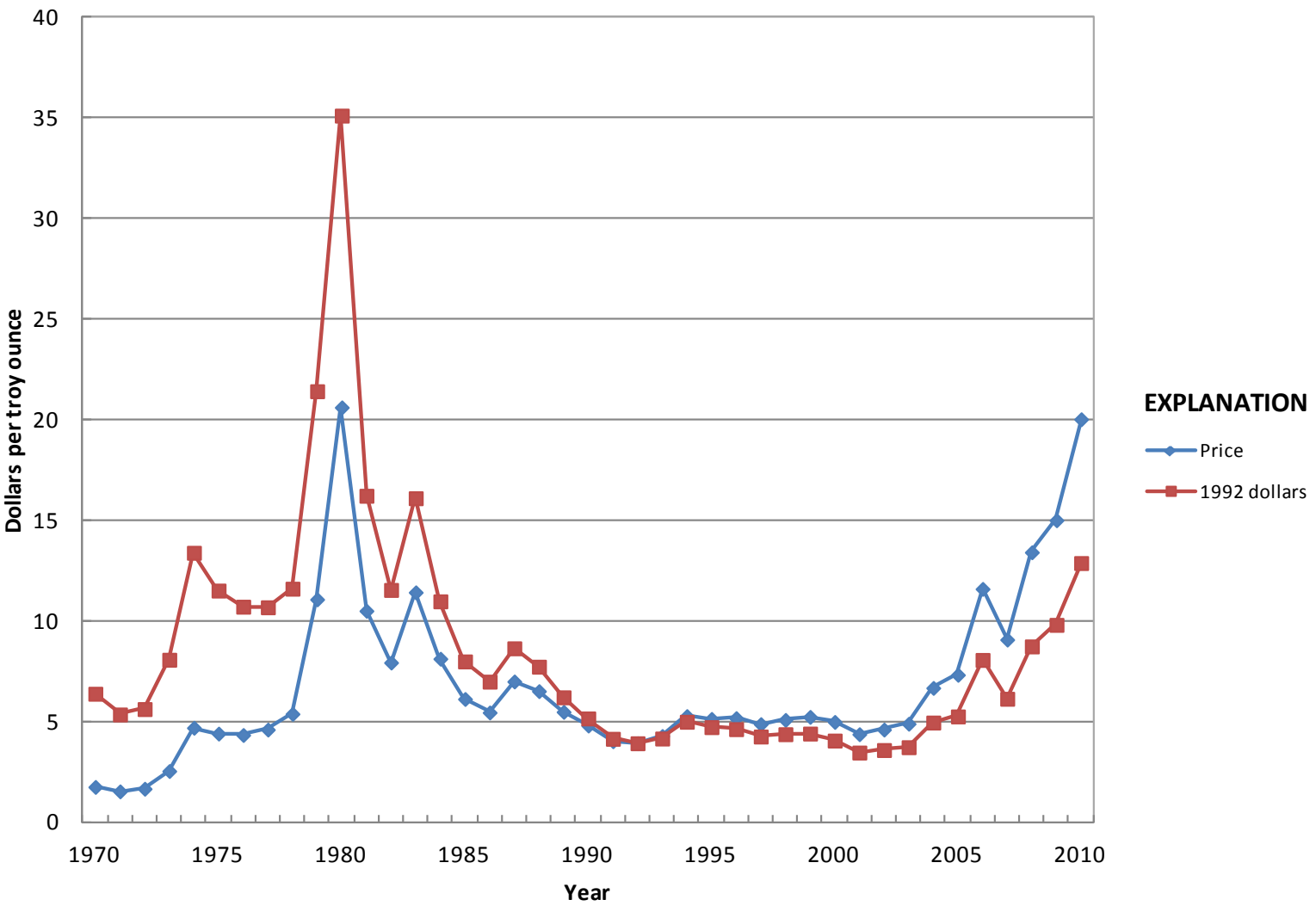

Figure 1. Annual average silver price. 


\section{Significant events affecting silver prices since 1970}

1979-80 Individual investors attempted to corner the silver market

1985 U.S. Mint authorized to begin minting a silver bullion coin

1982-97 U.S. Government disposed of silver in the National Defense Stockpile, using it for production of commemorative coins

1998 Price increased in the first quarter of 1998 following disclosure that an investment firm had accumulated approximately 4,000 metric tons (t) of silver

2006

Highest average price since 1983 owing to investment interest in newly established silver exchange-traded fund (ETF)

1999-2010 Price increased mainly because of investment demand and increased industrial use

Table 1. Annual average silver price.

[Values in dollars per troy ounce]

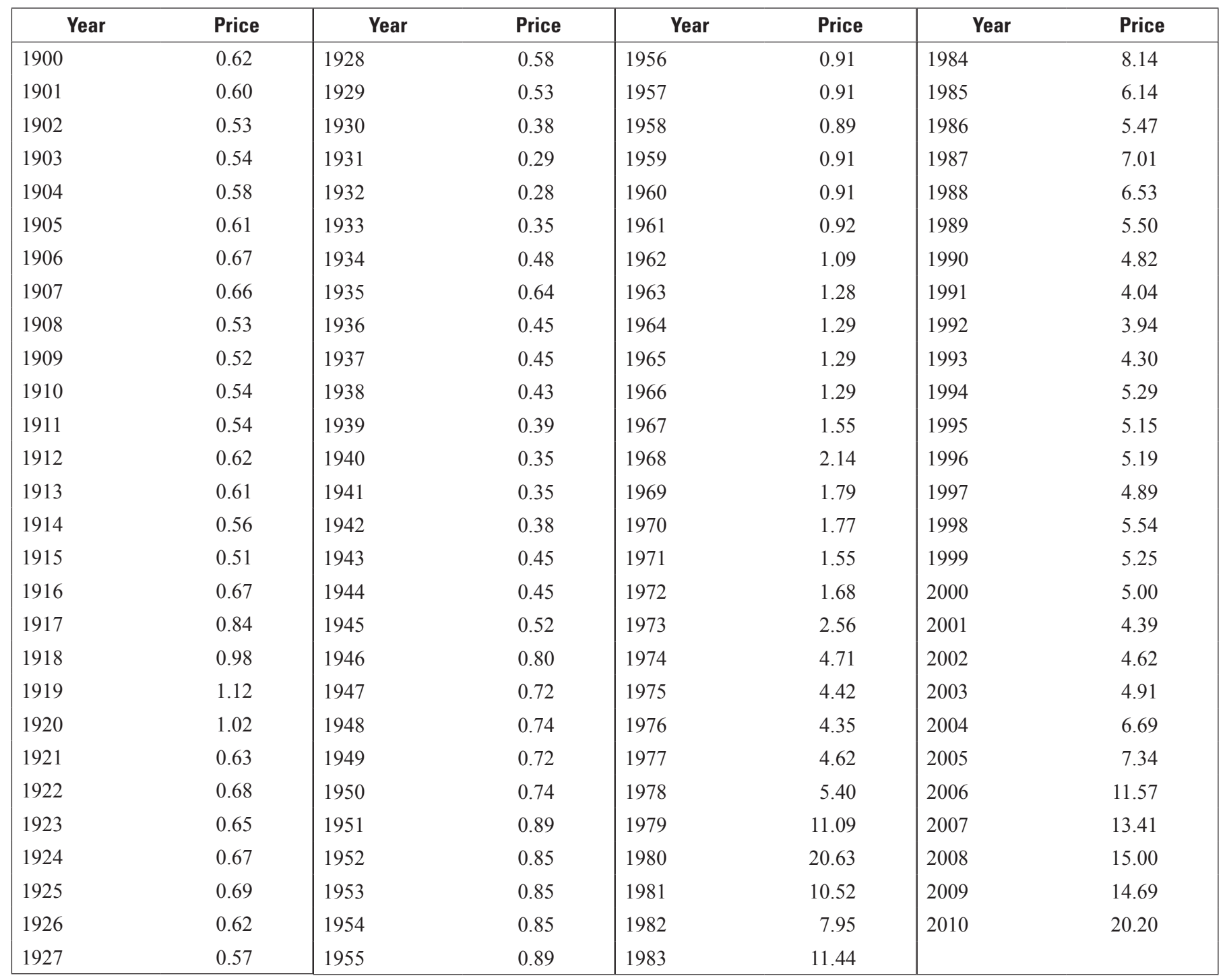

Notes:

1900-74, New York price of 99.9-percent-pure silver, in Silver, U.S. Bureau of Mines Minerals Yearbook 1974.

1974-93, New York price of 99.9-percent-pure silver, in Metals Week.

1993-2010, New York price of 99.9-percent-pure silver, in Platts (Platt's) Metals Week. 


\title{
Tantalum (Ta)
}

\author{
by John F. Papp
}

Tantalum is a refractory metal that is easily fabricated, has a high melting point, is highly resistant to corrosion by acids, and is a good conductor of heat and electricity. Tantalum's first commercial usage was as filament material in incandescent electric lamps in the early 1900s (Miller, 1959). Currently, the major use for tantalum, as tantalum metal powder, is in the production of electronic components, mainly tantalum capacitors. Alloyed with other metals, tantalum is also used in making carbide tools for metalworking equipment and in the production of superalloys for jet engine components. Substitutes, such as aluminum, rhenium, titanium, tungsten, and zirconium, exist for tantalum but are usually made at either a performance or economic penalty.

Tantalum ore (tantalite) is the leading source of tantalum, and the price for tantalum products is mostly affected by events in the supply of and demand for tantalite. Thus, the price for tantalum metal products generally follows the pattern for that of tantalum ore. The price for tantalum metal products is also affected by the size of the order/contract and material specification. The yearend 1998 price for tantalum ore was about $\$ 41.50$ per pound of contained tantalum compared to the selling price for the following tantalum metal products (per pound of contained tantalum) — vacuum-grade metal for superalloys, $\$ 75$ to $\$ 95$; sheet, $\$ 100$ to $\$ 150$; capacitor-grade metal powder, $\$ 135$ to $\$ 240$; and capacitor-grade wire, $\$ 180$ to $\$ 250$.

Australia is the leading producer of tantalum ore. U.S. tantalum mining has not been significant since 1959. The United States satisfies its tantalum requirements primarily by importing tantalum ore from Australia and Brazil and quantities of metal and powders from various countries. Many of the applications for tantalum are either directly or indirectly defense related because of its use in the aerospace, communications, energy, and transportation industries. Thus, tantalum was classified as critical and strategic by the Government of the United States, and during the years, various tantalum materials have been purchased for the National Defense Stockpile (NDS).

A significant activity during the 1950 s was the U.S. Government's worldwide program for the purchase of about 6,800 metric tons $(\mathrm{t})$ of combined niobium and tantalum oxides contained in niobium-tantalum ores. The purchase program was terminated in 1958 (Cunningham, 1985a, b). The program, which was initiated to encourage increased production of niobium-tantalum ores and concentrates of domestic and foreign origin, largely governed the market price for tantalum ore. It also resulted in the discovery of large lowgrade domestic and foreign deposits of tantalum minerals. The program, however, was less successful in developing domestic tantalum mineral production. The low grade of the discoveries precluded their development at the 1958 price or, at that time, expected future prices.

By 1960, tantalum demand for use in aerospace applications, capacitors, corrosion-resistant chemical and nuclear applications, high-temperature alloys, and machine cutting tools had increased substantially. Price peaks in 1961 and 1966 were occasioned by a sudden increase in demand for tantalum, which outstripped the supply, thus driving prices up (table 1). Increased demand stimulated tantalum production. After a leveling off of demand, however, overproduction ensued, resulting in a decline in tantalum prices. The higher cost operations, which had opened in response to the increased demand, closed down, and supply reverted back to previous levels.

The 1970s was a decade of increasing tantalum demand, ore shortages, escalating prices, and substitution. The record price levels during this period were attributed, in part, to a state of panic buying influenced by anticipated increases in tantalum demand amidst concerns of shrinking world tantalum supply (fig. 1). As demand for tantalum increased, some processors foresaw the coming production shortfall and began to stockpile inventories. The net effect was very competitive buying of tantalum feed materials to meet customer needs with associated spiraling prices. The high prices brought about substitution for tantalum and more-widespread search for and development of new tantalum supply sources.

During 1979 to 1980, the price for tantalum ore exploded. Tantalum ore production could not meet market demand, resulting in sustained inventory reduction. With optimistic forecasts of market growth, processors found themselves locked into a bidding contest for available tantalum ore. By yearend 1982, large high-cost inventories of tantalum ore were accumulated as a hedge against perceived future shortages.

During the late 1970s and early 1980s, processors, faced with runaway tantalum ore prices, were forced to pass along a large part of the price increases to end users. Because of escalating tantalum prices, consumers began to substitute alternate products, to decrease tantalum content in products, and to increase recycling to substitute for virgin tantalum materials. These demand-reducing activities were accelerated by the price volatility and resulted in increased inventories. In the consumer electronics sector, tantalum was designed out of some circuits and replaced primarily with aluminum-bearing electronic components.

The tantalum ore price reached a peak at midyear 1980, about $\$ 118$ per pound of contained tantalum pentoxide. By yearend 1980, prices began declining and, by yearend 1986, were the lowest since yearend 1976. The downturn in prices 
was hastened by weak tantalum demand and the overhang of the large inventories of tantalum source materials built up during the early 1980s. Industry sources estimated that these inventories were as high as 5,000 $\mathrm{t}$ of contained tantalum oxide in 1982 (Tantalum-Niobium International Study Center, 1986), a year in which production was estimated to have been $400 \mathrm{t}$ of contained tantalum pentoxide. By 1988, price increases for tantalum ore were again of major concern in the tantalum industry. The yearend 1988 price for tantalum ore of $\$ 50$ per pound of contained tantalum pentoxide was nearly double that of the yearend 1987 price. The price escalation was attributed to increased demand for tantalum ore following a drawdown of the tantalum inventories that had been built up.

The price for tantalum ore continued its cyclic pattern through 1993; thereafter, the price was steady with some moderate increases. From 1990 to 1998, the demand for tantalum remained strong, with increased consumption in most years. Demand was robust in the electronics sector for tantalum capacitors in such products as automotive electronics, pagers, personal computers, portable telephones, and video cameras. Overall growth in this sector, however, was slowed owing to the industry's continued emphasis on the miniaturization of electronic components, resulting in less tantalum used per unit.

In 1990, the Defense Logistics Agency (DLA) purchased about $91 \mathrm{t}$ of tantalum pentoxide contained in tantalum ore for the NDS. The price of the material purchased ranged from about $\$ 36.62$ to $\$ 37.00$ per pound of contained tantalum pentoxide. At about the time of material purchase, the price quote for tantalum ore ranged from about $\$ 27.00$ to $\$ 28.50$ per pound of contained tantalum pentoxide (Cunningham, 1993).

In 1991, Australia's largest tantalum ore producer, Talison Minerals Pty. Ltd., entered into contracts with the world's two largest tantalum processors for the long-term supply of tantalum ore. Under the terms of the contracts, tantalum ore would be supplied to the processors at fixed volumes and prices for 5 years (Gwalia Consolidated Ltd., 1991). Subsequently, the producer contracted with the processors for the sale of all its budgeted production of tantalum ore through 2003 (Sons of Gwalia Ltd., 1998).

In 1998, the DLA initiated the sale of tantalum ore from the NDS. In September and December, the DLA sold about 90 $\mathrm{t}$ of tantalum contained in tantalum ore valued at about $\$ 11.6$ million (Defense National Stockpile Center, 1998a, b). The overall average unit price for the sales, about $\$ 48$ per pound of contained tantalum oxide, was significantly higher than that being quoted for tantalum ore at the time, about $\$ 34$ per pound of contained pentoxide.

Jeangrand (2005, p. 25) noted that "the tantalum market has been marked by long periods of stability, punctuated by very sharp price hikes created by a combination of strong demand and fears about shortage." Significant changes in tantalum ore annual average price took place in 1980, 1988, and 2000. In 2000, price increased by a factor of 5 to $\$ 220$ per pound of contained tantalum pentoxide, and then returned to historical values. The price surge was attributed to over ordering (Minerals Bureau [South Africa], 2002, p. 14-15). Double and triple ordering of tantalum for capacitor production in late 2000 was done under a perceived looming supply shortage. Excessive ordering encouraged the perception that consumption was increasing, which in turn created the appearance that supply would fall short of demand. These perceptions can also contribute to price increases. The industry built up excessive inventories throughout the tantalum supply chain. The inventory reduction process was expected to remain a feature of the tantalum market for some time. The stability of tantalite price in 2008, along with the closure of the Wodgina Mine (Australia) in 2008, indicated that excess inventories were continuing to be worked off. World tantalum material stocks are not reported by the tantalum industry.

Demand for mobile phones and other consumer electronics boomed in 2000 causing concern that tantalum supply would go into deficit, resulting in increased competition for the limited supply. This caused prices to spike. Capacitor manufactures made long-term contracts at prevailing prices. The electronics market experienced a downturn and the anticipated supply shortage failed to materialize. In 2008, Talison Minerals Pty. Ltd. (Australia) halted production in the face of large inventories in the supply chain, falling prices, and a declining world economy. Noventa Ltd. (Mozambique) and Tantalum Mining Corporation of Canada Ltd. (Tanco) (Canada) subsequently suspended production. These three companies accounted for more than one-half of tantalum ore production in 2008 (Roskill Information Services Ltd., 2009, p. 141-151).

During 2008-09, consumers relied heavily on tantalum ore inventories and huge quantities of highly contentious and politically sensitive, low-cost columbite and tantalite from the Congo (Kinshasa) that appeared to have displaced producers in the conventional supply chain. The mainstream industry sought a way to exclude illegal tantalum ore from the supply chain. It was thought that a ban on such material by the United States and the European Union was possible. After the financial crisis and subsequent economic slowdown in 2008 and 2009 , an estimated 40 percent of tantalum mine production was put on care-and-maintenance status, including mines in Australia, Canada, and Mozambique. New production projects in Canada, Egypt, and Saudi Arabia offered the possibility that new mines could be brought into production between 2011 and 2013 if demand recovered. It was anticipated that as the global economy recovered, the demand for tantalum would as well (Roskill Information Services Ltd., 2009, p. 21-23).

\section{References Cited}

Cunningham, L.D., 1985a, Columbium, in Mineral facts and problems: U.S. Bureau of Mines Bulletin 675, p. 185-196.

Cunningham, L.D., 1985b, Tantalum, in Mineral facts and problems: U.S. Bureau of Mines Bulletin 675, p. 811-822.

Cunningham, L.D., 1993, Columbium and tantalum, in Metals and minerals: U.S. Bureau of Mines Minerals Yearbook 1990, v. I, p. 339-357. 
Defense National Stockpile Center, 1998a, Stockpile awards tantalum minerals: Fort Belvoir, VA, Defense National Stockpile Center news release, September 24, 1 p.

Defense National Stockpile Center, 1998b, Stockpile awards tantalum minerals: Fort Belvoir, VA, Defense National Stockpile Center news release, December 4, 1 p.

Gwalia Consolidated Ltd., 1991, Annual report 1991: West Perth, Western Australia, Gwalia Consolidated Ltd., 63 p.

Jeangrand, Joel, 2005, Comprehensive strategic analysis of the tantalum industry: Burnaby, British Columbia, Canada, Simon Fraser University Master thesis, summer, 77 p.

Miller, G.L., 1959, Tantalum and niobium, in Metallurgy of the rarer metals: London, Butterworths Scientific Publications, p. 2.

Minerals Bureau [South Africa], 2002, The tantalum marketA micro-economic analysis: Johannesburg, South Africa, Minerals Bureau Report R37/2002, 15 p., accessed May 30, 2006, at http://www.dme.gov.za/pdfs/minerals/r37 2002.pdf. (Also available at $h t t p: / / w w w . d o c s t o c . c o m / d o c s / 19838994 /$ THE-TANTALUM-MARKET-A-micro---economicanalysis\#.)
Roskill Information Services Ltd., 2009, The Economics of Tantalum, 2009 (10th ed.): London, United Kingdom, Roskill Information Services Ltd., 152 p.

Sons of Gwalia Ltd., 1998, Annual report 1998: West Perth, Western Australia, Sons of Gwalia Ltd., 92 p.

Tantalum-Niobium International Study Center, 1986, Perspectives on the development of the tantalum industry: Tantalum-Niobium International Study Center No. 48, October, p. 2-5.

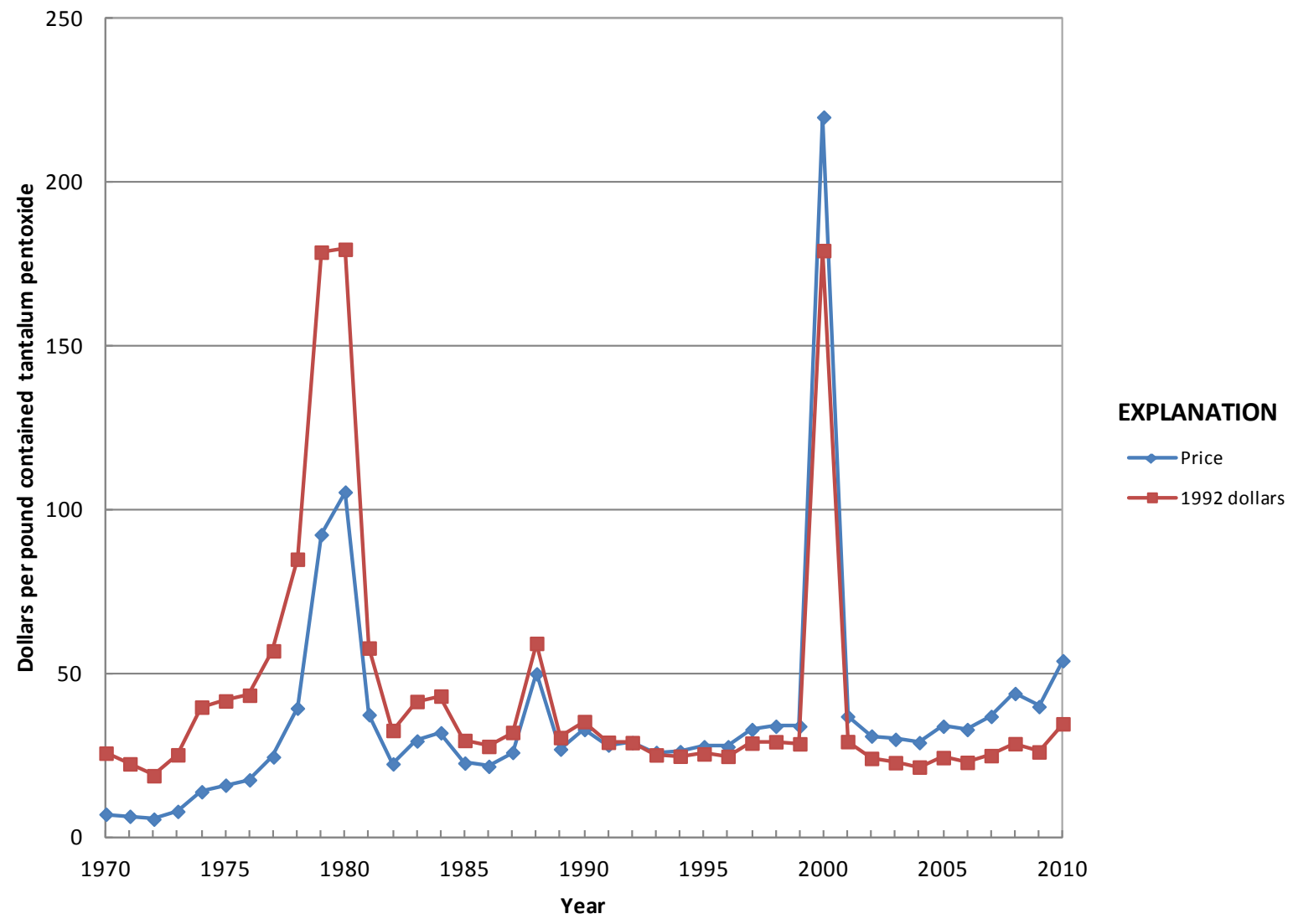

Figure 1. Yearend average tantalum concentrate price. 
Significant events affecting tantalum prices since 1970

1979-80 Tantalum price accelerated to record levels

1982 Industry's accumulation of large tantalum material inventories

1988 Drawdown of tantalum material inventories by processors

1990 Purchase of tantalum materials for the National Defense Stockpile (NDS)

1991 Long-term tantalum supply contracts between major producer and processors; dissolution of the Soviet Union

1998 Sales of tantalum minerals from the NDS

$1999 \quad$ Market opacity resulted in runaway demand

1990-2010 Rise of China as a leading steel-producing and -consuming nation

$2008 \quad$ Financial market problems and subsequent economic slowdown

Table 1. Yearend average tantalum concentrate price.

[Values in dollars per pound contained tantalum pentoxide. NA Not available]

\begin{tabular}{|c|c|c|c|c|c|c|c|}
\hline Year & Price & Year & Price & Year & Price & Year & Price \\
\hline 1940 & 2.50 & 1958 & 3.40 & 1976 & 17.63 & 1994 & 26.25 \\
\hline 1941 & 2.25 & 1959 & 4.80 & 1977 & 24.63 & 1995 & 27.75 \\
\hline 1943 & 2.50 & 1961 & 11.50 & 1979 & 92.50 & 1997 & 33.00 \\
\hline 1944 & 2.50 & 1962 & 5.50 & 1980 & 105.50 & 1998 & 34.00 \\
\hline 1947 & 2.50 & 1965 & 7.75 & 1983 & 29.50 & 2001 & 37.00 \\
\hline 1948 & 2.38 & 1966 & 13.00 & 1984 & 32.00 & 2002 & 31.00 \\
\hline 1949 & 2.25 & 1967 & 10.25 & 1985 & 22.75 & 2003 & 30.00 \\
\hline 1950 & 2.25 & 1968 & 6.50 & 1986 & 21.75 & 2004 & 29.00 \\
\hline 1954 & 3.40 & 1972 & 5.63 & 1990 & 33.00 & 2008 & 44.00 \\
\hline 1955 & 3.40 & 1973 & 8.00 & 1991 & 28.25 & 2009 & 40.00 \\
\hline 1956 & 3.40 & 1974 & 14.00 & 1992 & 29.00 & 2010 & 54.00 \\
\hline 1957 & 3.40 & 1975 & 16.00 & 1993 & 26.00 & & \\
\hline
\end{tabular}

Notes:

1940-41, published in Engineering and Mining Journal, Metal and Mineral Markets.

1942-43, U.S. Government purchase.

1944-51, published in Engineering and Mining Journal, Metal and Mineral Markets.

1952-58, U.S. Government purchase.

1959-62, published in U.S. Bureau of Mines Minerals Yearbooks.

1963-66, published in Engineering and Mining Journal, Metal and Mineral Markets.

1967-92, published in Metals Week.

1993-98, published in Platt's Metals Week.

1999-2003, U.S. Geological Survey Mineral Commodity Summaries 2004.

2004-10, published in Ryan's Notes. 


\title{
Tellurium (Te)
}

\author{
by Micheal W. George
}

Tellurium is a relatively rare element, tied for 71 st place with platinum and palladium in rank of crustal abundance. It is in the same chemical family as oxygen, sulfur, selenium, and polonium - oxygen and sulfur are nonmetals, polonium is a metal, and selenium and tellurium are metalloids, although they are often referred to as metals when in elemental form and have semiconducting electrical properties that make them suitable in electronics applications. Tellurium was first identified in 1782 in Transylvanian gold ore (Azimov, 1994, p. 260). For more than a century, tellurium was an experimental material having little commercial value. Small quantities of tellurium were produced from anode slimes generated during the electrolytic refining of copper. World tellurium production is still mainly a byproduct of copper processing. Because tellurium is a byproduct, supply and demand imbalances have developed that have had significant influences on price (Elkin, 1985, p. 1158).

By 1920, a small commercial demand had developed for tellurium in electronic equipment, electroplating, and chemical production (Heikes, 1922). Despite sales of only about 590 kilograms per year in 1928, production of tellurium rose to more than 5,200 kilograms per year by 1929 following the rise in electrolytic copper production. Much of the production was furnished free to researchers seeking new uses for tellurium and was not included in sales figures (Heikes, 1933).

Additional significant commercial uses for tellurium were developed during the 1930s; however, supply continued to exceed consumption. Major uses included the purification of zinc-refining solutions, alloying with lead to improve its tensile strength and corrosion resistance, and as an addition to rubber compounds to improve resistance to aging and abrasion.

Production and consumption of tellurium fluctuated markedly between 1940 and 1958, but generally supply outstripped consumption. A demand peak in 1941, attributed to World War II, corresponded to the increased use of tellurium as a carbon stabilizer in cast iron, and a peak in 1951-52 was attributed to the Korean Conflict and to tellurium's expanded use in copper alloying. Price-driven substitution of tellurium for selenium in some applications helped boost consumption from 1955 through 1958.

Because tellurium is a byproduct, with production essentially independent of demand, and its uses being in small and specialized applications, its market is volatile. Prices rose from $\$ 1.70$ per pound in 1958 to $\$ 6.00$ per pound in 1962 before stabilizing at the higher level (Lansche, 1963, p. 148) (table 1). This period was marked by increased shipments and speculative interest. The rise in price also corresponded to the growth in thermoelectric applications for tellurium, as well as its use in free-machining steel, which became the dominant use (Holowaty, 1964; Rathke and Morgan, 1965).

Prices remained stable at about $\$ 6.00$ per pound until the early 1970s, when growing demand for ferrous alloy applications was followed by a rapid growth in the catalytic applications of tellurium in petrochemicals processing. Tellurium prices declined sharply from 1980-83 following closure in 1979 of a large domestic consumer of tellurium catalyst, which reduced consumption and returned a large quantity of consumer stocks to the market; a slump in steel production in 1981 further reduced consumption (fig. 1). Production also decreased owing to a decline in the tellurium content of domestic copper ores (Wills, 1982). By 1983, in part owing to a decline in the tellurium content of domestic copper ores, only one domestic producer of tellurium remained. Domestic production decreased in 1985 when a smelter that processed imported high tellurium copper concentrates closed. By 1987, with increasing demand for free-machining steels and minimal production of tellurium, inventories became critically depleted, and prices rose substantially and remained fairly stable until 1993. A steady decline in prices began in 1994 that lasted through 2000. During this period, an oversupply developed as a fall in consumption exceeded the decline in production (Brown, 1998, p. 13-17).

In 2004 and 2005, increases in consumption from Chinese electronic manufacturers resulted in an increase in the price of tellurium. The price dropped in 2006, but in 2007 resumed its upward trend owing to increased production of cadmium telluride (CdTe) solar cells. Some of the price increase was also attributed to speculative buying in the belief that supplies would be insufficient to meet the growing demand for tellurium in solar cells.

\section{References Cited}

Azimov, Isaac, 1994, Azimov's chronology of science and discovery: New York, Harper Collins Publishers, 800 p.

Brown, R.D., Jr., 1998, Selenium tellurium supply-demand relationship: International Symposium on the Uses of Selenium and Tellurium, 6th, Scottsdale, Ariz., May 10-12, 1998, Proceedings, p. 13-17.

Elkin, E.M., 1985, Tellurium and tellurium compounds, in Kirk-Othmer concise encyclopedia of chemical technology: New York, John Wiley, 1318 p. 
Heikes, V.C., 1922, Selenium and tellurium, in Mineral resources of the United States 1920: U.S. Geological Survey, pt. I-Metals, p. 71-72.

Heikes, V.C., 1933, Arsenic, bismuth, selenium, and tellurium, in Mineral resources of the United States 1930, Part IMetals: U.S. Bureau of Mines, p. 25-30.

Holowaty, M.O., 1964, Free-machining steels: U.S. Patents $3,152,889$ and 3,152,890, assigned to Inland Steel Co., October 13.
Lansche, A.M., 1963, Tellurium, in Minerals and Metals Commodity Data Summaries: U.S. Bureau of Mines, p. 148-149.

Rathke, A.E., and Morgan, A.T., 1965, Free-machining steels: U.S. Patent 3,169,857, assigned to Inland Steel Co., February 16.

Wills, Frank, 1982, Inventories grow despite lower output of this copper byproduct: Engineering and Mining Journal, v. 183, no. 3, March, p. 122-123.

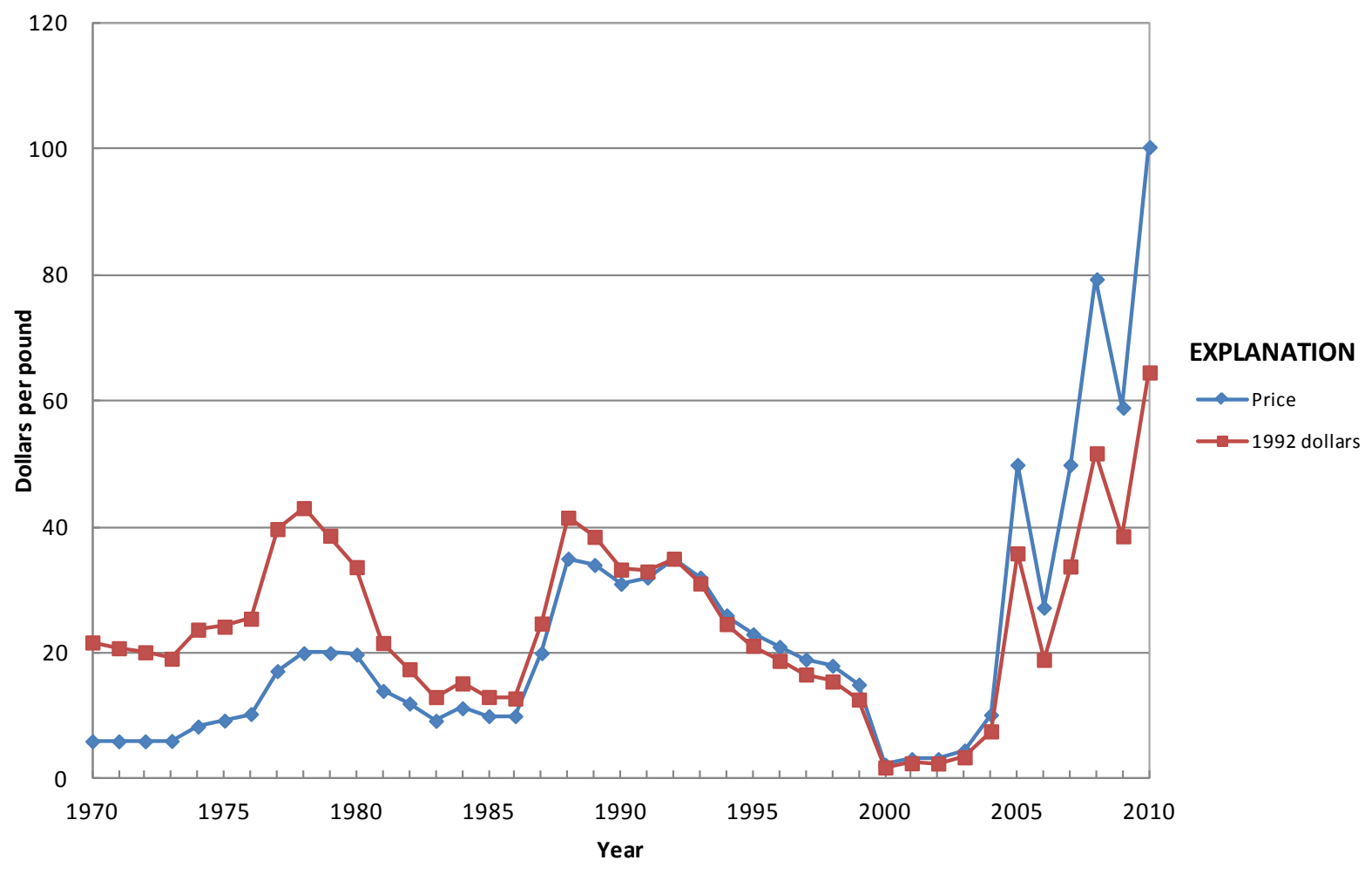

Figure 1. Yearend average tellurium price.

\section{Significant events affecting tellurium prices since 1970}

1973-80 Price controls in 1973 lifted in December; annual demand doubled stimulated by catalytic uses; reduced production from falloff in copper production and tellurium content of ores; speculation affected prices

1981-86 Demand plummeted in economic recession (1981-82); major catalytic use ended, and consumer inventories returned to marketplace; slumping domestic steel market

1987-88 Demand for free machining steel increased; reduced tellurium production; inventory depletion; price doubled

1993-2000 Oversupply situation developed as demand decreased faster than production declined, and inventories swelled

$1999 \quad$ Change in price data series to average yearend price for United Kingdom lump and powder; 99.95-percent-pure tellurium from U.S. producer price quotes

2004-05 Increase in demand from electronics producers in China

2007-10 Increases in demand from solar cell manufacturers and widespread speculative buying 
Table 1. Annual average tellurium price.

[Values in dollars per pound. NA Not available]

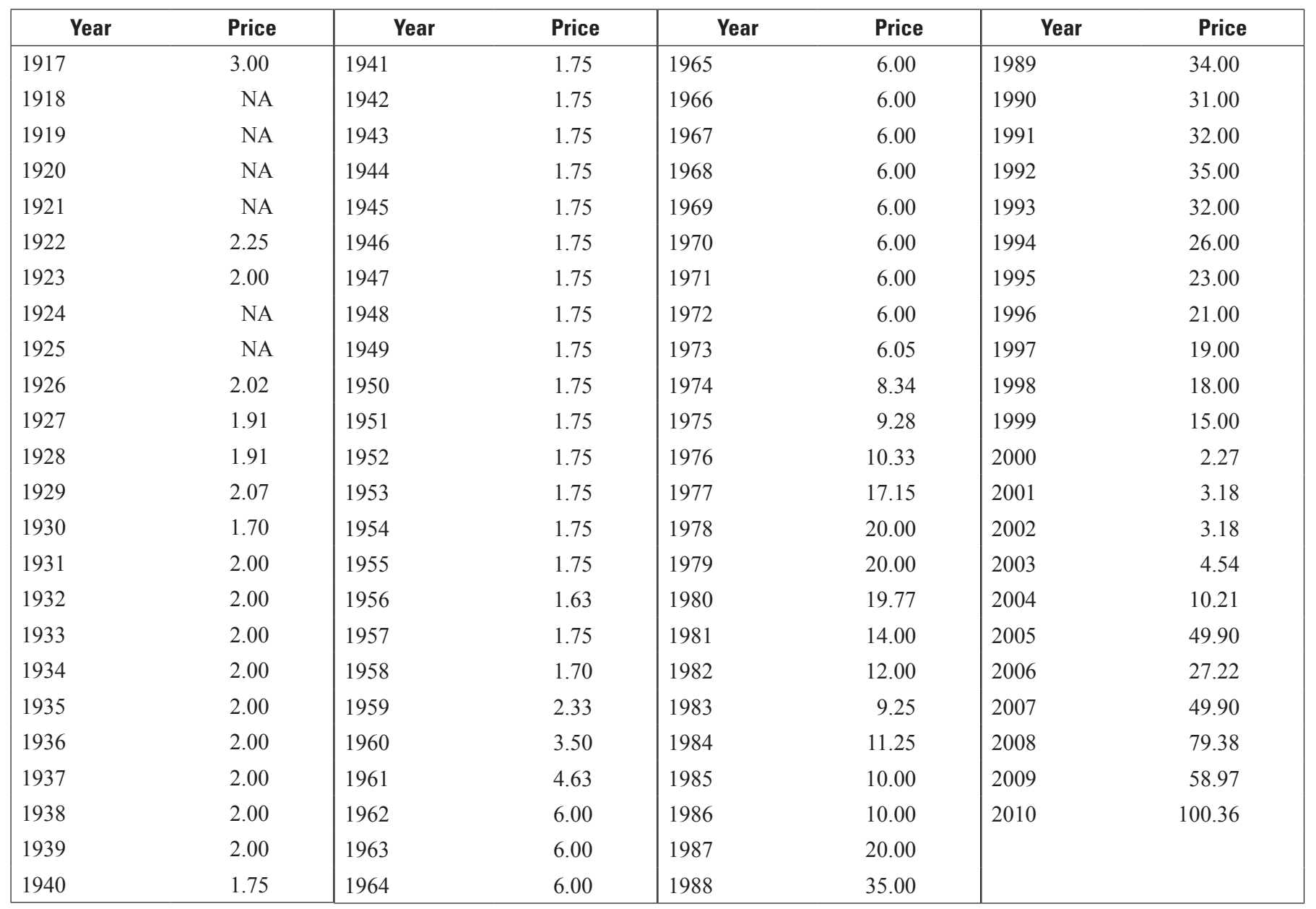

Notes:

1917-22, U.S. producer price for 99-percent-pure tellurium, in U.S. Geological Survey Mineral Resources of the United States.

1923-29, Domestic price for 99-percent-pure tellurium, in Engineering and Mining Journal.

1930-36, New York price for 99-percent-pure tellurium, in Engineering and Mining Journal.

1937-39, New York price for 99-percent-pure tellurium, in Engineering and Mining Journal, Metal and Mineral Markets.

1940-66, New York price for 99.7-percent-pure tellurium, in Engineering and Mining Journal, Metal and Mineral Markets.

1967-80, New York price for 99.7-percent-pure tellurium, in Metals Week.

1981-94, U.S. producer price quotes for 99.7-percent-pure tellurium, in U.S. Bureau of Mines Minerals Yearbook.

1995-99, U.S. producer price quotes for 99.7-percent-pure tellurium, in U.S. Geological Survey Minerals Yearbook.

2000-08, Average yearend price for United Kingdom lump and powder, 99.95-percent-pure tellurium originally reported as dollars per kilogram, in Mining

Journal.

2009, Average September 14 price for United Kingdom lump and powder, 99.95-percent-pure tellurium originally reported as dollars per kilogram, in Mining

Journal.

2010, Average annual price IWH Rotterdam price for 99.99-percent-pure tellurium originally reported as dollars per kilogram, in Metal-Pages.com. 


\title{
Thallium (TI)
}

\author{
by David E. Guberman
}

Thallium, a soft, bluish gray, malleable heavy metal, was discovered by Sir William Crookes in 1861 while he was making spectroscopic determinations for tellurium on residues from a sulfuric acid plant. Although the metal is relatively abundant in the Earth's crust at a concentration estimated to be about 0.7 part per million (close to antimony, germanium, and molybdenum), it exists mostly in association with potassium minerals in clays, soils, and granites and, thus, is generally considered to be commercially unavailable in this form. Several thallium minerals, containing from 16 percent to 60 percent thallium, occur in nature as sulfide or selenide complexes with antimony, arsenic, copper, lead, and silver but are rare and have no commercial importance as sources of this element. The major source of commercial thallium is the trace amounts found in copper, lead, zinc, and other sulfide ores. Thallium is recovered as a byproduct from the flue dust and residues generated during the roasting and smelting steps in the processing of these ores.

From 1912 to 1930, thallium compounds were used extensively for medicinal purposes; for example, in the treatment of ringworm, dysentery, and tuberculosis. The narrow margin between toxicity and therapeutic benefit, however, eventually eliminated the practical use of these compounds. The use of thallium salts as poison for rodents and later as insecticide led to increased use of thallium from 1925 to 1965; significant quantities of the rodenticide were used by the U.S. military to control rat infestation in World War II operations (Lee, 1971, p. 1-4; Smith and Carson, 1977, p. 9-16).

The postwar price of thallium metal reached $\$ 18.00$ per pound after the wartime allocation and price control system imposed on thallium chemicals was lifted by the War Production Board in 1946 (table 1). In 1965, the U.S. Government issued regulations prohibiting the household use of thalliumcontaining rodent poisons and insecticides because of their extreme toxicity to humans, resulting in a significant decline in thallium consumption. By 1973, all retail sales of these chemicals had been banned in the United States. Although thallium consumption declined sharply as a result of the loss of these markets, the decline was offset to some extent by increases in the uses of thallium in electronic applications, chemical synthesis, and such minor uses as components for solders, low-melting alloys, low-temperature thermometers, and optical glasses. During this period of transition in the enduse sectors, the published domestic producer price remained at $\$ 7.50$ per pound through 1980 (fig. 1). In 1981, ASARCO Incorporated, the only domestic producer of thallium and thallium compounds, stopped production. From 1981 through 1988 , the price of thallium metal was based upon information obtained from import data. By 1988, thallium prices had risen to $\$ 80.00$ per pound.

In the 1990s, consumption of thallium metal and compounds continued in most of the established end uses; for example, semiconductor material for selenium rectifiers, an activator in gamma radiation detection equipment, an electrical resistance component in infrared radiation detection and transmission equipment, a crystalline filter for light diffraction in acousto-optical measuring devices, an alloy with mercury for low-temperature measurements, an addition to glass to increase its refractive index and density, a catalyst or intermediate in the synthesis of organic compounds, and a high-density liquid for sink-float separation of minerals. In addition, research activity has been ongoing to develop hightemperature superconducting materials for such applications as magnetic resonance imaging, storage of magnetic energy, magnetic propulsion, and electric power generation and transmission. Since 1989, numerous patents have been issued for and reports have been published on the preparation of high-temperature superconductor compounds containing thallium. The use of radioactive thallium compounds for medical purposes in cardiovascular imaging to detect heart disease has increased steadily since the early 1980s.

With the advent of these newer and potentially safer uses for thallium, the demand for higher purity thallium metal, either in research or practical application, has increased. Consistent with the greater need for high-purity thallium and the lack of published or otherwise available producer or dealer quotations for thallium metal of any purity since 1988, the price of thallium metal has been based upon the metal price listed in retail supplier catalogues. The price of 99.999-percent-pure thallium granules has risen steadily from $\$ 250.00$ per pound in 1989 to $\$ 580.00$ per pound in 1998 . This price increase, an average of about 15 percent per year, reflects an increase in the retail price, but this increase is higher than the rate of inflation. To some extent, the price increase is probably the result of a greater demand for high-purity thallium.

The price for thallium metal increased significantly in 2006 as the supply worldwide became relatively tight. The average price for high-purity granules and rod was nearly three times higher than the average price during the previous 3 years. China instituted a policy of eliminating toll-trading tax benefits on exports of thallium that began in 2006, thus contributing to the shortage on the world market. In July 2010, China canceled a 5-percent value-added-tax rebate on exports of many minor metals, including fabricated thallium products, in order to help satisfy its increasing internal demand. 
One of the most significant events that affected the global thallium market and caused prices to increase in 2009 was the shortage of the medical isotope technetium-99, which had been widely used by physicians for medical imaging tests owing to its availability, relatively low cost, and the superior diagnostic quality of images produced with it. The thallium isotope 201 was the most common alternative to technetium-99 for use in scans, such as the cardiac-stress test that monitors blood perfusion into heart tissue during rigorous exercise. In response to the shortage of technetium-99, some medical imaging equipment producers increased production of thallium isotope 201 in order to meet anticipated demand, leading to tightening of the thallium supply. Because thallium is used in small quantities in limited applications, commercial- quantity pricing data, similar to that for other metals, are not available. Pricing changes listed may be caused by changes in the source of price quotations.

\section{References Cited}

Lee, A.G., 1971, The chemistry of thallium: Amsterdam, Netherlands, Elsevier, 336 p.

Smith, I.C., and Carson, B.L., 1977, Trace metals in the environment, v. 1-Thallium: Ann Arbor, Mich., Ann Arbor Science, 394 p.

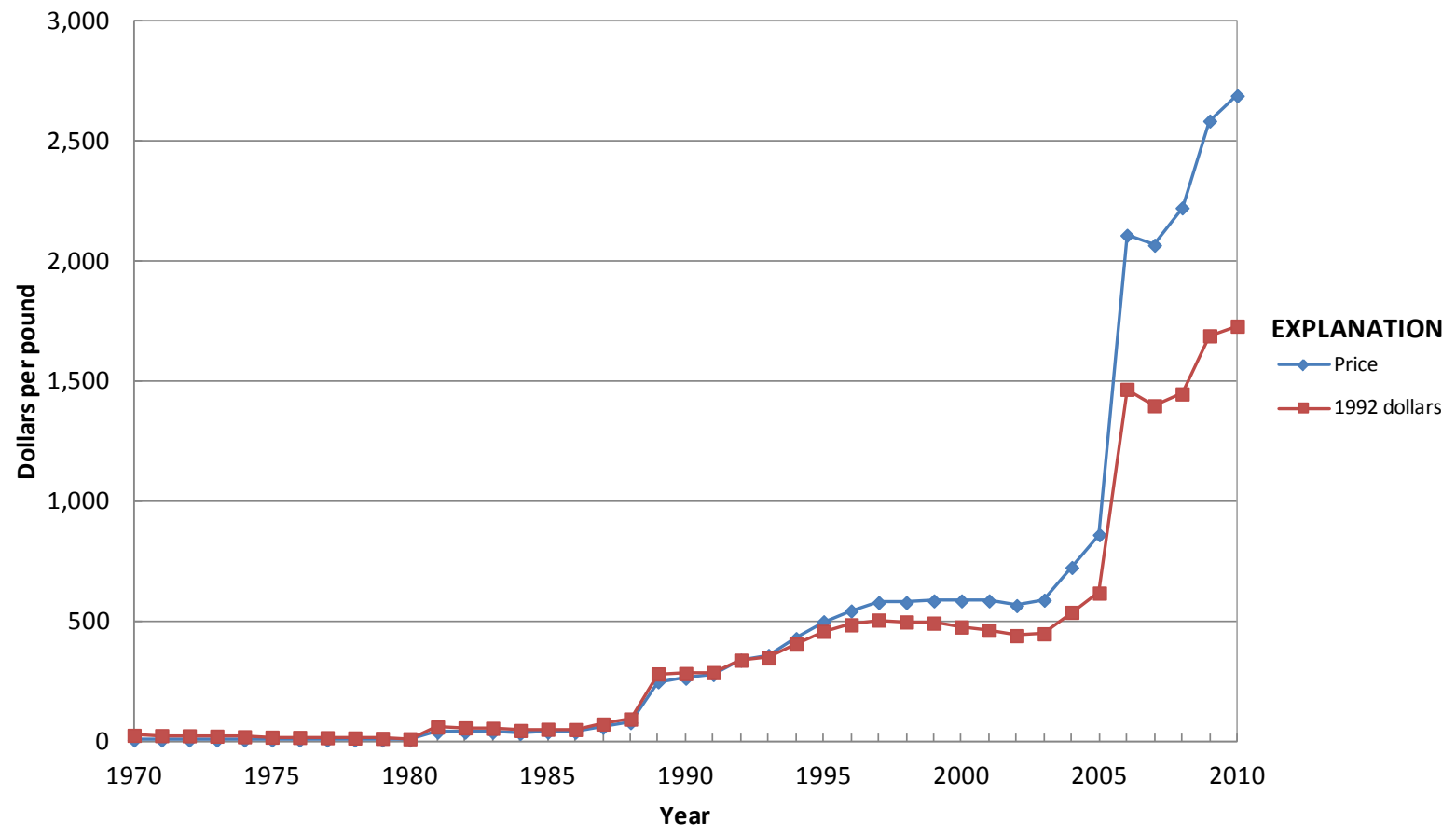

Figure 1. Annual average thallium price.

\section{Significant events affecting thallium prices since 1970}

1981 Domestic production was terminated; dependence on imports

1989-98 Used in superconductivity research and new medical applications; traditional uses continued

2006-10 Prices increased, global supplies tight

2009 Thallium prices increased owing to increased demand for use in medical imaging 
Table 1. Annual average thallium price.

[Values in dollars per pound]

\begin{tabular}{|c|c|c|c|c|c|c|c|}
\hline Year & Price & Year & Price & Year & Price & Year & Price \\
\hline 1942 & 10.00 & 1960 & 7.50 & 1978 & 7.50 & 1996 & 545.00 \\
\hline 1943 & 10.00 & 1961 & 7.50 & 1979 & 7.50 & 1997 & 580.00 \\
\hline 1945 & 12.50 & 1963 & 7.50 & 1981 & 40.00 & 1999 & 587.40 \\
\hline 1946 & 14.00 & 1964 & 7.50 & 1982 & 40.00 & 2000 & 587.40 \\
\hline 1948 & 15.00 & 1966 & 7.50 & 1984 & 35.00 & 2002 & 566.99 \\
\hline 1949 & 14.00 & 1967 & 7.50 & 1985 & 40.00 & 2003 & 589.67 \\
\hline 1950 & 12.50 & 1968 & 7.50 & 1986 & 40.00 & 2004 & 725.75 \\
\hline 1951 & 12.50 & 1969 & 7.50 & 1987 & 60.00 & 2005 & 861.83 \\
\hline 1952 & 12.50 & 1970 & 7.50 & 1988 & 80.00 & 2006 & $2,109.21$ \\
\hline 1956 & 12.50 & 1974 & 7.50 & 1992 & 340.00 & 2010 & $2,689.81$ \\
\hline 1957 & 12.50 & 1975 & 7.50 & 1993 & 360.00 & & \\
\hline 1958 & 7.50 & 1976 & 7.50 & 1994 & 430.00 & & \\
\hline 1959 & 7.50 & 1977 & 7.50 & 1995 & 500.00 & & \\
\hline
\end{tabular}

Notes:

1942-66, U.S. producer price (99.90-percent-pure thallium), in Engineering and Mining Journal, Metal and Mineral Markets. 1967-80, U.S. producer price (99.90-percent-pure thallium), in Metals Week.

1981-88, Imported dealer price (99.90-percent-pure thallium); private communications with suppliers.

1989-2010, Retail supplier price (99.9990-percent-pure thallium granules), in Aldrich and Alfa Aesar chemicals catalogues. 


\title{
$\operatorname{Tin}(\mathbf{S n})$
}

\author{
by James F. Carlin, Jr.
}

Tin was one of the earliest metals known to humanity. Because of its hardening effect on copper, tin was used in bronze implements as early as 3500 B.C., although the pure metal was not used until about 600 B.C. Bronze, a copper-tin alloy that can be sharpened and is hard enough to retain a cutting edge, was used in construction tools as well as weapons for hunting and war. The geographical separation between tinproducing and tin-consuming nations greatly influenced the patterns of early trade routes. Historians believe that, as early as 1500 B.C., Phoenicians travelled by sea to the Cornwall district of England to obtain tin.

Unique to tin has been its long history of commodity "agreements" dating back to 1921 . These agreements were usually structured between producer countries and consumer countries on a complex global basis. The earlier agreements tended to be somewhat informal and sporadic; they led to the "First International Tin Agreement" in 1956, the first of a continuously numbered series that essentially collapsed in 1985. Through this series of agreements, the International Tin Council (ITC) had a substantial influence on tin prices during that 29-year period. The ITC was able to support the price of tin during periods of low prices by buying tin for its buffer stockpile and was able, to some degree, to restrain the price during periods of high prices by selling tin from the stockpile (table 1). This was an anti-free-market approach, designed to assure a sufficient flow of tin to consumer countries and a decent profit for producer countries. During the 29-year run of the tin agreements, however, it was apparent that the buffer stockpile was not sufficiently large, especially to defend the artificial ceiling prices. Consequently, during most of those 29 years, tin prices rose, sometimes sharply, especially from 1973 through 1980 when rampant inflation plagued the American and many foreign economies (fig. 1).

During the late 1970 s and early 1980 s, the U.S. Government tin stockpile was in an aggressive selling mode, partly to take advantage of the historically high tin prices. The sharp recession of 1981-82 proved to be quite harsh on the tin industry, as well as on the other metal-using industries of the United States and most industrialized countries. Tin consumption declined dramatically. The ITC was able to avoid truly steep declines through accelerated buying for its buffer stockpile; this activity required the ITC to borrow extensively from banks and metal trading firms to augment its resources. The ITC continued to borrow until late 1985, when it reached its credit limit. Immediately, a major "tin crisis" followed - tin was delisted from trading on the London Metal Exchange for about 3 years, the ITC dissolved soon afterward, and the price of tin, now in a free-market environment, plummeted sharply to the $\$ 4$ per pound level (Roskill Information Services Ltd., 1995, p. 283-290). The price of tin has remained in that lower range since 1985, except for a diversion to the \$5 level in 1989.

From 1990 through 2006, the tin price hovered in the $\$ 2$ - to $\$ 5$-per-pound price range. In 2007, the price rose significantly to the $\$ 8$ level, and in 2008 and 2010 , rose to the $\$ 11$ and $\$ 12$ range, respectively. These price increases, which began in 2007, were due to several factors - (a) events in China, the world's leading tin producer, such as mine disasters and occasional extensive flooding, which led to shortfalls in production; (b) increased world tin consumption, especially in Asia, as tin increasingly substituted for lead and some other metals because of their toxicity; (c) shortfalls in production during certain periods of the world's second leading tin producer, Indonesia; (d) the winding down of the U.S. Government stockpile of tin so that less tin was available for disposal; and (e) the increasing role of investment funds.

During the 1980s and 1990s, a series of drastic and widespread worldwide legal restrictions limited or eliminated lead's usage in many applications owing to its toxicity. Since many of these applications used alloys in which lead was combined with tin, and tin was often seen as a nontoxic metal, tin gradually replaced lead (at least partially) in those alloys. This was especially true for solder (often a 70-percent tin 30-percent lead alloy for electronic applications in earlier decades). By the 1990s, the typical electronics solder composition was more than a 95-percent tin-balance antimony or bismuth or silver alloy. These gradual trends boosted tin's global consumption substantially and thus supported higher tin prices in the 1980s and 1990s.

Tin production difficulties in Indonesia, the world's second leading tin-producing country, were critical to intermittent tin price increases and decreases in the period from 2002 to 2009. Some of the Indonesian tin mine output declines were due to organizational reconfiguration, some were due to illegal mining operations, and some were due to natural occurrences such as tsunamis. In 2002, the world's leading tin mining organization, PT Timah, went through a severe streamlining of organizational functions, resulting in such moves as halting operations at most of its dredges. From 2002 to 2008, the Indonesian Government gradually eliminated as many as 130,000 illegal tin mining operations. Both these events had the effect of decreasing tin supply from Indonesia and thereby tending to boost world tin prices.

From 2003 to 2010, various actions by the Government of China, the world's leading tin-producing country, toward imposing tin export quotas led to pressures to raise the world 
tin price. These actions were designed to meet China's own growing domestic tin requirements.

The 2008-09 world economic crisis lowered tin consumption in many countries substantially, especially in durable goods consumption categories, such as brass/bronze and machinery, which led to a brief price decline in 2009.

\section{Reference Cited}

Roskill Information Services Ltd., 1995, The economics of tin: London, Roskill Information Services Ltd., 299 p.

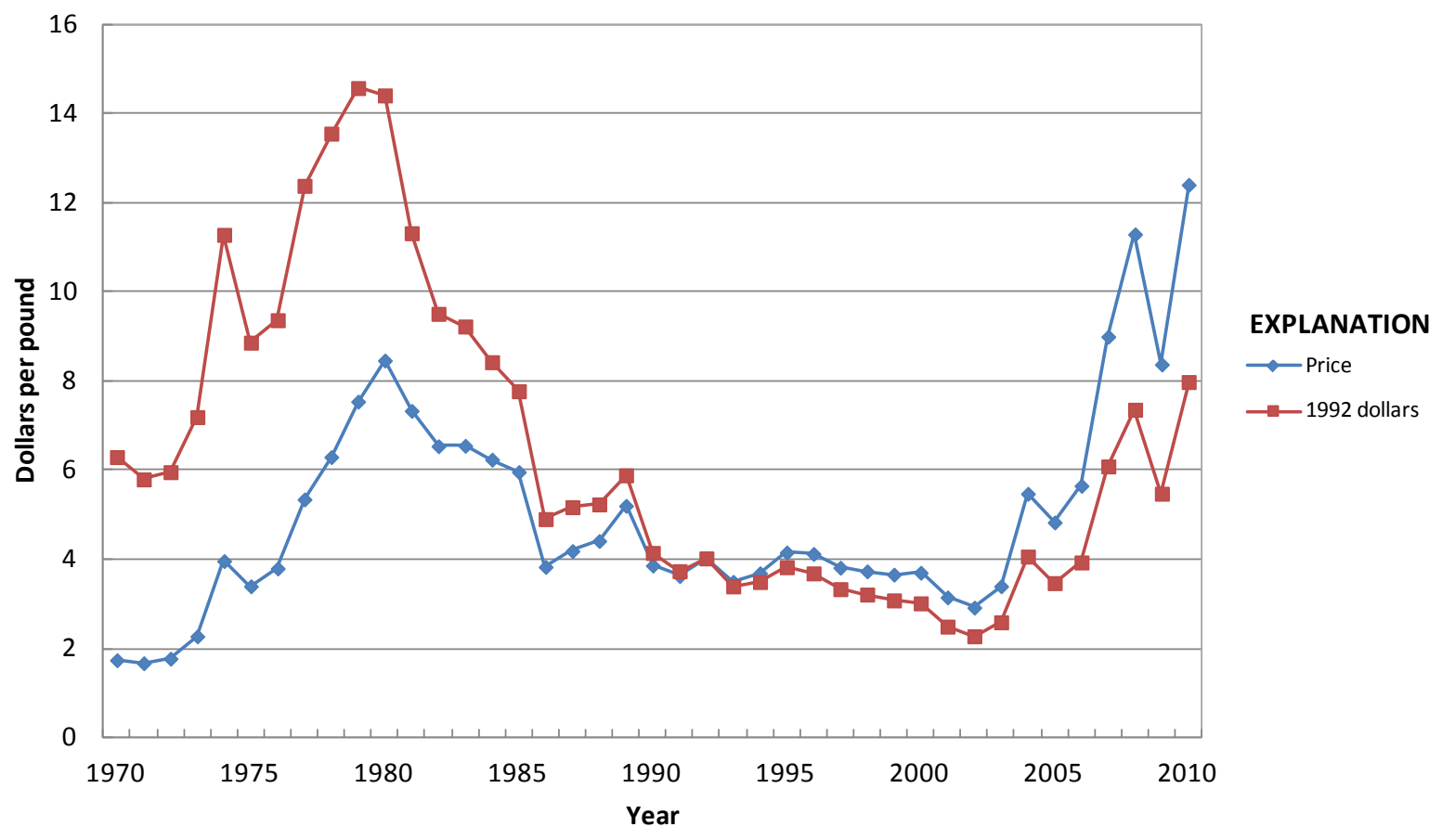

Figure 1. Annual average tin price.

\section{Significant events affecting tin prices since 1970}

1956-85 International Tin Agreements (a continuous series of complex, global, 4-year pacts)

1973-80 Rampant inflation

1981-82 Sharp recession

1980-2010 Increased toxicity issues with lead, leading to increased tin consumption as a lead replacement

2002-08 A period of world steel company (tinplate producers) consolidations and mergers that often resulted in lower available world tinplate and increased tin pricess

2002-09 Tin mine and smelter production declined in Indonesia owing to Government closures of illegal tin smelters, smuggling, and severe weather

2008-09 Global financial crisis 
Table 1. Annual average U.S. tin price.

[Values in dollars per pound]

\begin{tabular}{|c|c|c|c|c|c|c|c|}
\hline Year & Price & Year & Price & Year & Price & Year & Price \\
\hline 1880 & 0.208 & 1913 & 0.443 & 1946 & 0.545 & \begin{tabular}{|l|}
1979 \\
\end{tabular} & 7.539 \\
\hline 1881 & 0.208 & 1914 & 0.343 & 1947 & 0.779 & 1980 & 8.460 \\
\hline 1882 & 0.234 & 1915 & 0.386 & 1948 & 0.993 & 1981 & 7.331 \\
\hline 1883 & 0.208 & 1916 & 0.435 & 1949 & 0.993 & 1982 & 6.539 \\
\hline 1884 & 0.181 & 1917 & 0.618 & 1950 & 0.955 & 1983 & 6.548 \\
\hline 1885 & 0.195 & 1918 & 0.888 & 1951 & 1.271 & 1984 & 6.238 \\
\hline 1886 & 0.216 & 1919 & 0.633 & 1952 & 1.205 & 1985 & 5.960 \\
\hline 1887 & 0.249 & 1920 & 0.483 & 1953 & 0.958 & 1986 & 3.832 \\
\hline 1888 & 0.262 & 1921 & 0.299 & 1954 & 0.918 & 1987 & 4.188 \\
\hline 1889 & 0.209 & 1922 & 0.326 & 1955 & 0.947 & 1988 & 4.414 \\
\hline 1890 & 0.214 & 1923 & 0.427 & 1956 & 1.014 & 1989 & 5.202 \\
\hline 1891 & 0.208 & 1924 & 0.502 & 1957 & 0.963 & 1990 & 3.863 \\
\hline 1892 & 0.206 & 1925 & 0.579 & 1958 & 0.951 & 1991 & 3.628 \\
\hline 1893 & 0.201 & 1926 & 0.653 & 1959 & 1.021 & 1992 & 4.024 \\
\hline 1894 & 0.181 & 1927 & 0.644 & 1960 & 1.014 & 1993 & 3.498 \\
\hline 1895 & 0.141 & 1928 & 0.504 & 1961 & 1.133 & 1994 & 3.691 \\
\hline 1896 & 0.132 & 1929 & 0.452 & 1962 & 1.146 & 1995 & 4.156 \\
\hline 1897 & 0.136 & 1930 & 0.317 & 1963 & 1.166 & 1996 & 4.124 \\
\hline 1898 & 0.157 & 1931 & 0.245 & 1964 & 1.577 & 1997 & 3.815 \\
\hline 1899 & 0.251 & 1932 & 0.220 & 1965 & 1.782 & 1998 & 3.733 \\
\hline 1900 & 0.299 & 1933 & 0.391 & 1966 & 1.640 & 1999 & 3.660 \\
\hline 1901 & 0.167 & 1934 & 0.522 & 1967 & 1.534 & 2000 & 3.702 \\
\hline 1902 & 0.268 & 1935 & 0.504 & 1968 & 1.481 & 2001 & 3.149 \\
\hline 1903 & 0.281 & 1936 & 0.464 & 1969 & 1.644 & 2002 & 2.920 \\
\hline 1904 & 0.280 & 1937 & 0.543 & 1970 & 1.741 & 2003 & 3.398 \\
\hline 1905 & 0.314 & 1938 & 0.423 & 1971 & 1.673 & 2004 & 5.473 \\
\hline 1906 & 0.398 & 1939 & 0.503 & 1972 & 1.775 & 2005 & 4.830 \\
\hline 1907 & 0.382 & 1940 & 0.498 & 1973 & 2.276 & 2006 & 5.651 \\
\hline 1908 & 0.295 & 1941 & 0.520 & 1974 & 3.963 & 2007 & 8.995 \\
\hline 1909 & 0.297 & 1942 & 0.520 & 1975 & 3.398 & 2008 & 11.290 \\
\hline 1910 & 0.341 & 1943 & 0.520 & 1976 & 3.798 & 2009 & 8.371 \\
\hline 1911 & 0.423 & 1944 & 0.520 & 1977 & 5.346 & 2010 & 12.400 \\
\hline 1912 & 0.461 & 1945 & 0.520 & 1978 & 6.296 & & \\
\hline
\end{tabular}

Notes:

1880-1936, New York price for Grade A Straits (Malaysian) tin (99.85-percent-pure), in Engineering and Mining Journal.

1937-66, New York price for Grade A Straits (Malaysian) tin (99.85-percent-pure), in Engineering and Mining, Journal Metal and Mineral Markets.

1967-76, New York price for Grade A Straits (Malaysian) tin (99.85-percent-pure), in Metals Week.

1976-2010, Metals Week composite price, in Metals Week and Platts (Platt's) Metals Week. 


\title{
Titanium (Ti)
}

\author{
by Joseph Gambogi
}

Discovered in 1790, titanium is well known as a light metal with excellent corrosion resistance (Barksdale, 1966, p. 3). Titanium sponge is the most basic form of titanium metal and can be produced from the minerals ilmenite, leucoxene, and rutile. Titanium metal is consumed primarily in the commercial and military aerospace industries. Largescale production capacity of sponge exists in China, Japan, Kazakhstan, Russia, Ukraine, and the United States. Unlike some metals, titanium is not sold on any market exchanges. Although often unspecified, sponge prices are normally based on a minimum 93.3-percent titanium content with a Brinell hardness of less than 120. Titanium sponge prices normally lag market condition because supply agreements are often negotiated on an annual basis. Titanium sponge consumption precedes aircraft production, and a change in consumption often correlates with a change in aircraft orders.

Although commercial production of titanium pigments began in the early 1900 s, commercially produced titanium metal was not available until 1948. During the first two decades of the commercial development of titanium metal, the price per pound declined significantly (table 1). Cancellation of the Supersonic Transport program in 1971 tended to keep demand and prices for titanium sponge low through 1973. From 1973 through 1981, however, prices rose along with generally increasing orders for commercial aircraft and other industrial uses (fig. 1). The historic high price in 1981 and the subsequent price collapse were believed to have been accentuated by an overestimation of aircraft orders that did not materialize or were later canceled as the aircraft market deteriorated, leaving some producers with substantial inventories of titanium metal products to be drawn from during a period of lower demand (National Materials Advisory Board, 1983, p. 7-22). From 1985 through 1989, titanium metal prices were again on the rise, reflecting renewed strength in the commercial aircraft and other industrial markets. Military aircraft programs, such as the B-1B bomber program, also contributed to the rise in demand during this period. Owing to this increased demand, two of the domestic sponge producers made moderate expansions to their existing capacity during 1988 and 1989 (Titanium Development Association, 1990, p. 3).

The early 1990s marked the end of the Cold War and the beginning of sharp cuts in defense spending. Concurrently, commercial aircraft and engine producers were reducing raw material inventory levels, causing a significant fall in titanium metal demand and prices. Domestic consumption of titanium sponge fell by 42 percent in 1991, compared with consumption in the prior year.
Owing to decreased demand and the availability of imported material, RMI Titanium Co. closed its 10,900-metric-ton-per-year (t/yr) sponge production plant at Ashtabula, Ohio, in 1992 (RMI Titanium Co., 1992, p. 11). The closure left two remaining producers in the United States.

In 1993, Titanium Metals Corp. commissioned a 10,000-t/yr sponge plant at its Henderson, Nev., facility. The expansion was based on a derivation of the Kroll process called the Vacuum Distillation Process (VDP). According to industry reports, the new plant produced a higher quality sponge at lower operating costs. Following the commissioning of the VDP plant, much of the old Kroll plant capacity was idled (American Metal Market, 1993a).

Imports of titanium sponge rose sharply during the mid1990s. Although it is not apparent from published prices of domestic sponge, imports were available at substantially less than the domestic published price (American Metal Market, 1993b). In 1994, the average unit value of imports reached a record low of $\$ 1.58$ per pound. A new use for titanium metal in golf club heads led to a resurgence in consumption for titanium in 1995 (American Metal Market, 1996). In addition, new commercial aircraft orders rose sharply from 1995 to 1997 (Aviation Week \& Space Technology, 1997). By 1997, domestic consumption of titanium sponge reached a record high of 32,000 metric tons (t). Also in 1997, the total value of sponge imports reached a record high. According to U.S. Customs statistics, the average unit value of sponge imports was $\$ 3.42$ per pound.

The instabilities in Asian economies caused cancellations of aircraft orders in 1998 (Institute of Scrap Recycling Industries, Inc., 1998). These cancellations resulted in a moderate fall in consumption of titanium during 1998. Although prices for titanium metal products were also affected, long-term supply agreements between aircraft producers and titanium producers helped stabilize prices for some titanium products (Metal Bulletin, 1998). In 1999, titanium consumption declined significantly, falling to 18,100 t compared with $28,200 \mathrm{t}$ in 1998. Weak demand for titanium sponge continued in 2000. Owing to increased construction of commercial aircraft, titanium sponge consumption surged to 26,200 $\mathrm{t}$ in 2001; however, the terrorist attacks of September 11, 2001, caused titanium sponge consumption to plummet in 2002 and reach a low of $17,100 \mathrm{t}$ in 2003. Titanium prices followed the downward trend in consumption, reaching a low of $\$ 3.34$ per pound in 2003. In 2004, the consumption in the aerospace industry began to rise along with consumption in the steel industry where titanium is used for deoxidation, grain-size control, or carbon and nitrogen control and stabilization typi- 
cally in interstitial-free, stainless, and high-strength low-alloy steels. From 2004 to 2008, titanium sponge consumption and prices increased significantly, and producers began projects to increase sponge production capacity. The global financial crisis that began in 2008 caused consumption and prices of titanium to decrease as commercial airlines delayed aircraft deliveries. In 2010, titanium consumption from commercial aircraft recovered as aircraft producers prepared to expand production of new wide-body aircraft lines. Because titanium sponge prices normally lag market conditions, prices of titanium sponge were lower in 2010, and continued a downward trend that began in 2008 .

\section{References Cited}

American Metal Market, 1993a, Greater penalty sought against CIS's titanium: American Metal Market, v. 101, no. 174, September 9, p. 1.

American Metal Market, 1993b, Titanium prices drop as Timet strike continues: American Metal Market, v. 101, no. 247, December 27, p. 1.

American Metal Market, 1996, Titanium tees off to a birdie: American Metal Market, v. 104, no. 147, September 9, p. 1.
Aviation Week \& Space Technology, 1997, Boeing suppliers warn of protracted delays: Aviation Week \& Space Technology, v. 147, no. 13, p. 22.

Barksdale, Jelks, 1966, Titanium-Its occurrence and technology: New York, The Ronald Press Company, 691 p.

Institute of Scrap Recycling Industries, Inc., 1998, TitaniumA titanic slide: ISRI Commodities Report, v. 4, no. 24, December 16, p. 1-2.

Metal Bulletin, 1998, RMI secures new long-term aerospace contracts: Metal Bulletin, no. 8253, February 16, p. 13.

National Materials Advisory Board, 1983, Titanium-Past, present, and future: Washington, D.C., National Academy Press, 209 p.

RMI Titanium Co., 1992, Annual report 1992: Niles, Ohio, RMI Titanium Co., 33 p.

Titanium Development Association, 1990, Statistical review 1980-1989: Dayton, Ohio, Titanium Development Association, $27 \mathrm{p}$.

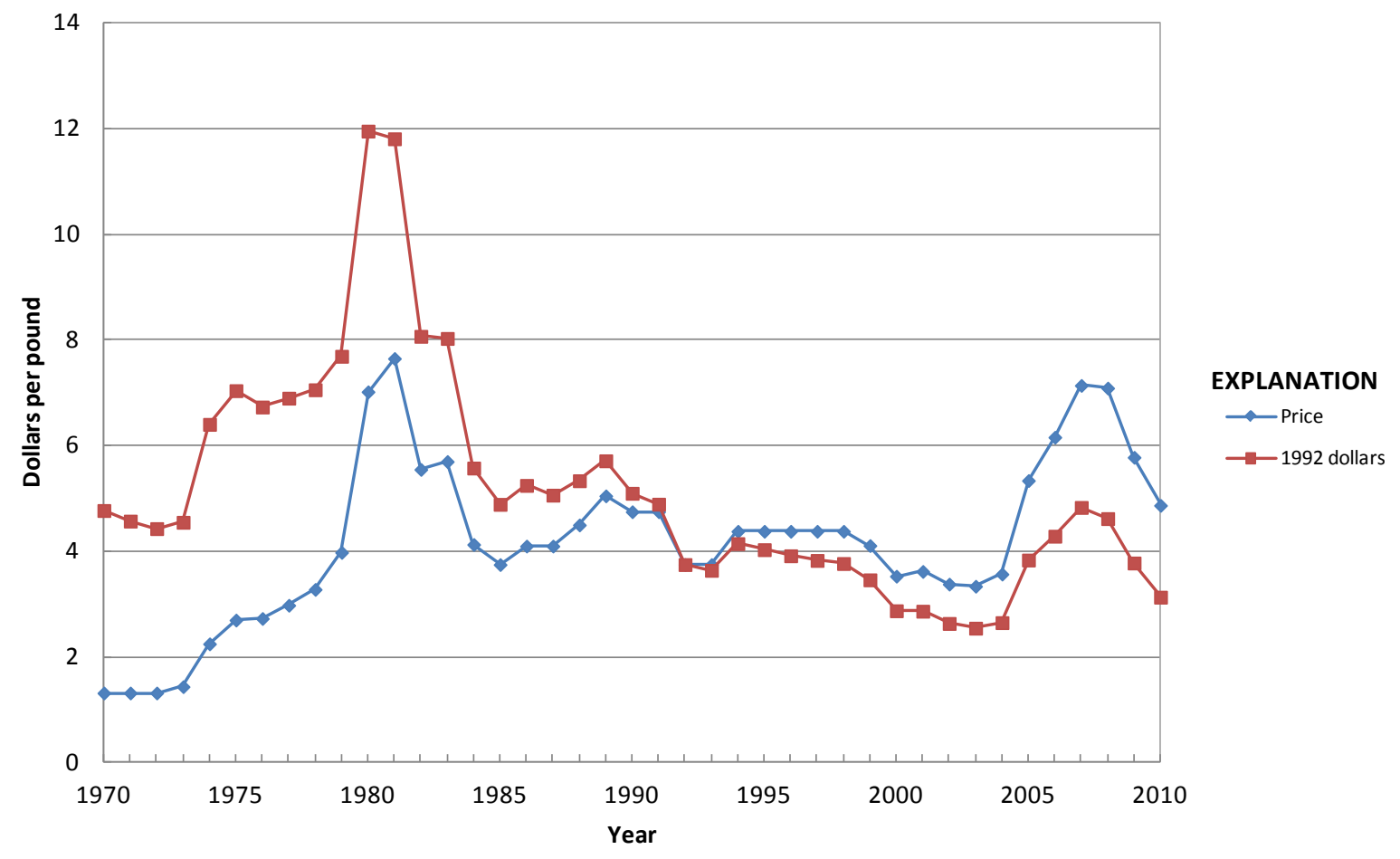

Figure 1. Average yearend titanium sponge price. 


\section{Significant events affecting titanium prices since 1970}

1971 Research for Supersonic Transport terminated

1975-76 Military aircraft production peak (F-14 and F-15)

1977-81 Rapid increase in orders for commercial aircraft

1982-84 Collapse of the commercial aircraft market

1984-86 Production of B-1B bombers

1985-89 Renewed strength in the commercial aircraft market

1988-89 Increases in U.S. sponge production capacity

1990-94 Reductions in military and commercial aerospace (post Cold War)

1992

1993

1994-97

Sodium-reduction sponge plant closed at Ashtabula, Ohio

1997-98

2001

2004-08

2008-09

Titanium sponge plant commissioned at Henderson, Nev.

2009

Surge in consumer goods and commercial aerospace orders

Asia financial crisis

September 11 terrorist attacks

Increased consumption from commercial aircraft and steel

Global financial crisis

Titanium sponge plant commissioned at Rowley, Utah

Table 1. Average yearend titanium sponge price.

[Values in dollars per pound]

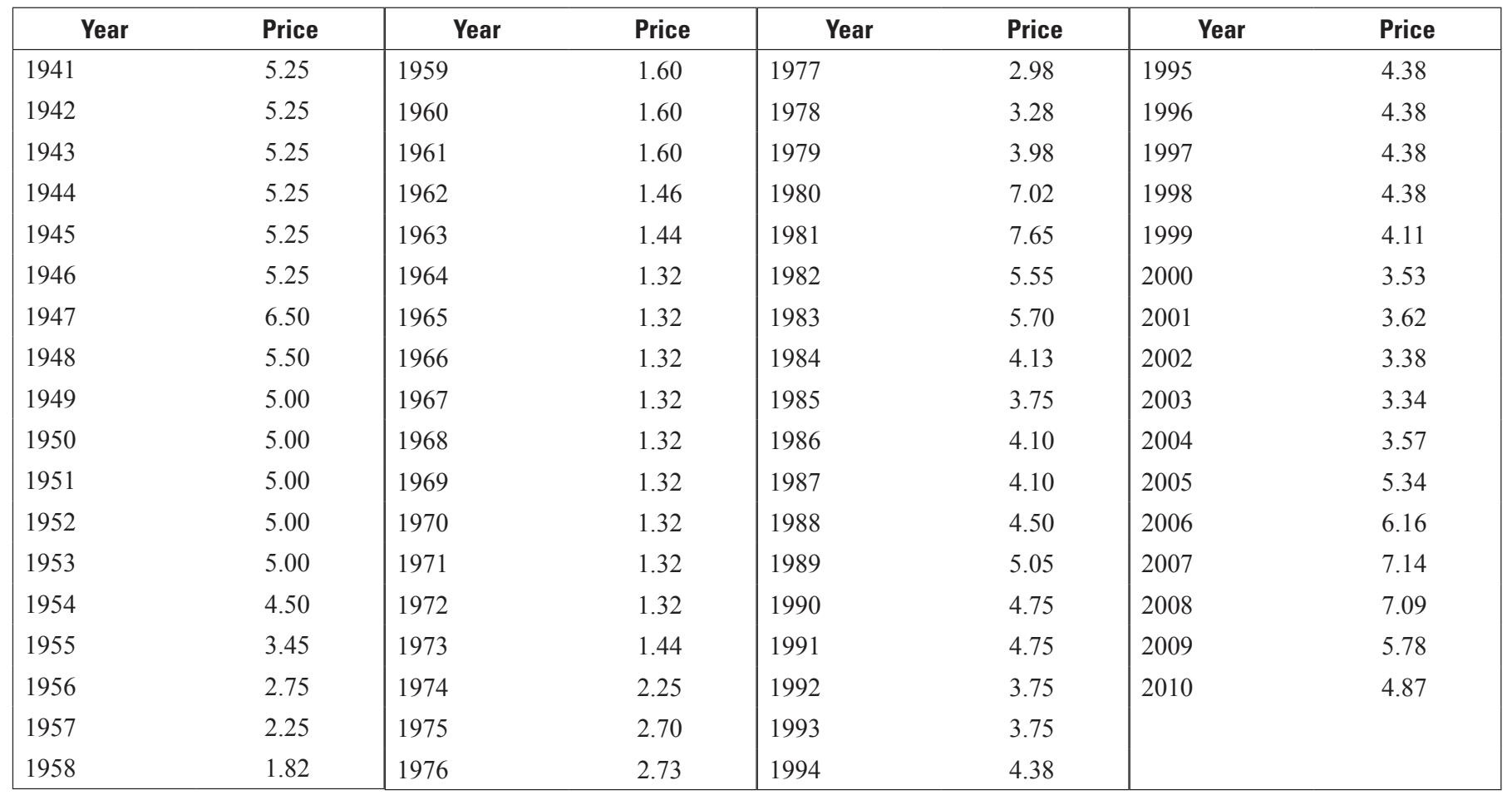

Notes:

1941-51, 1952-65, 1972-82, prices are an average of a range, in Engineering and Mining Journal, Metal and Mineral Markets.

1952-65, 1972-82, published by the U.S. Bureau of Mines, but origin is unknown.

1967-71, prices are an average of a range, in Metals Week.

1983-98, prices are an average of a range, in American Metal Market.

1999-2010, unit value of landed duty-paid imports (Japan and Russia). 


\title{
Tungsten (W)
}

\author{
by Kim B. Shedd
}

In the 16th century, smelters in what is now Germany observed that something was reducing their tin yield. This material, which was called "Spuma Lupi" in Latin and "Wolfram" in German, turned out to be wolframite, now one of the two commercially important minerals mined for the metal tungsten. Two hundred years later, in the mid-18th century, European chemists and mineralogists extracted tungsten from wolframite and scheelite, the other commercially important tungsten mineral. The name "tungsten," from the Swedish "tung sten" or "heavy stone," was first used for the mineral we now call scheelite. Today the name for the element is either a derivative of "tungsten" or "wolfram," depending on the country and language spoken, and it is identified in the periodic table by the letter "W" (International Tungsten Industry Association, 2009, p. 25-29).

Tungsten has the highest melting point of all metals, one of the highest densities, and, when combined with carbon, is almost as hard as diamond. These and other properties make it useful in a wide variety of important commercial, industrial, and military applications. One hundred years ago, the main use of tungsten was as an additive to steel, and scientists were just beginning to research the use of tungsten filaments in light bulbs. Today, although lamp filaments may be the most familiar use of tungsten, the leading use is in cemented carbides. Cemented carbides (also called hardmetals) are wear-resistant materials used by the construction, metalworking, mining, and oil and gas drilling industries. Tungsten metal contacts, electrodes, filaments, wires, and other products are used in electrical, electronic, heating, lighting, and welding applications. Tungsten is also used to make corrosion- and wearresistant alloy parts and coatings; specialty steels for pipes, tools, and valves; superalloys for turbine engine parts; and tungsten heavy alloys (also called "heavy metal alloys") for armaments, heat sinks, and high-density applications, such as weights and counterweights. Tungsten, often in combination with less-dense materials, is used as a substitute for lead in ammunition, fishing weights, hunting shot, radiation shielding, wheel weights, and other high-density applications. Chemical uses of tungsten include catalysts, inorganic pigments, and high-temperature lubricants.

Tungsten prices and many tungsten statistics are quoted in units of tungsten trioxide $\left(\mathrm{WO}_{3}\right)$. The short ton unit, used in the United States, is 1 percent of a short ton (20 pounds) and tungsten trioxide is 79.3 percent tungsten. Therefore, a short ton unit of $\mathrm{WO}_{3}$ equals 20 pounds of $\mathrm{WO}_{3}$ and contains 7.19 kilograms (15.86 pounds) of tungsten. The metric ton unit, used in most other countries, is 1 percent of a metric ton (10 kilograms). A metric ton unit of $\mathrm{WO}_{3}$ contains 7.93 kilograms (17.48 pounds) of tungsten.

Tungsten is not traded on any exchange, such as the London Metal Exchange Ltd. Sales are negotiated between producers and consumers or between traders and consumers. Prices published by trade journals, such as Metal Bulletin, Platts Metals Week, and Ryan's Notes, are derived from information collected from consumers, producers, and traders. This approach has the potential for bias or manipulation, particularly when a reported price change is the result of a small tonnage of material traded (Roskill Information Services Ltd., 2011, p. 223).

Historically, the main reference price for tungsten was the price of tungsten concentrates. In the early 1990s, the trade in tungsten concentrates decreased, and the market shifted towards the price of the intermediate product ammonium paratungstate as a reference price (International Tungsten Industry Association, 1997, p. 32). Prices of tungsten concentrates and ammonium paratungstate generally follow similar trends. One would expect the price of ammonium paratungstate to exceed that of concentrate by an amount equivalent to the processing costs to convert concentrate to ammonium paratungstate. In 1992, however, the Metal Bulletin price for ammonium paratungstate actually fell below that for concentrate. At that time, the normal premium for ammonium paratungstate was estimated to be between $\$ 23$ and $\$ 32$ per short ton unit. Possible explanations for this unusual pricing situation were the availability of very inexpensive feedstock for Chinese ammonium paratungstate plants or Government subsidies for those plants (Maby, 1993).

The main forms of tungsten used by downstream consuming industries are ferrotungsten, tungsten carbide powder, tungsten metal powder, and various tungsten chemical compounds. Of these materials, ammonium paratungstate and ferrotungsten are the ones for which prices are most often provided. Prices for tungsten concentrates are also still available.

Historically, tungsten prices have fluctuated widely as the market alternated between periods of scarcity and oversupply. General economic conditions and industrial activity, China's position as the world's leading producer, and more recently, China's position as its leading consumer, have significantly influenced the tungsten market over time. The following additional factors have also been cited as influences on the tungsten market and price: changes in availability from Communist or formerly Communist countries; purchases for or sales from various Government stockpiles; trade controls; buildup or reduction in inventories held by industry; fluctuations in production by a large number of widely dispersed small 
producers; differing political, social, and economic objectives of producing countries; industry fragmentation in that most countries that produce tungsten are not large consumers; rapid shifts in demand; increases in demand in support of military activity; interest rates; exchange rates; and inflation or deflation (Engineering and Mining Journal, 1967; Burrows, 1971, p. 1-7 and 36-37; Rawlings, 1974; Lincoln, 1986; Mines Dynacor Inc., 2007, p. 21).

From the late 1950 s to early 1960 s, the tungsten market was characterized by oversupply and low prices (table 1). This was a result of several factors. Following the Korean conflict, high prices combined with U.S. Government programs to stockpile tungsten and to encourage domestic production by purchasing tungsten concentrates from U.S. mines at a fixed price led to an increase in production (Geehan, 1955; Grainger, 1960). This was followed by reduced demand when the U.S. Government's tungsten acquisition program was completed and increased supply as a result of the disposal of stockpiled ore from the United Kingdom, the resumption of shipments from Korea, and increased offers of tungsten from China and Russia (Grainger, 1960, 1962).

In late 1963, exports of tungsten from China, North Korea, and Russia suddenly decreased significantly from those of previous years. The apparent withdrawal of these countries from the world market combined with an increase in demand from Eastern Europe resulted in a supply squeeze and a significant increase in prices by late 1964 . The high prices led to an increase in mine production from non-Communist countries and increased recycling of tungsten-bearing scrap. In 1965, the U.S. Government began a long-term sales program of tungsten concentrates from Defense Production Act inventories. The increase in supply from these sources was not enough to balance the loss of tungsten from Communist countries during a period of strong worldwide demand (Grainger, 1965; Engineering and Mining Journal, 1967). As a result, the annual average U.S. price of tungsten concentrate in 1966 was more than four times greater than that of 1963 .

Prices remained relatively high during the late 1960s owing to strong demand and only limited exports of tungsten from China. United States tungsten consumption was strong, at least in part, in support of the war in Vietnam and for increased production of tungsten carbide balls for ballpoint pens and studs for automobile snow tires. Sales of tungsten concentrates from the U.S. Government at fixed prices contributed to the stabilization of the U.S. market (Stevens, 1969). Between March 1966 and December 1973, the U.S. Government's General Services Administration (GSA) "off-the-shelf" fixed prices for tungsten concentrates were quoted as the price of concentrates in the U.S. market (fig. 1). Between October 1969 and February 1970, European prices for tungsten concentrates quoted in Metal Bulletin increased from approximately $\$ 46$ per short ton unit to a high of approximately $\$ 80$ per short ton unit (Ratzker, 1971). The increase in European prices was reported to be primarily the result of a continued high level of industrial activity in combination with the absence of significant quantities of tungsten shipments from China. In 1969, as a result of stable fixed prices in the United States, increasing market prices in Europe, and the availability of tungsten from the U.S. Defense Production Act inventories, the United States became a net exporter of tungsten concentrates for the first time in history (Stevens, 1970).

A worldwide economic slowdown in 1971 led to reduced demand for tungsten, particularly from the machine tool and steel industries (Mining Journal, 1972). During 1972 and 1973, economic conditions improved, and demand for tungsten increased. United States prices were quoted at the GSA "off-the-shelf" fixed price of $\$ 55$ per short ton unit. European prices decreased to a low of approximately $\$ 30$ per short ton unit by late 1972. The downward trend in European prices during a period of increasing demand was attributed to substantial inventories overhanging the market. By late 1972early 1973, the rate of consumption had increased enough to cause a significant reduction in inventory levels, and European prices began to increase (Rawlings, 1974).

Toward the end of 1973, the GSA discontinued its "offthe-shelf" fixed-price sales of tungsten concentrates in favor of monthly sales on a sealed-bid basis (Stevens, 1975). From 1974 through 1976, awards of tungsten concentrates from U.S. Government stockpiles were at unit values close to the prevailing European prices quoted in Metal Bulletin. In 1974, high levels of tungsten consumption in the United States and Europe and reduced inventory levels resulted in an increase in the Metal Bulletin price to more than $\$ 100$ per short ton unit (Rawlings, 1975). The Metal Bulletin price was relatively stable in 1975 in spite of recessionary economic conditions in Western World markets and a corresponding decrease in tungsten demand. During the next 2 years, tungsten prices increased sharply to record highs as a result of worldwide inflation, strong buying by Eastern European countries, a recovery in Western World demand, and reports of decreased quantities of tungsten offered by China (Ho, 1977). Metals Week began publishing U.S. spot prices for tungsten concentrates in January 1977 after a hiatus of more than 10 years. By March 1977, this price exceeded $\$ 160$ per short ton unit.

By late 1977-early 1978, the price of tungsten concentrates began to decline. Although mine production from the Western World had steadily increased, it was tungsten exports from China and releases from U.S. Government stockpiles that balanced a shortfall in production relative to consumption. The decline in prices during 1978 was attributed to the following factors: an increase in Western World tungsten inventories during 1977; reduced demand in Western Europe, particularly for ferrotungsten; increased Western World mine production; and the absence of Eastern European buyers as a significant influence in the Western World market (Thurber, 1979).

Between late February 1979 and late October 1981, the average of Metals Week prices for tungsten concentrate was relatively stable in the $\$ 120$ - to $\$ 140$-per-short-ton-unit range. By late 1981, the worldwide recession began to affect tungsten demand. In addition, China was exporting steadily increasing amounts of tungsten concentrates and intermediate products to Western World markets (Thurber, 1982; Ho, 1986). In the mid- 
1980s, the availability of low-priced intermediate products from China contributed to the downward trend in the price of tungsten concentrates. There was a marked change from concentrate prices governing the price of intermediate products to intermediate product prices governing concentrate prices (Ho, 1986). The price of concentrate trended downward to a low of $\$ 28$ per short ton unit by late 1986 , and then generally trended upward to $\$ 64$ per short ton unit in 1988. From September 1988 to late 1990 , the price steadily decreased to $\$ 31$ per short ton unit. The decrease in price during a 3-year period of strong Western World consumption was attributed to continued oversupply of Chinese tungsten (Bunting, 1991).

In early 1991, China's State Council listed tungsten as a special metal under State protection, which resulted in restrictions on its mining, processing, and export (Zhang, 1991; Huang, 2009). Later in the year, the U.S. Government determined that imports of Chinese tungsten ores and concentrates were being sold in the United States at less than fair market value and imposed a 151 percent antidumping duty on them. By mid-1991, the concentrate price increased to \$67 per short ton unit. During the next 2 years, the price steadily fell to $\$ 28$ per short ton unit. This price decline was attributed to continued exports of tungsten materials from China during a period of reduced demand as a result of the worldwide economic recession, a decrease in imports by former Soviet countries following the breakup of the Soviet Union in 1991, and destocking by consumers (Maby, 1993). By 1993, imports of Chinese tungsten concentrates and intermediate products had grown to 75 percent of market economy countries' supply of primary tungsten (Bunting, 1994). Added to the increasing supply from China were exports of tungsten materials from Russia and other countries of the former Soviet Union.

By 1994, almost all of the tungsten mines in market economy countries had ceased production, and Chinese mine production was at a low level as a result of the persistent low price of tungsten concentrates (Bunting, 1997). In 1994, the world economy and industrial activity improved, demand for tungsten increased, and prices began to rise (Maby, 1995). By mid-1995, the concentrate price rose to $\$ 70$ per short ton unit. This led to large releases of tungsten from Government stockpiles in China, Kazakhstan, and Russia; releases of inventories from Russian mines; and an increase in mine production. By early 1996, an oversupply situation had developed. As a result, prices decreased and mine production was reduced. By late 1996, most of the inventories that had been overhanging the market had been drawn down (Bunting, 1997).

From 1997 to 1999, prices continued to decrease owing to plentiful supplies from China, Russia, and other countries in the former Soviet Union. In 1998, two events occurred that would have an effect on future supply - the U.S. Congress authorized the sale of tungsten materials from the National Defense Stockpile, which would add to supply, and the Chinese Government began to restructure its tungsten industry, which would reduce supply. With respect to demand, China's growing economy resulted in a steady increase in Chinese tungsten consumption that continued through 2010 (Bunting,
1999; Maby, 1999, p. 2, 8-9; Shedd, 2000, p. 80.1-80.2, 80.4; Zhu, 2004; Fang, 2011, p. 20).

In 1999, the Chinese Government began to increase control of its domestic tungsten industry to conserve its resources and ensure supplies to meet anticipated domestic demand. During the next 12 years, the Chinese Government controlled tungsten production and exports by closing illegal mines; limiting the number of exploration, mining, and export licenses; limiting or forbidding foreign investment; imposing constraints on mining and processing; establishing quotas on mine production and exports; adjusting export quotas to favor value-added downstream materials and products; and shifting from export tax rebates to export taxes. In addition, Chinese tungsten industry associations set minimum prices for tungsten materials. The near doubling of ammonium paratungstate prices between mid-2000 and mid-2001 was attributed to Chinese export quotas, which limited supplies of tungsten intermediates to leading processors, and may have been enhanced by panic buying or consumer stockpiling. The decrease in prices during the latter part of 2001 was attributed to a severe reduction in production of tungsten end products resulting from a slowdown of the world economy, which was compounded by the terrorist attacks in the United States on September 11; an increase in smuggling of primary tungsten materials, including tungsten concentrates, from China; and the buildup of inventories by consumers and traders. Demand for tungsten in 2002 was almost 25 percent lower than that of 2001 (American Metal Market, 1999; Metal Bulletin, 1999a, b; Zhou, 2000; Avocet Mining PLC, 2001; Ross, 2001, p. 2, 5, 13; North American Tungsten Corp. Ltd., 2002; Interfax Ltd., 2007; Roskill Information Services Ltd., 2007, p. 214; Fang, 2011, p. 3-4, 23-24, 44, 46, 48).

In 2004 and 2005, tight supplies of tungsten concentrates within China led to reduced production and exports of ammonium paratungstate and ferrotungsten, which resulted in steep increases in world tungsten prices. In 2005, ammonium paratungstate prices in the United States and Europe reached highs that were three times higher than the maximum prices in 2004. Various factors were cited as contributing to the shortage of tungsten concentrates and price increases. In early 2004, drought conditions in the tungsten mining regions of southern China resulted in severe shortages of electrical power, which affected the production of tungsten concentrates. In addition, a major Chinese producer announced that it planned to cease operations at 4 of its 11 mines for a period of 6 months as part of a reorganization. Other factors included mine closures for environmental reasons, withdrawal of Government subsidies to tungsten mines, the need for companies to be profitable, the realization by mining companies that they controlled the market, the lack of new resource development, speculation, and increasing demand for tungsten products within China. In 2005, tungsten consumption from Europe, Japan, and the United States also increased. This period of high prices prompted increased interest in developing new mines and reopening inactive mines outside of China (Metal Bulletin, 2004; Wong, 2004; Wong and Magnowski, 2004; Zhu, 2004; 
Martin, 2005, p. 24, 27; Roskill Information Services Ltd., 2007, p. 214-15).

After a peak in ammonium paratungstate prices in mid2005 , prices remained high, but generally trended slightly downward for the next 3 to 4 years. The financial crisis in late 2008 and global economic downturn that followed had a significant impact on industrial activity and tungsten consumption in Europe, Japan, and the United States. In late 2008-early 2009, tungsten prices dropped dramatically. By mid-2009, U.S. and European ammonium paratungstate prices were 35 percent lower than those of 2008. During this period, Chinese domestic tungsten consumption remained strong, although Chinese exports decreased by more than 40 percent because of weak demand elsewhere. Global economic conditions began to improve in late 2009, and in 2010, world tungsten consumption increased to approach that of 2008. As a result, tungsten prices began to rise. By yearend 2010, the U.S. price of ammonium paratungstate was nearly back to that of 2008, and the European price exceeded the high of 2005. Some analysts forecast that tungsten supplies could remain tight until at least 2013, when sufficient new mine capacity could come online to balance demand (Fang, 2011, p. 20, 26-27; Malaga Inc., 2011, p. 10; North American Tungsten, 2012, p. 5; Seddon, 2011, p. 7-9, 26).

\section{References Cited}

American Metal Market, 1999, China halts new mining permits for 8 minerals: American Metal Market, v. 107, no. 103 , May 28, p. 5.

Avocet Mining PLC, 2001, Interim results for the six months ended 30 September 2001 - Chairman's statementTungsten: London, Avocet Mining PLC news release, December $18,8 \mathrm{p}$.

Bunting, R.M., 1991, Tungsten-A strong year-But: Engineering and Mining Journal, v. 192, no. 3, March, p. 27-29.

Bunting, R.M., 1994, Presentation to I.T.I.A. AGM-11/3/94, in International Tungsten Industry Association annual general meeting, 7th, Huntsville, AL, November 2-4, 1994, Proceedings: London, International Tungsten Industry Association, $16 \mathrm{p}$.

Bunting, R.M., 1997, Tungsten - Can the industry meet future demand?: Engineering and Mining Journal, v. 198, no. 3, March, p. 37-41.

Bunting, R.M., 1999, Tungsten: Engineering and Mining Journal, v. 200, no. 3, March, p. 43-46.

Burrows, J.C., 1971, Tungsten-An industry analysis: Lexington, MA, D.C. Heath and Co., 287 p.

Engineering and Mining Journal, 1967, Tungsten: Engineering and Mining Journal, v. 168, no. 2, February, p. 165-167.
Fang, Jiyun, 2011, Update of China tungsten market and its forecast: International Tungsten Industry Association Annual General Meeting, 24th, Nice, France, September 20-22, 2011, Presentation, 54 p.

Geehan, R.W., 1955, Tungsten, in Metals and minerals (except fuels): U.S. Bureau of Mines Minerals Yearbook 1952, v. I, p. 1066-1082.

Grainger, P.E., 1960, Tungsten, in Annual review 1960: Mining Journal, p. 41.

Grainger, P.E., 1962, Tungsten, in Annual review 1962: Mining Journal, p. 41.

Grainger, P.E., 1965, Tungsten, in Mining annual review 1965: Mining Journal, p. 48-49.

Ho, Eric, 1977, Tungsten, in Mining annual review 1977: Mining Journal, p. 82-83.

Ho, Eric, 1986, Tungsten, in Mining annual review 1986: Mining Journal, p. 73.

Huang, Guoping, 2009, The background and analysis of relevant policies and reforms to tungsten industry in China: International Tungsten Industry Association Annual General Meeting, 22d, Vancouver, British Columbia, Canada, September 16-17, 2009, Presentation, 5 p.

Interfax Ltd., 2007, China to ban foreign investment in scarce metal resource development: China Metals Report Weekly, v. 6, issue 41, November 3-9, p. 9-10.

International Tungsten Industry Association, 1997, Tungsten: London, International Tungsten Industry Association, 33 p.

International Tungsten Industry Association, 2009, Tungsten: London, International Tungsten Industry Association, 134 p.

Lincoln, G.M., Jr., 1986, Tungsten-Bleak market environment: Engineering and Mining Journal, v. 187, no. 3, March, p. 59-61.

Maby, Michael, 1993, Tungsten, in Metals and minerals annual review 1993: Mining Journal, p. 72-73.

Maby, Michael, 1995, Tungsten, in Metals and minerals annual review 1995: Mining Journal, p. 63-64.

Maby, Michael, 1999, Market report: International Tungsten Industry Association International Tungsten Symposium, 8th, Fukuoka, Japan, October 12-15, 1999, Presentation, $15 \mathrm{p}$.

Malaga Inc., 2011, Annual information form relating to the year ended December 31, 2010: Montreal, Quebec, Canada, Malaga Inc., 28 p. 
Martin, Robert, 2005, China tungsten today: Platts Steel \& Ferroalloys Conference-2005, Pittsburgh, PA, June 14-15, 2005, Presentation, $50 \mathrm{p}$.

Metal Bulletin, 1999a, China sets floor price for tungsten: Metal Bulletin, no. 8396, July 26, p. 8.

Metal Bulletin, 1999b, China shakes up tungsten industry: Metal Bulletin, no. 8383, June 10, p. 8.

Metal Bulletin, 2004, Chinese APT prices push above $\$ 70$ per mtu: Metal Bulletin, no. 8829.4, February 13, p. 3.

Mines Dynacor Inc., 2007, Annual information form relating to the year ended December 31, 2006: Montreal, Quebec, Canada, Mines Dynacor Inc., $30 \mathrm{p}$.

Mining Journal, 1972, Tungsten, in Mining annual review 1972: Mining Journal, p. 80-83.

North American Tungsten Corp. Ltd., 2002, Management discussion-For the three months ended September 30, 2001-Tungsten market: The Canadian Depository for Securities Ltd., 4 p.

North American Tungsten Corp. Ltd., 2012, Annual management discussion and analysis 2011: Vancouver, British Columbia, Canada, North American Tungsten Corp. Ltd., January $27,34 \mathrm{p}$.

Ratzker, Menno, 1971, Tungsten: Engineering and Mining Journal, v. 172, no. 3, March, p. 149-150.

Rawlings, J.W., 1974, Tungsten-'73 market firmed, but GSA remains pricing key: Engineering and Mining Journal, v. 175, no. 3, March, p. 130-131.

Rawlings, J.W., 1975, Tungsten-Prices take off in '74 on good demand and lack of surplus inventories: Engineering and Mining Journal, v. 176, no. 3, March, p. 133-134.

Roskill Information Services Ltd., 2007, The economics of tungsten: London, United Kingdom, Roskill Information Services Ltd., 9th ed., 220 p.

Roskill Information Services Ltd., 2011, Tungsten-Market outlook to 2016: London, United Kingdom, Roskill Information Services Ltd., 10th ed., $230 \mathrm{p}$.

Ross, Brian, 2001, Tungsten: Ryan's Notes Ferroalloys Conference, Orlando, Fla., October 28-30, 2001, Presentation, $19 \mathrm{p}$.
Seddon, Mark, 2011, Review of recent events in the market and status of mining projects: International Tungsten Industry Association Annual General Meeting, 24th, Nice, France, September 20-22, 2011, Presentation, 37 p.

Shedd, K.B., 2000, Tungsten, in Metals and minerals: U.S. Geological Survey Minerals Yearbook 1998, v. I, p. $80.1-80.16$.

Stevens, R.F., Jr., 1969, Tungsten: Engineering and Mining Journal, v. 170, no. 3, March, p. 130-133.

Stevens, R.F., Jr., 1970, Tungsten: Engineering and Mining Journal, v. 171, no. 3, March, p. 106-109.

Stevens, R.F., Jr., 1975, Tungsten, in Metals, minerals, and fuels: U.S. Bureau of Mines Minerals Yearbook 1973, v. I, p. $1245-1261$.

Thurber, W.C., 1979, Tungsten - U.S. consumption at highest level since 1974: Engineering and Mining Journal, v. 180, no. 3, March, p. 139-143.

Thurber, W.C., 1982, Tungsten-Production and consumption drop as economies weaken: Engineering and Mining Journal, v. 183, no. 3, March, p. 98-100.

Wong, K.L., 2004, Mine shutdowns deepen tungsten supply concerns: Metal Bulletin, no. 8838, April 19, p. 18.

Wong, K.L., and Magnowski, Daniel, 2004, Chinese FeW exporters push for further increases: Metal Bulletin, no. 8830 , February 23 , p. 18 .

Zhang, Qi, 1991, China tungsten in for dramatic decline in '92: American Metal Market, v. 99, no. 171, September 6, p. 4.

Zhou, Juqiu, 2000, Re-organization of China's non-ferrous metals industry: International Tungsten Industry Association, Annual General Meeting, 13th, Washington, D.C., September 27-28, 2000, Presentation, 4 p.

Zhu, Guang, 2004, An update of China tungsten market: International Tungsten Industry Association, Annual General Meeting, 17th, Lisbon, Portugal, September 27-29, 2004, Presentation, $7 \mathrm{p}$. 


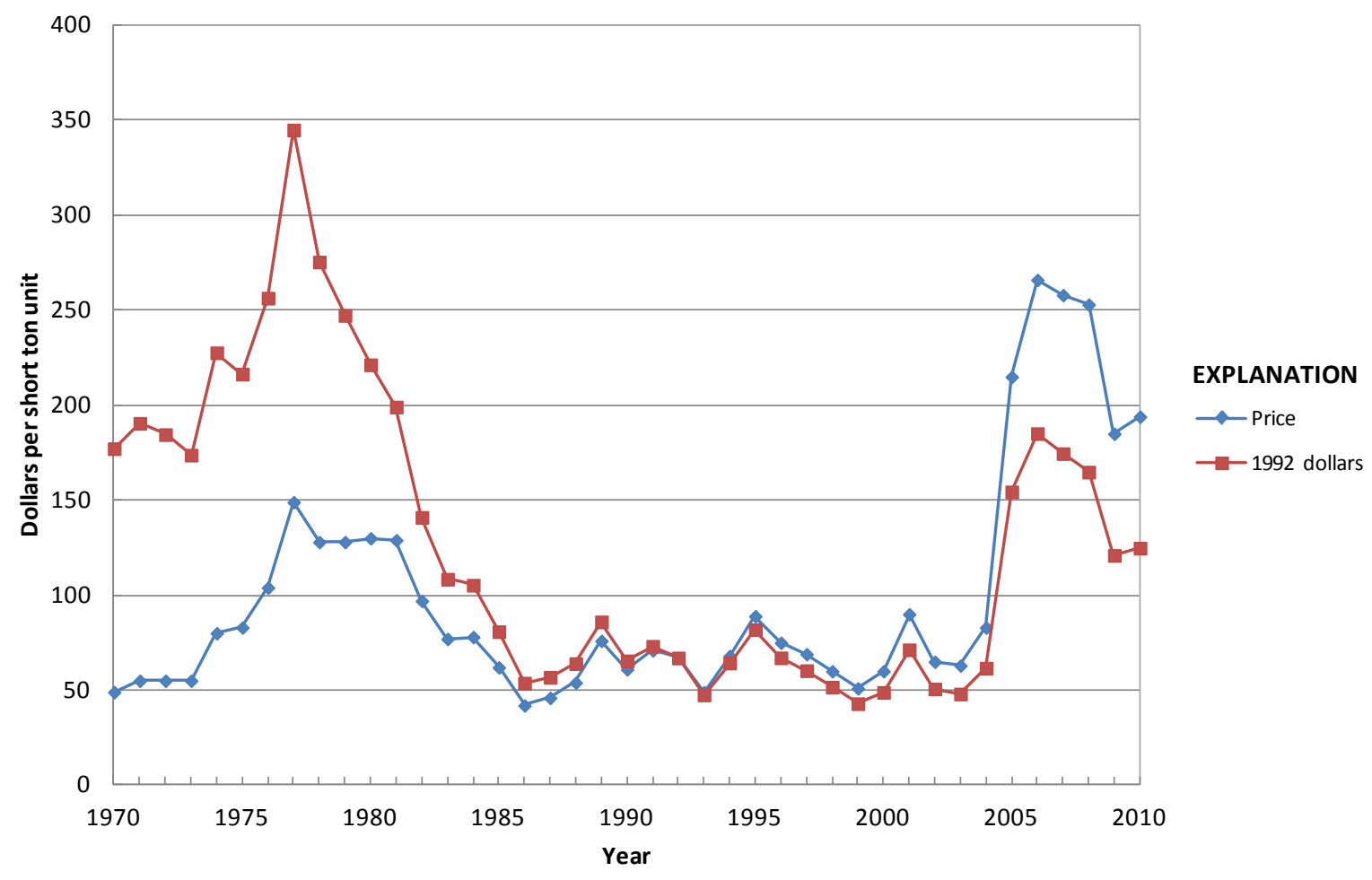

Figure 1. Annual average tungsten price.

\section{Significant events affecting tungsten prices since 1970}

1970-89 Disposal of tungsten concentrates from U.S. Government stockpiles

1970-73 U.S. Government sold stockpiled tungsten at fixed "off-the-shelf" prices

1970-74 Improved economic conditions; strong demand for tungsten; reduction in inventory levels

1973 U.S. Government sales method for stockpiled tungsten changed from fixed price to sealed bid

1976-77 Recovery in Western World tungsten demand (during the Cold War era, Western World referred to North American Treaty Organization members and other countries aligned with the United States, and was distinguished from Eastern Bloc countries under Soviet influence and third world countries), strong buying by Eastern European countries, limited sales of tungsten concentrates from China

1978 Reduced demand for tungsten in Western Europe; increased Western World mine production and inventories; absence of Eastern European buyers

1979-2000 Increasing dominance of China as global supplier of tungsten

1981-82 Sharp recession, increase in tungsten exports from China

1991 Chinese Government listed tungsten as a protected resource; U.S. antidumping duty imposed on Chinese concentrates; dissolution of the Soviet Union

1992 Start of tungsten exports to the world market from Russia and other countries of the former Soviet Union

1994 Improved global economic conditions and increase in industrial activity

1994-95 Large releases of tungsten from Government stockpiles in China, Kazakhstan, and Russia; releases of Russian mine stocks; increase in mine production

1998-2010 Steady increase in Chinese tungsten consumption

$1999 \quad$ U.S. Government resumed sales of stockpiled tungsten for the first time since 1989

1999-2010 Chinese Government increased control of domestic tungsten production and exports

$2001 \quad$ Chinese export quotas limited the supply of tungsten intermediates

2001-02 Slowdown in world economy

2004-05 Tight supplies of tungsten concentrates in China, followed by an increase in global demand

2006

2008 Chinese Government began a steady reduction of annual export quotas for tungsten materials Chinese domestic consumption of tungsten exceeded exports for the first time

2008-09 Global financial crisis and economic downturn caused decrease in non-Chinese tungsten consumption 
Table 1. Annual average tungsten price.

[Values in dollars per short ton unit]

\begin{tabular}{|lc|lc|lc|lc|}
\hline \multicolumn{1}{|c|}{ Year } & Price & \multicolumn{2}{c|}{ Year } & Price & Year & Price & \multicolumn{2}{c|}{ Year } & Price \\
\hline 1959 & 13 & 1972 & 55 & 1985 & 62 & 1998 & 60 \\
1960 & 19 & 1973 & 55 & 1986 & 42 & 1999 & 51 \\
1961 & 17 & 1974 & 80 & 1987 & 46 & 2000 & 60 \\
1962 & 12 & 1975 & 83 & 1988 & 54 & 2001 & 90 \\
1963 & 9 & 1976 & 104 & 1989 & 76 & 2002 & 65 \\
1964 & 15 & 1977 & 149 & 1990 & 61 & 2003 & 63 \\
1965 & 23 & 1978 & 128 & 1991 & 71 & 2004 & 83 \\
1966 & 38 & 1979 & 128 & 1992 & 67 & 2005 & 215 \\
1967 & 43 & 1980 & 130 & 1993 & 49 & 2006 & 266 \\
1968 & 43 & 1981 & 129 & 1994 & 68 & 2007 & 258 \\
1969 & 43 & 1982 & 97 & 1995 & 89 & 2008 & 253 \\
1970 & 49 & 1983 & 77 & 1996 & 75 & 2009 & 185 \\
1971 & 55 & 1984 & 78 & 1997 & 69 & 2010 & 194 \\
\hline
\end{tabular}

Notes: Annual average prices were derived from price changes reported in the following sources:

1959-66, tungsten ore (wolframite) in New York, "ordinary quality," excluding duty, in American Metal Market.

1967-73, tungsten ore, domestic quote reflecting the U.S. Government's General Services Administration price, in American Metal Market's Metal Statistics 1972 and Metal Statistics 1974.

1974-76, tungsten ore, minimum 65-percent tungsten trioxide, European market, excluding duty, in U.S. Bureau of Mines Minerals Yearbook, converted from pounds sterling per metric ton unit as reported in Metal Bulletin.

1977-88, tungsten ore; minimum 65-percent tungsten trioxide; U.S. spot price; cost, insurance, and freight; excluding duty, in Metals Week.

1989-2010, ammonium paratungstate, U.S. free market, in Metal Bulletin. 


\title{
Vanadium (V)
}

\author{
by Désirée E. Polyak
}

Vanadium was first described by Andrés Manuel del Río in 1801. He had isolated it from lead ores from Zimapan, Mexico (Busch, 1961, p. 18). At the start of the 20th century, vanadium remained little more than a chemical curiosity with no commercial value because of its rarity and high cost. The supply and cost restrictions were significantly altered in the early years of the 20th century with the discovery of rich vanadium deposits in several countries, including the United States. In 1905, the American Vanadium Co. was established to extract vanadium from ores discovered in Colorado (Kuck, 1985 , p. 985). Commercial production began shortly thereafter.

Two main prices are associated with vanadium — one is for the ferroalloy ferrovanadium, and the other for vanadium pentoxide; prices for vanadium ore and metal are not published. Because much of the world's ferrovanadium is made from vanadium pentoxide, the price for vanadium pentoxide has been described in this report.

Owing in part to the absence of free market trading, the vanadium pentoxide price has historically been a producer price. This has resulted in low volatility and relatively stable prices, showing a gradual upward trend in current dollars, for the period from 1959 through 1988 (table 1). Since the late 1980s, the vanadium pentoxide price appears to have become more volatile. Given the close relationship between the vanadium and steel markets, the outlook for steel production has a large bearing on the outlook for the vanadium market.

The vanadium industry has moved through several cycles of oversupply and undersupply that have resulted in sharp and rapid price movements. Long periods of oversupply, usually the result of investments in new capacity during brief periods of high prices, have often led to cutbacks in utilization of capacity, which eventually led to the next price spike. The rapid increase in supply from 1994 to 2002 was largely the result of increased vanadium production from Australia and China. The increased Chinese vanadium supply was primarily vanadium-bearing slag that was coproduced with iron from magnetite ore. In 2002, consumption of vanadium decreased and prices began to decrease (fig. 1). Many of the larger producers did not react to the price decreases and maintained production at high levels. Prices dropped to historically low levels, and many smaller companies were forced to reduce production, suspend operations, or completely shut down plants (Lee, 2006).

In 2003, at about the same time as some of these closures, vanadium consumption started to rise sharply owing to a sharp rise in global steel production. The balance quickly tipped to undersupply, with the result that inventories began to fall and the price of vanadium climbed sharply. The large market inventory that had built up before 2002 helped cushion the gap between the soaring demand and reduced production through 2004; however, in early 2005, the stockpile was exhausted. The market reacted and the vanadium price increased dramatically to unprecedented levels. In China, the price rose to such a high level that there was a sudden cutback in the use of vanadium. Vanadium production increased throughout 2005 , and by late 2005, the market was in better balance and prices decreased to an annual average of $\$ 7.85$ per pound vanadium pentoxide (Bunting, 2006).

In 2006 through early 2008, vanadium consumption and production were in balance and prices increased, but nowhere near the levels of 2005 . Prices hit a high of $\$ 18.40$ per pound in June 2008. Prices remained high during the second and third quarters of 2008 owing to the effects of a large earthquake in China, which not only forced mines to close, but also caused damage to rail infrastructure, stagnating production of vanadium. At the same time, South Africa suffered from electricity shortages and power cuts.

Prices began to dramatically decrease at the beginning of the fourth quarter of 2008 owing to the global financial downturn. However, during the recession, the vanadium pentoxide price did not fall to the lows experienced between 1998 and 2003. Many producers outside China and Russia quickly cut production in 2009, which helped control inventories and thus limited the dramatic fall in prices. Prices stabilized in late 2009 and recovered in 2010 as growth continued in China and other emerging markets, although prices did not reach their previous historic highs.

\section{References Cited}

Bunting, R.M., 2006, Vanadium-How market developments affect the titanium industry: International Titanium Association Conference, San Diego, Calif., October 3, Presentation, $17 \mathrm{p}$.

Busch, P.M., 1961, Vanadium-A materials survey: U.S. Bureau of Mines Information Circular 8060, 95 p.

Kuck, P.H., 1985, Vanadium, in Mineral facts and problems: U.S. Bureau of Mines Bulletin 675, p. 895-915.

Lee, John, 2006, The vanadium market: GoldInsider, June 26, $7 \mathrm{p}$. 


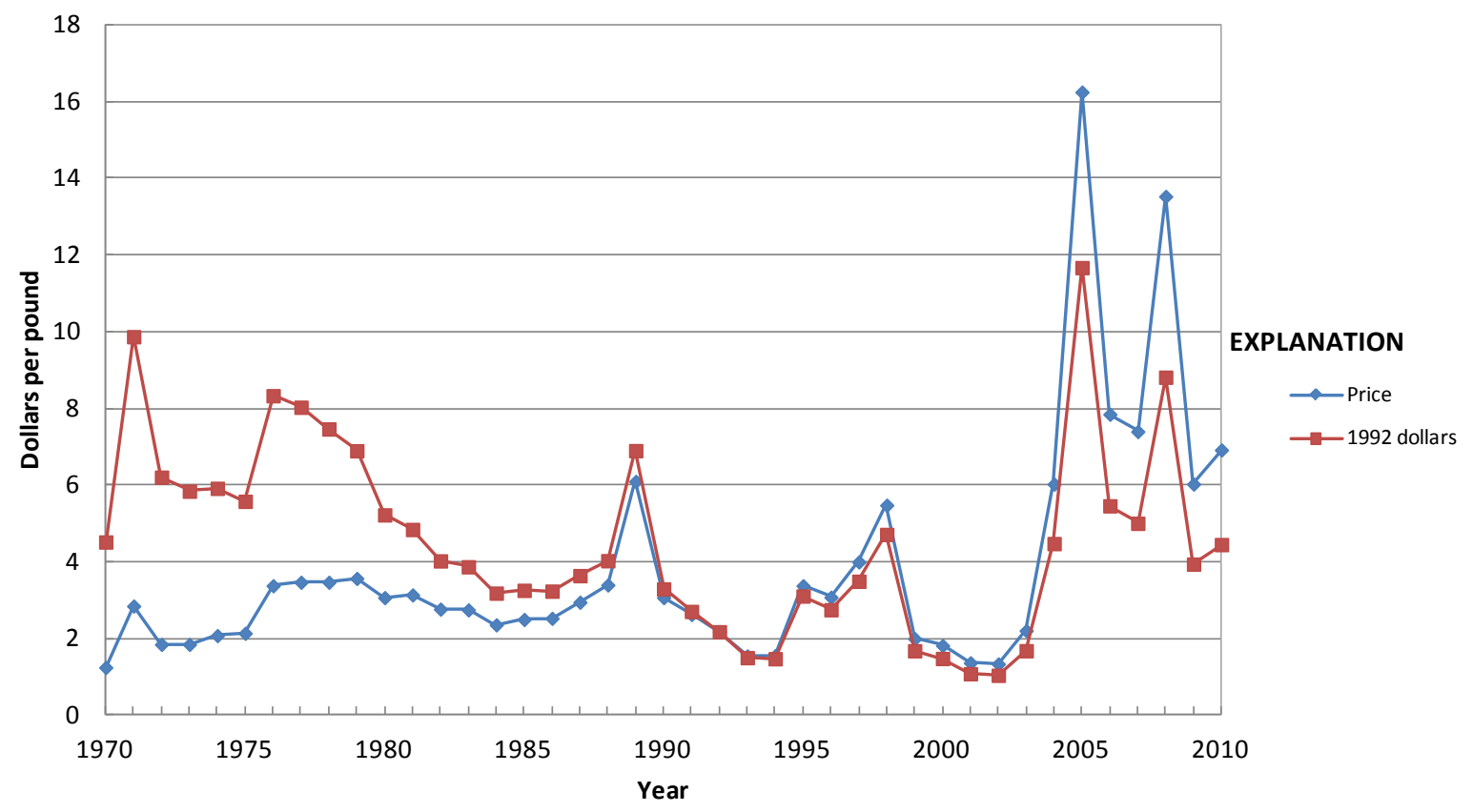

Figure 1. Annual average vanadium pentoxide price.

\section{Significant events affecting vanadium prices since 1970}

1988-89 Low supply owing to technical problems at some producers, and to increased demand from steel and aerospace industries

Market oversupply all year; price fell despite increase in consumption

2005

Disposal of last vanadium pentoxide holdings in the U.S. National Defense Stockpile

Surge in global steel production created an unprecedented demand for vanadium that reduced stockpiles, and sent prices to an alltime high

2008-09 Global financial crisis; prices declined 
Table 1. Annual average vanadium pentoxide price.

[Values in dollars per pound. Minimum 98 percent vanadium pentoxide anhydride]

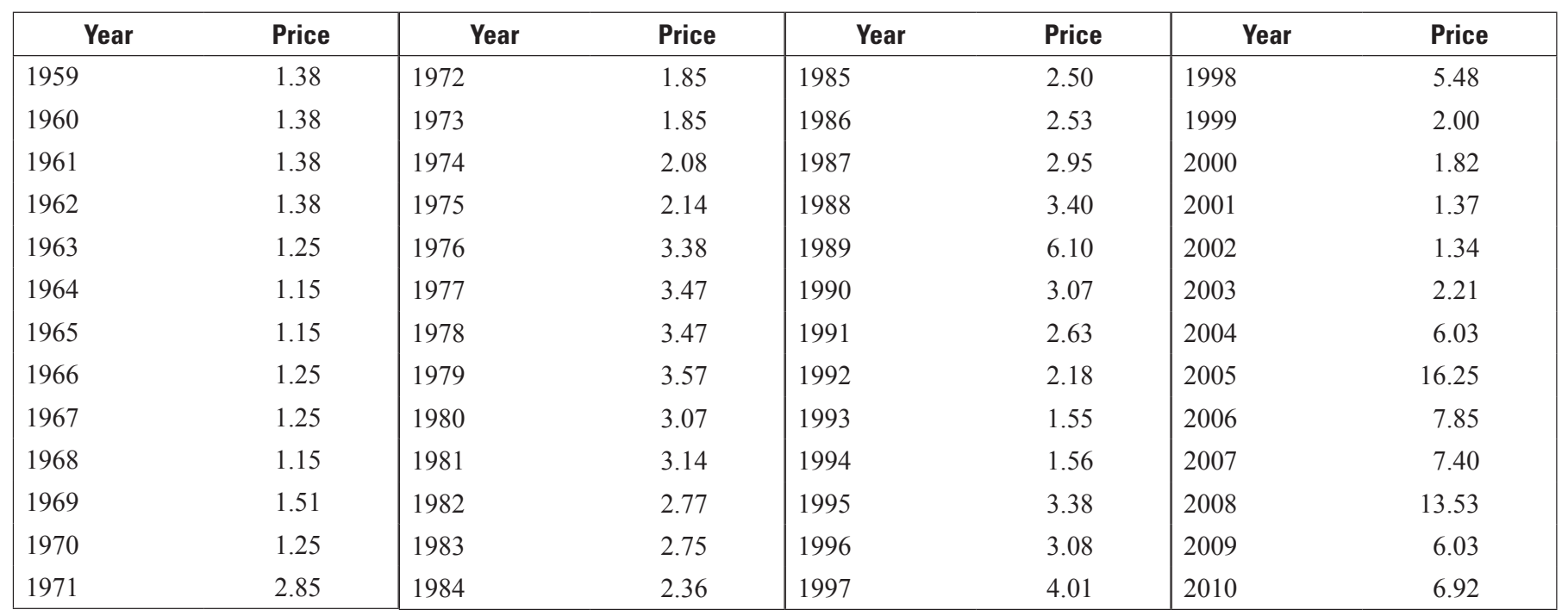

Note:

1959-2010, published in Metal Bulletin. 


\title{
Zinc (Zn)
}

\author{
By Amy C. Tolcin
}

Zinc use before zinc smelting involved the use of zinc compounds that resulted from the smelting of lead and copper ores. Zinc's presence in early bronze was most likely accidental and dependent on the ores used. By the time brass was developed and manufactured, zinc compounds were recognized and deliberately mixed with copper by the process of cementation. In the sixth century, the Chinese were credited with producing the first articles of zinc metal, and by the 13th century, zinc was smelted on a large scale in India. Zinc smelting technology was thought to have been brought to Europe from Asia around 1730. By the end of the 18th century, largescale commercial smelting had begun in Europe. In the United States, the first zinc metal was produced in 1835 at the Arsenal in Washington, D.C., for the manufacture of brass standard units of weights and measures. The U.S. zinc mining industry commercially began around 1850 with the production of compounds from zinc ores in New Jersey and Pennsylvania. By the turn of the century, U.S. zinc smelting activity had grown rapidly, mainly developing in Illinois, Kansas, Missouri, and Pennsylvania. The development of the vast Joplin, Mo., zinc mining district in the early 1870 s was stimulated by the growing use of zinc by U.S. industry. During the first half of the 20th century, two pricing centers emerged-St. Louis, Mo., and New York, N.Y. The New York price was usually higher because it included shipping charges. Because the prevailing method of production was pyrometallurgical, yielding Prime Western (PW) zinc, both prices were based on that grade. Higher grades of zinc cost more because of the expense of additional refining.

During the 1960s, the East St. Louis, Ill., price of zinc remained stable, which can be attributed partially to Government policies pertaining to stockpile programs and import quotas and tariffs (table 1). The price increase in this decade was about 13 percent. In 1965, import quotas were lifted, and Public Law 89-322, authorizing the first of the annual zinc disposals from the Government stockpile, was enacted. In 1971, the importance of the East St. Louis price diminished when a major producer began to include shipping charges in its price quotation. The emergence of the New York price coincided with Metals Week becoming the main pricing medium for zinc in the United States.

Because price controls were in force from 1971 through 1973 and any increase of price had to be approved by the U.S. Cost of Living Council, zinc prices increased only gradually (fig. 1). After price controls were abolished, the price for high-grade (HG) zinc metal rose abruptly, nearly doubling by mid-1975. For the next 11 years, the annual average price fluctuated within an \$0.18-per-pound band (Jolly, 1993).
By 1980 , more than a decade after electrolytic refining had become dominant in the production of domestic zinc, HG was made the base grade for pricing purposes, and Metals Week introduced its weighted average price, which it based on daily sales of HG. The largest increase in the history of the zinc price began with a small $\$ 0.04$-per-pound increase in November 1987, and escalated to a $\$ 0.20$ increase in February 1989. The main impetus for this steep increase was tightness of supply brought about by strong world demand; strikes, technical problems at some smelters, and hurricane-related delays of zinc shipments from Mexico were also contributing factors. In the 1980s, U.S. refinery production supplied only about one-third of domestic demand. As a result, world price became the dominant factor in setting the domestic price.

Outside of the United States, the world pricing basis for zinc has essentially been the price quoted by the London Metal Exchange Ltd. (LME), which introduced its first zinc contract in 1915. In order to stabilize the sometimes volatile LME prices, a group of non-U.S. zinc producers established the European Producer Price (EPP) in 1964. Later, dissatisfaction with the EPP pricing system, mainly as it related to the settlement price of zinc concentrate and the determination of smelter treatment charges, led to the reemergence of LME zinc quotations as the principal basis for world zinc pricing (Jolly, 1997, p. 218-221). The choice of an LME basis was further solidified when the LME switched from British pounds to U.S. dollars for all its transactions in 1998.

During the 1990s, the price for refined zinc remained rather stable, reflecting the supply and demand of the market.

In 2000, zinc prices fell sharply during the last quarter of the year as U.S. economic activity slowed during that time. In 2001, prices continued to decrease owing to an oversupply in the metal market, mainly caused by substantial Chinese exports and low global demand. Many Chinese smelters were prompted to export zinc metal to take advantage of higher international prices as compared with those in the domestic market. Prices were also suppressed during this time by a significant decline in automobile sales in the United States. In 2002, the price of zinc on the LME reached its lowest level in 15 years. Smaller companies that operated small underground mines or low-capacity smelters could not absorb prolonged financial losses and were forced to either temporarily suspend production or close entire operations. Larger companies with ample financial resources and diversified production were in better position to withstand the downturn of the zinc industry. Some even increased production in order to take advantage of economies of scale. In 2003, zinc prices shifted upward, coinciding with the metal market moving out of a supply surplus 
and into balance. Increased global demand for zinc was largely supported by China's rapidly growing economy and infrastructure, while production was constrained by curtailments and mine closures that were implemented as a result of low prices during the late 1990s and early 2000s. In 2005, zinc metal consumption between January and November was almost 1 percent higher than that of the similar period of 2004, which was enough to push the supply-demand balance into a deficit.

A rapid price increase took place in 2006 as a result of several factors - a 15-year low in LME stocks of zinc, increased world demand, tight world supply, and investment buying. Many zinc mines reopened or expanded during this time, causing the supply deficit for refined zinc to narrow, and by 2008 , the metal market was back in surplus. However, monthly average zinc prices strengthened during the first quarter of 2008 in conjunction with most other base metals. Global monthly zinc consumption continued to increase during the first half of 2008 owing predominantly to increasing consumption in China, which offset decreases reported in Europe and the United States as economic activity slowed in these areas. Thereafter, global consumption began to deteriorate, moderately in the third quarter, then more sharply during the fourth quarter as the financial crisis spread globally. Sharply lower vehicle sales and a slowdown in the construction industry largely were responsible for the decline in zinc consumption during this period.
Declining zinc prices in 2008 led to several mine closures, mostly during the second half of the year. Junior mining companies were also unable to advance projects owing to reduced access to capital. Investment in new mining projects declined along with falling zinc prices. Global economic activity continued to contract during the first half of 2009, with the notable exception of China and India. Global zinc consumption began to recover during the second quarter of 2009. As global economic activity began recovering during the third quarter, global demand for zinc began to increase. Despite the zinc metal market being in surplus during 2009, average monthly zinc prices increased during the course of the year, possibly owing to speculative investment. Prices then began to decline in the first half of 2010, and then rebounded during the second half of the year. Global economic activity expanded during 2010, albeit at a sluggish pace.

\section{References Cited}

Jolly, J.H., 1993, Zinc, in Metal prices in the United States through 1991: U.S. Bureau of Mines, p. 191-195.

Jolly, J.H., 1997, U.S. zinc industry: Baltimore, Md., American Literary Press, Inc., 312 p.

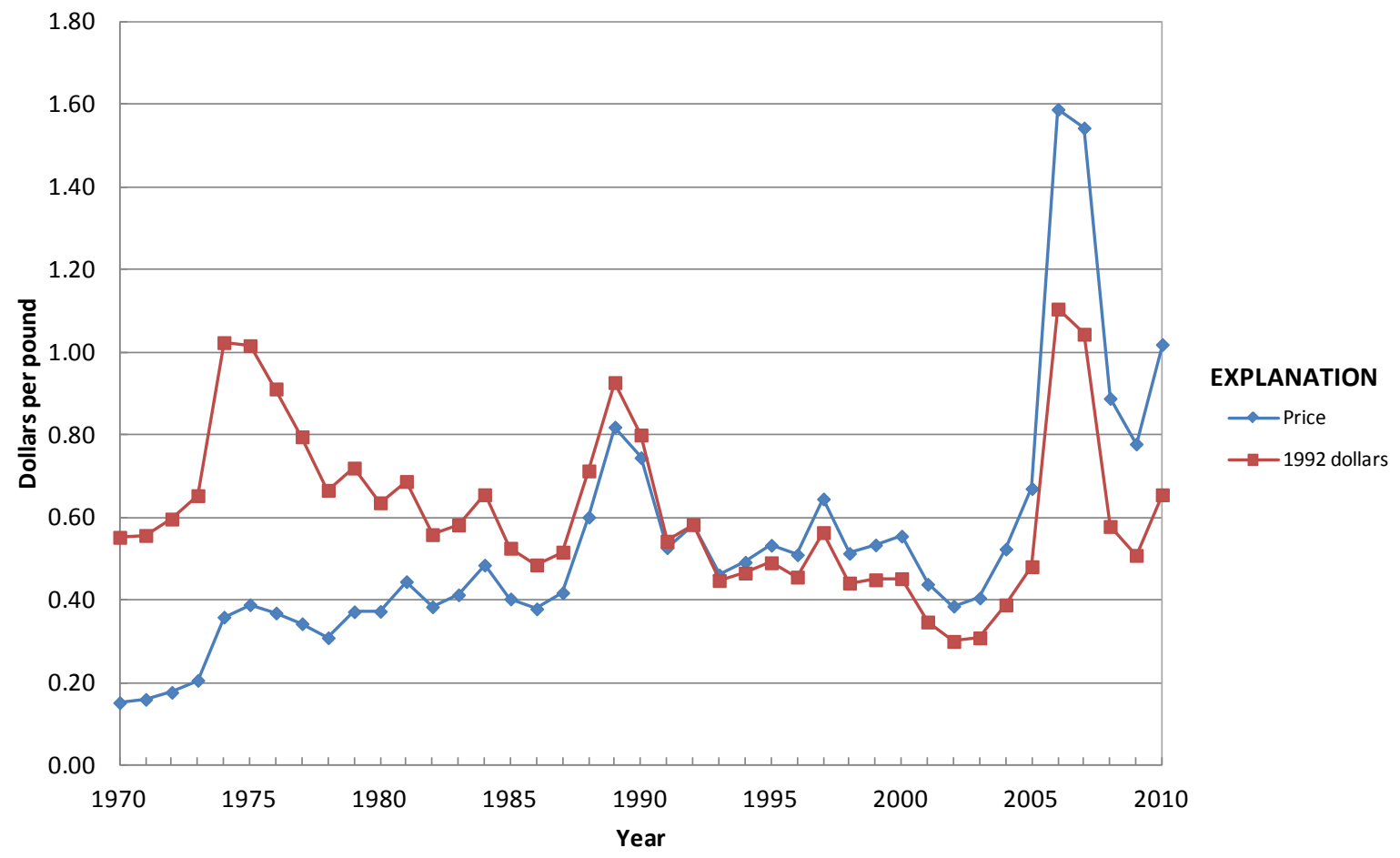

Figure 1. Annual average zinc price. 


\section{Significant events affecting zinc prices since 1970}

1971-73 Price controls in the United States; slow price increase

1975-82

1982

1983-89

1987-89

2002-06

Stockpile sales terminated; declining production

Recession; prices decreased

Period of sustained economic growth; stagnating domestic production; high zinc imports and prices

Limited supply of zinc metal; strong world demand

Increasing zinc consumption in China outpaces production; prices increased

2008-09

Global economic crisis; prices declined 
Table 1. Annual average zinc price.

[Values in dollars per pound]

\begin{tabular}{|c|c|c|c|c|c|c|c|}
\hline Year & Price & Year & Price & Year & Price & Year & Price \\
\hline 1875 & 0.070 & 1909 & 0.054 & 1943 & 0.083 & 1977 & 0.344 \\
\hline 1876 & 0.072 & 1910 & 0.054 & 1944 & 0.083 & 1978 & 0.310 \\
\hline 1877 & 0.060 & 1911 & 0.056 & 1945 & 0.083 & 1979 & 0.373 \\
\hline 1878 & 0.049 & 1912 & 0.068 & 1946 & 0.087 & 1980 & 0.374 \\
\hline 1879 & 0.052 & 1913 & 0.055 & 1947 & 0.105 & 1981 & 0.446 \\
\hline 1880 & 0.055 & 1914 & 0.051 & 1948 & 0.136 & 1982 & 0.385 \\
\hline 1881 & 0.052 & 1915 & 0.142 & 1949 & 0.122 & 1983 & 0.414 \\
\hline 1882 & 0.053 & 1916 & 0.136 & 1950 & 0.139 & 1984 & 0.486 \\
\hline 1883 & 0.045 & 1917 & 0.089 & 1951 & 0.180 & 1985 & 0.404 \\
\hline 1884 & 0.044 & 1918 & 0.080 & 1952 & 0.162 & 1986 & 0.380 \\
\hline 1885 & 0.043 & 1919 & 0.070 & 1953 & 0.109 & 1987 & 0.419 \\
\hline 1886 & 0.044 & 1920 & 0.078 & 1954 & 0.107 & 1988 & 0.602 \\
\hline 1887 & 0.046 & 1921 & 0.047 & 1955 & 0.123 & 1989 & 0.820 \\
\hline 1888 & 0.049 & 1922 & 0.057 & 1956 & 0.135 & 1990 & 0.746 \\
\hline 1889 & 0.050 & 1923 & 0.066 & 1957 & 0.114 & 1991 & 0.528 \\
\hline 1890 & 0.055 & 1924 & 0.063 & 1958 & 0.103 & 1992 & 0.584 \\
\hline 1891 & 0.050 & 1925 & 0.076 & 1959 & 0.115 & 1993 & 0.462 \\
\hline 1892 & 0.046 & 1926 & 0.073 & 1960 & 0.130 & 1994 & 0.493 \\
\hline 1893 & 0.040 & 1927 & 0.062 & 1961 & 0.116 & 1995 & 0.534 \\
\hline 1894 & 0.035 & 1928 & 0.060 & 1962 & 0.116 & 1996 & 0.511 \\
\hline 1895 & 0.036 & 1929 & 0.065 & 1963 & 0.120 & 1997 & 0.646 \\
\hline 1896 & 0.039 & 1930 & 0.046 & 1964 & 0.136 & 1998 & 0.514 \\
\hline 1897 & 0.041 & 1931 & 0.036 & 1965 & 0.145 & 1999 & 0.535 \\
\hline 1898 & 0.046 & 1932 & 0.029 & 1966 & 0.145 & 2000 & 0.556 \\
\hline 1899 & 0.058 & 1933 & 0.040 & 1967 & 0.139 & 2001 & 0.440 \\
\hline 1900 & 0.044 & 1934 & 0.042 & 1968 & 0.135 & 2002 & 0.386 \\
\hline 1901 & 0.041 & 1935 & 0.043 & 1969 & 0.147 & 2003 & 0.406 \\
\hline 1902 & 0.048 & 1936 & 0.049 & 1970 & 0.153 & 2004 & 0.525 \\
\hline 1903 & 0.054 & 1937 & 0.065 & 1971 & 0.161 & 2005 & 0.671 \\
\hline 1904 & 0.051 & 1938 & 0.046 & 1972 & 0.178 & 2006 & 1.589 \\
\hline 1905 & 0.059 & 1939 & 0.051 & 1973 & 0.207 & 2007 & 1.544 \\
\hline 1906 & 0.061 & 1940 & 0.063 & 1974 & 0.360 & 2008 & 0.889 \\
\hline 1907 & 0.058 & 1941 & 0.075 & 1975 & 0.390 & 2009 & 0.779 \\
\hline 1908 & 0.046 & 1942 & 0.083 & 1976 & 0.370 & 2010 & 1.020 \\
\hline
\end{tabular}

Notes:

1875-1904, New York price for Prime Western zinc (98-percent-pure), in Ingalls, W.R., Lead and Zinc in the United States, McGraw-Hill, N.Y., 1980, p. 342. 1905-70, St. Louis/East St. Louis producer price for Prime Western zinc, in American Metal Market/Metal Statistics.

1971-79, U.S. Dealers Prime Western delivered price, in Metals Week.

1980-93, U.S. Dealers High Grade zinc (99.9-percent-pure) delivered price, in Metals Week.

1994-98, U.S. Dealers Special High Grade zinc (99.99-percent-pure) delivered price, in Platt's Metals Week.

1999-2010, North American Special High Grade zinc (99.995-percent-pure) delivered price, in Platts Metals Week. 


\title{
Zirconium (Zr)
}

\author{
By Joseph Gambogi
}

Martin H. Klaproth discovered the element in Germany in 1789 by analyzing zircon (Weeks and Leicester, 1968). The first impure zirconium metal was produced by Jöns Jakob Berzelius in 1824 (Berzelius, 1825). Commercial quantities of the ductile metal were not produced until 100 years later when Anton Eduard van Arkel and Jan Hedrik de Boer discovered the iodide, or crystal bar, process (van Arkel and de Boer, 1925). Powdered zirconium metal was available on domestic markets as early as 1930, when it was used primarily for its pyrophoric and alloying properties. Principal uses were for ammunition primers, vacuum-tube getters, flash powder used in photography, and corrosion-resistant steel alloys. An economic process to produce zirconium metal sponge (Kroll, or magnesium-reduction, process) was developed in the mid-1940s and became commercially available in the early 1950s (Etherington, Dalzell, and Lillie, 1955, p. 1-5). Zirconium sponge is used in the production of zirconium metal and alloys, especially for use in nuclear fuel cladding, corrosion-resistant piping in chemical processing plants, and heat exchangers. Crystal bar, which is a very high-purity form of zirconium metal that is used mostly in research and special applications, is not covered in this report.

In January 1945, the U.S. Bureau of Mines (USBM) began research to develop a commercial process for making zirconium sponge metal (Etherington, Dalzell, and Lillie, 1955, p. 1). By 1947, the USBM was operating a 27-kilogramper-week pilot plant in Albany, Oreg., using the Kroll process. In response to the U.S. Navy's interest in zirconium for possible use in nuclear-powered submarines, capacity at the pilot plant was expanded in 1949 [11,800 kilograms $(\mathrm{kg})]$, 1950, and twice in 1951 (Shelton and others, 1956, p. 1). By 1951, USBM capacity had reached about 136,000 kilograms per year $(\mathrm{kg} / \mathrm{yr})$. That same year, commercial price quotations for zirconium sponge began at \$22 per kilogram. In 1952, the Atomic Energy Commission (AEC) contracted with Carborundum Metals Co., Akron, N.Y., to supply the metal for 5 years. By 1955, the Carborundum plant was producing more sponge than was needed for the U.S. Navy's nuclear submarine program. At this time, the USBM's zirconium plant was converted to a metallurgical research facility. From 1959 to 1977, the price of zirconium sponge remained fairly stable, averaging from about $\$ 14$ to $\$ 17$ per kilogram and peaking in the 1960s (table 1). The decline in the 1970s was also attributed to the slowing of the nuclear submarine program and the use of substitute materials for commercial powerplants. Beginning in 1978, prices for zirconium sponge increased (fig. 1). The substantial price increase has been attributed primarily to the U.S. economy because lagging U.S. economic activity and double-digit inflation increased operating costs throughout the industry. The twofold price increase for zirconium sponge may have been associated with the 50 percent reduction in capacity by the sole domestic producer, the cost of implementing process environmental controls to regulate naturally occurring radioactive materials, and the continued demand for replacement fuel cladding and structural repairs at nuclear powerplants (Templeton, 1993).

In the 1980s and 1990s, the use of zirconium sponge in military and commercial nuclear powerplants, heat exchangers, and specialty chemical piping for corrosive environments overshadowed the use of the metal in powder and crystal bar applications (Hedrick, 1989). With no new domestic construction of nuclear powerplants, domestic demand for zirconium metal grew only slightly in the 2000s.

Although nuclear power construction in much of the world leveled off, nuclear power in Asia grew significantly. As of April 2010, in east and south Asia, there were 112 nuclear power reactors in operation, 37 under construction, and plans to construct an additional 84 (World Nuclear Association, 2010.)

Increasing global demand and rising prices have led domestic producers to plan expansions. In 2009, ATI Wah Chang was increasing nuclear-grade zirconium sponge production capacity at its Albany, Oreg., facility to about 3,630 metric tons per year (t/yr) (Allegheny Technologies Inc., 2010, p. 3). Westinghouse Electric Co. made an agreement with the State Nuclear Power Technology Co., Ltd. (SNPT) to construct a nuclear-grade zirconium sponge plant at Nantong, Jiangsu Province, China. The plant was expected to supply nuclear-grade sponge to Westinghouse's Western Zirconium Plant in Ogden, Utah, and the market in China. SNPT expected to produce up to $1,000 \mathrm{t} / \mathrm{yr}$ of nuclear sponge within 3 years (World Nuclear News, 2009).

Because there are only a few producers of zirconium, published prices have not been available since 2002. U.S. imports of unwrought zirconium are included under the Harmonized Tariff Schedule category 8109.20 that includes all unwrought zirconium, including bar, sponge, powder, and waste and scrap. The import value of unwrought zirconium from France was considered to be the best available price for zirconium; however, because this price may include a variety of material, it may not accurately reflect market conditions.

Prices for zirconium metal from 2000 to 2010 reflected growing global demand and reached a peak of $\$ 99.76$ per kilogram in 2010. In 2004, prices peaked because of rising costs of raw materials, energy, and other costs. The price peak in 2010 was believed to have been caused by rising consump- 
tion by the nuclear industry. Increasing global demand for nuclear powerplants and corrosion-resistant industrial process equipment was expected to correspond to an increase in future demand for zirconium metal.

\section{References Cited}

Allegheny Technologies Inc., 2010, ATI annual report 2009: Pittsburgh, Pa., Allegheny Technologies Inc., April 5, 114 p., accessed July 1, 2010, via http://ir.atimetals.com/ phoenix.zhtml? $c=98187 \& p=$ irol-sec.

Berzelius, J.J., 1825, Zirconium reducirt aus flusfspathfaurem Zirconkali, und einige Eigenschaften der Zirconerde [Zirconium obtained by the reduction of potassium-zirconium fluoride, and certain properties of zirconium earth (oxide)]: Leipzig, Germany, (Poggendorf), Annalen der Physik, v. 4, p. 121-156.

Etherington, H., Dalzell, R.C., and Lillie, D.W., 1955, Zirconium and its applications to nuclear reactors, chap. 1 of The metallurgy of zirconium: New York, McGraw-Hill, 18 p.

Hedrick, J.B., 1989, Zirconium and hafnium, in Metals and minerals: U.S. Bureau of Mines Minerals Yearbook 1988, v. I, p. 1049-1057.
Kalish, H.S., 1953, The preparation of zirconium powder, chap. 5 of Zirconium and zirconium alloys: Cleveland, Ohio, American Society for Metals, p. 5-36.

Shelton, S.M., and others, 1956, Zirconium-Its production and properties: U.S. Bureau of Mines Bulletin 561, 180 p.

Templeton, D.A., 1993, Zirconium, in Metal prices in the United States through 1991: U.S. Bureau of Mines, p. 197-199.

van Arkel, A.E., and de Boer, J.H., 1925, Preparation of pure titanium, zirconium, hafnium, and thorium metal: Zeitschrift für Anorganische und allgemeine Chemie, v. 148 , no. 1, p. 345-350.

Weeks, M.E., and Leicester, H.M., 1968, Discovery of the elements (7th ed.): Easton, Pa., Journal of Chemical Education, p. 517-520.

World Nuclear Association, 2010, Asia's nuclear energy growth: London, United Kingdom, accessed at World Nuclear Association, April, accessed October, 12, 2011, at http://www.world-nuclear.org/info/inf47.html.

World Nuclear News, 2009, Westinghouse in Chinese zirconium JV: London, United Kingdom, World Nuclear News, April 22, accessed July 7, 2010, at http://www.worldnuclear-news.org/C-Westinghouse_in_Chinese_zirconium JV-2204094.html.

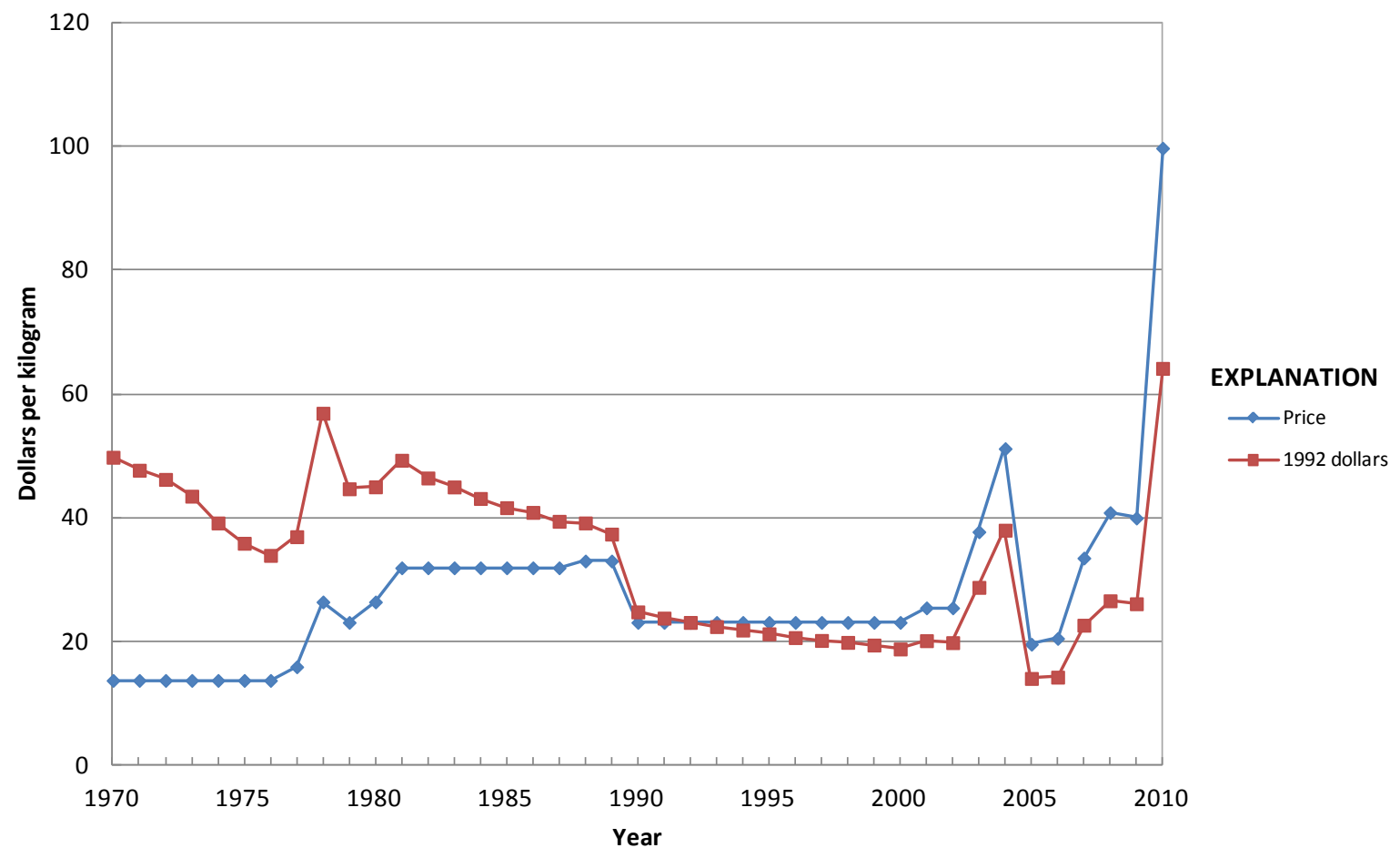

Figure 1. Yearend zirconium sponge metal price. 


\section{Significant events affecting zirconium prices since 1970}

1977-78 Number of producers reduced to one; inflation and lack of competition; demand increased for high-purity specialty powders and metal

2004 Price increases driven by rising costs of raw materials, energy, and other costs

$2008 \quad$ China planned to significantly expand atomic energy production

$2010 \quad$ Rising consumption by the nuclear industry and increased raw material costs

Table 1. Yearend zirconium sponge metal price.

[Values in dollars per kilogram]

\begin{tabular}{|ll|ll|ll|lc|}
\hline Year & Price & Year & Price & Year & Price & Year & Price \\
\hline 1959 & 13.78 & 1972 & 13.78 & 1985 & 31.97 & 1998 & 23.15 \\
1960 & 14.05 & 1973 & 13.78 & 1986 & 31.97 & 1999 & 23.15 \\
1961 & 13.78 & 1974 & 13.78 & 1987 & 31.97 & 2000 & 23.15 \\
1962 & 13.50 & 1975 & 13.78 & 1988 & 33.07 & 2001 & 25.50 \\
1963 & 16.53 & 1976 & 13.78 & 1989 & 33.07 & 2002 & 25.50 \\
1964 & 16.53 & 1977 & 15.98 & 1990 & 23.15 & 2003 & 37.79 \\
1965 & 16.53 & 1978 & 26.46 & 1991 & 23.15 & 2004 & 51.23 \\
1966 & 16.53 & 1979 & 23.15 & 1992 & 23.15 & 2005 & 19.63 \\
1967 & 16.53 & 1980 & 26.46 & 1993 & 23.15 & 2006 & 20.56 \\
1968 & 13.23 & 1981 & 31.97 & 1994 & 23.15 & 2007 & 33.55 \\
1969 & 13.78 & 1982 & 31.97 & 1995 & 23.15 & 2008 & 40.89 \\
1970 & 13.78 & 1983 & 31.97 & 1996 & 23.15 & 2009 & 40.01 \\
1971 & 13.78 & 1984 & 31.97 & 1997 & 23.15 & 2010 & 99.76 \\
\hline
\end{tabular}

Notes:

1959-62 and 1969-2002, prices are an average of a range, converted from pounds, in American Metal Market.

1963-67, prices are an average of a range, converted from pounds, in Engineering and Mining Journal.

1968, prices are an average of a range, converted from pounds, Wah Chang Albany Corp., Albany, Oreg.

2003-10, unit value based on the duty-paid unit value of imported unwrought zirconium from France. 


\section{Appendix 1. Price Deflators}

[Consumer Price Index - All urban consumers]

\begin{tabular}{|lc|lc|lc|lc|}
\hline \multicolumn{1}{|c|}{ Year } & $\mathbf{1 9 9 2 = 1 . 0 0 0}$ & \multicolumn{2}{c|}{ Year } & $\mathbf{1 9 9 2 = 1 . 0 0 0}$ & Year & $\mathbf{1 9 9 2 = 1 . 0 0 0}$ & \multicolumn{2}{c|}{ Year } & $\mathbf{1 9 9 2 = 1 . 0 0 0}$ \\
\hline 1959 & 4.821 & 1972 & 3.356 & 1985 & 1.304 & 1998 & 0.861 \\
1960 & 4.740 & 1973 & 3.160 & 1986 & 1.280 & 1999 & 0.842 \\
1961 & 4.692 & 1974 & 2.846 & 1987 & 1.235 & 2000 & 0.815 \\
1962 & 4.646 & 1975 & 2.608 & 1988 & 1.186 & 2001 & 0.792 \\
1963 & 4.585 & 1976 & 2.466 & 1989 & 1.131 & 2002 & 0.780 \\
1964 & 4.526 & 1977 & 2.315 & 1990 & 1.073 & 2003 & 0.763 \\
1965 & 4.454 & 1978 & 2.152 & 1991 & 1.030 & 2004 & 0.743 \\
1966 & 4.330 & 1979 & 1.933 & 1992 & 1.000 & 2005 & 0.718 \\
1967 & 4.201 & 1980 & 1.703 & 1993 & 0.971 & 2006 & 0.696 \\
1968 & 4.032 & 1981 & 1.543 & 1994 & 0.947 & 2007 & 0.677 \\
1969 & 3.823 & 1982 & 1.454 & 1995 & 0.921 & 2008 & 0.652 \\
1970 & 3.616 & 1983 & 1.409 & 1996 & 0.894 & 2009 & 0.654 \\
1971 & 3.464 & 1984 & 1.350 & 1997 & 0.874 & 2010 & 0.643 \\
\hline
\end{tabular}

Source: U.S. Department of Labor, Bureau of Labor Statistics.

The Consumer Price Index (CPI) (All urban consumers) is used as an economic indicator. As the most widely used measure of inflation, the CPI is an indicator of the effectiveness of government policy. In addition, business executives, labor leaders, and other private citizens use the index as a guide in making economic decisions.

The CPI also is used as a deflator of other economic series. The CPI and its components are used to adjust other economic series for price change and to translate these series into inflation-free dollars.

For more information about the CPI, please see the U.S. Department of Labor, Bureau of Labor Web site at http://www.bls.gov/cpi/home.htm. 

